Angela Rosch Rodrigues

\title{
Ruína e patrimônio cultural no Brasil
}





\section{Angela Rosch Rodrigues}

\section{Ruína e patrimônio cultural no Brasil}

Tese apresentada à Faculdade de Arquitetura e Urbanismo da Universidade de São Paulo para a obtenção do título de Doutor em Arquitetura e Urbanismo.

Área de Concentração: História e Fundamentos da Arquitetura e do Urbanismo.

Orientadora: Profa. Dra. Mônica Junqueira de Camargo.

EXEMPLAR REVISADO E ALTERADO EM RELAÇÃO À VERSÃO ORIGINAL, SOB RESPONSABILIDADE DA AUTORA E ANUENCIA DA ORIENTADORA.

$\mathrm{O}$ original se encontra disponível na sede do programa.

São Paulo 10 de abril de 2017. 
AUTORIZO A REPRODUÇÃO E DIVULGAÇÃO TOTAL OU PARCIAL DESTE TRABALHO, POR QUALQUER MEIO CONVENCIONAL OU ELETRÔNICO, PARA FINS DE ESTUDO E PESQUISA, DESDE QUE CITADA A FONTE.

E-MAIL DA AUTORA: arqangelarr@gmail.com

Rodrigues, Angela Rosch

R696r Ruína e patrimônio cultural no Brasil / Angela Rosch

Rodrigues. -- São Paulo, 2017.

301 p. : il.

Tese (Doutorado - Área de Concentração: História e Fundamentos

da Arquitetura e do Urbanismo) - FAUUSP.

Orientadora: Mônica Junqueira de Camargo

1.Patrimônio cultural (Preservação) 2.Arquitetura 3.Ruínas I.Título

CDU 7.025.3 
Dedico este trabalho aos meus queridos pais Elisa e Miguel e ao meu querido irmão André, pelo apoio, incentivo, carinho e amor incondicionais. 



\section{Agradecimentos}

Agradeço imensamente à querida profa. Dra. Mônica Junqueira de Camargo pelo seu incentivo, apoio, ensinamentos e orientação; sempre tão precisa e prestativa durante toda a trajetória do doutorado.

À Fundação de Amparo à Pesquisa do Estado de São Paulo (FAPESP) pela confiança e apoio referentes à: concessão de bolsa de Doutorado (Processo: 2012/24457-7) e bolsa para Estágio de Pesquisa no Exterior (Processo: 2015/07250-8).

À prezada profa. Dra. Beatriz Mugayar Kühl por seus ensinamentos desde o início deste trabalho e contribuições na banca de qualificação; e também por seu papel fundamental para a viabilização do estágio de pesquisa desenvolvido em Roma. À profa. Dra. Cristina Meneguello (UNICAMP) por suas preciosas contribuições durante as análises da banca de qualificação. E às importantes considerações e atentas leituras da Dra. Claudia Suely Rodrigues de Carvalho (Fundação Casa de Rui Barbosa) e da Dra. Lia Mayumi (PMSP/DPH).

Também agradeço ao prof. Dr. Hugo Segawa e à prof. Dra. Nilce C. Aravecchia Botas pelas aulas e conversas durante a experiência do PAE (Programa de Aperfeiçoamento de Ensino).

Ao caro prof. Dr. Mário Henrique D`Agostino, com o qual tive a oportunidade de compartilhar verdadeiras e preciosas "aulas" in loco, durante minha estada em Roma.

Durante meu Estágio de Pesquisa no Exterior na Università degli Studi di Roma La Sapienza, Facoltà di Architettura, Dipartamento di Storia, Disegno e Restauro dell'Architettura (DSDRA), devo um enorme agradecimento à profa. Dra. Simona M. C. Salvo, por sua supervisão durante este período contribuindo com suas acuradas observações e comentários. Ao prof. Dr. Giovanni Carbonara, que tão solicitamente me atendeu concedendo orientações extremamente valiosas. À profa. Dra. Daniela Esposito, por sua atenção e magníficas aulas. Ao Dr. Jukka Jokilehto por sua prontidão e inestimáveis comentários. Aos professores Dr. Marcello Barbanera e Dr. Lucio Altarelli que gentilmente me atenderam e comentaram sobre seus respectivos trabalhos sobre o tema das ruínas. E ao Dr. Martin Gegner que tão atenciosamente me recebeu em Berlin.

A todos os entrevistados mencionados ao longo deste trabalho que disponibilizaram seu tempo e sua atenção para me atender prontamente adicionando informações, material relevante e referências bibliográficas. Em especial ao prof. Dr. Paulo Bruna. 
A todos que colaboraram com informações, dados, referências bibliográficas e material iconográfico durante esta pesquisa. Em especial aos funcionários da biblioteca do ICCROM (Roma) pela atenção e presteza em atender às minhas solicitações; e ao corpo técnico do arquivo do IPHAN/SP, do CONDEPHAAT, CONPRESP (PMSP/SMC) e DPH (PMSP/SMC).

À querida profa. Dra. Manoela Rossinetti Rufinoni pelo fornecimento de dados e materiais importantes e, principalmente, pela amizade, encorajamento e disposição em diversos momentos desse longo percurso. À cara colega Luciana M. Inoue pelas frutíferas trocas de ideias; e à profa. Dra. Iná Rosa da Silva pelo incentivo.

A todos os colegas e amigos pelo apoio e carinho ao longo dessa trajetória, em especial, aos queridos: Adriana Jardim Gouveia, Amanda Moutinho, Eduardo Canejo, Leusa Maria Vieira, Sara C. Silva e Wagner Nascimento.

Ao Pensionato Sante Rufina e Seconda, com todas as estimadas freiras, funcionários e amigos que me acolheram afetuosamente durante minha estada em Roma, tornando meus dias na "Cidade Eterna" inesquecíveis, não somente pela experiência acadêmica e arquitetônica, mas, principalmente, pela vivência humana. Em especial a: Suor Matilde Ambrosca e Suor Simona Santoro; e às caras amigas: Antonietta e Giuseppina Colucciello, Gerarda Cervone, Mariateresa Sessa, Suor Martin Shayo e Yolanda Valero Cárdenas.

À minha amada família - Miguel, Elisa, André e Fabiana - com quem eu sempre pude contar e que me dão o suporte necessário através de seu amor, carinho e compreensão incondicionais, para que eu encontre os meios de alcançar meus objetivos.

E a Deus, pela dádiva da vida. 
Les ruines existent par le regard qu `on porte sur elles (AUGÉ, 2003) 



\section{Resumo}

As ruínas constituem um profícuo campo de experimentações e digressões teóricas que concernem à preservação patrimonial. Diferentes formas de compreensão, reconhecimento de valor e significação atribuídos aos bens em ruínas orientam tratamentos com resultados distintos para a preservação ou não desse status quo. Esta pesquisa tem por objetivo analisar as várias interpretações de ruína na identificação e tratamento do patrimônio cultural edificado na esfera institucional do Brasil. Considerando ruína como uma condição de degradação e descaracterização de bens arquitetônicos de qualquer idade acometidos por arruinamentos ocasionados por diferentes causas e distanciamentos cronológicos, nossa análise se concentra no patrimônio tombado, ou com abertura de tombamento, no Estado de São Paulo. Esse levantamento nos sugeriu a organização dos casos selecionados em três grupos - ruínas do tempo, ruínas da incúria e ruínas do incidente - que subsidiam a investigação dos dois principais questionamentos desta tese: ruínas - o que são? E como intervir? A complexidade no entendimento de ruína deve-se a muitas variáveis - causa, grau e tempo decorrido do arruinamento, data da edificação e condição de uso da mesma - que, combinadas direcionam posicionamentos diversos em relação à abordagem e tratamento desses bens. As teorias da preservação - especialmente os preceitos do restauro crítico apresentam prescrições de operações segundo o grau de degradação dos bens. No campo da preservação patrimonial no Brasil há uma multiplicidade de resultados para a conservação ou não do substrato preexistente em estado de ruína, sobre o qual esta tese se debruçou e pretende contribuir.

Palavras chave: ruínas, patrimônio cultural, preservação, arquitetura paulista. 


\section{Abstract}

The ruins constitute a profitable field of experiments and theoretical digressions that concern the patrimonial preservation. Different forms of understanding, recognition of value and significance attributed to the ruined goods guide treatments with distinct results for the preservation or not of this status quo. The present research aims to analyze the various interpretations of ruin in the identification and treatment of cultural heritage built in the institutional sphere of Brazil. Considering ruin as a condition of degradation and decharacterization of architectural assets of any age affected by ruin caused by different causes and chronological distances, our analysis focuses on the listed patrimony, or that has been studied to be listed in the State of São Paulo. This survey suggested the organization of the selected cases in three groups - ruins of time, ruins of negligence and ruins of incident that contribute the investigation of the two main questions of this thesis: ruins - what are they? And how to intervene? The complexity of the understanding of ruin is due to many variables cause, degree and time elapsed from the ruin, date of construction and condition of use - that, combined, direct diverse positions in relation to the approach and treatment of these assets. Preservation theories - especially the precepts of critical restoration - prescribe operations according to the degree of degradation of goods. In the field of patrimonial preservation in Brazil there is a multiplicity of results for the conservation or not of the preexisting substrate in a state of ruin, on which this thesis has focused and intends to contribute.

Key words: ruins, cultural heritage, preservation, paulista architecture. 


\section{Lista de Figuras}

Fig.01 Povoado São Miguel das Missões (RS), gravura de Demersay, 1846.

Fonte: Wikimedia Commons, domínio público. Disponível em:

<https://commons. wikimedia.org/w/index.php?curid=8431918>, acesso em 23 set. 2016

Fig.02 Ruínas da Igreja Nossa Senhora da Conceição, Guarapari (ES) - CNSA: ES 00061, 2016.

(i-ii) Fotos: Autora.

Fig.03 Fortificação de Carcassonne antes dos trabalhos de restauração.

Fonte: Wikimedia Commons, domínio público. Disponível em:

<https://commons.wikimedia.org/w/index.php?curid=25175159>, acesso em abril 2016.

Foto: Gustave Le Gray (1820-1884), publicada c. 1851

Fig.04 Panorama da fortificação de Carcassonne após os trabalhos de restauro, 2009.

Fonte: Wikimedia Commons. Disponível em:

<https://fr.wikipedia.org/wiki/Cit\%C3\%A9_de_Carcassonne\#/media/File:Cit\%C3\%A9_de_Carca ssonne.jpg>, acesso em 16 abril 2016.

Fig.05 Gravura de Viollet-le-Duc descrevendo a situação de incompletude do Castelo Pierrefonds antes da restauração. Fonte: Wikimedia Commons, domínio público.

Disponível em: <https://commons.wikimedia.org/w/index.php?curid=66643>, acesso em 16 abril 2016.

Fig.06 Uma das pinturas de William Turner (1775-1851) sobre as ruínas de Tintern Abbey - The Chancel and Crossing of Tintern Abbey, 1784. Fonte: Wikimedia Commons, domínio público.

Disponível em: <https://commons.wikimedia.org/w/index.php?curid=2543506> acesso em 16 abril 2016.

Fig.07 Tintern Abbey, 2011. Fonte: Wikimedia Commons, domínio público. Disponível em:

<https://commons.wikimedia.org/w/index.php?curid=15358619> acesso em 16 abril 2016.

Foto: Saffron Blaze

Fig.08 Arco de Trajano por Giovanni Battista Piranesi, Vedute di Roma (Tomo II, tav. 26).

Fonte: Wikimedia Commons, domínio público. Disponível em:

<https://commons.wikimedia.org/w/index.php?curid=18586275>, acesso em 08 ago. 2015.

Fig.09 Goethe in der Campagna, pintura de Tischbein retratando Goethe em sua estadia em Roma, 1787. Ao fundo ruínas romanas: Túmulo de Cecília Metella e aquedutos.

Fonte: Wikimedia Commons, domínio público. Disponível em:

<https://commons. wikimedia.org/w/index.php?curid=29098753> acesso em 08 ago. 2015.

Fig.10 Vista de Olinda, Frans Jansz Post, 1662 - Rijksmuseum, Amsterdam (Holanda).

Fonte: Wikipedia, domínio público. Disponível em:

<https://commons.wikimedia.org/w/index.php?curid=34318090>, acesso em 20 nov. 2016.

Fig.11 Pátio do Colégio, ruínas de paredes de taipa quinhentistas, 1953.

Fonte: Acervo fotográfico da Superintendência do IPHAN/SP.

Fig.12 Pátio do Colégio, exposição das ruínas de paredes de taipa quinhentista, 2016.

Foto: Autora.

Fig.13 Ruínas do Pátio do Colégio, fundações da cripta proveniente do século XVII, 2016. Foto: Autora.

Fig.14 Mapa Capitania de São Vicente, 1631, João Teixeira Albernaz. Ao centro, indicação do Engenho São Jorge dos Erasmos.

Fonte: Mapoteca do Ministério das Relações Exteriores no Rio de Janeiro. 
Fig.15 "St. Vicent", ilustração elaborada por Joris van Spilbergen, c. 1615.

Fonte: REIS, 2000, p.193.

Fig.16 Engenho São Jorge dos Erasmos, levantamento c. 1960 (s.d.).

Fonte: IPHAN, 1962, s.p.

Fig.17 Situação das ruínas do Engenho São Jorge dos Erasmos.

(i-ii) Fonte: Caderno de Obras 1963-1966 (n.32), Luis Saia, acervo fotográfico IPHAN/SP.

Fig.18 Vista panorâmica das ruínas do Engenho São Jorge dos Erasmos, 2013. Foto: Autora

Fig.19 Escavações e fôrmas de pão de açúcar encontradas.

(i-ii) Fonte: Caderno de Obras 1963-1966, Luis Saia, acervo fotográfico IPHAN/SP.

Fig.20 Ruínas - lado esquerdo: cemitério (parte baixa) e capela (paredes ao fundo), 2013. Foto: Autora.

Fig.21 Mapa esquemático.

Fonte base: Google Maps, 2013. Elaborado pela autora.

Fig.22 Engenho São Jorge dos Erasmos e entorno.

(i-ii) Fonte: Caderno de Obras 1963-1966, Luis Saia, acervo fotográfico IPHAN/SP.

Fig.23 Área coberta com dois lanços antes da "restauração".

(i-ii) Foto: Herman H. Graeser (Germano), década de 1960, acervo fotográfico IPHAN/SP.

Fig.24 Consolidação do pilar central e reconstrução de parte da cobertura.

(i-ii) Fonte: Caderno de Obras 1963-1966, Luis Saia, acervo fotográfico IPHAN/SP.

Fig.25 Pavilhão Saia, três lanços de telhado, 2013.

Foto: Autora.

Fig.26 Engenho São Jorge dos Erasmos, situação em 1980.

(i-ii) Fonte: IPHAN, 1962, s.p.

Fig.27 Engenho São Jorge dos Erasmos, situação em 1980. Fonte: Acervo fotográfico IPHAN/SP.

Fig.28 Situação da área envoltória do Engenho São Jorge dos Erasmos derivada de terraplanagem

(i-ii) indevida, 1987.

Fonte: IPHAN, 1962, s.p.

Fig.29 Trabalhos de recuperação do "Pavilhão Saia", 2001.

(i-ii) Fonte: IPHAN, Relatório MORI, Victor Hugo In: IPHAN, 1962, s.p

Fig.30 "Pavilhão Saia", estrutura metálica de sustentação, 2013. Foto: Amanda Moutinho.

Fig.31 Base da USP, vista a partir do platô do Engenho São Jorge dos Erasmos; e vista da Base para o platô, 2013. Fotos: Autora.

Fig.32 Áreas circunvizinhas ao Engenho São Jorge dos Erasmos, 2013. Foto: Autora.

Fig.33 Em primeiro plano o fosso onde foram encontradas as fôrmas de pão de açúcar, durante a década de 1960, 2013. Foto: André Rosch Rodrigues.

Fig.34 Perspectiva da proposta para o sítio arqueológico, com a torre mirante e passarela. 
Fig.35 Ruínas da Capela do Morumbi, 1936.

Fonte: Reprodução do álbum fotográfico de Santo Amaro, SMC/DPH/DIM/Seção Arquivo de Negativos In: SÃO PAULO - cidade, SMC/CONPRESP, 1992, p.60.

Fig.36 Divulgação publicitária do Jardim Morumby, no canto inferior direito há representações da

Capela e Casa Sede.

Fonte: Revista Habitat, n. 25, dez. 1955. In: Pasta 03A.004.3 - SMC/DPH Seção Levantamento e Pesquisa

Fig.37 Capela do Morumbi - área interna utilizada para instalações de arte, 2014.

Foto: Autora

Fig.38 Ruínas da "Capela do Morumbi" e o arquiteto Gregori Warchavchik.

Fonte: Reproducão do álbum fotográfico de Santo Amaro, SMC/DPH/DIM/Seção Arquivo de Negativos In: SẪO PAULO - cidade, SMC/CONPRESP, 1992, p.60.

Fig.39 Projeto Gregori Warchavchik elaborado em 1949, planta e fachadas.

(i-iii) Fonte: Acervo FAU USP PE W196 725.85 fm. p.16.

Fig.40 Projeto Gregori Warchavchik elaborado em 1949, cortes.

(i-ii) Fonte: Acervo FAU USP PE W196 725.85 fm. p.16.

Fig.41 Pinturas murais do batistério, executadas por Lucia Suané em 1951

(i-ii) Fonte: SMC/DPH/Seção Técnica de Levantamento e Pesquisa In: SÃO PAULO - cidade, SMC/CONPRESP, 1992, p. 57.

Fig.42 Capela do Morumbi, entre 1973-1976.

(i-iv) Fonte: SMC/DPH/DIM Seção Arquivo de Negativos In: SÃO PAULO - cidade, SMC/CONPRESP, 1992, p.61-65.

Fig.43 Capela do Morumbi, detalhes internos, 2014

(i-iii) Fotos: Autora.

Fig.44 Capela do Morumbi, detalhes das taipas conservadas, 2014.

(i-iv) Fotos: Autora.

Fig.45 Planta da Capela do Morumbi tombada, canto inferior direito batistério.

Fonte: Resolução de Tombamento CONPRESP 11/05. Disponível em:

$<$ http://www.prefeitura.sp.gov.br/cidade/upload/ca566_11_T_Capela_Casa_Sede_Morumbi_co m_plantas.pdf > acesso em 20 jul. 2016

Fig.46 Trabalhos de consolidação da Igreja de São Miguel das Missões (RS), 1940.

(i-ii) Fonte: Acervo fotográfico IPHAN/SP

Fig.47 Atual situação da Igreja de São Miguel das Missões (RS), 2014.

(i-iii) Fotos: Monica dos Santos Dolce Uzum.

Fig.48 Sítio Santo Antônio - Casa do Barão, ruínas, São Roque (SP), 1940.

(i-ii) Fonte: Acervo fotográfico da Superintendência do IPHAN/SP. Fotos: Hernan H. Graeser (Germano).

Fig.49 Sítio Querubin, ruínas, São Roque (SP), s.d.

(i-ii) Fonte: IPHAN, c.1941, s.p.

Fig.50 Ruínas do Abarabebê, Guarujá (SP), 2013.

(i-ii) Fotos: Sara Caroline Silva.

Fig.51 Ermida de Santo Antônio do Guaíbe, Guarujá (SP), 2009.

Fonte: Relatório Final dos Serviços de Conservação, 2009, p.7 In: IPHAN, 1964.

Fig.52 Fortaleza de São José da Ponta Grossa, Florianópolis (SC) em estado de ruína, 1991, antes do início dos trabalhos de restauro.

Fonte: <http://fortalezas.org/midias/jpg_originais/00012_006816.jpg> acesso em 14 nov. 2016. 
Fig.53 Fortaleza de São José da Ponta Grossa, Florianópolis (SC) reconstituída, 2016.

(i-iii) Fotos: Autora.

Fig.54 Situação de arruinamento da Casa de Armas Brancas, Real Fábrica de Ferro São João do

(i-ii) Ipanema, Iperó (SP), 1961.

Fonte: IPHAN, 1964, s.p.

Fig.55 Casa de Armas Brancas, Real Fábrica de Ferro São João do Ipanema, Iperó (SP), 2009.

(i-ii) Fotos: Autora.

Fig.56 Projeto para o Centro de Interpretação do Pampa, Jaguarão (RS) - perspectivas externas.

(i-ii) Fonte: Brasil Arquitetura, disponível em: <http://brasilarquitetura.com/projetos/centro-deinterpretacao-do-pampa/> acesso em 10 out. 2016.

Fig.57 Andamento das obras para o Centro de Interpretação do Pampa, Jaguarão (RS), 2013 consolidação e completamento das ruínas.

Fonte: CAU - Notícias sobre Arquitetura, disponível em: <http://zh.clicrbs.com.br/rs/vida-eestilo/casa-e-cia/noticia/2013/07/projeto-em-jaguarao-preserva-ruinas-para-narrar-a-historia4217452.html>, acesso em 10 out. 2016.

Fig.58 Praça Nova - Castelo de São Jorge, Lisboa (Portugal), 2013.

(i-iii) Fotos: Autora.

Fig.59 Casa da Torre de Garcia D `Ávila, Mata de São João (BA), 2013.

(i-iii) Fotos: Autora.

Fig.60 Cobertura projetada por Franco Minissi, Villa Romana del Casale, Piazza Armerina (Itália), 2015.148 (i-ii) Fotos: Autora.

Fig.61 Ruínas e cobertura da Igreja Matriz de Vila Bela da Santíssima Trindade (MT), 2007. Fonte: <https://pt.wikipedia.org/wiki/Vila_Bela_da_Sant\%C3\%ADssima_Trindade>, acesso em 21 maio 2015. Foto Pedro Spoladore.

Fig.62 Museu a Céu Aberto, ruínas - muralha holandesa, Recife (PE), 2016. Foto: Renato Pinto, 2016.

Fig.63 Situação de alguns casarões no centro histórico de Salvador (BA), cidade baixa, 2013. Foto: Autora.

Fig.64 Situação da Escola de Meninas Vila Maria Zélia, São Paulo (SP), 2009.

(i-iii) Fotos: Autora.

Fig.65 Sede do Sítio Mirim, 1945.

Fonte: Acervo fotográfico da Superintendência do IPHAN/SP. Foto: Luis Saia

Fig.66 Croquis da planta da Sede do Sítio Mirim, Luis Saia, capa do Caderno de Obras de 1967. Fonte: Acervo fotográfico da Superintendência do IPHAN/SP.

Fig.67 Sede do Sítio Mirim - planta baixa, cortes A-A e B-B. Desenhos elaborados pela autora baseados

(i-iii) no levantamento de Eideval Bolanho de 1964.

Fonte: KATINSKY, 1972, p.29.

Fig.68 Sede do Sítio Mirim, 1965.

Fonte: Acervo fotográfico da Superintendência do IPHAN/SP.

Foto: Hernan H. Graeser (Germano).

Fig.69 Sede do Sítio Mirim, arruinamentos após chuvas.

Fonte: Caderno de Obras, 1967, Luis Saia - acervo fotográfico da Superintendência do IPHAN/SP.

Fig.70 Sede do Sítio Mirim, escoramentos.

Fonte: Caderno de Obras, 1967, Luis Saia - acervo fotográfico da Superintendência do IPHAN/SP 
Fig.71 Foto aérea do entorno da antiga Sede do Sítio Mirim - localizada no canto inferior esquerdo 1954.

Fonte: PMSP/SMC/DPH/Seção Técnica de Projeto, Restauro e Conservação (STPRC).

Fig.72 Foto aérea do entorno da antiga Sede do Sítio Mirim - localizada no canto inferior esquerdo 2000. Verifica-se a retificação do Rio Tietê e o adensamento urbano.

Fonte: PMSP/SMC/DPH/Seção Técnica de Projeto, Restauro e Conservação (STPRC).

Fig.73 Sede do Sítio Mirim, início do processo de depredação em 1972.

Fonte: IPHAN, 1965, s.p. Foto: Luis Saia.

Fig.74 Praça do Índio, caminho para passagem sob linha férrea; lado direito ruínas da antiga Sede do

Sítio Mirim, 2010.

Fonte: PMSP/SMC/DPH/Seção Técnica de Projeto, Restauro e Conservação (STPRC).

Foto: Lia Mayumi.

Fig.75 Muro de divisa entre a linha férrea da CPTM e terreno do Sítio Mirim, com vista das ruínas ao

lado direito, 2010.

Fonte: PMSP/SMC/DPH/Seção Técnica de Projeto, Restauro e Conservação (STPRC).

Foto: Lia Mayumi.

Fig.76 Ruínas do Sítio Mirim - remanescentes em taipa; aos fundos, muro de divisa com a CPTM, e CDHU, 2010.

Fonte: PMSP/SMC/DPH/Seção Técnica de Projeto, Restauro e Conservação (STPRC).

Foto: Lia Mayumi.

Fig.77 Ruínas do Sítio Mirim - remanescentes em taipa; aos fundos, muro de divisa com a CPTM, 2005.166 Fonte: Acervo fotográfico da Superintendência do IPHAN/SP.

Foto: João Bacellar.

Fig.78 Sede do Sítio Mirim trabalhos de restauração, 1967.

Fonte: Caderno de Obras, 1967, Luis Saia - acervo fotográfico da Superintendência do IPHAN/SP.

Fig.79 Sede do Sítio Mirim, placas de concreto junto à taipa.

Fonte: Caderno de Obras, 1967, Luis Saia - acervo fotográfico da Superintendência do IPHAN/SP.

Fig.80 Sede do Sítio Mirim, vigas para amarração.

Fonte: Caderno de Obras, 1967, Luis Saia - acervo fotográfico da Superintendência do IPHAN/SP.

Fig.81 Sede do Sítio Mirim, colunas e vigas de concreto.

Fonte: Caderno de Obras, 1967, Luis Saia - acervo fotográfico da Superintendência do IPHAN/SP

Fig.82 Levantamento das ruínas e proposta de restauração desenvolvida pela arquiteta Helena Saia

(i-ii) PMSP/DPH, 1976.

Fonte: Projeto consultado junto à PMSP/SMC/DPH - Seção Técnica de Projeto, Restauro e

Conservação, Pasta: D.O.M. Julho/98, s.p.

Fig.83 Proposta desenvolvida pelos técnicos da PMSP/DPH para a cobertura e manutenção das ruínas do Sítio Mirim - corte, 1999.

Fonte: Projeto consultado junto à PMSP/SMC/DPH - Seção Técnica de Projeto, Restauro e Conservação, Pasta: D.O.M. Julho/98, s.p.

Fig.84 Proposta desenvolvida pelo escritório Apiacás Arquitetos, 2007 - perspectivas e relação com o

(i-iii) entorno 2007

Fonte: <http://www.apiacasarquitetos.com.br>, acesso em 25 fev. 2013.

Fig.85 Sede do Sítio Itaim, 1913.

Fonte: SÃO PAULO - Estado, CONDEPHAAT, 1978, p.13 
Fig.86 Planta do levantamento métrico arquitetônico, 1979.

Fonte: CONDEPHAAT, 1978, p. 25.

Fig.87 Sanatório Bela Vista. Levantamento fotográfico, 1980.

(i-v) Fonte: SÃO PAULO - Estado, CONDEPHAAT, 1978, p.14-25.

Fig.88 Demolição parcial do imóvel, 1980.

Fonte: CONDEPHAAT (site), disponível em:

<http://www.cultura.sp.gov.br/portal/site/SEC/menuitem.bb3205c597b9e36c3664eb10e2308ca0 /?vgnextoid=91b6ffbae7ac1210VgnVCM1000002e03c80aRCRD\&Id=946cc73fb46cc010VgnVCM2 $000000301 \mathrm{a} 8 \mathrm{c} 0$ $>$, acesso em 15 jun. 2016.

Fig.89 Perspectiva da proposta de projeto multifuncional (residência e serviços) apresentado pela 179 Comercial Bela Vista S/A, 1981; destaque à recomposição da casa do Sítio Itaim. Fonte: SÃO PAULO - Estado, CONDEPHAAT, 1978, p. 244.

Fig.90 Áreas autorizadas para a demolição (amarelo) conforme liberação em 1981; e área a conservar (retângulo 50m x 40m).

Fonte: SÃO PAULO, Estado - CONDEPHAAT, 1978, p.329.

Fig.91 Sede do Sítio Itaim, situação em 1988.

Fonte: Folha de São Paulo, Cidades, 05.04.1988, A-13 In: SÃO PAULO - Estado, CONDEPHAAT, 1978, p.468.

Fig.92 Sede do Sítio Itaim, trabalhos de consolidação das ruínas e prospecções arqueológicas, 1988.

(i-vii) Fonte: Acervo Fotográfico CONDEPHAAT

Fig.93 Proposta do arquiteto Samuel Kruchin - croquis de planta e de elevação.

(i-ii) Fonte: SÃO PAULO - Estado, CONDEPHAAT, 1978, p. 320 e 321.

Fig.94 Proposta de restauração elaborada por Helena Saia, elevação com esquema de cobertura e de preenchimento das lacunas da taipa. Fonte: SAIA, Casa Bandeirista - Proposta de Restauro, 1997 In: São Paulo - cidade, SMC/CONPRESP, 1997, p.164 e 169.

Fig.95 Escritório Júlio Neves - perspectiva e implantação do centro de serviços (torres de escritório e centro de compras) aprovado, casa Sítio Itaim no centro (conforme indicado).

Fonte: MAYUMI, Parecer Técnico, 2012 In: SÃO PAULO - cidade, SMC/CONPRESP, 2011, p.827.

Fig.96 Projeto Botti Rubin Arquitetos - perspectiva e implantação do projeto de torres de escritório modificativo e que foi executado, casa do Sítio Itaim ao centro (conforme indicado). Fonte: MAYUMI, Parecer Técnico, 2012 In: SÃO PAULO - cidade, SMC/CONPRESP, 2011, p.828.

Fig.97 Situação das ruínas da Casa Sede do Sítio Itaim (esquerda) e da edificação em anexo (direita),

(i-ii) 2006. Fonte: Acervo PMSP/SMC/DPH.

Fotos: Lia Mayumi.

Fig.98 Ruínas de edificação próxima à casa Sede do Sítio Itaim, 2014.

Foto: Autora.

Fig.99 Trabalhos na antiga Sede do Sítio Itaim, 2008.

(i-vi) Fonte: Acervo PMSP/SMC/DPH. Fotos: Lia Mayumi

Fig.100 Situação da casa do Sítio Itaim com a área envoltória comprometida.

Fonte: Jornal do Metrô, 2009 In: IPHAN, 2009, s.p.

Fig.101 Detalhes de danos ocorridos durante a paralização da obra.

(i-ii) Fonte: Relatório Ilustrativo - Restauro Casa Bandeirista do Itaim, Helena Saia Arquitetos Associados In: IPHAN, 2009, s.p.

Fig.102 Sede do Sítio Itaim - implantação, planta, fachada e corte D-D.

(i-iv) Fonte: Projeto Executivo de Restauração, Helena Saia Arquitetos Associados, In: IPHAN, 2009, s.p. 
Fig.103 Sede do Sítio Itaim reconstruída. Parte interna, detalhes construtivos, 2014.

(i-vii) Fotos: Autora.

Fig.104 Sede do Sítio Itaim reconstruída. Área externa, 2014.

(i-iii) Fotos: Autora

Fig.105 Sede da Fazenda Conceição, Paraibuna (SP), 1978.

(i-ii) Fonte: IPHAN, 1974, s.p. Fotos: Odair Carlos de Almeida.

Fig.106 Arruinamento completo da Sede da Fazenda Conceição, Paraibuna (SP), 1983.

(i-ii) Fonte: IPHAN, 1974, s.p. Fotos: Jorge Hirata.

Fig.107 Penitenciária de Eastern State, Filadélfia (EUA), 2013.

(i-ii) Fotos: Hugo Segawa.

Fig.108 Convento do Carmo, Lisboa (Portugal), 2013.

(i-ii) Fotos: Autora.

Fig.109 Teatro Cultura Artística - Planta pavimento térreo e corte do projeto de Rino Levi Associados.

(i-ii) Fonte: Revista Acrópole, n. 145, maio/1950. Arquivo Digital FAU USP.

Disponível em: <http://www.acropole.fau.usp.br/edicao/145>, acesso em 04 de mar. 2015.

Fig.110 Parte interna do teatro recém-inaugurado.

(i-iii) Fonte: Revista Acrópole, n. 145, maio/1950.

Arquivo Digital FAU USP. Disponível em: <http://www.acropole.fau.usp.br/edicao/145>, acesso em 04 mar. 2015.

Fig.111 Teatro Cultura Artística - projeto das poltronas.

(i-ii) Fonte: Projeto Rino Levi, cópias In: IPHAN, 2010, p. 146-147.

Fig.112 Fachada do Teatro Cultura Artística.

Fonte: Revista Acrópole, n. 145, maio/1950. Arquivo Digital FAU USP. Disponível em:

<http://www.acropole.fau.usp.br/edicao/145>, acesso em 04 mar. 2015.

Fig.113 Fachada do Teatro Cultura Artística no contexto urbano.

Fonte: SÃO PAULO - Estado, CONDEPHAAT, 1995, p. 05 e p.86.

Fig.114 Imagens da fachada do Teatro, década de 1990.

(i-iv) Fonte: SÃO PAULO - Estado, CONDEPHAAT, 1995, p. 69-71

Fig.115 Situação do Teatro Cultura Artística pós-incêndio.

(i-iv) Fonte: SÃO PAULO - Estado, CONDEPHAAT, 2008, p. 22-28.

Fig.116 Situação pós-incêndio.

Fonte: SÃO PAULO - Estado, CONDEPHAAT, 2008, p. 29.

Fonte: Paulo Bruna Arquitetos Associados.

Fig.118 Vistas da estrutura metálica montada para o restauro do painel, 2014.

(i-ii) Fotos: Autora.

Fig.119 Prospecção para restauro do painel.

Fonte: SÃO PAULO - Estado, CONDEPHAAT, 2008, p. 127

Fig.120 Teatro Cultura Artística, projeto aprovado em 2015. Planta baixa - cota 100,00. Escala 1:200. Fonte: Paulo Bruna Arquitetos Associados

Fig.121 Teatro Cultura Artística, projeto aprovado em 2015. Planta baixa - cota 103,90. Escala 1:200. Fonte: Paulo Bruna Arquitetos Associados. 
Fig.122 Teatro Cultura Artística, projeto aprovado em 2015. Planta baixa - cota 107,80. Escala 1:200. Fonte: Paulo Bruna Arquitetos Associados

Fig.123 Teatro Cultura Artística, projeto aprovado em 2015. Corte A-A. Escala 1:200. Fonte: Paulo Bruna Arquitetos Associados

Fig.124 Teatro Cultura Artística, projeto aprovado em 2015. Perspectiva interna - foyer "histórico". Fonte: Paulo Bruna Arquitetos Associados

Fig.125 Teatro Cultura Artística, projeto aprovado em 2015. Perspectivas externas.

(i-ii) Fonte: Paulo Bruna Arquitetos Associados

Fig.126 Vista de São Luiz do Paraitinga, $1^{\mathrm{a}}$ metade do século XX.

Fonte: Arquivo da Superintendência do IPHAN em São Paulo. In: IPHAN, Dossiê, 2010, p.8.

Fig.127 Vista de São Luiz do Paraitinga sob a enchente do Rio Paraitinga, janeiro, 2010. Fonte: Jornal Folha de São Paulo. In: IPHAN, Dossiê, 2010, p.9.

Fig.128 Igreja Matriz São Luiz de Tolosa somente com uma torre, 1884.

Fonte: Coleção Particular reprodução do arquivo do CONDEPHAAT.

In: IPHAN, Dossiê, 2010, p.75.

Fig.129 Igreja Matriz São Luiz de Tolosa reformada na década de 1930.

Fonte: Coleção Particular Cinira dos Santos. In: IPHAN, Dossiê, 2010, p.150.

Fig.130 Igreja Matriz São Luiz de Tolosa, s.d.

Fonte: SAIA, Luis; TRINDADE, Jaelson B. São Luiz do Paraitinga. Pub. N. 2:

CONDEPHAAT/Secretaria da Cultura, Ciência e Tecnologia, s.d. In: IPHAN, 2010.

Fig.131 Croquis da planta da Igreja Matriz, esc. 1:200.

Desenho de Antônio Luis Dias de Andrade, s.d.

Fonte: IPHAN, Dossiê, 2010, p.152

Fig.132 Interior da Igreja Matriz, retábulo na capela-mor, 2007.

Fonte: IPHAN, Dossiê, 2010, p.151.

Foto: Jaelson Britan Trindade.

Fig.133 Estado da Igreja Matriz após a enchente, janeiro, 2010.

Fonte: IPHAN, Dossiê, 2010, p.10.

Foto: Anita Miriam Hirschbruch.

Fig.134 Levantamento das ruínas da Igreja Matriz.

Fonte: Projeto de Restauração e Reconstrução, F. 02/09 In: IPHAN, Matriz, 2010, p. 166.

Fig.135 Igreja Matriz - Plantas Pav. Térreo e Pav. Superior.

(i-ii) Fonte: Projeto de Restauração e Reconstrução. F. 03/09.

In: IPHAN, Matriz, 2010, p. 167.

Fig.136 Igreja Matriz - fachada principal com escada de acesso, 2014. Foto: Autora.

Fig.137 Igreja Matriz - escada de acesso ao pavimento superior em estrutura metálica, 2014.

(i-ii) Fotos: Autora.

Fig.138 Igreja Matriz - Corte D-D.

Fonte: Projeto de Restauração e Reconstrução. F. 07/09: Cortes.

In: IPHAN, Matriz, 2010, p. 171.

Fig.139 Igreja Matriz - canteiro de obras, diversas fases em que é possível verificar a técnica construtiva

(i-ix) aplicada - estrutura metálica e alvenaria, s.d.. Fotos: Natália dos Santos Moradei. 
Fig.140 Igreja Matriz - galeria lateral interna do pavimento superior, 2014. Foto: Autora.

Fig.141 Igreja Matriz - vista interna da nave principal reconstruída, 2014. Foto: Autora

Fig.142 Elementos decorativos internos, 2014.

(i-ii) Fotos: Autora.

Fig.143 Igreja Matriz - elementos decorativos na fachada reconstruída, 2014 Foto: Autora.

Fig.144 Igreja Matriz - Fachadas principal e lateral Norte.

(i-ii) Fonte: Projeto de Restauração e Reconstrução. F. 08/09. In: IPHAN, Matriz, 2010, p. 172.

Fig.145 Igreja Matriz - aspecto externo da após sua reconstituição, 2014. Foto: Autora

Fig.146 Igreja Matriz - Corte C-C com elementos que foram mantidos. Fonte: Projeto de Restauração e Reconstrução. F. 07/09: Cortes. In: IPHAN, Matriz, 2010, p. 171.

Fig.147 Igreja Matriz - Galeria lateral esquerda com a indicação das ruínas. Planta e corte.

(i-ii) Fonte: Projeto de Restauração e Reconstrução. F. 26: Detalhamento das Taipas Remanescentes. In: IPHAN, Matriz, 2010, p. 211.

Fig.148 Igreja Matriz - Galeria lateral com a exposição das ruínas das paredes originais e de fragmentos (i-vi) avulsos, 2014.

Fotos: Autora

Fig.149 Igreja Matriz - detalhes internos com a integração das ruínas e relação com o novo sistema

(i-v) construtivo, 2014.

Fotos: Autora.

Fig.150 Frauenkirche, contraste entre os blocos mais escuros (pátina) e elementos novos (mais claros) e (i-iii) fragmento não recolocado, Dresden (Alemanha), 2009. Fotos: Autora

Fig.151 Chiesa Madre di San Nicolò, aspecto externo e interno após reconstituição, Noto (Itália), 2015. (i-ii) Fotos: Autora

Fig.152 Casarão do Valongo, Santos (SP), 1982.

Fonte: SÃO PAULO - Estado, CONDEPHAAT, 1974, p. 50.

Foto: Tania Martinho

Fig.153 Casarão do Valongo, Santos (SP), 1997.

Fonte: SÃO PAULO - Estado, CONDEPHAAT, 1974, p. 279.

Foto: Aldo P. de Carvalho

Fig.154 Casarão do Valongo durante as obras para a instalação do Museu Pelé, 2013.

Foto: Autora

Fig.155 Museu Pelé, Santos (SP), 2016

Foto: Adriana Jardim Gouveia

Fig.156 Kaiser Wilhelm - Gedächtniskirche, igreja em ruínas e edificações construídas na década de

(i-v) 1960, Berlim (Alemanha), 2015. Fotos: Autora

Fig.157 Interior do Neues Museum, intervenção do escritório David Chipperfield Architects, Berlim

(i-iii) (Alemanha), 2015. Fotos: Autora.

Fig.158 Santuário do Caraçá, Catas Altas (MG). Área externa e interna, 2014.

(i-iii) Fotos: Rodrigo Baeta. 



\section{Lista de Tabelas}

Tabela 01 Bens tombados pelo IPHAN, décadas de 1930-1960 - ruínas e termos derivados.

Fonte: Arquivo Noronha Santos, disponível em <http://www.iphan.gov.br/inicial.htm> acesso em: 01 Jun. de 2015. Elaborada pela autora. Colaboração: Wagner Nascimento.

Tabela 02 Bens tombados pelo IPHAN décadas de 1970-2015 - ruínas e termos derivados. Fonte: Arquivo Noronha Santos, disponível em <http://www.iphan.gov.br/inicial.htm> acesso em: 01 Jun. de 2015. Elaborada pela autora. Colaboração: Wagner Nascimento.

Tabela 03 Conjuntos em ruínas no Cadastro Nacional de Sítios Arqueológicos (CNSA).

Fonte: Cadastro Nacional de Sítios Arqueológicos CNSA/SGPA, disponível em: <http://www.iphan.gov.br/sgpa/?consulta=cnsa> acesso em 13 set. 2016. Elaborada pela autora.

Tabela 04 Bens tombados pelo CONDEPHAAT - ruínas e termos derivados. Fonte: Arquivo Noronha Santos, disponível em <http://www.iphan.gov.br/inicial.htm>, acesso em: 01 Jun. de 2015. Elaborada pela autora. Colaboração: Wagner Nascimento. 



\section{Lista de Siglas}

\begin{tabular}{|c|c|}
\hline BNDES & Banco Nacional de Desenvolvimento Econômico e Social \\
\hline CIESP & Centro das Indústrias do Estado de São Paulo \\
\hline CNRC & Centro Nacional de Referência Cultural \\
\hline CNSA & Cadastro Nacional de Sítios Arqueológicos \\
\hline CONDEPASA & Conselho de Defesa do Patrimônio Cultural de Santos \\
\hline CONDEPHAAT & $\begin{array}{l}\text { Conselho de Defesa do Patrimônio Histórico, Arqueológico, Artístico e } \\
\text { Turístico do Estado de São Paulo }\end{array}$ \\
\hline CONPRESP & $\begin{array}{l}\text { Conselho Municipal de Preservação do Patrimônio Histórico, Cultural e } \\
\text { Ambiental da Cidade de São Paulo }\end{array}$ \\
\hline CPTM & Companhia Paulista de Trens Metropolitanos \\
\hline $\mathrm{DPH}$ & Departamento do Patrimônio Histórico \\
\hline ICCROM & $\begin{array}{l}\text { International Centre for the Study of the Preservation and Restoration of } \\
\text { Cultural Property }\end{array}$ \\
\hline ICOMOS & International Council on Monuments and sites \\
\hline IGEPAC - SP & Inventário Geral do Patrimônio Ambiental e Cultural Urbano de São Paulo \\
\hline IHGB & Instituto Histórico e Geográfico Brasileiro \\
\hline IPHAN & Instituto do Patrimônio Histórico e Artístico Nacional \\
\hline$O A B$ & Ordem dos Advogados do Brasil \\
\hline SEMPLA & Secretaria Municipal de Planejamento \\
\hline SCA & Sociedade de Cultura Artística \\
\hline SGPA & Sistema de Gerenciamento do Patrimônio Arqueológico \\
\hline SMC & Secretaria Municipal de Cultura \\
\hline SPHAN & Serviço do Patrimônio Histórico e Artístico Nacional \\
\hline UNESCO & United Nations Educational, Scientific and Cultural Organization \\
\hline USP & Universidade de São Paulo \\
\hline
\end{tabular}





\section{Sumário}

Apresentação

\section{Capítulo 1}

A noção de ruína: identificação, valorização e tratamento

1.1 Ruínas nas políticas de salvaguarda no Brasil: principais incidências e 39 associações

1.1.1 Tombamentos e atribuições de valor

1.2 Ruínas: uma possível definição

1.2.1 Grupos identificados

1.3 Ruínas em outros contextos culturais: salvaguarda e teorias da preservação

1.3.1 Alternativas de intervenção

\section{Capítulo 2}

Ruínas do tempo: passado e permanência

\subsection{Engenho São Jorge dos Erasmos}

2.1.1 Implantação e partido arquitetônico

2.1.2 Bem cultural e intervenções

2.1.3 Situação atual

2.2 Capela do Morumbi

2.2.1 Intervenção e abandono

2.2.2 Debates para o tombamento

2.3 Ruínas do tempo: similaridades e dicotomias

2.3.1 Identificação e valorização

2.3.2 Intervenções e as contraposições à conservação

\section{Capítulo 3}

Ruínas da incúria: salvaguarda e negligência 


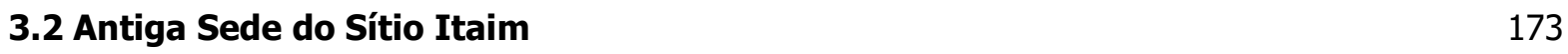

3.2.1 Tombamento e arruinamento 177

3.2.2 Projetos desenvolvidos 182

3.3 Ruínas da incúria: controvérsias e paradoxos 192

3.3.1 Identificação e valorização 192

3.3.2 Intervenções e as digressões sobre a restauração 201

\section{Capítulo 4}

Ruínas do incidente: trauma e memória 215

$\begin{array}{ll}\text { 4.1 Teatro Cultura Artística } & 220\end{array}$

4.1.1 Incêndio e providências 225

4.1.2 Novo projeto $\quad 230$

4.2 Igreja Matriz São Luiz de Tolosa 236

$\begin{array}{ll}\text { 4.2.1 Caracterização e arruinamento } & 238\end{array}$

4.2.2 Reconstrução $\quad 242$

4.3 Ruínas do incidente: dilemas e premências 253

4.3.1 Identificação e valorização 253

4.3.2 Intervenções e os impasses conceituais da reconstrução 257

$\begin{array}{ll}\text { Considerações finais } & 277\end{array}$

Referências bibliográficas 283

$\begin{array}{ll}\text { Instituições consultadas } & 301\end{array}$ 




\section{Apresentação}

Ao longo dos séculos, remanescentes arquitetônicos em estado de ruína têm sido objeto de diversas interpretações e abordagens tornando-se referências cruciais para vários campos de estudo (artes, filosofia, história, arqueologia), dentre os quais história da arquitetura e preservação patrimonial, no qual se insere este trabalho.

A importância das ruínas é geralmente aferida a partir de duas principais perspectivas: documental e simbólica. Do ponto de vista documental, é notório que ruínas proporcionam um profícuo campo de estudos de caráter multidisciplinar. Para a arquitetura, o acesso, estudos e levantamentos dos remanescentes sempre foi uma fonte preciosa de registros, muitas vezes as únicas evidências físicas de técnicas construtivas, configurações e partidos arquitetônicos do passado. Por outro lado, as ruínas também são os testemunhos históricos dos processos de destruição de uma edificação.

Do ponto de vista simbólico, as ruínas podem evocar ideias associadas à vanidade das obras humanas mediante a passagem do tempo, à eternidade do que remanesce, à destruição, à perda e ao abandono. Nos séculos XVIII e XIX na Europa, as ruínas exerceram especial fascínio no âmbito da estética, nutrindo o desenvolvimento da visão romântica. No século $\mathrm{XX}$, esse caráter evocativo adquiriu contornos mais drásticos; com as massivas destruições das duas Guerras Mundiais (1914-1918 e 1939-1945) o tema da ruína definitivamente se atualizou deixando de ser somente uma referência a civilizações antigas e arquiteturas distanciadas pelo tempo, mas também constituindo a prova da barbárie humana na contemporaneidade.

No campo da preservação patrimonial, a apreciação às ruínas tem sido fundamental durante o longo processo de maturação do conceito de monumento histórico e das formas de preservá-lo que teve início no Renascimento e se sedimentou a partir do século XIX. As intervenções no Coliseu (obras iniciadas em 1806) e no Arco de Tito (entre 1817 e 1824) foram paradigmáticas para o desenvolvimento e conformação das ideias sobre as formas de intervir em monumentos antigos na Europa. Já no século XX, num contraponto ao tratamento e experimentações nas ruínas de monumentos antigos, o emblemático colapso do Campanário de San Marco em Veneza (1912) e as Guerras Mundiais configuraram o desafio de enfrentar o problema dos arruinamentos recentes, em arquiteturas ou trechos urbanos inteiros que faziam parte do cotidiano das pessoas. 
As ruínas constituem, portanto, um profícuo campo de experimentações, aplicações de métodos, práticas e digressões teóricas que concernem à preservação do patrimônio edificado. É relevante considerar que, em princípio, a ruína é a antítese dos propósitos finais da preservação patrimonial, cujo principal objetivo é impedir ou, ao menos, conter os processos de degradação que possam acometer um bem ao qual se atribui valores históricos ou artísticos. Mas, uma vez constatado o estado de ruína de um patrimônio, o que fazer?

Tendo em vista a recorrência e relevância das ruínas no âmbito dos debates e práticas patrimoniais considera-se pertinente e justificável estabelecer uma pesquisa que tenha como propósito estudar como esses remanescentes são abordados no cenário brasileiro. A pesquisa aqui apresentada buscou analisar, no âmbito dos órgãos de preservação, as várias interpretações de ruína e como vêm sendo aplicadas para a identificação e o tratamento do patrimônio cultural edificado no Brasil. Nossa hipótese parte da premissa de que as diferentes formas de compreensão, reconhecimento de valor e significação atribuídos aos bens em ruínas têm orientado diversas abordagens, tratamentos e intervenções cujos resultados são distintos para a preservação ou não de sua condição (status quo) de ruína.

O objetivo geral desta pesquisa é verificar a partir da análise dos estudos de casos selecionados, como os remanescentes arquitetônicos em estado de ruína são identificados e compreendidos enquanto bens culturais e, consequentemente, como são tratados, de modo a situar a tese no âmbito das práticas de preservação patrimonial brasileiras e contribuir para a ampliação dessa discussão.

Os objetivos específicos são analisar: $\mathbf{1}$ as definições e atribuições de significado às ruínas verificando a influência dos diferentes graus de antiguidade e dos diferentes graus de degeneração; a situação de bens tombados, mas que, posteriormente, atingiram um estado de degeneração irreversível e a problemática do arruinamento súbito através de eventos traumáticos; 2 como essas definições e atribuições de significado têm norteado os critérios para o tratamento e as eventuais intervenções que incidem sobre os referidos bens culturais verificando: em que medida se preserva ou não o status quo de ruína e como se dá a apropriação desses conjuntos; 3 qual é a vigência das definições e das premissas teóricas relativas à preservação patrimonial na abordagem dos estudos de caso selecionados; $\mathbf{4}$ qual é o valor cultural, documental e simbólico das ruínas para as políticas de preservação brasileiras.

A problematização para o desenvolvimento desta análise está condensada em duas principais indagações que se interligam: Ruínas - O que são? E como intervir? 
Há contextos culturais (cidades como Roma, Atenas, Cidade do México, dentre tantas outras) em que as estratificações históricas são visivelmente exponencializadas pela sobreposição de preexistências de vários momentos do passado. No entanto, para esta tese, a denominação de ruína é entendida como um avançado estado de degradação, não se referindo exclusivamente aos restos de edificações antigas há muito danificadas e das quais se perdeu a referência da obra existente. Consideram-se aqui também processos mais recentes de arruinamento deflagrados por várias causas que acometem edificações com datações diversas.

Sendo assim, ao utilizarmos a designação de ruínas, nos referimos a conjuntos edificados em diferentes graus de abandono e destruição promovidos por uma junção de fatores como: a mera passagem e ação incondicional do tempo; a perda da função original e a falta de um uso constante; a incúria; ou ainda como consequência de catástrofes de ordem natural ou antrópica. As operações que incidem sobre esses remanescentes se relacionam à leitura e compreensão da condição de ruína, que pode ser influenciada pelas seguintes características: grau de antiguidade da edificação, causa e grau de degeneração, antiguidade do processo de arruinamento e condição de uso.

Para o estudo e análise das ruínas no cenário brasileiro, foram selecionados alguns casos no Estado de São Paulo, dada a proximidade das obras e da documentação primária, e por constituírem uma amostragem da situação nacional que permite questionamentos pertinentes a esta análise. A compreensão sobre a condição de ruína e de suas múltiplas e complexas características é o principal critério que orienta as abordagens e o tratamento que incidem nesses bens culturais.

Os casos foram organizados em três grupos cujo critério se fundamenta na causa e no tempo decorrido do processo de arruinamento: ruínas do tempo - Engenho São Jorge dos Erasmos (Santos, SP) e Capela do Morumbi (São Paulo, SP); ruínas da incúria - antiga Sede do Sítio Mirim (São Paulo, SP) e antiga Sede do Sítio Itaim (São Paulo, SP); e ruínas do incidente - Teatro Cultura Artística (São Paulo, SP) e Igreja Matriz São Luiz de Tolosa (São Luiz do Paraitinga, SP). Não há aqui qualquer pretensão de classificação das ruínas, nossa intenção é tão somente de ordem analítica, de modo a facilitar a exposição e o desenvolvimento de reflexões relevantes para a verificação da hipótese.

Considerando que elegemos para a análise as discussões no âmbito institucional, os critérios de seleção dos casos foram: bens de reconhecido valor cultural - tombados ou em estudo de tombamento - em uma ou mais esferas institucionais (nacional, estadual ou municipal); e a notoriedade de suas implicações e relações com o tema da ruína em diversos 
momentos da historiografia da preservação patrimonial brasileira chegando à contemporaneidade.

O desenvolvimento e comprovação da tese estrutura-se em quatro capítulos. O primeiro capítulo apresenta as bases de entendimento sobre o tema a partir de um panorama da abordagem das ruínas no cenário brasileiro verificando sua importância para o reconhecimento de bens culturais pelo órgão nacional IPHAN (desde sua instituição em 1937 até a atualidade). Em seguida, conceituamos o que consideramos como ruína para esta tese, cuja definição balizou a metodologia de análise dos estudos de caso.

$\mathrm{Na}$ sequência passamos a uma verificação do significado das ruínas para a configuração das teorias patrimoniais e salvaguarda em outros contextos culturais o que é fundamental para a compreensão das possíveis formas de intervenção que incidem sobre esses bens, contribuindo para a análise dos estudos de caso selecionados que são analisados nos capítulos seguintes, segundo o critério apresentado: as ruínas do tempo no capítulo 2; as ruínas da incúria no capítulo 3; e ruínas do incidente no capítulo 4.

Para cada um há uma breve introdução situando o entendimento que foi estabelecido nesta tese sobre esse grupo de ruínas, seguido da apresentação dos respectivos estudos de caso com seus aspectos arquitetônicos, processos de valorização cultural e tutela, arruinamento, propostas e intervenções efetuadas; a partir da apresentação desses elementos é feita uma análise de ambos identificando os pontos pertinentes para o desenvolvimento da tese lançada, circunstanciando referências teóricas da preservação patrimonial e, quando pertinente, buscando correspondências tanto nacionais como internacionais, sem perder de vista o desenvolvimento da problemática no âmbito das políticas de preservação no Brasil.

Durante o Estágio de Pesquisa desenvolvido na Università degli Studi di Roma La Sapienza, Facoltà di Architettura, Dipartamento di Storia, Disegno e Restauro dell Architettura (2015-2016, sob a orientação da professora Dra. Simona M. C. Salvo) foi possível constatar que o tema da ruína vem sendo sistematicamente estudado. No âmbito dos campos de estudo da história da arquitetura e preservação patrimonial, encontros científicos recentes ${ }^{1}$ situam a extrema pertinência e atualidade do assunto no cenário internacional com

\footnotetext{
${ }^{1}$ Dentre os quais se destaca: Fait-il-restaurer les ruines? Caen, França, 1990 - Colóquio internacional promovido pelo Ministério da Cultura Francês, no qual são apresentados vários pontos relevantes sobre as ruínas e sua conservação. Durante a estada em Roma, seminários internacionais que a autora participou: Studies on Architecture for Archaeology - "The Design of Archeology" (Roma, 2015); Attualità delle rovine, (Roma, 2015); mesa redonda: La distruzione dei monumenti e della memoria. Quale ruolo per il restauro?" (Facoltà de Architettura, Scuola di Specializzazione in Beni Architettonici e del Paesaggio, Sapienza Università di Roma, 2015). Exposição: La forza delle rovine (Museo Nazionale Romano, Roma, 2015).
} 
uma extensa produção que aborda sua multiplicidade e complexidade de aspectos situando a problemática de abordagem às ruínas na contemporaneidade.

Considerando esses mesmos campos de estudo (história da arquitetura e preservação patrimonial), o desdobramento científico do tema da ruína no Brasil está se ampliando nos últimos anos. Destacam-se alguns trabalhos acadêmicos (dentre outros que constam nas referências bibliográficas): a pesquisa de Cristina Meneguello (2008) ${ }^{2}$ com uma abordagem voltada ao reconhecimento do valor da ruína para o desenvolvimento da arquitetura neogótica na Inglaterra; o trabalho de Cecília R. Santos e Ruth V. Zein $(2011)^{3}$ com interpolações sobre o entendimento da ruína na Era Moderna pautando uma crítica aos processos de arruinamento no patrimônio da arquitetura modernista; os artigos de Luciana N. Diniz (2014) 4 e Rodrigo E. Baeta e Juliana C. Nery $(2015)^{5}$, que tratam de edificações em ruína em contraposição a projetos arquitetônicos contemporâneos aludindo a exemplos nacionais; e a pesquisa de mestrado de Anna Maria de Lira Pontes $(2011)^{6}$ que aborda o tema da ruína sob o viés da preservação patrimonial no Brasil, com enfoque nos bens tombados pela esfera federal no Estado da Paraíba.

Tendo em vista essas paulatinas e recentes incursões científicas às ruínas, este trabalho pretende ser uma contribuição para o desenvolvimento do tema no Brasil, já que ainda é pouco explorado em nossas pesquisas acadêmicas e constitui um profícuo campo de estudos que ensejam questionamentos que podem enriquecer os debates no campo da preservação patrimonial.

\footnotetext{
2 MENEGUELLO, Cristina. Da ruína ao edifício. Neogótico, reinterpretação e preservação do passado na Inglaterra vitoriana. São Paulo: Annablume / FAPESP, 2008.

${ }^{3}$ SANTOS, Cecília R. e ZEIN, Ruth V. Rápidas considerações sobre a preservação das ruínas na modernidade. Arquitextos (eletrônica), ano 12, jul. 2011. Disponível em: <http://www.vitruvius.com.br/revistas/read/arquitextos/12.135/3997>. Acesso em: 08 set. 2011.

${ }^{4}$ DINIZ, Luciana N. Projetos contemporâneos em ruínas: o passado compartilhado no presente. In: Anais do III Encontro da Associação Nacional de Pesquisa e Pós Graduação em Arquitetura e Urbanismo - arquitetura, cidade e projeto: uma construção coletiva. São Paulo, 2014. Disponível em: <http://www.anparq.org.br/dvdenanparq-3/htm/Artigos/ST/ST-PCI-007-4.pdf>. Acesso em: 28 out. 2016.

${ }^{5}$ BAETA, Rodrigo E.; NERY, Juliana C. Escavações arqueológicas, ruínas e arquitetura contemporânea. In: Anais $4^{\circ}$ Seminário Ibero-americano - Arquitetura e documentação, Belo Horizonte, 2015. Disponível em: $<$ http://www.forumpatrimonio.com.br/arqdoc2015/artigos/pdf/53.pdf>. Acesso em: 28 set. 2016.

${ }^{6}$ PONTES, Anna Maria de Lira. Entre fragmentos: os ditos e não ditos das ruínas patrimoniais. Dissertação (Mestrado) - Faculdade de Arquitetura e Urbanismo, Universidade Federal da Paraíba, 2011.
} 

Capítulo 1

A noção de ruína:

identificação, valorização e tratamento 



\section{A noção de ruína: identificação, valorização e tratamento}

As ruínas constituem um tema complexo no âmbito do patrimônio cultural, cuja compreensão incide no seu reconhecimento e na sua preservação. É primordial estabelecer um panorama dos debates patrimoniais no Brasil do início do século XX à atualidade para situar a abordagem às ruínas e delinear o cenário no qual serão destacados os casos a serem analisados. Na interposição das questões estruturais desta tese - ruínas: o que são? E como intervir? - perscrutamos na historiografia nacional e internacional referências que nos auxiliem a identificar aspectos e características relevantes para estabelecermos uma metodologia de análise. A relevância da ruína nos debates patrimoniais de outros contextos culturais, nas teorias da preservação, bem como as possíveis formas de preservá-las são subsídios fundamentais para compreender as prescrições operacionais que se estabelecem na contemporaneidade e se aplicam aos conjuntos edificados em estado de ruína.

\subsection{Ruínas nas políticas de salvaguarda no Brasil: principais incidências e associações}

A ampliação e desenvolvimento das discussões e práticas de preservação no Brasil tiveram um início efetivo a partir das primeiras décadas do século XX quando se acentuaram os debates sobre a necessidade da implantação de um projeto para a instituição da salvaguarda patrimonial a fim de estabelecer o quê e como preservar relacionando-se ao desenvolvimento do ideário cultural da "essência da nação brasileira" (ANDRANDE, A. L. D., 1993, p. 106). O problema do abandono que assolava e comprometia a materialidade dos monumentos arruinando-os era um desafio a ser confrontado compondo a pauta para a implementação da política de preservação no Brasil.

Ao verificar os incipientes discursos desse contexto, constata-se que as menções às ruínas enfatizam o problema do estado físico de conservação de um bem arquitetônico. As considerações do deputado pernambucano Luiz Cedro no discurso de apresentação de seu projeto de lei para a criação da Inspetoria dos Monumentos Históricos dos Estados Unidos do Brasil em 1923 são muito elucidativas: "O culto do passado, senhores, não deve limitar-se à comemoração [...]. Comemoremo-lo também por outros modos menos platônicos, como o de evitar a destruição deste patrimônio [...]” (ANDRADE, R. M. F., 1952, p. 19 - grifo nosso). 
Assim como as palavras de Mário Lima (1886-1936) em 1929 a respeito da situação da cidade de Ouro Preto: "E pensar que a vetusta e legendária cidade vai, de ruína em ruína, para o aniquilamento, desamparada dos poderes públicos, desde que se mudou a capital de Minas para Belo Horizonte! [...]” (LIMA apud PINHEIRO, 2011, p.276 - grifo nosso).

Em 1937, foi elaborado o Decreto Lei n. 25 (30.11.1937) que instituiu o Serviço do Patrimônio Artístico Nacional (SPHAN) ${ }^{7}$; para a compreensão da formulação desse decreto é relevante considerar o respectivo contexto político. A constituição do Estado Novo por Getúlio Vargas (1882-1954) estava conceitualmente atrelado à ideia de conformação da nação através de seus referenciais simbólicos dos quais o patrimônio cultural tem um papel determinante (FONSECA, 1997), e a sua preservação tornou-se objeto de interesse do então ministro da Educação e Saúde Gustavo Capanema (1900-1985) ${ }^{8}$. Mário de Andrade (18931945) foi convidado por Capanema para a elaboração de um anteprojeto para instituir as bases de uma legislação para salvaguardar o patrimônio a nível federal. Conforme Fonseca (1997) esse anteprojeto é caracterizado por uma concepção antropológica de cultura enfatizando o caráter popular e as identidades locais; o tema do patrimônio e sua preservação tem um embasamento conceitual que enfatizava o valor histórico da obra de arte patrimonial, da qual as ruínas são especificadas como elementos representativos da "arte histórica" (ANDRADE, M. 1936 In: MEC, 1980, p. 92).

De um modo geral, esse anteprojeto não dispunha sobre a organização do instituto e suas implicações legais e jurídicas; sua redação final ficou a cargo de Rodrigo Melo Franco de Andrade (1898-1969). Segundo Antônio Luiz Dias de Andrade (1993), o “tombamento" é a única característica em comum com o anteprojeto de Mário. No Decreto Lei n. 25, a definição do que constitui o patrimônio nacional ${ }^{9}$ não faz alusão às ruínas e tampouco uma especificação sobre o estado de conservação dos bens a serem tombados. Há, porém, designações a respeito dos efeitos do tombamento estabelecendo que: “Art. 17 As coisas tombadas não poderão, em caso nenhum ser destruídas, demolidas ou mutiladas sem prévia

\footnotetext{
${ }^{7}$ Tomaremos como referência prevalente de todas as fases desse órgão a nomenclatura IPHAN. O Serviço do Patrimônio Histórico e Artístico Nacional (SPHAN) foi instituído pelo Decreto-lei n. 25 de 30.11.1937; em 1946 passou a ser designado Departamento do Patrimônio Histórico e Artístico Nacional (DPHAN); em 1970 o DPHAN foi transformado em Instituto do Patrimônio Histórico e Artístico Nacional (IPHAN).

${ }^{8}$ Gustavo Capanema, titular da pasta de Educação no Governo de Getúlio Vargas entre 1934 e 1945.

9 “Art. $1^{\text {o: }}$ Constitui o patrimônio histórico e artístico nacional o conjunto dos bens móveis e imóveis existentes no país e cuja conservação seja de interesse público, quer por sua vinculação a fatos memoráveis da história do Brasil, quer por seu excepcional valor arqueológico ou etnográfico, bibliográfico ou artístico.” (DECRETO LEI n.25, 30 de novembro, 1937 In: MEC, 1980, p. 111 - grifo nosso).
} 
autorização especial do Serviço do Patrimônio Histórico e Artístico Nacional [...]" (DECRETO LEI n. 25, 30 de novembro, 1937 In: MEC, 1980, p. 115 - grifo nosso).

Embora não esteja explícito no Decreto Lei n.25, o ideário que associa a ruína à urgência de salvaguarda permeia e norteia a estruturação da política de salvaguarda nacional, o que pode ser constatado através das seguintes colocações de Rodrigo M. F. de Andrade que esteve à frente da diretoria do SPHAN de 1937 a 1967:

[...] A iniciativa do chefe da Nação tem uma finalidade prática relevante, que é a de dotar o Brasil de uma legislação adequada a impedir que se arruínem ou se dispersem os bens de notável valor artístico e histórico existente no país. [...] $\mathrm{O}$ que o projeto governamental tem em vista é poupar à nação o prejuízo irreparável do perecimento e da evasão do que há de mais precioso no seu patrimônio. Grande parte das obras de arte mais valiosas e dos bens de maior interesse histórico, de que a coletividade brasileira, tem desaparecido ou se arruinado irremediavelmente, em consequência da cobiça dos particulares A subsistência dessas mesmas circunstâncias ameaça, pois, gravemente o que resta ainda das nossas riquezas artísticas e históricas. [...] (ANDRADE, R. M. F., 1936 - Matéria publicada em O Jornal, RJ In: ANDRADE, R. M. F., 1987, p. 48 - grifo nosso)

Essa noção de ruína estruturada a partir da iminente possibilidade de "perda irreparável" (FONSECA, 2009, p.81) de um patrimônio também pode ser detectada no Plano de Trabalho para a Divisão de estudos e tombamento (1944) do SPHAN elaborado por Lucio $\operatorname{Costa}^{10}(1902-1998)$ :

Ora, a colheita desse material é tanto mais necessária e premente quanto sabemos que, devido ao estado ruinoso da maior parte dos monumentos e dos livros onde se contém a respectiva documentação, estado esse decorrente não só da ação natural do tempo, como da falta de recursos e do desleixo das pessoas ou autoridades responsáveis pela sua guarda, ambos se acham permanentemente ameaçados: os monumentos de destruição, mutilação ou desmantelo; os livros de extravio ou deterioração. (COSTA, In: PESSOA, 1999, p. 85-86 - grifo nosso).

A premência pela a proteção dos bens, embasa a necessidade da salvaguarda que se legitima através da instituição de um órgão oficial com a devida competência técnica, em que podem ser destacados dois aspectos. Primeiramente, a importância dos arquitetos no órgão de preservação fundamentam a ação e o valor do técnico - um profissional que teria um maior grau de conhecimento a fim de detectar e proteger o nosso legado arquitetônico - um patrimônio que se deixado a outros, estaria condenado ao total abandono e arruinamento. $\mathrm{O}$ segundo, se refere à utilização da designação "ruína" pelo olhar do técnico para minimizar o valor de evidências materiais que não se encaixam em um determinado tipo de referência historiográfica. Esse aspecto pode ser identificado na seguinte colocação de Mário de

\footnotetext{
${ }^{10}$ Lucio Costa foi diretor da Divisão de Estudos e Tombamentos do IPHAN de 1937 até a sua aposentadoria em 1972.
} 
Andrade elaborada durante suas incursões na década de 1930 no Estado de São Paulo para o reconhecimento de potenciais bens culturais para a divisão paulista do SPHAN em que é possível detectar certa inclinação para um tipo de patrimônio cultural encontrado em outros Estados (Minas Gerais e capitais do nordeste do Brasil), e que, por contraponto, em São Paulo são encontradas "ruínas" e "restos":

Vagar assim, pelos mil caminhos de São Paulo, em busca de grandezas passadas, é trabalho de fome e de muita, muita amargura. Procura-se demais e encontra-se quase nada. Vai subindo no ser uma ambição de achar, uma esperança de descobrimentos admiráveis, quem sabe se em tal capela denunciada vai-se topar com alguma S. Francisco? Já não digo tão inédita como a de São João D’El Rei, mas pelo menos tão linda como a de João Pessoa... E encontramos ruínas, tosquidões. Vem a amargura. [...] há de reverenciar e defender especialmente as capelinhas toscas, as velhices dum tempo de luta e os restos de luxo esburacado que o acaso se esqueceu de destruir. (ANDRADE, M., 1937, p.119 - grifo nosso).

A explícita aceitação e reconhecimento do estado de arruinamento como uma característica que poderia conferir ou agregar algum valor (histórico ou estético) a um monumento não está em pauta nos debates e legislações brasileiras. Equivocadamente, podese configurar um entendimento de que não haja bens em ruínas de valor cultural em nosso território nacional. Contudo, no rol dos monumentos nacionais, há conjuntos em ruínas e os mesmos passaram por algum tipo de valorização.

\subsubsection{Tombamentos e atribuições de valor}

O já mencionado Decreto Lei n. 25 (1937) que instituiu o SPHAN como órgão de preservação nacional estabeleceu o tombamento como o instrumento que dá a chancela por excelência para o reconhecimento do valor cultural do patrimônio brasileiro. Foram estabelecidos quatro Livros do Tombo que se relacionam aos principais critérios de valorização aos bens culturais ${ }^{11}$ : Livro do Tombo Arqueológico, Etnográfico e Paisagístico, Livro do Tombo Histórico, Livro do Tombo das Belas Artes, Livro do Tombo das Artes Aplicadas.

Um meio de aferir a quantidade de bens em ruínas classificados como patrimônio cultural é através da verificação das inscrições nos Livros do Tombo em que há denominações

\footnotetext{
${ }^{11}$ Cf.: "Art. $4^{\circ}[\ldots] 1^{\circ}$ ) no Livro do Tombo Arqueológico, Etnográfico e Paisagístico, as coisas pertencentes às categorias de arte arqueológica, etnográfica, ameríndia e popular, e bem assim as mencionadas no $\S 2^{\circ}$ do citado art. $1^{\mathrm{o}} ; 2^{\circ}$ ) no Livro do Tombo Histórico, as coisas de interesse histórico e as obras de arte histórica; $3^{\circ}$ ) no Livro do Tombo das Belas Artes, as coisas de arte erudita nacional ou estrangeira; $4^{\circ}$ ) no Livro do Tombo das Artes Aplicadas, as obras que se incluírem na categoria das artes aplicadas, nacionais ou estrangeiras." (DECRETO LEI n.25, 30 de novembro, 1937 In: MEC, 1980, p. 111 - grifo nosso).
} 
no título de sua identificação ou em sua descrição das designações: ruína, ruínas (ou termos derivados como: remanescentes, restos e vestígios). A Tabela 01 foi elaborada tendo como referência cronológica a fase inicial do SPHAN, que compreende os primeiros trinta anos de atuação do órgão (1937-1967) ${ }^{12}$, período em que esteve sob a coordenação de Rodrigo Melo Franco de Andrade.

Ao verificar a tabela 01, é possível constatar que há uma concentração de inscrições pautadas pelo valor histórico do bem arruinado (Livro do Tombo Histórico). Alguns poucos bens foram apreciados exclusivamente pelo seu valor artístico (Livro de Belas Artes) como o conjunto de São Miguel das Missões (RS), tombado logo no início da atuação do SPHAN. A primeira atribuição de Lucio Costa no órgão recém-fundado foi junto às Missões ${ }^{13}$ (RS). Em seu relato sobre o povoado de São Miguel, Costa enfatiza o tácito valor da arquitetura original que se deteriorou abordando o caráter estético da fachada da Igreja, não havendo especiais menções à condição de ruína:

Naquela ocasião também estranhei de ver em construção de tanto 'estilo', uma fachada assim, no pórtico, como indica a gravura de Demersay, 'redundância' jamais vista em composição de arquitetura. [...] O mais estranho, porém é que a sua arquitetura, tanto no conjunto como no detalhe, revela, da parte de quem o projetou e dos que o executaram, conhecimentos seguros de 'modenatura' e proporção, senão um certo apuro. (COSTA apud PESSOA, 1999, p.26-27 - grifo nosso).

\footnotetext{
${ }^{12}$ A denominada fase "heroica" (FONSECA, 2009, p. 81) do IPHAN.

${ }^{13}$ A região das Missões engloba sete povos missioneiros: São Francisco de Borja (1682), São Nicolau (1687), São Miguel Arcanjo (1687), São Lourenço Mártir (1690), São João Batista (1697) e Santo Ângelo Custódio (1706/1707); sendo que a de São Miguel era a mais populosa e importante desde fins do século XVII. Em 1938 o sítio arqueológico de São Miguel Arcanjo foi o único tombado. Os povos de São João Batista, São Lourenço e São Nicolau foram tombados pelo IPHAN nos anos 1970, onde trabalhos de consolidação e conservação também foram executados (COMAS, 2007). É relevante pontuar que nas viagens ao Brasil de Auguste de Saint-Hilaire (1779-1853) que esteve no território do Rio Grande do Sul entre 1820 a 1821, há descrições dos conjuntos das Missões e de seu estado deteriorado. Sobre São Nicolau: "A igreja não está em tão mau estado quanto a de S. Borja; entretanto a abóbada e as colunas caem em ruínas" (SAINT-HILAIRE, 1974, p. 145). Sobre São Miguel: "S. Miguel é a primeira aldeia onde vejo realizar algumas reparações. Se desde o início tivessem cuidado disso, sempre que fosse necessário, em todas elas, as aldeias não estariam em quase total destruição, mas numa região onde não são reparados os próprios edifícios públicos não se pode esperar que os administradores, cujo principal interesse é o lucro, cuidem de fazer consertos em imóveis que lhes não pertencem e que pouco lucro lhes dão." (Op. cit., p. 153).
} 
Tabela 01 - Bens tombados pelo IPHAN, décadas de 1930-1960 - ruínas e termos derivados

\begin{tabular}{|c|c|c|c|c|c|c|}
\hline & Objeto & Local & Construção & Processo & Tombo & Data Tomb. \\
\hline 1 & $\begin{array}{l}\text { Casa da Torre de Garcia D`Avila } \\
\text { e Capela de Nossa Sra. Da Conceição: ruínas }\end{array}$ & BA-Mata de São João & 1551 & $0128-\mathrm{T}-38$ & L.B.A. & $30 / 04 / 1938$ \\
\hline 2 & Povo de São Miguel: remanescentes e ruínas da igreja & $\begin{array}{l}\text { RS-São Miguel das } \\
\text { Missões }\end{array}$ & 1687 & 0141-T-38 & L.B.A. & $\begin{array}{l}\text { 16/05/1938 } \\
\text { *UNESCO } \\
05 / 12 / 1983\end{array}$ \\
\hline 3 & Casa da Pólvora: ruínas & PB-João Pessoa & 1710 & $0272-\mathrm{T}-41$ & $\begin{array}{l}\text { L.B.A. } \\
\text { L.H. }\end{array}$ & $\begin{array}{l}24 / 05 / 1938 \\
24 / 05 / 1938\end{array}$ \\
\hline 4 & Fábrica de Ferro Patriótica: ruínas & MG-Ouro Preto & 1811 & 0031-T-38 & L.H. & $30 / 06 / 1938$ \\
\hline 5 & Forte Velho: ruínas & PB-Cabedelo & 1584 & 0048-T-38 & L.H. & 09/08/1938 \\
\hline 6 & Igreja de Nossa Senhora dos Navegantes: ruínas & PB-Cabedelo & 1589 & 0041-T-38 & L.H. & $12 / 08 / 1938$ \\
\hline 7 & $\begin{array}{l}\text { Convento e Igreja Franciscanos de } \\
\text { Nossa Senhora da Conceição }\end{array}$ & SP-Itanhaém-SP & Séc. XVIII & 0215-T-39 & $\begin{array}{l}\text { L.B.A. } \\
\text { L.H. }\end{array}$ & $07 / 03 / 1941$ \\
\hline 8 & Convento de Santo Antônio de Paraguassú: igreja e ruínas & BA-Cachoeira & 1660 & $0280-\mathrm{T}-41$ & $\begin{array}{l}\text { L.B.A. } \\
\text { L.H. }\end{array}$ & $\begin{array}{l}25 / 09 / 1941 \\
25 / 09 / 1941\end{array}$ \\
\hline 9 & Capela de Nossa Senhora da Pena e ruínas do sobrado anexo & BA-Cachoeira & 1660 & 0231-T-41 & $\begin{array}{l}\text { L.B.A. } \\
\text { L.H. }\end{array}$ & $\begin{array}{l}08 / 07 / 1943 \\
08 / 07 / 1943\end{array}$ \\
\hline 10 & $\begin{array}{l}\text { Convento de São Bernardino de Sena: ruínas } \\
\text { e Capela dos Terceiros }\end{array}$ & RJ-Angra dos Reis & 1758 & 0371-T & L.H. & $23 / 07 / 1947$ \\
\hline 11 & $\begin{array}{l}\text { Conjunto arquitetônico e urbanístico } \\
\text { Ruínas Igreja Matriz }\end{array}$ & MA-Alcântara & 1621 & 0390-T-48 & $\begin{array}{l}\text { L.B.A. } \\
\text { L.A.ET.P. }\end{array}$ & $\begin{array}{l}10 / 10 / 1974 \\
10 / 10 / 1974 \\
29 / 12 / 1948\end{array}$ \\
\hline$\overline{12}$ & Forte Príncipe da Beira & RO-Costa Marques & Séc. XVIII & 0395-T-50 & L.H. & $07 / 08 / 1950$ \\
\hline 13 & Recolhimento de Santa Teresa: remanescentes & RJ-Niterói/Itaipú & 1764 & 0365-T-46 & L.B.A. & 08/01/1955 \\
\hline$\overline{14}$ & $\begin{array}{l}\text { Igreja de Nossa Senhora do Rosário e ruínas } \\
\text { da Igreja de São José do Tocantins }\end{array}$ & $\begin{array}{l}\text { GO-Niquelândia } \\
\text { (distrito de Traíras) }\end{array}$ & Séc. XVIII & 0510-T-54 & L.B.A. & $19 / 01 / 1955$ \\
\hline 15 & Vila colonial de Porto Calvo: remanescentes & AL- Porto Calvo & 1636 & 0515- $\mathrm{T}$ & L.A.ET.P & $17 / 01 / 1955$ \\
\hline$\overline{16}$ & $\begin{array}{l}\text { Remanescentes da antiga Vila Colonial - Igreja Matriz (obras } \\
\text { de talha e imagens antigas), conjunto arquitetônico }\end{array}$ & SP-São Vicente & 1560 & 0514-T-51 & L.H. & $17 / 01 / 1955$ \\
\hline 17 & Forte de São Matheus: remanescentes & RJ-Cabo Frio & 1617 & 0447-T-51 & L.H. & $05 / 10 / 1956$ \\
\hline 18 & Igreja de Santana: ruínas & BA-Rio de Contas & Séc. XVIII & 0446-T-51 & L.H. & $29 / 08 / 1958$ \\
\hline 19 & $\begin{array}{l}\text { Convento Carmelita: ruínas e Igreja de } \\
\text { Nossa Senhora de Nazaré }\end{array}$ & $\begin{array}{l}\text { PE-Cabo de Santo } \\
\text { Agostinho }\end{array}$ & Séc. XVI & 0619-T-61 & L.B.A. & $06 / 07 / 1961$ \\
\hline 20 & Engenho dos Erasmos: ruínas & SP-Santos & Séc. XVI & 0678-T-62 & L.H. & $02 / 07 / 1963$ \\
\hline 21 & Engenho do Cunhau: ruínas da capela & RN-Canguaretama & 1614 & 0666-T-62 & L.H. & $16 / 06 / 1964$ \\
\hline 22 & Casa de Câmara e Cadeia: ruínas & RN-Vila Flor & 1768 & 0665-T-62 & L.H. & $16 / 06 / 1964$ \\
\hline 23 & $\begin{array}{l}\text { Real Fábrica de Ferro São João do Ipanema: } \\
\text { remanescentes }\end{array}$ & SP-Iperó & $\begin{array}{l}\text { Séc. XVI } \\
\text { a XIX }\end{array}$ & 0727-T-64 & L.H. & $24 / 09 / 1964$ \\
\hline 24 & Forte de São Felipe & SP-Guarujá & 1765 & 0752-T-64 & L.H. & $31 / 03 / 1965$ \\
\hline
\end{tabular}

Legenda: L.A.ET.P. - Livro Arqueológico, Etnográfico e Paisagístico; L.A.A. - Livro de Artes Aplicadas; L.B.A. - Livro de Belas Artes; L.H - Livro Histórico. Fonte: Arquivo Noronha Santos, disponível em <http://www.iphan.gov.br/inicial.htm> acesso em: 01 Jun. de 2015. Elaborada pela autora. Colaboração: Wagner Nascimento. 
Em São Miguel das Missões (cuja intervenção será analisada no capítulo 2) a atribuição de um valor exclusivamente artístico, não se refere, portanto, à estética da ruína per se com seus atributos derivados de uma configuração própria que restabelece novas relações espaciais redimensionando a noção de espaço interno e externo como retratado na gravura do explorador francês Alfred Demersay ${ }^{14}$ (1815-1891), uma das poucas imagens pictóricas de ruínas do Brasil.

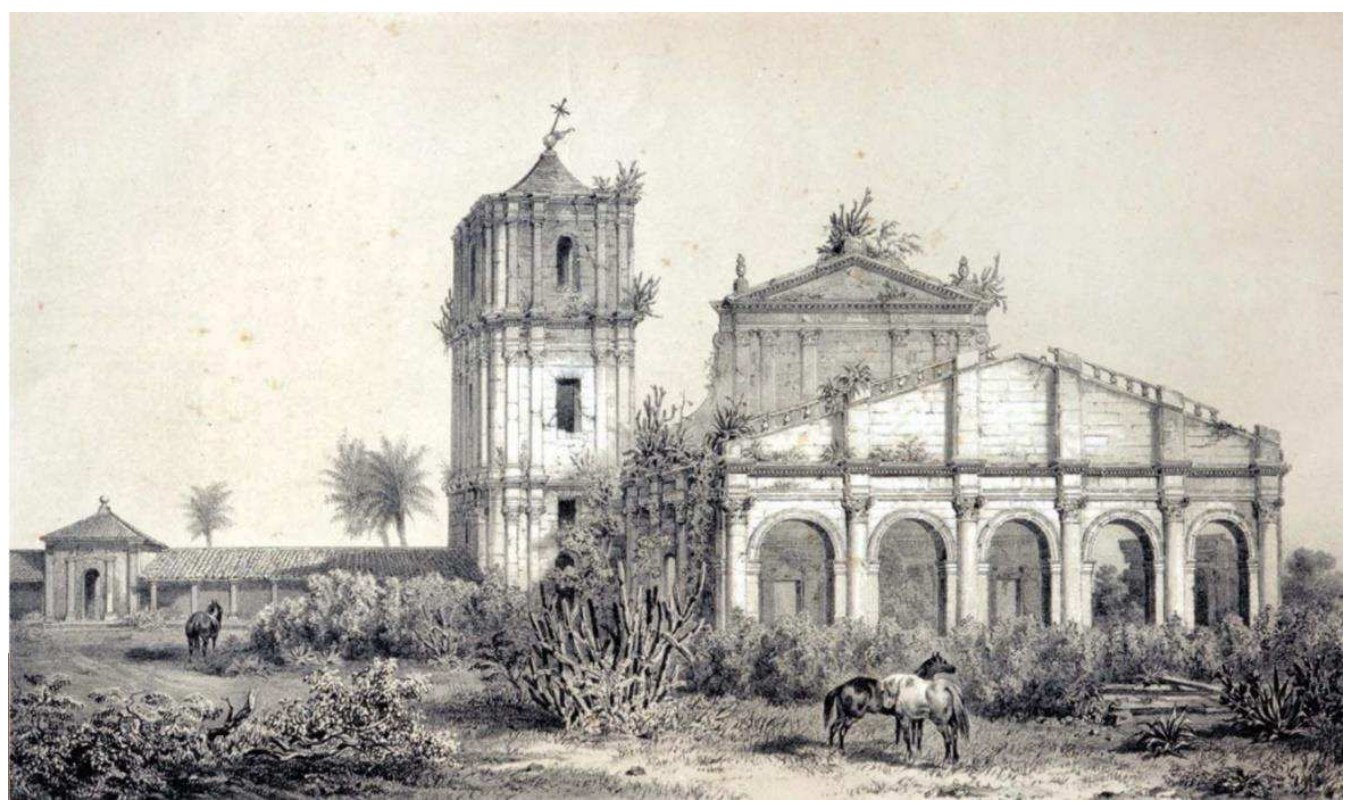

Fig. 01: Povoado São Miguel das Missões (RS), gravura de Demersay, 1846. Fonte: Wikimedia Commons, domínio público. Disponível em: <https://commons.wikimedia.org/w/index.php?curid=8431918>, acesso em 23 set. 2016

No período destacado na Tabela 01, as inscrições de conjuntos em ruínas no Livro do Tombo Arqueológico, Etnográfico e Paisagístico são escassas. Na descrição que concerne a esse Livro do Tombo $^{15}$, não há uma explícita descrição de ruínas, mas à caracterização de "vestígios da ocupação humana pré-histórica ou histórica" (IPHAN In: $<$ http://portal.iphan.gov.br/pagina/detalhes/608> acesso em 30. jan. 2016).

A exiguidade de bens arruinados tombados por seu valor arqueológico, etnográfico e paisagístico nessa fase do IPHAN pode ser um aspecto particularmente indicativo de uma realidade que implica diretamente na apreciação à noção da ruína nas práticas patrimoniais

\footnotetext{
${ }^{14}$ Em meados no século XIX, Demersay ver incursões no Paraguai e Sul do Brasil a fim de retratar a história natural, geografia e antropologia locais.

${ }^{15}$ Cf.: “[...] onde são inscritos os bens culturais em função do valor arqueológico, relacionado a vestígios da ocupação humana pré-histórica ou histórica; de valor etnográfico ou de referência para determinados grupos sociais; e de valor paisagístico, englobando tanto áreas naturais, quanto lugares criados pelo homem aos quais é atribuído valor à sua configuração paisagística, a exemplo de jardins, mas também cidades ou conjuntos arquitetônicos que se destaquem por sua relação com o território onde estão implantados." (IPHAN In: <http://portal.iphan.gov.br/pagina/detalhes/608> acesso em 30. jan. 2016 - grifo nosso).
} 
Brasil: no território nacional as referências pré-coloniais não são constituídas por ruínas de um legado arquitetônico associado a civilizações longínquas tais como aquelas encontradas em alguns outros continentes e outras regiões da América. Nosso legado paleoameríndio se caracteriza essencialmente por outros tipos de evidências materiais tais como artefatos, geóglifos, pinturas rupestres, sambaquis, dentre outros (BASTOS, 2008) que não englobam edificações. Sendo assim, a apreciação dos conjuntos em ruínas do Brasil não entra na discussão patrimonial através do viés arqueológico, conforme atesta Rodrigo M. F. Andrade:

O pensamento de proteger o acervo arqueológico do Brasil se teria manifestado talvez bem cedo entre nós, se os colonizadores portugueses encontrassem nesse país, como sucedeu aos castelhanos em outras regiões da América, restos monumentais de uma civilização materialmente mais evoluída. [...] (ANDRADE, R. M. F., 1952, p.11 grifo nosso)

Nessa perspectiva, é interessante pontuar que, ainda durante o século XIX concomitantemente ao desenvolvimento e fundamentação do campo disciplinar da arqueologia na Europa, aqui no Brasil foi criado o Instituto Histórico e Geográfico Brasileiro (1838) e, posteriormente, os segmentos estaduais - Instituto Arqueológico e Geográfico Pernambucano (1862) e Instituto Histórico e Geográfico de São Paulo (1894) com o objetivo de buscar e estudar evidências físicas de nosso passado.

Na publicação inaugural da Revista do Instituto Histórico e Geográfico Brasileiro, pode-se constatar pelo teor das apresentações e o discurso ${ }^{16}$ de constituição da entidade, que em princípio o tema do patrimônio edificado não é o principal objetivo dos intelectuais envolvidos com esses institutos e não há uma conexão da noção da ruína às pesquisas desenvolvidas. Contudo, conforme consta em um dos artigos publicados pela Revista do $\mathrm{IHGB}^{17}$ havia indícios de um ideário que no território baiano houvesse uma cidade perdida; de acordo com o trabalho de Langer (2001), há registros de expedições por membros do instituto financiados por D. Pedro II (1825-1891) para tentar localizar esses vestígios arqueológicos que nunca foram de fato encontrados ${ }^{18}$.

\footnotetext{
${ }^{16}$ Discurso recitado no acto de estatuir-se o Instituto Histórico e Geographico Brazileiro, pelo secretário perpétuo e cônego Januário da Cunha Barbosa. In: Revista IHGB, Rio de Janeiro, n. 1, Tomo I, p. 9-17, 1839. Disponível em: <https://ihgb.org.br/publicacoes/revista-ihgb/itemlist/filter.html?category=9\&moduleId=147>, acesso em 28 abr. 2016.

${ }^{17}$ Memória: sobre a situação da antiga cidade abandonada, que se diz descoberta nos sertões do Brasil por certos aventureiros em 1753 - Escripta pelo sócio correspondente o Sr. Conego Benigno José de Carvalho e Cunha. In: Revista IHGB, Rio de Janeiro, n. 10, Tomo III, p. 197-203, 1842. Disponível em: $<$ https://ihgb.org.br/publicacoes/revista-ihgb/itemlist/filter.html?category=9\&moduleId=147>, acesso em 28 abr. 2016.

${ }^{18}$ Cf.: LANGER, Johnni. Ruínas e mitos: a arqueologia do Brasil imperial. Tese (Doutorado) - Faculdade de História, Universidade Federal do Paraná, Curitiba, 2001, p. 31, 35, 37 e 62.
} 
No início do século XX, durante os já mencionados debates que antecederam o Decreto Lei n.25 (1937) pode-se verificar que em 1920 Alberto Childe foi encarregado para elaborar um anteprojeto de lei em defesa do patrimônio nacional, no qual incluiu especificamente as ruínas ${ }^{19}$ como "riquezas nacionais [...] encontradas na superfície ou debaixo da terra" (CHILDE apud ANDRADE, R. M. F., 1952, p. 16-17), provavelmente devido à sua formação de arqueólogo e atuação no setor de antiguidades do Museu Nacional. No entanto, esse projeto não foi desenvolvido; conforme analisado por Rubino (1991), o conceito de patrimônio aplicado por Childe era restrito por não incorporar os aspectos artísticos dos potenciais bens culturais e por estar demasiadamente relacionado a uma visão que atrela a história à evidência material arqueológica. Posteriormente, na acepção do anteprojeto de Mário de Andrade a "arte arqueológica e ameríndia" (ANDRADE, M. In: MEC, 1980, p. 92) não inclui especificamente as ruínas.

Ainda considerando a aproximação do tema das ruínas através da arqueologia, em 1961 surgiu no Brasil a primeira Lei Federal $\left(\mathrm{N}^{\mathrm{o}} 3.924\right)$ que prescreve exclusivamente sobre os monumentos arqueológicos e pré-históricos nacionais. Como aponta DeBlasis (2006) em relação ao Decreto de 1937 essa lei apresenta de modo mais claro a proteção legal para todos os sítios arqueológicos do país.

$\mathrm{Na}$ definição sobre monumentos arqueológicos ${ }^{20}$ ou pré-históricos há uma ênfase na caracterização de vestígios paleoameríndeos sendo que as designações mais próximas a remanescentes edificados seriam: “[...] b. os sítios nos quais se encontram vestígios positivos de ocupação pelos paleoameríndios tais como grutas, lapas e abrigos sob rocha; c. os sítios identificados como cemitérios, sepulturas ou locais de pouso prolongado ou de aldeamento, 'estações' e 'cerâmicos';" (LEI N ${ }^{0}$ 3.924/61 - Art. 20 In: BASTOS, 2008, p.5-6). Essas

\footnotetext{
19 "São consideradas como riquezas nacionais e de propriedade exclusiva de cada estado e da União, as ruínas, edifícios, jazidas, grutas, cemitérios, sambaquis, pedras levantadas, poços, etc., contendo ou não fósseis, ou objetos de natureza paleontológica ou arqueológica, histórica, etc., sejam elas encontradas na superfície, ou debaixo da terra, em florestas, campo aberto ou propriedades particulares, dentro dos limites territoriais da nação.” (CHILDE apud ANDRADE, R. M. F., 1952, p. 16-17).

20 "Art.2 - Consideram-se monumentos arqueológicos ou pré-históricos: a. as jazidas de qualquer natureza, origem ou finalidade, que representem testemunhos de cultura dos paleoameríndios do Brasil, tais como sambaquis, montes artificiais ou tesos, poços sepulcrais, jazigos, aterrados, estearias e quaisquer outras não especificadas aqui, mas de significado idêntico a juízo da autoridade competente; $b$. os sítios nos quais se encontram vestígios positivos de ocupação pelos paleoameríndios tais como grutas, lapas e abrigos sob rocha; c. os sítios identificados como cemitérios, sepulturas ou locais de pouso prolongado ou de aldeamento, "estações" e "cerâmicos", nos quais se encontram vestígios humanos de interesse arqueológico ou paleoetnográfico; d. as inscrições rupestres ou locais como sulcos de polimentos de utensílios e outros vestígios de atividades de paleoameríndios." (LEI N ${ }^{\mathrm{o}} 3.924 / 61$ In: BASTOS, 2008, p.5-6).
} 
definições reiteram o fato de que nosso passado indígena, por suas características organizacionais intrínsecas, não nos tenha legado remanescentes arquitetônicos edificados.

A partir da década de 1960 se configurou um quadro de mudanças no que concerne à visão patrimonial. No cenário internacional pós Segunda Guerra Mundial houve a integração das ciências humanas às discussões, a ampliação do conceito de bem cultural, a promulgação da Carta de Veneza ${ }^{21}$ (1964) e seus desdobramentos em documentos tais como as Normas de Quito (1967) ${ }^{22}$. No Brasil, após a aposentadoria de Rodrigo M. F. de Andrade em 1967, Renato Soeiro assumiu o cargo da diretoria do IPHAN e o órgão entrou em outra fase. Nesse contexto, também ocorreu a disseminação da preservação patrimonial para órgãos nas esferas estaduais $^{23}$.

No âmbito legislativo nacional, a definição de patrimônio cultural apresentada no Decreto lei de 1937 foi reiterada na Constituição Federal de 1988 incorporando a pluralidade social da conformação cultural do Brasil ${ }^{24}$. Nessa nova conjuntura delineada a partir de 1967 , dando prosseguimento à análise a partir das inscrições de tombamentos em que há menção ao termo ruína, ruínas (ou derivados: remanescentes, restos ou vestígios) no título ou descrição, é possível constatar pela Tabela 02 que, assim como no período anterior, a maioria das inscrições se concentra no Livro do Tombo Histórico.

\footnotetext{
${ }^{21}$ Carta Internacional sobre conservação e restauração de monumentos e sítios, definida no II Congresso Internacional de Arquitetos e Técnicos dos Monumentos Históricos - ICOMOS - Conselho Internacional de Monumentos e Sítios.

${ }^{22}$ Reunião sobre conservação e utilização de Monumentos e lugares de interesse histórico e artístico. Promovida pela Organização dos Estados Americanos (OEA), Quito (Peru), novembro de 1967.

${ }^{23}$ Surgem órgãos como o Instituto Estadual do Patrimônio Cultural - RJ (INEPAC) em 1964; Instituto do Patrimônio Artístico e Cultural da Bahia - BA (IPAC) em 1967; e Conselho de Defesa do Patrimônio Histórico, Arqueológico, Artístico e Turístico - SP (CONDEPHAAT) em 1968.

${ }^{24}$ Cf.: "Art. 216: Constituem patrimônio cultural brasileiro os bens de natureza material e imaterial, tomado individualmente ou em conjunto, portadores de referência à identidade, à ação, à memória dos diferentes grupos formadores da sociedade brasileira, nos quais se incluem: [...] V. os conjuntos urbanos e sítio de valor histórico, paisagístico, artístico, arqueológico, paleontológico, ecológico e científico." (CONSTITUIÇÃO FEDERAL, 1988 In: BASTOS, 2008, p.3-4).
} 
Tabela 02 - Bens tombados pelo IPHAN décadas de 1970-2015 - ruínas e termos derivados

\begin{tabular}{|c|c|c|c|c|c|c|}
\hline & Objeto & Local & Construção & Processo & Tombo & Data Tomb. \\
\hline$\overline{1}$ & Povo de São João: ruínas e remanescentes do povoado & RS-Entre-ijuís & Séc. XVII e XVIII & $0813-T-69$ & L.H. & $22 / 01 / 1970$ \\
\hline 2 & Povo de São Nicolau: ruínas e remanescentes & RS-São Nicolau & Séc. XVII e XVIII & 0813-T-69 & L.H. & $22 / 01 / 1970$ \\
\hline 3 & $\begin{array}{l}\text { Povo de São Lourenço das Missões: ruínas } \\
\text { e remanescentes do povoado }\end{array}$ & RS-São Luiz Gonzaga & Séc. XVII e XVIII & 0813-T-69 & L.H. & $18 / 03 / 1970$ \\
\hline 4 & Forte de Santa Tecla: fundações & RS-Bagé & 1774 & 0392-T-48 & L.H. & $26 / 11 / 1970$ \\
\hline 5 & Fazenda do Pombal: remanescentes & MG-Ritápolis & Séc. XVIII & 0832-T-70 & L.H. & 21/09/1971 \\
\hline 6 & $\begin{array}{l}\text { Conjunto arquitetônico e paisagístico: } \\
\text { ruínas da Igreja São Francisco e } \\
\text { Igreja N. Sra. Do Outeiro }\end{array}$ & BA-Porto Seguro & Séc. XVI & 0800-T-68 & $\begin{array}{l}\text { L.A.ET.P. } \\
\text { L.H. }\end{array}$ & $\begin{array}{l}01 / 03 / 1974 \\
01 / 03 / 1974\end{array}$ \\
\hline 7 & $\begin{array}{l}\text { Conjunto Paisagístico do Sítio da Trindade } \\
\text { Arraial Velho Bom Jesus (antiga fortificação) }\end{array}$ & PE-Recife & Séc. XVI & 0487-T-53 & L.H. & $17 / 06 / 1974$ \\
\hline 8 & Fazenda da Conceição: casa & SP-Paraíbuna & 1841 & 0910-T-74 & L.H. & $22 / 11 / 1974$ \\
\hline 9 & Fortaleza de Santo Antônio: remanescentes & MA-São Luís & Séc. XVII & 0930-T-75 & L.A.ET.P. & $06 / 08 / 1975$ \\
\hline 10 & Arraial Novo do Bom Jesus & PE-Recife & Séc. XVII & 0942-T-76 & L.H. & 08/04/1980 \\
\hline 11 & $\begin{array}{l}\text { Convento de São Boaventura: ruínas } \\
\text { Fazenda Macacu }\end{array}$ & RJ-Itaboraí & 1612 & 0690-T-63 & $\begin{array}{l}\text { L.B.A. } \\
\text { L.H. }\end{array}$ & $\begin{array}{l}28 / 04 / 1980 \\
28 / 04 / 1980\end{array}$ \\
\hline 12 & Sítio Santo Antônio das Alegrias ou do Físico: ruínas & MA-São Luis & Séc. XVIII & $1017-\mathrm{T}-80$ & $\begin{array}{l}\text { L.A.ET.P. } \\
\text { L.H. }\end{array}$ & $\begin{array}{l}29 / 01 / 1981 \\
29 / 01 / 1981\end{array}$ \\
\hline 13 & $\begin{array}{l}\text { Engenho do Murucutu: ruínas e Capela de } \\
\text { Nossa Senhora da Conceição }\end{array}$ & PA-Belém & Séc. XVIII & 0439-T-50 & L.H. & $08 / 10 / 1981$ \\
\hline 14 & Serra da Barriga - República dos Palmares & AL-União dos Palmares & 1630 & $1069-T-82$ & $\begin{array}{l}\text { L.A.ET.P. } \\
\text { L.H. }\end{array}$ & $19 / 02 / 1986$ \\
\hline 15 & $\begin{array}{l}\text { Conjunto arquitetônico, urbanístico e paisagístico } \\
\text { Ruína da Igreja Nossa Senhora do Rosário }\end{array}$ & TO-Natividade & 1734 & $1117-\mathrm{T}-84$ & $\begin{array}{l}\text { L.B.A. } \\
\text { L.A.ET.P. } \\
\text { L.H. } \\
\end{array}$ & $\begin{array}{l}16 / 10 / 1987 \\
16 / 10 / 1987 \\
16 / 10 / 1987 \\
\end{array}$ \\
\hline 16 & Vila Bela: ruínas & $\begin{array}{l}\text { MT-Vila Bela da } \\
\text { Santíssima Trindade }\end{array}$ & 1730 & 0877-T-73 & L.H. & $13 / 06 / 1988$ \\
\hline 17 & $\begin{array}{l}\text { Conjunto arquitetônico, urbanístico e paisagístico: } \\
\text { ruínas de habitações de pedra }\end{array}$ & $\begin{array}{l}\text { BA-Andaraí } \\
\text { (Igatu) }\end{array}$ & Séc. XIX & 1411-T-98 & $\begin{array}{l}\text { L.B.A. } \\
\text { L.A.ET.P. } \\
\text { L.H. }\end{array}$ & $\begin{array}{l}20 / 06 / 2000 \\
20 / 06 / 2000 \\
20 / 06 / 2000\end{array}$ \\
\hline 18 & Quilombo do Ambrósio: remanescentes & MG-Ibiá & 1726 & 1428-T-98 & L.H. & $11 / 07 / 2002$ \\
\hline 19 & $\begin{array}{l}\text { Conjunto da Fortificações Brasileiras } \\
\text { Forte de São Joaquim do Rio Branco: Ruína }\end{array}$ & RR-Caracaraí & Séc. XVIII & $1613-T-2010$ & $\begin{array}{l}\text { L.A.ET.P. } \\
\text { L.H. }\end{array}$ & $11 / 09 / 2014$ \\
\hline 20 & $\begin{array}{l}\text { Conjunto das Fortificações Brasileiras } \\
\text { Forte Vera Cruz ou do Calvário: Ruína }\end{array}$ & MA-Rosário & 1620 & 1613-T-2010 & $\begin{array}{l}\text { L.A.ET.P. } \\
\text { L.H. }\end{array}$ & $11 / 09 / 2014$ \\
\hline
\end{tabular}

Legenda: L.A.ET.P. - Livro Arqueológico, Etnográfico e Paisagístico; L.A.A. - Livro de Artes Aplicadas; L.B.A. Livro de Belas Artes; L.H - Livro Histórico. Fonte: Arquivo Noronha Santos, disponível em <http://www.iphan.gov.br/inicial.htm> acesso em: 01 Jun. de 2015. Elaborada pela autora. Colaboração: Wagner Nascimento. 
Há, porém, uma maior incidência de inscrições no Livro Arqueológico, Etnográfico e Paisagístico que estão associadas a inscrições nos outros livros, como o conjunto arquitetônico e urbanístico de Alcântara (MA) (com as ruínas da Igreja Matriz e do Convento do Carmo) - Livro Histórico (1948) e Livro Arqueológico, Etnográfico e Paisagístico (1974); e o Sítio do Físico (MA) tombado em ambos os Livros em 1981. Em nossa análise, esse aumento de tombamentos no Livro Arqueológico, Etnográfico e Paisagístico reflete o desenvolvimento da preocupação com as pesquisas arqueológicas no Brasil que foi instituído a partir da promulgação da já mencionada Lei $\mathrm{N}^{0} 3.924 / 1961$.

É relevante atestar que os tombamentos dos bens em ruínas devem ser interpretados tendo como pano de fundo os critérios e juízos de valor adotados pelo IPHAN. Com a constituição do Estado Novo e a instituição do SPHAN em 1937 se desenvolveu um modelo de abordagem em que se buscava a origem da nação brasileira através de remanescentes arquitetônicos que pudessem constituir o ideário de patrimônio nacional articulando a cognição de uma identidade cultural (LEITE, 2004 e MICELI, 1987). Os tombamentos das ruínas após a década de 1960 reproduzem esse modelo. A tipologia arquitetônica dos monumentos descritos como ruínas é similar ao que tinha sido tombado no período inicial do IPHAN; ou seja, há uma concentração de edificações provenientes do período colonial brasileiro (séculos XVI ao XVIII), que são basicamente: fortificações, estruturas religiosas e edificações rurais ligadas à manufatura de produtos (casas de fazenda e engenhos). Pelas tabelas apresentadas, pode-se constatar que são poucos conjuntos de uma datação de construção mais recente (séculos XIX e XX); e não há um aumento significativo dos bens designados como ruínas em relação ao período anterior.

Outro aspecto que pode ser evidenciado nessa conjuntura após a década de 1960 é que no cenário internacional, houve uma transposição do bem cultural de "objeto de culto à indústria" (CHOAY, 2001, p. 206); ou seja, o bem é o mesmo, mas a forma de abordagem é diferente e se insere na necessidade de valorização - "mise-en-valeur” (Op. cit., p. 212). Nesse contexto, foram promulgadas as Normas de Quito (1967), das quais o Brasil é signatário, em que há recomendações para aliar o turismo às práticas de salvaguarda como uma chave para o desenvolvimento econômico e de autogestão patrimonial.

Nesse momento, ocorreram as primeiras missões da UNESCO (United Nations Educational, Scientific and Cultural Organization) no Brasil. A convite do IPHAN, Michel Parent (1916-2009) - técnico do Serviço Principal de Inspeção dos Monumentos e de Inspeção de Sítios na França - esteve em nosso país entre 1966 e 1967 com o objetivo de inseri-lo no 
programa de "Turismo Cultural" da UNESCO. Em seu relatório ${ }^{25}$, Parent insere a problemática do patrimônio cultural brasileiro no cotidiano das pessoas diferenciando em relação a outros países da América Latina como Peru e México identificados por seus sítios arqueológicos:

Em relação a esses dois países, suas civilizações pré-colombianas prestigiosas exaltam a imaginação ocidental; seus sítios artísticos e arqueológicos eminentes conta-se entre os mais famosos do mundo e constituem um apelo para os homens, com toda a sugestão de seus mistérios. (PARENT In: LEAL, 2008, p.158)

Já no Brasil “[...] há para admirar cidades (de arte) em atividade e não ruínas de monumentos enterrados." (Op. cit., p.160). Ainda que a convite do IPHAN, Parent ressalta a péssima condição do estado de conservação de nosso patrimônio "Trata-se então, para nós, de recensear bem mais do que os destroços de um cenário que ainda permanece o mais fecundo e homogêneo do continente americano." (Op. cit., p.46) e alerta sobre um futuro "[...] cuja ruína, brevemente será irreversível." (Op. cit., p.46).

Pela orientação das viagens empreendidas, documentação acessada e prioridades estabelecidas, evidencia-se que o relatório de Parent não tinha como objetivo a identificação do patrimônio brasileiro partindo do pressuposto de que o mesmo já tinha sido reconhecido pelas práticas do IPHAN. Dos bens brasileiros associados a ruínas já tombadas na ocasião, é possível identificar proposições de urgência salientadas por Parent para o conjunto urbano de Alcântara (MA) e a possibilidade de "apelo turístico" do Rio Grande do Sul voltado para a Argentina, referindo-se aos Povos Missioneiros. Percebe-se que Parent reitera, portanto, a leitura de que no Brasil não há ruínas suficientemente relevantes associadas a uma civilização distante; por outro lado, se interpõe, mais uma vez, a necessidade de "salvar da ruína" o nosso patrimônio.

A Assembleia Geral da UNESCO ${ }^{26}$, em 1972, estabeleceu a "Convenção do Patrimônio Mundial, Cultural e Natural" que contribui para estabelecer a mundialização dos valores e das referências ocidentais nas práticas patrimoniais (CHOAY, 2001). Paulatinamente o Brasil teve inscrições no seleto rol do "Patrimônio da Humanidade"; no que tange às ruínas, a Missão de São Miguel (RS) entrou para essa listagem em 1983 em conjunto

\footnotetext{
${ }^{25}$ Essas visitas originaram o relatório "Proteção e valorização do patrimônio cultural brasileiro no âmbito do desenvolvimento turístico e econômico" (2008) - Protectión et mise em valeur du patrimoine culturel brésilien dans le cadre du developpement touristique et économique. (Paris: Unesco, 1968).

${ }^{26}$ Conferência Geral da Organização das Nações Unidas para a Educação, Ciência e Cultura, reunida em Paris de 17 de Outubro a 21 de Novembro de 1972, na sua décima sétima sessão. Texto completo disponível em: $<$ http://whc.unesco.org/en/conventiontext/>, acesso em 21 set. 2016.
} 
com quatro outras missões jesuíticas na Argentina (San Ignácio Miní, Santa Ana, Nuestra Señora de Loreto e Santa María la Mayor).

No cômpito geral, embora haja poucos patrimônios tombados como ruínas no Brasil, há um estoque considerável que pode ser potencialmente valorizado. A implementação em 1997 do Sistema de Gerenciamento do Patrimônio Arqueológico (SGPA) pelo IPHAN tem colaborado para uma apreciação desse potencial enquanto objeto de estudo. O SGPA foi criado a fim de estabelecer padrões nacionais para identificação dos sítios, coleções arqueológicas e registro da documentação arqueológica produzida, procurando atender às determinações dispostas na Lei n. 3.924/61.

Todos os sítios e coleções arqueológicas que são objetos de pesquisas devem ser cadastrados nesse sistema que mantém um banco de dados para a identificação através do Cadastro Nacional de Sítios Arqueológicos (CNSA). Além de estarem automaticamente protegidos pela referida legislação específica esses sítios também podem ser tombados em nível municipal, estadual ou federal. Um dos critérios de identificação nas fichas desse cadastro é a existência de "vestígios de edificações". Atualmente há $25.450^{27}$ itens cadastrados a partir dos quais foi elaborado um levantamento dos sítios em que há a designação "ruínas" no título e foram localizados conjuntos no território nacional classificados sob a categoria de importância "histórica",28 (ver tabela 03).

\footnotetext{
${ }^{27}$ Esse número se atualiza constantemente devido ao aumento do número de pesquisas. Consulta ao IPHAN Cadastro Nacional de Sítios Arqueológicos CNSA/SGPA, disponível em: <http://www.iphan.gov.br/sgpa/?consulta=cnsa> acesso em 13 set. 2016.

${ }^{28}$ A classificação das categorias é: pré-colonial, de contato ou histórico, podendo ser unicomponencial ou multicomponencial.
} 
Tabela 03 - Conjuntos em ruínas no Cadastro Nacional de Sítios Arqueológicos (CNSA)

\begin{tabular}{|c|c|c|c|c|c|c|}
\hline & Objeto & Local & CNSA & Categoria & Data registro & Data ficha \\
\hline$\overline{1}$ & Ruínas São Luís & TO-Natividade & TO 01290 & histórico & - & - \\
\hline$\overline{2}$ & Ruínas da praia da Pedreira & $\begin{array}{l}\text { RJ-Angra dos } \\
\text { Reis }\end{array}$ & RJ 00008 & histórico & $26 / 08 / 1978$ & $06 / 08 / 1997$ \\
\hline 3 & Ruínas da Armação da Piedade & $\begin{array}{l}\text { SC-Governador } \\
\text { Celso Ramos }\end{array}$ & SC 00423 & histórico & 1987 & $20 / 08 / 1997$ \\
\hline 4 & Ruínas do Abarebebê & SP-Peruíbe & SP 00337 & histórico & - & $24 / 09 / 1997$ \\
\hline 5 & Ruínas & $\begin{array}{l}\text { PR-Doutor } \\
\text { Camargo }\end{array}$ & PR 00113 & histórico & $11 / 02 / 1967$ & $02 / 09 / 1997$ \\
\hline 6 & $\begin{array}{l}\text { Ruínas da Igreja de N.S.da Glória } \\
\text { Outeiro }\end{array}$ & BA-Porto Seguro & BA 00155 & histórico & $20 / 12 / 1984$ & $22 / 09 / 1997$ \\
\hline 7 & Ruínas de Loreto & PR-Itaguaré & PR 00915 & histórico & $17 / 02 / 1970$ & $13 / 10 / 1997$ \\
\hline 8 & Ruínas das Feitorias dos Jesuítas & RJ-Rio de Janeiro & RJ 00632 & histórico & - & $02 / 12 / 1997$ \\
\hline 9 & Ruínas do Rio Salinas & ES-Anchieta & ES 00255 & histórico & $18 / 09 / 1995$ & - \\
\hline 10 & $\begin{array}{l}\text { Ruínas da Igreja de Nossa } \\
\text { Sra. Da Conceição }\end{array}$ & ES-Guarapari & ES 00061 & histórico & 09/10/1995 & $19 / 12 / 1997$ \\
\hline$\overline{11}$ & $\begin{array}{l}\text { Ruínas do Convento da Igreja de } \\
\text { Santa Maria dos Anjos }\end{array}$ & RJ-Cabo Frio & RJ 00343 & histórico & - & $22 / 12 / 1997$ \\
\hline$\overline{12}$ & Ruínas do Arpoador & SP-Peruíbe & SP-00680 & histórico & 1997 & $08 / 01 / 1998$ \\
\hline$\overline{13}$ & Ruínas da Praia da Pedreira & $\begin{array}{l}\text { RJ - Angra dos } \\
\text { Reis }\end{array}$ & RJ 00537 & histórico & 1978 & $27 / 07 / 1998$ \\
\hline$\overline{14}$ & Ruínas do Forte Cumaú & AP-Santana & AP00150 & histórico & 2004 & $30 / 12 / 1998$ \\
\hline$\overline{15}$ & $\begin{array}{l}\text { Ruínas da Mata de Santa } \\
\text { Teresinha }\end{array}$ & RS-Bom Princípio & RS 02083 & histórico & $28 / 12 / 1999$ & $11 / 04 / 2000$ \\
\hline 16 & Ruínas & AL - Piranhas & AL 00078 & s/ categoria & - & $09 / 05 / 2000$ \\
\hline 17 & Ruínas do Jatobá & $\begin{array}{l}\text { MT-Vila Bela da } \\
\text { Santíssima } \\
\text { Trindade }\end{array}$ & MT 00697 & histórico & 2003 & - \\
\hline 18 & $\begin{array}{l}\text { Ruínas do Registro no } \\
\text { Caminho do Ouro }\end{array}$ & RJ-Parati & RJ-01066 & histórico & $05 / 01 / 2003$ & - \\
\hline 19 & Ruínas de Mapele & BA-Simões Filho & BA 00708 & histórico & $23 / 12 / 2004$ & $23 / 12 / 2004$ \\
\hline$\overline{20}$ & Sítio ruínas Rio Goiabeira & $\begin{array}{l}\text { PE-Jaboatão } \\
\text { dos Guararapes }\end{array}$ & PE 00391 & histórico & 2007 & $14 / 04 / 2007$ \\
\hline
\end{tabular}




\begin{tabular}{|c|c|c|c|c|c|}
\hline 21 & Ruínas do Tombadouro & MG-Ouro Preto & MG 01006 histórico & $21 / 05 / 2008$ & $21 / 05 / 2008$ \\
\hline 22 & Ruínas de São João Marcos & RJ-Claro & RJ-00932 - & 2008 & - \\
\hline 23 & Ruínas do Carmo & RN-Mossoró & RN 00193 histórico & $14 / 03 / 2006$ & $03 / 07 / 2009$ \\
\hline 24 & Ruínas do Baixio & RJ- Parati & RJ-00670 histórico & $13 / 08 / 2009$ & - \\
\hline 25 & Ruínas Fazenda Monte Santo & MG-Ouro Preto & MG 01200 histórico & $11 / 03 / 2010$ & - \\
\hline 26 & $\begin{array}{l}\text { Ruínas da fazenda da Baronesa } \\
\text { do Capivari }\end{array}$ & MG-Santa Bárbara & MG-02620 histórico & $18 / 10 / 2011$ & $18 / 10 / 2011$ \\
\hline 27 & Ruínas 26 & PR-Guaraqueçaba & PR-01365 histórico & 1987 & $25 / 01 / 2013$ \\
\hline 28 & Ruínas da Igreja Matriz & $\begin{array}{l}\text { MT-Vila Bela da } \\
\text { Santíssima } \\
\text { Trindade }\end{array}$ & MT 00827 histórico & $13 / 06 / 1905$ & $12 / 07 / 2013$ \\
\hline 29 & Ruínas Olaria & MG-Brumadinho & MG 02517 histórico & $11 / 09 / 2013$ & $13 / 01 / 2014$ \\
\hline 30 & Ruínas de São Miguel Arcanjo & PB-Baía da Traição & PB-00179 histórico & $19 / 11 / 2014$ & $19 / 11 / 2014$ \\
\hline 31 & Ruínas de São Caetano da Moeda & MG-Moeda & MG-02573 histórico & 2008 & $03 / 12 / 2014$ \\
\hline 32 & $\begin{array}{l}\text { Sítio Histórico Ruínas da Chapada } \\
\text { dos Negros }\end{array}$ & TO-Arraias & TO-01309 histórico & $08 / 12 / 2014$ & $08 / 12 / 2014$ \\
\hline 33 & $\begin{array}{l}\text { Ruínas da Casa de Pedra do } \\
\text { Gambá }\end{array}$ & $\begin{array}{l}\text { MG-Entre Rios de } \\
\text { Minas }\end{array}$ & MG 01213 histórico & - & - \\
\hline 34 & Ruínas da Fazenda Bom Retiro & RJ-Parati & RJ-00675 histórico & - & - \\
\hline 35 & Ruínas do Saco de Cima & RJ-Mangaratiba & RJ-00844 histórico & - & - \\
\hline
\end{tabular}

Fonte: Cadastro Nacional de Sítios Arqueológicos CNSA/SGPA, disponível em: <http://www.iphan.gov.br/sgpa/?consulta=cnsa > acesso em 13 set. 2016. Elaborada pela autora. 

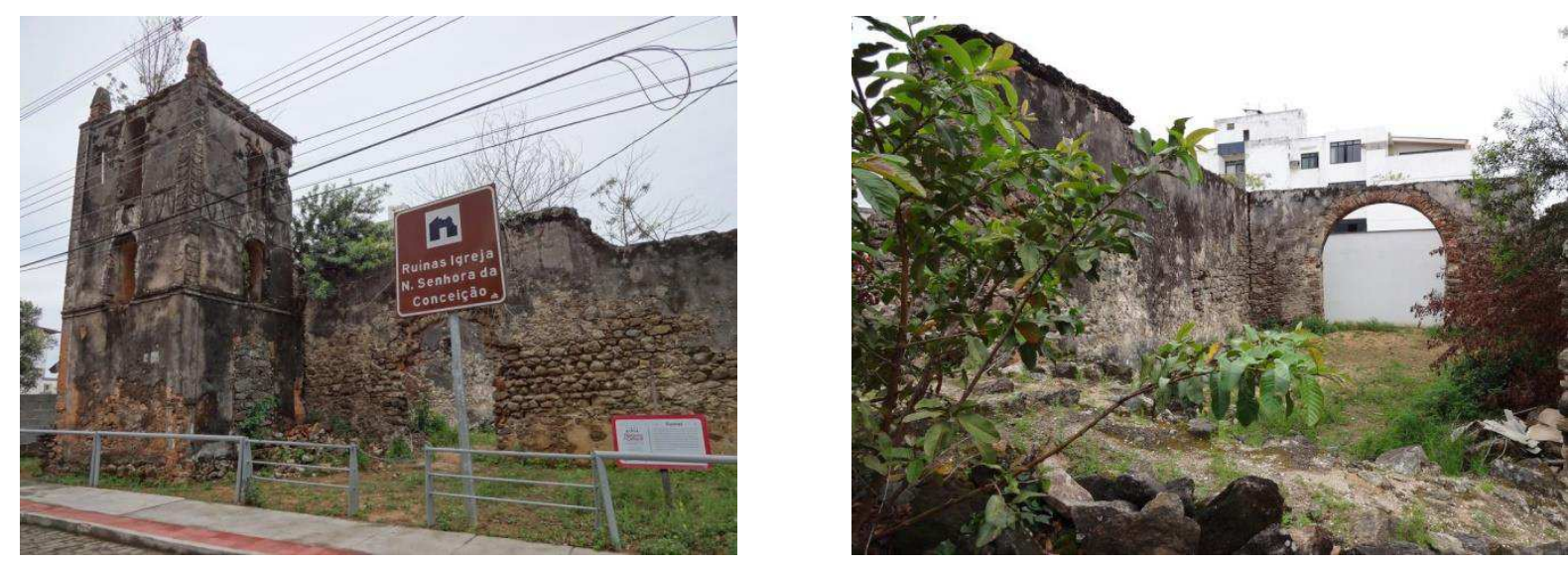

Fig. 02 (i-ii): Ruínas da Igreja Nossa Senhora da Conceição, Guarapari (ES) - CNSA: ES 00061, 2016. Fotos: Autora.

Com esse panorama foi possível verificar algumas características intrínsecas ao processo de valorização das ruínas enquanto bens culturais no Brasil: a latente predisposição em associá-la a um problema do estado físico periclitante de um bem a ser "salvo" orientou a instituição da política de salvaguarda; os bens tombados demonstram que a apreciação do patrimônio edificado reduzido ao estado de ruína ainda é exígua e se estabelece essencialmente através do valor histórico de estruturas relacionadas a determinadas tipologias arquitetônicas provenientes dos séculos XVI ao XVIII; a correlação do viés arqueológico como elemento para valorização das edificações em estado de ruína no Brasil é tênue, mas tem avançado nas últimas décadas.

A elaboração das tabelas a partir da identificação dos tombamentos, a compreensão do critério de aproximação que se estabelecesse essencialmente pelo valor histórico e a apresentação da legislação que vem sendo desenvolvida naquilo que concerne a uma possível apreciação das ruínas por parte das políticas de salvaguarda implicam somente numa parte da problemática que se estrutura a partir de alguns questionamentos básicos para o desenvolvimento desta tese: o que pode ser entendido como ruína no Brasil? Como a identificação da condição de ruína orienta as posturas de intervenção para esses bens?

Para desenvolver essas reflexões, é necessário esclarecer que partimos do pressuposto de que o tema da ruína não se restrinja aos conjuntos edificados listados em que há uma explícita identificação dessa condição no título ou na descrição do tombamento. Consideramos aqui que há outros patrimônios arquitetônicos que passaram por processos de arruinamento (total ou parcial) após terem sido reconhecidos como bens culturais. Para melhor situar essas inflexões torna-se imperativo apresentar uma definição de ruína com suas peculiaridades e limiares. 


\subsection{Ruínas: uma possível definição}

No âmbito da historiografia da preservação patrimonial foram localizadas algumas poucas definições sobre ruínas. Em 1825, o erudito, historiador da arte e arqueólogo Antoine Chrysostome Quatremère de Quincy (1755-1849) publicou o verbete "Ruína, Ruínas" na Encyclopédie Métodique. Architecture, um trabalho pioneiro em razão da iniciativa de estabelecer reflexões para compreender esse tema. Quincy fez um retrospecto histórico em relação ao valor atribuído às ruínas até então e apresentou parâmetros para as intervenções nesses conjuntos. A definição apresentada por ele se estrutura a partir do viés semântico:

Esta palavra, no singular e em seu sentido ordinário, exprime o estado de degradação e de destruição no qual se encontra, ou está ameaçado, um edifício. Diz-se que um edifício está ameaçado de 'ruína' usa-se essa palavra também no singular para exprimir o estado de destruição consumado. Mas nesse caso, é mais usual empregá-la no plural e a razão é que esse estado de destruição, apresentando a dissolução de todas as partes, de todos os materiais de um edifício, oferece melhor, no plural, a imagem da realidade. Desse modo, dir-se-á que tal acidente operou a 'ruína' de um edifício e dir-se-á que se veem em tal lugar as 'ruínas' desse edifício. (QUINCY apud KÜHL, 2003, p.112-113 - grifo nosso).

Em relação a essa pioneira definição de Quincy, Cesare Brandi (1906-1988) é o único, na historiografia da preservação patrimonial levantada, que chega a definir a ruína. Em sua Teoria da Restauração (1963) Brandi apresenta que: “[...] Ruína [rudere] será, pois, tudo aquilo que é testemunho da história humana, mas com um aspecto bastante diverso e quase irreconhecível em relação àquele de que se revestia antes. [...].” (BRANDI, 2004, p.65 - grifo nosso).

Embora haja um intervalo cronológico de mais de um século entre essas duas definições (Quincy e Brandi) é possível evidenciar como o entendimento do que seja a ruína é complexo, pois depende da correlação de alguns aspectos: distanciamento temporal em relação ao processo de arruinamento, grau de descaraterização da construção e razões que geraram o processo de arruinamento.

A ruína caracterizada pela "[...] dissolução de todas as partes [...]”, como apresentado por Quincy e por um “[...] aspecto bastante diverso e quase irreconhecível [...]” como mencionado por Brandi, condensa a problemática da interpretação e leitura de um objeto edificado que foi parcial ou totalmente deteriorado.

Essa complexa diferenciação entre uma ruína, em que se perdeu efetivamente a identificação da espacialidade arquitetônica e de um bem que foi danificado, mas que se reconhece ainda a sua totalidade espacial também foi mencionado por Alois Riegl (1858- 
1905) em sua obra Der moderne Denkmalkultus, sein Wesen, seine Entstehung (1903). Para Riegl, a degradação do monumento tem um limite para a mínima compreensão do objeto edificado e está associada à apreciação de seu aspecto pictórico:

As ruínas tornam-se sempre mais pitorescas, quando mais partes cedem à degradação; [...]. Mas esse processo tem também o seu limite; porque se ao fim a capacidade extensiva do efeito tenha sido completamente perdida, não restará mais nem sequer uma base para um efeito intensivo. Um simples monte de pedras não é suficiente para oferecer um valor de antigo: deve existir ao menos ainda um traço claro da forma original da obra humana antiga, de um porvir passado. Um monte de pedras ao invés representa somente um fragmento morto e sem forma da natureza na sua totalidade sem o traço de um porvir que sobrevive. (RIEGL, 1990, p.46 - trad. nossa - grifo nosso) ${ }^{29}$.

Para a compreensão desse aspecto pode-se retomar o conceito da unidade potencial da obra de arte desenvolvido por Brandi (1963) como uma unidade qualitativa (e não necessariamente quantitativa); assim, uma obra de arte pode ser lida na sua totalidade ainda que fisicamente fracionada, pois a unidade subsiste potencialmente como um todo indivisível. É nesse sentido que se caracteriza a dificuldade de entendimento da condição material da ruína, definido por Brandi como: “[...], naquele momento-limite (e é limite tanto no espaço quanto no tempo) em que a obra de arte, reduzida a poucos vestígios de si mesma, está prestes a cair no disforme.” (BRANDI, 2004, p.68). Segundo Brandi há uma grande complexidade em distinguir a ruína de um monumento histórico ou de uma obra de arte em relação à obra que ainda contém uma vitalidade implícita e da qual poderia ser reintegrada a sua unidade potencial originária: "não é [...] fácil definir quando, na obra de arte, cessa a obra de arte e aparece a ruína [...]" (Op. cit., p. 67).

A dificuldade para identificar o estado de ruína é um ponto que permanece atual e decisivo para estabelecer uma relação de valorização a esses conjuntos, cuja extrapolação se configura ao contrapor ruínas e escombros provocados por uma destruição catastrófica. $\mathrm{O}$ grau de destruição pode ser identificado pela dimensão e causa da lacuna. Em alguns casos a perda material é tamanha que impede a possibilidade de leitura do que a edificação pode ter sido em algum momento de sua história; em outros casos há evidencias maiores e mais precisas sobre a estrutura, seus materiais de construção, acabamentos etc.

\footnotetext{
${ }^{29}$ Trecho original: "Le rovine, diventano sempre più pittoresche, quante più parti di esse cedono al degrado; [...]. Ma questo processo ha anche un suo limite; perchè se alla fine la capacità estensiva dell'effetto andrà completamente perduta, non resterà più neppure alcuna base per un effetto intensivo. Un semplice mucchio di sassi non è sufficiente per offrire um valore dell antico: ci deve essere almeno ancora una chiara traccia della forma originale dell opera umana antica, di un divenire ormai passato. Un mucchio di sassi invece rappresenta soltanto un frammento morto e senza forma della natura nella sua totalità senza traccia di un divenire che soppravive.” (RIEGL, 1990, p. 46).
} 
Umberto Baldini se referiu ao momento da destruição que acomete um bem como thánatos $^{30}$ : "que pode se verificar por nossa inação total (incúria e abandono à deterioração), ou por um violento e traumático acontecimento externo (terremoto, guerra, queda, incêndio, etc.);" (BALDINI, 1981, p. 9 - trad. nossa) ${ }^{31}$. Segundo Baldini, o grau e o tipo de destruição podem gerar dois tipos de lacuna que tem conotações diversas: a "lacuna mancante" e a "lacuna perdita" (Op. cit. , p.22). A lacuna mancante remete à efetiva falta de algo que não se pode mais completar; a lacuna perdita remete à perda de partes de um todo que se conhecia. Essas diferentes lacunas ensejam diferentes tipos de aproximação aos bens em estado arruinado.

Além da compreensão da dimensão espacial da ruína, outro ponto importante para compor esta análise é a questão do uso. Pode-se considerar que o "estado de ruína" de um edifício se refira ao fato de: "[...] não está mais em grau de absolver a própria função original” (MARINO, 2003, p. 29 - trad. nossa) ${ }^{32}$, ou ainda ao fato de não poder abrigar uma função utilitária específica. Tendo como referência os três aspectos da arquitetura destacados no tratado de Vitruvius firmitas, utilitas e venustas (Livro I, cap. III apud MACIEL, 2009), podese considerar que a ruína é aquilo que sobrou do edifício ao desvanecer desses três elementos, mas principalmente com a perda de sua utilitas.

Tendo em vista esse argumento de que o processo de arruinamento de um edifício é quase sempre derivado da perda (ou falta) de um uso, podemos trazer à discussão o tema da classificação dos monumentos em "mortos" e "vivos" que durante o século XIX e início do século XX foi um parâmetro para a apreciação das ruínas. Essa classificação aparece em algumas referências da historiografia da preservação patrimonial.

No final do século XIX o arquiteto belga Louis Cloquet (1849-1920) apresentou que os monumentos "mortos" fazem parte do domínio da história e podem encontrar possíveis limites nas formas de utilização. Esses bens remanescem como lembranças e não podem ser restituídos ao uso original, como o caso dos templos gregos, das ruínas de Pompeia e de muitos castelos e abadias medievais. Gustavo Giovannoni (1837-1947) estabeleceu essa distinção considerando que os monumentos "mortos" são aqueles mais antigos como os da

\footnotetext{
${ }^{30}$ Thánatos: figura que na mitologia grega personifica da morte.

${ }^{31}$ Trecho original: "[...] che può verificarsi per nostra inazione totale (incuria e abbandono al deperimento) come per violento e traumatico accadimento esterno (terremoto, guerra, caduta, incendio etc.)" (BALDINI, 1981, p. 9).

${ }^{32}$ Trecho original: "[...] non è più in grado di assolvere alla propria funzione originaria [...]” (MARINO, 2003, p. 29).
} 
Antiguidade Clássica, aos quais normalmente se exclui uma transformação do estado de ruína e uma utilização atual; e monumentos "vivos" são aqueles mais recentes como palácios e igrejas para os quais deveriam ser destinadas funções não muito diversas das primitivas (GIOVANONNI, 1936).

Tendo em vista essa distinção, poderíamos nos questionar: em que medida as ruínas são consideradas monumentos "mortos"? No entanto, essa classificação pautada pelo uso das edificações passou por uma estrita revisão em meados do século XX. O texto de Roberto Pane (1897-1987) e Piero Gazzola (1908-1979) para a proposição da Carta de Veneza ${ }^{33}$ (1964) se refere ao fato de que a denominação de monumentos "mortos" e "vivos" deveria ser abolida, pois se embasava em dados empíricos que não englobam a abrangência do tema:

Se considerarmos um monumento 'vivo', na medida que é utilizável, sabemos bem que não poucas ruínas são mais vivas e utilizáveis que muitos monumentos íntegros; e isso considerando o significado geral do conceito de utilização, o que não pode ser limitado ao pressuposto de uma ocupação material. (GAZZOLA, PANE In: Il Monumento [...], 1964, p. 16 - trad. nossa - grifo nosso) $)^{34}$

O problema incorre na acepção do conceito de uso, conforme menciona Serafini (2005) a própria concessão da insígnia de "monumento" contradiz a ideia de monumento "morto", pois o bem com sua reconfiguração espacial derivada do processo de arruinamento estabelece continuamente novas relações e passa a exercer um tipo de "função social" que pode ser meramente memorial (ainda que não estritamente "utilitária") para um contexto urbano, para a vida de uma comunidade. Nesse sentido se estabelece a fruição dos monumentos no presente, enquanto herança cultural, mencionado por Roberto Pane na conferência introdutória da Carta de Veneza ${ }^{35}$ : "Não queremos conservar os monumentos do passado como um raro mundo de imagens que serve de refúgio à nossa nostalgia, mas como um patrimônio vivo e atual do nosso presente. [...]” (PANE In: Il Monumento [...], 1964, p. 12 e apud RUFINONI, 2013, p. 137 - grifo nosso).

\footnotetext{
${ }^{33}$ Proposte per una Carta Internazionale del Restauro In: Il Monumento per L'Uomo. Atti del II Congresso Internazionale del Restauro, 1964.

${ }^{34}$ Trecho original: "Se si vuole alludere ad un monumento 'vivo', in quanto utilizzabile, sappiamo bene che non pochi ruderi sono più vivi ed utilizabili di molti monumenti integri; e ciò, beninteso, nel signigicato generale del concetto di utilizzazione, quale è quello che non può essere limitato al presupposto di una materiale occupazione." (GAZZOLA, PANE In: Il Monumento [...], 1964, p. 16).

${ }^{35}$ Conférence Introductive In: Il Monumento per L'Uomo. Atti del II Congresso Internazionale del Restauro, 1964.
} 
Desse modo, a Carta de Veneza prescreve preferencialmente um uso ${ }^{36}$ aos monumentos, desde que o mesmo não comprometa a integridade física dos edifícios enquanto testemunhos históricos. As ruínas se enquadram, portanto, na noção de "testemunho vivo" apresentada na Carta de Veneza, que condensam um êxito dinâmico de modificação e transfiguração espacial que se rearticula com o meio.

À percepção do grau (mais ou menos arruinado) e da causa da ruína (ação do tempo, destruição violenta de ordem natural ou antrópica, falta de um uso, abandono) se interpõe o distanciamento temporal em relação ao processo de arruinamento. Conforme aponta Squassina (2012), o tempo é um relevante instrumento para a leitura de um bem estruturando um complexo sistema de relações que se estabelece nas ambivalências da continuidade e distanciamento; progresso e degradação ${ }^{37}$. No âmbito da preservação patrimonial, o texto de Quincy faz alusão ao fator temporal como meio para apreciação e valorização das ruínas:

\begin{abstract}
A palavra 'ruína' ou 'ruínas', [...], aplica-se, portanto, quase sempre a monumentos antigos. Aconteça o que acontecer com as 'ruínas' modernas, e isso por mais de uma causa, é certo, no entanto, que essas ruínas não têm e não podem ter para as artes, e em geral para o espírito, o mesmo grau de mérito e interesse. Milhares de ideias, milhares de lembranças, milhares de sentimentos ligam-se às ruínas dos monumentos antigos que não poderiam ser produzidos por aquelas de uma data recente. É por isso que as 'ruínas', à medida que envelhecem, parecem adquirir mais direitos pelo nosso respeito e, por consequência, pela sua conservação. (QUINCY apud KÜHL, 2003, p.113 - grifo nosso).
\end{abstract}

Através dessas asserções, Quincy aponta para a distância temporal em relação ao processo de arruinamento e para a idade da edificação arruinada. As ruínas mais antigas têm mais "direitos" pelo nosso respeito e nossa conservação? Obviamente que um bem mais "antigo" por ter sido mais exposto ao fator tempo, consequentemente pode ter acumulado um maior grau de arruinamento ao longo dos anos. Porém, bens mais "novos", de construção mais recente também podem ter sido arruinados e já há bastante tempo. Desse modo, pode-se considerar que o limiar temporal se concentra no distanciamento cronológico em relação ao processo de arruinamento podendo ser condensado na seguinte impostação: há quanto tempo o bem está em ruína?

\footnotetext{
36 “Art. 5': A conservação dos monumentos é sempre favorecida por sua destinação a uma função útil à sociedade; tal destinação, portanto, desejável, mas não pode nem deve alterar a disposição ou a decoração dos edifícios. É somente dentro destes limites que se deve conceber e se podem autorizar as modificações exigidas pela evolução dos usos e costumes." (ICOMOS, 1964 In: CURY, 2004, p.92).

${ }^{37}$ A relação do tempo com a duração da arquitetura é o argumento de recentes trabalhos, dos quais foram consultados: SQUASSINA, Angela. Tiempo que destruye, tiempo que conserva: sentido del tiempo y conciencia conservativa. Loggia, Madrid, n. 24-25, p.26-43, 2012. E: QUILICI, Vieri. La Vita delle Opere - Una riflessione e vari pretesti sulla durata in architettura. Roma: Palombi \& Partner Srl, 2011.
} 
Há, portanto, uma complexidade e multiplicidade de aspectos que implicam na definição da condição de ruína de um bem edificado: graus e causas de destruição, tempo do processo de arruinamento, idade das edificações arruinadas e estado de uso configuram paradoxos que por vezes são mais evidentes e outras vezes são muito tênues.

Na língua portuguesa a definição de ruína também envolve essa complexidade de fatores associados à sua identificação:

Ruína: 1 ato ou efeito de ruir 2 restos ou partes mais ou menos informe de um ou mais prédios desmoronados ou destruídos pelo tempo, explosão, incêndio etc.; escombros, destroços, ruinaria 3 fig estado de destruição, de degradação; modificação para pior; aniquilamento, extermínio [...] 8 p. ext. que não é mais como era, que perdeu seus atributos ou encantos; sombra Etim. lat. Ruina,ae 'queda, ruína; destruição, desgraça, desventura [...]; pl. ruínas, escombros, entulho' [...]. (HOUAISS e VILLAR, 2001, p. 2482 - grifo nosso).

Para esta tese, é utilizada essa definição, cuja caracterização se dá pelo estado de degeneração de um bem arquitetônico de qualquer datação que pode ter sido motivado por uma ou mais causas (tempo, abandono, incidentes, demolições, etc.). Entendemos por ruína uma condição física caracterizada pela degradação da matéria edificada com perdas de suas características anteriores, não sendo apenas o fator temporal o único elemento que causa o arruinamento.

A própria terminologia atribuída aos bens arquitetônicos em estado de ruína é relevante para sua compreensão. Na língua italiana, por exemplo, há duas palavras distintas para a designação de ruínas: rudere e rovina, que enfatizam a diferenciação na leitura espacial do objeto. Rudere se refere a não espacialidade, aos fragmentos e restos, aquilo que perdeu a referência estética do que um dia pode ter sido, não há a possibilidade de ligação com a consciência integral daquilo que um dia foi. Rovina se refere a um bem que foi acometido por um processo de arruinamento inesperado (deriva do verbo rovinare), sua totalidade espacial arquitetônica e seu ordenamento tectônico ainda é legível (DI MUZIO, 2010).

$\mathrm{Na}$ língua portuguesa há alguns termos que são usados para se referir ao estado arruinado como: destroços, escombros, fragmentos, remanescentes, restos e vestígios ${ }^{38}$. Como

\footnotetext{
${ }^{38}$ Conforme as seguintes designações: "Destroço: 1 estado de ruína; devastação [...] 2 ato ou efeito de destroçar; desbaratamento, derrota, destruição. [...]" (HOUAISS e VILLAR, 2001, p. 1019 - grifo nosso). "Escombros: destroços, entulhos (a bomba reduziu a casa a e.) [...]" (Op. cit., p. 1207). "Fragmento: 1 pedaço de coisa que se quebrou, cortou, rasgou etc. [...] 2 parte de um todo; fração [...] 3 resto de uma obra literário ou artística cuja maior parte se perdeu ou foi destruída; [...]" (Op. cit., p. 1384). "Remanescente: que ou o que remanesce, que sobeja, que resta; [...]"; "Remanescer: subsistir como sobrevivente, sobra, resto, etc.; [...]" (Op. cit., p. 2423). "Resto: 1 . O que sobra, o que fica de um todo de que se retirou uma ou várias partes 2 aquilo que resta, que permanece; remanescente [...] 5. Fragmentos, traços daquilo que foi arruinado; ruínas, destroços. 6. Coisas que sobraram; [...];" (Op. cit., p. 2443). "Vestígio: 1 pisada ou marca deixada por homem ou animal nos caminhos
} 
não há uma diferenciação pautada por um critério específico tomamos como referência o termo "ruína".

Para o entendimento das ruínas, há que se considerar ainda que a leitura de suas intrínsecas características pode ser orientada a partir de duas perspectivas: documental e simbólica. Na acepção do documento - monumento ${ }^{39}$ desenvolvido pelo historiador Jacques Le Goff (2010) pode-se considerar que as ruínas são elementos fundamentais que atestam o testemunho da sobrevivência material do que um dia existiu - de onde é possível extrair informações sobre a composição anterior do objeto; mas as ruínas também são um testemunho das causas de sua destruição e do que pode ter sido esquecido. As ruínas refletem, portanto, uma dúplice capacidade informativa sobre a reminiscência e a perda.

Sob a perspectiva simbólica, o caráter evocativo e alegórico das ruínas é latente conforme destacado por Walter Benjamin (1892-1940): “As alegorias são, no campo do pensamento, o que as ruínas são no campo das coisas" (BENJAMIN apud BARBANERA e CAPODIFERRO, 2015, p.11 - trad. nossa $)^{40}$. Uma rede de significados pode ser atribuída às ruínas (PRESSOUYRE, 1991) a partir da ambiguidade de sua própria materialidade que remete simultaneamente: à presença e à ausência; à continuidade e à descontinuidade; à permanência e à efemeridade. A problemática de enfrentamento com a realidade do arruinamento encerra evocações à passagem do tempo, às perdas, à destruição e ao abandono. No âmbito da noção de patrimônio e memória, segundo Henri-Pierre Jeudy, a atribuição desses simbolismos é uma construção relativa a uma "história longa" (JEUDY, 2005, p.22) na qual se percebe a continuidade e a "história imediata" (Op. cit., p.22) relacionada a uma experiência recente que pode comprometer o senso de continuidade.

por onde passa; rastro pegada 2 fig. Aquilo que restou (de alguma coisa que se destruir, que desapareceu) [estas ruínas são v. de uma antiga civilização] [...] 3 qualquer marca, traço, indício, sinal que localizem alguém ou algo [...] v. arqueológico o material (fósseis, artefatos, monumentos, etc.) que restou da vida de povos antigos, que permite estudar suas culturas, costumes e condições de vida. Etim. Vestigium: 'planta ou sola dos pés (das pessoas ou dos animais), pegada, pista, rastro, traço, sinal, marca';"' (Op. cit., p. 2853).

${ }^{39}$ Cf.: "O documento não é inócuo. É antes de mais nada, o resultado de uma montagem, consciente ou inconsciente, da história, da época, da sociedade que o produziram, mas também das épocas sucessivas durante as quais continuou a viver, talvez esquecido, durante as quais continuou a ser manipulado, ainda que pelo silêncio. O documento é uma coisa que fica, que dura, e o testemunho, o ensinamento (para evocar a etimologia) que ele traz devem ser em primeiro lugar analisados, desmitificando-lhe o seu significado aparente. $O$ documento é monumento.” (LE GOFF, 2010, p. 537-538)

${ }^{40}$ Trecho original: "Le allegorie sono, nel campo del pensiero, ciò che le rovine sono in quello delle cose" (BENJAMIN apud BARBANERA e CAPODIFERRO, 2015, p.11). 
A confluência dessas características apresentadas e sua interpretação sob o ponto de vista documental e simbólico estabelece uma complexa relação com os bens em estado de ruína que é relevante para direcionar as formas de intervenção.

\subsubsection{Grupos identificados}

$\mathrm{Na}$ interpolação dessas reflexões que constituem a problemática para a identificação do que é uma ruína distinguimos uma possível metodologia com o objetivo de aplicá-la à verificação do tema dos bens em estado arruinado no patrimônio cultural brasileiro. Para desenvolver esta análise identificamos três principais grupos em que pode ser utilizada a noção de ruína, tendo como critério a correlação de dois aspectos prevalentes: a conjunção dos fatores que causaram a degradação e o tempo decorrido desse processo.

1 Ruínas do tempo: bens edificados que chegam ao momento de reconhecimento de seu valor cultural em estado arruinado. O fator tempo aqui foi o principal agente da degradação e há certo distanciamento cronológico (com graduações diversas de anos, décadas ou séculos) em relação ao arruinamento.

2 Ruínas da incúria: edificações íntegras até o reconhecimento de seu valor cultural e que posteriormente foram acometidas por processos de arruinamento. A deterioração ocorreu lentamente nos últimos anos por fatores que podem ser derivados da negligência com sua manutenção e a falta de um uso contínuo.

3 Ruínas do incidente: edificações de reconhecido valor cultural que foram acometidas por um episódio súbito e inesperado - causado por catástrofes de ordem natural ou antrópica - que gerou a sua degradação.

A organização desses grupos que serão analisados nos próximos capítulos pretende tão somente direcionar a discussão de modo a abranger os possíveis questionamentos engendrados a partir da verificação da aplicação da noção de ruína para o tratamento do patrimônio cultural edificado no Brasil. Não é nossa pretensão estabelecer categorias de classificação, pois como demonstrado na definição, a acepção de ruína envolve uma complexa gama de características e fatores.

Cada um desses grupos será apresentado através de dois estudos de caso para aferir como as características que constituem a sua respectiva condição de ruína interferem na valorização desses bens e nas formas de intervenção. Cabe esclarecer que os casos foram selecionados entre os bens sob a tutela do tombamento (listados ou com abertura de processo), 
já que esse é o principal instrumento legal de reconhecimento do valor cultural do patrimônio no Brasil. Para estabelecer uma amostragem do panorama brasileiro, optou-se por selecionar bens no recorte geográfico do Estado de São Paulo, mas a sua análise pode implicar na correlação com casos de outras localidades (tendo como referência a esfera institucional: bens tombados ou com abertura do processo de tombamento).

Para o grupo das ruínas do tempo são analisados o Engenho São Jorge dos Erasmos (Santos, SP) e a Capela do Morumbi (São Paulo, SP); para o grupo das ruínas da incúria o a antiga Sede do Sítio Mirim (São Paulo, SP) e a antiga Sede do Sítio Itaim (São Paulo, SP); e para o grupo das ruínas do incidente o Teatro Cultura Artística (São Paulo, SP) e a Igreja Matriz São Luiz de Tolosa (São Luiz do Paraitinga, SP). O critério para a seleção desses bens está embasado na sua relação ao tema da ruína e à forma de afrontá-lo em diversos momentos da historiografia da preservação patrimonial brasileira chegando à contemporaneidade, através de ações recentes. 


\subsection{Ruínas em outros contextos culturais: salvaguarda e teorias da preservação}

A partir da contextualização do panorama brasileiro e da definição de ruína que estrutura esta tese, considera-se pertinente entendê-la em outros ambientes culturais a fim de verificar como se estabelece a relação entre o entendimento sobre patrimônios arruinados, o desenvolvimento de teorias fundamentais da preservação e o tratamento desses bens, evidenciando aspectos que serão desenvolvidos nas análises dos capítulos posteriores.

As principais formas de intervenção em ruínas convergem para duas posturas que poderiam ser sintetizadas em salvar um bem da ruína ou conservar esse estado de ruína; posições que refletem parte de preceitos teóricos que sinalizam para duas vertentes distintas e até mesmo antagônicas que se desenvolveram durante o século XIX: a vertente voltada aos refazimentos e completamentos em estilo cujo expoente foi Eugène Emmanuel Viollet-le-Duc (1814-1879) e a vertente mais conservativa representada por John Ruskin (1819-1900). Por um lado, a necessidade de reportar uma edificação ao momento presente através de intervenções que desconsideram a passagem do tempo e retomam a uma possível e selecionada imagem de passado; por outro, a apreciação do monumento enquanto documento único e irreprodutível que contém a sobreposição de diversas fases.

Essas manifestações teóricas e práticas alimentaram debates e revisões, confluindo para o desenvolvimento de teorias intermediárias, muitas das quais afloraram na Itália, em especial na Lombardia, e podem ser sintetizadas nas ideias de Camillo Boito (1836-1914) que foi um dos principais mentores do denominado "restauro científico" ou "filológico", configurando um eixo de tratamento aos bens em que se trabalha a partir de sua materialidade intrínseca, com sua historicidade e marcas temporais.

Embora o foco e ênfase deste trabalho seja a averiguação do cenário brasileiro, considera-se válido compreender o desenvolvimento dessas vertentes em seus respectivos meios culturais através da relação que foi estabelecida com um legado edificado em condição de ruína.

Em suas viagens ${ }^{41}$ pelo território francês, Viollet-le-Duc empreendeu uma sistemática análise dos remanescentes medievais - muitos dos quais em estado de ruína - em sintonia com

\footnotetext{
${ }^{41}$ Durante a década de 1830, Viollet-le-Duc realizou algumas viagens, primeiro para a França e posteriormente à Itália, visitando diversas cidades e realizando estudos detalhados dos monumentos antigos em companhia do gravador León Gaucherel (1816-1886).
} 
o crescente interesse em relação à arquitetura medieval europeu de modo a configurar uma consciência de identidade cultural que poderia sustentar o ideário de nação; um fenômeno que não era exclusivo da França, mas que se estendia a territórios da Inglaterra e futura Alemanha ${ }^{42}$.

Entre 1854 e 1868 Viollet-le-Duc publicou o Dictionnaire Raisonné de L'Architecture Française du XIe au XVIe siècle, um minucioso inventário ilustrado sobre a arquitetura medieval. É sugestivo verificar que nessa obra Viollet-le-Duc não dedicou nenhum verbete às ruínas como o fizera Quatremère de Quincy algumas décadas antes (já mencionado neste capítulo). Nas discussões patrimoniais apresentadas por Viollet-le-Duc ao desenvolver o Verbete Restauração há um destaque para o papel da Commission des Monuments Historiques $^{43}$ diante do legado arquitetônico medieval francês recentemente identificado e em mau estado de preservação:

Por certo, os primeiros que pensaram em salvar da ruína os mais belos edifícios sobre nosso solo, [...]. Ficaram horrorizados com a destruição que ameaçava todos esses remanescentes tão notáveis e com os atos de vandalismo realizados todo dia com a mais cega indiferença; [...] (VIOLLET-LE-DUC, 2000, p.61 - grifo nosso).

Por contraponto ao estado de ruína dos bens arquitetônicos identificados, Viollet-leDuc ressaltou: "Os trabalhos de restauração empreendidos na França [...] não somente salvaram da ruína obras de incontestável valor, mas prestaram serviço imediato. [...], pois esses edifícios, [...], preservados da ruína, ficarão ainda de pé durante séculos, $[\ldots]$ ” ( $O p$. cit., p.64 - grifo nosso).

Essas considerações de Viollet-le-duc em relação às ruínas e aos trabalhos da Commission des Monuments Historiques são invocadas para apresentar a estrutura principal de sua metodologia de intervenção ao patrimônio edificado: "Restaurar um edifício não é mantê-lo, repará-lo ou refazê-lo, é restabelecê-lo a um estado completo que pode não ter

\footnotetext{
${ }^{42} \mathrm{Na}$ Alemanha, um dos grandes protagonistas do restauro estilístico e da cultura arqueológica medieval foi Sulpiz Boisseré (1783-1854). A partir de 1808 iniciou o projeto que lhe conferiria grande fama: o restauro da Catedral de Colônia, edificação que por séculos ficou incompleta e que apresentava graves condições de abandono e degradação. O projeto, a despeito de controverso, agregou muitos partidários e teve predomínio o estilo gótico com o objetivo de conformar um novo símbolo que expressasse a união e a força da nação em desenvolvimento. O projeto foi publicado em 1823 (Cf: SETTE, 2004, p.168-170).

${ }^{43}$ Comissão criada em 1837. Ludovic Vitet (1802-1873) foi o primeiro a ocupar o cargo de inspetor geral presidindo a Comissão até 1848, período em que várias edificações foram estudadas no território francês, não só da Idade Média, mas também da Antiguidade Romana (VIOLLET-LE-DUC, 2000, p.44). A partir de 1830 foram feitas várias viagens e foram gerados relatórios de grande repercussão, com detalhados estudos sobre edificações até então desconhecidas. As posteriores incursões de Prosper Mérimée (1803-1870), também foram relevantes. Para mais detalhes ver: La naissance des Monuments historiques - la correspondance de Prosper Mérimée avec Ludovic Vitet (1840-1848).
} 
existido nunca em um dado momento." (VIOLLET-LE-DUC, 2000, p.29) ${ }^{44}$. Desse modo, ele definiu o princípio fundamental do retorno a uma pretensa unidade de estilo que marca sua atuação em relação aos monumentos e que fundamenta o conceito do denominado restauro “estilístico". Viollet-le-Duc compreende, portanto, que o passado está morto, a passagem do tempo e suas marcas não devem ser aceitas e a intervenção é necessária para restituir o edifício a um estado "original”, salvando os mesmos da ruína iminente. Um ideário que permite compreender as intervenções que Viollet-le-Duc realizou em conjuntos medievais arruinados.

Como destaca Sette (2004), há um notável acento nos aspectos criativos dos completamentos da fortificação da cidade de Carcassonne - cujas obras tiveram início a partir de 1852; e no Castelo de Pierrefonds - intervenção a partir de 1857. Nesses casos o arquiteto procurou revelar o potencial informativo das ruínas existentes, não dissimulando elementos pertencentes a momentos diversos, mas, ao mesmo tempo, se lançando a uma projetação em grande medida fantasiosa, reconstruindo as partes faltantes segundo o que deveria ter sido (CARBONARA, 1997).

As prerrogativas leducianas influenciaram muitas intervenções e experimentações na práxis da restauração em toda a Europa; no entanto, não foram isentas de críticas e alimentaram discursos com uma postura mais conservativa cujos argumentos se desenvolveram principalmente por parte de arqueólogos no que concerne aos monumentos mais antigos na medida em que se procurava respeitar a obra enquanto documento histórico. No cenário francês, o arqueólogo Adolphe Didron (1806-1867) diretor dos Annales archéologiques enunciou um axioma em 1845 que ilustra essa preocupação:

De fato, nos monumentos antigos, é melhor consolidar que reparar, é melhor reparar que restaurar; é melhor restaurar que refazer; é melhor refazer que embelezar; em nenhum caso se deve acrescentar e em nada suprimir (DIDRON In: CARBONARA, 1997, p.107 - trad. nossa) $)^{45}$

\footnotetext{
${ }^{44}$ Trecho original: "Restaurer un édifice, ce n'est pas l'entretenir, le réparer ou le refaire, c'est le rétablir dans un état complet qui peut n'avoir jamais existè à un moment donné." (VIOLLET LE-DUC, 1967, Tomo 8, p. 14).

${ }^{45}$ Texto original: "En fait de monuments anciens, il vaut mieux consolider que réparer; mieux réparer que restaurer; mieux restaurer que refaire; mieux refaire qu'embellir; en aucun cas, il ne faut rien ajouter, surtout rien retrancher" (DIDRON In: CARBONARA, 1997, p.107).
} 


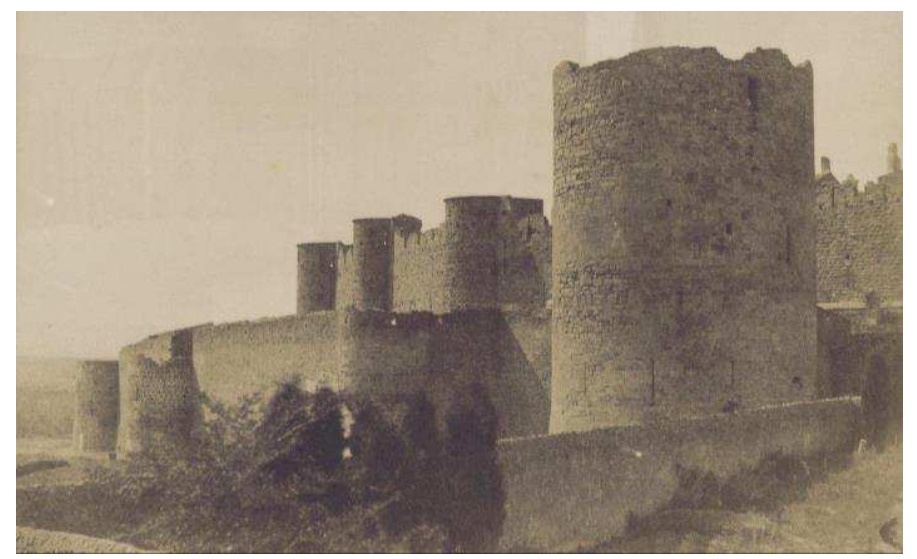

Fig. 03: Fortificação de Carcassonne antes dos trabalhos de restauração. Fonte: Wikimedia Commons, domínio público. Disponível em: <https://commons.wikimedia.org/w/index.php?curid=25175159>, acesso em abril 2016. Foto: Gustave Le Gray (1820-1884), publicada c. 1851.

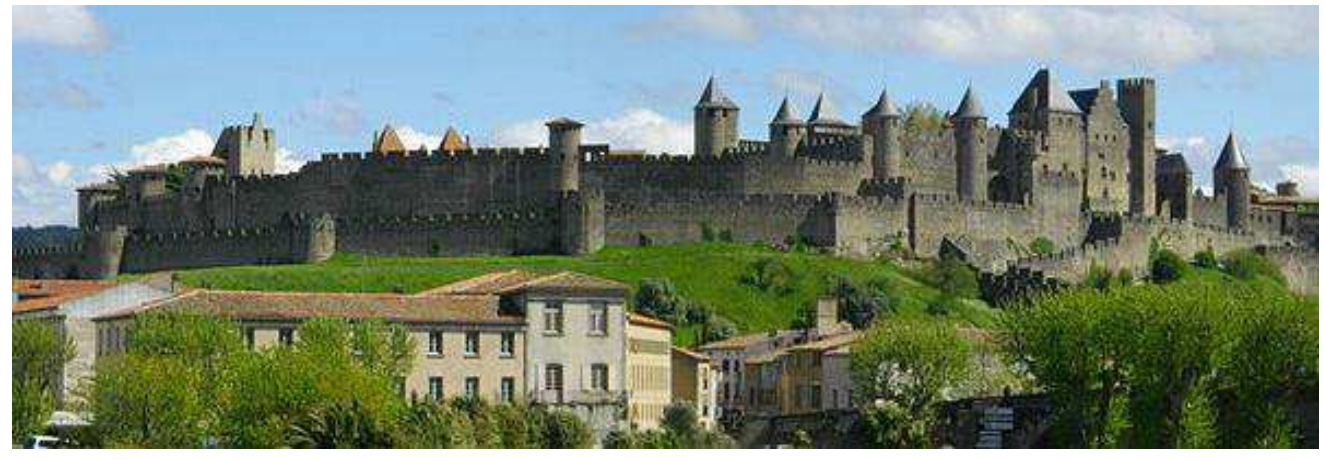

Fig. 04: Panorama da fortificação de Carcassonne após os trabalhos de restauro, 2009. Fonte: Wikimedia Commons. Disponível em:

<https://fr.wikipedia.org/wiki/Cit\%C3\%A9_de_Carcassonne\#/media/File:Cit\%C3\%A9_de_Carcassonne.jpg>, acesso em 16 abril 2016.

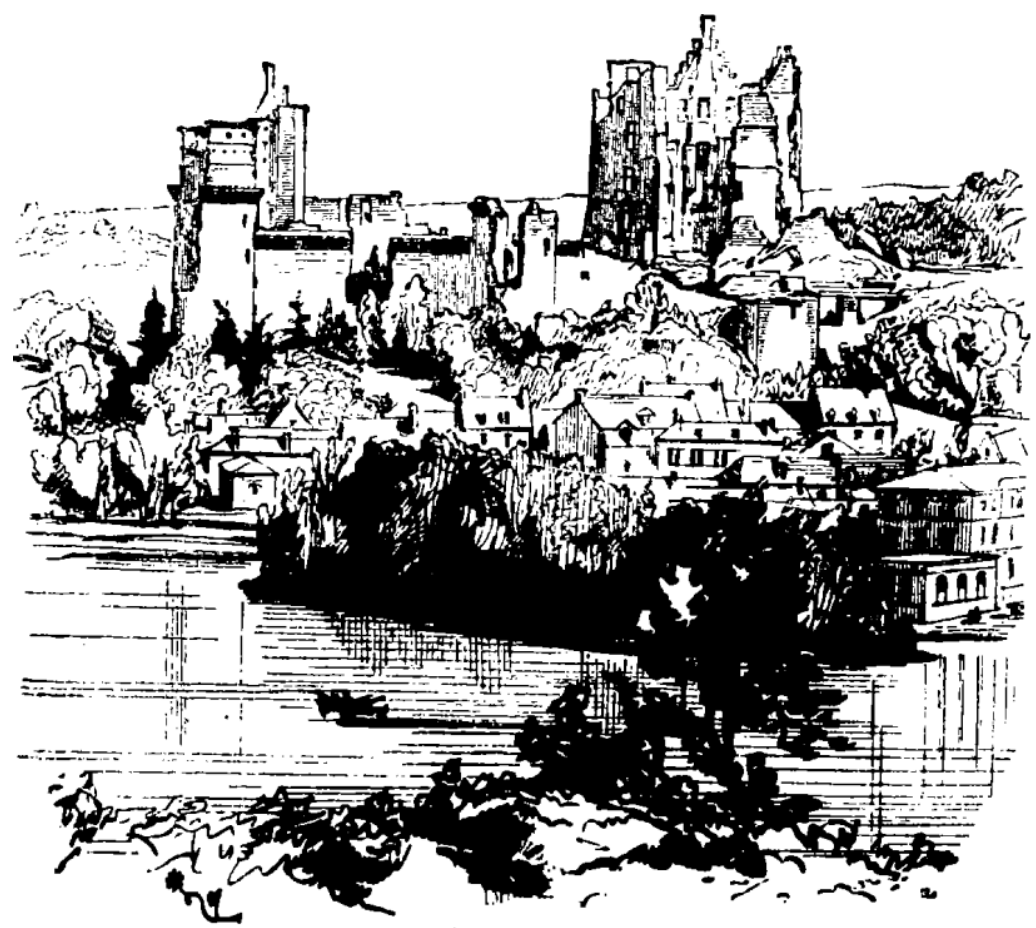

Fig. 05: Gravura de Viollet-le-Duc descrevendo a situação de incompletude do Castelo Pierrefonds antes da restauração. Fonte: Wikimedia Commons, domínio público. Disponível em:

<https://commons. wikimedia.org/w/index.php?curid=66643>, acesso em 16 abril 2016. 
No cerne dessas considerações conservativas está a valorização da arquitetura do passado em contraposição ao modo de vida contemporâneo que se interpunha de modo massivo às cidades. O Reino Unido encontrou nos monumentos antigos, suas ruínas e despojos, objetos de reflexão sobre a ruptura traumática proporcionada pelos efeitos da industrialização, sobre a inerente transitoriedade das obras humanas agregando valores pictóricos e pitorescos a esses bens.

As ruínas tiveram um papel fundamental para embasar os debates patrimoniais no Reino Unido e nortear diretrizes de preservação até a contemporaneidade. Conforme destacado por Thurley (2013), ainda durante o século XVIII, as primeiras reuniões da Society of Antiquaries of London (1707-08) colaboraram para a promoção da ideia de que as ruínas do período medieval deveriam ser preservadas como monumentos culturais.

A maioria desse legado medieval é proveniente da Reforma devido à abrupta interrupção da vida monástica na Inglaterra e Gales. Entre 1536 e 1541, durante o Reinado de Henrique VIII (1509-1547), houve a separação da Igreja Católica da Igreja Anglicana; nesse contexto foram tomadas medidas administrativas e jurídicas para dissolver mosteiros, conventos e confrarias na Inglaterra, País de Gales e Irlanda, como consequência esses conjuntos entraram em decadência e depredação, constituindo: “[...] a mais dramática criação de ruínas na história da Inglaterra."46 (THOMPSON, 1981, p.14 - trad. nossa). As consequências dessa dissolução monástica e as ruínas que foram produzidas nesse período influenciaram as posteriores percepções em relação a esse legado ${ }^{47}$.

A apreciação dos conjuntos arruinados no Reino Unido relaciona-se também às transformações econômicas e culturais na Europa da Revolução Industrial e do Iluminismo, quando surgiram os chamados Grand Tours, cujo roteiro englobava Paris e as principais cidades Italianas: Roma, Veneza, Florença, Nápoles e região da Sicília (SALGUEIRO, 2002). O Grand Tourist provinha da França, da Alemanha e primordialmente da Inglaterra, em geral por parte de suas sociedades antiquárias privadas, mas também para a formação de intelectuais e artistas. Conforme destaca Thurley (2013), a grande viagem continental estimulava a ideia de um turismo "em casa"; enquanto o roteiro pela Europa era uma atividade restrita à aristocracia, pessoas de diversas classes sociais podiam se deslocar por

\footnotetext{
${ }^{46}$ Trecho original: “[...] the most dramatic creation of ruins in England.” (THOMPSON, 1981, p.14).

${ }^{47}$ Durante o século XVIII, em termos estéticos essa apreciação das ruínas no Reino Unido levou ao gothic revival. O trabalho Da ruína ao edifício - Neogótico, reinterpretação e preservação do passado na Inglaterra vitoriana (2008) da historiadora Cristina Meneguello investiga em detalhes esse processo de valorização do gótico enquanto estilo no cenário inglês.
} 
distâncias mais reduzidas em pequenas jornadas de um dia ou fim de semana e vislumbrar grandes monumentos em ruínas mais próximos.

Concomitantemente, entre 1840 e 1890, como destaca Meneguello (2008) surgiram inúmeras sociedades históricas, arqueológicas, de arquitetura e história natural nos diversos condados, cujo objetivo era estudar a história local a partir de seus vestígios e de seus monumentos, fundamentando discursos que enalteciam a importância em conhecer e apreciar suas origens e seu legado cultural através das ruínas da arquitetura medieval (Castelos, Fortalezas, Monastérios e Igrejas), da dominação do Império Romano e os assentamentos préhistóricos. Nesse contexto, foram publicados manuais que serviam como guias turísticos ${ }^{48}$ com as indicações dos principais locais para a visitação.

Essa valorização cultural dos monumentos do passado com especial atenção às ruínas permite estabelecer uma estreita relação com o desenvolvimento do ideário de John Ruskin e sua postura conservacionista. Em The Seven Lamps of Architecture ${ }^{49}$, (1849), no capítulo The Lamp of Memory (A Lâmpada da memória) ${ }^{50}$ Ruskin evidencia a importância da idade do edifício enfatizando a pátina como o elemento que materializa a passagem do tempo num contraste com a vanidade das obras humanas:

Pois, de fato, a maior glória de um edifício não está em suas pedras, ou em seu ouro. Sua glória está em sua Idade, [...]. [Sua glória] Está no seu testemunho duradouro diante dos homens, no seu sereno contraste com o caráter transitório de todas as coisas, na força que - através da passagem das estações e dos tempos, e do declínio e nascimento das dinastias, e da mudança da face da terra, e dos contornos do mar mantém sua forma esculpida por um tempo insuperável, conecta períodos esquecidos e sucessivos uns aos outros, e constitui em parte a identidade, por concentrar a afinidade das nações. É naquela mancha dourada do tempo que devemos procurar a verdadeira luz, a cor e o valor da arquitetura; [...] (RUSKIN, 2008, p.68 - grifo nosso)

Sua defesa da necessidade de conservação constante dos edifícios é um preceito fundamental em contraponto à necessidade da restauração. O conceito da mínima intervenção

\footnotetext{
${ }^{48}$ Conforme Thurley (2013) alguns exemplos de vulto foram: The Castles and Abbeys of England (1842) do físico e poeta escocês William Beattie (1793-1875). Ruined Abbeys and Castles os Great Britain (1862), trabalho desenvolvido por Mary e William Howitt; uma publicação pioneira pela forma de apresentação dos locais históricos arruinados associando ilustrações e fotografias, cobrindo 17 locais diferentes da Grã-Bretanha.

${ }^{49}$ Entre 1851 e 1853 Ruskin publicou The Stones of Venice. Nessa obra ele fez referência ao pintor Joseph Mallord William Turner e à arquitetura gótica: "[...] a escola da pintura inglesa de paisagens, que culmina em Turner, não é mais do que a piedosa tentativa de preencher o vazio deixado pela destruição da arquitetura gótica." (RUSKIN apud RUHL In: LAMERS-SCHÜTZE, 2003, p.464). Turner desenvolveu o tema das ruínas do gótico inglês tais como a série sobre Tintern Abbey: Tintern Abbey: the Transept (c. 1794); Tintern Abbey: the crossing and chancel, looking owards the east window (1794); Inside of Tintern Abbey, Monmouthside (1794); Ruins of West Front, Tintern Abbey (c. 1794-5).

${ }^{50}$ Além da Memória, as outras “Lâmpadas” são: Sacrifício, Verdade, Poder, Beleza, Vida e Obediência.
} 
é então apresentado por Ruskin na medida em que essa manutenção deva ocorrer de forma pontual respeitando a integridade da edificação em sua condição atual. Segundo o autor, a estabilização da preexistência deve ocorrer, ainda que em detrimento de seu aspecto formal, de modo a preservá-la enquanto herança que recebemos e devemos deixar às gerações futuras, mas aceitando que, a despeito de todos os esforços, fatalmente seu fim chegará ${ }^{51}$.

As teorias de Ruskin propiciam uma leitura em que o bem arruinado é valorizado a partir de seus atributos estéticos, históricos e evocativos, sem qualquer pretensão em reconstituí-lo, pois, parte-se da premissa que o status quo arruinado é fundamental para a apreciação e compreensão de sua história. Uma postura oposta à de Viollet-le-Duc, para quem a ruína é uma situação a ser sanada.

O pensamento de Ruskin teve grande repercussão na Inglaterra vitoriana propiciando o desenvolvimento de uma consciência favorável à conservação e salientado a importância do monumento enquanto documento histórico. Como destaca Pinheiro (2004), essa postura teórica anti-intervencionista tem um reflexo até hoje na abordagem ao tema da preservação patrimonial na Grã-Bretanha, onde se utiliza a palavra "conservação" (conservation) ao invés de "restauração" (restoration). Na política de salvaguarda na Grã-Bretanha, o projeto de lei de 1873, cujo principal mentor foi o intelectual John Lubbock (1834-1913), previa a segmentação dos monumentos entre: "historic monuments" (monumentos históricos) e "ancient monuments" (monumentos antigos). Os bens em ruínas que se enquadram na categoria dos ancient monuments são em sua maioria edificações inabitadas, sem um uso regular, representativas da pré-história, do legado romano e do período medieval. Enquanto os historic monuments englobam bens de construção mais recente e em atividade (THOMPSON, 1981). Esse projeto tomaria maiores proporções com o Ato Legislativo de $1882^{52}$ que efetivamente tratava da proteção aos monumentos antigos; após esse Ato, outras leis complementares foram incorporadas.

Devido à ausência de uso, a maioria dos monumentos antigos passou para a administração do Estado que tem investido em sua conservação ao longo do tempo. Muitas intervenções foram realizadas pela Inspectorate of Ancient Monuments do Office of Works -

\footnotetext{
${ }^{51}$ Cf.: "[...] coloque sentinelas em volta dele como nos portões de uma cidade sitiada; amarre-o com tirantes de ferro onde ele ceder; apoie-se com escoras de madeira onde ele desabar; não se importe com a má aparência dos reforços: é melhor uma muleta do que um membro perdido; e faça-o com ternura, e com reverência, e continuamente, e muitas gerações ainda nascerão e desaparecerão sob sua sombra. Seu dia fatal por fim chegará; mas que chegue declarada e abertamente, e que nenhum substituto desonroso e falso prive o monumento das honras fúnebres da memória." (RUSKIN, 2008, p.82 - grifo nosso).
}

${ }^{52}$ The Ancient Monuments Protection Act (1882). 
instituição estabelecida no século XIV para a manutenção das propriedades da Coroa, que com o aumento das atividades nos séculos seguintes, passou a ter um departamento específico para os ancient monuments implantado no final do século XIX. Nesse contexto, havia uma prescrição para que o tratamento dos conjuntos arruinados fosse orientado pelo critério da mínima intervenção sem alterar seu caráter defendendo a necessidade de valorizá-los enquanto documentos históricos e como tal, deveriam ser "preservados como encontrados" (THURLEY, 2013, p. 132 - trad. nossa) ${ }^{53}$, a despeito de sua danificação ou fragmentação.

Conforme Gill Chitty (1987) esse paradigma permeia a maioria das intervenções em monumentos antigos arruinados no Reino Unido e passou por adaptações nas intervenções do início do século XX a fim de transformar as decadentes e "pitorescas" ruínas das paisagens rurais em "ruínas instrutivas" (THURLEY, 2013, p. 133 - trad. nossa) ${ }^{54}$. O arquiteto e arqueólogo Charles Peers (1868-1952), inspetor chefe do Inspectorate of Ancient Monuments $^{55}$ do Office of Works entre 1913 a 1933, estabeleceu um método para potencializar uma leitura didática de uma determinada história dos conjuntos arruinados a partir da limpeza da vegetação, liberação de acréscimos, consolidação estrutural e produção de livros guia.

É desse período alguns dos primeiros grandes programas de reparações aos conjuntos monásticos medievais. Tintern Abbey (Monmouthshire, Wales), proveniente do século X, era uma Abadia que foi transferida ao Estado em 1914 cujos trabalhos envolveram escavações, consolidações, sistematização da implantação e demolição de adições que obscureciam os detalhes medievais. O conjunto monástico de Rievaulx Abbey ${ }^{56}$ (Yorkshire) foi transferido para o Estado em 1917 e inclui a primeira grande abadia Cisterciense a ser construída na Inglaterra. As intervenções iniciaram-se em 1919 a cargo de Peers que optou por promover a estabilidade física utilizando materiais recentes como ferro e concreto. O projeto baseava-se na visibilidade do conjunto retirando adições e vegetações para torná-lo legível e acessível ao grande público, tomando a edificação como um manuscrito que pudesse revelar o sistema de vida relacionado àquela arquitetura preterida.

\footnotetext{
53 Texto original: “[...] preserved as found.” (THURLEY, 2013, p. 132).

${ }^{54}$ Texto original: “instructive ruins" (Op. cit., p. 133).

${ }^{55} \mathrm{O}$ primeiro inspetor foi o arqueólogo Augustus Lane-Fox Pitt-Rivers (1827-1900).

56 “[...] Rievaulx é talvez a mais bonita de todas as nossas abadias arruinadas, [...]” (PEERS apud Op. cit., p. 100 - trad. nossa). Texto original: “[...] Rievaulx is perhaps the most beautiful of all our ruined abbeys [...]”.
} 
No entanto, para preservar as ruínas "tal como encontradas", muitos remanescentes foram, segundo Rizzi (2007), reposicionados e restaurados, descaracterizando sua real condição inicial. Embora os trabalhos partissem da premissa "preserve as found", muitos desses sítios foram modificados de modo a garantir sua inteligibilidade e acessibilidade ao público. A abordagem pouco científica desses trabalhos suscitou muitas críticas, uma vez que as escavações revelaram fragmentos de diversas fases e camadas, muitos dos quais foram reenterrados, privilegiando a fase mais antiga da arquitetura das abadias. Além disso, tendo em vista a composição pictórica desses conjuntos, como mencionado pela escritora inglesa Rose Macaulay (1881-1958) em sua publicação Pleasure of Ruins (1953): “As abadias inglesas estão em geral perfeitamente limpas e cuidadas, o que as fez perder sem dúvida alguma grande parte de seu mistério e de seu ar nostálgico" (MACAULAY, 1965, p. 163 trad. nossa $)^{57}$.

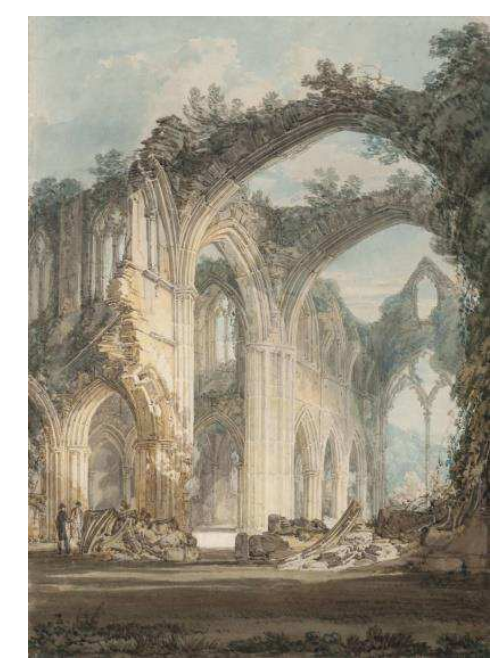

Fig. 06: Uma das pinturas de William Turner (1775-1851) sobre as ruínas de Tintern Abbey -The Chancel and Crossing of Tintern Abbey, 1784. Fonte: Wikimedia Commons, domínio público. Disponível em: <https://commons. wikimedia.org/w/index.php?curid=2543506> acesso em 16 abril 2016.

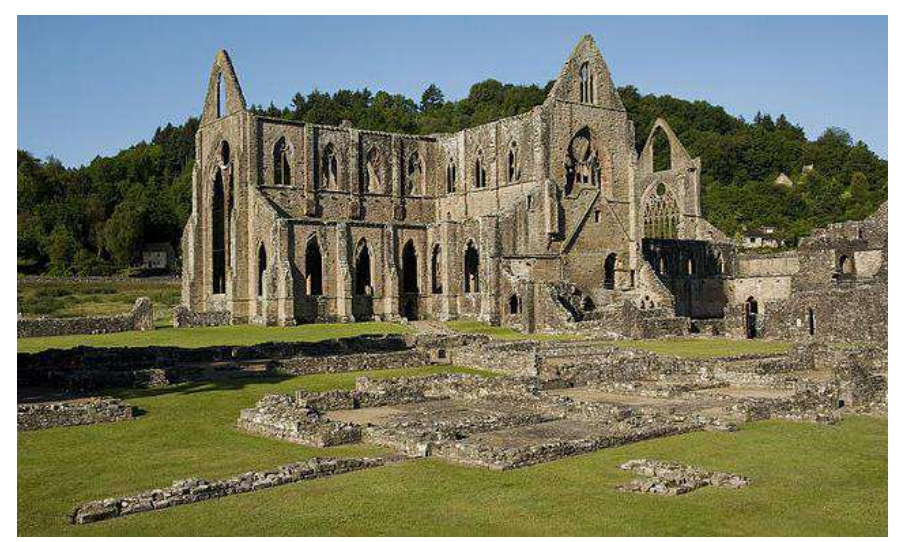

Fig. 07: Tintern Abbey, 2011. Fonte: Wikimedia Commons, domínio público. Disponível em: <https://commons. wikimedia.org/w/index.php?curid=15358619> acesso em 16 abril 2016. Foto: Saffron Blaze

\footnotetext{
${ }^{57}$ Trecho original: "Las abadías inglesas están por lo general perfectamente limpias y cuidadas, lo cual les ha hecho perder sin duda alguna gran par de su misterio y de su aire nostálgico.” (MACAULAY, 1965, p. 163).
} 
É latente, portanto, o papel da ruína para o desenvolvimento do pensamento e práticas de preservação patrimonial no Reuni Unido. Uma situação que se repete na Itália, onde o tema da ruína tem sido notório para diversos campos das humanidades, dentre eles a arquitetura, história da arquitetura e preservação patrimonial. Nesse caso, é necessário um maior recuo temporal já que a preocupação e relação com o legado em ruínas pode ser retomado a partir do Renascimento em que se vislumbrou uma nova relação com a cultura de épocas precedentes, introduzindo uma avaliação crítica em relação às obras do passado recente (Idade Média) e de exaltação da herança da Antiguidade Clássica, não só pelo aspecto histórico, mas também pelo artístico. A partir de então, múltiplas formas de aproximação às ruínas se desenvolveram. Os antigos conjuntos não somente eram fontes de extração de materiais para novas construções, mas constituíam inestimáveis referências documentais para a instituição de preceptivas artísticas.

O interesse pela arquitetura da Antiguidade Clássica permaneceu ao longo dos séculos seguintes e Roma se manteve como centro internacional de estudos devido à riqueza de seu legado. No século XVIII, com o advento do já mencionado Grand Tour, o interesse sistemático pela Antiguidade difundiu a necessidade de viagens de estudo pelo Mediterrâneo em especial Itália ${ }^{58}$. As viagens colaboraram para o início de estudos sistemáticos de antigos conjuntos arruinados que embasaram a fundamentação da arqueologia enquanto disciplina autônoma, processo impulsionado com as descobertas de Herculano (1711), Pesto (1746) e Pompeia (1748) seguidas pelas primeiras escavações na Sicília (CHOAY, 2001).

Nesse contexto se destaca a figura do pesquisador alemão Johann Joachim Winckelmann (1717-1768) que se tornou o responsável pelas antiguidades de Roma com o objetivo de estabelecer uma metodologia científica para os estudos e escavações arqueológicas. Winckelmann acreditava que o desenvolvimento artístico atingiu seu ponto mais alto na Grécia Antiga, buscando o paradigma de beleza ideal nessa arte e não na romana. Suas publicações ${ }^{59}$ são referências fundamentais para o estudo da Antiguidade e conferem-lhe a distinção de ter sido o "pai da arqueologia" (JOKILHETO, 2005, p.87 - trad. nossa) ${ }^{60}$.

\footnotetext{
${ }^{58}$ Paulatinamente as viagens eruditas passaram a englobar a possibilidade de ir além da Europa ocidental, ampliou-se o raio à Grécia, sob o domínio otomano até o século XIX; e ao Oriente Médio, atravessando o Egito até o Sudão (SALGUEIRO, 2002).

59 Em 1755 publicou Gedanken uber die Nachahnmung der griechischen Werke in der Malerei und Bildhauerkunst, em 1764 publicou Die Geschichte der Kunst des Altertums, uma obra de extrema importância por ser a primeira a apresentar uma periodização geral da arte antiga embasada em critérios formais e numa pesquisa histórica acompanhada de análises estéticas aprofundadas (JOKILHETO, 2005 e LE GOFF, 2010).

${ }^{60}$ Trecho original: “father of archaeology” (JOKILHETO, 2005, p.87 - trad. nossa).
} 
Para além dessa abordagem documental das ruínas, o arquiteto e gravador veneziano Giovanni Battista Piranesi (1720-1778) explorou os atributos pictóricos do estado físico da ruína per $s e^{61}$. Piranesi acompanhou as escavações de Herculano e se fixou em Roma em 1745 onde se destacou na cena cultural, principalmente, como gravador ao elaborar as pranchas Vedute di Roma, além das obras Antichità Romane de`Tempi dela Repubblica e de`Primi Imperatori (1748), Nuova Pianta di Roma (1748) e Le Antichità di Roma (1756).

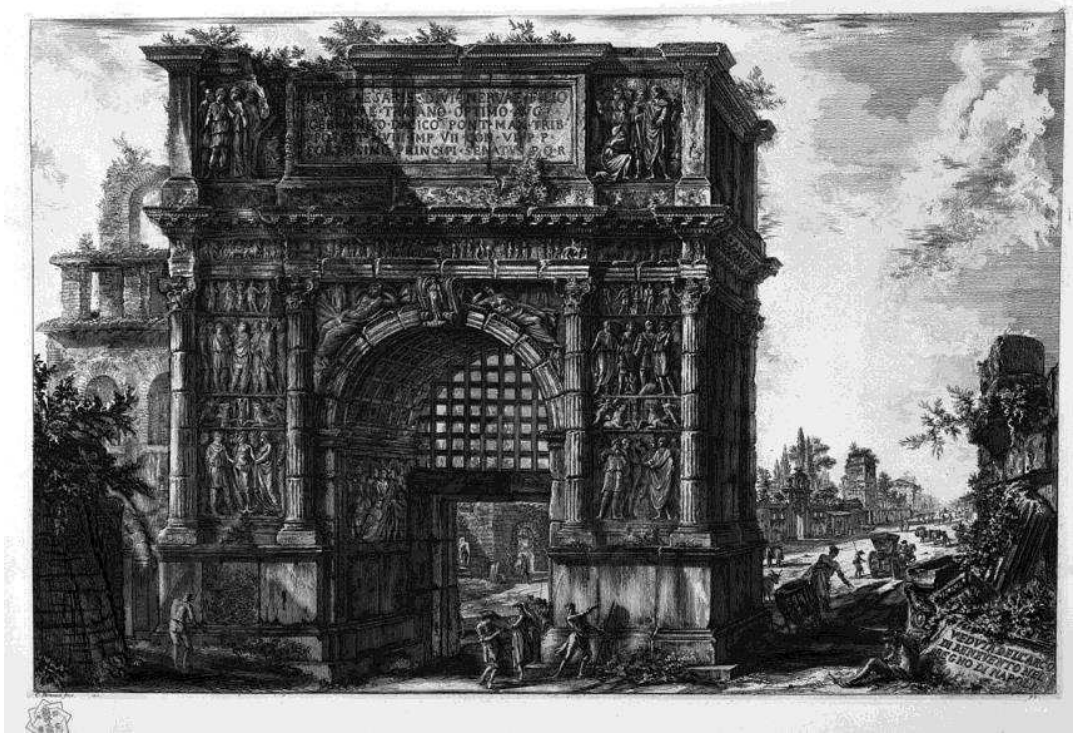

Fig. 08: Arco de Trajano por Giovanni Battista Piranesi, Vedute di Roma (Tomo II, tav. 26). Fonte: Wikimedia Commons, domínio público. Disponível em: <https://commons. wikimedia.org/w/index.php?curid=18586275>, acesso em 08 ago. 2015.

As ruínas de Roma - a cidade eterna ${ }^{62}$ e destino por excelência do Grand Tour - eram objeto de gravuras (vedute) apreciadas pelos visitantes abastados que as compravam como recordação. Um dos exemplos mais emblemáticos é o caso de Johann Wolfgang von Goethe (1749-1832) que durante sua viagem à Itália entre 1786 e 1788 se fez retratar por Johann Heinrich Wilhelm Tischbein (1751-1828) recostado às ruínas na região da Campanha romana (SALGUEIRO, 2002). A divulgação e circulação desse material pictórico explorando cenários em ruínas alimentaram a imaginação de viajantes, cujo caráter pitoresco forneceu material para a fantasia, gerou sentimentos de perturbação e angústia, que impregnaram o desenvolvimento da visão romântica em fins do século XVIII e parte do XIX.

\footnotetext{
${ }^{61}$ O tema da ruína esteve presente na obra de muitos artistas: o inglês Robert Adam (1728-1792); os italianos Giovanni Paolo Panini (c.1692-1765) e Salvator Rosa (1615-1673); e os franceses Hubert Robert (1733-1808), Claude Lorrain (1600-1682) e Gaspard Dughet - conhecido como Poussin (1615-1675), dentre outros (CHOAY, 2001).

${ }^{62}$ Ao se referir a Roma como a "cidade eterna" Johann Wolfgang von Goethe não quer dizer que ela sempre existiu e que sempre existirá, mas que todas as épocas são presentes, uma sobre a outra produzindo um único conjunto que é cidade atual: "Roma sucede a Roma, a nova à antiga e em cada uma todas as Romas diferentes, antigas e novas." (GOETHE apud INSOLERA I. et. al., 1985, p. 78 - trad. nossa). Trecho original: "Roma sucede a Roma, la nuova all antica e in ognuna tutte le Rome differenti, antiche e nuove.".
} 


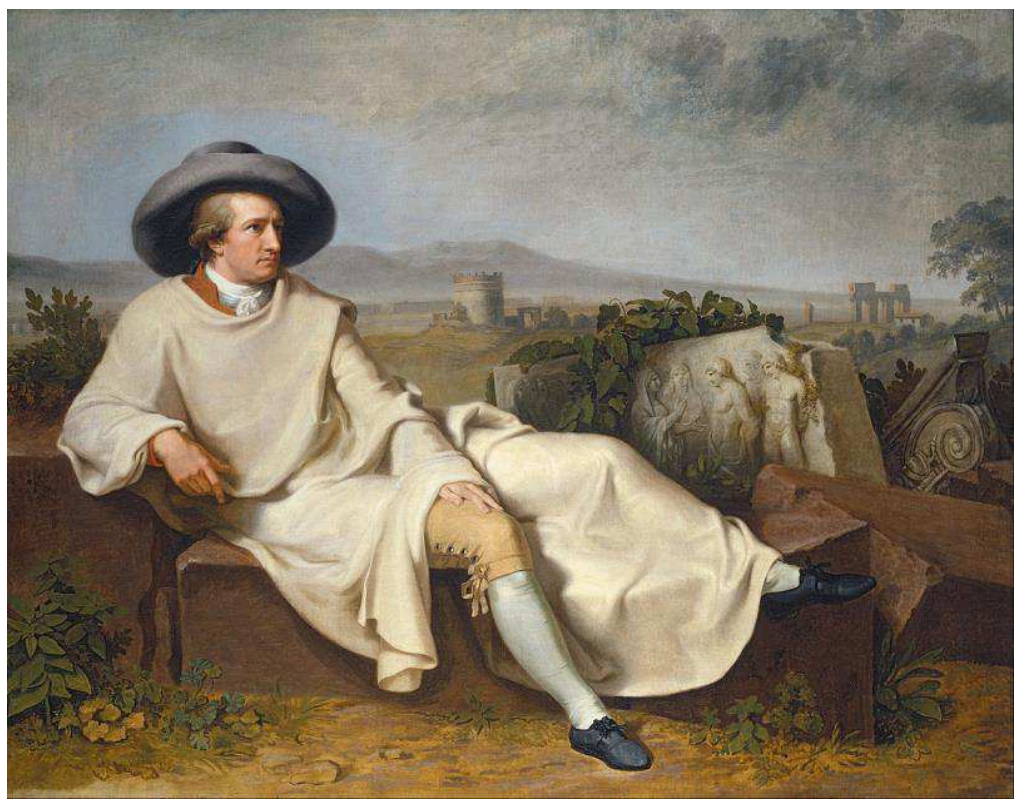

Fig. 09: Goethe in der Campagna, pintura de Tischbein retratando Goethe em sua estadia em Roma, 1787. Ao fundo ruínas romanas: Túmulo de Cecília Metella e aquedutos. Fonte: Wikimedia Commons, domínio público. Disponível em: <https://commons. wikimedia.org/w/index.php?curid=29098753> acesso em 08 ago. 2015.

Assim como no Reino Unido, a relação que se estabeleceu com as ruínas na Península Itálica foi determinante na estruturação da legislação de proteção ao patrimônio. Em Roma, durante o Renascimento, algumas Bulas Papais foram decretadas visando a tutela e a valorização dos edifícios antigos, proibindo a demolição e a espoliação das antigas ruínas e a alienação dos bens da Igreja ${ }^{63}$. A preocupação em estabelecer uma normativa legal para a proteção do legado da Antiguidade paulatinamente foi se aprimorando e culminou com a promulgação de um Editto ${ }^{64}$ (7 de abril de 1820) elaborado pelo Cardeal Bartolomeo Pacca, que teve, segundo Carbonara (1997), uma maior profundidade normativa que os anteriores enfatizando uma oposição às demolições - mesmo que parciais - de antigos edifícios estipulando sanções e regulação às escavações arqueológicas.

Esse Editto foi uma referência para os outros Estados Italianos, principalmente para o Reino de Nápoles disciplinar as escavações de Pompeia e, posteriormente, foi fundamental para a estruturação legislativa de conservação dos bens culturais da Itália Unificada (1870). Atualmente a estruturação do Ministeri dei Beni Culturali (Ministério dos Bens Culturais) na Itália tem um segmento específico para os "Bens Arqueológicos" cujo principal critério para o enquadramento é a datação: são aqueles que foram concebidos até a queda do Império Romano (476 D.C.). Os demais entram no segmento "Bens Arquitetônicos e Ambientais",

\footnotetext{
${ }^{63}$ Bula Etsi de cuctarum (1425) promulgada por Martino V; Bula Cum almam nostram urbaem (1462), promulgada por Pio II; Bula Cum provida Sanctorum Patrum (1474) promulgada por Sisto IV (CARBONARA, 1997).

${ }^{64}$ Documento elaborado pelo Governo Pontifício (Op. Cit.).
} 
que abrange um universo extremamente amplo, pois, uma edificação com mais de 70 anos que não seja propriedade privada passa automaticamente a integrar esse rol de bens arquitetônicos e ambientais ${ }^{65}$.

Em Roma, a atenção em relação às ruínas da Antiguidade não foi somente determinante para a configuração legislativa de instrumentos de proteção e salvaguarda do patrimônio; as ruínas estão imbricadas de tal forma no território, que a dinâmica de desenvolvimento da cidade se configura a partir do confronto com esse legado numa relação que se potencializou durante o século XIX com a necessidade de estruturar uma cidade moderna. Até então, o Coliseu e a Colina do Palatino haviam remanescido abandonados e ilegíveis, à margem da conformação da cidade. Com o início das escavações de modo sistemático no eixo principal (fóruns imperiais e Palatino), essa complexa zona monumental de Roma ganhou destaque e passou a evidenciar o confronto diacrônico como destaca Benevolo: “ [...] entre a magnificência do passado e a ruína do presente;” (BENEVOLO, 1985, p. 165 - trad. nossa) $)^{66}$.

As paulatinas escavações faziam aflorar ruínas que constituíam um profícuo laboratório para a aplicação de diversos métodos para a valorização e conservação desse tipo de bem. As escavações do Arco de Settimo Severo (1803) e da Basílica Ulpia (1812) introduziram dois tipos de aproximação ao objeto: o rebaixamento do terreno da quota moderna para a antiga e a demolição de edifícios mais recentes sobrepostos aos antigos (BENEVOLO, 1985). Durante a ocupação francesa (1809-1814) de Roma foi criada uma Commission d'Embellissements de la Ville de Rome para a segunda capital do império napoleônico, que colocou em prática ações que visavam o embelezamento da cidade e a realização de pesquisas, relatórios e memoriais sobre seu patrimônio.

Essa contextualização é importante para situar a realização das paradigmáticas intervenções no Coliseu e Arco de Tito realizadas no início do século XIX. O Coliseu encontrava-se em estado precário após séculos de delapidação; o papado de Pio VII (18001823) promoveu uma intervenção convidando Raffaele Stern (1774-1820) para o início das obras em 1806. Os trabalhos consistiam essencialmente na consolidação do conjunto, através da construção de um esporão oblíquo de tijolos em uma das extremidades, as marcas da

\footnotetext{
${ }^{65}$ Conforme informações obtidas com a Dra. Antonella Negri, arquiteta no Ministero dei Beni Culturalle, ICCD - Istituto Centrale per il Catalogo e per la Documentazione, Servizio per i Beni Archeolgici (responsável), Itália. Entrevista concedida a autora em 15.12.2015.

${ }^{66}$ Trecho original: "fra la magnificenza del passato e la rovina del presente" (BENEVOLO, 1985, p. 165).
} 
degradação do tempo também foram mantidas evidenciando o caráter conservativo da intervenção. Durante o papado de Leão XII (1823-1829), uma segunda fase de obras foi executada pelo arquiteto Giuseppe Valadier (1762-1839); algumas reconstituições foram feitas através da utilização de tijolos, com o objetivo de voltar à forma primitiva.

Os trabalhos no Arco de Tito ocorreram entre 1817-1824 coordenados primeiro por Stern e, após seu falecimento, por Valadier; as escavações em curso revelaram as fundações, o que colaborou para a reconstituição de algumas partes originais. Partes do arco foram desmontadas, um novo arcabouço de tijolos foi feito e as peças foram recolocadas; as partes reconstituídas tinham forma simplificada e revestimento em travertino - um material diferente e mais econômico que o original (mármore grego).

Como destaca Carbonara (1997), a intervenção no Coliseu conjugou o respeito filológico ao monumento e uma apreciação da ruína per se, influenciada pela obra de Piranesi ou ainda, por uma visão "romântica". Já as obras no Arco de Tito conduzidas por Valladier podem ter sido ditadas por razões práticas e econômicas, mas têm um resultado extremamente válido pela proposição de um paradigma de beleza através da complementação da leitura do objeto com materiais diversos dos originais. Esses trabalhos com abordagens e resultados díspares revelam a dicotomia das possibilidades de intervenção em conjuntos parcialmente arruinados - privados de um uso prático e valorizados pelo seu papel memorial e cultural constituindo uma problemática recorrente nas posteriores asserções teóricas da preservação patrimonial. Essas duas intervenções foram particularmente significativas e de grande repercussão para o desenvolvimento e conformação das ideias a respeito das atuações em monumentos antigos na Europa ${ }^{67}$.

Camillo Boito, para embasar o desenvolvimento dos princípios de sua teoria, remete às intervenções no Arco de Tito e no Coliseu ${ }^{68}$. Pode-se considerar que as proposições de Boito são essenciais para a compreensão das ruínas na medida em que a tônica é o respeito pela materialidade da edificação em suas várias fases, incluindo sua respectiva vetustez e autenticidade, de modo a enfatizar o valor documental de um bem.

Nesse sentido são reveladoras as asserções de Prosper Mérimée que foram recuperadas por Boito para articular sua teoria:

\footnotetext{
${ }^{67}$ Há repercussões desses procedimentos nas teorias de Quatremère de Quincy, no desenvolvimento do pensamento de Camillo Boito e de Gustavo Giovannoni.

68 “A enorme barbacã que o papa mandou construir em 1805 para reforçar o Coliseu não é uma restauração, mas um benéfico provimento, graças ao qual os restos do anfiteatro, [...], não caíram por terra.” (BOITO, 2002, p.46).
} 
[...] Convém deixar incompleto e imperfeito tudo aquilo que se encontra incompleto e imperfeito. Não é necessário permitir-se corrigir as irregularidades, nem alinhar os desvios, porque os desvios, as irregularidades, os defeitos de simetria são fatos históricos repletos de interesse, os quais frequentemente fornecem os critérios arqueológicos para confrontar uma época, uma escola, uma ideia simbólica. Nem acréscimos, nem supressões." (MÉRIMÉE apud BOITO, 2002, p.59 - grifo nosso).

Boito evidenciou ainda a bipolaridade do monumento enquanto obra de arte e documento histórico prescrevendo a prevalência do antigo, assim sua teoria pode ser resumida na medida em que reitera o valor da conservação e o princípio da distinguibilidade:

$1^{\circ}$ É necessário fazer milagres para conservar no monumento o seu velho aspecto artístico e pitoresco; $2^{\circ}$ É necessário que os completamentos, se indispensáveis, e as adições [...], demonstrem não ser obras antigas, mas obras de hoje. (BOITO, 2002, p.60-61).

Essa intermediação entre a antiguidade e beleza levantada por Boito é um ponto crucial que configura um eixo de tratamento para os monumentos arruinados que fica entre uma postura embasada na manutenção de um status quo (postura mais conservativa) ou a restituição de uma condição originária - verdadeira ou presumida (restauro estilístico).

O papel das ruínas em diferentes contextos culturais evidencia a necessidade de confrontar a situação de arruinamento para pautar o desenvolvimento dos debates patrimoniais, das teorias fundamentais, das políticas de salvaguarda e das práticas de intervenção. Ao estabelecer uma relação com o cenário brasileiro verifica-se uma afinidade entre as asserções de Viollet-le-Duc e os debates iniciais no Brasil quanto à associação da condição de arruinamento à urgência de salvaguarda de um determinado bem. Já no Reino Unido e na Itália as intrínsecas características históricas e estéticas da condição de ruína são per se um valor.

Embora a complexidade normativa das legislações patrimoniais desses países não seja objeto desta pesquisa, convém destacar as distinções que são feitas em relação aos bens antigos (Reino Unido) ou arqueológicos (Itália) dos bens arquitetônicos de importância histórica. Essa diferenciação a partir de sua idade não existe na legislação de tombamento no Brasil, na qual a distinção das ruínas se dá pela atribuição de valores que estruturam as inscrições nos respectivos livros do Tombo, sendo a maior incidência no livro do Tombo Histórico.

Ainda assim, a noção de ruína nos bens tombados no Brasil está geralmente associada a edificações mais antigas; sendo a maioria de conjuntos do período colonial com datação até o século XVIII. Verificamos, portanto, uma conexão com o contexto dos outros países 
mencionados na medida em que os bens em que se reconhece a condição de ruína são exemplares arquitetônicos que remontam a uma determinada ideia de "origem" para embasar e configurar a identidade cultural de uma nação.

\subsubsection{Alternativas de intervenção}

Os posicionamentos teóricos apresentados por Viollet-le-Duc, Ruskin e Boito no século XIX lançam as bases para o tratamento dos bens culturais, dentre os quais estão os bens em grave estado de degradação. Essas linhas teóricas sugerem possíveis formas de intervenção da mais conservativa aos refazimentos em estilo. No início do século XX o engenheiro Gustavo Giovannoni ampliou a ideologia do restauro "filológico", da qual Boito foi o principal mentor. Ao desenvolver essa "teoria intermediária" (GIOVANNONI, 1936, p. 128), Giovannoni reiterou uma postura de abordagem científica e documental dos monumentos que se coloca entre as tendências puramente conservativas e as atitudes “estilísticas" que postulavam o repristino de um estado original.

Em seu livro Questioni di architettura nella storia e nella vita (1929), Giovannoni apresentou distinções entre os tipos de restauro ${ }^{69}$ com especificações que continuam sendo de extrema pertinência: "consolidação" - quando novas técnicas contribuem para dar resistência às antigas construções; "recomposição (anastilose)", quando os elementos retornam à própria posição com acréscimos secundários; "liberação", quando são retiradas massas amorfas para se retomar o aspecto artístico; "completamento" e "renovação" quando acréscimos tendem a reintegrar a obra com elementos novos.

Essas asserções configuraram a base para a formulação da Carta de Atenas de $1931^{70}$, documento internacional inaugural do campo da preservação. Nessa Carta, a designação específica sobre ruínas tende a uma acepção relacionada aos monumentos antigos e às escavações arqueológicas $^{71}$ sob a estrita recomendação da anastilose e complementos com materiais reconhecíveis:

\footnotetext{
${ }^{69}$ A síntese dessas ideias foi apresentada no Verbete escrito em 1936 para a Enciclopédia Italiana.

${ }^{70}$ Produto da conferência organizada pelo Office International des Muséé, Société des Nations que ocorreu entre 21 e 30 de outubro de 1931 na Grécia.

${ }^{71}$ Os debates da Carta de Atenas ocorreram durante os trabalhos na Acrópole coordenados pelo arquiteto e arqueólogo Nikolaos Balanos (1860-1942) que foi o responsável pelo processo de restauração do Partenon entre 1898 e 1933, num período em que a Grécia procurava se firmar enquanto nação moderna. Esses trabalhos
} 
VI Técnica de Conservação: Quando se trata de ruínas uma conservação escrupulosa se impõe, com a recolocação em seus lugares de elementos originais encontrados (anastilose), cada vez que o caso o permita; os materiais novos necessários a esse trabalho deverão ser sempre reconhecíveis.[...] (SOCIEDADE DAS NAÇÕES, 1931 In: CURY, 2004, p.15)

Dentre os princípios gerais enunciados para todos os tipos de monumentos há prescrições para uma manutenção permanente; à consideração da obra no bojo de seus aspectos históricos e artísticos; à utilização respeitosa dos monumentos; e o emprego de materiais e recursos modernos de modo a não alterar o aspecto e o caráter do edifício.

Nas duas décadas que se seguiram à Segunda Guerra Mundial em decorrência da destruição massiva e das diversas experiências na área do restauro embasadas nas especificações da Carta de Atenas verificou-se a necessidade de revisão e aprimoramento dos conceitos e princípios da preservação patrimonial. Os debates travados entre as décadas de 1940 e 1960 convergiram para o restauro crítico conservativo, entendido como uma ação cultural, independente do momento de criação da obra e atrelada a outros campos como história da arte, sociologia e urbanismo lançando assim, as bases teóricas e práticas da concepção do restauro contemporâneo.

Nesse processo de revisão e amadurecimento dos princípios da preservação no Segundo pós-guerra, Cesare Brandi apresenta amplas e sistemáticas considerações conceituais que são referenciais para o restauro crítico. Na sua Teoria da Restauração (1963), Brandi identificou o ato do reconhecimento da obra de arte como o fator primordial para a operacionalização da atividade do restauro, um método que deve se preocupar em compreender o bem na totalidade de sua consistência material englobando as instâncias estéticas e históricas ${ }^{72}$.

A instância estética tem prevalência para a orientação das escolhas operacionais do restauro, pois, “[...] se ela perder-se, não restará nada além de um resíduo.” (BRANDI, 2004,

deflagraram debates sobre a coerência em reerguer elementos originais (colunas, tríglifos, etc.) que haviam caído. Questionava-se sobre a preservação da autenticidade do monumento, pois mesmo utilizando o material original os planos de restauração incluíam a reconstrução de trechos inteiros do antigo templo. Os resultados dessas intervenções foram analisados e discutidos durante a Conferência de Atenas e fazem parte do escopo do documento final "Sob a orientação do professor Karo, os membros da conferência procederam a uma longa troca de opiniões, especialmente sobre os seguintes pontos: a. Recuperação da colunata do Partenon e recuperação do peristilo sul; b. emprego de cimento como revestimento dos tambores de substituição; c. escolha dos metais a serem empregados para os grampos; d. oportunidade do emprego de moldes como complemento da "anastilose"; e. proteção do friso contra as intempéries.” (SOCIEDADE DAS NAÇÕES, 1931 In: CURY, 2004, p.18).

${ }^{72} \mathrm{Cf}$ : "a restauração constitui o momento metodológico do reconhecimento da obra de arte, na sua consistência física e na sua dúplice polaridade estética e histórica, com vistas à transmissão para o futuro.” (BRANDI, 2004, p.30). 
p.32). Enquanto que a instância histórica não se refere somente ao momento da criação da obra, mas ao presente (que se desloca continuamente) em que se reconhece os valores desse bem. No decorrer do tempo a obra pode conter e ter conservado, portanto, traços desses tantos presentes históricos que também já se tornaram passado.

No cerne da necessidade de compreender a condição de ruína para direcionar a intervenção, Brandi reforça a duplicidade das instâncias histórica e estética salientando uma postura conservativa: “A legitimidade da conservação da ruína está, pois, no juízo histórico que dela se faz, como testemunho mutilado, porém ainda reconhecível, de uma obra e de um evento humano.” (BRANDI, 2004, p. 68). E “o conceito de que a 'ruína', também para instância estética, deve ser tratada como 'ruína' e a ação a conduzir deve permanecer conservativa e não integrativa." (Op. cit., p. 83).

Sobre o estrito tratamento dos bens arquitetônicos em estado de ruína os desafios se coadunam na medida em que se faz necessária a real compreensão de sua condição de degradação com suas complexas características e limiares, como apresentado no item de sua definição apresentado neste capítulo. Desse modo, para Brandi a única forma possível de restaurar a ruína é a sua conservação em seu ambiente, a partir da compreensão de seu estado desarticulado ou desestruturado da forma original:

O reconhecimento da qualificação de ruína se relaciona, então, com aquele primeiro grau de restauração que se pode individuar na restauração preventiva, ou seja, mera conservação, salvaguarda do status quo, e representa um reconhecimento que de forma implícita exclui a possibilidade de outra intervenção direta a não ser a vigilância conservativa e a consolidação da matéria, [...] (Op. cit., p.66 - grifo nosso)

Segundo a teoria brandiana e o restauro crítico a restauração é definida como um campo disciplinar que tem princípios fundamentais vinculados a uma unidade conceitual e metodológica própria, tais como: distinguibilidade, de modo a não induzir o observador ao engano de confundir a intervenção ou eventuais acréscimos com o que existia antes; reversibilidade $^{73}$ : de modo a não impedir ou comprometer intervenções futuras; mínima intervenção: de modo a não descaracterizar o documento histórico devendo respeitar suas estratificações; e a compatibilidade de técnicas e materiais: considerando a consistência física do objeto, com a aplicação de técnicas compatíveis ao bem e não nocivas (KÜHL, 2008).

\footnotetext{
${ }^{73}$ Recentemente este princípio tem sido enunciado de forma mais precisa como "re-trabalhabilidade" (KÜHL, 2009, p.78).
} 
O restauro enquanto campo disciplinar fundamenta qualquer ação embasada conceitualmente num juízo histórico-crítico dos bens de reconhecido interesse cultural visando a sua preservação. Desse modo, a conservação e a restauração diferem quantitativamente e não qualitativamente e são modalidades vinculadas aos diferentes graus de ingerência sobre o monumento.

A estrita caracterização das operações (conservação e restauração) pode ser detectada no texto da Carta de Veneza (1964), promulgada com o objetivo de delinear uma unidade metodológica para as intervenções nos bens culturais embasada numa concepção históricocrítica. A conservação ${ }^{74}$ engloba ações (como a manutenção) que precedem a restauração ${ }^{75}$ (que tem um caráter mais incisivo e excepcional na obra).

O conjunto de intervenções entendidas no âmbito do campo disciplinar da restauração (gradativamente: manutenção, conservação e restauração) fundamenta-se, portanto, numa profunda análise histórica e crítica do objeto, no respeito à materialidade da obra e a seus aspectos documentais e estéticos. As motivações para essas operações são primordialmente de cunho cultural e científico envolvendo uma pormenorizada análise do bem e sua intrínseca materialidade para identificar seu grau de degradação.

Reiterando a postura da Carta de Atenas, a Carta de Veneza atrela a designação da ruína às prescrições para as escavações arqueológicas ${ }^{76}$ e estabelece o ordenamento e a conservação dos remanescentes arquitetônicos de modo respeitoso recomendando a anastilose:

\footnotetext{
${ }^{74}$ Cf: "Conservação: Artigo $4^{\circ}$ - A conservação dos monumentos exige, antes de tudo, manutenção permanente. Artigo $5^{\circ}$ - A conservação dos monumentos é sempre favorecida por sua destinação a uma função útil à sociedade; tal destinação, portanto, desejável, mas não pode nem deve alterar a disposição ou a decoração dos edifícios. [...] Artigo $6^{\circ}$ - A conservação de um monumento implica a preservação de um esquema em sua escala. Enquanto subsistir, o esquema tradicional será conservado, e toda construção nova, toda destruição e toda modificação que poderiam alterar as relações de volumes e de cores serão proibidas." (ICOMOS, 1964 In: CURY, 2004, p.92-93 - grifo nosso).

${ }^{75}$ Cf: "Restauração: Artigo $9^{\circ}$ - A restauração é uma operação que deve ter caráter excepcional. Tem por objetivo conservar e revelar os valores estéticos e históricos do monumento e fundamenta-se no respeito ao material original e aos documentos autênticos. Termina onde começa a hipótese; no plano das reconstituições conjeturais, todo trabalho complementar reconhecido como indispensável por razões estéticas ou técnicas destacar-se - á da composição arquitetônica e deverá ostentar a marca do nosso tempo. A restauração será sempre precedida e acompanhada de um estudo arqueológico e histórico do monumento." (Op. cit., p.92-93 grifo nosso).

${ }^{76}$ Em relação aos trabalhos de escavação, a Carta de Veneza usa como referência a "Recomendação Definidora dos Princípios Internacionais a serem aplicados em Matéria de Escavações Arqueológicas" - a denominada Carta de Nova Delhi - promulgada em 1956 durante Conferência das Nações Unidas. Esse primeiro documento internacional cujo escopo é exclusivamente a arqueologia faz recomendações para definir os princípios internacionais a serem aplicados às pesquisas arqueológicas. Dentre as prescrições há menções sobre a necessidade de criar critérios de proteção legal ao patrimônio arqueológico vislumbrando sua preservação. $\mathrm{O}$ documento também enfatiza o caráter potencialmente "didático" da prática arqueológica na medida em que
} 
Escavações: Art. 15 : [...] Devem ser assegurados o ordenamento das ruínas e as medidas necessárias à conservação e proteção permanente dos elementos arquitetônicos e dos objetos descobertos. Além disso, devem ser tomadas todas as iniciativas para facilitar a compreensão do monumento trazido à luz, sem jamais deturpar seu significado. Todo trabalho de reconstrução, [...], deve ser excluído $a$ priori, admitindo-se apenas a anastilose, ou seja, a recomposição de partes existentes, mas desmembradas. Os elementos de integração deverão ser sempre reconhecíveis e reduzir-se ao mínimo necessário para assegurar as condições de conservação do monumento e restabelecer a continuidade de suas formas. (ICOMOS, 1964, In: CURY, 2004, p.95 - grifo nosso)

Considerando essa recorrente associação das ruínas às escavações arqueológicas, é relevante considerar que, como aponta Varagnoli $(2005)^{77}$, não há uma distinção metodológica entre o restauro para bens "arquitetônicos" e o restauro para bens “arqueológicos". É certo que os restos antigos serviram como um profícuo campo de experimentação para a aplicação de métodos e conceitos do restauro como distinguibilidade, anastilose direta e indireta, mínima intervenção, compatibilidade e reversibilidade; mas conceitualmente, no campo do restauro crítico não se faz necessário uma distinção das operações pautada pela antiguidade dos bens:

[...] é difícil imaginar o restauro dos restos arqueológicos como um setor autônomo, dotado de um status, métodos e objetivos próprios. É talvez um sinal dos nossos tempos de excessiva especialização - e de interessada divisão de competências - a tentativa de fragmentar disciplinas multiformes e heterogêneas como o restauro em tantas subáreas, delineadas por embasamentos assinalados acriticamente [...] partindo algumas vezes da datação dos próprios edifícios [...] e às vezes se referindo à condição de degradação e aos métodos de pesquisa, como é o caso do restauro arqueológico. (VARAGNOLI, 2005, p. 53 - grifo e trad. nossa) ${ }^{78}$

Ao retomar o entendimento das possíveis operações incidentes em patrimônios edificados que serão úteis para balizar as análises nos capítulos seguintes, é necessário evidenciar que, como atesta Carbonara (2009) há ações que não podem ser compreendidas no cômpito do campo disciplinar do restauro, pois comprometem a leitura da passagem temporal e suas respectivas marcas interpondo motivações de ordem estética às motivações de ordem

\footnotetext{
prescreve sobre a necessidade de empreender: "[...] uma ação educativa para despertar e desenvolver o respeito e a estima ao passado, [...]" (SOCIEDADE DAS NAÇÕES UNIDAS, 1956 In: CURY, 2004, p.74).

${ }^{77}$ Cf: VARAGNOLI, Claudio. Ruderi e restauro: sperimentazioni in Abruzzo. In: Conservare il passato: metodi ed esperienze di protezione e restauro nei siti archeologici: atti del convegno. Chieti-Pescara, 25-26, set.,2003. Antico Futuro, 1. Roma: Gangemi editore, 2005, p.53-78.

${ }^{78}$ Trecho original: "[...] resulta difficile immaginare il restauro di resti archeologici come un settore autonomo, dotato di status, metodi e obiettivi propri. È forse un segno dei nostri tempi di eccesiva specializzazione - e di interessata spartizione di competeze - il tentativo di frammentare discipline multiformi e eterogene como il restauro in tante sottoaree, perimetrate sulla base a volte di definizioni registrate acriticamente [...] a volte partendo dalla datazione degli stessi edifici [...] a volte infine riferendosi alla condizione di degrado e ai metodi d'indagine, come è appunto il caso del restauro archeologico." (VARAGNOLI, 2005, p. 53).
} 
documental e histórica. São práticas em que a matéria antiga não é completamente respeitada e transfiguram o monumento renovando-o e reduzindo-o a uma mera citação do antigo como a repristinação, que é uma ação que envolve a reconstituição formal de um aspecto primitivo removendo o que foi acrescentado ao longo do tempo, com uma orientação mais artística que científica; e o refazimento - reconstrução ${ }^{79}$ ou reconstituição - que visam restabelecer formalmente a edificação anterior utilizando materiais diferentes ou semelhantes (ICOMOS, 1980 In: CURY, 2004).

Assim como há uma distinção entre essas operações (repristino, refazimento e reconstrução) em relação ao estrito entendimento do campo disciplinar da restauração, também há que se pontuar a expressiva diferença de objetivos entre um projeto arquitetônico que estabelece uma correlação ou diálogo com a matéria preexistente e um projeto de restauro. Conforme Renato Bonelli (1959), o restauro é um ato de natureza crítica e criativa que trabalha a partir do material remanescente visando sua preservação. Já, um projeto arquitetônico, pode até utilizar e integrar os remanescentes edificados, mas não parte necessariamente da premissa de sua preservação, o que potencializa o risco em se estabelecer uma relação ambígua, cuja dialética entre o antigo e o novo se restrinja à mera coexistência que pode reduzir a preexistência a um papel literalmente de "pré-texto" (PIANO Renzo apud CARBONARA, 2013, p. 12). Para Carbonara (2013), falta uma pesquisa de unidade de método entre o projeto de restauro e o projeto arquitetônico a fim de desenvolver uma sensibilidade de diálogo com o passado convergindo para uma coincidência entre essas atividades projetuais.

Tendo em vista essas alternativas de intervenção em patrimônios edificados e o que foi delineado neste capítulo - panorama da abordagem das ruínas no cenário brasileiro; definição de ruína utilizada como referência para esta tese; e a importância das ruínas para outros contextos culturais em que se desenvolveram teorias chaves da preservação - foram lançadas as bases conceituais e teóricas para serem aplicadas (e eventualmente ampliadas) na análise dos estudos de casos organizados a partir dos grupos identificados, a fim de verificar: como a compreensão da condição de ruína de um patrimônio cultural direciona as respectivas intervenções.

\footnotetext{
${ }^{79}$ Uma definição sobre reconstrução consta na Carta de Burra, produto da reunião do ICOMOS na Austrália em 1980: "a reconstrução, será o restabelecimento, com o máximo de exatidão, de um estado anterior conhecido; ela se distingue pela introdução na substância existente de materiais diferentes, sejam novos ou antigos. A reconstrução não deve ser confundida nem com a criação, nem com a reconstrução hipotética, ambas excluídas do domínio regulamentado pelas presentes orientações;” (ICOMOS, 1980 In: CURY, 2004, p.247).
} 



\section{Capítulo 2}

Ruínas do tempo: passado e permanência 



\section{Ruínas do tempo: passado e permanência}

Este capítulo se dedica a analisar os bens arquitetônicos que acumularam um processo de arruinamento ao longo de um período de tempo que precede o momento do reconhecimento de seu valor cultural. Os anos de espoliações, exposições às intempéries, demolições parciais e alterações de seus elementos descaracterizam gravemente sua constituição arquitetônica (espacialidade, acabamentos, integridade física, etc.). Para verificar as possíveis aproximações a esse grupo considera-se a interposição das perspectivas simbólica, documental e estética que vão estruturar a identificação, valorização e tratamento desses bens.

A perspectiva documental desses bens arruinados tem sido uma referência fundamental, pois, a ruína não é somente um testemunho histórico, mas também é a fonte física (em alguns casos a única) de informações sobre técnicas construtivas, materiais, revestimentos, partidos arquitetônicos, etc. que embasam estudos e que podem direcionar diversos tipos de intervenções com modificações, extrações ou completamentos de lacunas.

Do ponto de vista simbólico, a contemplação da passagem do tempo - kronos - tem sido um fator crucial de apreciação a esse grupo de ruínas. A noção da linearidade temporal e de sua irremediável ação na matéria (o que foi, não o será mais) compõe uma das mais recorrentes evocações reportando à vanidade das obras humanas e à constatação de que o tempo é o elemento que tudo consome. Se retomarmos ao período do Renascimento, os conjuntos arruinados eram entendidos como referências de um passado grandioso destruído pelo porvir do tempo e pela ira de povos inimigos ${ }^{80}$.

Essa apologia à caducidade das coisas terrenas relaciona-se a um recurso retórico que remete ao motivo bíblico Ubi sunt ${ }^{81}$ - "Onde estão? - Onde estão aqueles que foram antes de nós?” (GRASSI apud D`AGOSTINO, 2003, p.116). Nas ruínas do tempo, os sinais da

\footnotetext{
${ }^{80}$ Uma referência de vulto nesse período foi o De Fortunae varietate urbis Romae: et de ruina eiusdem Descriptio (1431-48) de Poggio Bracciolini (1380-1459) em que há uma comparação entre os monumentos degradados de Roma ao esqueleto despojado de suas carnes (CHOAY, 2001), metáfora que aparece desde Francesco Petrarca (1304-1374) e que seria retomada na Carta de Rafael (1482-1520) ao Papa Leão X (14751521) escrita em 1519: “[...] grandíssima dor vendo quase o cadáver daquela nobre pátria, que foi a rainha do mundo, assim miseravelmente dilacerado. [...] Daí aquelas famosas obras, que hoje mais que nunca seriam florescentes e belas, foram queimadas e destruídas pela raiva celerada e pela fúria cruel de homens malvados, ou melhor, feras, mas não tanto que não permanecesse visível a estrutura quase inteira, mas sem ornamentos, e por assim dizer, os ossos do corpo sem a carne." (RAFAEL, 2010, p.45).

${ }^{81}$ Evocado por Isaías $(33,18)$ e São Paulo (I Coríntios 1,20) (D`AGOSTINO, 2003).
} 
decadência natural implicam na capacidade de transmitir o sentido da distância evocativa que constitui a profundidade temporal e histórica dos objetos.

A evocação da ruína como elemento que transcende a temporalidade não teve somente o caráter de inevitável finitude das obras humanas. Ainda durante o século XVIII, os artistas procuravam representar não só a degradação material, mas também a duração de formas perfeitas de uma arquitetura ideal, a arquitetura Clássica. As representações de ruínas teriam, portanto, um sentido duplo que contrapõe a vanidade à eternidade ${ }^{82}$, sendo muito elucidativas as palavras de Denis Diderot (1713-1784) a respeito das representações pictóricas de ruínas elaboradas Hubert Robert (1733-1808) expostos em 1767:

Senhor Robert, o senhor não sabe por que as ruínas causam tanta alegria. Quero lhe dizer o que me ocorre neste momento a respeito [...] tudo desaparece, se desmorona e passa [...] só permanece o tempo [...] Que antigo é o mundo! Vagueio entre duas eternidades [...] Qual é o meu sentido em comparação com essa rocha que se dobra sobre si mesma? (DIDEROT apud BIALOSTOCKI, 1972, p.209).

Há aqui uma espécie de veneração velada àquilo que foi feito e que não se compreende em sua totalidade, pois os vestígios não nos permitem uma total compreensão daquilo que uma vez fora construído cuja magnitude está preservada, ainda que de modo exíguo, nas ruínas que o tempo consumiu. Na contemplação desse caráter evocativo referente ao porvir do tempo que foi particularmente explorado durante o Romantismo (como apresentado no capítulo 1) a distância temporal do processo de arruinamento é um fator crucial para a atribuição de valores sublimes e pitorescos às características estéticas da ruína enquanto elemento de memento mori ("Lembre-se de que você é mortal") que evidencia o caráter de finitude humana e a veleidade de suas realizações.

A partir do século XIX, essa alegoria à vanidade e à perenidade, se transmuta essencialmente para uma emoção de ordem estética (AUGÉ, 2003). Sob essa ótica, no âmbito da historiografia da preservação patrimonial, como apresentado no capítulo 1 , o aspecto pictórico e pitoresco das ruínas foi um dado chave para John Ruskin fundamentar a importância da valorização e da conservação da pátina como elemento que materializa o porvir do tempo. O aspecto pitoresco é evidenciado por Ruskin através da ruína:

\footnotetext{
${ }^{82}$ Nessa apologia à eternidade, houve os que se valeram de uma perspectiva inversa para perscrutar como seriam as ruínas de determinadas edificações no futuro. Hubert Robert fez um ensaio sobre a Grande Galeria do Louvre em ruínas - Vue imaginaire de la Grande Galerie du Louvre em ruines (c.1796). No século XX, a possibilidade de ser eternizado através de ruínas foi considerada nos projetos arquitetônicos do Terceiro Reich (1929-41); o arquiteto Albert Speer (1905-1981) previa uma "lei das ruínas" a ser aplicada aos novos edifícios, cuja estrutura não deveria usar armaduras de metal, para que no futuro suas ruínas pudessem ser tão sublimes quanto as da arquitetura Clássica (PRESSOUYRE, 1991).
} 
XVI. [...] em arquitetura, [...] o pitoresco é assim procurado na ruína, e supõe-se que consista em deterioração [...]. Mas na medida em que possa tornar-se compatível com o caráter inerente da arquitetura, o pitoresco ou a sublimidade extrínseca terá exatamente essa função, mais nobre nela do que em qualquer outro objeto: a de evidenciar a idade do edifício. [...] (RUSKIN, 2008, p. 77 - grifo nosso)

Essa aproximação e valorização à composição estética das ruínas também consta em textos mais recentes. Em seu ensaio Ruins (1911), o sociólogo alemão George Simmel (18581918) evidencia a interação do objeto artificial (arquitetura) tomado pela natureza - um fenômeno que produz uma nova forma com outras forças atuantes compondo uma nova unidade característica: “[...] totalmente significativa, compreensível, diferenciada.” (SIMMEL In: DILLON, 2011, p.13 - trad. nossa) ${ }^{83}$. Essa abordagem sobre a composição pitoresca das ruínas na paisagem é retomada por Max Dvořák (1874-1921) em sua obra Katechismus der Denkmalpflege (1916) a fim de prescrever orientações para sua preservação:

Em casos de ruínas, é preciso antes de tudo levar em consideração que não se pode destruir aquilo que consiste seu atrativo singular: o caráter de uma construção vítima dos senhores dos tempos e seu aspecto pitoresco na paisagem. (DVOŘÁK, 2008, p.97 - grifo nosso).

Trazendo a discussão ao cenário brasileiro, as considerações evocativas de vanidade e transitoriedade das obras humanas não são abordagens recorrentes para delinear a apreciação de nossas ruínas. Algumas das primeiras (dentre as poucas) ${ }^{84}$ representações pictóricas de conjuntos arruinados foram as obras realizadas pelo pintor Frans Jansz Post (1612-1680) membro da comitiva artística que veio com Maurício de Nassau (1604-1679) durante a dominação holandesa no Nordeste brasileiro. Trata-se de uma série de pinturas elaboradas na década de 1660 que retratam os remanescentes da Matriz de Olinda em meio à paisagem, danificada durante o grande incêndio da cidade em 1631 em meio às ofensivas para a invasão de Pernambuco.

\footnotetext{
${ }^{83}$ Texto original: "[...] entirely meaningful, comprehensible, differentiated." (SIMMEL In: DILLON, 2011, p.13).

${ }^{84}$ Como mencionado no capítulo 1, há a obra do explorador francês Alfred Demersay sobre as ruínas da Missão de São Miguel elaborada em 1846.
} 


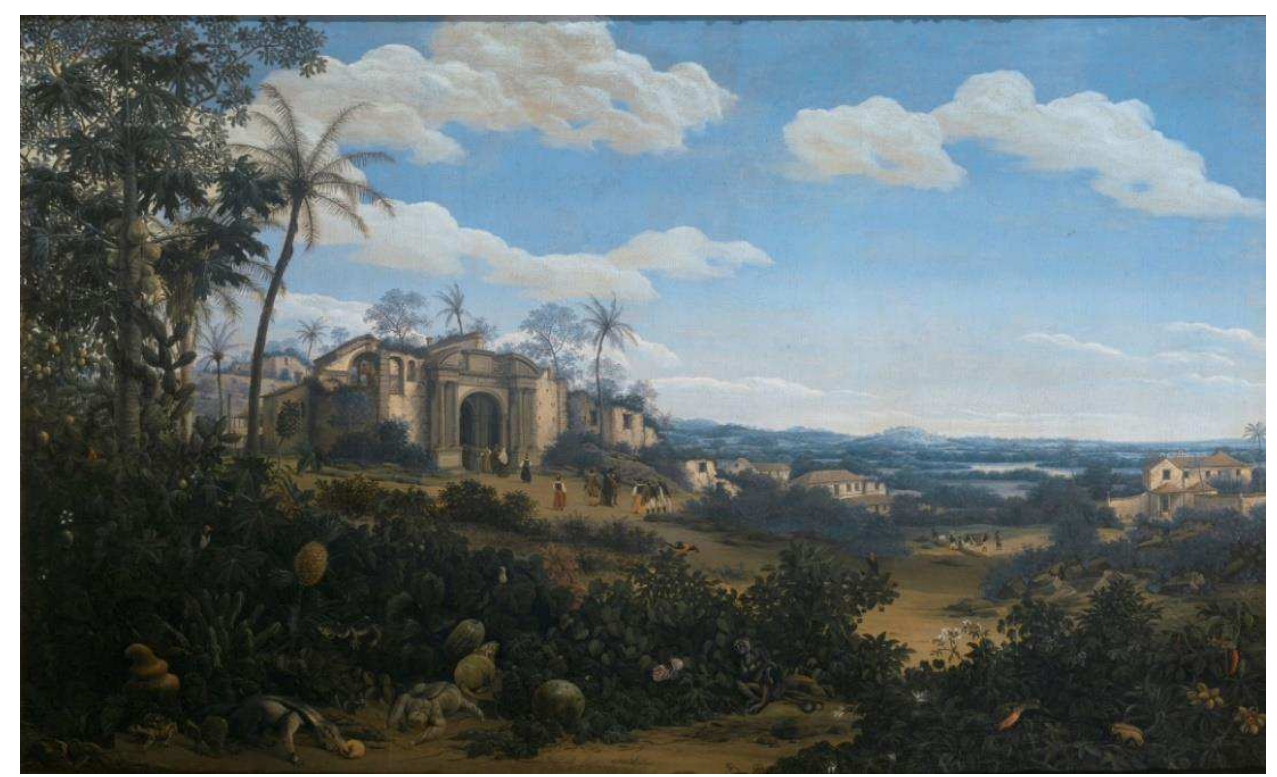

Fig. 10: Vista de Olinda, Frans Jansz Post, 1662 - Rijksmuseum, Amsterdam (Holanda). Fonte: Wikipedia, domínio público. Disponível em: <https://commons. wikimedia.org/w/index.php?curid=34318090>, acesso em 20 nov. 2016.

No que se refere à percepção do valor pictórico de ruínas e às prescrições de ações para a sua preservação, é interessante verificar as asserções de Euclides da Cunha (18661909) para os fortes de Bertioga (SP) - Forte de São Tiago e Forte de São Felipe - derivadas de visita realizada em 1904; comentários que demonstram uma eloquente sensibilidade à condição degenerada derivada do porvir do tempo:

Trata-se de conservar duas grandes relíquias, [...] Compreende-se, porém, que tais reparos tendam apenas a sustar a marcha das ruínas. Quaisquer melhoramentos ou retoques, que se executem, serão contraproducentes, desde que o principal encanto dos dois notáveis monumentos esteja, como de fato está, na sua mesma vetustez, no aspecto característico que lhe imprimiu o curso das idades. (CUNHA, 1904 In: IPHAN, 1964, s.p. - grifo nosso)

No entanto, como apresentado no capítulo 1, na instituição da preservação patrimonial do Brasil, a maioria dos discursos e debates não tem esse caráter evocativo, mas apresentam um teor diverso que associa a condição de ruína a uma situação emergencial, catalisando a necessidade e a justificativa de tombamento. Na esfera nacional (IPHAN), a tipologia do patrimônio em ruínas abrange principalmente fortificações, estruturas religiosas, edificações rurais e ligadas à manufatura de produtos (casas de fazenda e engenhos); a maioria das inscrições se dá através do Livro Histórico; e a partir da década de 1960 houve um aumento das inscrições no Livro Arqueológico, Etnográfico e Paisagístico.

Esse modelo também se aplica ao recorte do Estado de São Paulo, como é possível constatar através dos bens tombados como ruínas ou ruína (e termos derivados: remanescentes, restos e vestígios) pelo CONDEPHAAT (Conselho de Defesa do Patrimônio 
Histórico, Arqueológico, Artístico e Turístico do Estado de São Paulo) ${ }^{85}$ (tabela 04). Assim como na esfera nacional, é possível constatar que a identificação de edificações em estado de ruína com uma datação mais recente (séculos XIX e XX) é exígua. A acepção da ruína está relacionada aos bens mais antigos, uma caracterização que configura o remanescente enquanto um testemunho histórico que fundamenta o ideário de origem e a constituição de uma identidade cultural local (RODRIGUES, 2000).

Tabela 04 - Bens tombados pelo CONDEPHAAT - ruínas e termos derivados ${ }^{86}$

\begin{tabular}{|c|c|c|c|c|c|c|}
\hline & Objeto & Local & Construção & Processo & Tombo & Data \\
\hline 1 & Ruínas do Engenho do Rio Quilombo & SP-Santos & Séc. XVI & $00382 / 73$ & L.H. & $18 / 03 / 1974$ \\
\hline 2 & $\begin{array}{l}\text { Real Fábrica de Ferro São João de } \\
\text { Ipanema }\end{array}$ & SP-Iperó & $\begin{array}{l}\text { Séc. XVI a } \\
\text { XIX }\end{array}$ & $00372 / 73$ & L.H. & $\begin{array}{c}11 / 09 / 1974 \\
\text { ex of IPHAN }\end{array}$ \\
\hline 3 & Engenho São Jorge dos Erasmos & SP-Santos & Séc. XVI & $00362 / 73$ & L.H. & $\begin{array}{c}11 / 12 / 1974 \\
\text { ex of IPHAN }\end{array}$ \\
\hline 4 & Capela do Sítio Querubin & SP-São Roque & 1680 & $00375 / 73$ & L.H. & $\begin{array}{l}11 / 12 / 1974 \\
\text { ex of IPHAN** }\end{array}$ \\
\hline 5 & $\begin{array}{l}\text { Igreja e Convento de Nossa Senhora } \\
\text { da Conceição }\end{array}$ & SP-Itanhaém & Séc. XVIII & $00350 / 73$ & L.H. & $\begin{array}{c}26 / 12 / 1974 \\
\text { ex of IPHAN }\end{array}$ \\
\hline 6 & Ermida de Santo Antônio de Guaíbe & SP-Guarujá & 1552 & $20075 / 76$ & L.H. & $09 / 12 / 1977$ \\
\hline 7 & Ruínas do Abarabebê & SP-Peruíbe & Séc. XVII & $09515 / 69$ & L.H. & $11 / 08 / 1979$ \\
\hline 8 & Forte de São Felipe & SP-Guarujá & 1557 & $00347 / 73$ & L.H. & $\begin{array}{c}05 / 05 / 1980 \\
\text { ex of IPHAN }\end{array}$ \\
\hline 9 & Sede da Fazenda Conceição & SP-Paraibuna & 1841 & $22055 / 82$ & L.H. & $\begin{array}{c}12 / 05 / 1982 \\
\text { ex of IPHAN }\end{array}$ \\
\hline 10 & $\begin{array}{l}\text { Portal de pedra do antigo } \\
\text { Presídio Tiradentes } \\
\text { (remanescente) }\end{array}$ & SP-São Paulo & 1825 & $23345 / 85$ & L.H. & $25 / 10 / 1985$ \\
\hline 11 & Ruínas do Engenho da Lagoinha & SP-Ubatuba & Séc. XVII & $00554 / 75$ & L.H. & $16 / 12 / 1985$ \\
\hline
\end{tabular}

Legenda: L.A.ET.P.: Livro Arqueológico, Etnográfico e Paisagístico; L.A.A.: Livro de Artes Aplicadas; L.B.A.: Livro de Belas Artes; L.H: Livro Histórico; ex of.: bens tombados pelo IPHAN. Fonte: Arquivo Noronha Santos, disponível em <http://www.iphan.gov.br/inicial.htm>, acesso em: 01 Jun. de 2015. Elaborada pela autora. Colaboração: Wagner Nascimento.

\footnotetext{
${ }^{85}$ Órgão estadual de preservação patrimonial criado pela Lei no 10.247 de 22 de outubro de 1968.

${ }^{86}$ Essa tabela foi elaborada seguindo os mesmos critérios que as tabelas 01 e 02 (no capítulo 1); porém, vale pontuar que o tombamento da Capela do Sítio Querubin na esfera nacional se limita aos elementos dos painéis de madeira do forro, sendo assim, ela não consta nas tabelas do IPHAN.
} 
Como ilustração, pode-se pontuar que um dos poucos conjuntos de ruínas musealizadas na cidade de São Paulo remente à fundação da capital paulista pelos jesuítas: trata-se dos remanescentes expostos no Pátio do Colégio ${ }^{87}$ referentes às edificações anteriores do local - um muro de taipa de pilão proveniente de 1554 e fundações de pedra limonita da cripta de uma terceira fase da igreja (concluída em 1671) constituindo um legado de valor histórico inegável pela relação com a fundação da cidade de São Paulo.

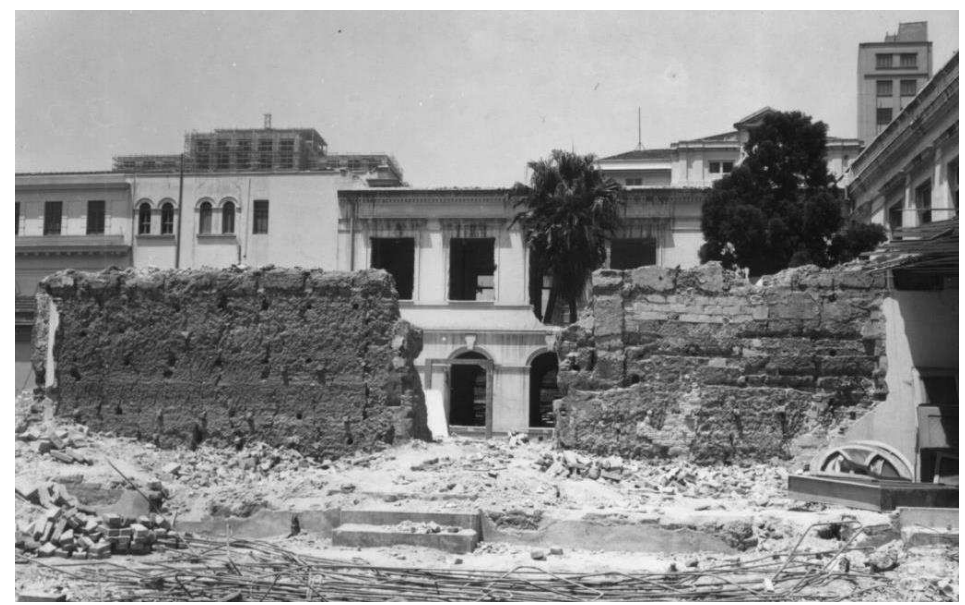

Fig. 11: Pátio do Colégio, ruínas de paredes de taipa quinhentistas, 1953. Fonte: Acervo fotográfico da Superintendência do IPHAN/SP.

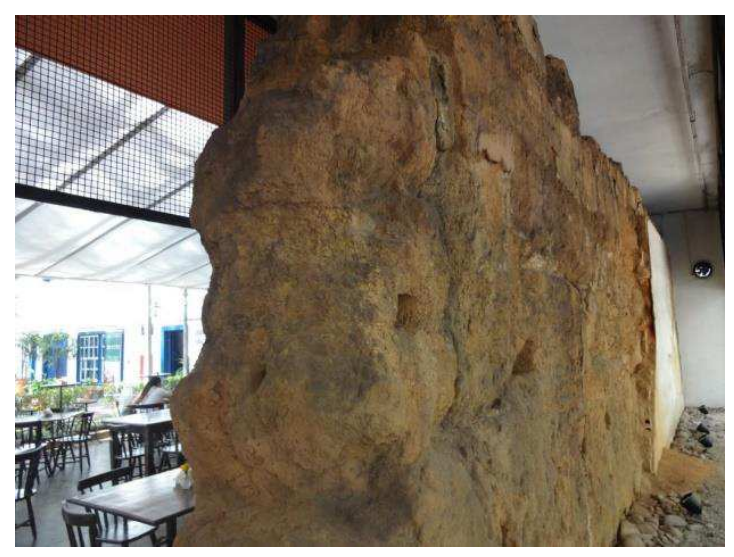

Fig. 12: Pátio do Colégio, exposição das ruínas de paredes de taipa quinhentista, 2016. Foto: Autora.

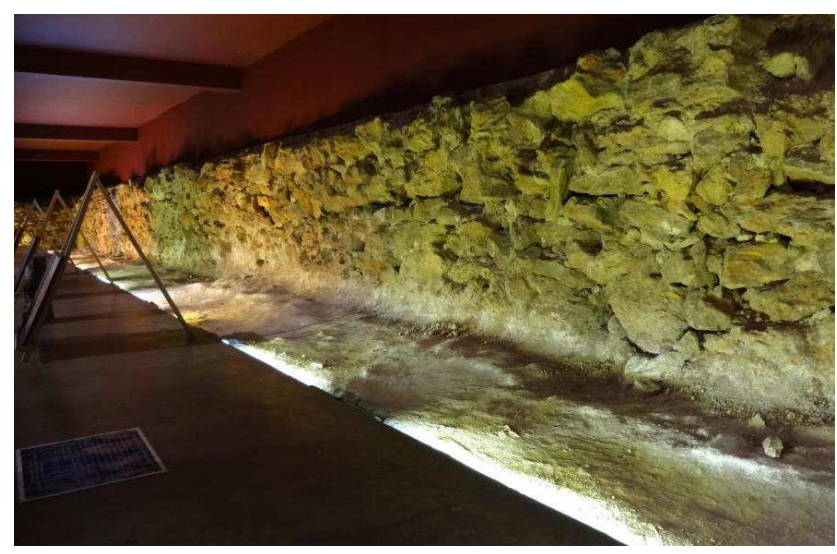

Fig. 13: Ruínas do Pátio do Colégio, fundações da cripta proveniente do século XVII, 2016. Foto: Autora.

\footnotetext{
${ }^{87}$ O Pátio do Colégio está contido no estudo desenvolvido pelo CONDEPHAAT (processo SC 538/75) e no processo de tombamento da área central da cidade (SMC/DPH/CONPRESP Resolução: 17/07). É um caso complexo, pois, ao longo dos séculos houve no local uma sucessão de edificações. Em 1896, as antigas edificações deterioradas foram demolidas dando lugar ao Palácio do Governo do Estado de São Paulo. Durante a década de 1930 iniciou a saída dessas funções político-administrativas, com a demolição do Palácio foram descobertos os remanescentes das edificações anteriores. Nos anos 1950, em decorrência das comemorações do IV Centenário da Cidade de São Paulo e de um movimento para a volta dos jesuítas para esse local originário da cidade, a Sociedade Brasileira de Educação (representando a Companhia de Jesus) apresentou um projeto visando a "reconstrução da primeira igreja de São Paulo" (SÃO PAULO - Estado, 1977, p.15) aos moldes da construção pré-existente que havia chegado até o século XIX. Para a execução desses trabalhos, o sítio arqueológico seria parcialmente descaracterizado comprometendo os vestígios originais. A execução do projeto foi retomada em meados da década de 1970. Apesar das polêmicas e repercussões a reconstrução da Igreja foi realizada e remanescem algumas referências originais. Visita realizada em 01.11.16 acompanhada pela historiadora Carla Galdeano - coordenadora do Museu Anchieta, Pateo do Collegio.
} 
Para analisar como se articula a composição das perspectivas simbólica, estética e documental para esse grupo de ruínas e como essa aproximação tem orientado o tratamento a esses bens foram selecionados dois estudos de casos em nosso recorte geográfico (Estado de São Paulo): Engenho São Jorge dos Erasmos (Santos) e Capela do Morumbi (São Paulo) verificando os contextos e motivações que levaram às respectivas abordagens, valorizações e intervenções que incidiram nesses bens ao longo dos anos.

O Engenho São Jorge dos Erasmos é constituído por ruínas em cantaria de um dos primeiros complexos de produção açucareira no Brasil, proveniente do século XVI que foi tombado em 1963 pelo IPHAN. Atualmente há um projeto em andamento para a valorização do conjunto enquanto sítio arqueológico e a fruição do público. A Capela do Morumbi é produto de um projeto elaborado em 1949 que conserva e integra as ruínas de taipa provenientes do século XVII, a Capela foi tombada pela esfera municipal em 2005.

Esses casos contêm algumas similaridades em seus históricos de aproximação ao objeto arruinado pelo fato de estabelecerem propostas mais conservativas com um respeito à vetustez de sua condição e, simultaneamente, conterem propostas de reconstituições (parciais ou totais). Também é possível situar a discussão na contemporaneidade já que ambos têm passado por recentes ações de valorização (Engenho: implantação de sistematização do Sítio Arqueológico e na Capela: discussões para o respectivo tombamento). Ao verificar os respectivos panoramas históricos, contextos e motivações que levaram à identificação e intervenções nesses patrimônios será possível delinear alguns questionamentos pertinentes e estabelecer algumas correlações com outros casos (nacionais e eventualmente internacionais) a fim de situar a problemática da ruína do tempo no cenário brasileiro das práticas de preservação patrimonial. 


\subsection{Engenho São Jorge dos Erasmos ${ }^{88}$}

O Engenho São Jorge dos Erasmos (Santos, SP) foi uma das primeiras unidades produtivas de açúcar no Brasil remontando à fundação do núcleo inicial de ocupação portuguesa. O processo de urbanização no Brasil se deu com a chegada dos colonizadores comandados por Martim Afonso de Sousa (1490-1564) donatário da Capitania de São Vicente e teve como marco inicial a fundação da vila do mesmo nome em 21 de Janeiro de 1532. Devido à terra e ao clima favoráveis, Martim Afonso trouxe da Ilha da Madeira a cana-deaçúcar, produto de alto valor comercial na Europa, para cultivo na região noroeste da Ilha de São Vicente e em 1534 construiu a unidade ${ }^{89}$ que seria conhecida como Engenho do Governador ou São Jorge, devido à capela dedicada ao santo.

Posteriormente, Martim Afonso fundou uma empresa comercial com seu irmão Pero Lopes de Souza (1497-1539) e outros investidores formando a sociedade Armadores do Trato. Dentre os sócios estavam Francisco Lobo, Vicente Gonçalves e Johan van Hielst, feitor em Lisboa de Erasmus Schetz (c.1476-1550), importante nobre europeu. Através dessa conexão, a firma comercial dos Schetz de Antuérpia teria adquirido a totalidade do Engenho em $1544^{90}$ mantendo-o entre 1557 a 1603 para seus filhos e netos. Gaspar Schetz foi o principal sucessor e se tornou responsável pelo comércio e navegação para o Brasil em 1579. É nesse período que o Engenho passou a ser chamado dos Erasmos, denominação que perdura até hoje.

Em meados do século XVI, a cultura de açúcar em São Vicente entrou em declínio e desapareceu, o que se relaciona a fatores prováveis como: a proibição da escravidão de índios (1570); a baixa qualidade do açúcar devido à umidade; o espaço geográfico limitado para expansão; e o inexorável êxodo da produção açucareira para o nordeste brasileiro, $1500 \mathrm{~km}$ mais perto da Europa, onde o governador-geral instalado na Bahia tinha condições de assegurar maior defesa (MEURS, 1995).

Após vários conflitos o conjunto foi disputado por colonos e foi vendido em fins do século XVI pelos seus administradores numa transação denunciada como ilícita pelos Schetz

\footnotetext{
${ }^{88} \mathrm{O}$ material consultado sobre o Engenho São Jorge dos Erasmos foi obtido junto à Superintendência do IPHAN/SP: processo de tombamento IPHAN 0678-T-62 (IPHAN, 1962) e respectivo acervo fotográfico. Foi realizada visita ao local (05.10.2013) acompanhada pelo historiador e educador Rodrigo Christofoletti. E foram feitas entrevistas (05.05.2015) com os arquitetos Apoena Amaral e Vito Macchione do escritório doisamaisv, responsável pela recente proposta de sistematização do sítio arqueológico no local.

${ }^{89}$ Data provável; segundo Andreatta (1999) há divergências, pois, poderia ser em 1533 ou 1535.

90 Data provável, mas há outra versão que registra o ano de 1550 cuja fonte seria uma escritura pública (UNIVERSIDADE [...], 2005).
} 
que não conseguiram mais reavê-lo (CORDEIRO, 2007). Pouco depois, os edifícios foram destruídos por um incêndio em 29 de janeiro de 1615 pela frota militar-mercantil do almirante holandês Joris van Spilbergen ${ }^{91}$ cujo relato de viagem menciona o fato: "Prosseguimos até o edifício e tomamos tudo em volta ali, laranjas e limões, o quanto nós poderíamos por nos barcos e ao partir nós pusemos fogo ao edifício, a igreja e tudo que estava por ali, [...]" (SPILBERGEN In: CORDEIRO, 2007, p. 39).

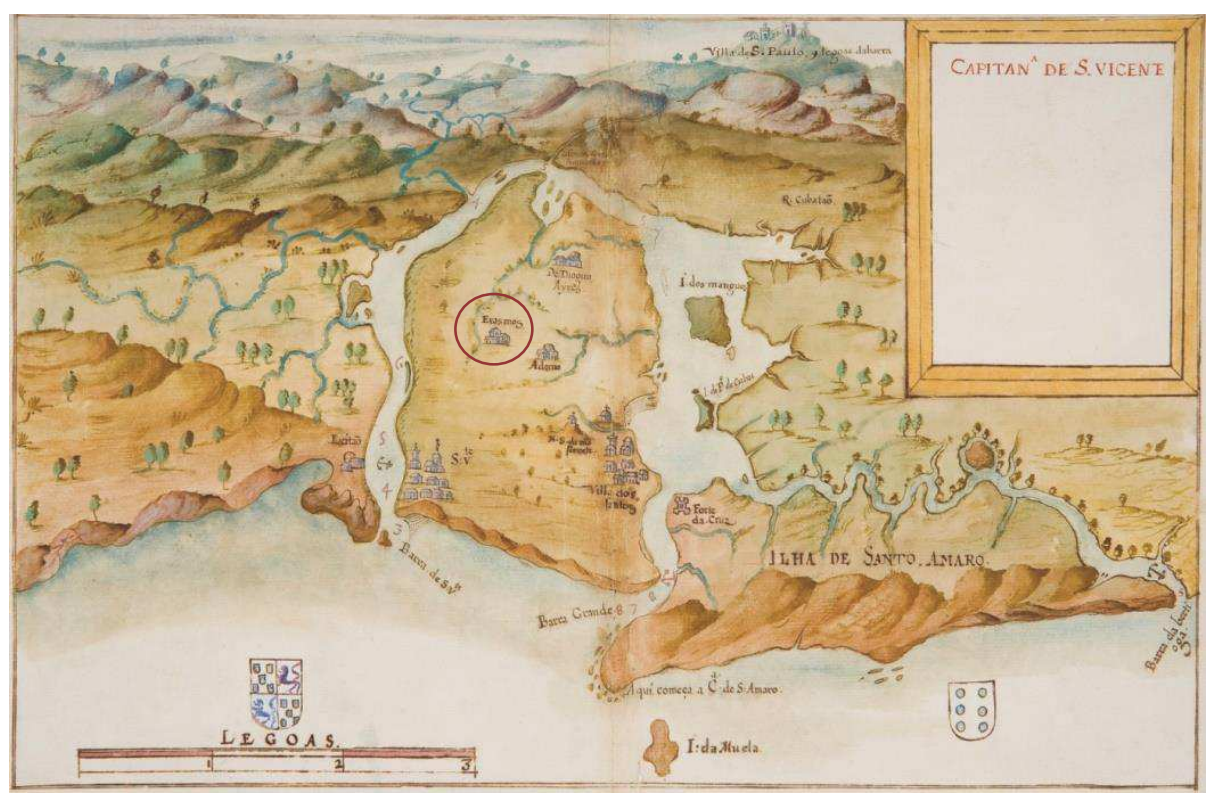

Fig. 14: Mapa Capitania de São Vicente, 1631, João Teixeira Albernaz. Ao centro, indicação do Engenho São Jorge dos Erasmos. Fonte: Mapoteca do Ministério das Relações Exteriores no Rio de Janeiro.

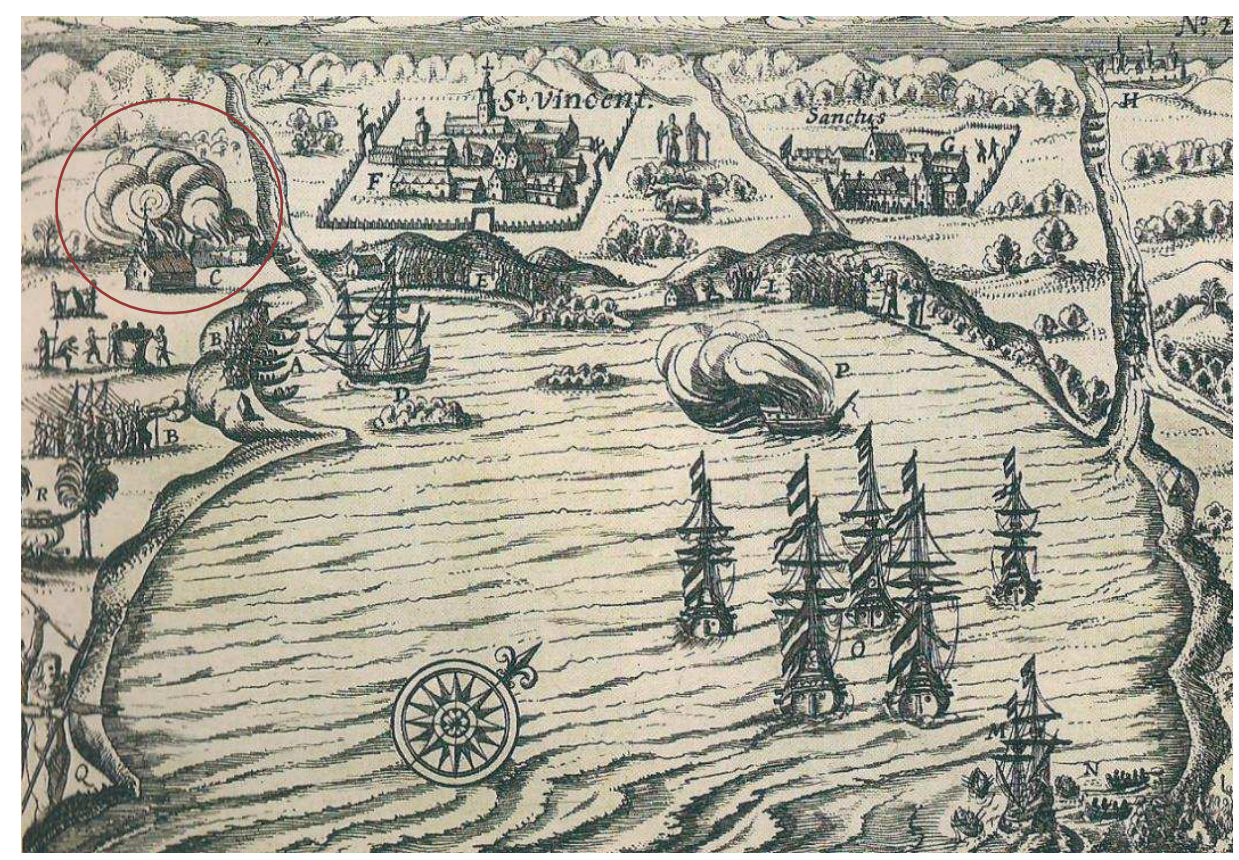

Fig. 15: "St. Vicent", ilustração elaborada por Joris van Spilbergen, c. 1615. No canto esquerdo indicação do Engenho São Jorge dos Erasmos em fogo. Fonte: REIS FILHO, 2000, p.193.

\footnotetext{
${ }^{91}$ O Engenho também teria sido incendiado em 25 de dezembro de 1591 por Thomas Cavendish (ANJOS, 1998 e UNIVERSIDADE [...], 1995).
} 
Com a edificação arruinada e o término da produção açucareira, nos séculos seguintes, a propriedade passou para várias famílias locais e foi usada para agricultura em menor escala. A partir de 1952, a professora de História Geral Maria Regina da Cunha Rodrigues passou a estudar o conjunto estabelecendo contato com os proprietários: Octavio Ribeiro de Araújo e outros. O desenvolvimento e a divulgação dessas pesquisas levaram à doação de uma área de $3.250,30 \mathrm{~m}^{2^{92}}$ onde se localizam as ruínas para a Faculdade de Filosofia, Ciências e Letras da Universidade de São Paulo em 1958. Na escritura de doação ${ }^{93}$ havia prerrogativas para preservar as ruínas com uma destinação didática-cultural. Iniciou-se então uma discussão com apelo ao reconhecimento do valor cultural desse bem. Nesse contexto, o engenheiro e arquiteto Luis Saia ${ }^{94}$ (1911-1975) - então diretor do $4^{\circ}$ Distrito do Departamento do Patrimônio Histórico e Artístico Nacional - foi convidado para visitar o local e realizou a seguinte descrição do estado encontrado:

B: os "restos" encontrados constam de umas paredes, uma coluna, alicerces e a definição topográfica do local, parcialmente desfigurada pelo entulho consequente das paredes ruídas. Em dois pontos os restos de paredes formavam um agenciamento identificável na parte posterior da construção era ainda visível um oitão bem desenhado e, contíguas, as paredes laterais com as respectivas envasaduras. No alinhamento destas paredes laterais, os alicerces documentam a disposição geral da construção e seu travamento funcional com as demais ruínas, inclusive com as ruínas de um compartimento perfeitamente definido, cuja posição e disposição indicam fosse a capela do engenho. Fora do perímetro da construção o entulho das paredes ruídas encobriam as soluções de acesso e de arranjo das imediações do edifício. Junto às paredes do fundo, uma coluna perfeitamente conservada marcava o pé-direito mais elevado, na cumeeira do telhado, confirmando aquela cota marcada pela empena da parede do fundo. (SAIA, L., Relatório dos trabalhos realizados In: IPHAN, 1962, s.p.)

A partir dos estudos e identificação da importância histórica do local foi solicitada a abertura do processo de tombamento na esfera nacional ${ }^{95}$ pelo professor Dr. Cândido Lima da Silva Dias (vice diretor da Faculdade de Filosofia, Ciências e Letras da Universidade de São

\footnotetext{
${ }^{92}$ Equivalia a uma quadra do projeto para o loteamento Villa Santa Terezinha, que os proprietários pretendiam implantar no local e que não foi executado.

${ }^{93}$ Consultada junto ao arquivo do IPHAN/SP: IPHAN, 1962, p. 147-149.

${ }^{94} \mathrm{O}$ engenheiro arquiteto Luis Saia foi diretor do $4^{\mathrm{o}}$ Distrito do Departamento do Patrimônio Histórico e Artístico Nacional - DPHAN (Regional São Paulo) de 1937 a 1975. Teve uma intensa atuação e foi responsável pela restauração de mais de 30 edificações, dentre as quais os casos do Engenho dos Erasmos estudado neste capítulo e a Casa do Sítio Mirim (estudo de caso do capítulo 3). Saia esteve à frente de proposições e instruções de tombamento de diversos monumentos e coleções de obras de arte, distribuídas pelos estados do sul do Brasil. Além disso, foi o coordenador do Curso de Especialização em Restauro de Bens Culturais e Conjuntos Arquitetônicos promovido pelo IPHAN e pela Faculdade de Arquitetura da USP, em 1974.

95 Tombamento no IPHAN (Processo: 0678-T-62): Livro Histórico, 02.07.1963. O tombamento na esfera estadual (CONDEPHAAT) ocorreu em 1974 (ex of.); e na esfera municipal (Conselho de Defesa do Patrimônio Cultural de Santos - CONDEPASA) em 1990 (ex of.).
} 
Paulo). O tombamento estava embasado na datação do "engenho quinhentista" (ANDRADE, R. M. F. Of. n.699, 1962 In: IPHAN, 1962, p.20) e foi deferido por unanimidade em 1963.

Entre 1963 e 1966 foram realizados importantes trabalhos no local tais como: prospecções arqueológicas, restituição de parte da cobertura e consolidação das ruínas. O Caderno de Obras (n.32) ${ }^{96}$ elaborado por Luis Saia constitui um registro valioso em que constam imagens e levantamentos da situação do local.

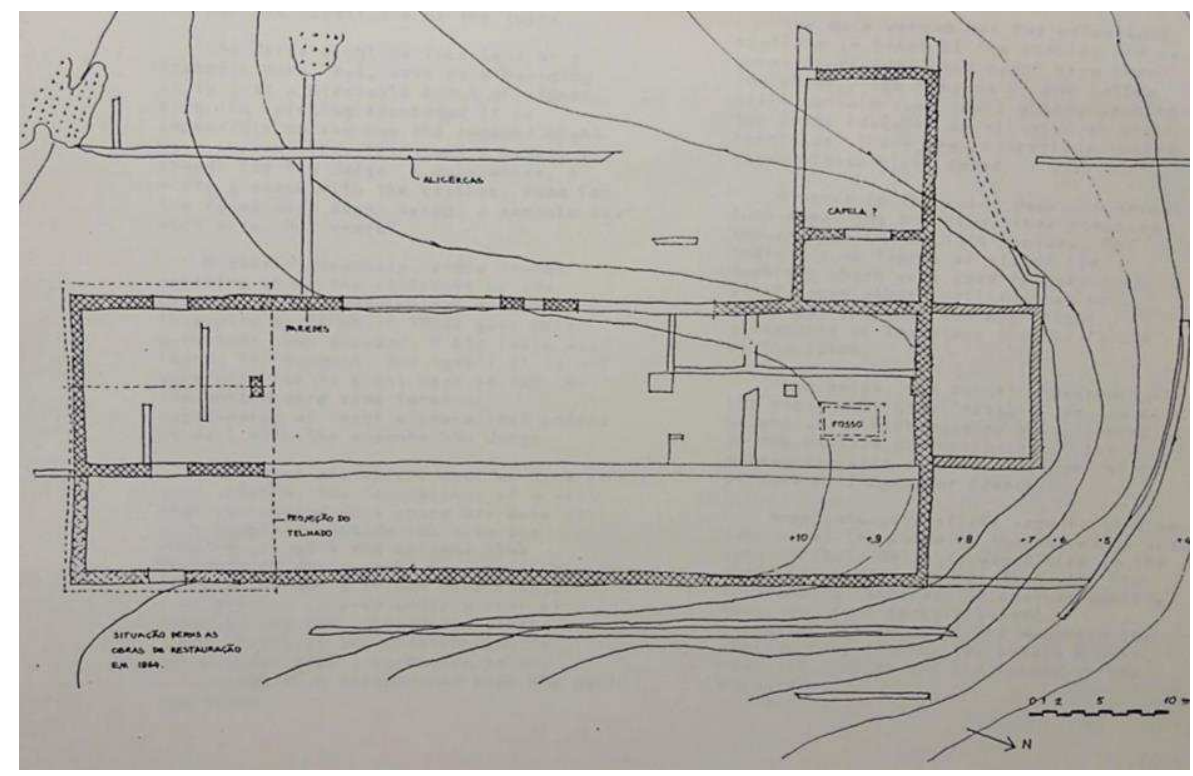

Fig. 16: Engenho São Jorge dos Erasmos, levantamento c. 1960 (s.d.). Fonte: IPHAN, 1962, s.p.
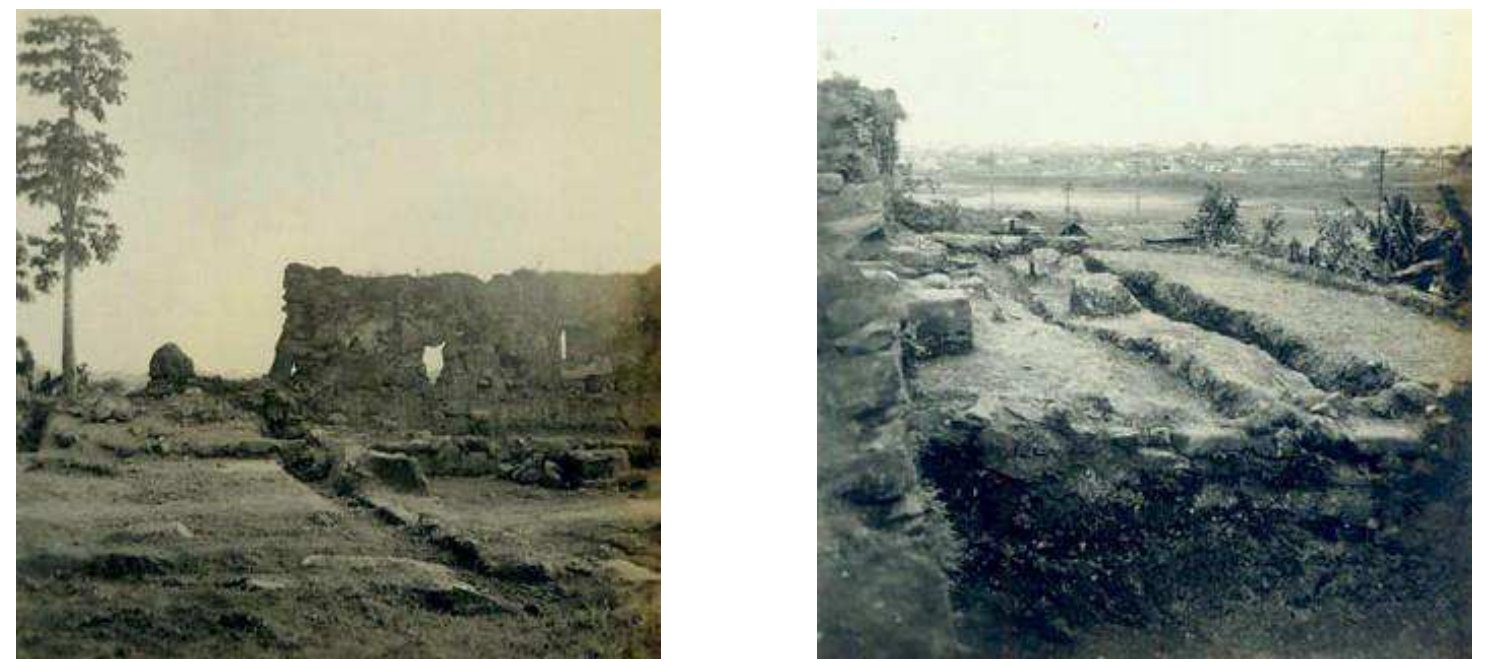

Fig. 17 (i-ii): Situação das ruínas do Engenho São Jorge dos Erasmos.

Fonte: Caderno de Obras 1963-1966 (n.32), Luis Saia, acervo fotográfico IPHAN/SP.

\footnotetext{
${ }^{96}$ Consultado junto ao arquivo e acervo fotográfico do IPHAN/SP. A importância da incorporação da prática em elaborar "Cadernos de Obra" como registro das intervenções realizadas está sintetizada nas seguintes asserções da arquiteta Lia Mayumi: "O Caderno de Obras foi adotado pelo IPHAN no Estado de São Paulo, na Igreja do Embu (1938), e passou a fazer parte da metodologia de trabalho em todas as obras seguintes, pelo menos até o final da década de 1970 no DPH. O objetivo era constituir um registro fotográfico, técnico e explicativo de todas as etapas de restauração. Ao final da restauração as imagens mais representativas de cada etapa eram selecionadas, coladas num caderno segundo critério cronológico e identificadas." (MAYUMI, 2008, p. 94).
} 
Após esses trabalhos, o Engenho entrou em outra fase de anonimato com consequências à sua conservação. A partir dos anos 1980 iniciaram mobilizações e discussões para a revalorização do sítio que se acentuaram em 1987, quando a empresa Vip Empreendimentos Imobiliários na tentativa de executar um loteamento na região efetuou uma terraplanagem irregular no entorno do Engenho danificando a parte rochosa da planta baixa do terreno. A obra foi embargada; a Pratex Empreendimentos Imobiliários (sucessora da Vip) apresentou novo projeto com proposta de doação de área aproximada de $44 \mathrm{mil} \mathrm{m}^{2}$ para a USP como indenização física pelos danos ao patrimônio.

Depois de vários ajustes sobre os limites dessa área, concluiu-se no início de 1990 que a cessão seria feita ao município que depois repassou parte ao usufruto da USP. O estado de abandono do bem, porém, perdurou e foi objeto de uma ação civil por parte de vereadores solicitando a instalação de auditoria pelo Ministério Público em 1995. Após reuniões para decidir sobre o destino do conjunto foi apresentado um projeto de pesquisa arqueológica pela USP; a área foi cercada e os estudos iniciaram em 1996 com recursos do Museu Paulista (USP) e da Prefeitura de Santos. Após a finalização desses trabalhos em 2003 o Engenho foi efetivamente aberto à visitação pública.

\subsubsection{Implantação e partido arquitetônico}

Pesquisadores têm se debruçado sobre fontes documentais e sobre os parcos vestígios físicos do Engenho São Jorge dos Erasmos para tentar estabelecer como era seu partido arquitetônico. Nos anos 1950 foram descobertos documentos de 1548 a 1652 dos Schetz em poder do descendente Duque D`Ursel na Bélgica dos quais a USP teve interesse em obter cópias. Houve grande expectativa de que essas informações poderiam ajudar na recuperação histórica do Engenho. As microfilmagens chegaram ao Brasil e foram traduzidas pelo pesquisador Eddy Stols (1968), porém, não foram suficientemente esclarecedoras sobre como de fato teria sido este conjunto edificado.

Um dos documentos mais reveladores, segundo Anjos (1998), é uma carta datada de 1548 enviada de Santos a Lisboa, provavelmente do feitor do engenho, endereçada a Van Hielst. O documento informa sobre a produção, as terras, o número de escravos e algumas características das construções: 
[...] a saber uma casa muito grande de seis lanços e uma senzala com uma ferraria, todas providas de baluartes, e ainda duas casas cobertas de telhas, muito boas e fortes. [...] Todas estas casas se erguem numa altura e todas juntas e próximas de maneira que nenhuma fazenda seja tão forte para os contrários, nem tenha melhores casas em todos estes engenhos. Daí se pode defende-lo facilmente com 3 ou 4 berços. (STOLS In: MEURS, 1995, p. 5; ANJOS, 1998, p. 24 e CORDEIRO, 2007, p. 59).

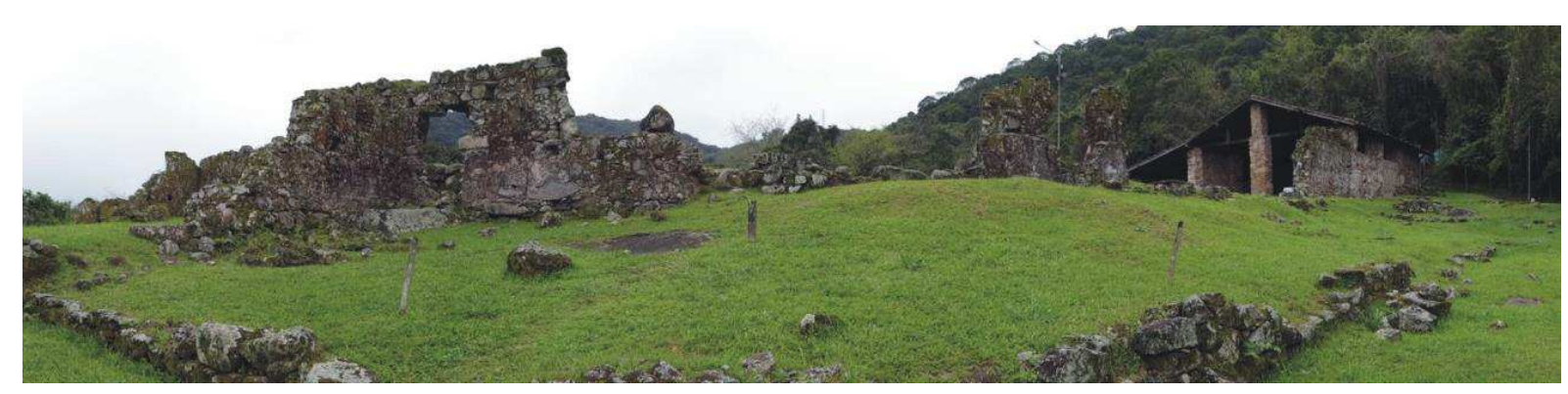

Fig. 18: Vista panorâmica das ruínas do Engenho São Jorge dos Erasmos, 2013. Foto: Autora.

No Relatório de Obras de 1963-1966 (IPHAN, 1962), Luis Saia lançou duas teses sobre o engenho. A primeira se refere ao tipo da moenda. Os moinhos movidos à água, denominados do tipo "real" (GAMA, 1983, p. 130) devido à propriedade real sobre as águas, tinham as mesmas dimensões dos movidos à tração animal, mas eram mais eficazes pela rotina ininterrupta. Para Saia, o Engenho São Jorge dos Erasmos era desse tipo; segundo ele, nos anos 1960 ainda era possível ver uma linha de vegetação diferente que teria acompanhado a canaleta que trazia água das cachoeiras próximas ao conjunto. No entanto, nas pesquisas arqueológicas realizadas na década de 1990 não foram encontrados vestígios que comprovassem essa teoria.

A outra tese de Saia se referia ao partido. Havia, segundo Gama (1983), dois tipos de engenhos implantados no Brasil: partido aberto, mais comum na região Nordeste com vários edifícios para alocar as seções produtivas e o senhor vivia isolado; e o partido unitário, mais encontrado na região de São Paulo, no qual tudo se concentrava sob um único telhado e o senhor vivia no local (GAMA, 1983). Segundo Saia, o Engenho se enquadraria nessa categoria, embora essa tese não tenha sido comprovada:

[...] Ficou evidente uma solução de plataformas sucessivas para vencer a diferença de nível entre a baixada geral e o ponto do aclive onde está assentado o edifício. Restos de coluna evidenciaram uma solução de acesso alpendrado para a residência do engenho. Com tais elementos se pode adiantar que este projeto obedecia à tradição dos engenhos das ilhas açorianas e a um tipo de produção do porto reduzido. Toda a instalação estaria disposta sob um mesmo teto, segundo um partido aglutinado. A solução do partido aberto, com um edifício para cada função, é posterior e parece invenção do ciclo nordestino do açúcar, onde se inaugurou uma produção volumosa em escala internacional e capitalista. (SAIA, L., Relatório dos trabalhos realizados In: IPHAN, 1962, s.p.) 
A prospecção de 1963 detectou a atividade local por restos de fôrmas de pão de açúcar encontradas em um fosso. Segundo as recentes pesquisas arqueológicas ${ }^{97}$, as estruturas localizadas na área edificada basicamente retangular numa plataforma no sopé do Morro da Caneleira abrindo-se para visuais elevadas em relação ao rio São Jorge foram: paredes (cuja espessura varia de $0,60 \mathrm{~m}$ a 1,30 m), numa delas há evidência de piso superior; seteiras; fosso; alicerces; soleiras; bases de pilares; muros de arrimo. O material construtivo de pedras e argamassa de cal e conchas é proveniente da região (ANJOS, 1998).

Porém, essas estruturas não puderam ser articuladas para determinar a que funções precisas correspondiam devido ao alto grau de arruinamento causado por processos naturais e antrópicos. Foi possível identificar a provável "capela" com o resto de três paredes; ao lado desta, o cemitério com sepultamentos datados de fins do século XVI (MORAIS et. al., 2004/2005).
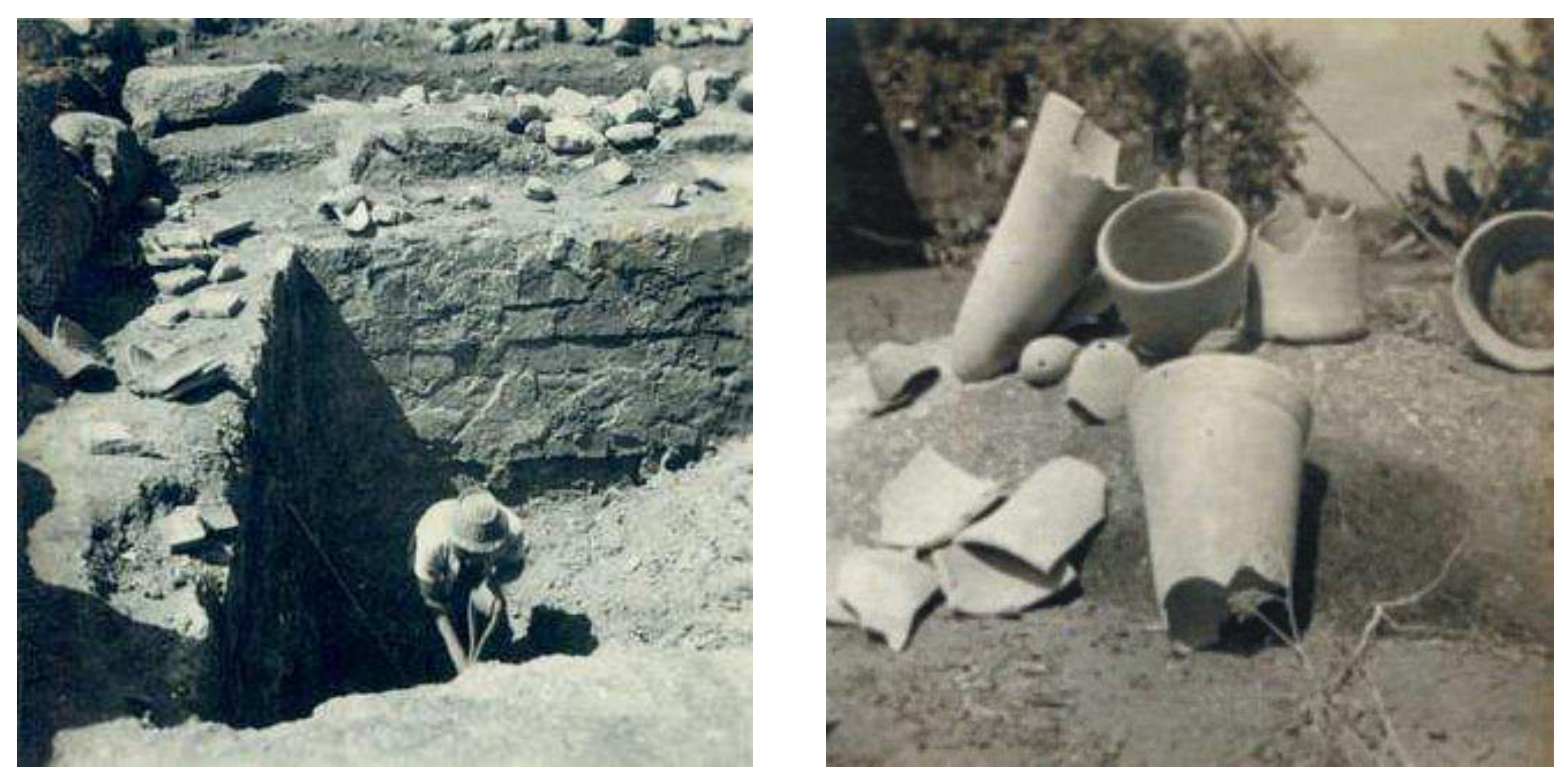

Fig. 19 (i-ii): Escavações e fôrmas de pão de açúcar encontradas.

Fonte: Caderno de Obras 1963-1966, Luis Saia, acervo fotográfico IPHAN/SP.

\footnotetext{
${ }^{97}$ Ver trabalhos: Anjos (1998); Andreatta (1999); Morais \& Piedade \& Maximino (2004/2005) e Cordeiro (2007).
} 


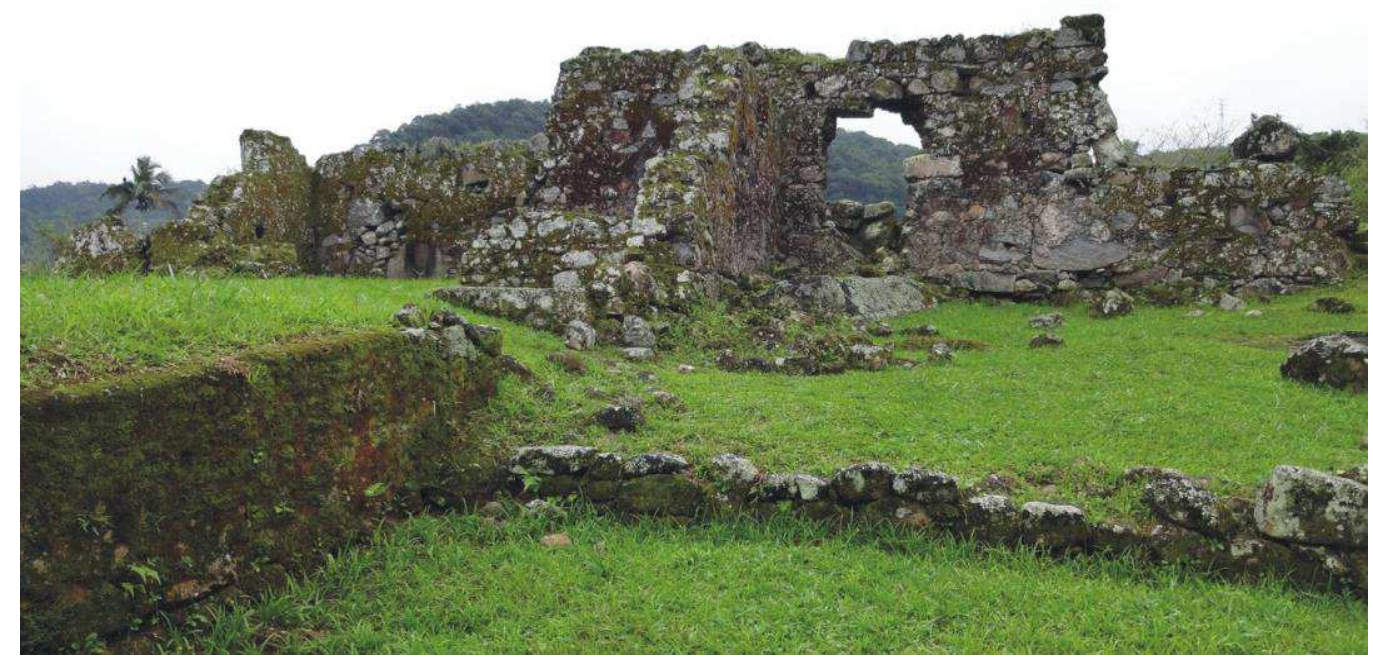

Fig. 20: Ruínas - lado esquerdo: cemitério (parte baixa) e capela (paredes ao fundo), 2013. Foto: Autora.

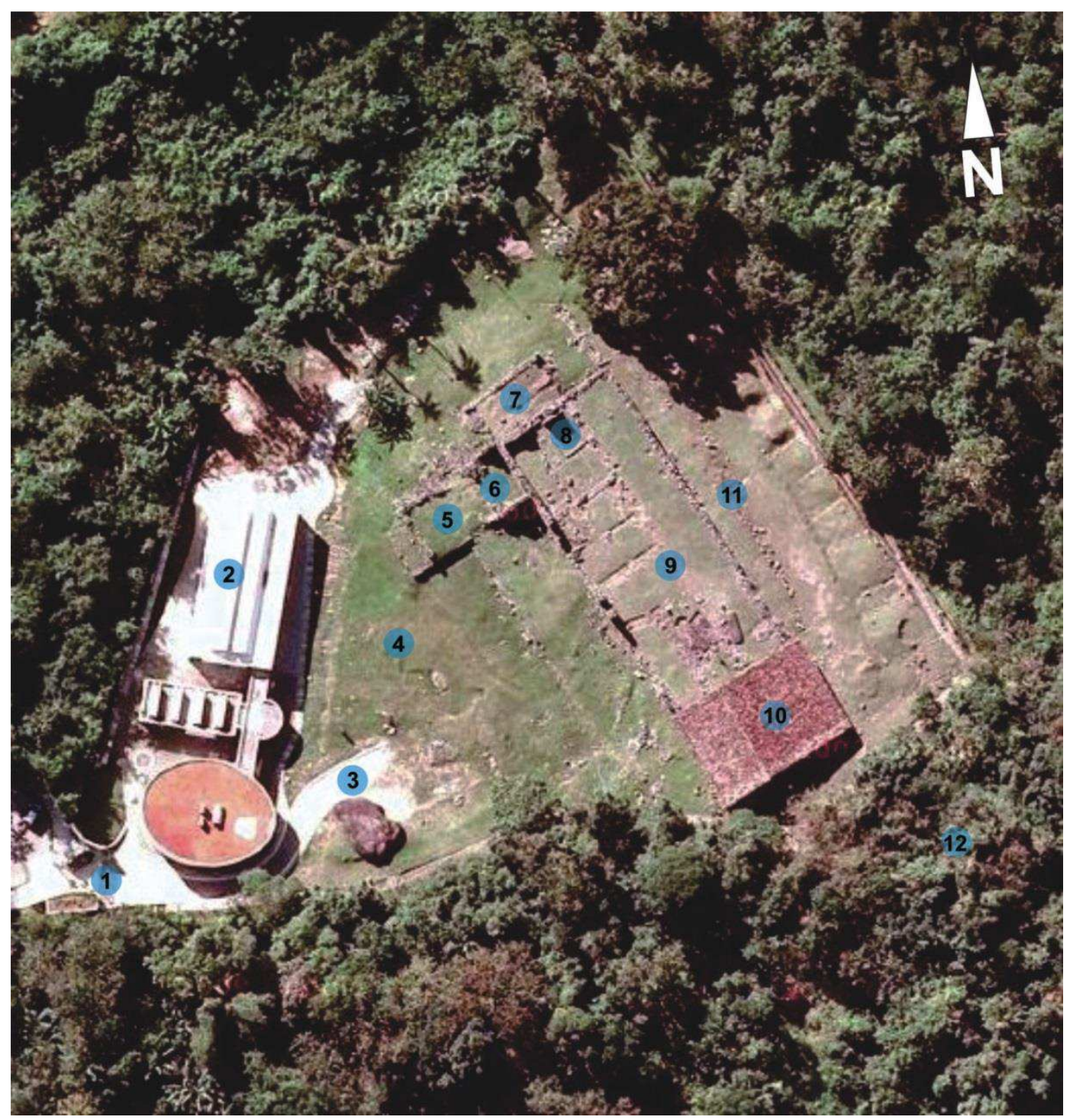

Fig. 21: Mapa esquemático - 1 Acesso; 2 Base USP; 3 Rampa acesso ruínas; 4 Área que passou por terraplanagem; 5 Cemitério; 6 Capela; 7 "Terraço"; 8 Fosso (4×2×2m); 9 Platô principal; 10 "Pavilhão Saia"; 11 Antigo acesso; 12 Morro da Caneleira. Fonte base: Google Maps, 2013. Elaborado pela autora. 
Apesar das teses levantadas e devido às evidências pouco conclusivas, remanesce a questão: qual foi de fato o modelo arquitetônico do Engenho São Jorge dos Erasmos? No que se refere à evolução tecnológica, ele poderia ser um "elo de ligação" (ANJOS, 1998, p. 67) para a produção açucareira em grande escala no Brasil. É possível constatar com maior convicção que a implantação desse engenho é condicionada às necessidades técnicas e defensivas situando-se num ponto estratégico que dispõe de recursos naturais como terras férteis, madeira para fornalhas e caldeiras e água para navegação e força motriz, numa encosta de morro em semicírculo de uma região plana, numa plataforma com ampla vista protegendo $^{98}$ a propriedade; essa topografia também facilitou a disposição em platôs para os diversos estágios da manufatura, aproveitando a gravidade.
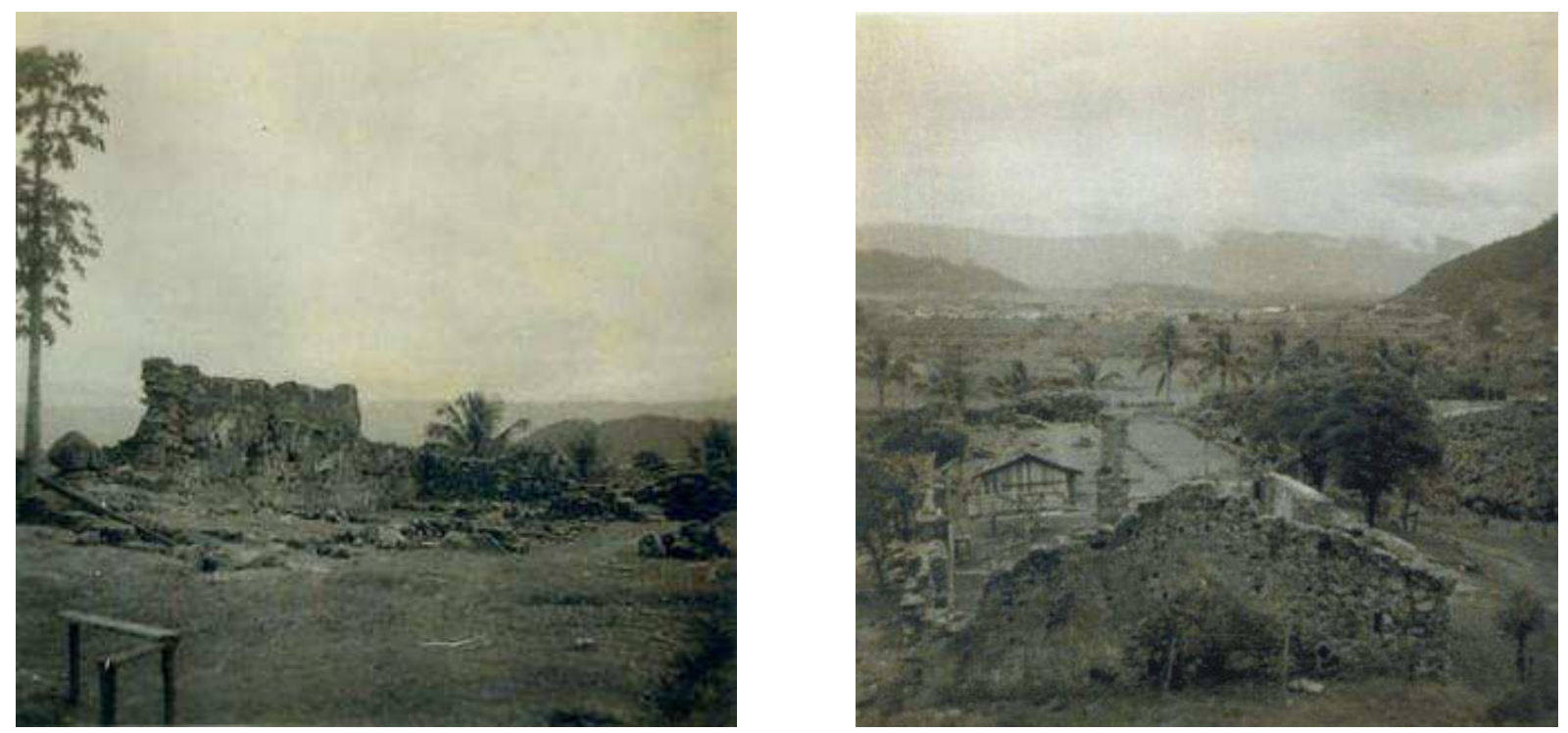

Fig. 22 (i-ii): Engenho São Jorge dos Erasmos e entorno.

Fonte: Caderno de Obras 1963-1966, Luis Saia, acervo fotográfico IPHAN/SP.

\subsubsection{Bem cultural e intervenções}

Entre 1963 e 1966 houve a primeira intervenção no Engenho. Sob responsabilidade técnica de Saia, as obras, conforme Relatório, constituíram de: serviços de limpeza; consolidação de muros e alvenarias; prospecções arqueológicas; construção de casa de zeladoria; e recomposição de parte da cobertura $\left(300 \mathrm{~m}^{2}\right)$ tendo como referência marcas localizadas nas paredes e pilar central e material iconográfico anterior em que se nota o telhado em duas águas com telhas de zinco - além desses dois lanços, um terceiro foi adicionado a leste. Essa área coberta ficou conhecida posteriormente como "Pavilhão Saia".

\footnotetext{
${ }^{98}$ O Engenho dos Erasmos estaria associado a um "sistema de fortificações" (MORAIS et al., 2004/2005, p. 356) que inclui a Fortaleza da Barra Grande (Santos), o Forte São Felipe (Guarujá) e o Forte São João da Bertioga (Bertioga).
} 

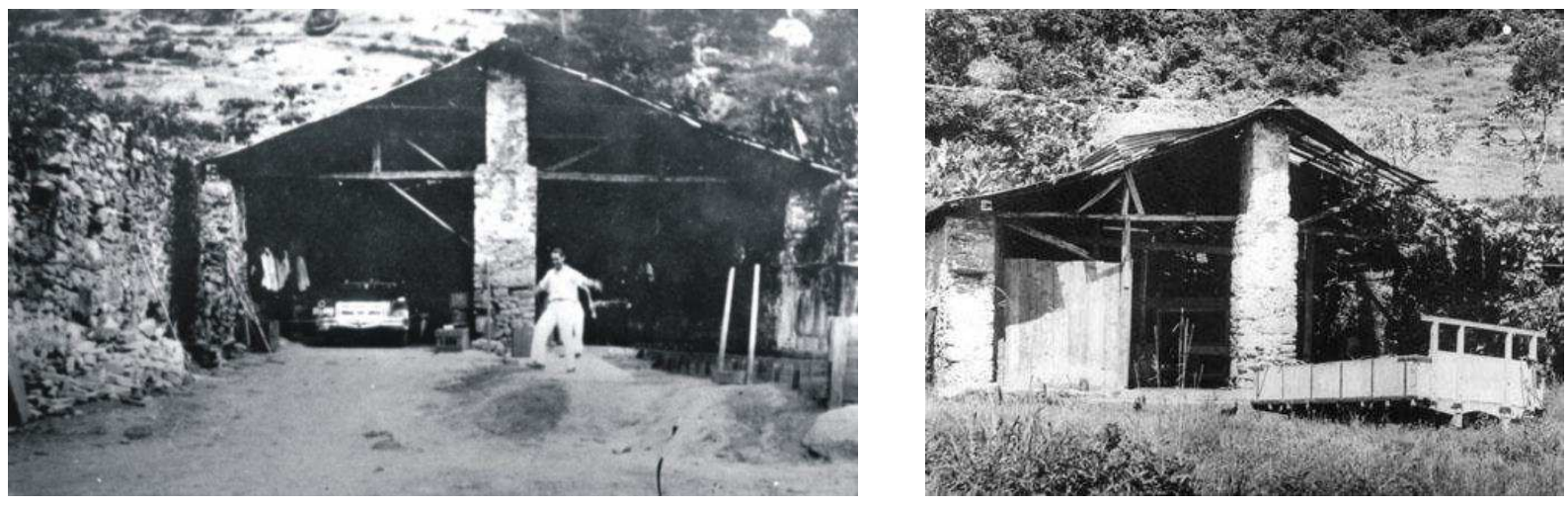

Fig. 23 (i-ii): Área coberta com dois lanços antes da "restauração".

Foto: Herman H. Graeser (Germano), década de 1960, acervo fotográfico IPHAN/SP.
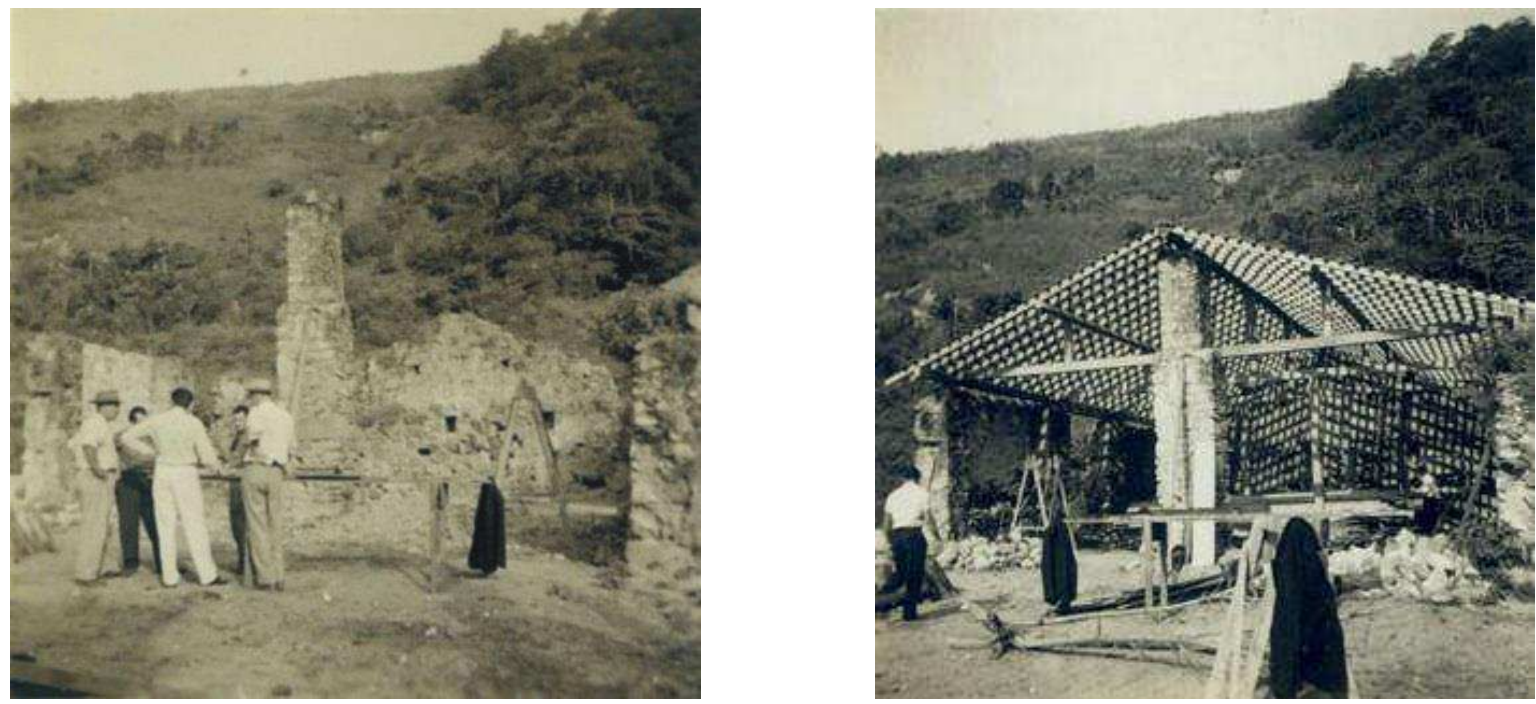

Fig. 24 (i-ii): Consolidação do pilar central e reconstrução de parte da cobertura. Fonte: Caderno de Obras 1963-1966, Luis Saia, acervo fotográfico IPHAN/SP.

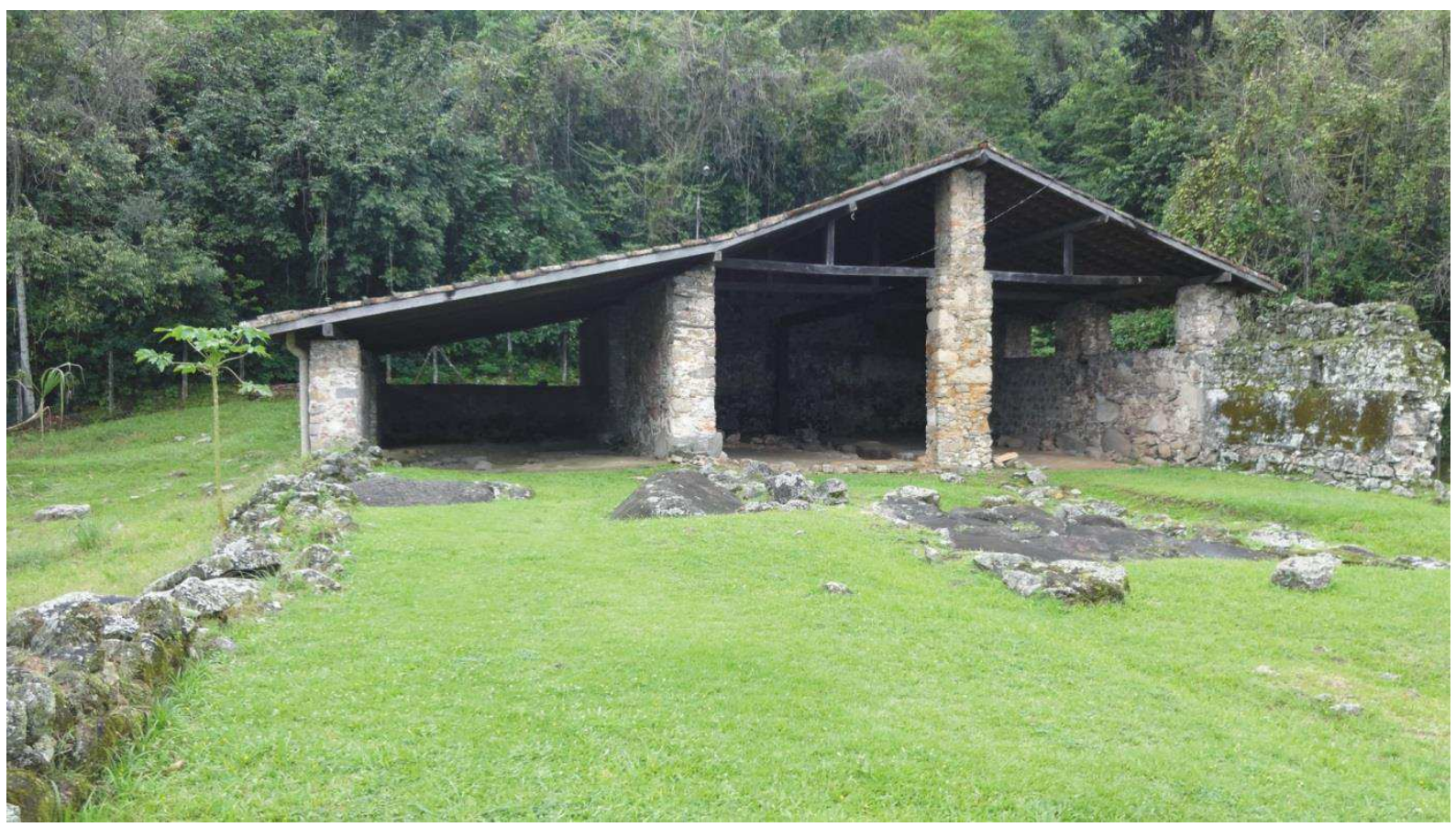

Fig. 25: "Pavilhão Saia", três lanços de telhado, 2013. Foto: Autora. 
Durante a década de 1980 foi iniciado um debate no sentido de revalorização do sítio. Houve mobilizações na Faculdade de Arquitetura e Urbanismo da Universidade de Santos e o CIESP (Centro das Indústrias do Estado de São Paulo) apresentou ao IPHAN em 1981 uma nova proposta de restauração tendo como argumento o fato de ter sido a primeira iniciativa industrial do país e marco pioneiro da colonização ${ }^{99}$. Nesse momento o engenho foi tombado ex officio pelo CONDEPHAAT.
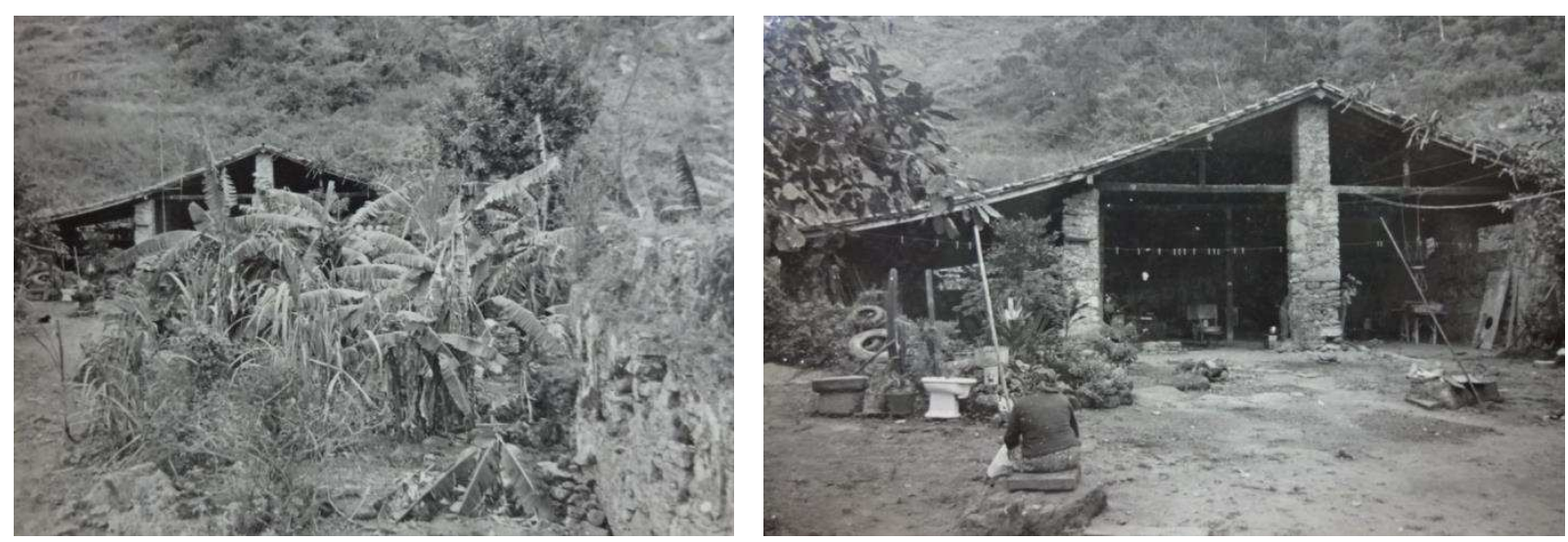

Fig. 26 (i-ii): Engenho São Jorge dos Erasmos, situação em 1980. Fonte: IPHAN, 1962, s.p.

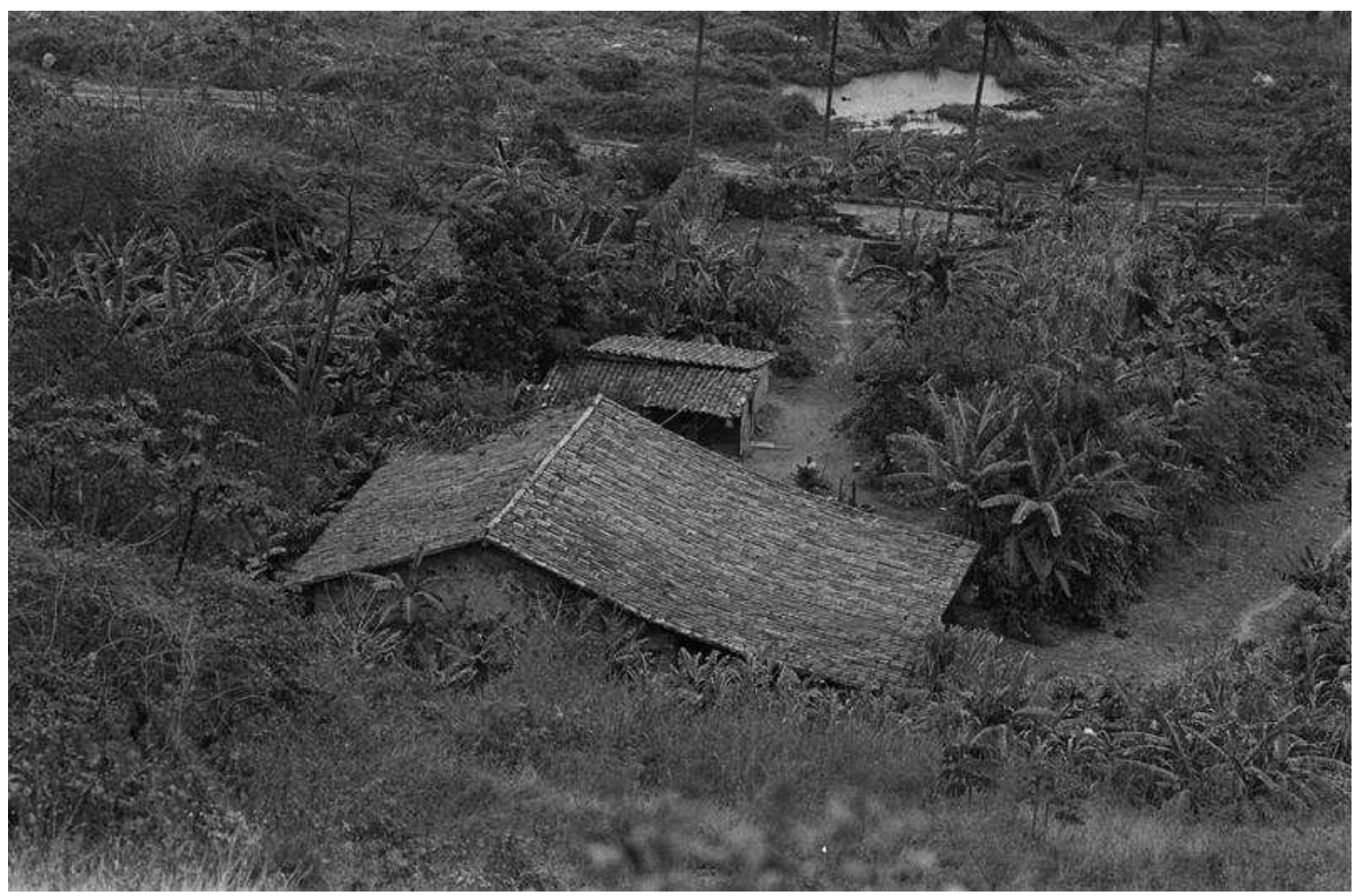

Fig. 27: Engenho São Jorge dos Erasmos, situação em 1980. Fonte: Acervo fotográfico IPHAN/SP.

${ }^{99}$ Carta de 06 de Agosto de 1981 enviada à diretoria do IPHAN/SP (IPHAN, 1962, p. 37). 
De acordo com o processo do IPHAN (1962), em 1983, o então diretor da regional de São Paulo Antônio Luiz Dias de Andrade ${ }^{100}$ (1948-1993) sugeriu trabalhos emergenciais como limpeza, consolidação dos remanescentes, criação de acesso adequado e implantação de apropriado arranjo paisagístico, assim como a relocação da precária residência do zelador, sem prejuízo às demais propostas e estudos da USP. Essas ações, no entanto, não foram executadas e a situação se agravou com as terraplanagens irregulares de 1987 extremamente danosas para a percepção de sua relação com o ambiente original. Durante os anos 1980 e 1990 a discussão sobre propostas para o Engenho sempre ocorreu em função de mobilizações da opinião pública e demais instituições ressaltando a dificuldade de acesso e o estado de abandono, associados à falta de um projeto de revalorização cultural que dispusesse sobre uma efetiva utilização do conjunto.
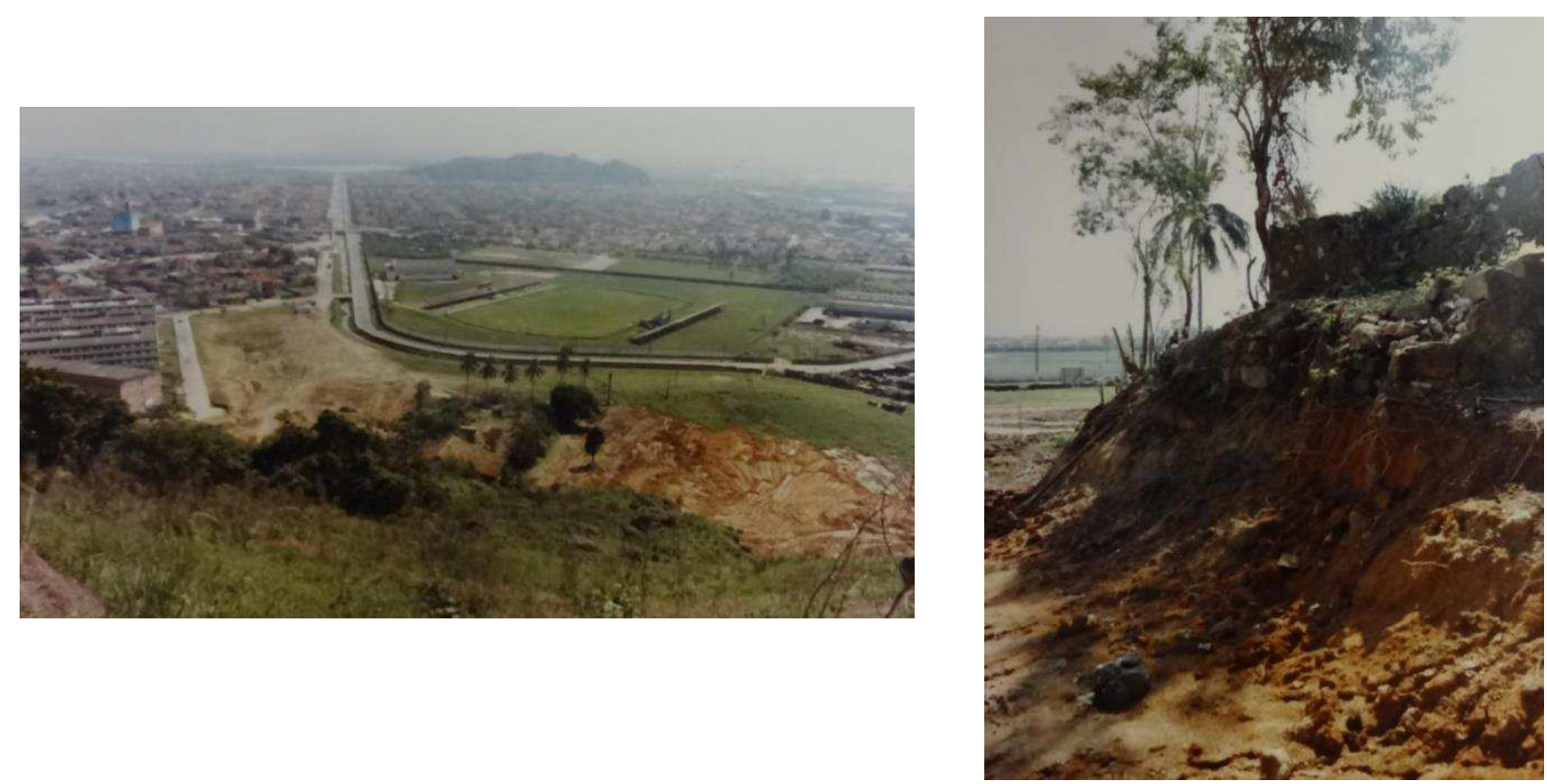

Fig. 28 (i-ii): Situação da área envoltória do Engenho São Jorge dos Erasmos derivada de terraplanagem indevida, 1987. Fonte: IPHAN, 1962, s.p.

O agravamento da situação e a denúncia ao Ministério Público em 1995 propiciou o desenvolvimento de pesquisas arqueológicas no local. Nessa ocasião o conjunto foi inscrito no Cadastro Nacional de Sítios Arqueológicos (CNSA); no início as pesquisas foram coordenadas por Margarida Davina Andreatta (1923-2015) do Museu Paulista (USP). Em 2001, passou para a coordenação de José Luiz de Morais do Museu de Arqueologia e Etnologia (USP), quando foram descobertas evidências de um cemitério local (2003).

$\mathrm{Na}$ fase inicial dos trabalhos foi executada limpeza das ruínas e seu entorno; na ocasião também foi solicitada a consolidação das mesmas e da cobertura do "Pavilhão Saia",

${ }^{100}$ Antônio Luiz Dias de Andrade esteve à frente da diretoria regional do Iphan em São Paulo de 1978 a 1994. 
operações essas que não foram executadas. Em 2000 houve obras de estabilização da encosta e execução de canais para melhoria da drenagem natural, pois o acesso ao Engenho ficava comprometido pelo transbordamento do rio São Jorge que fora canalizado. Em 2001, houve nova sugestão de reforma do "Pavilhão Saia" por parte de Júlio Roberto Katinsky, professor da Faculdade de Arquitetura e Urbanismo da USP designado como gestor do Engenho de 1998 a 2002. No decorrer de 2002 foram iniciadas obras ${ }^{101}$ de consolidação das ruínas; remoção de construções posteriores como zeladoria e tanques; e a recuperação do "Pavilhão Saia" com reforços estruturais e restauração do telhado com a implantação de pórtico metálico para a sustentação do mesmo.
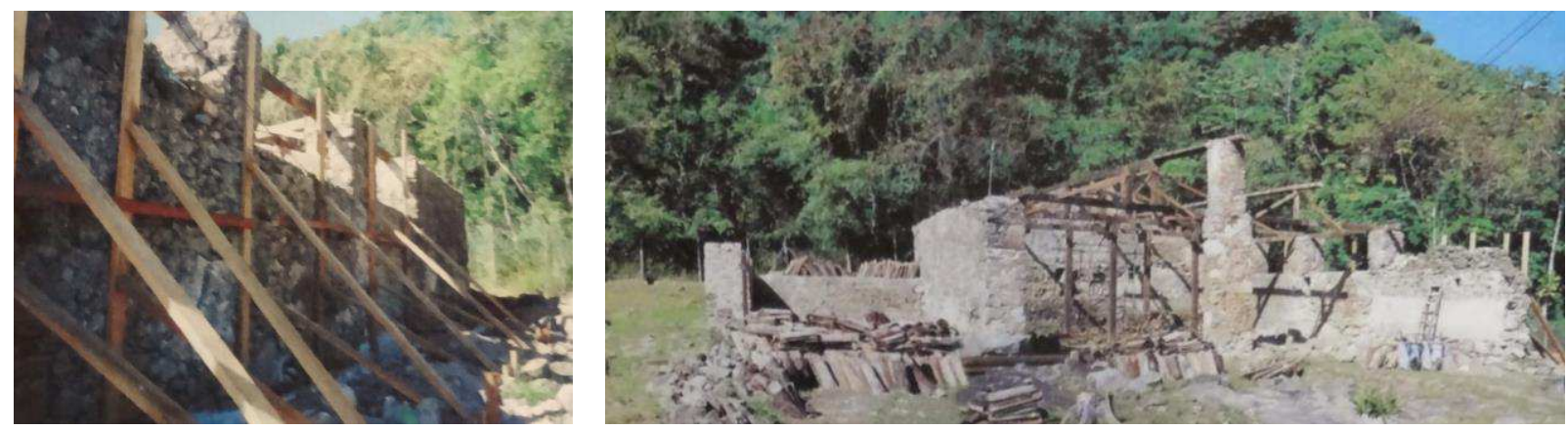

Fig. 29 (i-ii): Trabalhos de recuperação do "Pavilhão Saia", 2001.

Fonte: IPHAN, Relatório MORI, Victor Hugo In: IPHAN, 1962, s.p.

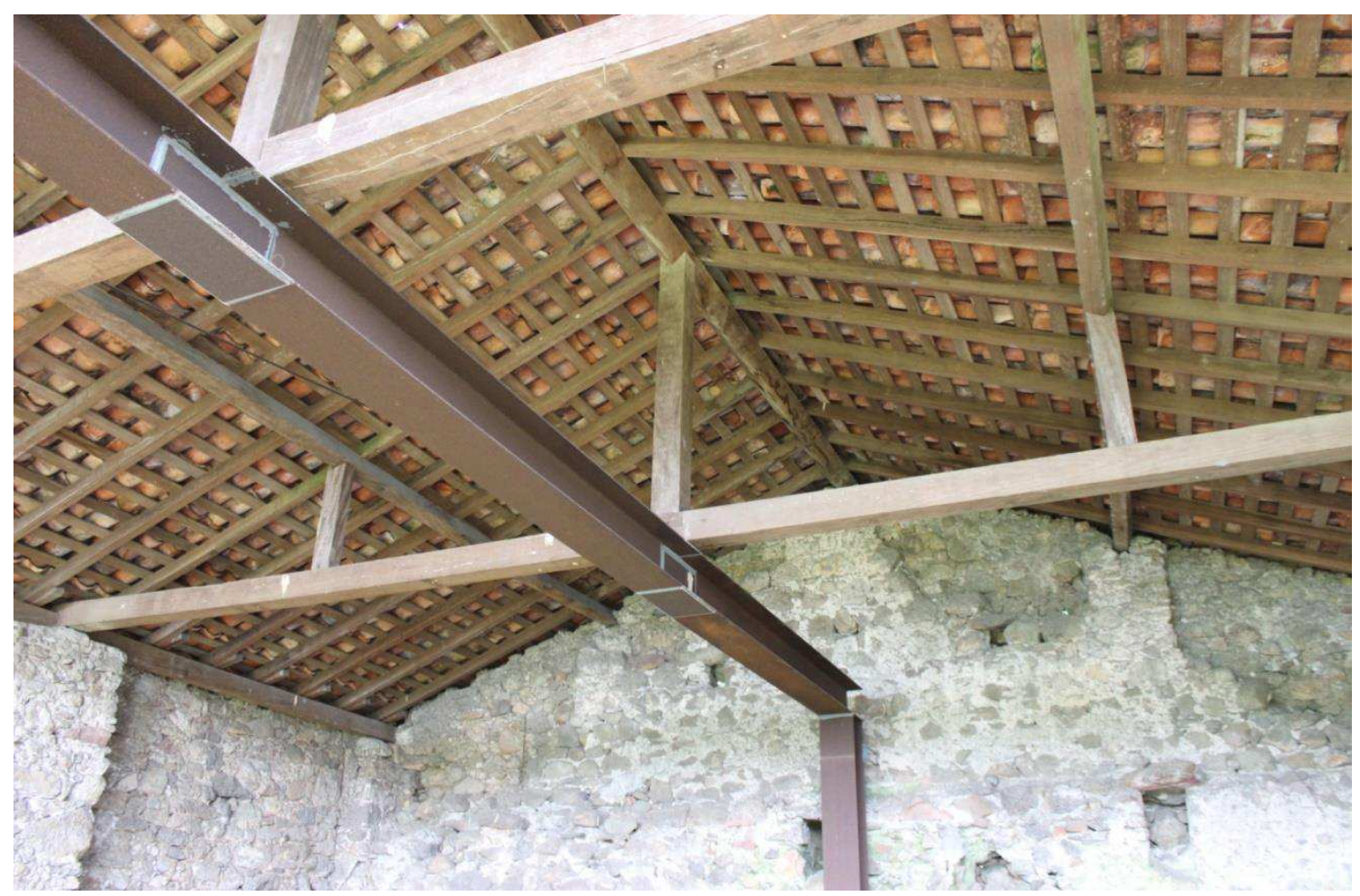

Fig. 30: "Pavilhão Saia", estrutura metálica de sustentação, 2013. Foto: Amanda Moutinho.

${ }^{101}$ Realizadas pela empresa FAZER Engenharia e Construções. 
Em 2008 foi inaugurada uma Base Avançada de Cultura e Extensão Universitária da USP, projeto do professor Katinsky constituída de instalações administrativas, auditório e sanitários. A Base, segundo o autor do projeto, não pretendia competir visualmente com as ruínas ficando numa cota abaixo com o objetivo de manter a visibilidade das mesmas (KATINSKY apud LOURENÇO et al., 2008).
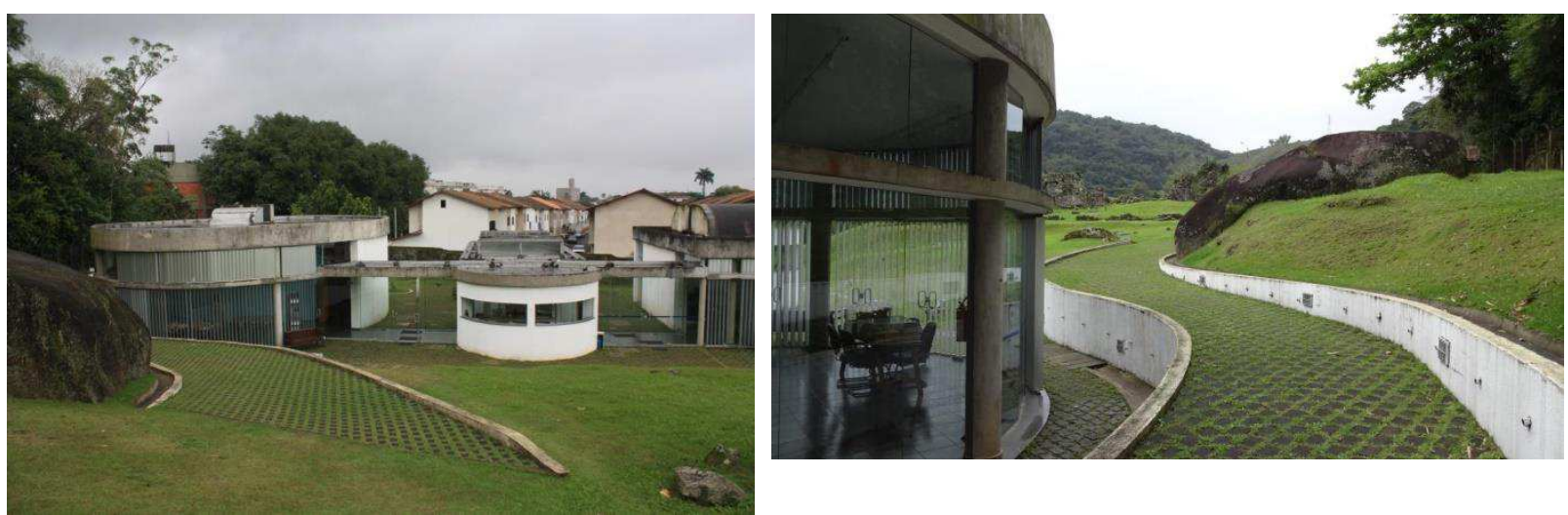

Fig. 31 (i-ii): Base da USP, vista a partir do platô do Engenho São Jorge dos Erasmos; e vista da Base para o platô, 2013. Fotos: Autora.

\subsubsection{Situação atual}

Atualmente o Engenho São Jorge dos Erasmos está situado numa área da cidade de Santos cuja mutação é o resultado de reconfigurações sociais e históricas que vem ocorrendo paulatinamente, com maior ênfase a partir dos anos 1950. Essa área noroeste de Santos tem sido considerada a última fronteira de expansão populacional e territorial da ilha e tem sediado a implantação de loteamentos e conjuntos habitacionais no entorno do Engenho constituindo a denominada Vila São Jorge. Porém, a despeito do reconhecimento cultural do Engenho, o desenvolvimento urbano ainda aguarda melhorias por parte de políticas públicas.

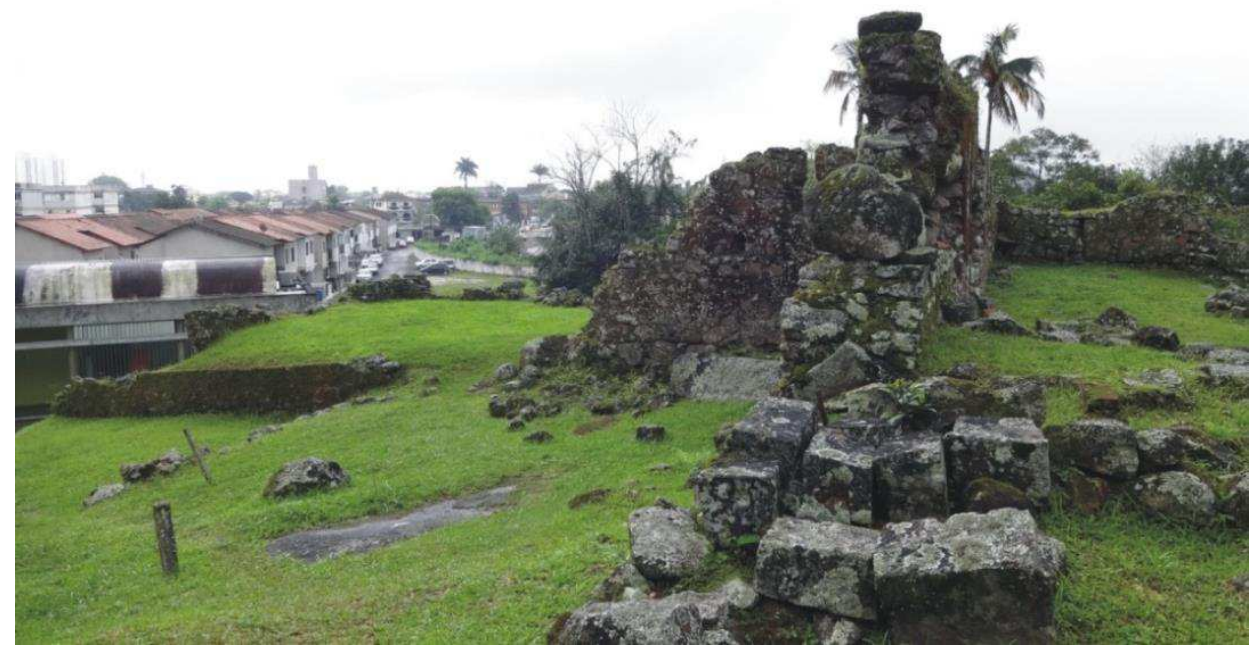

Fig. 32: Áreas circunvizinhas ao Engenho São Jorge dos Erasmos, 2013. Foto: Autora. 
Durante os anos 1990 o Engenho foi aberto esporadicamente à população para exercícios de leitura da paisagem de modo a interpretar a inserção do sítio arqueológico no contexto que vem se urbanizando. A partir de 2004, o espaço do Engenho foi efetivamente aberto ao público com programas didáticos ${ }^{102}$. A gestão desse patrimônio - pelas diretorias de Maria Cecília F. Lourenço (2003-2009) e Vera Lucia A. Ferlini (desde 2010) - passou a ter como premissa a necessidade da educação para promover o conhecimento e a interpretação do bem de forma crítica; e para criar identidade com a comunidade local, ressignificando o espaço em que vive. Assim, o Engenho se constitui na atualidade em um patrimônio que abarca múltiplos campos para a fruição do aprendizado e consequente preservação.

Desde 2010 vem sendo desenvolvida uma proposta com o objetivo de potencializar a visitação ao Engenho São Jorge dos Erasmos enquanto sítio arqueológico, possibilitando uma maior legibilidade das antigas ruínas e seu contexto através de um mirante (torre de observação) com 4 pavimentos (16,25 m de altura, com área total de $\left.546 \mathrm{~m}^{2}\right)$ que conta com um espaço expositivo; um sistema de passarelas que promove a interligação entre o mirante, a atual base da USP e o acesso para a visualização do sítio tendo como justificativa o menor impacto possível para as ruínas e sua ambiência. O projeto denominado "Parque Museu Arqueológico Engenho dos Erasmos" foi desenvolvido pelos escritórios Doisamaisv $(2 \mathrm{~A}+\mathrm{V})$ e Costa e Macedo ${ }^{103}$ com apoio do BNDES (Banco Nacional de Desenvolvimento Econômico e Social). Segundo entrevista com os arquitetos Apoena Amaral e Vito Macchione ${ }^{104}$, o projeto passou por uma seleção interna na USP, posteriormente foi apresentado ao BNDES e foi aprovado nas três esferas de preservação (federal, estadual e municipal).

A implementação desse projeto pretende incrementar as atividades educativas e culturais do local com enfoque arqueológico, arquitetônico e histórico. A tônica, portanto, é reforçar o papel documental do engenho integrando-o num circuito turístico cultural mais amplo de Santos que engloba a visitação de outros monumentos ${ }^{105}$ e numa rede de pesquisa para o mapeamento de edificações patrimônio em outros municípios do litoral paulista (Praia

\footnotetext{
${ }^{102}$ Como: Projeto Vou Volto (2004), Portas abertas (2004),Território e transformação (2006), dentre outros.

${ }^{103} \mathrm{O}$ arquitetos da equipe são: Ana Paula de Castro, Apoena Amaral e Vito Macchione (doisamaisv), Christiane Costa e José Maria de Macedo (costa e macedo).

${ }^{104}$ Entrevista concedida à autora em 05.05.2015.

${ }^{105}$ Como a Casa do Trem Bélico e o Museu Pelé (instalado no antigo Casarão do Valongo).
} 
Grande, São Vicente, Santos, Guarujá e Bertioga). As obras foram iniciadas em janeiro de 2016, porém estão sem uma efetiva previsão de término ${ }^{106}$.

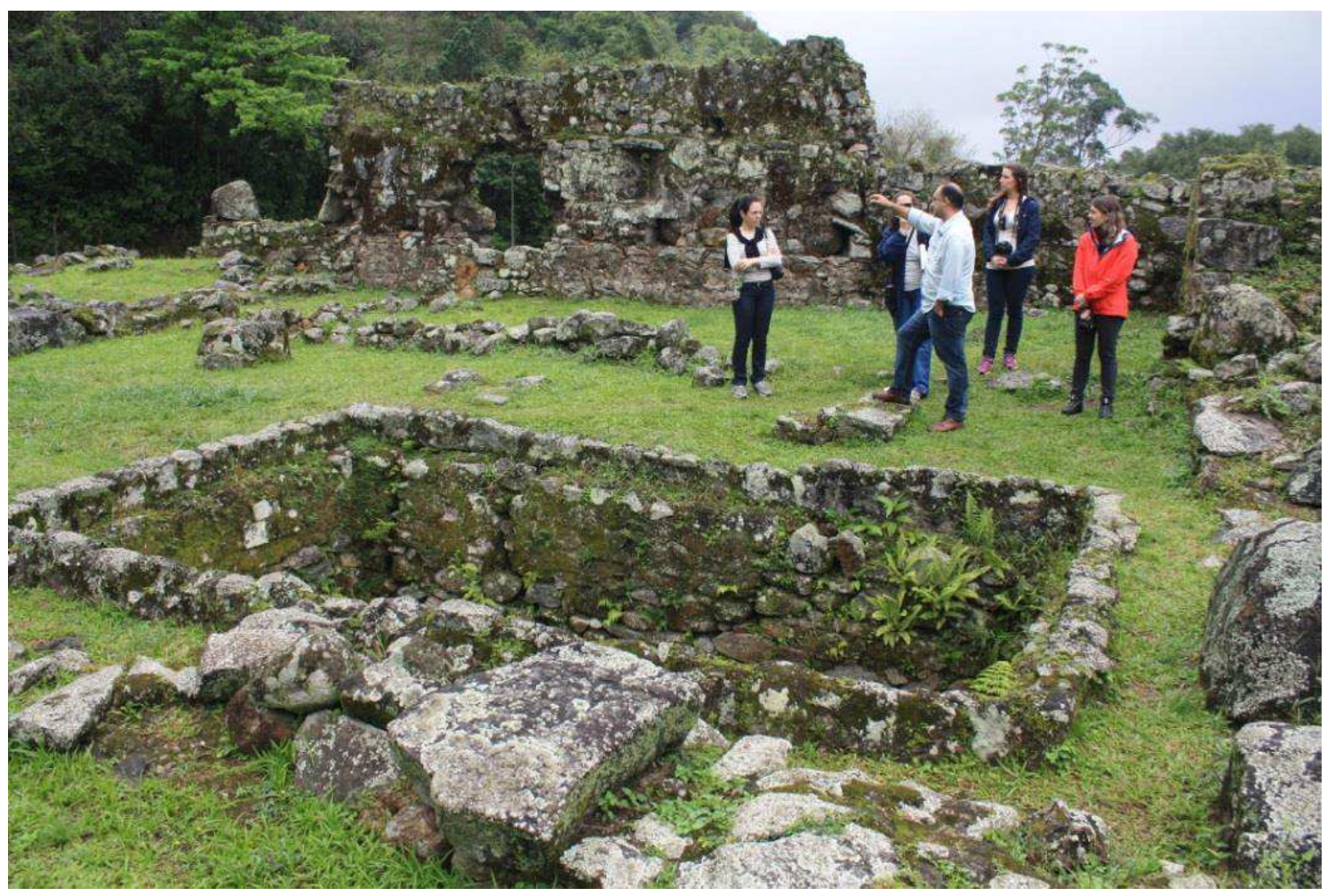

Fig. 33: Em primeiro plano o fosso onde foram encontradas as fôrmas de pão de açúcar, durante a década de 1960, 2013. Foto: André Rosch Rodrigues.

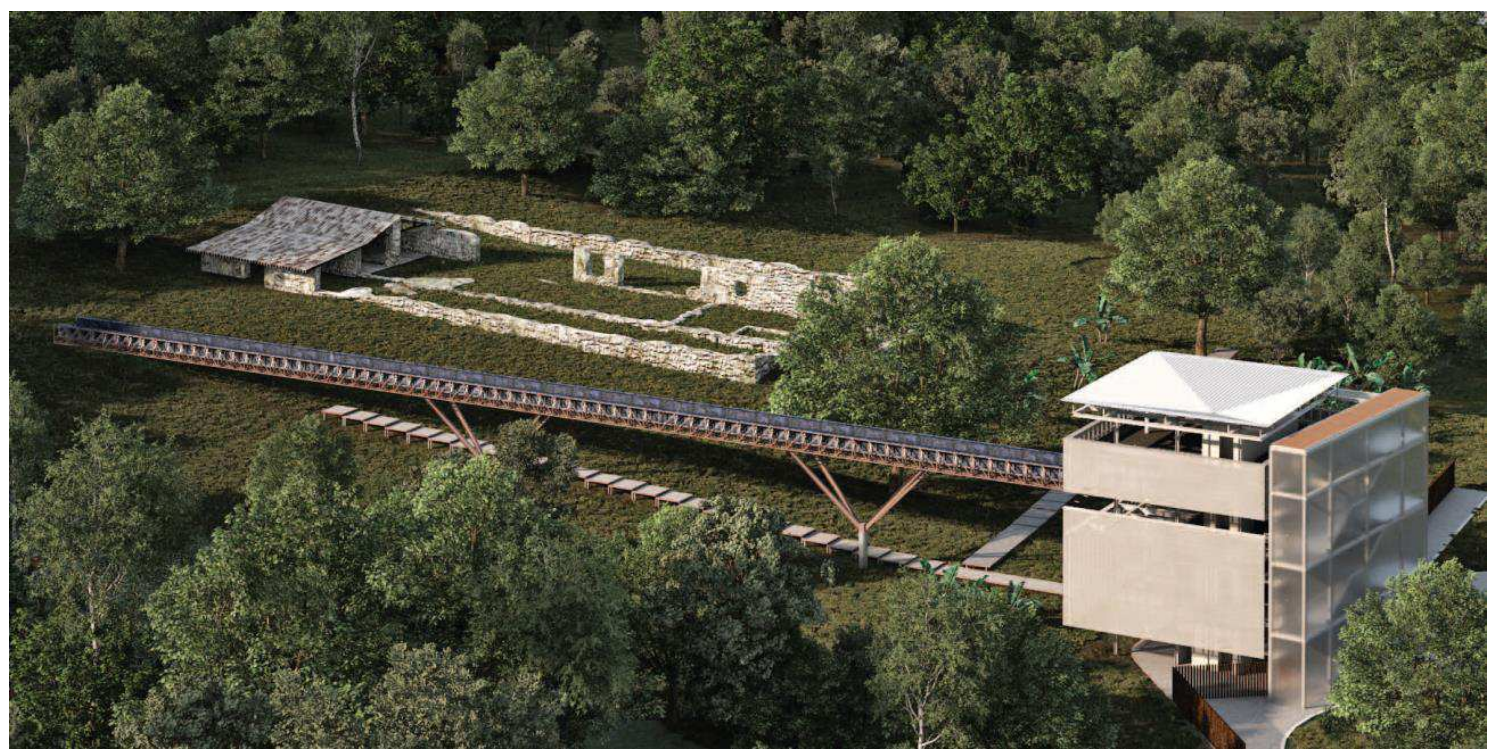

Fig. 34: Perspectiva da proposta para o sítio arqueológico, com a torre mirante e passarela. Fonte: Folder divulgação "Adaptação e Valorização Patrimonial Monumento Ruínas Engenho São Jorge dos Erasmos", 2014, p.7.

${ }^{106}$ Informação concedida à autora pelo arquiteto Apoena Amaral em 05.10.2016. 


\subsection{Capela do Morumbi ${ }^{107}$}

A denominada Capela São Sebastião do Morumbi está localizada numa área que compunha a antiga Fazenda do Morumbi, numa região rural afastada do triângulo central da cidade de São Paulo e a caminho de Santo Amaro. Havia indicações de que a fazenda teria sido constituída por um bandeirante, que com mão de obra indígena, organizou uma plantação de chá na região. No entanto, segundo as informações que puderam ser confirmadas e que constam nas pesquisas históricas ${ }^{108}$ realizadas durante os processos de tombamento, a propriedade pertenceu ao Pe. Ignácio Xavier Moreira Penteado e em 1825 o inglês John Rudge (1792-1854) adquiriu os 723 alqueires para implementar o cultivo de chá da Índia. Em 1873, a fazenda atingiu seu auge produtivo com 300 mil pés de chá, e a partir de meados de 1880 passou por uma sucessão de proprietários, que paulatinamente descaracterizaram sua estrutura e edificações, culminando com o processo de loteamento iniciado em 1949.

Há documentos referentes à Casa Sede e à "Capela" que datam do início de 1825 , associando essas construções ao período de John Rudge. Porém, não se sabe ao certo a destinação da edificação denominada "Capela". Há algumas hipóteses que foram desenvolvidas durante as pesquisas históricas: a edificação seria mais antiga e foi construída antes de Rudge comprar a propriedade; poderia também ter sido somente uma estrutura para um provável paiol, uma capela para os escravos (São Sebastião dos escravos), ou idealizada para abrigar a sepultura dos proprietários. Segundo o historiador Aureliano Leite, Rudge pretendia ser enterrado nessa Capela, porém, esse desejo não pôde ser atendido, pois, devido a uma grande epidemia de varíola em São Paulo o sepultamento nos templos religiosos passou a ser proibido. Há ainda outra conjectura de que as estruturas dessa provável Capela teriam ficado inacabadas devido a essa medida de secularização dos cemitérios (SÃO PAULO Estado, CONDEPHAAT, 1982, p. 33).

Contudo, segundo as pesquisas do Departamento do Patrimônio Histórico da Prefeitura Municipal de São Paulo (DPH) essa versão de que se tratava de uma edificação

\footnotetext{
${ }^{107}$ O material consultado sobre a Capela do Morumbi foi obtido junto ao: CONDEPHAAT - Processo 22263/82 (SÃO PAULO - Estado, CONDEPHAAT, 1982) e Prefeitura Municipal de São Paulo/SMC (DPH e CONPRESP): Processo 1992-0.007.730-7 (SÃO PAULO - cidade, SMC/CONPRESP, 1992) e Pasta 03A.004.3 - SMC/DPH Seção Levantamento e Pesquisa. Projeto de Gregori Warchavchik consultado na Seção Levantamento e Pesquisa e Acervo FAU USP, PW196 725.65 FM.

${ }^{108}$ Pesquisas elaboradas para a instrução do processo de tombamento: da historiadora Silvia Haskel P. do Nascimento (DPH), tendo como referências fontes primárias e os escritos de Vilma L. Gagliardi (DPH), de Aziz Ab`Saber, Eudes Campos, dentre outros (In: SÃO PAULO - cidade, SMC/CONPRESP, 1992, p. 33-65); e da arquiteta Clara Correia D`Alambert (In: Op. cit., p. 179-242).
} 
inacabada pode ser contestada já que foi localizado um documento de 1886 que associa essa "Capela" à sede de um cemitério inserido nos limites da Fazenda do Morumbi. Também foi identificada uma "provisão"109 do Arcebispo de São Paulo - D. Duarte Leopoldo e Silva concedendo autorização para celebração de missa na capela em 1912. Esse documento é importante, pois nomeia o espaço e atesta o seu estado físico: “[...] a capela, acha-se paupérrima, inteiramente desprovida de tudo que se requer para as funções sacras, possui apenas uma imagem de São Sebastião, duas pequenas imagens de outros Santos e um crucifixo [...]" (São Paulo - cidade, SMC/CONPRESP, 1992, p. 41). Não se sabe, no entanto, se essa missa foi celebrada e tão pouco foram encontrados outros documentos que atestem a função religiosa do espaço.

Segundo o geógrafo Aziz Ab'Saber ${ }^{110}$ : “a construção de um templo local, era uma exigência da religiosidade de uma época, traduzida pelo status social dos abastados proprietários das terras, do velho bairro rural do Morumbi” (AB `SABER, 1990 In: São Paulo - cidade, SMC/CONPRESP, 1992, p. 34). Ab Saber assinalou que a caracterização dessa edificação como "Capela" poderia indicar uma modificação estrutural em relação aos demais espaços de função religiosa nas propriedades rurais bandeiristas dos séculos XVII e XVIII da região de São Paulo, que possuíam capelas ou oratórios numa dependência interna à Casa Sede, próxima a um quarto de hóspedes e isolada dos demais ambientes. A Capela do Morumbi seria, portanto, uma referência para a diferenciação desse esquema anterior por ser um espaço apartado da Sede para o exercício de práticas religiosas da comunidade.

Porém, as características arquitetônicas e de uso das estruturas associadas à "Capela do Morumbi” são incertas pela exiguidade de fontes documentais. O fato é que em meados de 1930, quando foi feito um levantamento fotográfico do local, essas estruturas encontravam-se arruinadas, tendo sido mencionadas por Mário de Andrade em seu relatório sobre o Estado de São Paulo, porém sem maiores detalhamentos: “[...] taipas da casa-grande do Morumbi, onde se fez, no Brasil, a primeira plantação de chá. Ainda não se visitou este local." (ANDRADE, M., Relatório 1937 In: ANDRADE, M., 1981, p. 86).

\footnotetext{
${ }^{109}$ Provisão Quinquenal para a Capela do Morumbi, 17/05/1912. Arquivo da Curia Metopolitana de S. Paulo In: São Paulo - cidade, SMC/CONPRESP, 1992, p. 41.

${ }^{110}$ Cf.: AB’SABER, Aziz. Manuscrito "Falam as Taipas da Capela" para a exposição "Taipa, tijolo e fantasia", SMC/DPH/DIM/STAM, Capela do Morumbi, 1990 apud NASCIMENTO In: SÃO PAULO - cidade, SMC/CONPRESP, 1992, p. 33-46.
} 


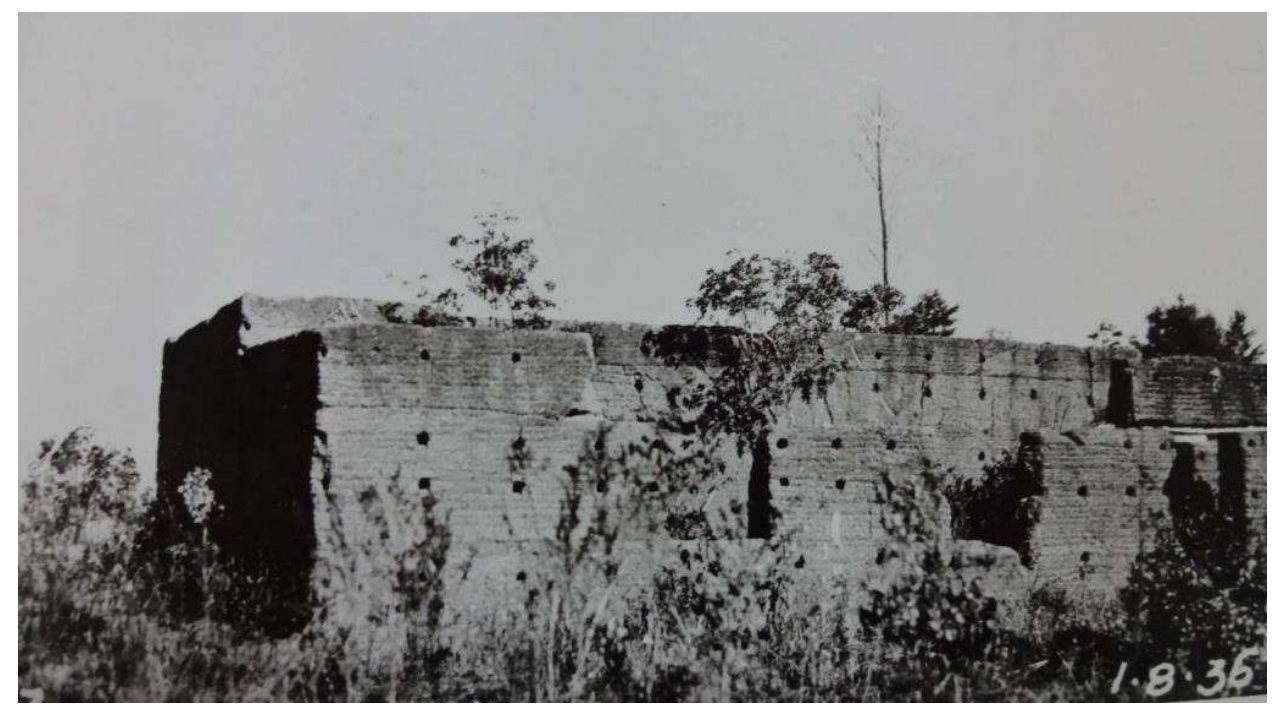

Fig. 35: Ruínas da Capela do Morumbi, 1936. Fonte: Reprodução do álbum fotográfico de Santo Amaro, SMC/DPH/DIM/Seção Arquivo de Negativos In: SÃO PAULO - cidade, SMC/CONPRESP, 1992, p.60.

Em 1948 foi iniciado o loteamento da área pela Companhia Imobiliária Morumby, configurando o que seria o "Jardim Morumbi"; como contrapartida, o terreno onde se encontrava a Capela seria doado à Prefeitura. A Companhia contratou o arquiteto Gregori Warchavchik (1896-1972) para fazer os projetos de intervenção na Casa da Sede da Fazenda e na Capela, cujo projeto de "restauro" foi submetido à prefeitura em 1949, e as obras foram concluídas em 1959.

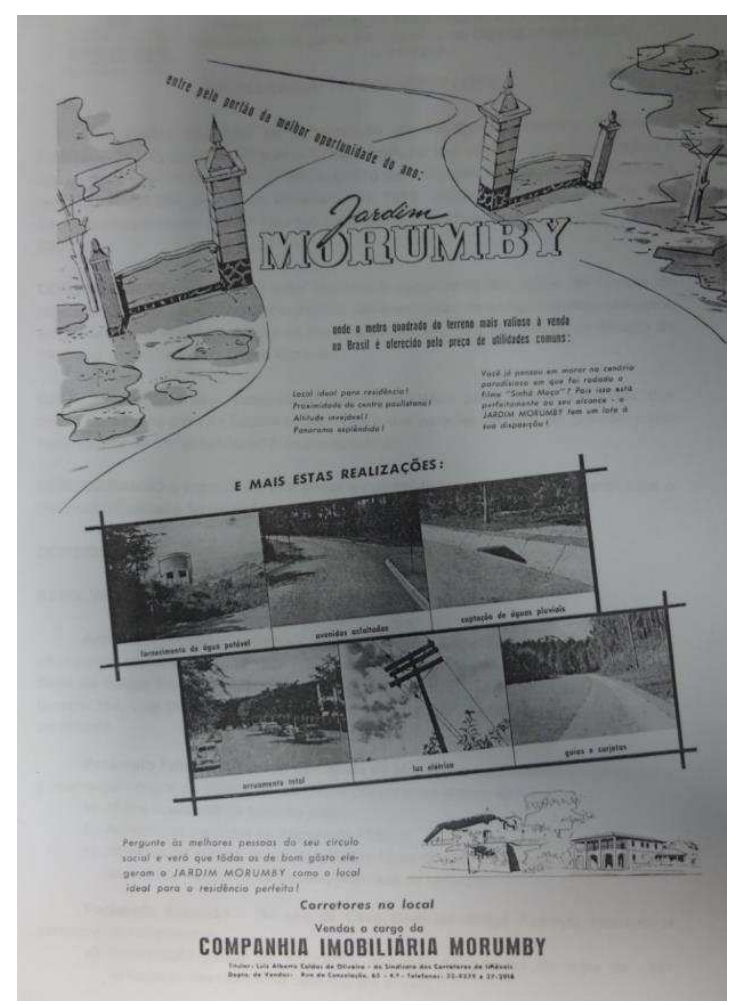

Fig. 36: Divulgação publicitária do Jardim Morumby, no canto inferior direito há representações da Capela e Casa Sede. Fonte: Revista Habitat, n. 25, dez. 1955.

In: Pasta 03A.004.3 - SMC/DPH Seção Levantamento e Pesquisa. 
Durante a década de 1970 a Capela e seu respectivo terreno passaram a ser de propriedade municipal. Em 1979, o DPH iniciou uma reforma ${ }^{111}$ na Capela projetada por Warchavchik retirando o altar e implementando algumas adaptações ao edifício para uma destinação voltada a um programa cultural. A Capela do Morumbi foi inaugurada em 25 de janeiro de 1980 e desde então abriga atividades culturais múltiplas e temporárias (exposições, peças teatrais, concertos de câmara, etc.) programadas pela Secretaria Municipal de Cultura de São Paulo. Atualmente a Capela integra o Museu da Cidade abrigando exposições de arte contemporânea.

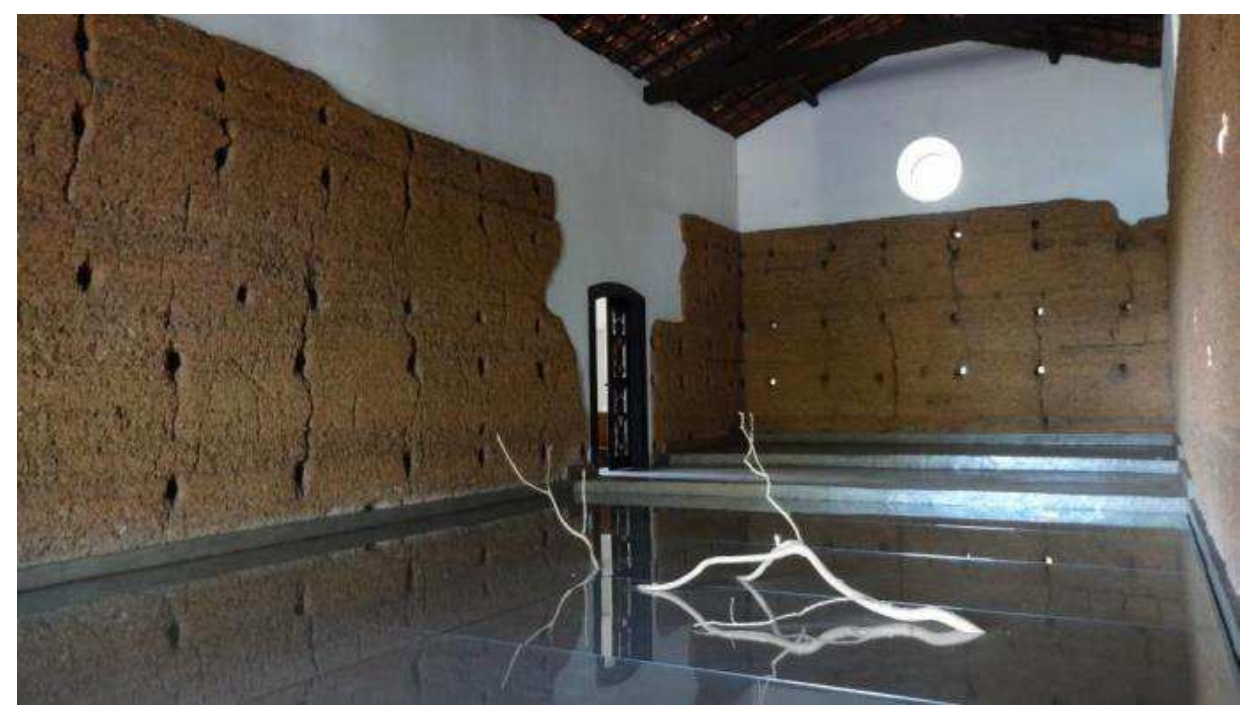

Fig. 37: Capela do Morumbi - área interna utilizada para instalações de arte, 2014. Foto: Autora.

\subsubsection{Intervenção e abandono}

O loteamento que deu origem ao bairro do Morumbi em meados da década de 1940, a exemplo dos outros bairros jardins já existentes na cidade de São Paulo, visava um público de alto poder aquisitivo. O então prefeito da cidade Fábio da Silva Prado (1887-1963) era um dos diretores da Companhia Imobiliária do Morumby e sua esposa, Renata Crespi da Silva Prado (1897-1981), ficou responsável pelas obras da Capela contratando o arquiteto russo Gregori Warchavchik radicado no Brasil desde 1923 para a elaboração dos projetos ${ }^{112}$.

\footnotetext{
111 Projeto elaborado pelo DPH e executado pela Sociedade de Comércio e Engenharia Marvic Ltda (SÃO PAULO - Estado, CONDEPHAAT, 1982, p.34).

112 Como destaca Invamoto (2012), para compreender a indicação de Warchavchik é necessário considerar que ele já havia trabalhado para as renomadas famílias Crespi e Prado em projetos para as residências de Luis da Silva Prado (R. Bahia), Antonio da Silva Prado Neto (R. Estados Unidos), o rancho de Marjorie e Jorge da Silva Prado na praia de Pernambuco (Guarujá), a casa de veraneio na Enseada (Guarujá) e a Fazenda Santa Maria Calunga do conde Raul Crespi.
} 


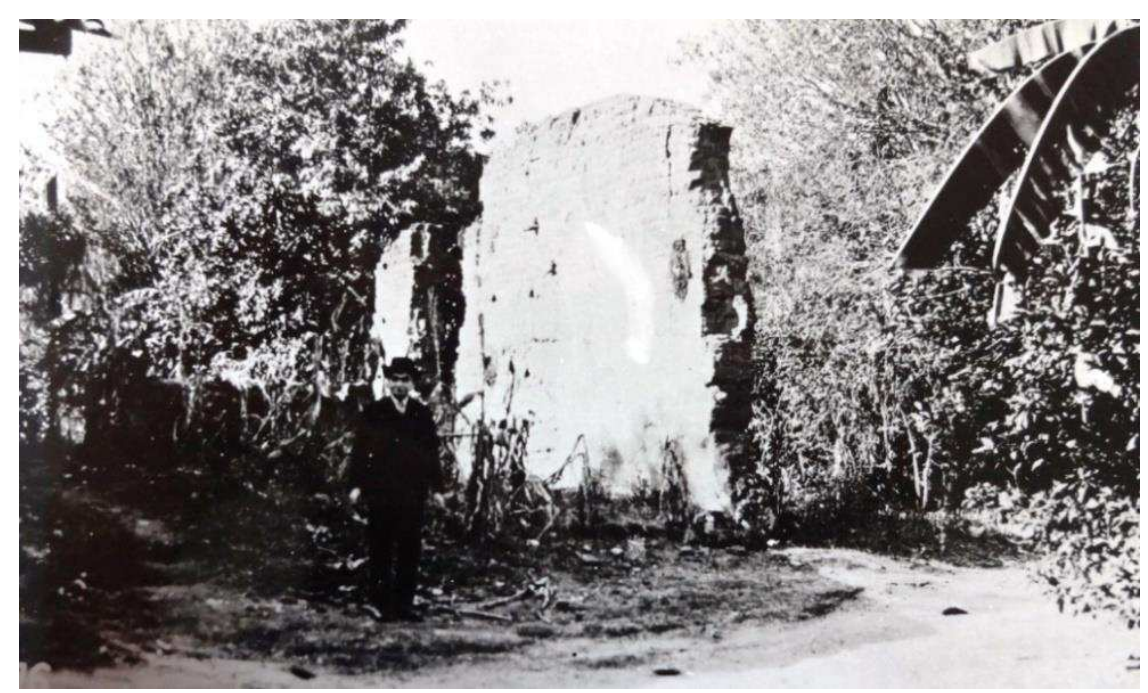

Fig. 38: Ruínas da Capela do Morumbi e o arquiteto Gregori Warchavchik.

Fonte: Reprodução do álbum fotográfico de Santo Amaro, SMC/DPH/DIM/Seção Arquivo de Negativos In: SÃO PAULO - cidade, SMC/CONPRESP, 1992, p.60.

O projeto de Warchavchik elaborado em 1949 utilizou como base as ruínas preexistentes e estabelecia um desenho que era uma releitura do partido arquitetônico de uma capela constituída por uma torre unida ao corpo da construção e frontispício com óculo acima da entrada principal; os elementos compositivos remetem a uma linguagem do "colonial paulista ou do neocolonial hispano-americano ou estilo Missões” (D`ALAMBERT In: SÃO PAULO, cidade - SMC/CONPRESP, 1992, p. 187). O Memorial Descritivo apresentado pelo arquiteto indicava as características básicas das ruínas e denominava a intervenção como "restauro":

Preliminares:

Características da Ruína - as paredes são de terra batida, variando sua espessura entre 0,45 a 0,60 .

Restauro:

Paredes de elevação: Sobre as ruínas de terra batida, serão levantadas paredes de alvenaria de tijolos, recuados 0,08 da existente, sem rejuntamento até atingir o respaldo. Cobertura: A cobertura será de telhas comuns sobre madeiramento de pau roliço. O forro será de madeira. Pisos: Todos os pisos serão de tijolos requeimados de cimento. Esquadrias: Janelas de 2 folhas, tipo calha, de abrir para dentro. Externamente grade de proteção de pau roliço. As portas serão de Cabreúva, em 2 folhas com tábuas largas. Pinturas: Todos os cômodos serão caiados, excetuando as paredes existentes. Os forros serão pintados a óleo. (MEMORIAL DESCRITIVO In: Pasta 03A.004.3 - SMC/DPH Seção Levantamento e Pesquisa e Acervo FAU USP, PW196 725.65 FM, p. 17)

Quando da execução, a alvenaria de tijolos foi revestida com uma superfície irregular e pintura, mas Warchavchik evidenciou as paredes de taipa originais deixando-as aparentes, sendo possível vislumbrar a técnica construtiva com os orifícios deixados para os cabodás elementos de madeira cilíndricos para a estruturação da taipa que eram retirados após a aplicação da terra. 

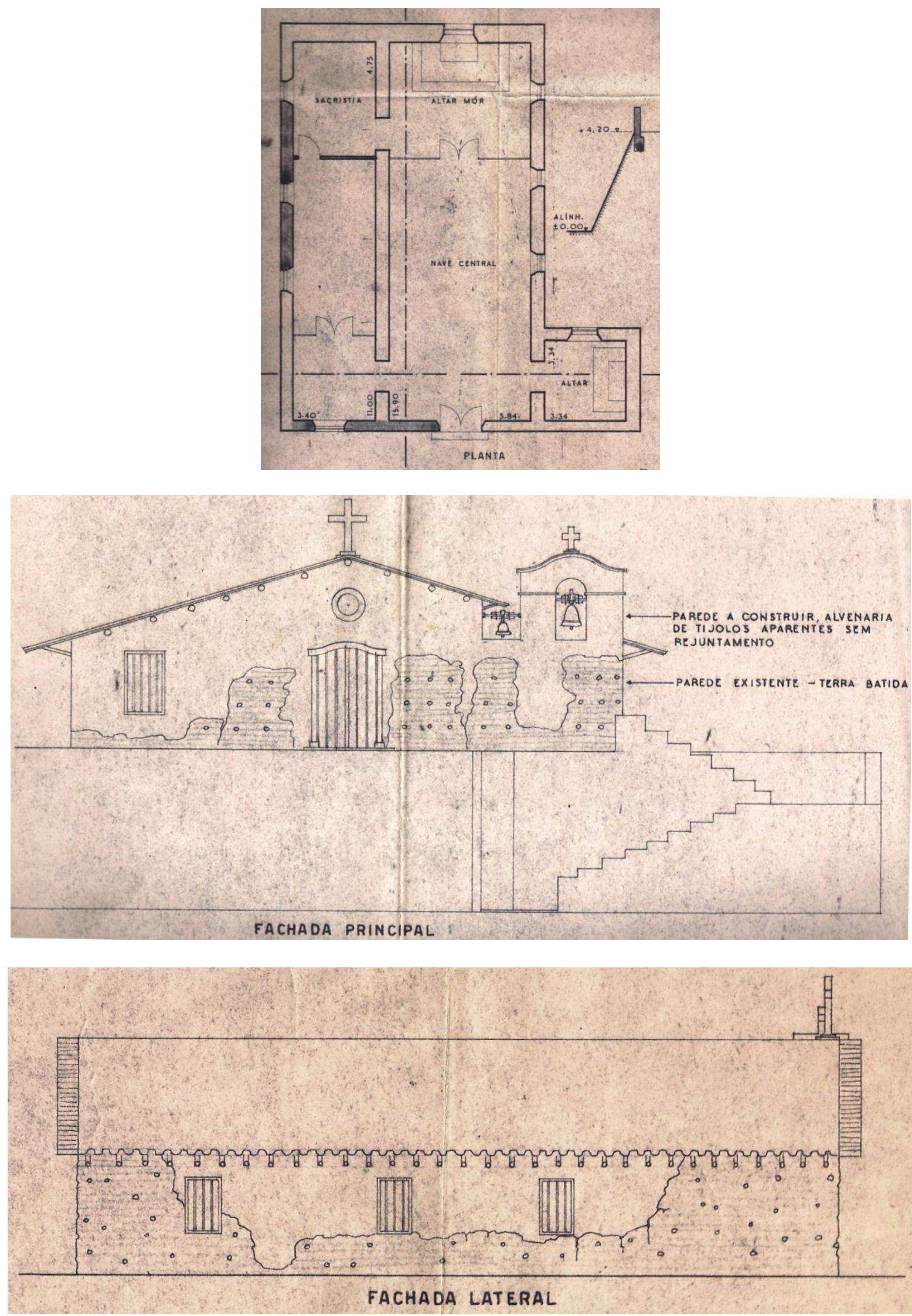

Fig. 39 (i-iii): Projeto Gregori Warchavchik elaborado em 1949, planta e fachadas. Fonte: Acervo FAU USP PE W196 725.85 fm. p.16. 

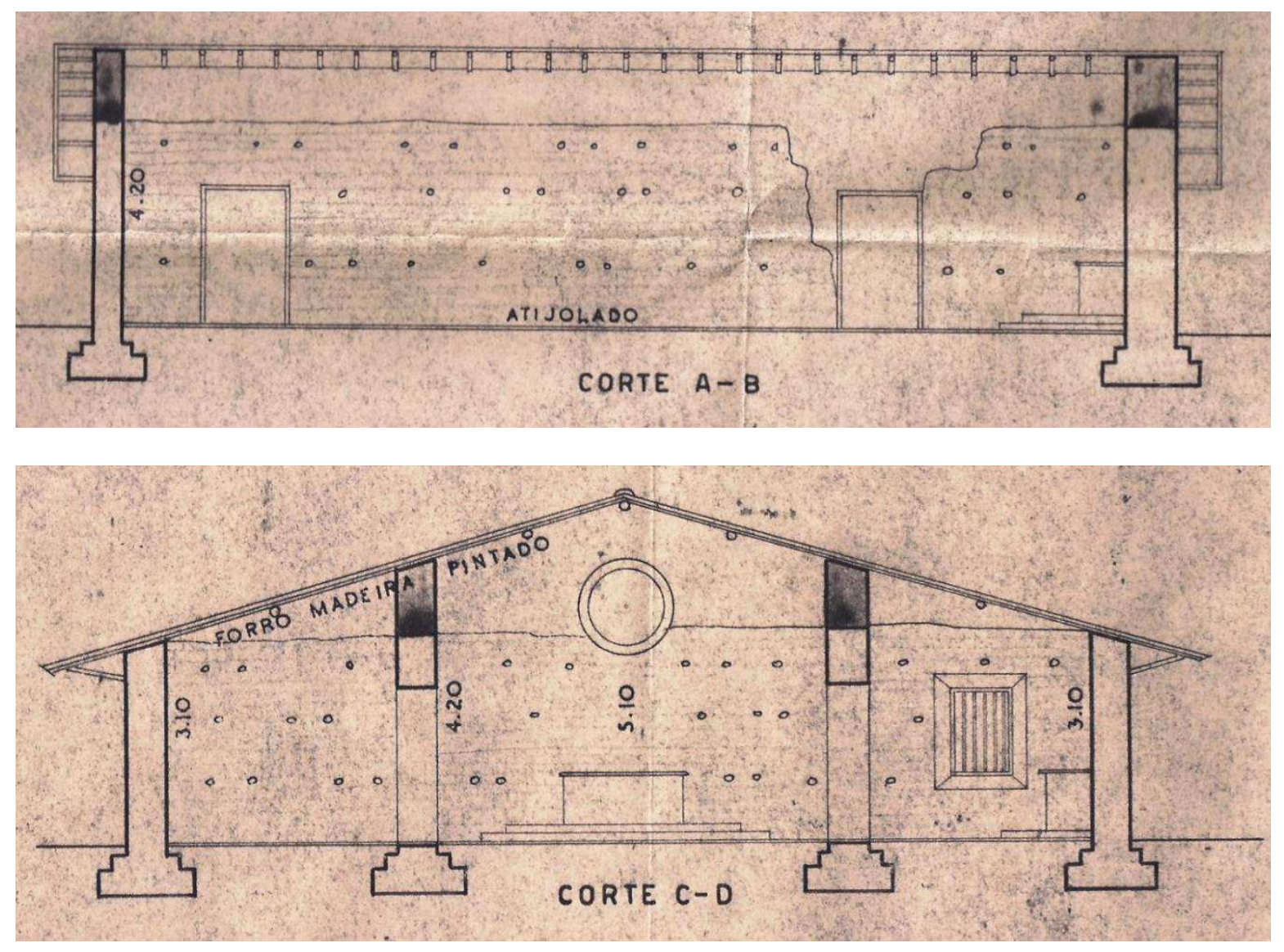

Fig. 40 (i-ii): Projeto Gregori Warchavchik elaborado em 1949, cortes. Fonte: Acervo FAU USP PE W196 725.85 fm. p.16.

A princípio o edifício foi projetado com a ideia de abrigar uma função religiosa retomando o presumido uso original das paredes de taipa, sendo assim, o programa foi dotado de altar, sacristia e batistério. Para as paredes do batistério a artista plástica Lucia Suané foi contratada para a realização de afrescos; as pinturas mesclam a representação do batismo de Cristo com elementos da cultura indígena.
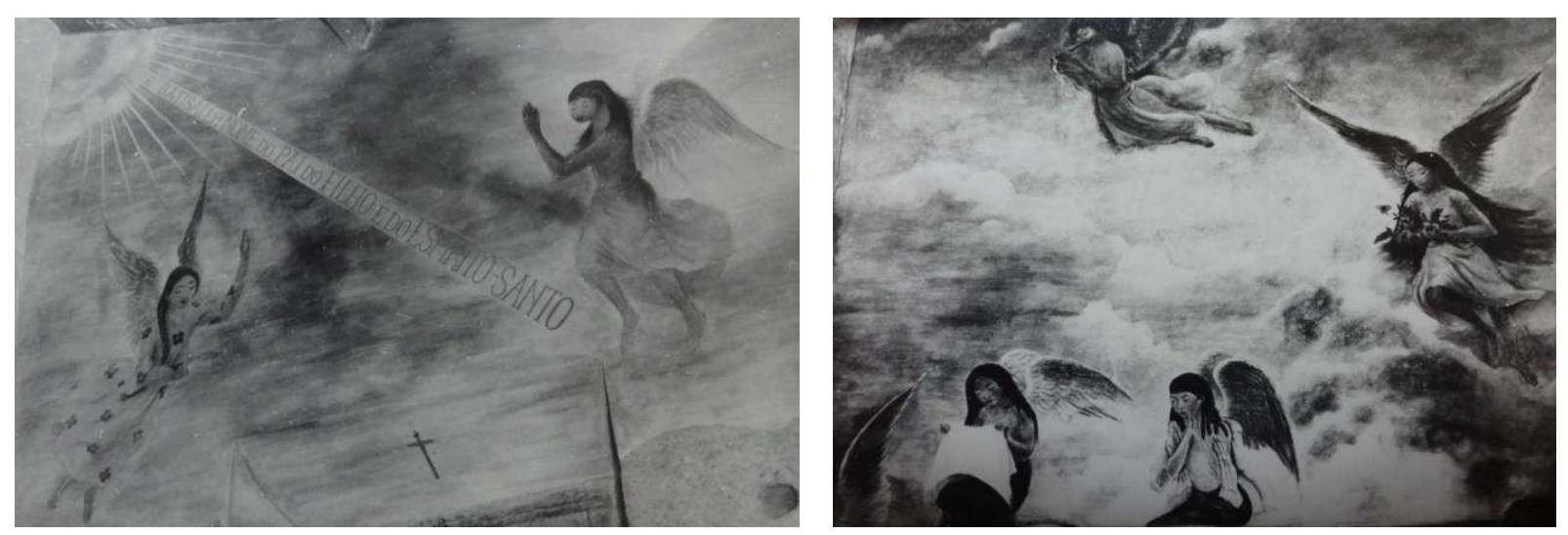

Fig. 41 (i-ii): Pinturas murais do batistério, executadas por Lucia Suané em 1951. Fonte: SMC/DPH/Seção Técnica de Levantamento e Pesquisa In: SÃO PAULO - cidade, SMC/CONPRESP, 1992, p. 57. 
Desde sua finalização em 1959 até 1970 a Capela esteve fechada. Houve pedidos da Cúria Metropolitana solicitando a utilização do espaço para a Comunidade Paroquial Nossa Senhora da Providência, no entanto esse pedido não seguiu adiante. Sem um uso definido e ações para sua conservação, a Capela passou por um processo degenerativo.
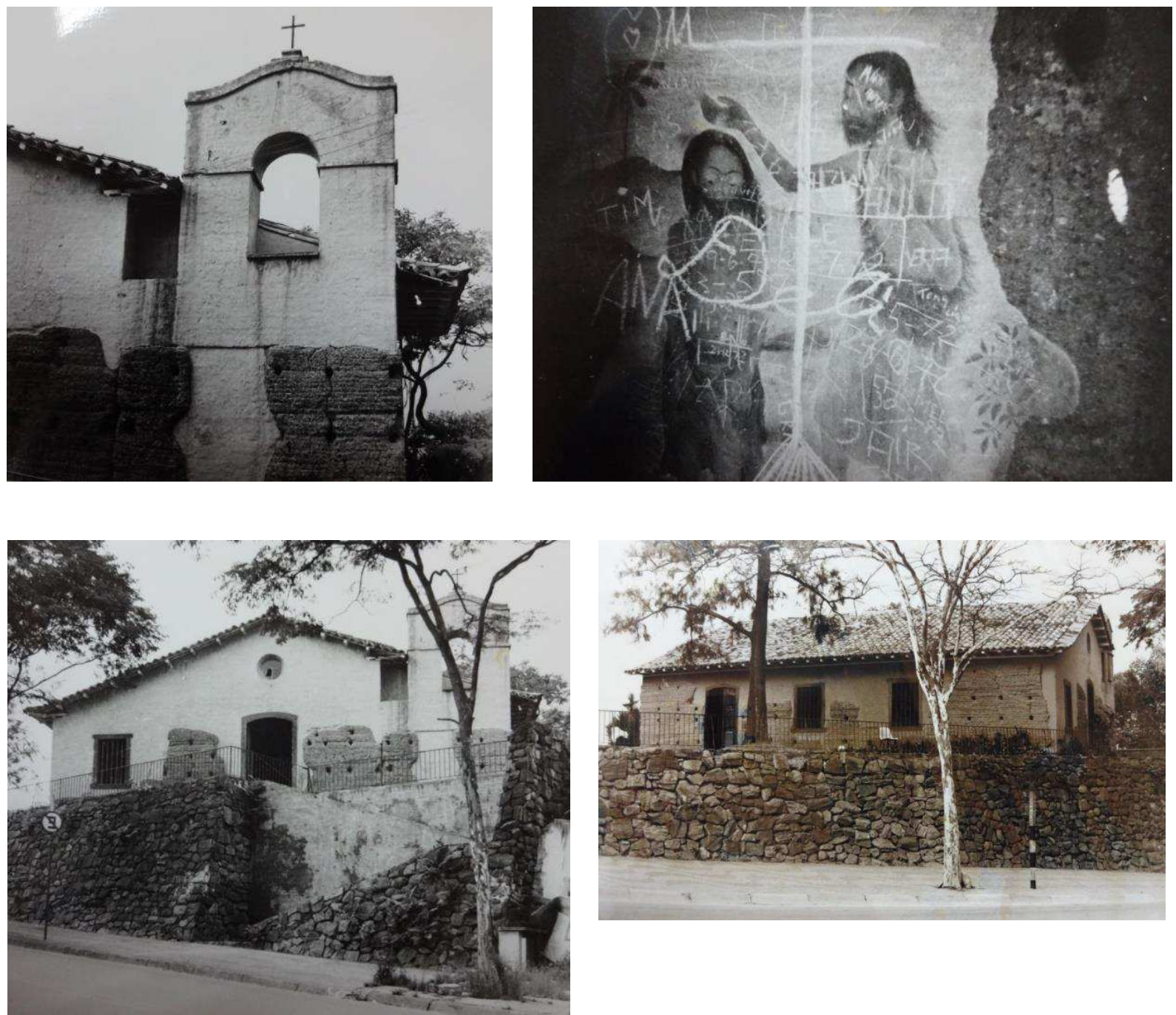

Fig. 42 (i-iv): Capela do Morumbi, entre 1973-1976. Fonte: SMC/DPH/DIM Seção Arquivo de Negativos In: SÃO PAULO - cidade, SMC/CONPRESP, 1992, p.61-65.

No início da década de 1970, surgiram denúncias ${ }^{113}$ acusando o estado de abandono do imóvel e em 1974 a Sociedade Amigos da Cidade Jardim fez uma solicitação de tombamento ao CONDEPHAAT ${ }^{114}$, que foi indeferido.

\footnotetext{
113 "Há goteiras em quase todo o telhado e em alguns lugares faltam telhas inteiras. Uma grade, de uma das janelas laterais, foi retirada [...] Na parede oposta a uma das janelas, permanentemente abertas, há uma pintura de Jesus sendo batizado por São João, pintado por Lucia Suané, [...] o afresco de Lucia tem riscos de giz feitos por mãos estranhas [...]." (A capela do Morumbi continua abandonada, O Estado de S. Paulo, 25 de novembro de 1972. In: SÃO PAULO - Estado, CONDEPHAAT, 1982, p.30).
}

${ }^{114}$ CONDEPHAAT - Processo 00497/74. 
Em 1975, o Departamento de Cultura solicitou a guarda do imóvel; e finalmente entre 1979 e 1980, após duas décadas de abandono, foram feitas reformas para reativar o espaço com um novo uso de teor cultural. Foram instalados sanitários, copa e depósito, foi executada uma recuperação da cobertura e das janelas, renovação das instalações hidráulicas e elétricas (SÃO PAULO - Estado, CONDEPHAAT, 1982, p. 31). Os afrescos da artista plástica Lucia Suané também passaram por trabalhos de recuperação. Desde sua efetiva inauguração em 1980, o DPH passou a ser responsável pela conservação do imóvel e tem realizado manutenções periódicas além de esporádicas obras de maior vulto como a recuperação da cobertura em 1987.
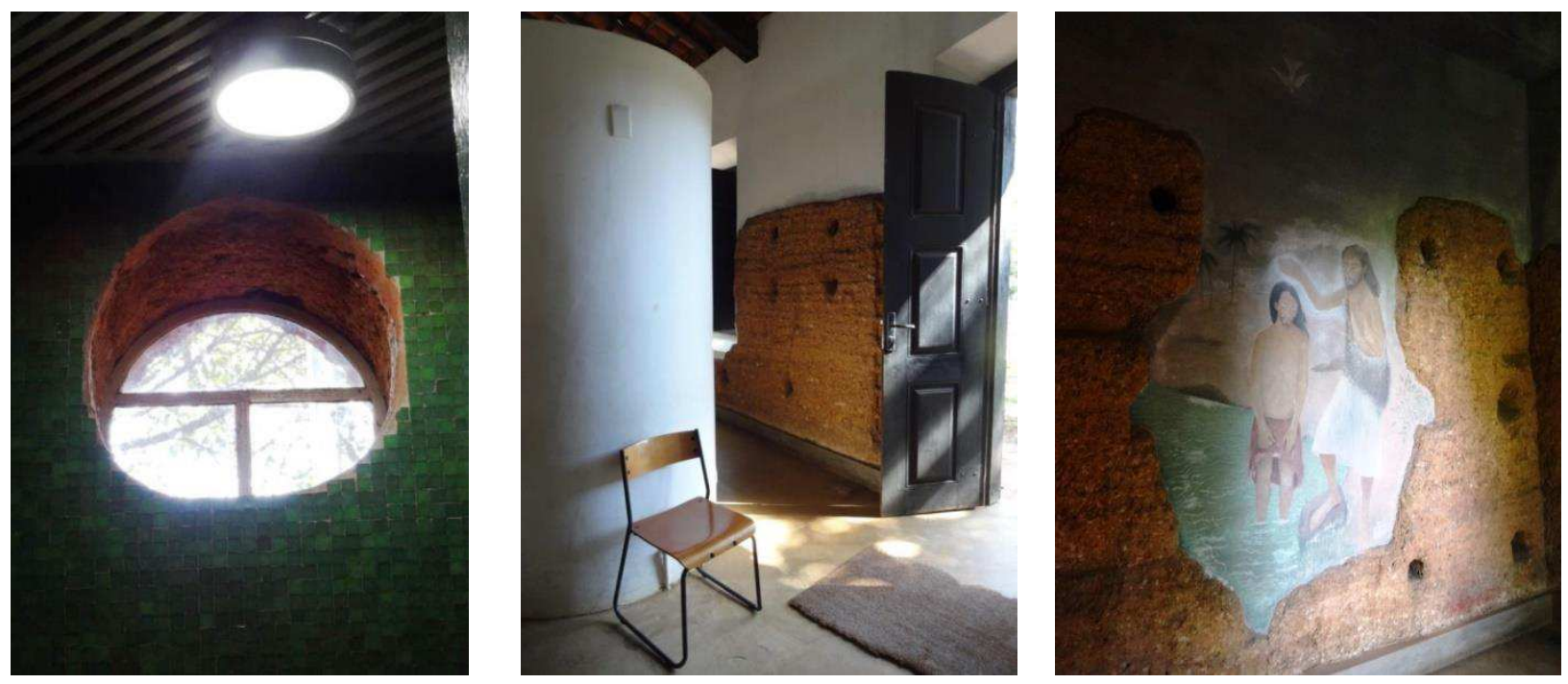

Fig. 43 (i-iii): Capela do Morumbi, detalhes internos, 2014. Fotos: Autora.

\subsubsection{Debates para o tombamento}

O pedido de tombamento apresentado pela sociedade civil em 1974 ao CONDEPHAAT foi indeferido, a despeito disso a Secretaria Municipal de Cultura tinha interesse no reconhecimento do valor cultural da Capela e apresentou um novo pedido ${ }^{115} \mathrm{em}$ 1982 englobando também as casas bandeiristas do Butantã ("Casa do Bandeirante") e do Caxingui ("Casa do Sertanista”), que tinham sido transformadas em Casas Museu ${ }^{116}$. Esse pedido de tombamento também foi indeferido e arquivado. As motivações para o não tombamento da Capela do Morumbi em 1975 e 1983 são semelhantes e estão embasadas na valorização (ou não) da intervenção de Warchavchik nas antigas ruínas de taipa.

\footnotetext{
${ }^{115}$ Ofício N. 1.530/82 In: SÃO PAULO - Estado, CONDEPHAAT, 1982, p.3.

${ }^{116}$ Casa do Butantã: restaurada entre 1954-1955 pela Comissão do IV Centenário da Cidade de São Paulo; Casa do Caxingui: restaurada em 1967. Ambas com projeto e orientação técnica de Luis Saia (MAYUMI, 2008).
} 
Em 1992 foi aberto outro pedido de tombamento ${ }^{117}$, agora na esfera municipal (Conselho Municipal de Preservação do Patrimônio Histórico, Cultural e Ambiental da Cidade de São Paulo - CONPRESP) ${ }^{118}$. Essa solicitação englobava a Capela e a Fazenda do Morumbi, ambos agregados pelo valor histórico enquanto testemunhos de pertencimento a uma propriedade que reflete a ocupação rural dessa região. Essa nova tentativa de efetivar o reconhecimento do valor cultural da Capela também era derivada de novos estudos que foram realizados para a exposição "Taipa, Tijolo e Fantasia" organizada pela Secretaria Municipal da Cultura no início da década de 1990 e que contou com pesquisadores como Eudes Campos e o já mencionado Aziz Ab 'Saber.

As paredes de taipa tinham sido objeto de pesquisa realizada por Schmidt ${ }^{119}$ em 1946 que enalteceu a qualidade da técnica executada com blocos iniciados pelos cantos através de montagem dos taipais em ângulo reto com amarração a $45^{\circ}$ graus nos vértices das paredes. $\mathrm{O}$ arquiteto Carlos Lemos ao relatar o indeferimento do tombamento pelo CONDEPHAAT em $1983^{120}$ também destacou o valor histórico das antigas paredes de taipa de pilão da Capela enaltecendo a unicidade e raridade da técnica construtiva aplicada. As informações sobre as "velhas taipas do Morumbi" (SCHMIDT, 1946, s.p.) foram complementadas e atualizadas por Ab`Saber (1990) que relatou que naquela região era difícil encontrar argilas puras, de fundo de vale, devido à distância e à altura (100 m de amplitude topográfica) em relação ao vale do rio Pinheiros.

Para a construção da "Capela" foi usado material local que aflorava dos caminhos escavados pelas trilhas das tropas de cavalo. Segundo Ab`Saber (1990) havia uma grande dificuldade em encontrar afloramentos rochosos em muitas áreas do Brasil Tropical Atlântico em especial na região do Planalto Paulistano em que havia uma bacia fluvio-lacustre com espessuras de até $200 \mathrm{~m}$ e densas florestas que envolviam as colinas, terraços e planícies aluviais. Devido a combinação dessas características geográficas é que reside a complexidade de encontrar pedras para a construção na região de São Paulo e explica a preponderante opção pela taipa como principal técnica construtiva.

\footnotetext{
${ }^{117}$ Resolução 04/CONPRESP/92, 25 de junho de 1992 In: SÃO PAULO - cidade, SMC/CONPRESP, 1992, p.2. 118 Órgão municipal de preservação patrimonial criado pela Lei N. 10.032, 27.dez.1985.

${ }^{119}$ SCHMIDT, Carlos Borges. Construções de Taipa: Alguns aspectos do seu emprego e da sua técnica. Boletim de Agricultura. São Paulo: Secretaria de Agricultura, 1946, série 47a.

${ }^{120}$ LEMOS In: SÃO PAULO - Estado, CONDEPHAAT, 1982, p.35.
} 

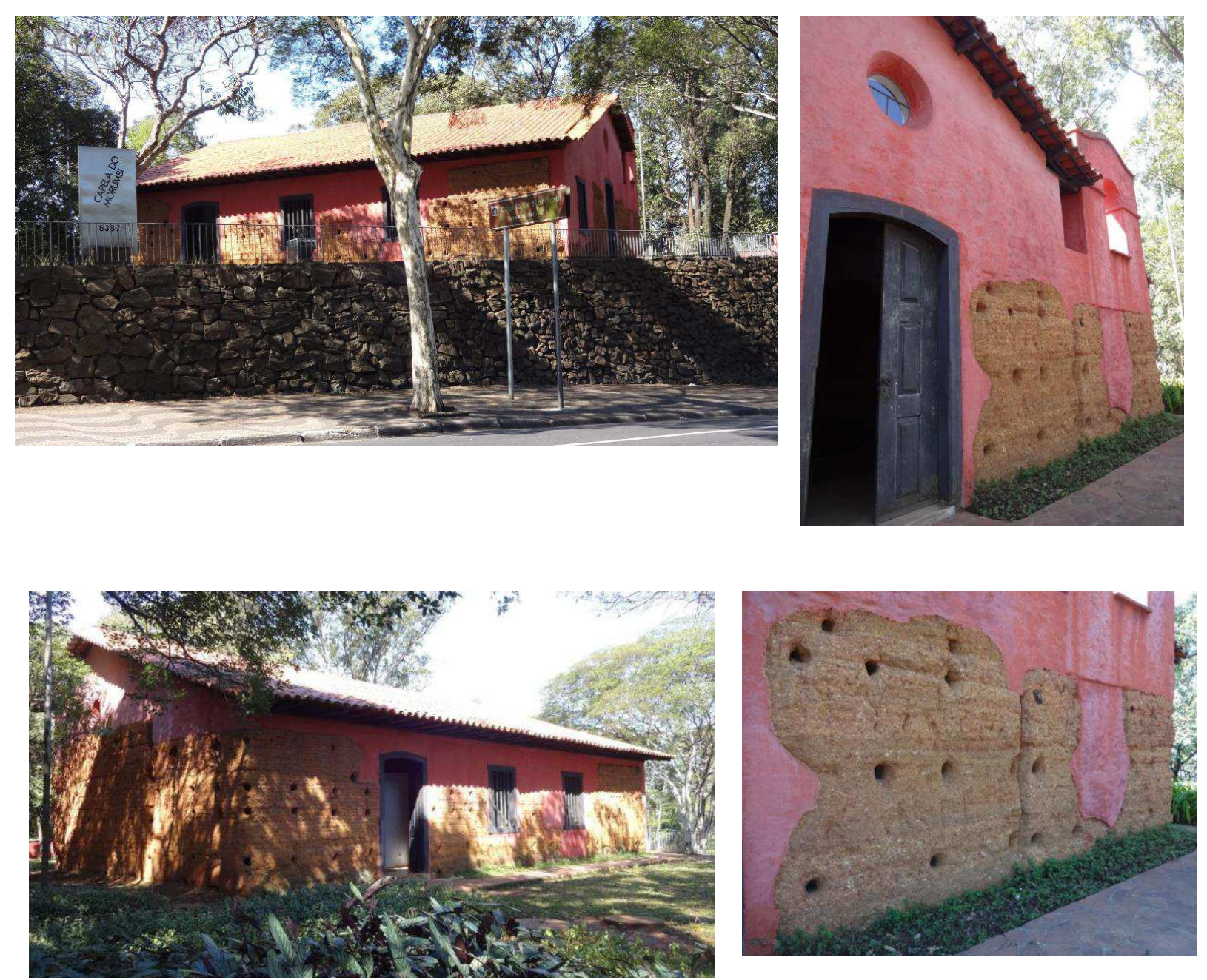

Fig. 44 (i-iv): Capela do Morumbi, detalhes das taipas conservadas, 2014. Fotos: Autora.

Assim poderia se compreender a construção da Capela, com uma técnica denominada taipa de pilão - ou taipa apiloada - não muito diversa do que se conhece em outras regiões do país, envolvendo a junção de pranchas sólidas de madeira, reforçadas por caibros laterais inclinados como molde para a colocação de argila socada com grande compactação através de um pilão.

A diferenciação da Capela, conforme salientado por Carlos Lemos nas pesquisas de tombamento de 1982, é que se tratava de uma técnica denominada "formigão" que é à base de terra socada misturada com pedregulho grosso, além da distinção na forma de execução: “[...] aquelas paredes mostram as evidências de um taipal de 'canto', formado de tábuas que permitiam cunhais inteiriços, com cabodás a $45^{\circ}$, solução rara, quando o normal era superposição de blocos em malhete." (LEMOS In: SÃO PAULO - Estado, CONDEPHAAT, 1982, p.35). 
A Capela do Morumbi foi tombada pelo CONPRESP em 2005, sendo que os elementos cruciais considerados nas instruções dos conselheiros e relatores para a aprovação do reconhecimento cultural foram basicamente: a importância histórica dos remanescentes da técnica construtiva (taipa de pilão), os afrescos da artista plástica Lucia Suané no batistério e a composição paisagística no contexto urbano ${ }^{121}$.

O tombamento da Capela englobou a totalidade do edifício e do lote em que está inserido: os muros aparentes de taipa, os acréscimos da intervenção da década de 1950 e os afrescos da artista Lucia Suané; não sendo admitidos quaisquer acréscimos na edificação tombada e tão pouco adaptações na compartimentação interna e nas áreas externas da Capela que compreendem seus jardins, muros de fechamento, arrimo e escadaria de acesso, a não ser que plenamente justificados com projeto de restauro e paisagístico.

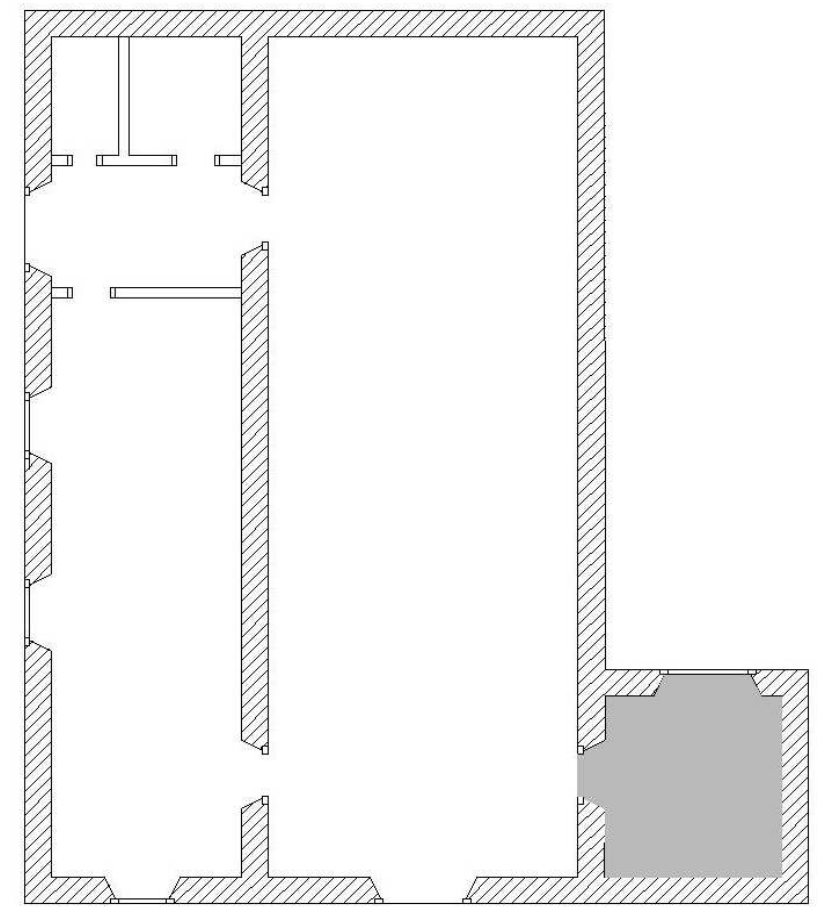

Fig. 45: Planta da Capela do Morumbi tombada, canto inferior direito batistério. Fonte: Resolução de Tombamento CONPRESP 11/05. Disponível em: <http://www.prefeitura.sp.gov.br/cidade/upload/ca566_11_T_Capela_Casa_Sede_Morumbi_com_plantas.pdf > acesso em 20 jul. 2016.

${ }^{121}$ Cf.: “o inestimável valor histórico e documental das taipas da Capela do Morumbi e da Casa Sede como construções remanescentes da antiga Fazenda Morumbi, propriedade rural produtora de chá da Índia no século XIX, cujo loteamento na década de 1950 deu origem ao bairro Jardim Morumbi; [...] o valor tecno-construtivo representado pelos restos aparentes dos muros de taipa de pilão da Capela do Morumbi e das paredes de taipa do casarão como testemunhos de um "saber-fazer" hoje desaparecido; [...] a importância referencial e paisagística da Capela do Morumbi para o Patrimônio Cultural e Ambiental daquela região da cidade de São Paulo; [...]" (Resolução n. 11/CONPRESP/2005, s.p.) 


\subsection{Ruínas do tempo: similaridades e dicotomias}

\subsubsection{Identificação e valorização}

A partir dos elementos - tempo de arruinamento, grau de destruição, antiguidade da edificação e condição de uso - determinantes na apreciação às ruínas, conforme apresentado no capítulo 1, analisaremos os estudos de casos, aferindo sua identificação, interpretação e as respectivas intervenções sugeridas aos mesmos.

A pesquisa identificou no histórico de cada caso - através de bibliografia, documentos, material gráfico e iconográfico e, especialmente, nas instruções dos processos de tombamento - que a denominação à condição de ruína das obras em análise por vezes se vale de termos distintos, como restos, remanescentes, vestígios, etc. No Engenho São Jorge dos Erasmos Luis Saia, menciona: “[...] todas as indicações, até o momento compulsadas, levam a meditar que as referidas ruínas são 'restos' [...]" (SAIA, Of. 17/55 In: IPHAN, 1962, p.04), e também são os "restos" do Engenho que constam no seu Relatório de Obras (1966-1963). Na Capela do Morumbi, a resolução final de tombamento do CONPRESP se refere aos "restos aparentes dos muros de taipa de pilão" (RESOLUÇÃO n. 11/CONPRESP/2005, s.p. - grifo nosso).

Embora essa diferenciação terminológica possa gerar dúvidas, é necessário ressaltar que os termos "ruínas" e "restos" são sinônimos; como destaca a pesquisadora Anna Maria de Lira Pontes (2010) ao verificar o dicionário de arquitetura Corona \& Lemos identifica-se que: "Resto: as ruínas de um edifício. O remanescente das antigas obras, recuperável ou não, que favorece indicações necessárias ao estudo da arquitetura avoenga [...]. Ruínas: O mesmo que Resto.” (CORONA \& LEMOS, 1989 apud PONTES, 2010, p. 24). A despeito da diferenciação dos termos, nos casos aqui analisados, há uma clareza da identificação da condição de ruína que é facilitada pela confluência dos seguintes fatores: a antiguidade da edificação, tempo decorrido do arruinamento e grau de degradação dos objetos.

O Engenho São Jorge dos Erasmos se enquadra na tipificação de patrimônio nacional em ruína apresentado no capítulo 1: construção proveniente do século XVI, vinculada ao processo de colonização. Já a Capela do Morumbi é constituída por paredes arruinadas com data provável do início do século XIX que constituem um documento de certa antiguidade e importância para a compreensão da ocupação dessa região da cidade de São Paulo. As ruínas em cantaria que indicam de modo pouco conclusivo a configuração 
arquitetônica do Engenho e as paredes de taipa de meia altura com uma implantação mais ou menos retangular do que teria sido a Capela do Morumbi constituem as únicas evidencias físicas de edificações das quais não se possui documentos gráficos originais.

Em ambos, a atribuição do valor histórico foi pautada pela antiguidade, raridade e unicidade presentes nos discursos para o seu reconhecimento como patrimônio cultural. A pesquisa realizada pela historiadora Maria Regina da Cunha Rodrigues que desenvolvia a tese sobre a conexão do Engenho São Jorge dos Erasmos com o início da produção açucareira no Brasil e a idade dos vestígios foram as principais motivações para a indicação de seu tombamento, o que pode ser evidenciado por sua missiva ao então diretor do IPHAN Rodrigo M. F. de Andrade:

1. Redescobertas as ruínas foram, a pedido nosso, autenticadas pelo $4^{\circ}$ Distrito da DPHAN, que opinou tratar-se dos restos residenciais quinhentistas, conhecidos, mais antigos do Brasil; 2. Divulgada uma pesquisa histórica sobre o marco inicial da produção industrial do açúcar no Brasil, [...] (RODRIGUES, 1962 In: IPHAN, 1962, s.p. - grifo nosso).

Esse Engenho tem sido considerado por alguns estudiosos ${ }^{122}$ como o primeiro do Brasil, porém, há controvérsias quanto ao seu pioneirismo na Capitania de São Vicente. Segundo Meurs (1995), a cultura do açúcar em escala industrial teve início em São Vicente e daí teria se espalhado para todo o território brasileiro, sendo o único de que se tem referência. Mário de Andrade, durante suas incursões na década de 1930 no Estado de São Paulo para a realização do já mencionado Relatório sobre os possíveis patrimônios locais, identificou o Engenho São Jorge dos Erasmos questionando seu pioneirismo e sem recomendações para o reconhecimento de seu valor cultural: “[...] É o terceiro engenho da Capitania, e não o primeiro, como afirmam alguns, desavisadamente. Não sabe este Serviço qual estado atual destas ruínas." (ANDRADE, M. Primeiro Relatório São Paulo, 6ª Região, 16.10.1937 In: ANDRADE, 1981, p. 95). J. P. L. Cordeiro, autor de um trabalho percursor no meio acadêmico sobre o Engenho publicado em $1945^{123}$, traz uma abordagem distinta dessas considerações de Mário reconhecendo o valor histórico de "[...] um dos primeiros engenhos de açúcar do Brasil [...]”' (CORDEIRO J. P. L., 1945 In: CORDEIRO S. L., 2007, p.69).

\footnotetext{
${ }^{122}$ Como: Frei Gaspar da Madre de Deus, Pedro Taques, Afonso de E. Taunay dentre outros (MEURS, 1995).

123 CORDEIRO, José P. L. O Engenho São Jorge dos Erasmos. São Paulo: Gráfica Bentivegna, 1945; originalmente publicado na Revista do Instituto Histórico e Geográfico de São Paulo. Segundo o pesquisador Silvio L. Cordeiro (2007) essa publicação de 1945 foi fundamental para inspirar as posteriores pesquisas da historiadora Maria Regina da Cunha Rodrigues.
} 
A atual descrição da página digital do Engenho reitera a antiguidade de suas reminiscências enquanto monumento nacional histórico e arqueológico: "A história e arqueologia do mais antigo engenho do Brasil" e "a mais antiga evidência física preservada da colonização portuguesa no Brasil" (In: <http://www.engenho.prceu.usp.br/> acesso em 15 maio 2016).

Muitos estudos arqueológicos se debruçaram sobre esse sítio, principalmente a partir de meados da década de 1990, quando o Engenho foi inscrito no Cadastro Nacional de Sítios Arqueológicos (CNSA), um indício que constata uma sincronia com a expansão das pesquisas arqueológicas e respectivas legislações em âmbito nacional para os bens em estado de ruína que vem ocorrendo nas últimas décadas, como mencionado no capítulo 1. As diversas pesquisas de campo no local culminaram no desenvolvimento do atual projeto de consolidação do "Parque Museu Arqueológico Engenho dos Erasmos", buscando conferir maior visibilidade e acessibilidade ao conjunto. Para a Capela do Morumbi, o valor histórico dos remanescentes das paredes de taipa de pilão, testemunhos das tradicionais técnicas do planalto paulista, figura como a principal justificativa na instrução de tombamento junto ao CONPRESP. Pode-se constar, portanto, que a apreciação a esses conjuntos se dá essencialmente pela instância histórica que documenta um ideário de origem - da produção açucareira no Brasil (ou ao menos em São Paulo) e da conformação da ocupação de uma área da capital paulista - que é validada pela datação das ruínas.

Essa abordagem predominantemente histórica e documental das ruínas pode ser compreendida a partir das asserções de Alois Riegl em sua já mencionada obra Der moderne Denkmalkultus, sein Wesen, seine Entstehung (1903), na qual o autor estabeleceu valores para a compreensão dos monumentos delineando o significado que a cultura contemporânea conferiu aos testemunhos do passado. Em sua teoria, Riegl apresentou os valores de "memória" distinguindo o valor de "antiguidade" e o valor "histórico", com os quais é possível estabelecer uma dialética da apreciação da ruína, seja respectivamente pelo seu aspecto pictórico ou pelo seu aspecto documental.

O valor "histórico" de um monumento consiste em vislumbrar no objeto a representação do desenvolvimento de algum campo de atividade da humanidade, independente da degradação que se manifesta no tempo transcorrido, interessando apenas o estado inicial enquanto obra humana. Uma vez que este valor pode ser fundamentado cientificamente, sua aferição pode ser mais racional. Essa designação do valor histórico é 
fundamental para compreender a apreciação documental e mais cognitiva das ruínas, enquanto suporte físico em que se vislumbra o decorrer das atividades humanas.

O valor de "antiguidade" se revela por uma aparência não atual que foi transfigurada e se fundamenta no âmbito da percepção atingindo de forma mais imediata ao sentimento. Esse valor é atribuído pela ação do decorrer do tempo, pela natureza ou pela ação do homem, isto é, por forças mecânicas ou químicas que decompõem o objeto e o recompõem com outra lógica. Como exemplo, Riegl invoca justamente a ruína como "O exemplo mais drástico [...]" (RIEGL, 1990, p.44 - trad. nossa) ${ }^{124}$, ressaltando o aspecto mais ótico que tátil que a pátina ou a decomposição podem provocar. É essa apreensão predominantemente visual que denota o valor de "antigo" e que pode ser útil para entender a apreciação das ruínas do ponto de vista estético, estruturado pelas marcas do tempo (vetustez, rusticidade, incompletude). Os sintomas de degradação que são determinantes para o valor de "antiguidade" constituem para o valor "histórico" um acumulo de informações a serem interpretadas sob a ótica estritamente documental.

Tendo como referência essa diagramação dos valores de Riegl e a necessária compreensão das ruínas a partir da dúplice acepção das instâncias estética e histórica coadunadas na Teoria de Brandi (apresentadas no capítulo 1) - é possível constatar que nos discursos de abordagem que constam nos autos consultados dos estudos de caso aqui analisados há uma maior ênfase ao juízo histórico como elemento que pauta a identificação do valor cultural desses bem. A apreciação do valor histórico das ruínas teve um papel relevante para o direcionamento dos trabalhos de Luis Saia no Engenho dos Erasmos e para o processo de tombamento das ruínas de taipa na Capela do Morumbi. A apreciação a partir da instância estética, ou da beleza da antiguidade das ruínas (valor de antigo - Riegl) não consta como um real indutor para a atuação de Saia; já, na Capela do Morumbi, Warchavchik explorou o potencial plástico e estético das ruínas ao integrá-las e deixá-las aparentes em seu novo projeto.

No material consultado sobre os estudos de caso, foram localizados exíguos discursos em que as ruínas são valorizadas através de sua constituição pictórica e evocativa. O já mencionado trabalho de J. P. L. Cordeiro faz uma descrição do Engenho com a exaltação de algumas dessas características:

${ }^{124}$ Trecho original: "L'esempio più drástico [...]" (RIEGL, 1990, p.44). 


\begin{abstract}
O Engenho de S. Jorge dos Erasmos desapareceu batido pelo tempo. Atualmente, de seu opulento passado, só existem ruínas que constituem um dos mais interessantes monumentos evocativos da Capitania Vicentina. Quem hoje se acerca do local, onde se levantava imponente um dos primeiros engenhos de açúcar do Brasil, vibra de emoção, ao contemplar aquelas paredes seculares [...] (CORDEIRO, J. P. L. 1945, p.33 In: CORDEIRO, 2007, p.69 - grifo nosso).
\end{abstract}

Conforme Brandi (2004), a instância histórica não se restringe ao momento da criação da obra de arte, mas ao presente (que se desloca continuamente) em que se reconhecem os valores desse bem. O objeto a preservar é, portanto, o produto de uma estratificação material e interpretativa, no decorrer do tempo, a obra pode conter e ter conservado traços desses tantos presentes históricos que também já se tornaram passados. Desse modo, nos processos de identificação e valorização dos estudos de caso aqui analisados é plausível considerar que, para ambos, além do valor histórico da reminiscência inicial, também há a historicidade das intervenções nesses conjuntos.

No Engenho dos Erasmos a reconstituição parcial da cobertura elaborada por Luis Saia nos anos 1960, mesmo que concebida para valorizar as ruínas, tem sido questionada por inferir uma interpretação de volumetria que não pode ser comprovada e não tem base documental é "[...] muito provavelmente, [...] um pouco distorcida da disposição primitiva." (Relatório das Obras de Restauro, 1987, p. 4 In: IPHAN, 1962, s.p.). A despeito das controvérsias essa cobertura em três lanços passou a ser denominada como "Pavilhão Saia" tendo sido definitivamente incorporada ao bem cultural ao ponto de passar por trabalhos de recuperação nos anos 2000.

Na Capela do Morumbi, a intervenção de Gregori Warchavchik nos anos 1950 também é polêmica do ponto de vista da preservação e gerou divergências entre os estudiosos durante o tombamento envolvendo o partido arquitetônico adotado e o comprometimento da matéria original:

[...] a obra realizada na época serviu apenas para proteger das intempéries os restos desabrigados de taipa de pilão, esses sim, documentos da maior importância para o estudo da história da cultura material paulistana. (D`ALAMBERT In: SÃO PAULO cidade - SMC/CONPRESP, 1992, p. 190)

Essa perspectiva de D`Alambert corrobora para o reconhecimento do valor histórico das ruínas das taipas per se, a despeito da intervenção elaborada por Warchavchik. O debate sobre a composição final e seu comprometimento da leitura dos vestígios originais, susteve os indeferimentos dos processos de tombamento no CONDEPHAAT que tiveram como conselheiro relator o arquiteto Carlos A. C. Lemos. 
Em 1973 Lemos apresentou como justificativa para sua negativa o caráter inventivo da obra de Warchavchik, alegando que o imóvel teria sido irremediavelmente descaracterizado $^{125}$. Em 1983, Lemos reforçou sua ideia em outro indeferimento, alegando que: o projeto de livre interpretação ${ }^{126}$ não se deteve às qualidades técnicas e construtivas da "arquitetura tradicional paulistana" (In: SÃO PAULO - Estado, CONDEPHAAT, 1982, p.35); e que o arquiteto teria recorrido a uma unidade estilística que apela à imitação - "Da arquitetura antiga de taipa de pilão praticamente nada mais há, [...] A principal intervenção, feita pelo arquiteto Warchavchik, desfigurou-a completamente, impedindo, praticamente, a reversão ao feitio original." (In: SÃO PAULO - cidade, SMC/CONPRESP, p.38 e p.113). Segundo Lemos, a Capela não teria, portanto, uma filiação arquitetônica que a qualificasse e que justificasse seu tombamento estadual e seu reconhecimento deveria ser circunscrito à esfera municipal. Porém, essas ruínas estão intrinsicamente associadas ao produto arquitetônico final, pois é a distinguibilidade e visibilidade do projeto de Warchavchik que possibilita a sua apreciação.

Em contrapartida às argumentações de indeferimento pelo CONDEPHAAT, o geógrafo Ab`Saber na década de 1990 demonstrou um grande apreço ao trabalho de Warchavchik reconhecendo o duplo valor histórico da Capela, cujas paredes de taipa são testemunhos de técnicas construtivas tradicionais e que a sua forma final denota a sensibilidade de um arquiteto da vanguarda moderna paulista que reintegra a preexistência numa solução formal de livre criação:

A base da capela é o passado; as paredes superiores e o telhado representam em estilo
pseudo-colonial livre e simbólico, formando um conjunto de inusitada beleza estética.
Uma concepção do passado, em estado de ruínas, acaba por ser aviventada por
uma concepção reconstrutiva da lavra de um modernista sensível e criativo.
(apud NASCIMENTO In: SÃO PAULO - cidade, SMC/CONPRESP, 1992, p. 43 -
grifo nosso)

Apesar dessas considerações de Ab`Saber, o estrito valor da obra de Warchavchik não figura como um elemento de destaque na resolução de tombamento final do CONPRESP que evidencia o "inestimável valor histórico e documental das taipas da Capela do Morumbi" (RES. n. 11/CONPRESP/2005, s.p.).

Outro aspecto relevante para a compreensão do processo de identificação e atribuição de valores a esse grupo de ruínas se refere ao uso. Na Capela do Morumbi, recuperada como

\footnotetext{
125 Ofício N.778/83 In: SÃO PAULO - cidade, SMC/CONPRESP, 1992, p. 12.

${ }^{126}$ Lemos classifica como: "[...] verdadeiras invenções que agora não vale a pena comentar [...]" (In: SÃO PAULO - Estado, CONDEPHAAT, 1982, p.35).
} 
bem arquitetônico, esse aspecto não se revela com tanta complexidade como no caso das ruínas do Engenho dos Erasmos em que a prerrogativa de um uso didático estava disposta pelos doadores da propriedade à USP em 1958. O conjunto de interesse cultural exerce um papel educativo e é um instrumento para o desenvolvimento do sentimento de pertencimento da população local cumprindo uma missão crucial não só pelo aspecto documental, mas pelo aspecto simbólico e evocativo como "testemunho vivo" e "portador de mensagem espiritual do passado", conforme disposto na Carta de Veneza (1964).

A função social e a leitura que se faz do Engenho dos Erasmos também podem ser entendidas através da integração com a paisagem em que está inserido. A questão do entorno ou do meio em que se situam os monumentos foi abordada na Carta de Atenas (1931) e na Carta de Veneza (1964), mas na Recomendação de Nairóbi (1976) ficou mais explícita: "Entende-se por ambiência [...], o quadro natural ou construído que influi na percepção estática ou dinâmica desses conjuntos, ou a eles se vincula de maneira imediata no espaço, ou por laços sociais, econômicos ou culturais." (UNESCO, 1976 In: CURY, 2004, p. 220). O conceito de ambiência é um pressuposto fundamental para perscrutar sobre a importância da relação entre ruínas e paisagem no processo de reconhecimento do valor cultural do Engenho São Jorge dos Erasmos o que transparece nas intervenções que incidiram sobre ele.

Tendo em vista essas considerações, verificaremos agora como a identificação e atribuição de valores às ruínas desses estudos de caso orientaram o tratamento dos conjuntos.

\subsubsection{Intervenções e as contraposições à conservação}

Em nossa análise, a antiguidade das estruturas, o tempo de arruinamento, o grau de degradação e a falta de referências precisas sobre esses estudos de caso não foram somente determinantes para balizar uma apreciação desses conjuntos mediada pelo valor histórico das estruturas originais, mas também direcionou as orientações para justificar as respectivas opções de intervenção.

A obra de Warchavchik para a Capela do Morumbi evidencia pontos relevantes sobre as operações em ruínas: conservação, integração e distinguibilidade dos aspectos estéticos desses remanescentes (vetustez e incompletude) e a criação de um projeto a partir de uma configuração espacial previamente delineada. No entanto, há dúvidas sobre as reais motivações que levaram o arquiteto a desenvolver tal proposta. 
Essa intervenção se deu no âmbito de uma iniciativa privada e não pública, fomentando alegações sobre as intenções de tal intervenção, que teria um apelo meramente publicitário, no sentido de valorizar um empreendimento imobiliário. Segundo Campos $(1991)^{127}$ a intervenção para transformar a Casa Sede da Fazenda no clube do empreendimento previsto e o projeto de uma Capela a partir das ruínas pré-existentes foram contratadas pela Companhia Imobiliária Morumby ao arquiteto Warchavchik com o objetivo de utilizar os edifícios como um: “[...] chamariz mercadológico [...], de pretenso caráter 'aristocrático'. $\mathrm{O}$ arquiteto [...] procurou inculcar aos compradores em potencial a ideia de 'nobreza' e 'tradição' ligada às terras loteadas" (CAMPOS In: PMSP/SMC/DPH, 1991, s.p.).

No Memorial Descrito a intervenção é denominada como um "restauro", demonstrando por parte de Warchavchik uma mínima sensibilidade e percepção ao potencial memorial e plástico da preexistência. A mera consolidação das ruínas em seu status quo não aparece como uma alternativa aventada pelo arquiteto. Porém, essa opção foi mencionada por alguns estudiosos e pareceristas ${ }^{128}$ para acentuar o caráter controverso da intervenção de Warchavchik; uma desqualificação que é respaldada por menções aos preceitos internacionais de preservação patrimonial, como pode ser detectado na seguinte argumentação de Carlos Lemos para o indeferimento do processo de tombamento em 1983:

[...] hoje as recomendações internacionais não toleram o aproveitamento de ruínas no intento da valorizá-las criando novos espaços úteis, ainda mais quando nessa intervenção recorre-se à "unidade estilística", isto é, apela-se à imitação de soluções próprias do tempo do monumento aproveitado. (LEMOS In: SÃO PAULO - Estado, CONDEPHAAT, 1982, p.35)

Essa observação também foi evidenciada por D’Alambert nos debates do CONPRESP:

Contrariando os preceitos contidos nas Cartas Patrimoniais, que recomendam a simples consolidação e proteção de ruínas, Warchavchik optou por uma intervenção projetual mais efetiva ao propor o aproveitamento dos restos de taipa como sustentáculo de uma nova edificação. (D`ALAMBERT In: SÃO PAULO - cidade, SMC/CONPRESP, 1992, p. 190)

Essas considerações se referem aos preceitos exarados na Carta de Atenas (1931) e Carta de Veneza (1964) sobre ruínas, como apresentado no capítulo 1, em que a recomendação é pela anastilose.

\footnotetext{
${ }^{127}$ Cf.: CAMPOS, Eudes. O arquiteto Gregori Warchavchik e a capela do Morumbi - Um ensaio interpretativo. In: Taipa, tijolo e Fantasia, 1991. Fonte: Pasta 03A.004.3 - SMC/DPH Seção Levantamento e Pesquisa.

${ }^{128}$ Há ainda o seguinte comentário: "Desta forma, hoje a atitude preconizada pelos órgãos internacionais de preservação do patrimônio seria a de consolidação e proteção de ruínas sem aventar-se a reconstrução." (COUTO, Of. 778/83 In: SÃO PAULO - cidade, SMC/CONPRESP, 1992, p.12-13).
} 
Não foi localizada uma justificativa por parte de Warchavchik que explicite um embasamento nos preceitos patrimoniais então vigentes. Na ocasião dessa intervenção em fins dos anos 1940 a principal documentação internacional válida era a Carta de Atenas (1931), derivada da matriz teórica italiana que reitera conceitos do restauro científico ou filológico delineado por Camillo Boito e ampliado por Gustavo Giovannoni (como apresentado no capítulo 1). A partir desse documento houve o florescer em muitos países europeus de regulamentações e cartas patrimoniais. Na Itália, a ação governamental elaborou a Carta del Restauro Italiana (1932), redigida por Giovannoni.

No caso de Warchavchik, tal contextualização poderia ter sido relevante na sua formação antes de chegar ao Brasil; segundo Eudes Campos (1991) e a pesquisadora Ana Paula Farah $(2012)^{129}$, esse poderia ser um dos fatores determinantes para delinear a sua abordagem às ruínas de taipa da Capela do Morumbi:

[...] nos faz pensar na influência que teria exercido sobre o arquiteto as técnicas italianas de restauração empregadas nas estruturas mortuárias romanas, onde a consolidação moderna também é recuada de alguns centímetros em relação às antigas ruínas. Com o propósito de melhor evidenciá-las. Técnicas essas provavelmente observadas pelo projetista durante seus estudos no Instituto Superior de Belas-Artes de Roma. (CAMPOS In: PMSP/SMC/DPH, 1991, s.p.)

Warchavchik estudou no Regio Istitutto Superiore di Belle Arti (Roma) e se formou em 1920, provavelmente esteve em contato com os debates patrimoniais que antecederam a promulgação da Carta de Atenas e da Carta del Restauro Italiana, considerando que a década de trinta acabou por consolidar um processo de debates que vinha se estruturando desde o século XIX, como apresentado no capítulo 1, com alguns pontos de convergência sobre o tratamento das ruínas primando por sua conservação na medida em que o bem é entendido como documento histórico, valorizando todas as suas estratificações e evidenciando a necessidade de distinguir a atuação contemporânea.

A sensibilidade e disposição em explorar o potencial estético da vetusta condição das ruínas, sua conservação e distinguibilidade denotam o alinhamento por parte de Warchavchik com o que estava sendo discutido no âmbito da preservação internacional daquele período. No entanto, como aponta Farah (2012), sua solução ao mesmo tempo em que pode ser considerada sob influência do restauro filológico na consolidação dos remanescentes, toma

129 Cf.: FARAH, Ana Paula. Restauro arquitetônico: a formação do arquiteto urbanista no Brasil para preservação do patrimônio edificado - o caso das escolas do Estado de São Paulo. Tese (Doutorado) - Faculdade de Arquitetura e Urbanismo, Universidade de São Paulo, São Paulo, 2012, p.171-184. 
"liberdades excessivas" (FARAH, 2012, p.183) no que diz respeito ao completamento da Capela em estilo.

Contudo, a obra de Warchavchik para a Capela do Morumbi se potencializa como uma intervenção paradigmática no Brasil, não somente por conservar as ruínas das taipas, mas por integrá-las em um objeto arquitetônico novo (ainda que questionável). Para melhor situar essa proposta mediante o cenário de atuação patrimonial do Brasil e do Estado de São Paulo pode-se retomar a duas operações pioneiras nesses respectivos contextos: a Missão de São Miguel (RS) e o Sítio Santo Antônio (São Roque, SP).

Como mencionado no capítulo 1, uma das primeiras intervenções do SPHAN se deu no conjunto de ruínas da Missão de São Miguel em 1937; nesta ocasião, Lucio Costa visitou a região dos Sete Povos realizando levantamentos e inventários. No escopo dos trabalhos ${ }^{130}$ a serem realizados, houve uma especial atenção a São Miguel e aos remanescentes de sua igreja para os quais Costa defendeu obras de consolidação ${ }^{131}$, partindo da percepção da impossibilidade de reconstrução: “Com efeito, não se pode pensar em reconstruir São Miguel ou mesmo recompor qualquer de suas partes; os trabalhos deverão limitar-se, tão somente, a consolidar e conservar." (COSTA In: PESSOA, 1999, p. 25-26 - grifo nosso).

Além disso, Lucio Costa projetou um pequeno museu ${ }^{132}$ no local para acolher as peças consideradas significativas dos outros Povos e articular a leitura e percepção da espacialidade dessa Missão. A concentração em S. Miguel foi justificada por ter sido a capital dos Sete Povos e pela condição mais legível de sua implantação e de seus vestígios por serem "os

${ }^{130}$ Cf.: "1 ${ }^{a}$ escavações em S. João, S Miguel, S. Lourenço e S. Nicolau; $2^{a}$ limpeza, em s. Miguel, de toda a área ocupada pelo antigo povo; $3^{\mathrm{a}}$. Levantamento da planta do conjunto em S. Miguel; $4^{\mathrm{a}}$. Consolidação das ruínas, em S. Miguel; $5^{\text {a }}$ construção do museu e da casa do zelador, em S. Miguel; $6^{a}$ remoção, para S. Miguel, do material encontrado em Sto. Ângelo, S. João, S. Lourenço, S. Luís, S. Nicolau e S. Borja." (COSTA In: PESSOA, 1999, p. 37).

${ }^{131}$ Cf.: "1. consolidação do terreno [...]; 2. amarração dos quatro cunhais da torre com braçadeiras e tirantes dispostos em diagonal, suprimindo-se em seguida a amarração existente; 3 . desmonte do pano de parede sobre o arco atualmente escorado com um pilar de alvenaria e que está fazendo pressão sobre o cunhal desaprumado do pórtico; 4. amarração provisória dessa peça à fachada da igreja; 5. retificação do seu prumo; 6. recomposição do arco e do pano de parede desmontados; 7. revisão de todas as vergas, escoradas ou não; 8. quando a segurança de qualquer elemento exigir que as juntas sejam tomadas com argamassa de cal ou cimento, dever-se-á evitar que a argamassa venha até ao paramento das pedras, o que prejudicaria o aspecto do aparelho, não se devendo, pelo mesmo motivo, "disfarçar" as juntas com o emprego de corantes." (COSTA In: Op. cit., p. 25-26 - grifo nosso).

${ }^{132}$ O projeto fez parte da publicação Brazil Builds (1943), saudado por Philip Goodwin (PESSOA, 1999): “A poucas centenas de metros das ruínas de São Miguel, o SPHAN construiu recentemente um encantador museu para abrigar o grande número de entalhes de pedra e madeira oriundos da igreja. $\mathrm{O}$ arquiteto das várias restaurações e construções feitas pelo SPHAN é o engenheiro Lucio Costa, muito conhecido pelos seus trabalhos de arquitetura moderna. [...] A construção, de simples paredes de vidro, proporciona um fundo agradável que não entra em competição com a escultura brilhantemente disposta. [...]” (GOODWIN, P. In: BRAZIL BUILDS, 1943, p. 42). 
únicos que ainda apresentam interesse como conjunto arquitetônico" (COSTA In: PESSOA, 1999, p. 37).
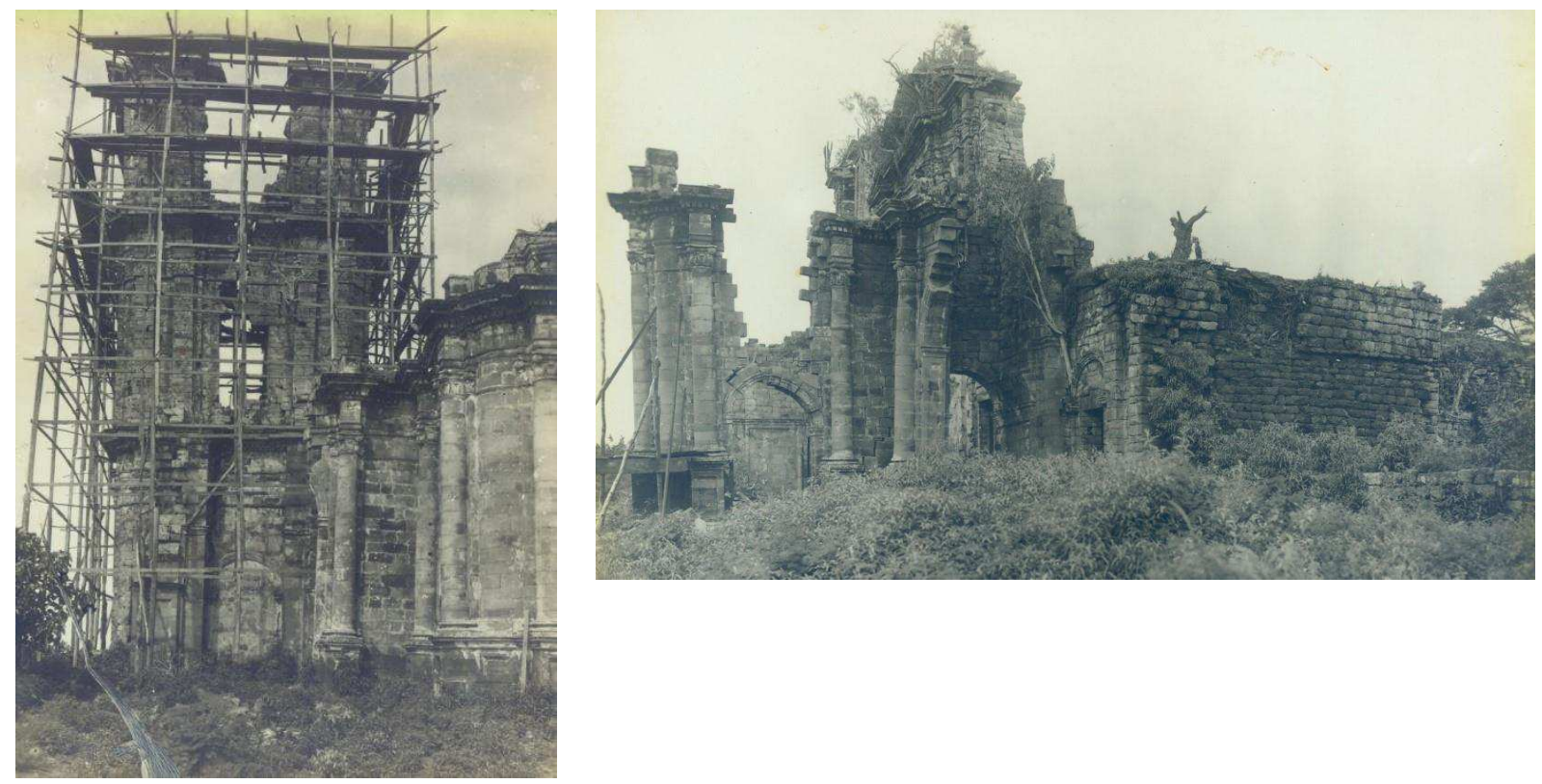

Fig. 46 (i-ii): Trabalhos de consolidação da Igreja de São Miguel das Missões (RS), 1940. Fonte: Acervo fotográfico IPHAN/SP.
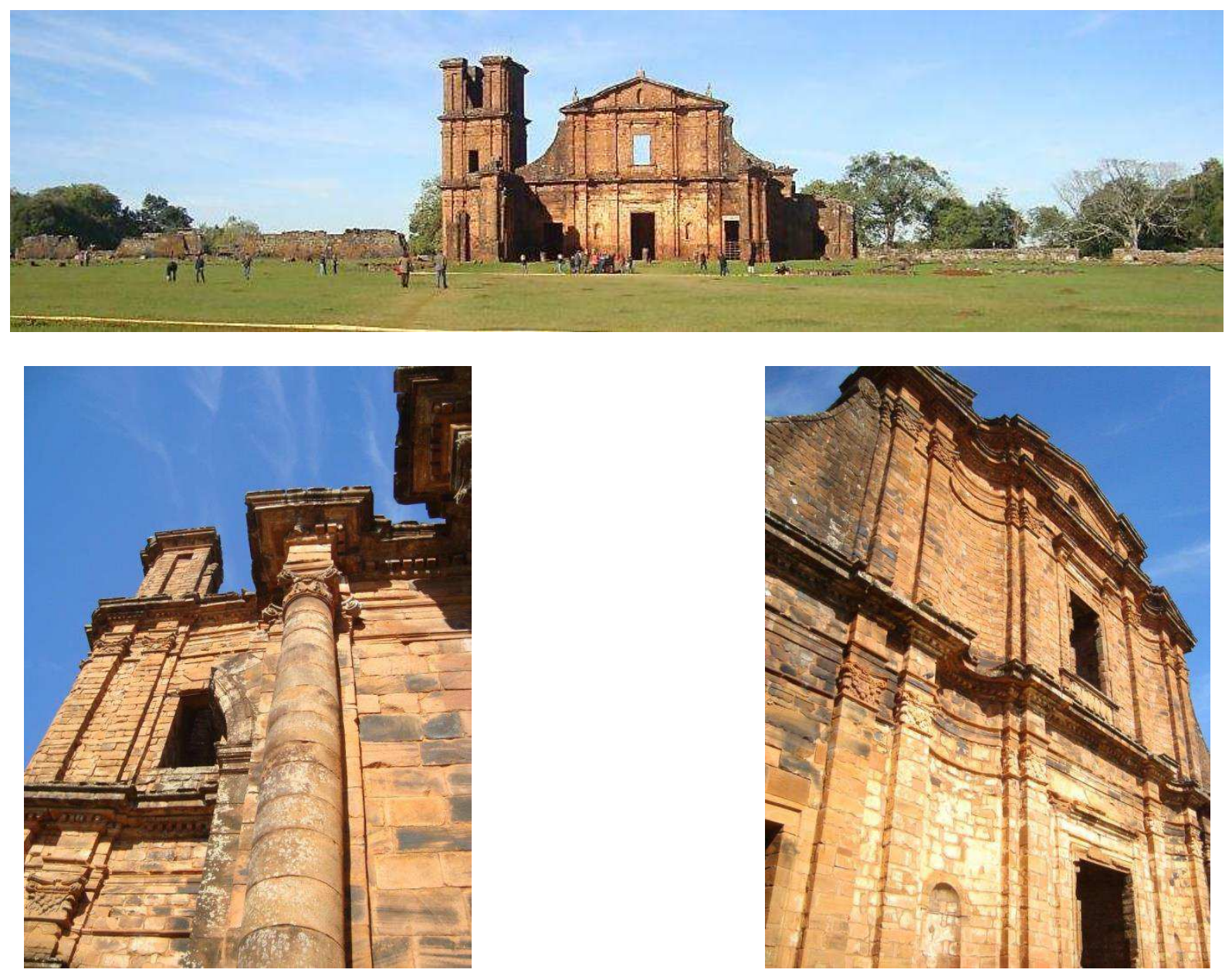

Fig. 47 (i-iii): Atual situação da Igreja de São Miguel das Missões (RS), 2014. Fotos: Monica dos Santos Dolce Uzum. 
Essa proposta de Lucio Costa em relação à Missão de São Miguel apresentou uma notória sensibilidade à sua condição de ruína (principalmente da igreja) e à espacialidade da implantação do conjunto. Porém, a indicação de uma cuidadosa consolidação e distinguibilidade de materiais não se estende às ruínas das demais Missões, para as quais a única proposta se restringiu a escavações para o recolhimento das peças isoladas que comporiam o museu ${ }^{133}$.

Contemporaneamente a esse caso inaugural da ação do SPHAN na esfera nacional, no Estado de São Paulo houve a intervenção no Sítio Santo Antônio (São Roque, SP) que foi identificado durante as já mencionadas incursões de Mário de Andrade em 1937. Contíguas à edificação principal do século XVII, havia ruínas de uma construção que teria sido habitada pelo Barão de Piratininga ${ }^{134}$ (1821-1886) no século XIX - a denominada "casa do Barão" que chegou ao século XX como remanescentes erodidos de paredes externas de taipa de pilão sem a cobertura original ${ }^{135}$.

A intervenção empreendida pelo SPHAN no Sítio Santo Antônio entre 1940 e 1947 foi uma das primeiras obras coordenadas por Luis Saia no Estado de São Paulo. Segundo Gonçalves (2007), nessa ocasião, a despeito da documentação escassa, as ruínas da "Casa do Barão" foram demolidas sem maiores perturbações por parte da diretoria técnica. Ou seja, o interesse documental não foi uma premissa suficientemente determinante para um levantamento daquelas ruínas e tão pouco para a proposição de trabalhos de conservação. Essa intervenção bastante emblemática da atuação do órgão de preservação em São Paulo não atribuiu valores a esses remanescentes restaurando somente a casa-principal, como um modelo puro da casa rural paulista.

\footnotetext{
${ }^{133}$ Cf.: "[...] escavações para a procura dos fragmentos esculpidos que porventura ainda existam entre os escombros das paredes ou soterrados, [...]" (COSTA In: PESSOA, 1999, p. 37).

${ }^{134}$ Antônio Joaquim da Rosa, o Barão de Piratininga, nasceu na vila de São Roque e teve uma influente ação política, tendo sido o Presidente Interino da Província de São Paulo num curto período do ano de 1869.

135 Conforme relato de Mário de Andrade: "Ao lado esquerdo da casa-primitiva, [...], se observa uma dependência recentemente construída ligando a um edifício quase quadrado, que não pertenceu à propriedade primitiva. Serviu este edifício de moradia principal ao barão de Piratininga, quando foi proprietário da fazenda. Neste edifício, de que restam apenas as ruínas das paredes exteriores, ainda se descobrem umas pinturas amortecidas pelo tempo, feitas por um agregado do barão, dizem, e representando cenas de caçada." (ANDRADE, M., 1937, p.121 - grifo nosso).
} 

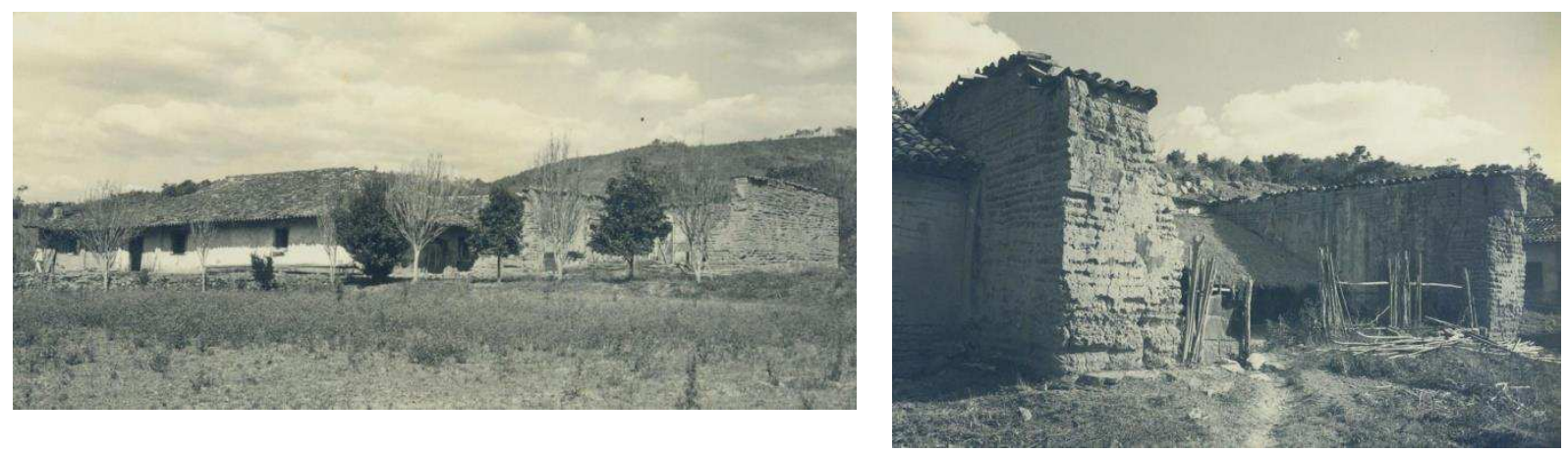

Fig. 48 (i-ii): Sítio Santo Antônio - Casa do Barão, ruínas, São Roque (SP), 1940.

Fonte: Acervo fotográfico da Superintendência do IPHAN/SP. Fotos: Hernan H. Graeser (Germano).

A restauração da casa do Sítio Santo Roque e de sua respectiva Capela é uma intervenção que se relaciona com outro objeto pertinente ao tema das ruínas: o Sítio Querubin ${ }^{136}$, uma casa rural com datação provável de 1680, também localizada no município de São Roque. Em 1946, Luis Saia em ofício a Rodrigo M. F de Andrade considerou a possibilidade de transferir o forro de madeira pintado da Capela interna do Sítio Querubin para compor o forro da Capela do Sítio São Roque que estava sendo restaurada (Of. 69/46 In: IPHAN, c.1941). A proposta dessa transposição (que foi executada) se devia ao grave estado de degradação da casa do Sítio Querubin, que acabou por ruir definitivamente pela falta de ações mais incisivas. Esse exemplar é representativo dos incontáveis bens que sucumbiram durante os debates para sua tutela; o processo de tombamento aberto pelo IPHAN em torno de 1941 acabou por incidir somente nos elementos do forro devido ao acentuado estado ruinoso da casa.
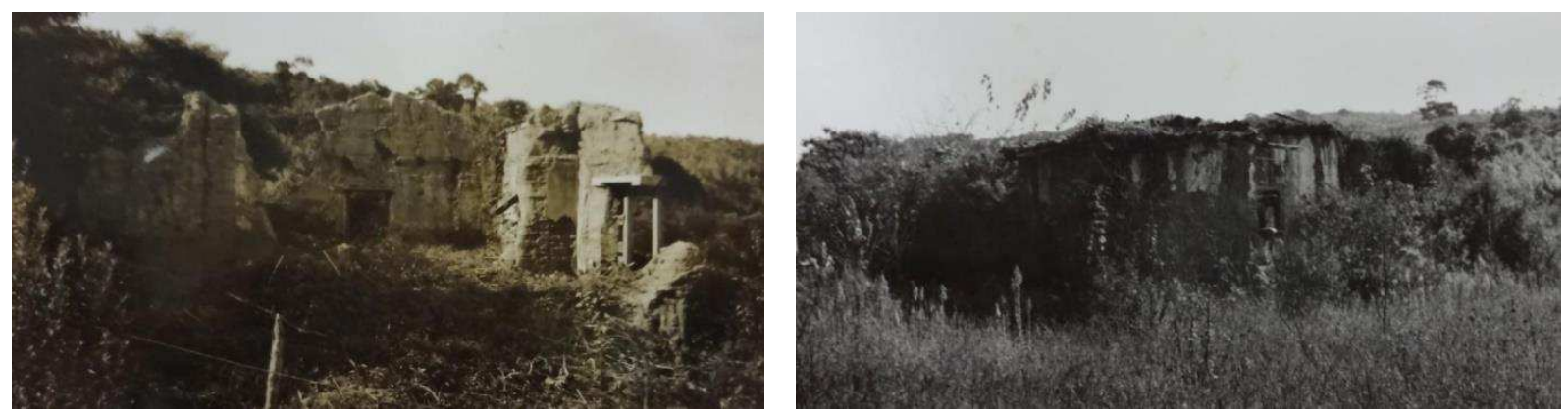

Fig. 49 (i-ii): Sítio Querubin, ruínas, São Roque (SP), s.d. Fonte: IPHAN, c.1941, s.p.

Na composição de um cenário que contextualiza a análise da Capela do Morumbi, as operações em São Miguel das Missões, Sítio Santo Antônio e Sítio Querubin são coetâneas às orientações internacionais da Carta de Atenas. Os resultados distintos evidenciam a dicotomia do tratamento às ruínas: a conservação de suas características através de trabalhos de

\footnotetext{
${ }^{136}$ Processos de tombamento: IPHAN - 0346-T- c.1941 - somente o forro; e CONDEPHAAT - 00375/73.
} 
consolidação (São Miguel) ou a completa negação e cancelamento através de uma restauração em “estilo” (Sítio São Roque).

Os trabalhos coordenados por Luis Saia na década de 1960 para as ruínas do Engenho dos Erasmos estabeleceu uma postura mais conservativa que para os remanescentes da "Casa do Barão" no Sítio Santo Antônio; no Engenho houve a atribuição de um valor cultural (essencialmente histórico), a despeito da constatação de que o grau de arruinamento configurava uma situação irremediável para a percepção da arquitetura anterior. Esses trabalhos foram determinantes para o Engenho, não só por terem sido os primeiros, mas por terem sido os únicos até os anos 1990.

Porém, a ideia da reconstituição das características arquitetônicas originais do engenho revestida pela acepção da palavra "restauração" apareceu em algumas ocasiões. No início da década de 1950, a historiadora Maria Regina propôs:

Na mais antiga de todas as vilas brasileiras se encontram as ruínas do mais antigo engenho de açúcar sul-americano, que está ameaçado de desaparecimento, se, desde logo, não for tomada uma medida capaz de evitar essa perda. Essa medida impõe-se justamente agora quando se intensificam os preparativos para o IV Centenário da Cidade de São Paulo, Capital do Estado que é também, incontestavelmente, o líder da produção açucareira do País. [...] Ninguém pode negar que a restauração do Engenho S. Jorge dos Erasmos, é uma obra patriótica, necessária, indispensável. Que se restaure na sua forma primitiva, baseando-se, se possível, nas gravuras da época, com painéis de azulejo que rememorem o fato histórico que tão admiravelmente representa. Assim, transformar-se-á num monumento nacional que será também um local de peregrinação, ao mesmo tempo, centro de estudos e motivo de turismo. (RODRIGUES, M. R., 1952 In: IPHAN, 1962, s.p. grifo nosso).

É latente que essa proposição está embasada na antiguidade da edificação e sua importância para a configuração da história nacional em meio ao contexto de comemoração do IV Centenário da fundação de São Paulo (1954), momento em que se procurou destacar e intensificar a identidade paulista pelo resgate de memórias atreladas a um passado grandioso. Por se tratar do que se considerava o "primeiro engenho brasileiro", essa recomendação foi endossada pela Associação dos Usineiros de São Paulo.

Contudo, a ideia de "restauração" foi contestada por Luis Saia em 1955, alegando que os "restos" encontrados não forneciam evidências suficientes para permitir tal intervenção e que as ações condizentes deveriam se concentrar na consolidação e valorização das ruínas:

f) é provável que o problema da restauração da referida peça tenha que ser posto de lado, uma vez que os "restos" encontrados não são de molde a permitir, senão em termos precários e anti-científicos, tal trabalho; 
g) o parecer desta Chefia é que se deverá estudar um agenciamento adequado, objetivando a consolidação e valorização das ruínas, agenciamento esse que incluirá, eventualmente, a amostra da documentação concernente ao assunto; (SAIA, Of. 17/55 In: IPHAN, 1962, p.04 - grifo nosso)

Em suas justificativas, Saia não faz alusão aos debates internacionais e a outras referências nacionais. Mas é possível verificar que essa convicção de Saia ao rechaçar a possibilidade de uma restauração do Engenho argumentando sobre a falta de evidências científicas está alinhada às principais postulações do restauro filológico e ao que seria prescrito na Carta de Veneza (1964) em que a restauração deve estar fundamentada no respeito à matéria original e em documentos autênticos: “Art. $9^{\circ}$ : [...] Termina onde começa a hipótese" (ICOMOS, 1964 In: CURY, 2004, p.93). No entanto, Saia não se privou de elaborar um exercício de reconstituição parcial da cobertura a partir de uma coluna preexistente que marcava a cota da empena da parede do fundo. Justamente pela falta de um sólido embasamento documental essa intervenção tornou-se controversa por induzir a uma dúbia leitura do conjunto.

Posteriormente, nos anos oitenta, a ideia da "restauração do prédio" também foi aventada pelo CIESP $^{137}$, mas não seguiu adiante. A opção pela consolidação das ruínas e a impossibilidade de sua completa reconstituição foi reiterada pelos técnicos do IPHAN na década de 1980 como destacado no Relatório das Obras de Restauro (1987):

Quem se decida de apenas preservar os restos ou, ao contrário, de promover uma revalorização mais completa do engenho, tendo como objetivo, por exemplo, de dar novamente às ruínas uma configuração mais "perceptível", de fazer entender de novo a articulação e a função dos prédios antigos, uma condição parece dever ser respeitada antes de mais nada: não comprometer nem os componentes originais do prédio nem o futuro deste. Enquanto a história do sítio e suas particularidades arquiteturais não sejam conhecidas com razoável exatidão, parece arriscado fazer qualquer intervenção que fosse além da simples consolidação. (Relatório de Obras de Restauro, 1987 In: IPHAN, 1962, p. 25)

Dos estudos de caso aqui enfocados o Engenho dos Erasmos expressa com maior ênfase essa opção pela consolidação das ruínas em seu status quo. Como apresentado no capítulo 1, ao desenvolver as bases teóricas do restauro "filológico" Giovannoni apontou a consolidação como uma modalidade de restauro que visa estabilizar uma situação atual pra que as condições de deterioração não se acentuem em que é possível aplicar, se necessário, novos elementos para conferir uma estabilidade estrutural à preexistência. A ruína é entendida

137 Artigo em jornal publicado em 1981: Estudos para reforma do Engenho, 26 maio 1981 In: IPHAN, 1962, p.33. 
como um estado degenerado passível de ser minimizado ou ao menos contido, mas nunca revertido.

Ao verificar os conjuntos tombados do Estado de São Paulo (conforme Tabela 04) nos deparamos com outros exemplos similares como as ruínas do Abarabebê ${ }^{138}$ (Peruíbe, SP) conjunto religioso proveniente de 1532 - e as ruínas do Forte de São Felipe e da Ermida de Santo Antônio do Guaíbe ${ }^{139}$ (Guarujá, SP); reminiscências quinhentistas do passado colonial cujas operações de consolidação estão embasadas em uma valorização histórica dos remanescentes e, principalmente, pelo entendimento que o grau e a antiguidade da edificação e da degradação torna inviável quaisquer outras tentativas de reconstituição, como atesta essa deliberação do arquiteto Victor Hugo Mori do CONDEPHAAT sobre os trabalhos realizados em 2009 na Ermida do Santo Antônio do Guaíbe e no Forte São Felipe: “Trata-se, portanto, de monumentos de natureza arqueológica sem possibilidade de restauro de completamento, conforme as recomendações das Cartas Internacionais" (Of. 752/07 In: IPHAN, 1964, s.p.).
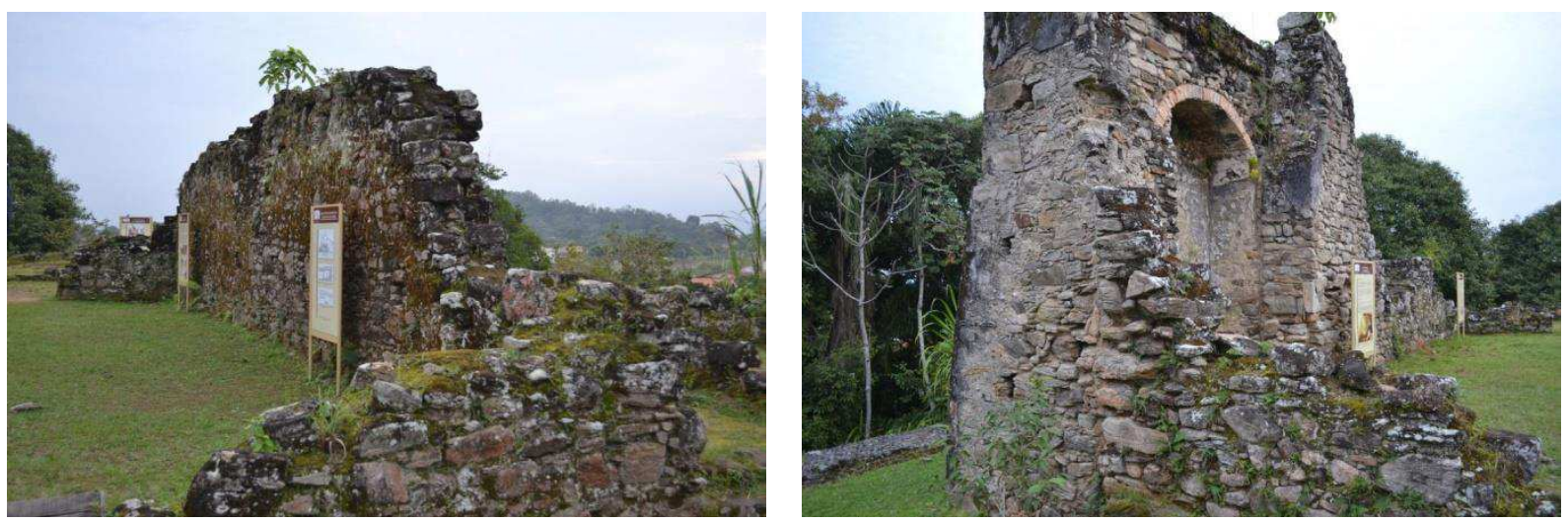

Fig. 50 (i-ii): Ruínas do Abarabebê, Guarujá (SP), 2013. Fotos: Sara Caroline Silva.

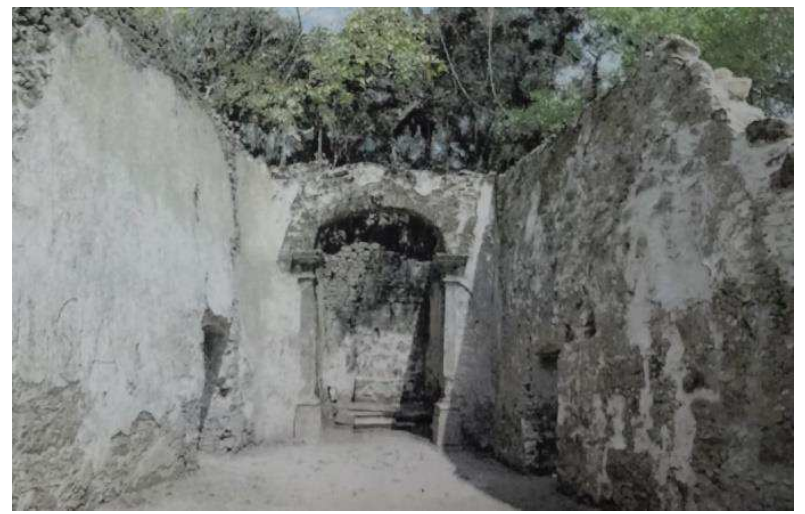

Fig. 51: Ermida de Santo Antônio do Guaíbe, Guarujá (SP), 2009. Fonte: Relatório Final dos Serviços de Conservação, 2009, p.7 In: IPHAN, 1964.

\footnotetext{
${ }^{138}$ Antigas reminiscências de uma Igreja datada de 1532 - CONDEPHAAT, processo: 09515/69.

${ }^{139}$ IPHAN, processo 0752-T-64 e CONDEPHAAT, processo: 20075/76.
} 
Nos outros patrimônios nacionais que possuem essas mesmas características (ruínas, com alto grau de degradação de monumentos provenientes do período colonial), a opção pela conservação e mínima intervenção não é uma orientação unívoca. Há situações em que se opta por intervenções que vão além da mera anastilose (recomposição de partes) - prescrita nos principais documentos internacionais de preservação patrimonial ${ }^{140}$.

Um exemplo bastante ilustrativo é a Fortaleza de São José da Ponta Grossa, Florianópolis (SC), situada na Ilha de Santa Catarina. O conjunto era constituído por diversas edificações (Casa do Comandante, Quartel da tropa e cozinha, Paiol de pólvora e Capela) provenientes dos anos 1740-1744, construídas em alvenaria de pedras com argamassa e revestimento à base de cal e distribuídas em três terraplenos conectados com rampas e um sistema de muralhas. O conjunto foi tombado pelo SPHAN $^{141}$ em 1938, quando já se encontrava em estado de ruína. Somente em 1977 ocorreu a primeira intervenção para uma consolidação emergencial. Em 1987 o local foi cadastrado como sítio arqueológico e foram iniciados trabalhos de prospecção. No início da década de 1990 as edificações passaram por uma restauração que primou pela reconstituição da volumetria original procurando fazer uma distinção das áreas completadas através do uso de materiais distintos, o local foi reaberto em $1992^{142}$.

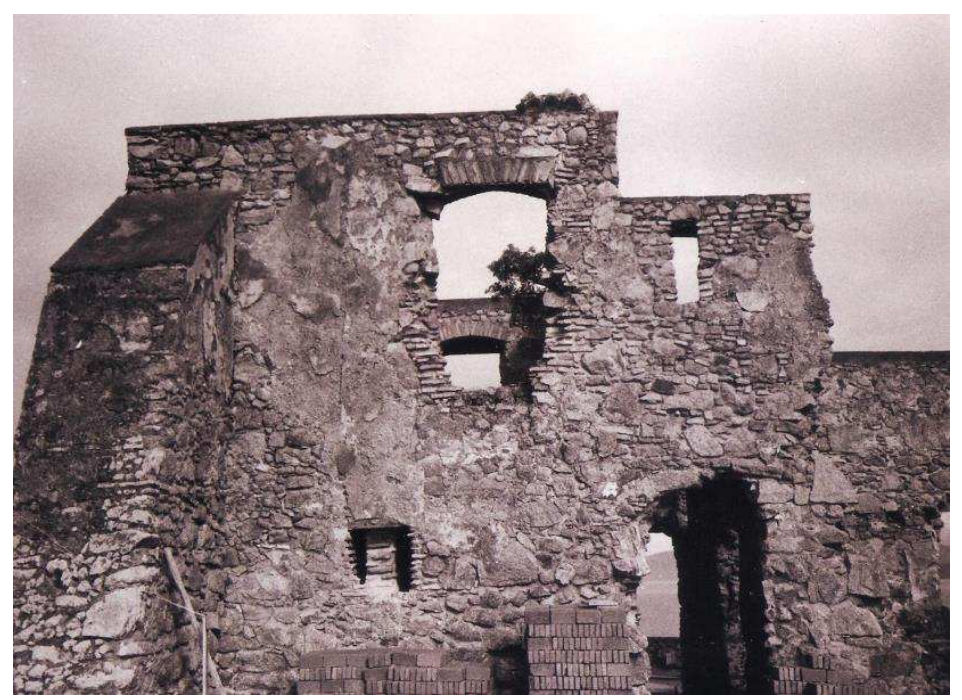

Fig. 52: Fortaleza de São José da Ponta Grossa, Florianópolis (SC) em estado de ruína, 1991, antes do início dos trabalhos de restauro. Fonte: <http://fortalezas.org/midias/jpg_originais/00012_006816.jpg> acesso em 14 nov. 2016.

\footnotetext{
${ }^{140}$ Como já mencionado: Carta de Atenas (1931), Carta del Restauro Italiana (1932) e Carta de Veneza (1964).

${ }^{141}$ IPHAN, processo: 0155-T-38, Livro de Tombo Histórico e Livro de Belas Artes. Não consta nas tabelas 01 pois em sua descrição não há referências ao estado de ruína do conjunto.

${ }^{142}$ Quando da visita ao local em abril de 2016, o monumento passava por novos serviços de manutenção com a troca de caixilharias. A Fortaleza de São José da Ponta Grossa faz parte do "Projeto Fortalezas" junto com as fortalezas de Santo Antônio (Ilha de Ratones) e de Santa Cruz (Ilha de Anhatomirim) administradas pela Universidade Federal de Santa Catarina.
} 

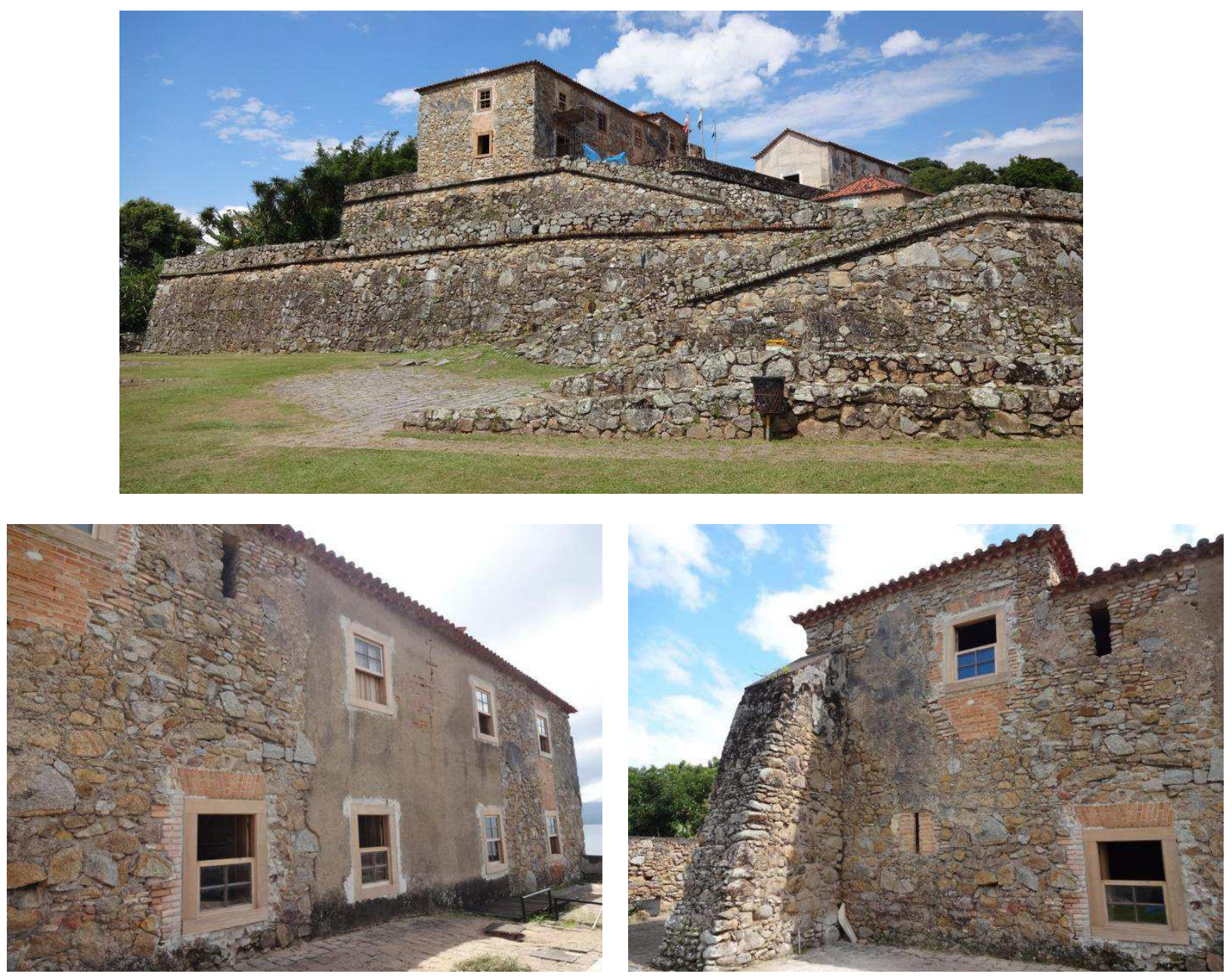

Fig. 53 (i-iii): Fortaleza de São José da Ponta Grossa, Florianópolis (SC) reconstituída, 2016. Fotos: Autora.

O restauro de completamento ou de recomposição para esses conjuntos de ruínas é uma opção extremamente questionável tendo em vista que a unidade potencial não pode ser restituída. Como apresentado no capítulo 1, nos debates da historiografia da preservação patrimonial travados durante o século XIX e início do século XX prevalecem prescrições mais conservativas para essa situação de arruinamento, em que se perdeu a caracterização da arquitetura anterior. Essas recomendações estão inseridas numa discussão mais ampla que acentua a diferença entre a conservação e a restauração - uma operação de caráter mais incisivo, que, quando efetuada sem o devido acuro crítico e metodológico, pode implicar em reconstituições. Às asserções de Quatremère de Quincy, John Ruskin, Camillo Boito, Alois Riegl e Gustavo Giovannoni que abordam ou tangenciam o tema das ruínas e alternativas de tratamento, pode-se acrescentar as orientações de Max Dvořák em sua obra Katechismus der Denkmalpflege (1916) criticando os perigos da reconstrução ${ }^{143}$ :

${ }^{143}$ No início do XX, uma das mais controversas experiências de reconstrução em áreas arqueológicas na historiografia da preservação patrimonial ocorreu no Palácio de Cnossos, em Creta sob a direção do arqueólogo 
Ruínas foram reconstruídas e deram lugar a falsos castelos. [...] Através de restaurações dessa natureza, os monumentos do passado não estarão protegidos contra a ruína, mas, ao contrário, estão sendo conduzidos a destruição em todos os aspectos. (DVOŘÁK, 2008, p.100 - grifo nosso)

Nos debates contemporâneos, a restauração é entendida como um campo disciplinar no qual há quantificações entre as operações de conservação e restauro (nas quais completamentos e reintegrações são admitidas segundo o juízo crítico que se faça da preexistência sob a dúplice valorização das instâncias histórica e estética e seguindo os princípios da mínima intervenção, distinguibilidade e reversibilidade). Conforme Brandi, para que a restauração seja uma operação legítima: “[...] não deverá presumir nem o tempo como reversível, nem a abolição da história" (BRANDI, 2004, p. 61).

Ao pretender retraçar a unidade originária de uma obra perdida, a restituição deve limitar-se a desenvolver o que está sugerido pelos fragmentos remanescentes ou pelos testemunhos autênticos do estado prévio, de forma bastante distinguível. Como evidencia Giovanni Carbonara (1976) sobre o problema da reintegração de imagens, não se trata de recuperar uma unidade estilística, mas sim, uma unidade figurativa do objeto; no restauro crítico conservativo, esse procedimento se estrutura a partir da relação dialética entre o processo crítico e criativo, integrando a preexistência. Essa acurada operação implica numa qualificação metodológica que a distingue conceitualmente das ações de mera "reconstituição" ou "reconstrução".

Como foi apresentado, no Engenho dos Erasmos houve solicitações por parte da sociedade civil para sua "restauração", que na verdade implicavam em apelos à sua “reconstrução”. Uma situação símile pode ser verificada no caso da Real Fábrica de Ferro São João Ipanema (Iperó, SP), tombada pelo IPHAN em 1964 ${ }^{144}$. A construção do conjunto teve início em 1589 com a localização de minério de ferro no Morro de Araçoiaba, as atividades se extinguiram em 1895. A partir de 1949 foram iniciados os estudos para verificar o valor histórico do conjunto. Nessa ocasião, na correspondência de Luis Saia a Rodrigo M. F. de Andrade há a seguinte recomendação: “[...] a iniciativa mais aconselhável no momento seria a proteção daquelas peças cujo estado ruinoso e interesse documentário mereça atenção mais imediata" (Of. 66/49 SAIA, 1949 In: IPHAN, 1964, s.p.).

inglês Arthur J. Evans (1851-1941). A reconstrução de partes da Era do Bronze Minoica do conjunto ilustra duas principais questões que depois foram destacadas nas Cartas patrimoniais: falta de autenticidade e trabalho especulativo. As críticas se concentram na utilização de materiais não condizentes com a arquitetura original (como a utilização de concreto) e evidencias escassas para uma reconstrução desse porte (WOOLFITT, 2007).

${ }^{144}$ IPHAN, processo: 0727-T-64, Livro de Tombo Histórico, consultado junto ao IPHAN/SP. 
Uma das estruturas de maior evidência e em grave estado de degeneração era a denominada "Oficina de Armas Brancas" (ou "Casarão"), um galpão de alvenaria de pedras que foi construído entre 1865-1890. A partir de 1961 surgiram proposições solicitadas pela comunidade local para que essa peça fosse "restaurada" ou "reconstruída": "[...] o referido imóvel que se encontra em precário estado, continua ruindo, o que dificultará ainda mais a sua reconstrução" (Of. 146/61 COSTA, 1961 In: Op. cit., s.p.). Entre 1968 e 1974 foram realizadas as obras que envolveram serviços de estabilização da estrutura, recomposição da cobertura, pisos e demais elementos arquitetônicos. O resultado apresenta uma estrutura completamente restituída em que não há distinguibilidade em relação à preexistência.
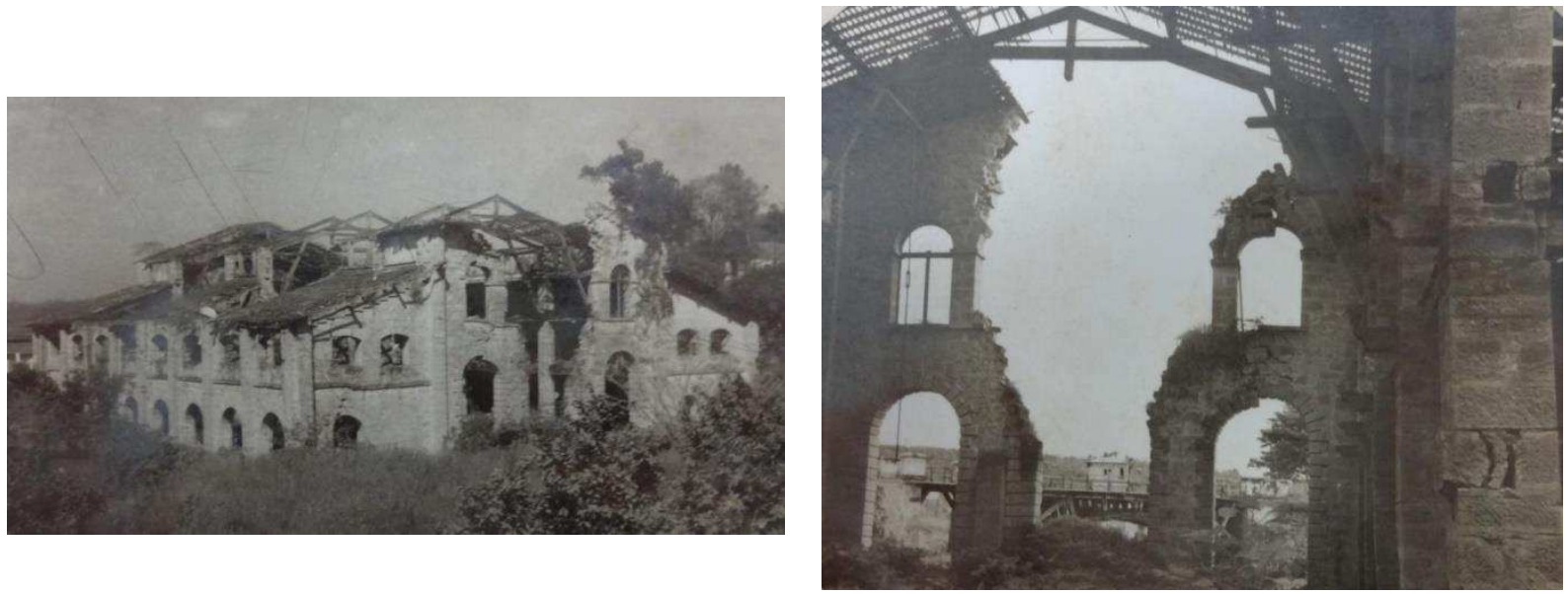

Fig. 54 (i-ii): Situação de arruinamento da Casa de Armas Brancas, Real Fábrica de Ferro São João do Ipanema, Iperó (SP), 1961. Fonte: IPHAN, 1964, s.p.
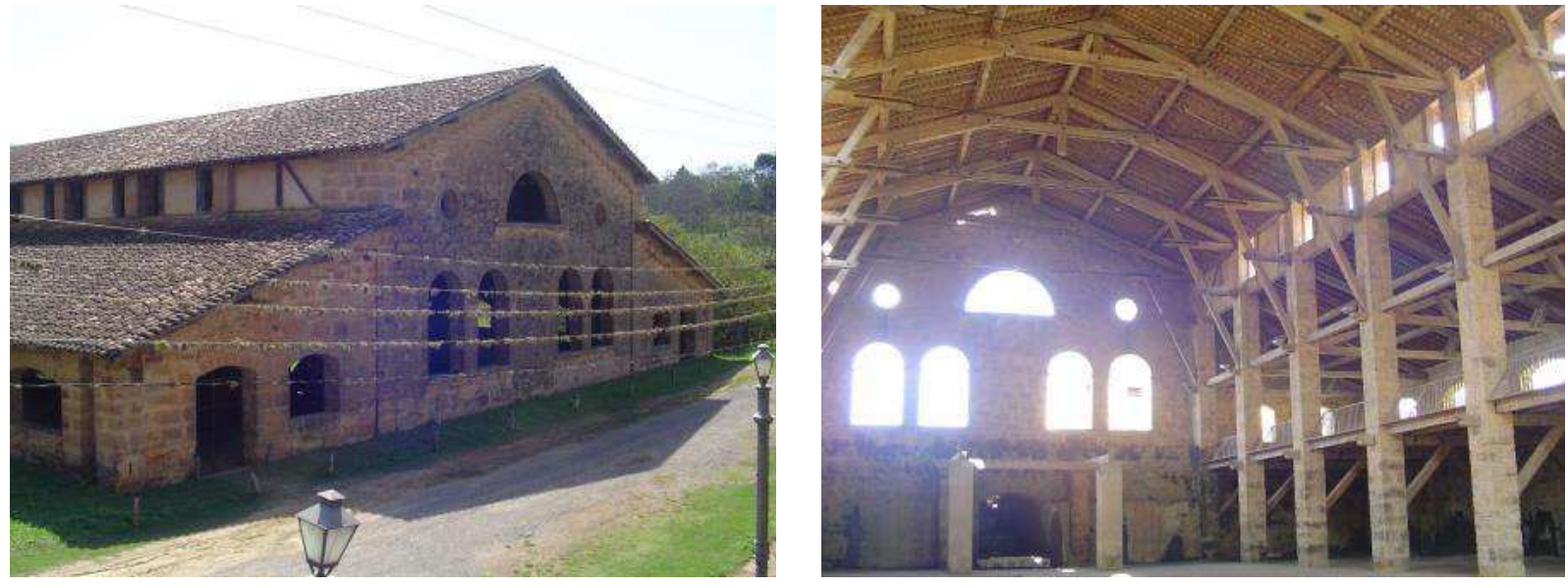

Fig. 55 (i-ii): Casa de Armas Brancas, Real Fábrica de Ferro São João do Ipanema, Iperó (SP), 2009. Fotos: Autora.

Em nossa análise, nessa intervenção do IPHAN executada contemporaneamente ao Engenho dos Erasmos, a indicação e execução dos trabalhos de "restauração" (que implicam em uma "reconstrução") para a edificação em estado ruinoso pode estar associada à conjunção 
de dois fatores principais: a maior legibilidade da constituição arquitetônica prévia viabilizando a sua restituição; e a datação mais recente da edificação, um remanescente de arquitetura industrial proveniente do século XIX. Em contraposição a esse resultado, pode-se apresentar uma referência no cenário recente das intervenções nacionais: o Centro de Interpretação do Pampa (CIP) - órgão da Universidade Federal do Pampa (UNIPAMPA) - em Jaguarão (RS) que está sendo implantado nas ruínas de uma antiga enfermaria militar datada do final do século XIX. Esse edifício faz parte do conjunto histórico e paisagístico de Jaguarão tombado pelo IPHAN em $2012^{145}$. Para tal projeto, foi contratado o escritório Brasil Arquitetura $^{146}$.

O prédio foi construído em 1883 em estilo neoclássico para abrigar um hospital militar nessa região de conflitos para a definição das fronteiras nacionais; no final da década de 1960 a unidade militar foi transferida e após utilizações diversas o edifício entrou em um processo de abandono e arruinamento (BÔAS, COSTA, 2013). Na década de 1990, com estudos desenvolvidos pela Universidade Federal de Pelotas houve o tombamento estadual; a partir de 2009 se desenrola a implantação do CIP através da ativação patrimonial das ruínas da antiga enfermaria. O programa de centro cultural articula novas estruturas contemporâneas aos remanescentes consolidados, cujo caráter de incompletude foi utilizado como um dado para o projeto a fim de compor um memorial sobre a temática do pampa gaúcho. As obras foram iniciadas em 2011 e seguem em andamento.
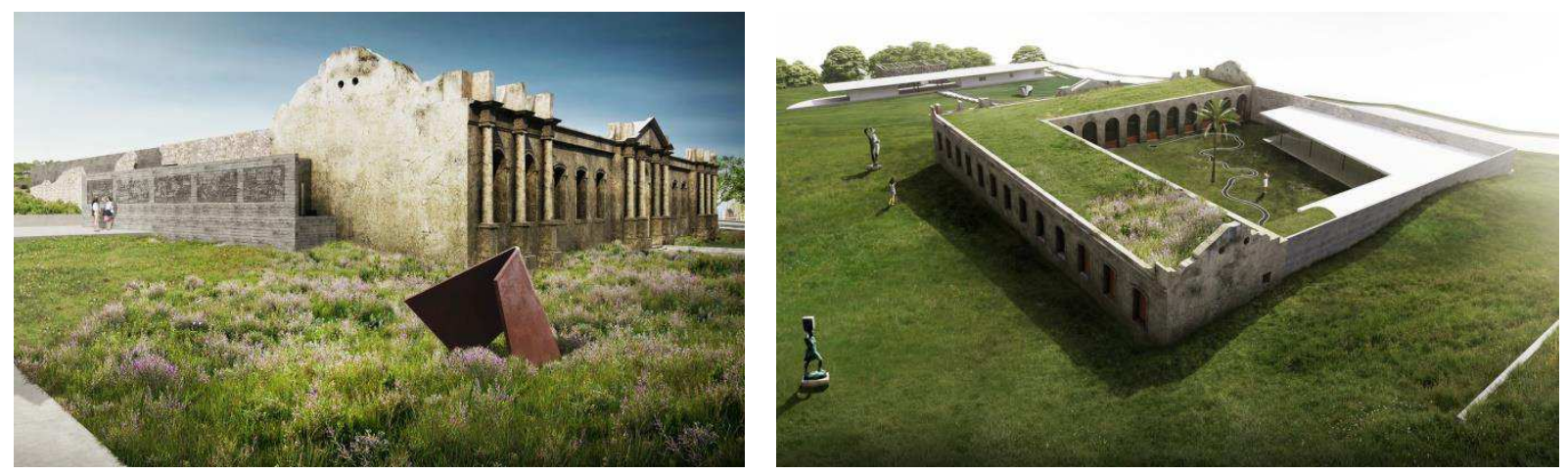

Fig. 56 (i-ii): Projeto para o Centro de Interpretação do Pampa, Jaguarão (RS) - perspectivas externas. Fonte: Brasil Arquitetura, disponível em: <http://brasilarquitetura.com/projetos/centro-de-interpretacao-dopampa/> acesso em 10 out. 2016.

\footnotetext{
${ }^{145}$ IPHAN, processo: 1570-T-09. Livro Arqueológico, etnográfico e paisagístico e Livro Histórico.

${ }^{146}$ Projeto elaborado pelos arquitetos: Francisco Fanucci, Marcelo Ferraz, Vinícius Spira e Gabriel Grinspum.
} 


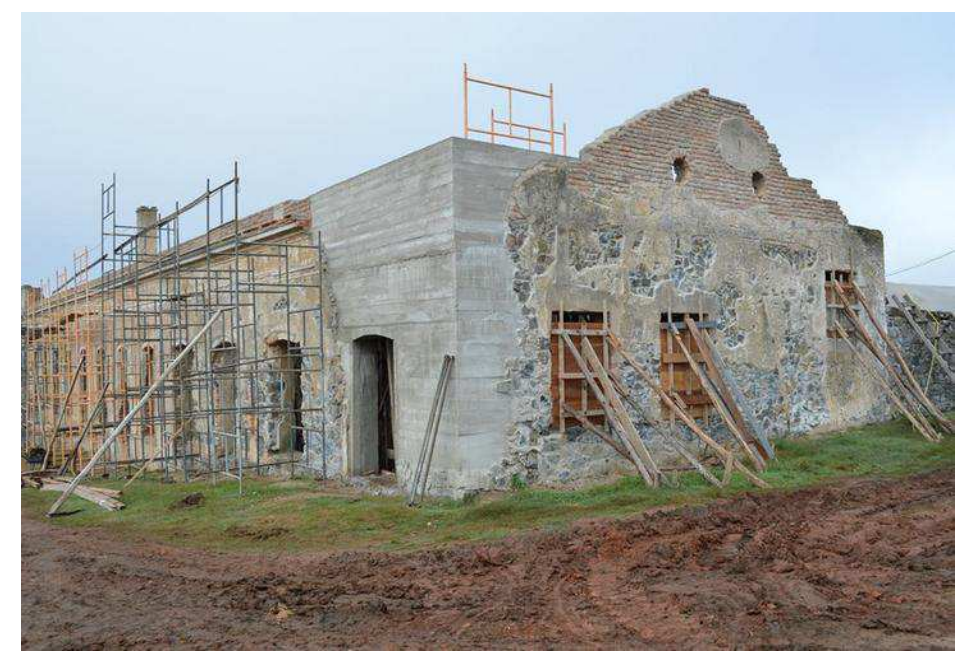

Fig. 57: Andamento das obras para o Centro de Interpretação do Pampa, Jaguarão (RS), 2013 - consolidação e completamento das ruínas. Fonte: CAU - Notícias sobre Arquitetura, disponível em:

<http://zh.clicrbs.com.br/rs/vida-e-estilo/casa-e-cia/noticia/2013/07/projeto-em-jaguarao-preserva-ruinaspara-narrar-a-historia-4217452.html>, acesso em 10 out. 2016.

Mesmo com a predominância de fatores semelhantes - edificação com datação do século XIX e maior legibilidade da constituição arquitetônica anterior - os tratamentos à Casa de Armas em Iperó e à antiga Enfermaria em Jaguarão são distintos. Em nossa análise, essa diferença está pautada no quanto se considera o estado de arruinamento como parte da história do bem cultural.

\subsubsection{Sítios arqueológicos: apresentação e fruição}

Ao impostar sobre a atual proposta que está em curso para a implantação do "Parque Museu Arqueológico Engenho dos Erasmos" é possível verificar que há um alinhamento com o atual contexto internacional no qual, conforme destaca Lagunes (2002), se multiplicam as iniciativas que visam interferir em áreas arqueológicas que não se restringem a operações de escavações, consolidação e restauros dos remanescentes identificados, mas também envolvem a implantação de museus, centros de acolhimento e interpretação com o escopo de salvaguardar e revelar o potencial cultural desses sítios. Essas operações englobam ações complementares com a inserção de elementos para a sistematização e fruição nas ruínas a fim de catalisar sua legibilidade; prescrições que são previstas no art. $15^{\circ}$ da Carta de Veneza para as escavações arqueológicas e suas ruínas (como apresentado no capítulo 1).

Há significativos exemplares, dentre os quais a obra realizada no início dos anos 1980 por Josè Rafael Moneo em Mérida (Espanha), no sítio arqueológico de uma das mais importantes cidades do Império Romano na Península Ibérica. O Museu Nacional de Arte Romana foi elaborado em frente às ruínas do teatro e do anfiteatro romano construídos em 19 A.C. e sobre os restos da antiga malha urbana. O Museu é constituído por dois volumes 
articulados por uma passarela, um projeto reconhecido internacionalmente por ter sido embasado num conceito de sobreposição à preexistência dando continuidade e comunicabilidade através de uma operação de monumentalização das ruínas num espaço dominado pela dialética entre o novo e o antigo em que a área arqueológica não é tratada como uma lacuna, mas como uma presença que faz parte da contemporaneidade (CALIARI, PERESSUT, 2014).

Conforme informações obtidas com Apoena Amaral e Vito Macchione ${ }^{147}$, dentre as muitas referências utilizadas pelos arquitetos para o Engenho dos Erasmos se destaca no contexto internacional a experiência no sítio arqueológico de Praça Nova (Lisboa, Portugal), o mais antigo complexo da cidade inserido no conjunto do Castelo de São Jorge. As escavações conduzidas desde 1996 trouxeram à luz uma intensa estratificação de testemunhos edificados de diversas épocas históricas que remontam à fundação da cidade (a mais antiga da Idade do Ferro, posteriormente uma Vila Islâmica do século XI e fragmentos de pisos em mosaico do século XV). O projeto elaborado pelos arquitetos João Luís Carrilho da Graça e João Gomes da Silva entre 2008 e $2010^{148}$ recompõe e ordena a sequência das ruínas interpretando e comunicando o significado de cada remanescente através de uma experiência bastante didática. Na solução adotada nas ruínas do século XI foi constituída uma edificação hipotética reconstituindo os ambientes domésticos da antiga vila. Ciente do caráter parcial das referências prévias, os arquitetos propuseram uma solução embasada numa arquitetura abstrata que se sobrepõe aos remanescentes através de um volume simplificado, monocromático, privado de elementos decorativos e construído por materiais contemporâneos que notadamente se contrapõe às ruínas (Op. cit., 2014).
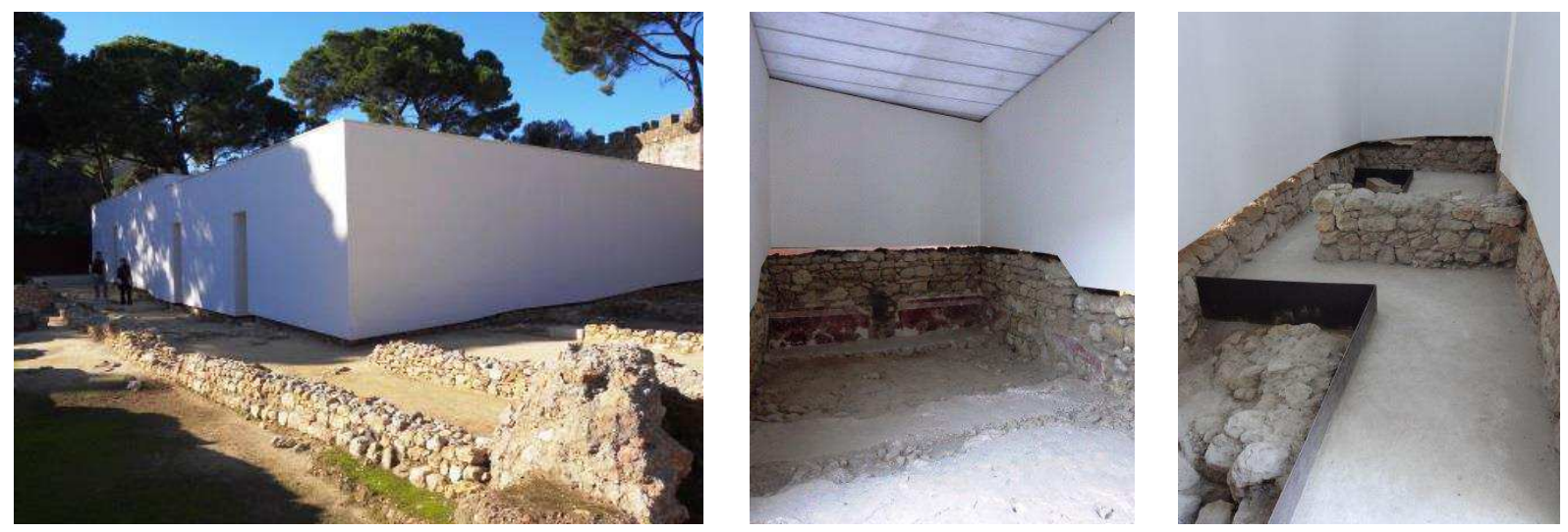

Fig. 58 (i-iii): Praça Nova - Castelo de São Jorge, Lisboa (Portugal), 2013. Fotos: Autora.

\footnotetext{
${ }^{147}$ Entrevista concedida à autora em 05.05.2015.

${ }^{148}$ A obra foi vencedora do Prêmio Piranesi Prix de Roma (2010).
} 
No cenário brasileiro, a referência destacada foi o Castelo Garcia D`Ávila (Mata de São João. BA) - uma das poucas residências rurais quinhentistas no Brasil e o primeiro bem tombado em ruínas pelo SPHAN em 1938 (ver Tabela 01, capítulo 1). O conjunto passou por uma intervenção nos anos 2000 coordenada pelo IPHAN em que os remanescentes foram consolidados através da pontual inserção de novos elementos de materiais diversos dos originais (como vigas de aço para contenções estruturais) e foi implantado um sistema de passarelas que conecta os percursos para a melhor fruição no conjunto.
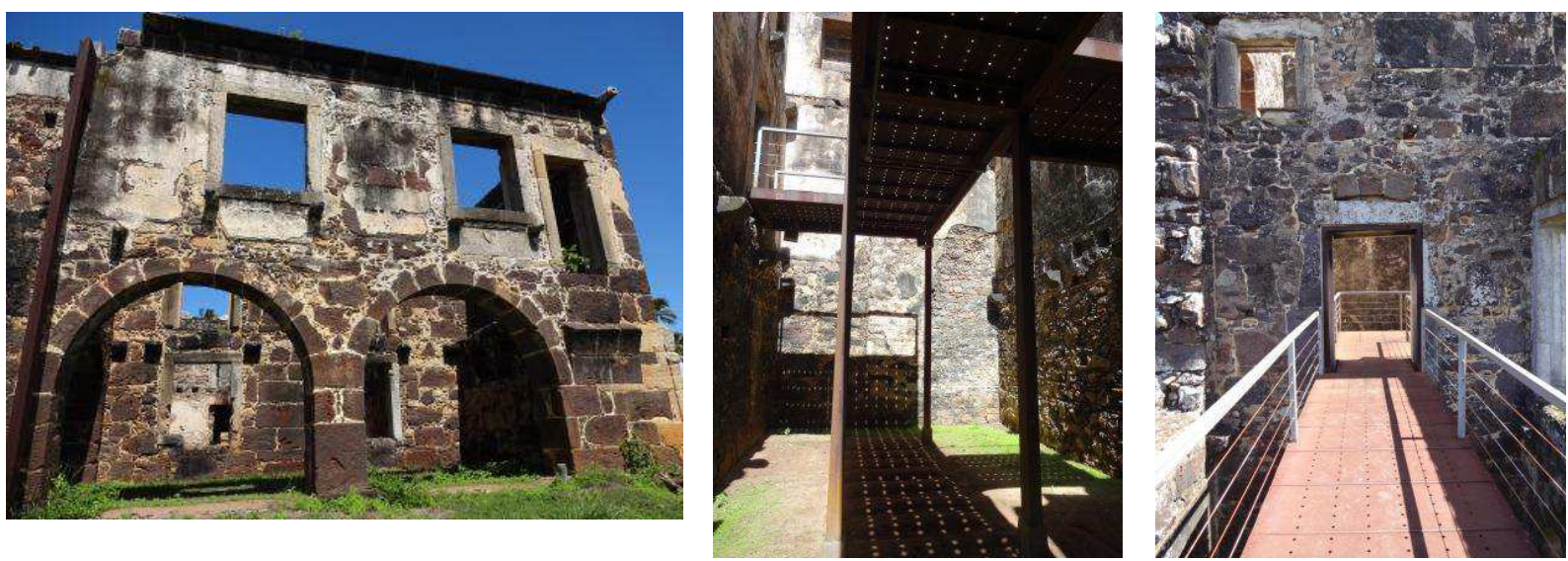

Fig. 59 (i- iii): Casa da Torre de Garcia D Ávila, Mata de São João (BA), 2013. Fotos: Autora.

A inserção de elementos contemporâneos em sítios arqueológicos é uma operação que deve ser criteriosamente avaliada, pois, ao mesmo tempo em que se pretende valorizar as ruínas através da disposição de percursos mais didáticos, pode-se incorrer em uma desconfiguração do estado inicial que desvirtua completamente o propósito maior que seria a preservação dos remanescentes. Esse desafio se potencializa através do delicado problema de elaborar coberturas para os remanescentes em áreas arqueológicas ${ }^{149}$.

A cobertura na Villa Romana del Casale (Piazza Armerina, Itália) foi uma das primeiras experiências internacionais em larga escala para a proteção e fechamento de áreas arqueológicas. A estrutura foi desenhada por Franco Minissi ${ }^{150}$ (1919-1996) sob as recomendações do Istituto Centrale del Restauro ${ }^{151}$ em 1957 em estrutura metálica e painéis translúcidos para o fechamento dos diferentes espaços do conjunto da antiga Vila romana com

\footnotetext{
${ }^{149} \mathrm{O}$ tema das coberturas para as ruínas foi especialmente investigado em: DI MUZIO, Anelinda. Rovine protette: conservazione e presentazione delle testimonianze archeologiche. Roma: L'Erma di Bretschneider, 2010.

${ }^{150}$ Os trabalhos de Franco Minissi foram objeto de extensa pesquisa desenvolvida pela arquiteta Beatrice Vivio, ver mais em: VIVIO, Beatrice. Franco Minissi: musei e restauri - la trasparenza come valore. Roma: Gangemi, 2010.

${ }^{151}$ Instituto fundado em 1939 por Cesare Brandi e Giulio Carlo Argan (1909-1992) a fim de fomentar as práticas de restauro. Brandi esteve na direção do mesmo até 1961; essa experiência teria sido fundamental para complementar as acepções que foram desenvolvidas em sua Teoria da Restauração (1963).
} 
seus pisos de mosaicos. O monumental sistema de cobertura elaborado por Minissi configurava uma nova e evocativa leitura espacial que estabelecia um refinado diálogo arquitetônico com a preexistência. Devido a problemas de ordem técnica e a eficácia para a proteção da área arqueológica, nos últimos anos houve uma revisão e adaptação dessa cobertura que foi parcialmente demolida sob a coordenação do Centro Regionale del Restauro. Um dos trechos mais significativos foi mantido, já que a própria criação de Minissi passou por um processo de historicização.
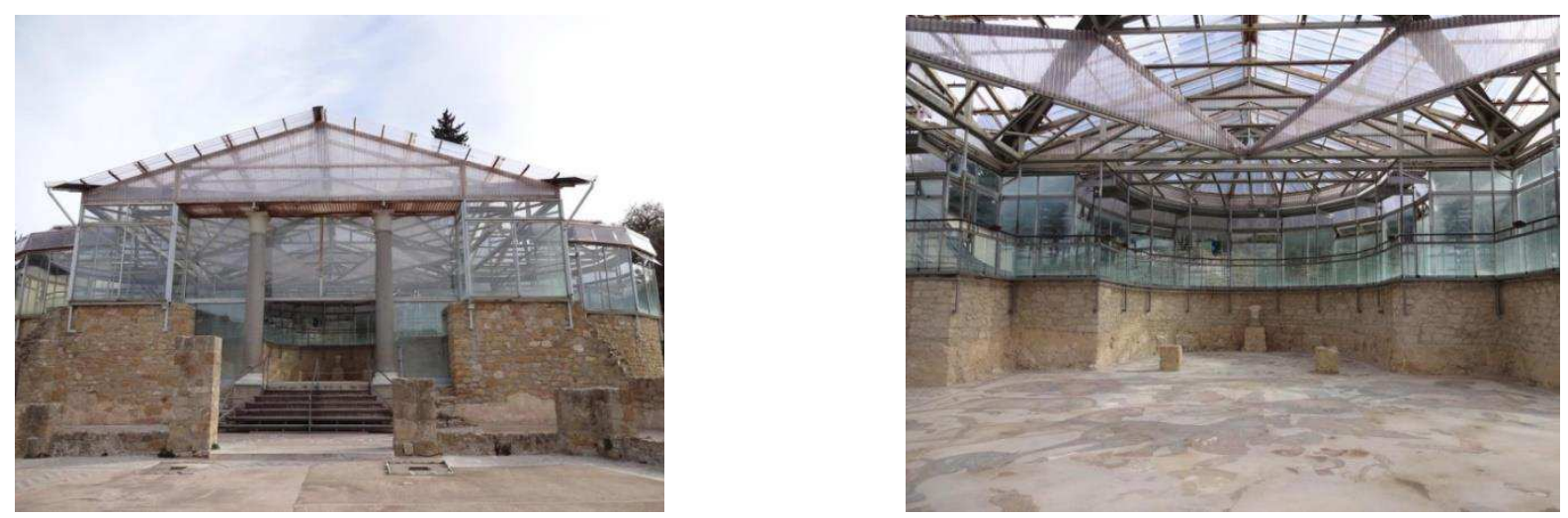

Fig. 60 (i-ii): Cobertura projetada por Franco Minissi, Villa Romana del Casale, Piazza Armerina (Itália), 2015. Fotos: Autora.

No Brasil, a cobertura é um elemento de extremo impacto no caso da Igreja Matriz de Vila Bela da Santíssima Trindade (MT); essa cidade foi a primeira capital do Estado do Mato Grosso e as ruínas da Matriz - que nunca foi concluída - foram tombadas pelo IPHAN em 1988 (ver Tabela 02, capítulo1). Nos anos 2000, em vista do estado de abandono do sítio arqueológico e do progressivo processo de degeneração das ruínas, foi determinado um Termo de Ajuste de Conduta (TAC) ao IPHAN, para a execução de uma cobertura para a área (cerca de $3.000 \mathrm{~m}^{2}$ ) e ações para a organização do local para constituir um museu ao ar livre. A cobertura é estritamente funcional e foi construída em estrutura metálica com elementos translúcidos. Trata-se de uma intervenção que contrasta com as ruínas.

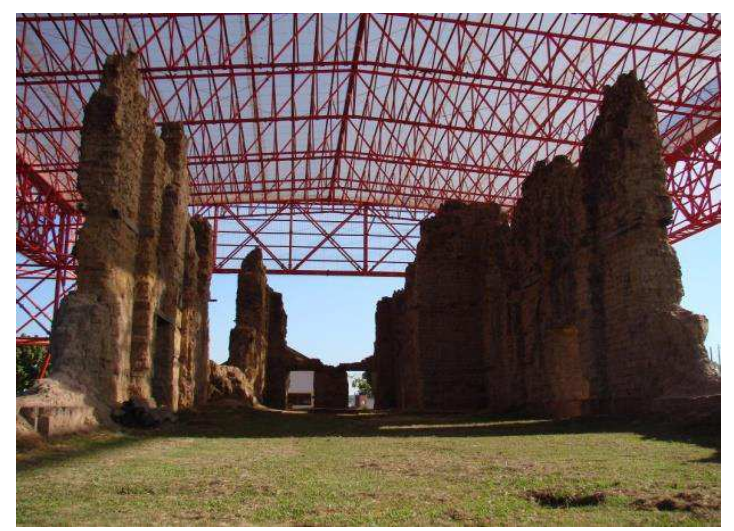

Fig. 61: Ruínas e cobertura da Igreja Matriz de Vila Bela da Santíssima Trindade (MT), 2007. Fonte: <https://pt.wikipedia.org/wiki/Vila_Bela_da_Sant\%C3\%ADssima_Trindade>, acesso em 21 maio 2015. Foto Pedro Spoladore. 
Como aponta Carbonara (2006) ${ }^{152}$ ao se referir ao tratamento e valorização de ruínas em sítios arqueológicos, na sinergia entre o antigo e o novo, há uma multiplicidade de acepções envolvidas (arquitetônica e arqueológica), mas também de restauro - pelo senso de conservação, reintegração e apresentação das estruturas, a fim de ressignificar aquilo que possa ser ilegível, mas merecedor de ser revelado. Assim, se coloca a necessidade de um bom projeto arquitetônico que não se limite a ser uma mera resposta a dados funcionais de fruição, mas se demonstre capaz de reconfigurar o sítio e seus testemunhos conferindo uma nova identidade ao conjunto mediante a sua situação contemporânea.

Em contraposição às experiências de valorização aos remanescentes arqueológicos em seus respectivos sítios há outras situações em que há uma total inexpressividade na apresentação dos resquícios como ocorre no projeto Museu a Céu Aberto em Recife (PE), que pretende tornar visível parte das ruínas da muralha holandesa proveniente do século XVII. No âmbito da recognição simbólica dos espaços públicos da capital pernambucana, conforme salienta Rogério P. Leite: "Embora a classe intelectual da cidade, sobretudo a acadêmica, reconheça obviamente a importância histórica desse achado arqueológico, ele não teve a repercussão pública desejada" (LEITE, 2004, p. 364).

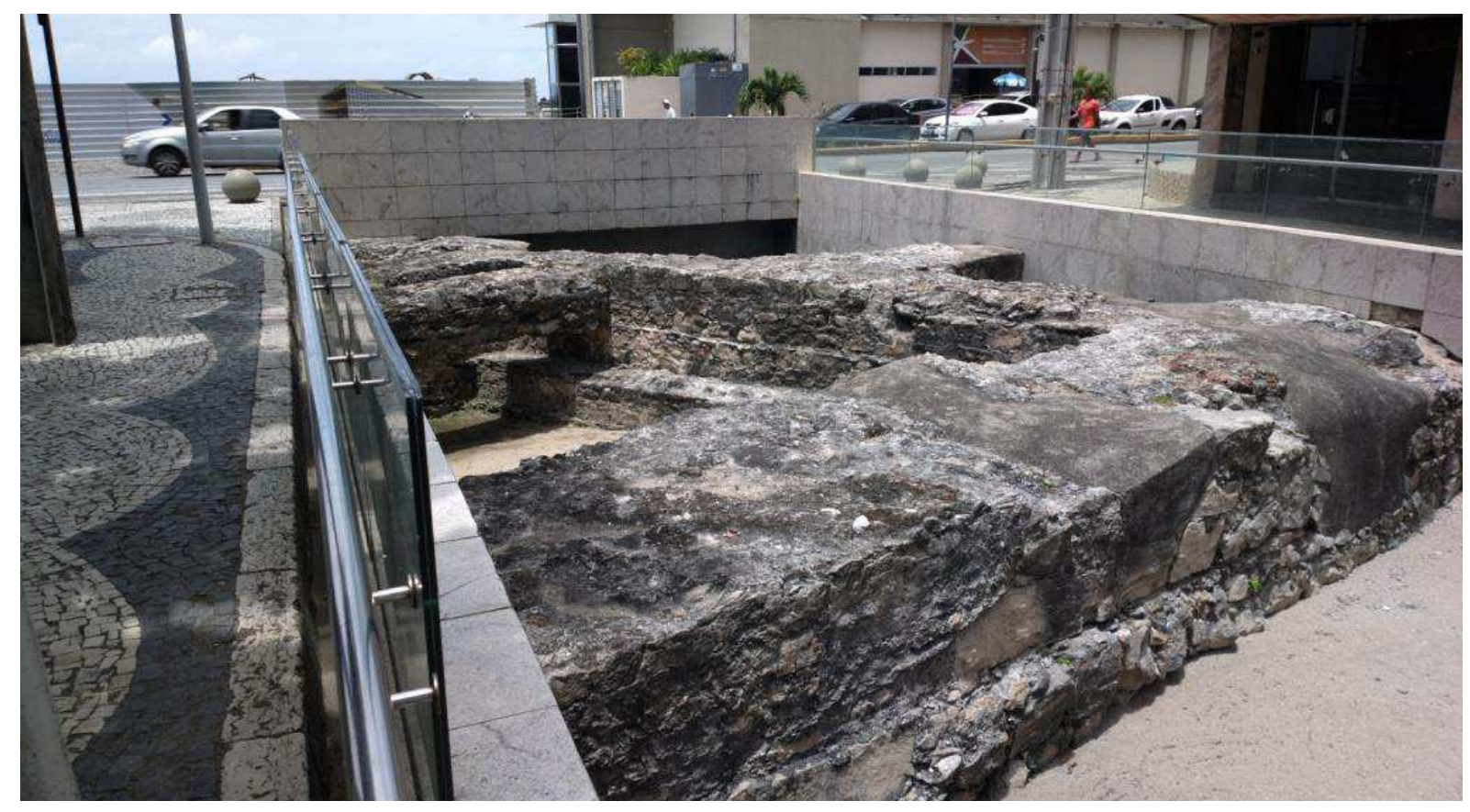

Fig. 62: Museu a Céu Aberto, ruínas - muralha holandesa, Recife (PE), 2016. Foto: Renato Pinto.

${ }^{152}$ Cf.: CARBONARA, Giovanni. Antichità archeologiche e periferia. In: CASSETTI R., SPAGNESI G. (a cura di). Roma Contemporanea. Storia e progetto. Roma, 2006, p. 401-407. 
A partir da análise do Engenho São Jorge dos Erasmos (envolvendo ações de consolidação, conservação, reconstituição parcial e a recente proposta para a valorização do sítio arqueológico) e da Capela do Morumbi (envolvendo a incorporação de ruínas preexistentes de forma legível com o objetivo de conservá-las em um novo objeto edificado) foi possível delinear algumas questões referentes à abordagem e tratamento ao grupo de ruínas do tempo no panorama dos bens tombados no Brasil.

A despeito das prescrições das principais Cartas Patrimoniais, evidencia-se uma multiplicidade de resultados desde o começo da atuação do SPHAN na década de 1930 até a atualidade. A problemática se articula através do seguinte questionamento: o quanto se pretende conservar um bem arruinado em seu respectivo status quo? $\mathrm{Na}$ ponderação de soluções para a aceitação ou não dessa realidade do patrimônio cultural constatou-se que há uma conjunção de fatores - tempo decorrido do arruinamento, o grau de destruição, a antiguidade do objeto edificado e suas respectivas condições de uso - que é determinante para a atribuição (ou não) de valores históricos ou artísticos a essa condição de ruína. O principal desafio que se vislumbra é coadunar as características das ruínas (vetustez, fragmentação e incompletude) a propostas de preservação estruturadas a partir da ambivalência das instâncias históricas e artísticas do substrato material remanescente. 
Capítulo 3

Ruínas da incúria: salvaguarda e negligência 



\section{Ruínas da incúria: salvaguarda e negligência}

Vislumbrar o valor cultural de um bem e tentar impedir a degradação e uma irremediável destruição é uma ação extremamente válida que está pautada pelo ideário da "urgência de salvaguarda" (LAMY apud RODRIGUES, 2001, p.32). Como apresentado no capítulo 1, a necessidade de salvar da ruína foi um ponto nodal para a estruturação da política de salvaguarda no Brasil; a constatação de uma iminente perda de bens arquitetônicos potencialmente representativos do passado que se pretende valorizar tem induzido a abertura de processos de tombamento com o propósito de salvaguardá-los de um latente processo de degeneração.

Em contrapartida, a despeito dessas motivações preservacionistas, há um grande número de edificações que se arruínam aguardando identificação, valorização cultural e uma iniciativa para sua salvaguarda. Essa situação não é exclusiva do Brasil e ocorre de forma flagrante em outros ambientes culturais, como evidenciado no trabalho Portugal em ruínas (SILVA, 2014):

As fases subterrâneas da História portuguesa pululam de ondas de descaracterização, de desleixo e de abandono de parte da sua memória arquitetônica, outrora significativa, que pura e simplesmente é deixada em estado de silenciosa agonia, em nome de uma ideia abastardada de progresso. Não só as guerras e as catástrofes naturais, os megassismos e os incêndios, as invasões estrangeiras e as fases de conturbação intestina, os maus restauros e as ondas de iconoclastia, contribuíram para essa perda do patrimônio comum, mas também a inconsciência das tutelas, a ambição de especuladores sem escrúpulos, a desmemoria de muitas comunidades e a falta de instrumentos legais de preservação e de salvaguarda. (SERRÃO In: SILVA, 2014, p.12-13 - grifo nosso)

A situação é substancialmente mais grave para os bens reconhecidos como patrimônio cultural que entraram em franco processo de arruinamento. A noção de "incúria" a que mencionamos ao delinear esse grupo de ruínas se estrutura justamente pela falta ou ineficiência de ações para preservar um patrimônio da ruína. É necessário ressaltar que estamos embasados na definição de ruína, apresentada no capítulo 1, em que se entende um estado de deterioração e modificação em que há perdas para a edificação das características anteriores. A ruína "da incúria" que assola muitos bens culturais é produto de um processo silencioso derivado da falta de ações concretas por parte das políticas de preservação e dos proprietários que vai se acumulando paulatinamente através de delapidações (revestimentos, cobertura, etc.), falta de manutenção, usos inadequados, dentre outros. Eventualmente há denúncias e clamores por parte de setores da sociedade civil, ou até mesmo dos órgãos de 
preservação, mas o processo continua até que num dado momento se constata a dolorosa realidade: um patrimônio arquitetônico íntegro se transformou em uma ruína.

Para procurar compreender as abordagens a que esse grupo de ruínas está suscetível é necessário pontuar: o grau de arruinamento (o tamanho das perdas e a intensidade das descaracterizações); tempo decorrido e causa do processo de arruinamento. A conjunção desses fatores delineia a complexidade em constatar e aceitar que de fato o bem se transformou de forma irremediável; uma dificuldade que é potencializada pela aceitação de que a causa da ruína é a confluência da negligência de todas as partes envolvidas (órgãos de preservação, proprietários e usuários).

Do ponto de vista simbólico à ideia de vanidade das obras do ser humano que estão associadas às ruínas (principalmente ao grupo apresentado no capítulo 2) pode ser acrescentada a ideia da incúria, da perda irreparável daquilo que poderia ter sido resguardado. O texto de Alberti no De Re Aedificatoria (L. X, cap.1 - 1452) é muito elucidativo ao se referir ao estado de conservação do legado da Roma Antiga ${ }^{153}$, consequência não só dos efeitos irremediáveis do tempo, mas também pela dolorosa negligência dos homens:

As destruições de proveniência externa podem - na minha opinião - ser arroladas com dificuldade tamanho o seu número e a sua variedade. A algumas delas referem-se as famosas sentenças: tudo é vencido pelo tempo; [...] Tem-se a seguir os danos provocados pelos homens... Por Deus! Às vezes não posso deixar de me rebelar ao ver como, por causa da incúria - para não usar uma apreciação mais crua: poderia ter dito avareza - de alguns, arruínam-se monumentos que por sua excelência e esplendor foram poupados até do inimigo bárbaro e desenfreado; e os quais, até o tempo, tenaz destruidor, teria facilmente deixado durar eternamente. (ALBERTI apud KÜHL, 2001, p. 26 - grifo nosso).

A evocação do abandono tem, portanto, um caráter diverso daquela do porvir do tempo, pois incorre na nulidade das ações, no arrependimento, ou na constatação da inoperância do que poderia ter sido feito e não o foi, conforme atesta o filósofo Henri-Pierre Jeudy: “A ruína antiga já tem um status patrimonial. Quando é atual, em vias de se transformar sob nossos olhos, dá ideia de abandono, de degradação, é um testemunho da incapacidade de preservar.” (JEUDY, 2005, p.70).

Assim como no grupo de ruínas analisado no capítulo 2 , os aspectos estéticos e pictóricos se configuram na medida em que a degeneração articula uma nova relação espacial. Mas a atribuição de um valor artístico a esses conjuntos exige uma sensibilidade que supere a

\footnotetext{
${ }^{153}$ Filarete (Antonio Averlino,1400-1469/70) também destaca em seu Trattato di architettura (c. 1460 - L.I): "Que isto seja verdadeiro - conclui o arquiteto - considere Roma, onde se vê aqueles edifícios que com maior razão deveriam ser eternos, e porque não tiveram alimento, ou seja, não foram mantidos, estão arruinados." (FILARETE apud D`AGOSTINO, 2003, p.116 - grifo nosso).
} 
dificuldade de aceitação das marcas da degradação causadas pela incúria. Do ponto de vista documental, a análise dessas ruínas não tem o mesmo peso que no grupo anterior. Por serem processos de arruinamento mais recentes, geralmente há um maior número de referências e estudos da edificação em sua integridade. A questão que se coloca é a aceitação do processo de arruinamento, ou seja, compreender essa ruína como um produto que testemunha a incúria e a negligência que também fazem parte da história do respectivo bem.

No quadro brasileiro, fica latente que o mero tombamento não é um elemento que per se garante a preservação de um bem. A instituição do tombamento é uma medida contida no âmbito da salvaguarda, cuja definição conforme a Carta do Restauro Italiana (1972) é: “Art. $4^{\text {o: }}$ [...] qualquer medida de conservação que não implique a intervenção direta sobre a obra." (MINISTÉRIO DA INSTRUÇÃO PÚLICA, Governo da Itália In: CURY, 2004, p. 147). Como destaca Sônia Rabelo de Castro (1991), no Brasil, chega a confundir-se preservação ${ }^{154}$ com tombamento ${ }^{155}$, que se trata de uma chancela de reconhecimento ou de atribuição de valores por um determinado grupo vinculado aos órgãos oficiais.

Tombar antes que seja tarde, antes que o bem se descaracterize ainda mais ou totalmente, não é suficiente. Diversas edificações que foram listadas como patrimônio, passam por paulatinos processos de arruinamento, seja pelo fato do instituto do tombamento "intervir no estatuto da propriedade e no uso do espaço físico" (FONSECA, 2009, p. 181); seja por falta de recursos dos proprietários; ou ainda por não corresponder às expectativas dos usuários envolvidos.

Como apresentado nos capítulos anteriores, é possível estabelecer algum tipo de mensuração para o grupo das ruínas "do tempo" através da contabilização dos respectivos tombamentos (apresentados pelas Tabelas). No entanto, para o grupo estudado neste capítulo (ruínas "da incúria”) a situação é mais complexa, pois seria necessário verificar o atual estado de conservação de cada edificação tombada, uma condição que é extremamente dinâmica pois envolve a forma de utilização do patrimônio e o conjunto de ações para sua preservação.

Ainda que essa quantificação seja difícil, podemos nos referir a situações pujantes para elucidar a sua compreensão. Há grandes trechos urbanos de cidades históricas com diversas

\footnotetext{
${ }^{154}$ Cf.: "Preservação é o conceito genérico. Nele podemos compreender toda e qualquer ação do Estado que vise conservar a memória de fatos ou valores culturais de uma Nação. É importante acentuar este aspecto já que, do ponto de vista normativo, existem várias possibilidades de formas legais de preservação." (CASTRO, 1991, p.5).

${ }^{155}$ Cf.: "[...] A lei o delimita, estabelecendo os lindes do exercício desse poder de polícia da administração, dispondo sobre seu conteúdo, seu procedimento e, a partir daí, estabelecendo os efeitos jurídicos que lhe são específicos.” (Op. cit. , p.8).
} 
edificações em grave estado de arruinamento. No centro histórico de Salvador - tombado pelo IPHAN em 1959 (Livro Arqueológico, Etnográfico e Paisagístico) e declarado pela UNESCO como Patrimônio Histórico e Cultural da Humanidade em 1985 - o grave estado de degeneração foi uma das motivações para o empreendimento de "revitalização" da área do Pelourinho a partir de 1993, uma intervenção que desapropriou e restaurou vários imóveis que estavam num visível processo de arruinamento (MARINS, 2012). Depois de mais de duas décadas, ainda é possível verificar muitos casarios arruinados nas adjacências da área de intervenção.

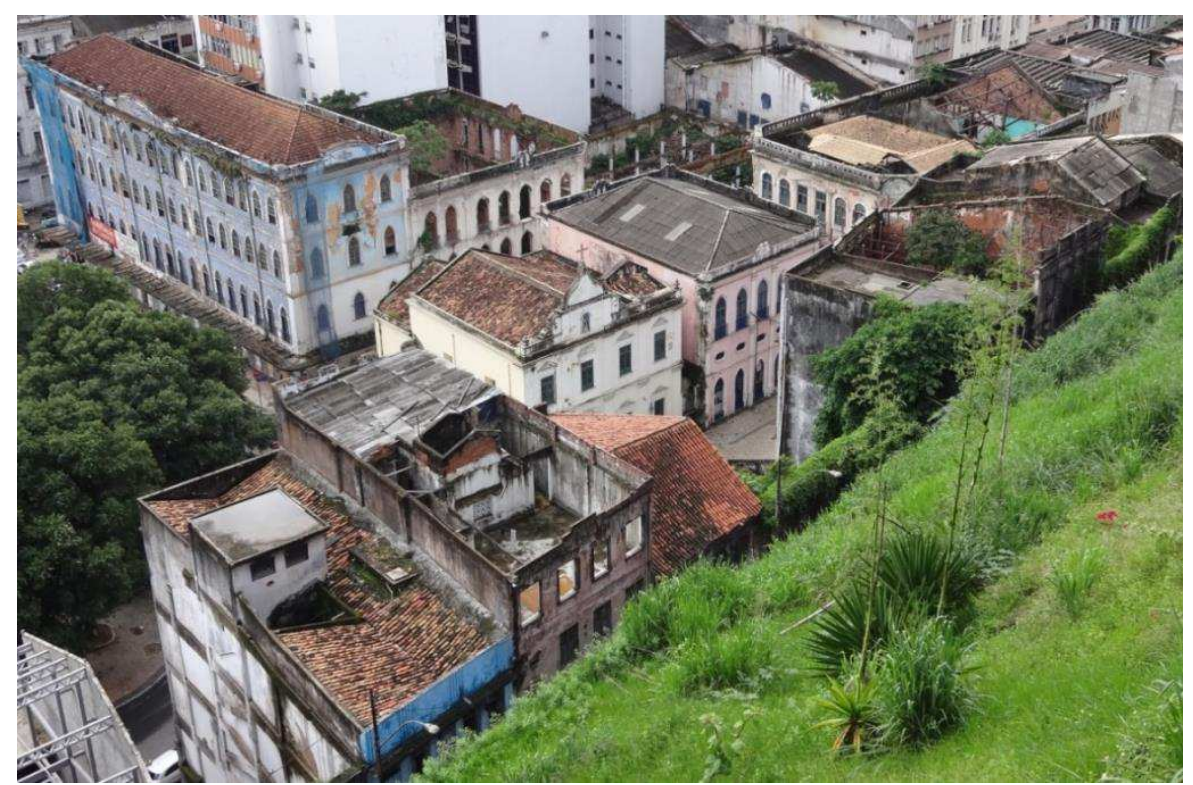

Fig. 63: Situação de alguns casarões no centro histórico de Salvador (BA), cidade baixa, 2013. Foto: Autora.

Ao considerar a escala do edifício, há uma imensa variedade de situações que acomete diversas tipologias arquitetônicas. Um caso flagrante é a Escola de Meninas na Vila Maria Zélia (São Paulo, SP), que constitui um patrimônio da industrialização da maior importância para a cidade de São Paulo. Em 1992 a Vila foi tombada pelos órgãos estadual e municipal. O CONDEPHAAT destacou o pioneirismo, a originalidade e a representatividade do conjunto e suas características de implantação e uso enquanto empreendimento do início do século. O CONPRESP também ressaltou os valores urbanístico, histórico, arquitetônico, ambiental e afetivo das edificações, destacando ser esse o "mais bem acabado exemplo de 'vila - cidadela' existente na cidade de São Paulo." (ROLNIK apud SÃO PAULO - cidade, SMC/CONPRESP, Res. 39/92, p. 91).

A despeito dessas considerações e do reconhecimento de seu valor cultural, a Escola de Meninas é uma das edificações da Vila que foi acometida por uma progressiva 
degeneração ao longo das décadas, o estado de ruína é notório. A Escola tem sido objeto de estudos, porém nada de concreto foi executado para mediar a situação.
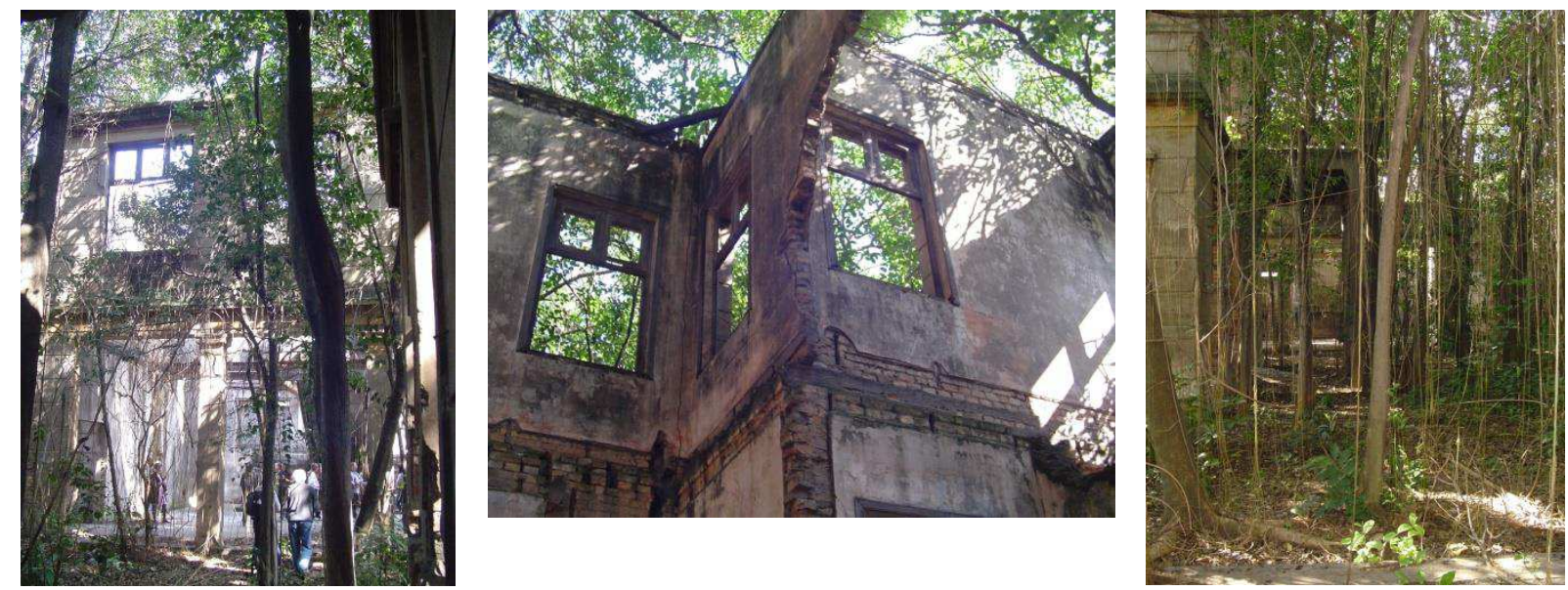

Fig. 64 (i-iii): Situação da Escola de Meninas - Vila Maria Zélia, São Paulo (SP), 2009. Fotos: Autora.

Tendo em vista essa aproximação ao que identificamos como ruínas da incúria, selecionamos os seguintes casos de estudo: antiga Sede do Sítio Mirim (São Paulo) e antiga Sede do Sítio Itaim (São Paulo) para desenvolver a nossa análise. A antiga Sede do Sítio Mirim (São Paulo, SP) é uma edificação rural cuja informação mais antiga remonta a 1750. Devido ao conjunto de suas características arquitetônicas, a casa foi tombada na década de 1960 e passou por trabalhos de restauração; sem um uso específico e em meio a uma região periférica da cidade, essa casa tem passado por um progressivo processo de degradação que se estende até a atualidade.

A antiga Sede do Sítio Itaim (São Paulo, SP) também é um exemplar representativo da arquitetura rural paulista, com data de construção que remonta a 1858. A edificação estava inserida na extensa chácara que foi loteada no início do século $\mathrm{XX}$ originando o bairro do Itaim Bibi. No início da década de 1980, a edificação foi tombada pelo CONDEPHAAT e a propriedade foi adquirida por um grupo empreendedor que deflagrou uma demolição parcial e irregular. Em meio a processos judiciais e atribuições de responsabilidade, o progressivo arruinamento perdurou até 2008, quando um novo proprietário executou a "restauração" da casa como condição para explorar o potencial imobiliário do terreno que está localizado em uma área supervalorizada da capital paulista.

Ao longo das décadas ambas antigas sedes rurais paulistas tiveram um destino similar: a despeito do reconhecimento de seu valor histórico, elas passaram por processos degenerativos em meio a uma ambiência de ampla aglomeração urbana. 
A partir desses casos selecionados pretende-se apresentar situações com históricos semelhantes que geraram a ruína do patrimônio cultural. Primeiramente é inevitável considerar que o processo degenerativo poderia ter sido evitado, ou ao menos minimizado, caso o bem tivesse sido devidamente conservado. Ao imputar as respectivas responsabilidades, é possível evidenciar o papel do tombamento como o principal instrumento de salvaguarda da política de preservação patrimonial brasileira e a falta de ações periódicas de manutenção - uma modalidade de intervenção que antecede qualquer eventual ação de restauro conforme prescrito em diversos momentos da historiografia da preservação patrimonial. Uma vez que o estado de ruína é uma realidade, o que fazer com esses remanescentes? Sendo assim, a análise é encaminhada para verificar como o status quo de ruína foi identificado e considerado nas abordagens que envolvem a discussão desses patrimônios edificados, com as respectivas propostas de intervenção. 


\subsection{Antiga Sede do Sítio Mirim ${ }^{156}$}

O Sítio Mirim se localiza em São Miguel Paulista (São Paulo) nas proximidades da margem esquerda do Rio Tietê. Embora não se saiba a idade precisa dessa edificação rural identificada também com o nome de Corumbataí, a informação mais antiga remonta a 1750, porém, a data é incerta e a construção poderia ser anterior. A respeito do histórico da residência também não há muitas informações; nessa casa teria residido o bandeirante Francisco de Godoy Preto (1688-1750), descobridor e guarda-mor das minas de Papuan, arraial do Pilar, em Vila Boa, Goiás.

Os primeiros estudos sobre o Sítio Mirim são de Luis Saia, que publicou em 1944 uma planta da casa no artigo "Notas sobre a arquitetura rural paulista do segundo século" na Revista do SPHAN ${ }^{157}$. Em levantamento fotográfico efetuado em 1945 e 1965, constatou-se que a casa apresentava alterações como o fechamento do alpendre central com parede de paua-pique, aberturas novas e falta de pilares originais no alpendre lateral.

Em 1965 Saia desenvolveu um relatório detalhado com gráficos da Sede do Sítio Mirim atestando que os detalhes construtivos (portas com vergas retas, espessuras das paredes de taipa, solução de detalhes da armadura do telhado, etc.) aproximavam este edifício daqueles que são comprovadamente do século XVIII; as modificações que ocorreram posteriormente não descaracterizaram o esquema básico dessa residência que se estruturava em dois setores, um privado onde acontecia a dinâmica familiar e outro mais social onde se compartilhavam algumas atividades comunitárias tais como cerimônias religiosas, hospedagem de viajantes e atividades administrativas (Capela, alpendre e quarto de hóspede). Saia destacou ainda que o alpendre se estendia por duas fachadas da casa configurando um "L", uma característica distinta das demais referências do mesmo partido e que, nesse caso também proporcionava uma solução diferente para o cunhal.

\footnotetext{
${ }^{156}$ Material consultado: Ofícios, relatórios e demais documentos referentes ao tombamento do Sítio Mirim pelo IPHAN foram consultados junto ao arquivo da Superintendência do IPHAN/SP: Processo 755-T-65 (IPHAN, 1965); processo CONPRESP: 1999-0.224.916-7; e material adicional PMSP/SMC/DPH - Seção Técnica de Projeto, Restauro e Conservação (STPRC) - Pasta: D.O.M. Julho/98; e. Entrevistas realizadas com: a arquiteta Lia Mayumi (PMSP/SMC/DPH -Seção Técnica de Projeto, Restauro e Conservação), em 22.02.2013; com o arquiteto Anderson Freitas do escritório Apiacás Arquitetos, em 26.02.2013; e com Marcos Cartum (PMSP/SMC), em 05.02.2014.

${ }^{157}$ SAIA, Luis. Notas sobre a arquitetura rural paulista do segundo século. Revista do Serviço do Patrimônio Histórico e Artístico Nacional. Rio de Janeiro, n. 8, p.268, 1944.
} 
No início da década de 1970, o arquiteto Eideval Bolanho desenvolveu mais alguns estudos para identificar detalhes arquitetônicos da casa, constatando que: a planta era em retângulo compartimentado; as paredes de taipa de pilão eram de $50 \mathrm{~cm}$ de espessura; o telhado em dois panos que confere uma incomum descontinuidade em relação às outras casas da mesma tipologia; a armadura do telhado era composta por madeiramento mergulhado na taipa; o piso era de terra batida; as portas e janelas eram exclusivamente de madeira; e as portas apresentavam detalhes decorativos em chanfro de 45 graus que variava para ambiente (KATINSKY, 1972).

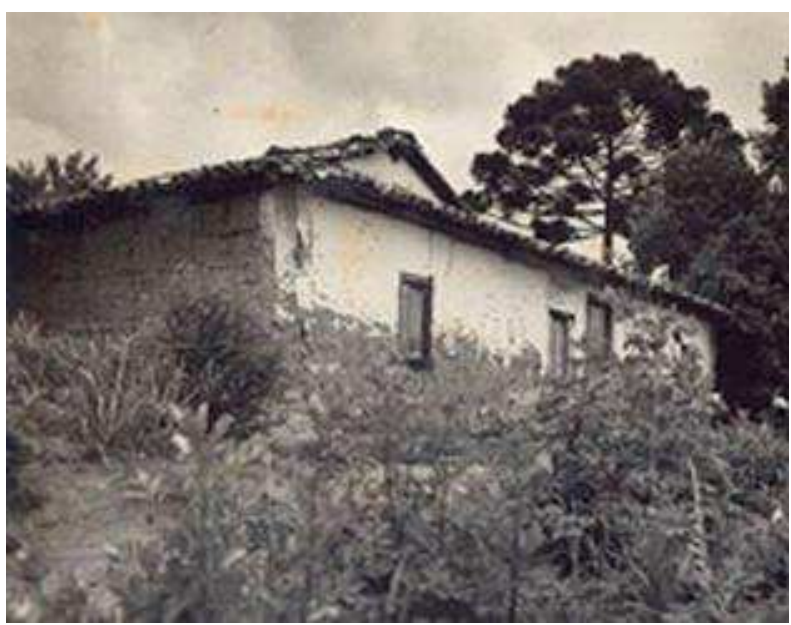

Fig. 65: Sede do Sítio Mirim, 1945.

Fonte: Acervo fotográfico da Superintendência do IPHAN/SP. Foto: Luis Saia.

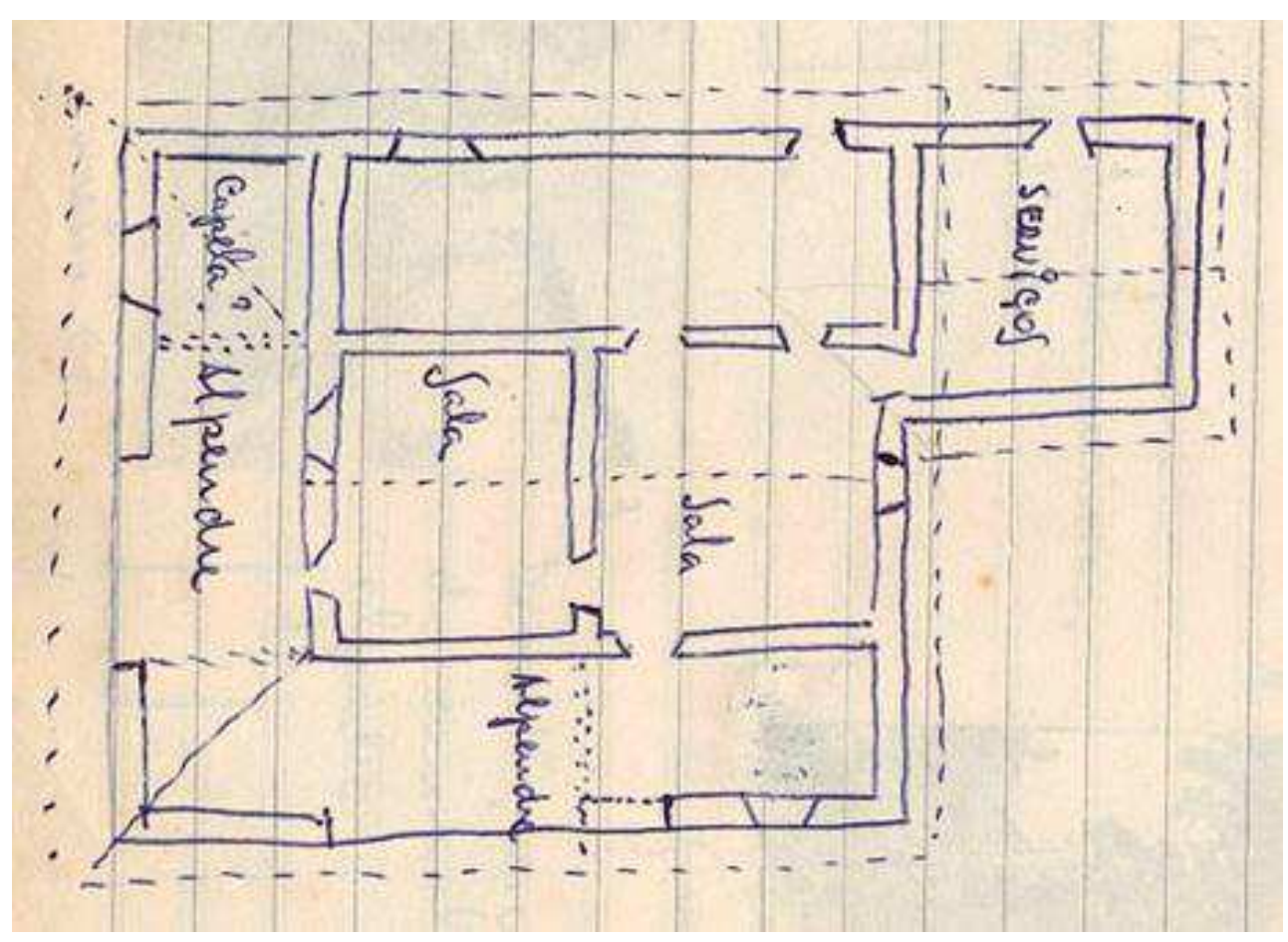

Fig. 66: Croquis da planta da Sede do Sítio Mirim, Luis Saia, capa do Caderno de Obras de 1967. Fonte: Acervo fotográfico da Superintendência do IPHAN/SP. 

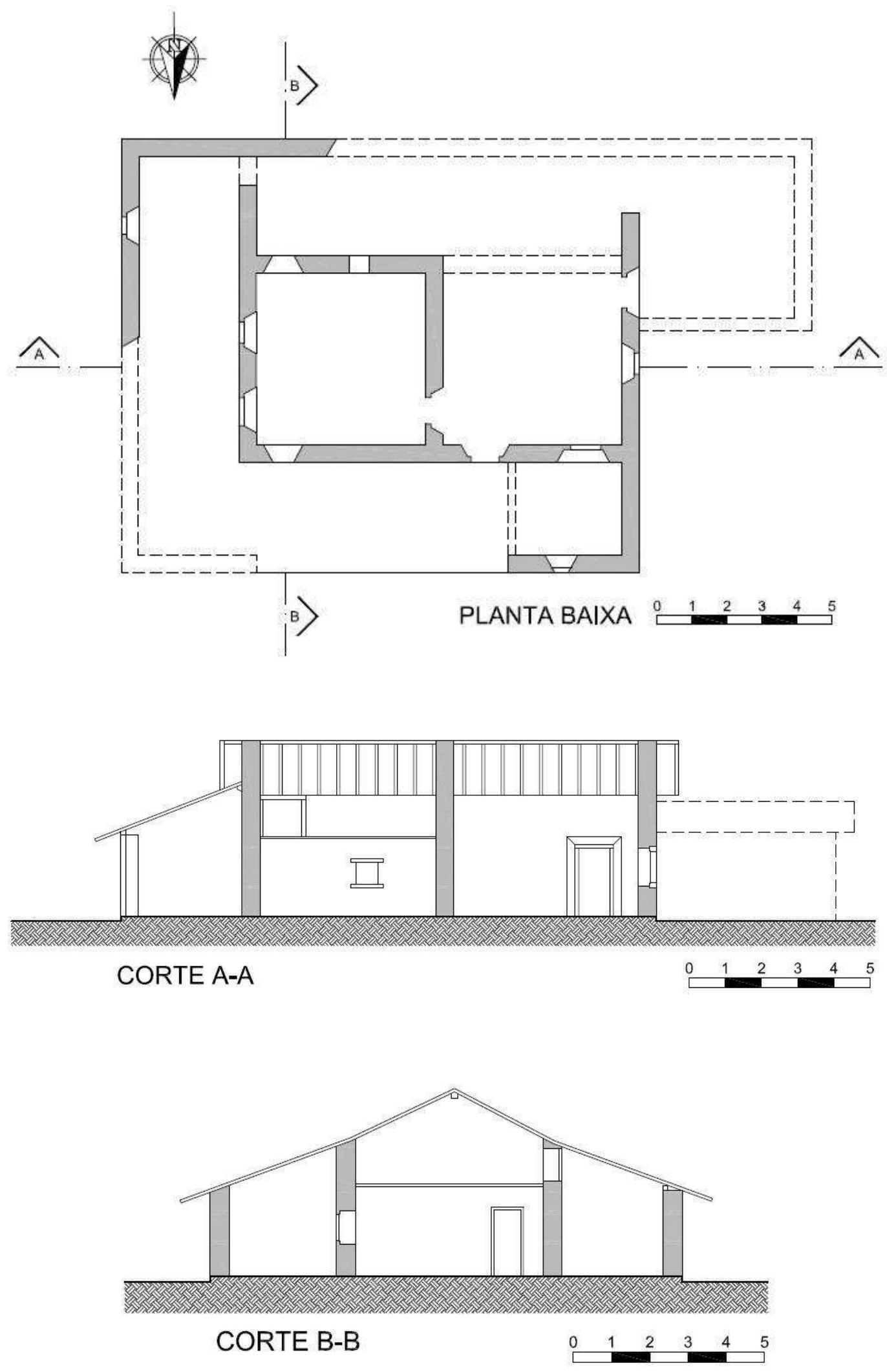

Fig. 67 (i-iii): Sede do Sítio Mirim - planta baixa, cortes A-A e B-B. Desenhos elaborados pela autora baseados no levantamento de Eideval Bolanho de 1964. Fonte: KATINSKY, 1972, p.29. 


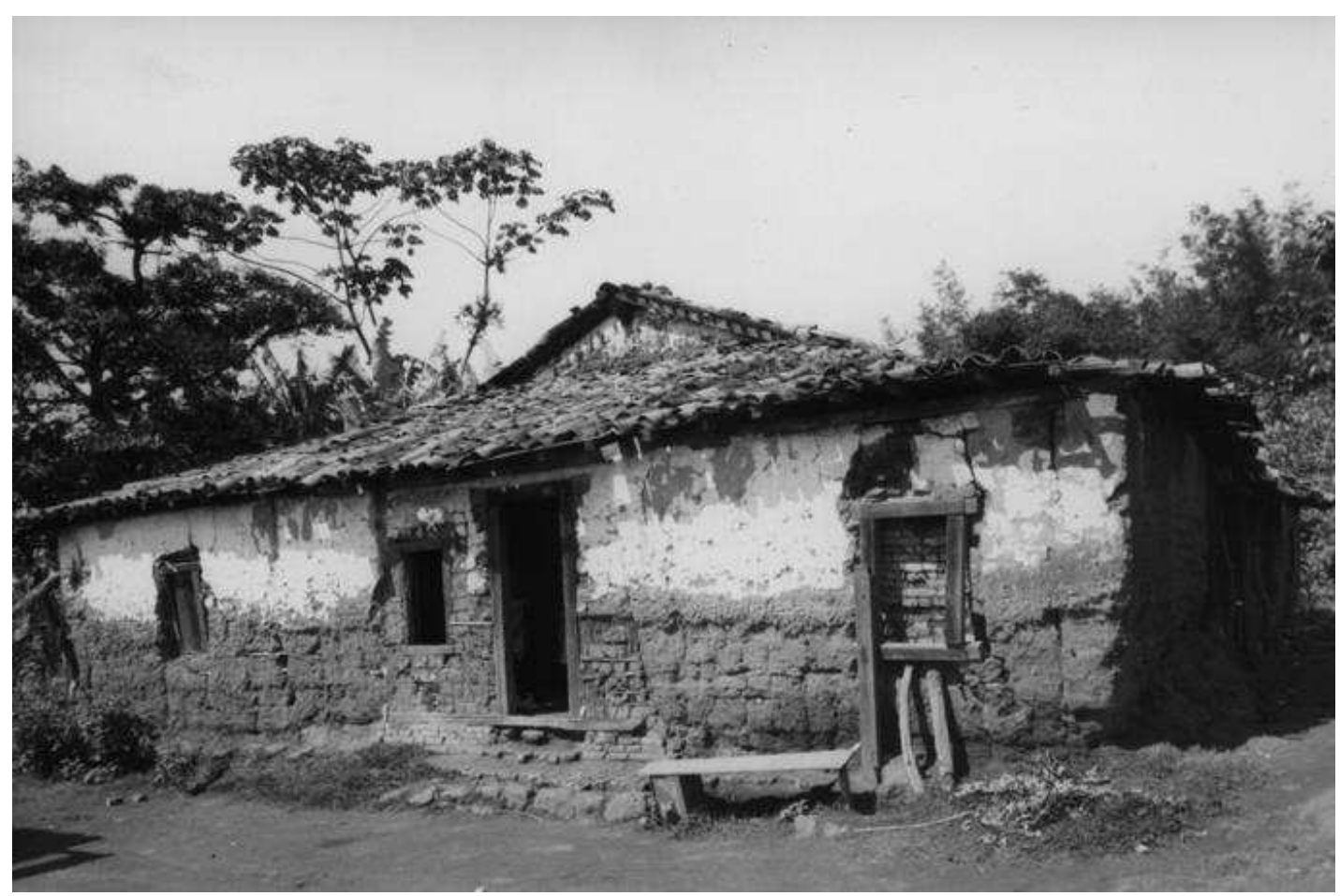

Fig. 68: Sede do Sítio Mirim, 1965. Fonte: Acervo fotográfico da Superintendência do IPHAN/SP. Foto: Hernan H. Graeser (Germano).

A partir dos estudos elaborados e reconhecendo-se que a casa possuía um valor histórico significativo como documento da arquitetura rural paulista Luis Saia elaborou a instrução para o tombamento embasada na excepcionalidade e unicidade do bem. A casa do Sítio Mirim foi efetivamente tombada pelo IPHAN em 1973, inscrita no Livro Histórico.

\subsubsection{Processo de arruinamento}

A preocupação com a urgência da necessidade de trabalhos para o Sítio Mirim já consta na instrução de tombamento de 1965, devido ao "estado ruinoso" (Of. 26/65 In: IPHAN, 1965, s.p.) da edificação que tinha se agravado pelas chuvas que levaram ao desabamento de parte de um compartimento indicado como cozinha na planta. Em 1967 Saia evidenciou a necessidade de intervenções: “[...] dado o estado bastante precário em que se encontrava a aludida casa do Sítio Mirim este Distrito iniciou imediatamente as obras de sua restauração [...] estas obras só foram iniciadas para evitar o perecimento total da pela arquitetônica [...]" (Of. 34/67 In: IPHAN, 1965, s.p.). Com os elementos encontrados, Luis Saia propôs trabalhos para conferir estabilidade à edificação; a operação, denominada como restauração, ocorreu em 1967 sob sua coordenação. Havia anseios de transformar a casa num museu histórico; para tanto se previa a necessidade da construção de uma pequena edificação dentro da área a ser desapropriada para manter um guarda permanente no local. 


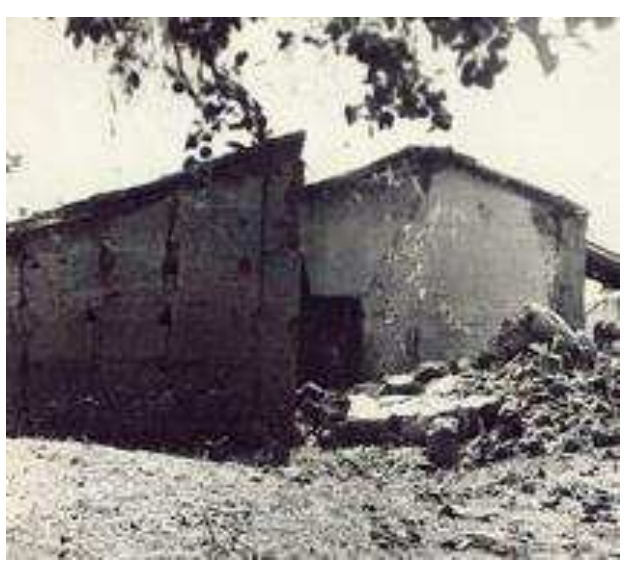

Fig. 69: Sede do Sítio Mirim, arruinamentos após chuvas. Fonte: Caderno de Obras, 1967, Luis Saia acervo fotográfico da Superintendência do IPHAN/SP.

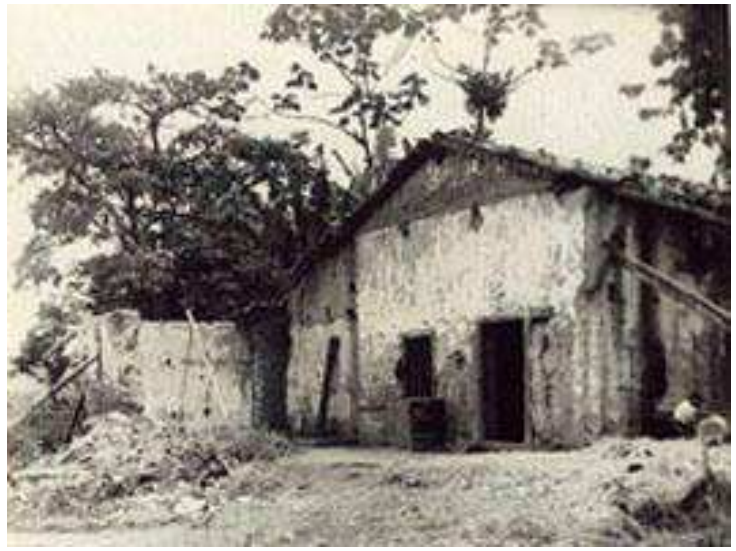

Fig. 70: Sede do Sítio Mirim, escoramentos. Fonte: Caderno de Obras, 1967, Luis Saia acervo fotográfico da Superintendência do IPHAN/SP

A área envoltória da casa bem como sua proximidade à linha férrea sempre foram objeto de atenções. Ainda em 1965 foram realizadas negociações com o então proprietário (Sr. Mário Albuquerque Pacini) que iria lotear os terrenos lindeiros para o destaque de uma área livre de um hectare em torno da edificação. Em 1971, foi assinado um decreto municipal ${ }^{158}$ que tornava de utilidade pública uma área necessária para a preservação, porém essa desapropriação somente ocorreu em 1975 quando passou para a guarda do recém-criado $\mathrm{DPH}^{159}$. No terreno onde se situa o Sítio Mirim foi constituída uma praça pública, popularmente conhecida como Praça do Índio.

Ao longo das décadas a região envoltória do Sítio Mirim tem sido cenário de um crescimento urbano desordenado; verificando imagens aéreas da década de 1950 e 2000 se constata o adensamento de uma comunidade desprovida de infraestrutura denominada Jardim Pantanal do Leste. A partir do início da década de 1970, a então recém "restaurada" casa do Sítio Mirim passou a ser depredada e seus materiais foram retirados (tijolos, telhas, madeiramento do telhado, etc.); exposta às intempéries a edificação entrou em franco processo de arruinamento.

\footnotetext{
${ }^{158}$ Decreto Municipal N. 9.334 de 12.06.71.

${ }^{159}$ A partir de 1975 começou a funcionar o Serviço Municipal do Patrimônio em São Paulo cuja política inicial era colaborar com as outras esferas (estadual e federal), completando ações iniciadas pelo IPHAN de desapropriação de transferência para o domínio municipal alguns bens tombados. Assim em 1979, a casa do Sítio Mirim fazia parte das seis casas bandeiristas (Butantã, Caxingui, Tatuapé, Sítio Morrinhos e Sítio da Ressaca) que formavam o núcleo inicial dos bens de propriedade municipal (MAYUMI, 2008).
} 


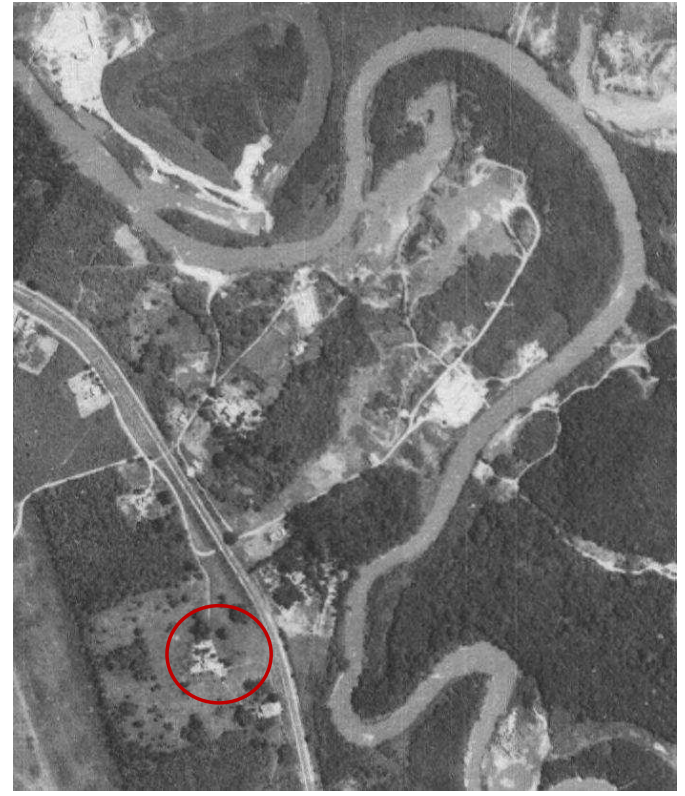

Fig. 71: Foto aérea do entorno da antiga Sede do Sítio Mirim - localizada no canto inferior esquerdo - 1954.

Fonte: PMSP/SMC/DPH/Seção Técnica de Projeto, Restauro e Conservação (STPRC).

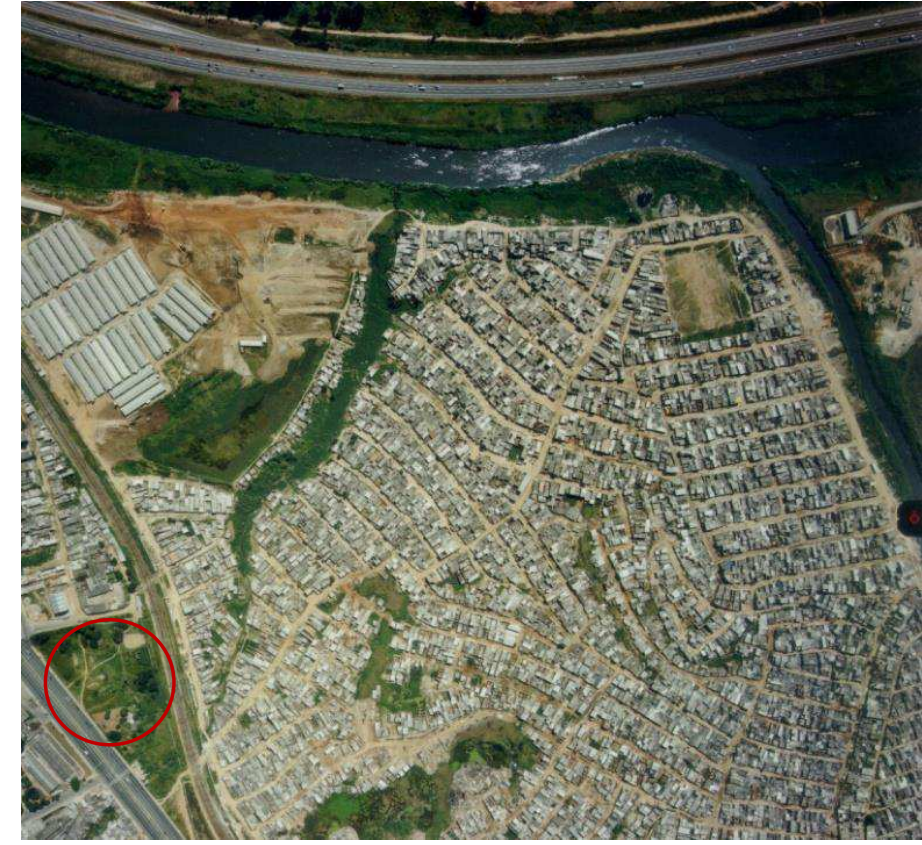

Fig. 72: Foto aérea do entorno da antiga Sede do Sítio Mirim - localizada no canto inferior esquerdo - 2000. Verifica-se a retificação do Rio Tietê e o adensamento urbano. Fonte: PMSP/SMC/DPH/Seção Técnica de Projeto, Restauro e Conservação (STPRC).

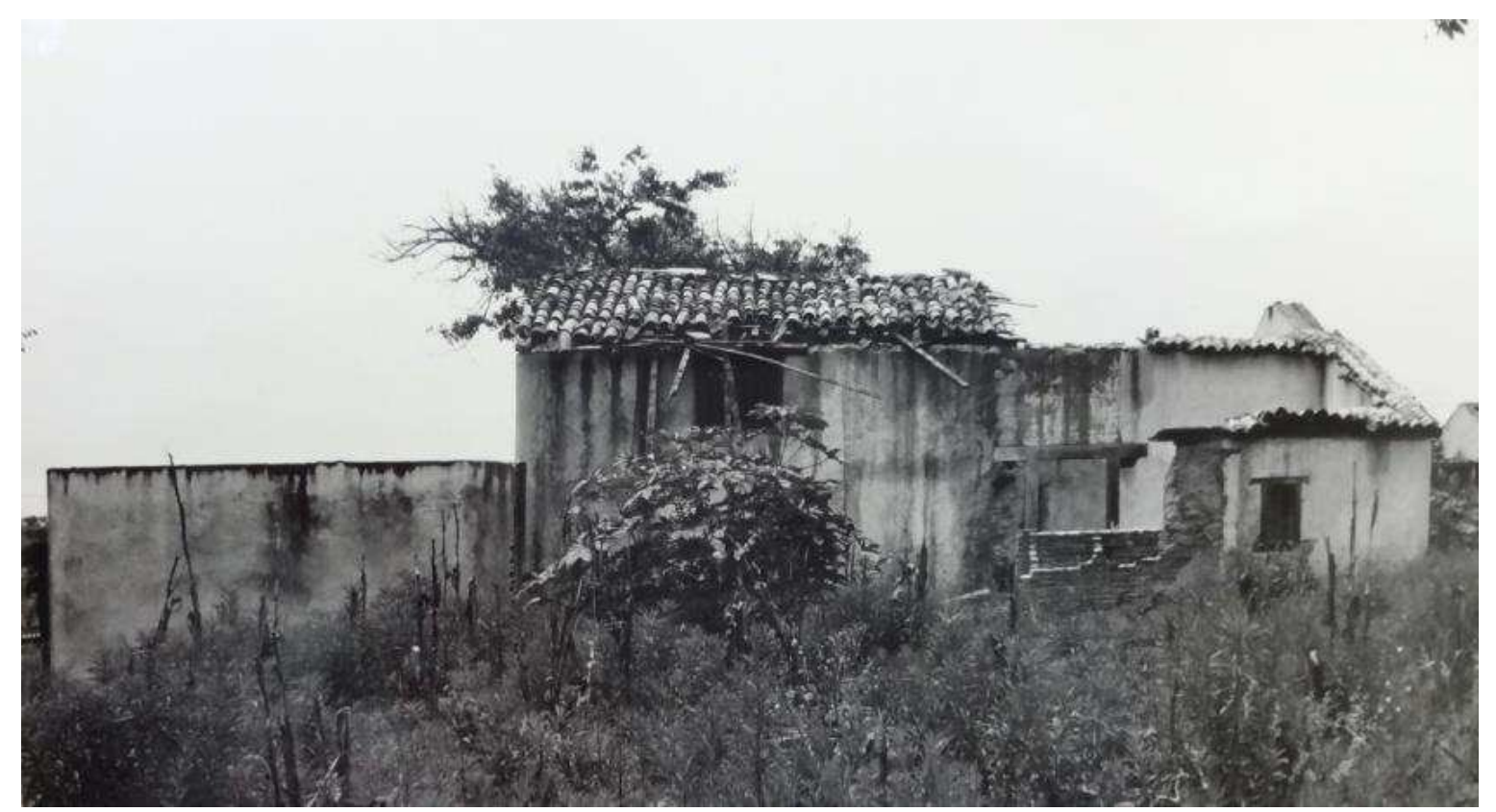

Fig. 73: Sede do Sítio Mirim, início do processo de depredação em 1972. Fonte: IPHAN, 1965, s.p. Foto: Luis Saia.

A situação da casa ficou ainda mais complexa em 1972, devido ao alargamento da pista da Estrada de Ferro Central do Brasil. Houve contundentes manifestações por parte de Luis Saia solicitando o embargo dessas obras no trecho que atingia a área envoltória do imóvel por comprometerem a sua estabilidade: 
As obras [...] já atingiram cerca de 5 metros dos terrenos fronteiros ao monumento tombado, denominado Sítio Mirim, situado na imediação da referida linha. Restam apenas 5 metros de desaterro para que a obra alcance a fachada principal do monumento. Em resumo, o projeto dessa firma implica na perda total do monumento em pauta e representa um atentado contra o patrimônio nacional, [...]. (Of. 215/72 In: IPHAN, 1965, s.p.)

De fato a polêmica dessas obras e do estado periclitante à que a antiga sede do Sítio Mirim estava exposta ganhou matéria em jornal $(1973)^{160}$, salientando o fato de que máquinas de terraplanagem chegaram a poucos metros da edificação. Nos anos que se seguiram a problemática do estado de arruinamento devido ao abandono e à incúria foi se agravando, somente no final da década de 1970 foram retomados trabalhos e propostas para o Sítio Mirim.

Em 1983 o Sítio Mirim foi tombado pelo CONDEPHAAT ${ }^{161}$; mas sem os devidos cuidados, continuou passando por processos de degradação. Em função de seu estado de abandono, a Administração da Regional de São Miguel solicitou em 1986 providências ao órgão estadual ${ }^{162}$. Em 1991 o Sítio Mirim foi tombado pelo CONPRESP ${ }^{163}$, porém, a situação se manteve: vandalismo, falta de controle da ocupação do entorno e abandono foram, paulatinamente, acentuando o estado de ruína do Sítio Mirim.

Em 1998, instaurou-se um inquérito civil na Promotoria de Justiça do Meio Ambiente da Capital versando sobre o abandono do local. No entanto, em meio a trâmites judiciais e definições conceituais sobre o partido a ser adotado para as ruínas, a situação perdurou.

Em 2010, a CPTM (Companhia Paulista de Trens Metropolitanos) apresentou o projeto da Estação Nova Vila Jacuí (aprovado pelos órgãos competentes) que será instalada a poucos metros do terreno do Sítio Mirim que serve de acesso à estação. Com a instalação dessa nova estrutura, que prevê passarelas sobre a linha férrea e a reurbanização do traçado, possivelmente a relação com o entorno será transformada e uma nova condição de uso poderá ser instaurada. No entanto, enquanto isso não ocorre, a situação das ruínas do Sítio Mirim segue inalterada.

\footnotetext{
${ }^{160}$ Folha de São Paulo: "São Paulo está perdendo um de seus derradeiros exemplares da arquitetura residencial paulista correspondente ao chamado período bandeirista: o Sítio Mirim”, LIMA (1973) In: IPHAN, 1965, s.p.

${ }^{161}$ CONDEPHAAT Processo: 22053/82, Livro do Tombo Histórico.

${ }^{162} \mathrm{Cf}$.: "Vimos através do presente informar a V. Sa. que o Sítio Mirim [...] está sendo depredado e danificado por vândalos e marginais, tendo sido sua cerca de tela roubada e que os guardas que prestavam serviços no local estão ausentes já há algum tempo. Face ao acima exposto e por encontrar-se no local, a antiga Casa dos Bandeirantes, marco importante da história de nossa região, solicitamos as dignas providências de V. Sa. no sentido de cercar e colocar vigilantes no local. [...]" (Of. 946/AR-MP.GAB/86 In: IPHAN, 1965, s.p.).

${ }^{163}$ CONPRESP: Resolução 05/1991.
} 


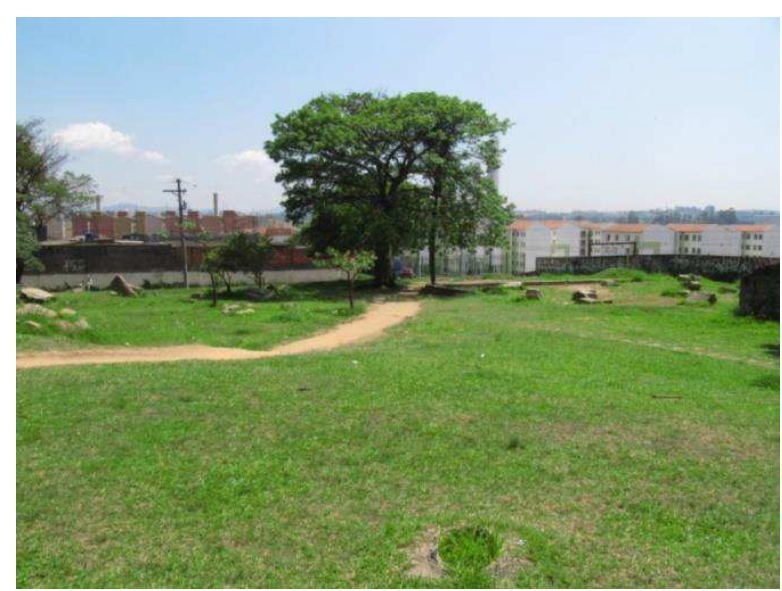

Fig. 74: Praça do Índio, caminho para passagem sob linha férrea; lado direito ruínas da antiga Sede do Sítio Mirim, 2010. Fonte: PMSP/SMC/DPH/Seção Técnica de Projeto, Restauro e Conservação (STPRC). Foto: Lia Mayumi.

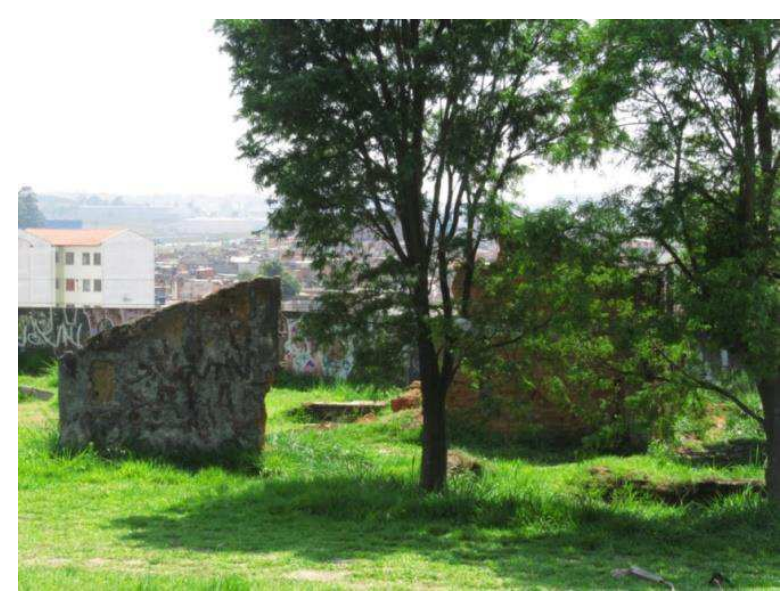

Fig. 76: Ruínas do Sítio Mirim - remanescentes em taipa; aos fundos, muro de divisa com a CPTM, e CDHU, 2010. Fonte: PMSP/SMC/DPH/Seção Técnica de Projeto, Restauro e Conservação (STPRC). Foto: Lia Mayumi.

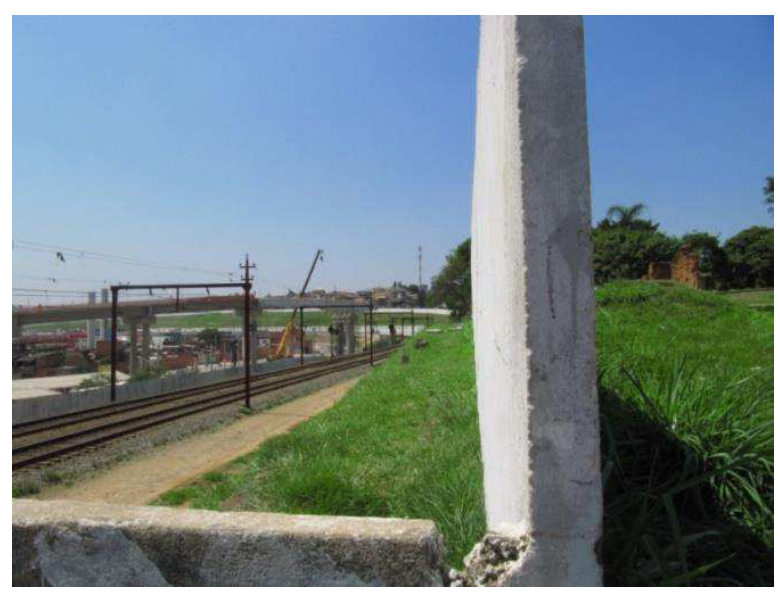

Fig. 75: Muro de divisa entre a linha férrea da CPTM e terreno do Sítio Mirim, com vista das ruínas ao lado direito, 2010. Fonte: PMSP/SMC/DPH/Seção Técnica de Projeto, Restauro e Conservação (STPRC). Foto: Lia Mayumi.

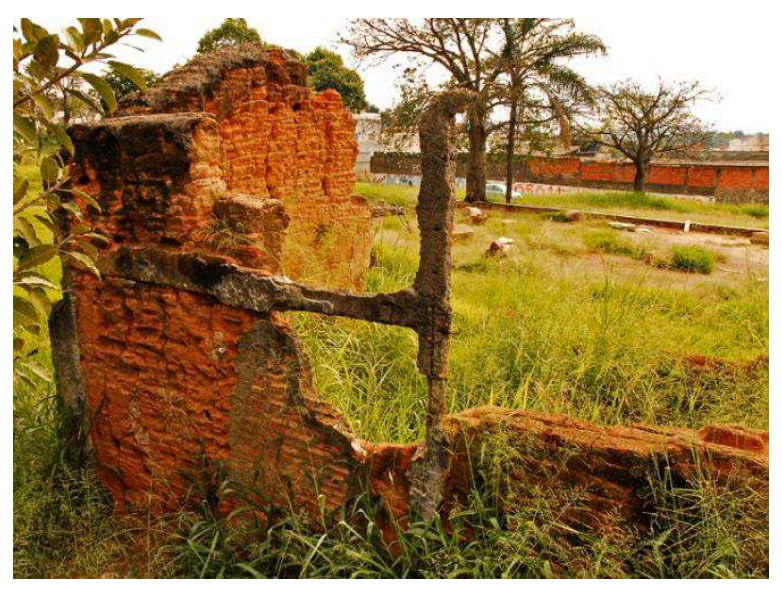

Fig. 77: Ruínas do Sítio Mirim - remanescentes em taipa; aos fundos, muro de divisa com a CPTM, 2005. Fonte: Acervo fotográfico da Superintendência do IPHAN/SP. Foto: João Bacellar.

\subsubsection{Propostas de intervenção}

Ao longo das décadas, como foi apresentado, a Sede do Sítio Mirim vem sendo objeto de estudos, propostas e intervenções. A primeira intervenção pela qual o bem passou foi a restauração de 1967 coordenada por Luis Saia. Há de se levar em conta, que aqui, a casa foi considerada tendo em vista a sua espacialidade arquitetônica que ainda era reconhecível. Embora bastante abandonada, Saia utilizou os elementos pré-existentes encontrados como referências fidedignas para a elaboração desse projeto de restauro que recompôs totalmente a edificação (SÃO PAULO - cidade, 1976). 
Através de levantamento iconográfico é possível constatar que foram instaladas placas de concreto junto às paredes de taipa (sem fundação) para proteção contra erosão provocada pelas águas pluviais. Além disso, foi executada uma malha de concreto com vigas (geralmente seções de 20x20 cm) e algumas colunas (seções de 30x30 cm) para a amarração das paredes. Para o completamento das partes erodidas, foram utilizados tijolos de barro; o telhado foi reconstituído com novo madeiramento e telhas de barro; e novas esquadrias em madeira foram instaladas.

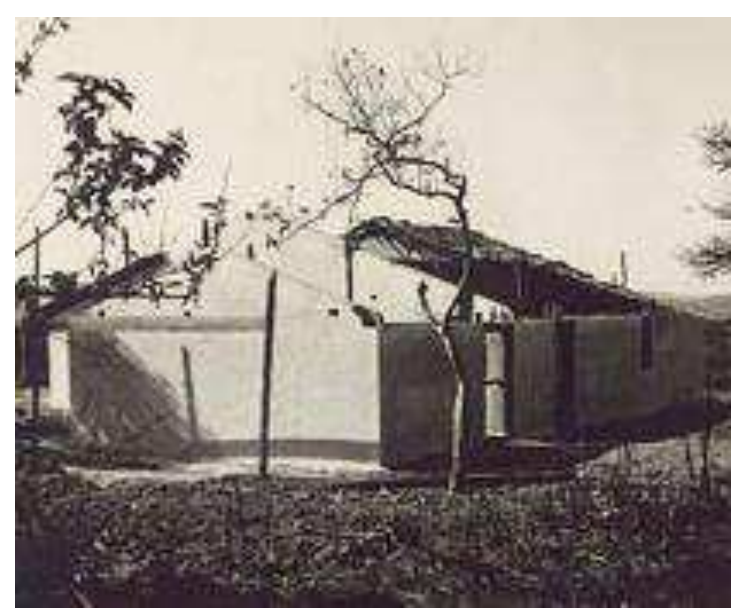

Fig. 78: Sede do Sítio Mirim trabalhos de restauração, 1967. Fonte: Caderno de Obras, 1967, Luis Saia acervo fotográfico da Superintendência do IPHAN/SP.

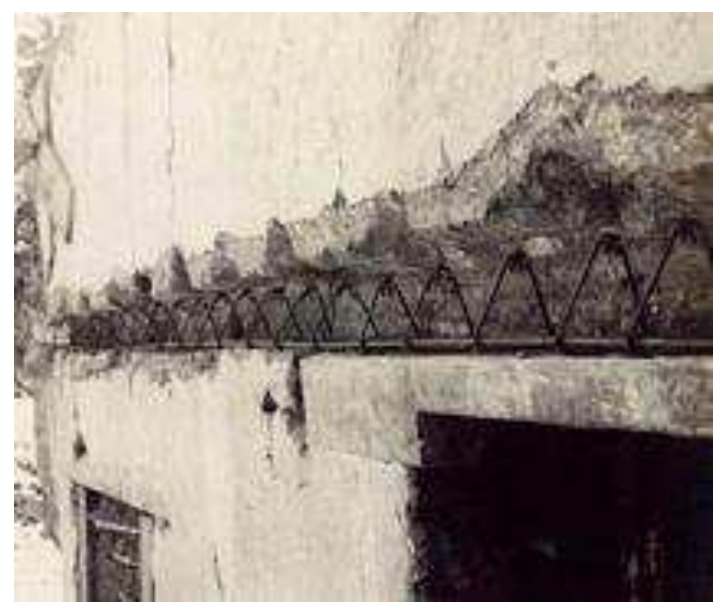

Fig. 80: Sede do Sítio Mirim, vigas para amarração. Fonte: Caderno de Obras, 1967, Luis Saia - acervo fotográfico da Superintendência do IPHAN/SP.

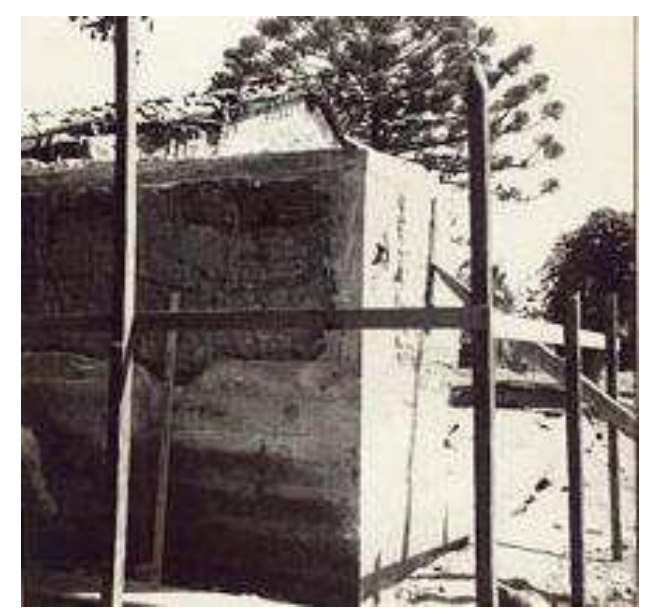

Fig. 79: Sede do Sítio Mirim, placas de concreto junto à taipa. Fonte: Caderno de Obras, 1967, Luis Saia - acervo fotográfico da Superintendência do IPHAN/SP.

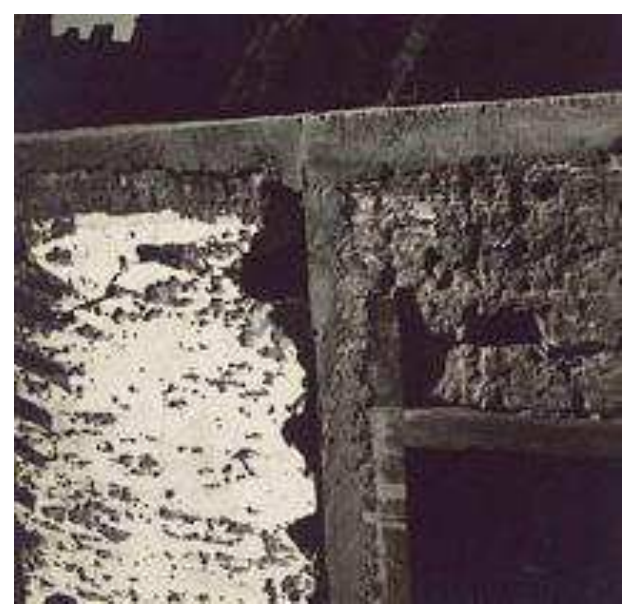

Fig. 81: Sede do Sítio Mirim, colunas e vigas de concreto. Fonte: Caderno de Obras, 1967, Luis Saia acervo fotográfico da Superintendência do IPHAN/SP

A partir de 1971, com sucessivas depredações e exposição às intempéries, o processo de arruinamento agravou-se. Em 1976, um estudo foi desenvolvido pelos técnicos do DPH; a arquiteta Helena Saia desenvolveu uma proposta ${ }^{164}$ em que se cogitou a restituição espacial da

\footnotetext{
${ }^{164}$ Trabalho consultado junto à PMSP/SMC/DPH - Seção Técnica de Projeto, Restauro e Conservação, Pasta: D.O.M. Julho/98.
} 
casa. É de 1977 também, um projeto de paisagismo a ser implantado na área envoltória (Praça do Índio) (Of. 147/77 In: IPHAN, 1965, s.p.). No início da década de 1980 com o andamento de projeto executivo para a restauração desenvolvido pelos técnicos da Seção Técnica de Projetos Restauro e Conservação do DPH liderados pela arquiteta Vera Santos Mauro de Menezes foram iniciadas prospecções arqueológicas no sítio coordenadas pela arqueóloga Margarida Davina Andreatta do Museu Paulista da USP; esses trabalhos foram importantes não só para informar sobre vários testemunhos arqueológicos da região, mas também, no que diz respeito à casa, dar detalhes sobre alicerces e evidências de soleiras de madeira nas portas de modo a contribuir para a interpretação da dimensão física arquitetônica do edifício na sua cota zero.

Porém, de acordo com o relatório da arquiteta Vera Santos Mauro de Menezes de 1983 (SÃO PAULO - cidade, 1983) as prospecções arqueológicas não foram conclusivas sobre a configuração original da casa. Devido à falta de evidências documentais precisas que justificassem a adoção do partido da reintegração espacial, a proposta de intervenção elaborada por Helena Saia não seguiu adiante.

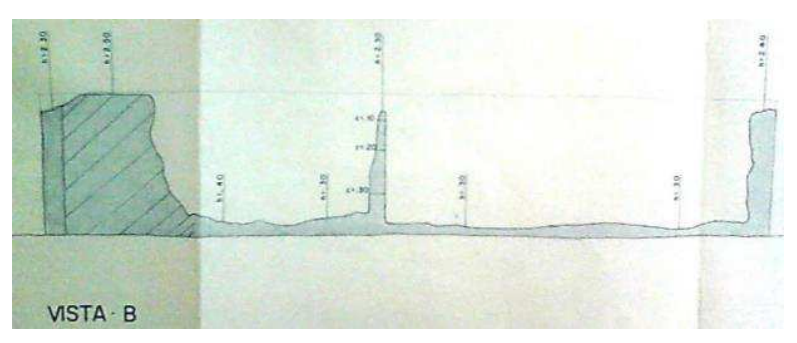

Fig. 82 (i-ii): Levantamento das ruínas e proposta de restauração desenvolvida pela arquiteta Helena Saia PMSP/DPH, 1976. Fonte: Projeto consultado junto à PMSP/SMC/DPH - Seção Técnica de Projeto, Restauro e Conservação, Pasta: D.O.M. Julho/98, s.p.

Nesse ínterim, enquanto se decidia sobre partido do projeto de restauro, foram solicitadas medidas para a contenção das paredes de taipa de pilão remanescentes, consolidando as ruínas da casa (Of. 221/78 In: IPHAN, 1965, s.p.); trabalhos que foram executados em 1978, devido à iminência de um "total arrasamento" (segundo o "Relatório das obras de emergência realizadas nas ruínas do Sítio Mirim"). Esse estado precário devia-se à ação de depredadores que ocorria mesmo com o cercamento da área; à ação incondicional de sua exposição às intempéries do tempo - a infiltração da água pluvial tirava a coesão do material e criava canais no interior das paredes de taipa; ao excessivo crescimento de vegetação que dificultava a evaporação da água; e também aos efeitos da vibração provocada pela passagem dos trens. 
Em função disso, foram tomadas medidas como: revestimento no topo das paredes com argamassa resistente, e, quando necessário, de fácil remoção; aplicação de silicone nas laterais das paredes; execução de canaleta com largura média de $35 \mathrm{~cm}$ por volta das ruínas para que fossem protegidas de enxurradas; escoramento de paredes com perigo de desabamento, execução de capina e limpeza da vegetação tomando-se o cuidado de que o trabalho com enxadas não danificasse as paredes; nivelamento do terreno; na ocasião desses trabalhos constatou-se que algumas paredes só não haviam desabado totalmente devido às obras de restauração executadas em 1967.

A partir de 1999, através de várias reuniões conjuntas envolvendo técnicos da PMSP/ DPH, CONDEPHAAT e IPHAN e representantes do Ministério Público foi decidido que uma nova proposta seria feita para uma solução das ruínas e a implantação de um centro cultural no local. O corpo técnico do DPH elaborou um anteprojeto ${ }^{165}$ (coordenado pelas arquitetas: Leila Regina Diêgoli, Cássia Magaldi e pelo engenheiro José Henrique Seraphini). Segundo o relatório de apresentação do anteprojeto, a proposta foi embasada na orientação teórica que aponta para a consolidação dos remanescentes em ruínas e não propriamente da reconstituição da edificação, pois não haveria elementos suficientes que possibilitariam esse partido, afirmando também que as ruínas deveriam ser tratadas de um ponto de vista arqueológico (SÃO PAULO - cidade, 1999).

As soluções apresentadas nesse momento englobam não só os remanescentes em taipa, mas a praça como um todo na construção de um centro cultural: 1. para as ruínas: construção de cobertura porticada de estrutura metálica com caixilharia envidraçada; execução de limpeza cuidadosa, consolidação e proteção química através da aplicação de produto impermeabilizante nos remanescentes de taipa de pilão; execução de pisos , com utilização de pedras tipo granito de coloração diferenciada, disposta de forma a permitir uma releitura da antiga planta da casa (ambientes - granito amêndoa e projeção das paredes - granito verde Ubatuba); execução de sistema de drenagem de águas pluviais; colocação de sistema de iluminação para a valorização das características do monumento; piso externo ao perímetro da casa revestido em mosaico português. 2. Para a praça: construção de marquise em concreto armado; execução de acesso em rampa para deficientes físicos; remanejamento e construção de quadra poliesportiva; remanejamento da vegetação de porte arbóreo compatível com a proteção do monumento; construção de anfiteatro; nova pavimentação; novo sistema de iluminação; mobiliário urbano; sistema de identificação do monumento. 3. Para a "Casa de

165 Anteprojeto de requalificação dos remanescentes do Sítio Mirim (Folhas 1 e 2) In: IPHAN, 1965, s.p. 
Cultura": construção de edifício em estrutura mista de concreto armado e metálica com três pavimentos com auditório, sala de exposições, sanitários e vestiários, salas de oficina, administração e diretoria (SÃO PAULO - cidade, 1999).

Devido à falta de consenso quanto ao partido a ser adotado pelos órgãos de preservação envolvidos (DPH, CONDEPHAAT e IPHAN), essa proposta, não foi integralmente aprovada e foi arquivada.

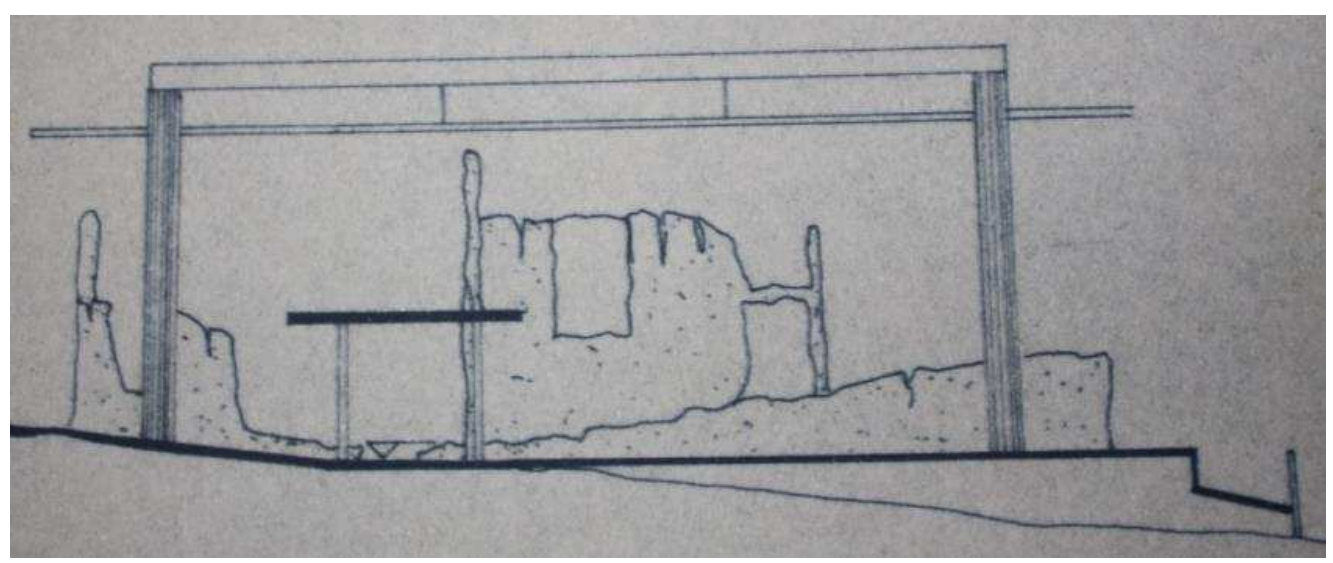

Fig. 83: Proposta desenvolvida pelos técnicos da PMSP/DPH para a cobertura e manutenção das ruínas do Sítio Mirim - corte, 1999. Fonte: Projeto consultado junto à PMSP/SMC/DPH - Seção Técnica de Projeto, Restauro e Conservação, Pasta: D.O.M. Julho/98, s.p.

Em 2003 foi instaurado um projeto da CDHU (Companhia de Desenvolvimento Habitacional e Urbano) para a reurbanização da ocupação vizinha à Praça do Índio e implementação de serviços e equipamentos públicos para cerca de 7.000 famílias (Vila Jacuí). Nesse momento, segundo relato da arquiteta Lia Mayumi ${ }^{166}$, em função da necessidade de interligar acessos a esse novo conjunto foi apresentada proposta de traçado viário que incidia no terreno do Sítio Mirim comprometendo a área envoltória do mesmo.

A Secretaria Municipal da Cultural havia incluído o Sítio Mirim num conjunto de propostas de intervenções ("reurbanizações urbanas") ${ }^{167}$, para que fosse desenvolvido um projeto que contemplasse a conservação das ruínas e a implantação de um Centro de Cultura e Convivência no terreno, o que ia ao encontro das reivindicações da população local que se organizou para solicitar providências quanto ao estado do bem cultural. Para tal projeto, o escritório Apiacás Arquitetos foi contratado junto à Secretaria Municipal da Cultura e desenvolveu estudos e propostas para uma revisão das alternativas viárias na área. Segundo

\footnotetext{
${ }^{166}$ Entrevista concedida pela arquiteta Lia Mayumi (PMSP/SMC/DPH -Seção Técnica de Projeto, Restauro e Conservação) à autora em 22.02.2013.

${ }^{167}$ Coordenadas pelo arquiteto Marcos Cartum (PMSP/SMC), entrevistado pela autora em 05.02.2014.
} 
informações do arquiteto Anderson Freitas ${ }^{168}$, por fim, foi construído um viaduto com um desenho distinto das alternativas apresentadas que, ao menos, não incide diretamente sobre o terreno do Sítio Mirim.

Para o terreno e ruínas da Sede do Sítio Mirim, o escritório Apiacás Arquitetos desenvolveu a proposta em 2007, partindo da premissa da preservação das ruínas e da implantação de um Centro de Cultura e Convivência que conferisse um uso e apropriação de toda a área.
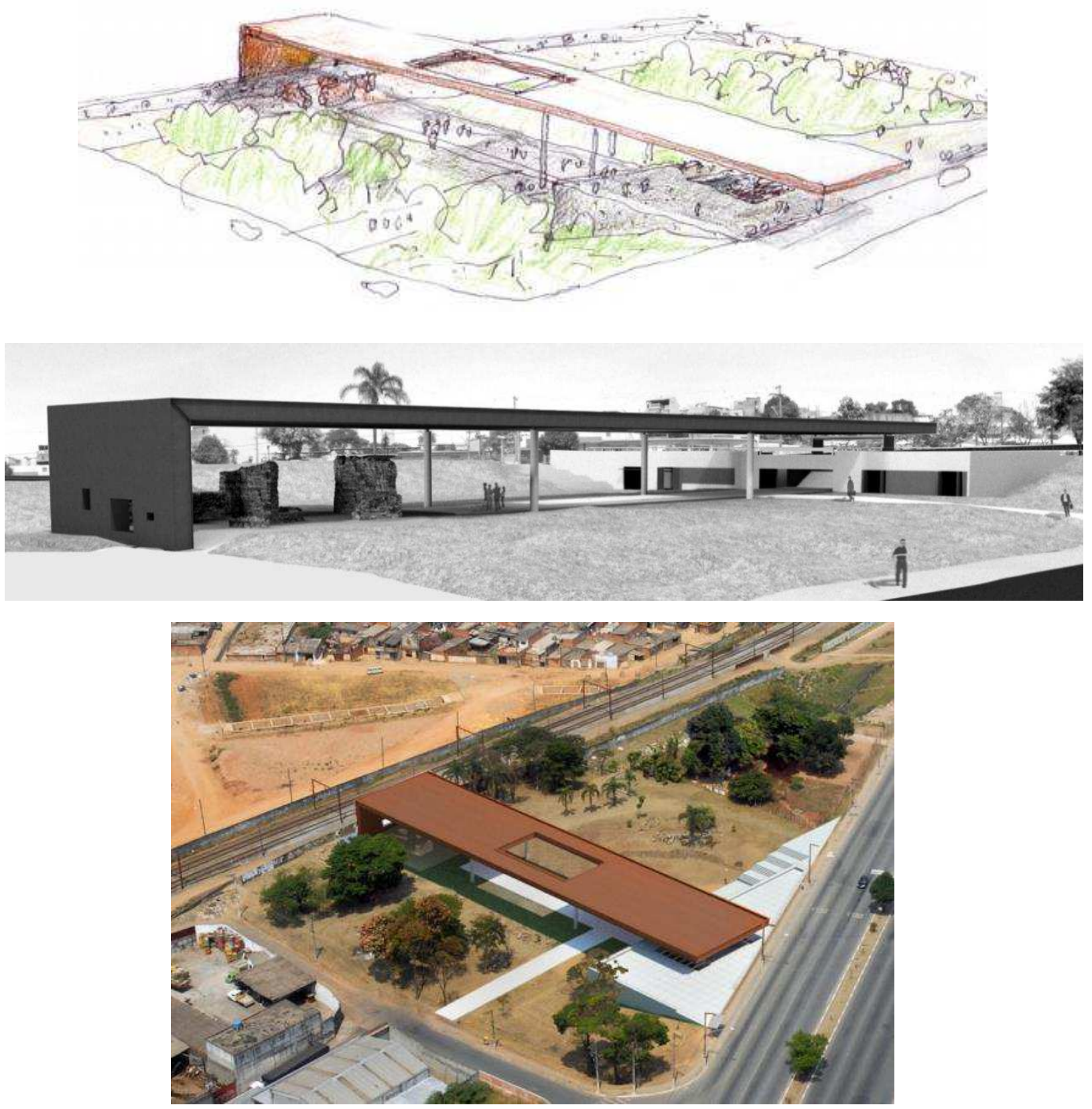

Fig. 84 (i-iii): Proposta do escritório Apiacás Arquitetos, 2007 - perspectivas e relação com o entorno 2007. Fonte: <http://www.apiacasarquitetos.com.br>, acesso em 25 fev. 2013.

168 Entrevista concedida pelo arquiteto Anderson Freitas do escritório Apiacás Arquitetos à autora em 26.02.2013. 
De acordo com Anderson Freitas, o desenvolvimento do projeto contou com a participação de uma equipe multidisciplinar que envolveu arqueólogos para a identificação da melhor maneira de intervir nas ruínas e garantir condições técnicas adequadas para a conservação desses maciços de taipa, daí a solução da cobertura, pois protegeria as ruínas e, ao mesmo tempo, seriam mantidos certos índices de umidade. Segundo o autor do projeto, houve a intenção de integrar a implantação ao desnível do terreno procurando recuperar para o visitante a ideia da implantação original da casa; foi idealizada uma marquise que cobre as ruínas e cujo acesso se dá pelo passeio público através de uma praça cujo nível é a cobertura do programa de convivência que conta com auditório, salas multiuso e foyer de exposição.

O projeto do Centro Cultural de Convivência não teve uma aprovação unânime nas esferas envolvidas (IPHAN, CONDEPHAAT e DPH) com ressalvas quanto a detalhes arquitetônicos como cota da cobertura que seria instalada sobre as ruínas, que deveria ser suficientemente compatível com a altura da edificação original, caso se optasse pela reconstituição da casa. Mais uma vez, a questão conceitual de como incorporar as ruínas arquitetônicas na intervenção, desencadeou discussões e acarretou em trâmites judiciais que impediram a execução do projeto. 


\subsection{Antiga Sede do Sítio Itaim ${ }^{169}$}

A então denominada Chácara "das Pedras" ou "Itahim"170, localizada na região que margeava o Rio Pinheiros, era uma unidade produtiva de caráter agrícola que envolvia plantação de chá, casa de farinha e pastagens. Segundo dados cartoriais e arquivos pesquisados $^{171}$ para o estudo de tombamento do CONDEPHAAT, a data provável da construção da respectiva casa sede remonta a 1846, quando a chácara pertencia a Anna Joaquina Ferraz. Em 1896, o General José Vieira Couto de Magalhães (1837-1898) ${ }^{172}$ comprou a propriedade; em 1898, a chácara passou para um de seus herdeiros (José Couto de Magalhães), na sequência a casa foi arrematada pelo irmão do General (Leopoldo Alberto Couto) que chamou um de seus filhos - Leopoldo Couto de Magalhães, conhecido como "Bibi" - para ajudar na administração do local. A partir de 1914, a propriedade com aproximadamente 120 alqueires passou a ser loteada; "Bibi” teria residido na casa até 1916.

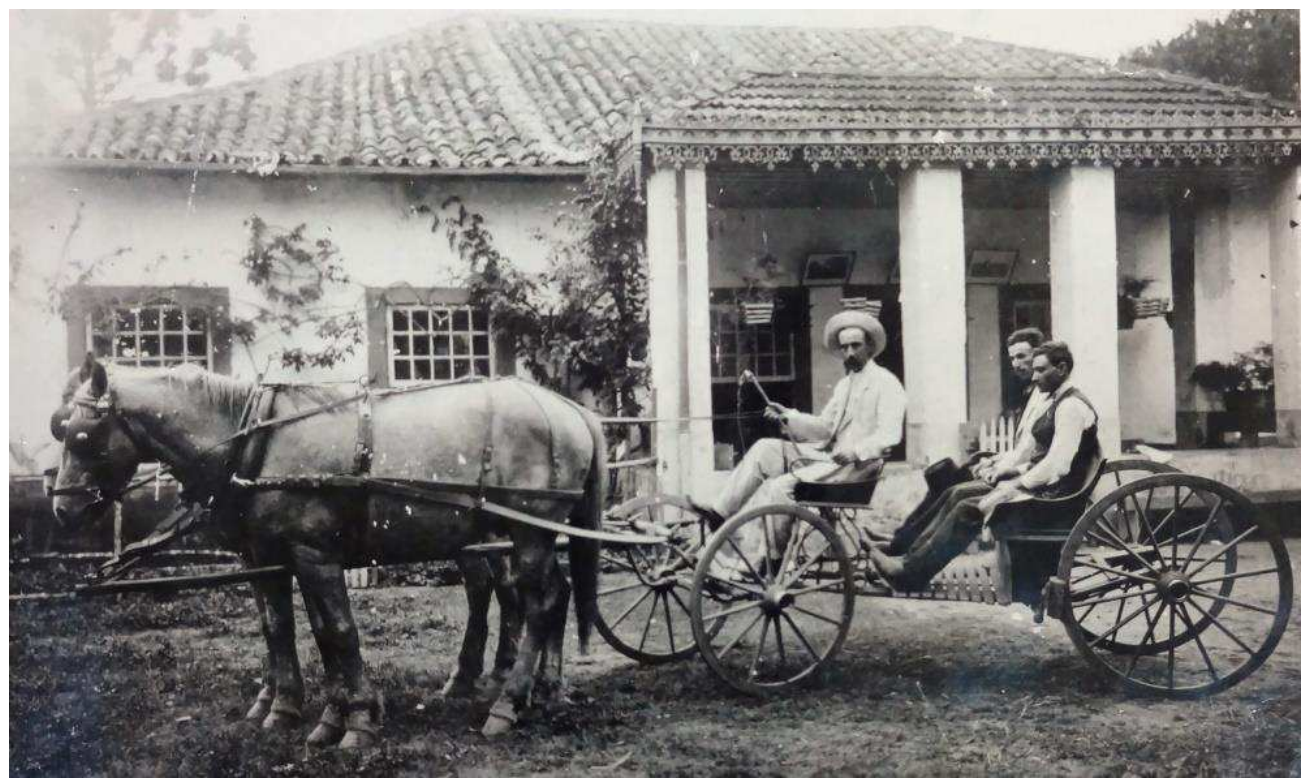

Fig. 85: Sede do Sítio Itaim, 1913. Fonte: SÃO PAULO - Estado, CONDEPHAAT, 1978, p.13.

\footnotetext{
169 Material consultado junto a: Superintendência do IPHAN/SP, processos: 01506.001662/2008-34 (IPHAN, 2008-34), 0156001873/2008-77 (IPHAN, 2008-77), 01502.000803/2009-82 (IPHAN, 2009) e 01506.002274/2010-95 (IPHAN, 2010); junto ao CONDEPHAAT, processo 20640/78 (SÃO PAULO - Estado, CONDEPHAAT, 1978); e à SMC/PMSP, CONPRESP processos administrativos: 1997-0.182.218-0 (SÃO PAULO - cidade, SMC/CONPRESP, 1997), 2009-0.143.969-6 (SÃO PAULO-cidade, SMC/CONPRESP, 2009) e 2011-0.357.476-7 (SÃO PAULO - cidade, SMC/CONPRESP, 2011). Entrevista com a arquiteta Lia Mayumi (PMSP/SMC/DPH - Seção Técnica de Projeto, Restauro e Conservação) em 20.08.2015. Visita autorizada pela empresa proprietária em 20.08.2014.

${ }^{170}$ Palavra que em tupi significa "Rio das Pedras" ou "Pedra d'Água".

171 Pesquisas realizadas pelas historiadoras Maria Auxiliadora Guzzo de Decca (CONDEPHAAT) e Vilma Gagliardi (PMSP/SMC/DPH) - In: CONDEPHAAT, 1978, p. 39.

172 “[...] herói da Guerra do Paraguai, governador de Províncias do Império, historiador, devassador de sertões, deixando crônicas saborosíssimas.” (LEMOS, Carlos apud LEMOS, 1980, In: CONDEPHAAT, 1978, p. 39).
} 
A princípio os lotes eram de $10.000 \mathrm{~m}^{2}$, ideais para o estabelecimento de pequenas chácaras que foram compradas principalmente por imigrantes italianos e portugueses que estabeleciam pequenos sítios com a produção de hortaliças, legumes e leite. Posteriormente, esses lotes seriam comercializados com dimensões menores, em torno de $500 \mathrm{~m}^{2}$ (ZANETTINI, 2009 In: IPHAN, 2009). A mudança do perfil do loteamento evidencia o processo de ocupação que se estabeleceu na região, consolidando-se como área francamente urbana a partir da década de 1930. Quando o bairro foi oficializado em 1934, o apelido familiar de "Bibi" foi definitivamente incorporado ao nome inicial da propriedade "Itahim".

A partir do loteamento, as características de uso da propriedade mudaram. Entre 1918 e 1921 a casa sede com o terreno envoltório esteve alugada para religiosas que constituíram o Abrigo de Santa Maria. Em 1922 a propriedade teria sido comprada pelo médico psiquiatra e homeopata Brasílio Marcondes Machado (1887-1953) que a transformou no Sanatório Bela Vista. Machado trabalhava com terapias de tratamento alternativas tais como homeopatia e atendia um grande público da alta burguesia paulistana. Em 1944 o Sanatório foi vendido aos psiquiatras Mário Yahn (1908-1977) e Nestor Solano Pereira (1900-1964) proprietários com outros colegas de um antigo hospital do Instituto Aché. Nessa ocasião, foi feita uma reformulação nos procedimentos terapêuticos embasados na psiquiatria tradicional e na experiência dos novos proprietários adquirida em sua atuação no Hospital Psiquiátrico de Franco da Rocha. O Sanatório Bela Vista aí se manteve até 1980, a instituição, por vezes denominada clínica ou hospital, foi bem sucedida tendo grande repercussão durante os quase 50 anos de atuação relacionada à psiquiatria e psicanálise no Estado de São Paulo.

A propriedade (com terreno reduzido a $18.600 \mathrm{~m}^{2}$ ) foi vendida à empreendedora Comercial Bela Vista S/A em 1980. O encerramento das atividades do Sanatório pode ser entendido num contexto de reformulação dos procedimentos de tratamento psiquiátrico e devido ao processo de crescimento da vocação comercial e de serviços do bairro; tornou-se inviável a manutenção de um terreno de grandes proporções mediante as novas demandas imobiliárias da região delineadas pela expansão do eixo da Av. Brigadeiro Faria Lima.

Em 1978, antes do encerramento das atividades de Sanatório na antiga Sede do Itaim, foi aberto um pedido de tombamento no CONDEPHAAT solicitado por Aluysio Soares (presidente da Sociedade Amigos do Itaim Bibi), alegando que a casa mantinha características relevantes que a associavam ao denominado "partido bandeirista" (SÃO PAULO - Estado, CONDEPHAAT, 1978, p. 11) motivando e direcionando os estudos de tombamento. 
No levantamento realizado para o tombamento, foram localizadas algumas descrições nos registros cartoriais que constatam alterações na propriedade ao longo dos anos. A primeira descrição da casa remonta a $1856^{173}$ apresentando também a situação de outras instalações (senzala, cocheira, estrebarias, depósitos, etc.); há menções ao mobiliário e à presença de uma Capela e suas respectivas imagens. Havia evidências de que além da casa sede havia outra grande construção de taipa contígua provavelmente para abrigo de empregados.

Paulatinamente, a casa e a propriedade como um todo sofreu alterações e no início dos 1900 a "casa de morada de construção antiga" (IPHAN, 2010, s.p.) contava com 18 cômodos, o terreno possuía 10 casas para empregados e demais dependências. Com o loteamento e a mudança de uso, a propriedade foi bastante descaracterizada. A partir de 1927, para melhor acolher os pacientes do Sanatório, houve ampliações do antigo núcleo adicionando pavilhões horizontais. Em 1944, a casa já se encontrava bastante subdividida e modificada, a área verde se encontrava apenas na frente do terreno e a grande construção de taipa contígua à casa fora demolida.

Embora sejam muito úteis para a compreensão do desenvolvimento histórico da propriedade, as descrições cartoriais não permitiam uma total espacialização da casa em seus diversos momentos. A partir das vistorias realizadas pelas arquitetas Vera Maria Ferraz e Silvia Finguerut envolvidas na pesquisa para o CONDEPHAAT, foi possível identificar em relação ao programa arquitetônico que o núcleo original era composto por nove cômodos, incluindo o alpendre central entre dois cômodos: um possível quarto de hóspedes e uma Capela. Esse alpendre havia sido acrescido de um terraço; a partir do alpendre se passava ao salão principal que se comunicava com quatro cômodos provavelmente usados como dormitórios e outras atividades domésticas. Havia um complemento posterior em um dos lances laterais que provavelmente teria sido a cozinha.

\footnotetext{
${ }^{173}$ Cf.: "1856: Huma chacara denominada do Ribeirão das Pedras com cazas de morar, trez lanços de frente, quase toda forrada e assoalhada, contendo senzálas, cocheira e estrebarias ao lado da caza de morar, e do outro dous quartos assoalhados e forrados, caza de depósito e fabrico de chá, e moinho, todas cobertas de telhas, tendo mais no fundo e em seguimento da caza de morar, caza para fabrico de farinha, com forno, roda e prensa; jardim com, horta e pomal, com grande plantação de chá, e terras de criação [...]" (GAGLIARDI, Pesquisa histórica In: IPHAN, 2010, s.p.).
} 


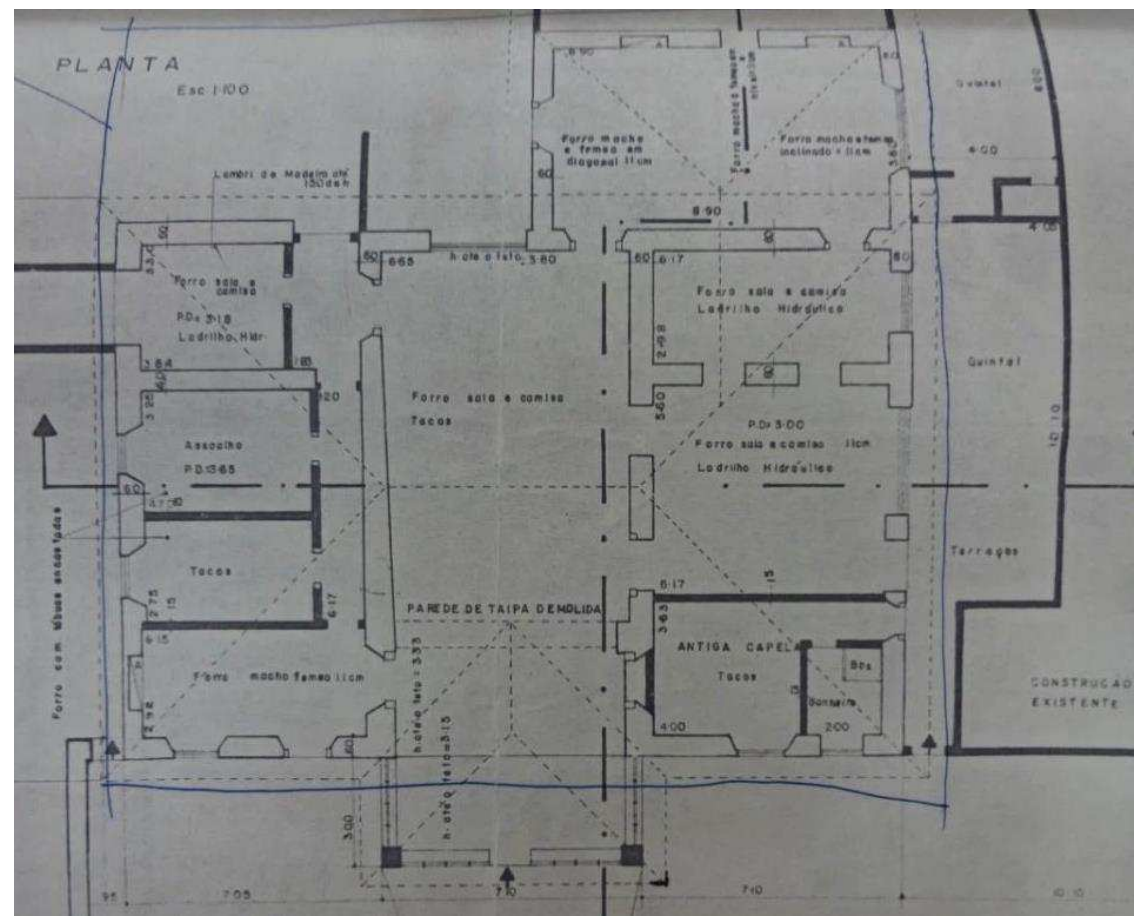

Fig. 86: Planta do levantamento métrico arquitetônico, 1979. Fonte: CONDEPHAAT, 1978, p. 25.
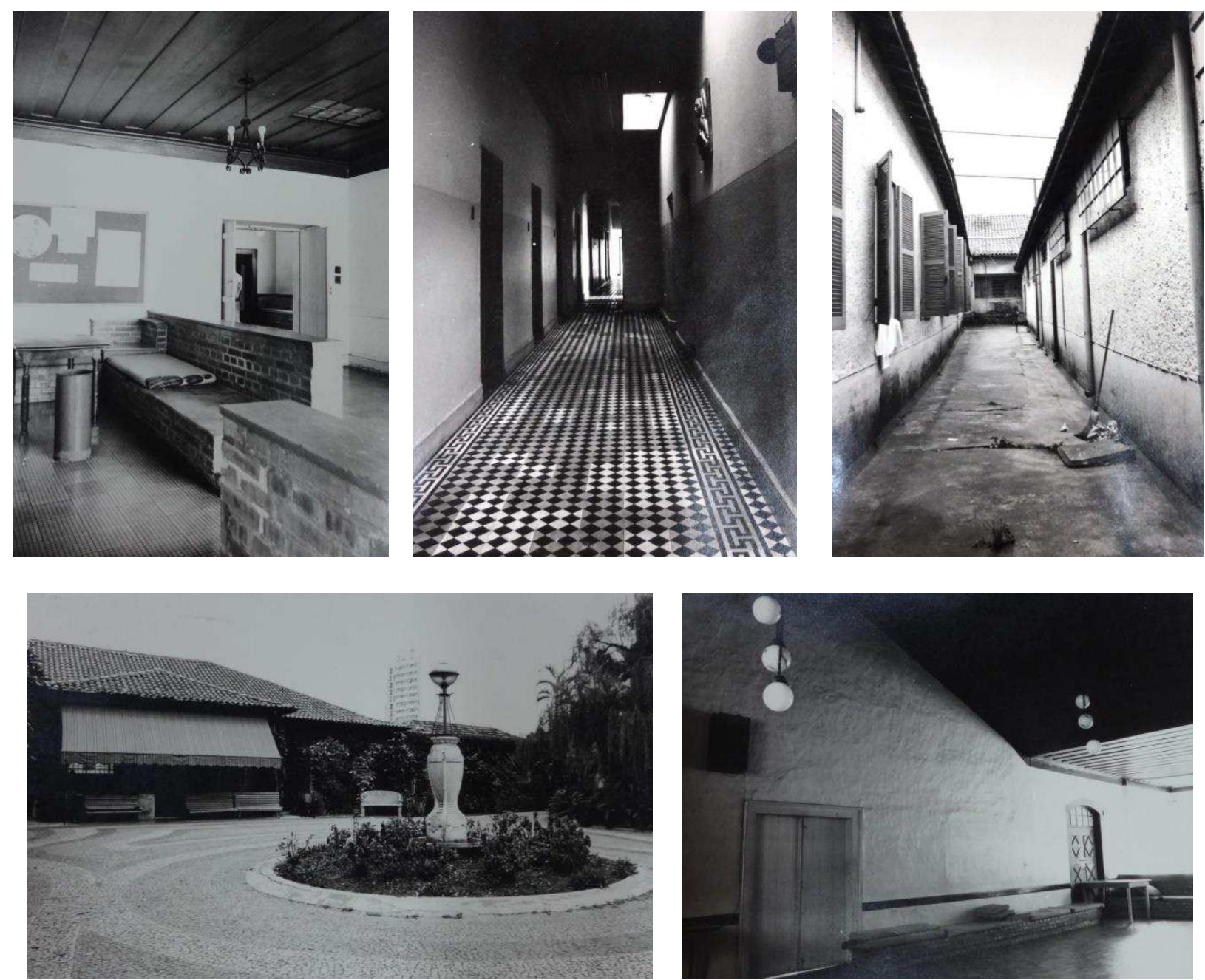

Fig. 87 (i-v): Sanatório Bela Vista. Levantamento fotográfico, 1980. Fonte: SÃO PAULO - Estado, CONDEPHAAT, 1978, p.14-25. 
As características arquitetônicas relacionavam-se a referências da residencial rural paulista do século XVIII, como a distribuição simétrica dos cômodos a partir do alpendre e do salão central; a técnica construtiva da taipa de pilão - com paredes com $60 \mathrm{~cm}$ de espessura; o uso de madeiras de lei, a tectônica do telhado e sua estrutura de amarração conhecida como caibro armado, além de detalhes construtivos como peitoris, soleiras e cachorros recostados; dentre outros elementos que corroboram o partido sugerido. As envasaduras remanescentes das portas e janelas e a distinção entre os panos cheios e vazios permitiram uma suposição do grau de antiguidade da construção (SÃO PAULO - Estado, CONDEPHAAT, 1978). Frente a esse caráter histórico, o CONDEPHAAT manifestou seu interesse pelo imóvel.

\subsubsection{Tombamento e arruinamento}

Quando a propriedade foi vendida à Comercial Bela Vista S/A aumentaram as preocupações em relação ao futuro do bem mediante a possibilidade da construção de um grande empreendimento no local; apreensões justificáveis já que poucos meses após ter sido vendida, a casa começou a ser parcialmente demolida e sua integridade física ficou ameaçada pelo início de um processo de arruinamento que se estenderia pelas décadas seguintes.

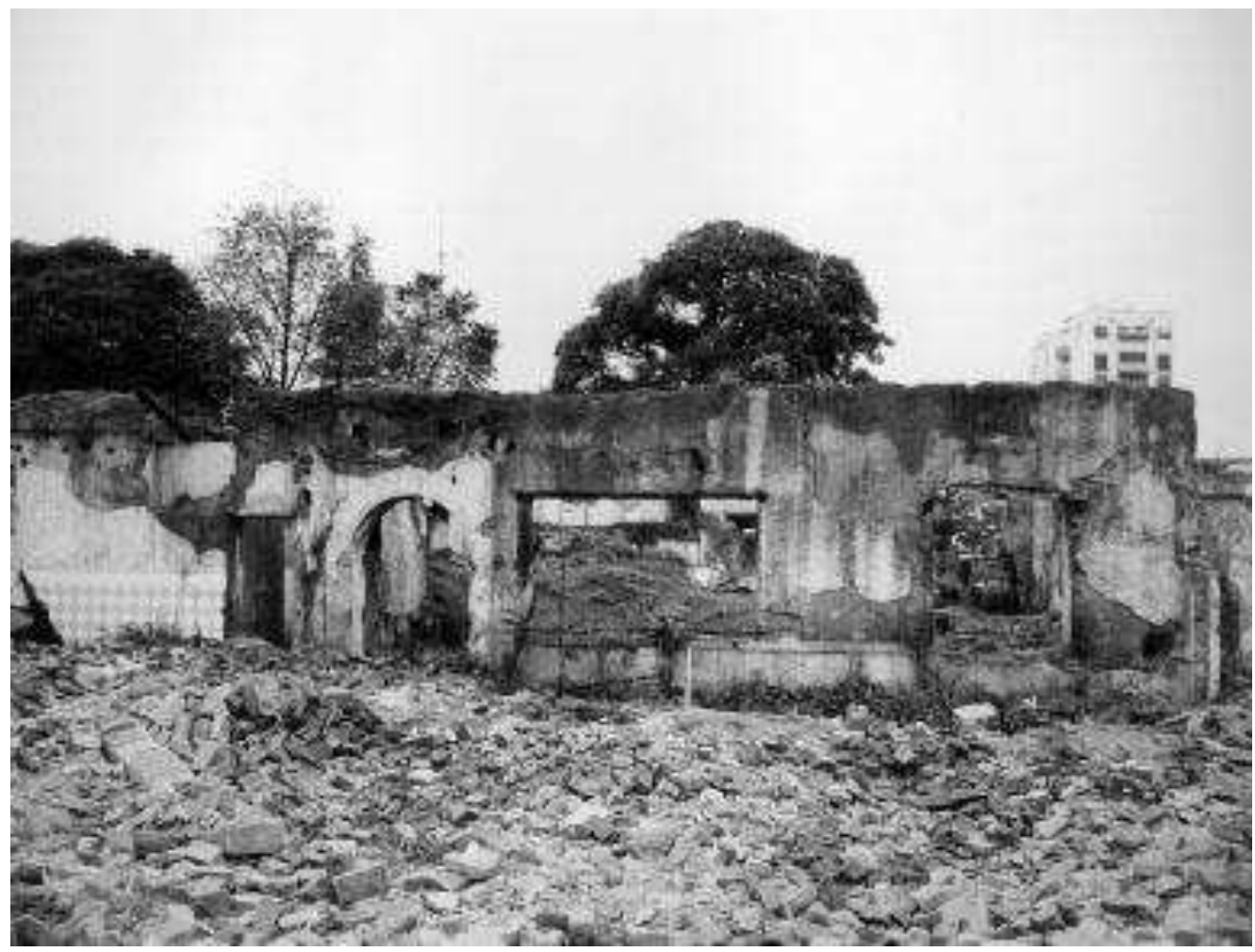

Fig. 88: Demolição parcial do imóvel, 1980. Fonte: CONDEPHAAT (site), disponível em: <http://www.cultura.sp.gov.br/portal/site/SEC/menuitem.bb3205c597b9e36c3664eb10e2308ca0/?vgnextoid= 91b6ffbae7ac1210VgnVCM1000002e03c80aRCRD\&Id=946cc73fb46cc010VgnVCM2000000301a8c0 $>$, acesso em 15 jun. 2016. 
Essa situação gerou mobilizações por parte da sociedade civil no sentido de acelerar as medidas de salvaguarda. Em meio a esses acontecimentos, o Conselho Estadual deliberou oficialmente pela abertura do processo de tombamento em outubro de 1980. A área a ser preservada equivalia a um retângulo de 40 x $50 \mathrm{~m}$ a partir dos limites do bem conformando uma área total de $2.000 \mathrm{~m}^{2}$.

Em novembro de 1980 foi realizada um nova vistoria ${ }^{174}$, em caráter de urgência para levantar a situação da casa e elaborar medidas de preservação para que o bem não se perdesse irremediavelmente. Esquadrias e dois terços da cobertura haviam sido removidos; algumas paredes de taipa de pilão tinham sido demolidas ou continham rasgos em seus ângulos comprometendo sua estabilidade. Mediante esse quadro, foram prescritas ações visando a consolidação da cobertura para manter o ponto de linha da cumeeira; coleta, numeração e documentação do madeiramento remanescente; proteção imediata dos topos das paredes de taipa de pilão e dos destroços no piso com plástico; registros dos destroços das paredes que poderiam ser reaproveitados; cimbramento dos vãos de portas e janelas e pesquisa arqueológica de piso.

Com a indevida demolição parcial, foi instaurada uma medida cautelar por parte da municipalidade de São Paulo para a interdição do imóvel (SÃO PAULO - Estado, CONDEPHAAT, 1978) impedindo qualquer alteração ou reforma no mesmo já que a empresa não apresentava o respectivo alvará de demolição. Além disso, desde 1981, tramitava um projeto do empreendimento comercial que se pretendia construir no local, cujo partido arquitetônico englobava a casa por ser um bem de reconhecido valor cultural. O bem foi efetivamente tombado em maio de $1982^{175}$; porém, a despeito da proteção legal a situação do imóvel continuou instável. As áreas construídas subjacentes ao que se entendia como núcleo “original” foram demolidas com autorização do CONDEPHAAT.

Depois de uma série de negociações foi estabelecido em 1982 um acordo ${ }^{176}$ entre a empresa proprietária e o CONDEPHAAT para a execução da "restauração da Casa

\footnotetext{
${ }^{174}$ Realizada por Luiz Alberto do Prado Pasaglia (técnico do CONDEPHAAT).

${ }^{175}$ Cf.: "Artigo 1": Fica tombado como monumento de interesse histórico arquitetônico a Sede do Antigo Sítio Itaim, situada na rua Iguatemi, 9 - São Paulo, Capital, exemplar remanescente de arquitetura do século XVIII, cuja construção em paredes de taipa de pilão obedece ao "partido bandeirista", típico das construções residenciais rurais daquela época. Artigo $2^{\circ}$ : As construções que vierem a ser erigidas na área envoltória do bem cultural tombado, delimitada pelas ruas Iguatemi, Aspásia, prolongamento da Avenida Brigadeiro Faria Lima e Horácio Lafer deverão obedecer rigorosamente ao plano de massas apresentado pela proprietária em estudo preliminar constante às fls.241, 242, 243 e 244 do processo CONDEPHAAT 20640-78." (Res. 46 de 13.05.1982 In: SÃO PAULO - Estado, CONDEPHAAT, 1978, p. 343).

${ }^{176}$ Medida cautelar n. 1469/80, 27 de janeiro de 1982 (SÃO PAULO - Estado, CONDEPHAAT, 1978, p. 330327).
} 
Bandeirista" (SÃO PAULO, Estado CONDEPHAAT, 1978, p. 335). A empresa arcaria com todos os custos de material, mão de obra e emolumentos e o CONDEPHAAT elaboraria todos os projetos relacionados com as respectivas aprovações na Prefeitura. O prazo para a finalização da "restauração" da casa foi estipulado em 270 dias a partir da data de expedição do alvará de execução (13 de Agosto de 1982). Também foi determinado que a empresa proprietária seria responsável pelas obras de manutenção e conservação da casa que somente seria utilizada para fins culturais.

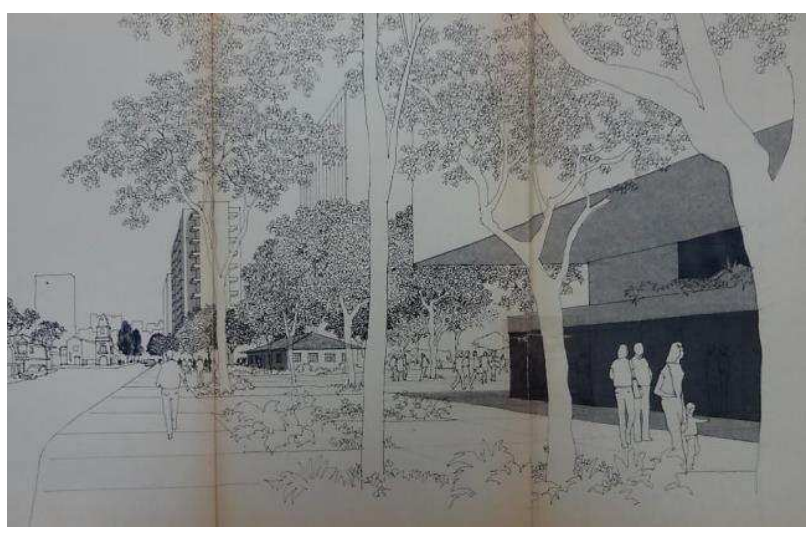

Fig.89: Perspectiva da proposta de projeto multifuncional (residência e serviços) apresentado pela Comercial Bela Vista S/A, 1981; destaque à recomposição da casa do Sítio Itaim. Fonte: SÃO PAULO - Estado, CONDEPHAAT, 1978, p. 244.

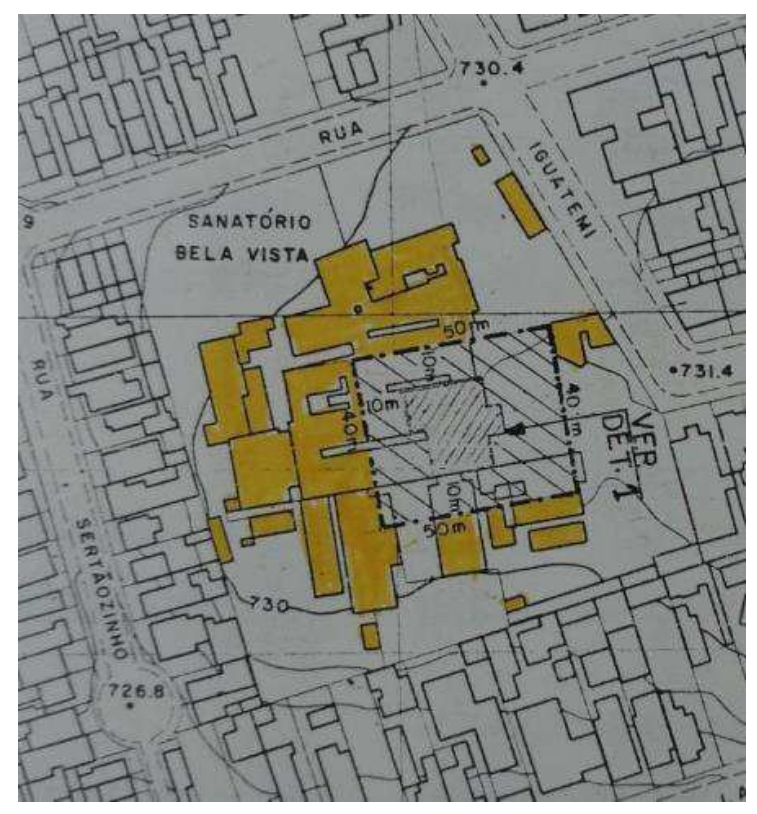

Fig. 90: Áreas autorizadas para a demolição (amarelo) conforme liberação em 1981; e área a conservar (retângulo $50 \mathrm{~m} \times 40 \mathrm{~m}$ ). Fonte: SÃO PAULO, Estado - CONDEPHAAT, 1978, p.329.

Essa obra, porém, não foi realizada; em vistoria ao local realizada pelo CONDEPHAAT $^{177}$ em 1983 constatou-se a negligência da empresa proprietária para com a obrigação acordada. Uma parede de taipa de 20 metros de comprimento por 2,5m de altura havia sido demolida bem como outras que extrapolavam o determinado pelo alvará de demolição ${ }^{178}$; das quatro vergas originais do salão interno só sobrava uma, a cobertura de proteção de lona e plástico não protegia mais a infiltração das águas pluviais agravando o estado das paredes de taipa que estavam se extinguindo. $\mathrm{O}$ processo de arruinamento continuou durante os anos posteriores. Em 1984 foram retomadas as reuniões entre o CONDEPHAAT e a Comercial Bela Vista S/A para discutir providências e foi aventada a necessidade de se realizarem prospecções arqueológicas no local.

\footnotetext{
${ }^{177}$ Efetuada pelo arquiteto Vitor José Baptista Campos, 30 de maio de 1983.

${ }^{178}$ Alvará de demolição n. 28-008-305-80*94 expedido pela Administração Regional de Pinheiros (PMSP).
} 
No entanto, essas pesquisas não foram realizadas, assim como as demais ações de consolidação e limpeza. Em 1987 novas vistorias foram realizadas no local pelo CONDEPHAAT e foi atestado pelo conselheiro relator Antônio Luiz Dias de Andrade que a antiga residência estava ameaçada de completa ruína já que estava desprotegida das intempéries e de possíveis vandalismos tornando-se urgente a execução dos serviços de prospecção e pesquisa arqueológica, considerados imprescindíveis para estabelecer um projeto de consolidação das estruturas remanescentes.

Surgiram clamores populares em $1988^{179}$ denunciando a gradativa deterioração, principalmente em decorrência das chuvas daquele verão que levaram ao desabamento do que restara das coberturas provisórias colocadas em 1980 para a proteção das paredes de taipa. Outra grave irregularidade foi identificada com o indevido depósito de toneladas de terra em torno da casa.

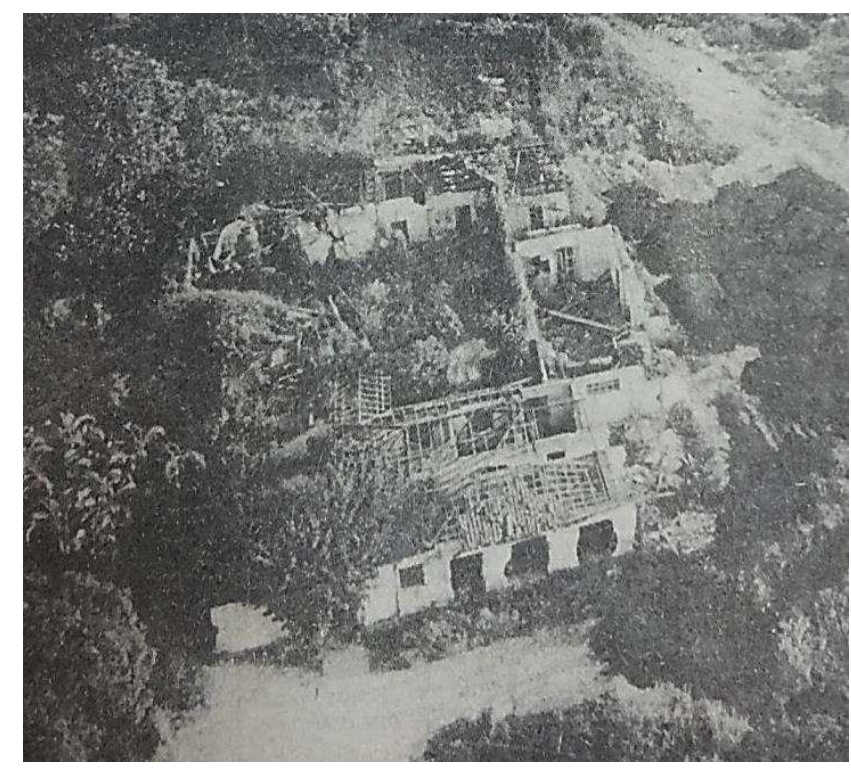

Fig. 91: Sede do Sítio Itaim, situação em 1988.

Fonte: Folha de São Paulo, Cidades, 05.04.1988, A-13 In: SÃO PAULO - Estado, CONDEPHAAT, 1978, p.468.

Diante dessa situação, houve abertura de inquérito e um novo acordo com a empresa proprietária foi estabelecido para providenciar a cobertura com lonas plásticas das paredes de taipa, o escoramento dos vãos de portas e janelas e a limpeza dos "restos" (N. 029/88 In: CONDEPHAAT, 1978, p. 475) da casa e da área envoltória liberando o local para o início de pesquisas arqueológicas. A arqueóloga e conselheira do CONDEPHAAT Dorah Pinto Uchôa solicitou a colaboração do Instituto de Pré-história e do Museu Paulista da USP através da pesquisadora Margarida Davina Andreatta para o início de trabalhos de prospecções do local,

179 "Infiltrações podem destruir a Casa Bandeirista" - Reportagem local, Artigo Folha de São Paulo, 21 de fevereiro de 1988, p. A-26 In: SÃO PAULO - Estado, CONDEPHAAT, 1978, p. 443. 
contando também com técnicos do DPH/SMC. Um dos objetivos dessas pesquisas era fornecer subsídios para recuperar o imóvel e seu entorno. A primeira etapa desses trabalhos ${ }^{180}$ foi realizada entre 15 de julho e 23 de setembro de 1988. Uma nova etapa de trabalhos de prospecção tinha sido prevista na sequência, porém não foi realizada.
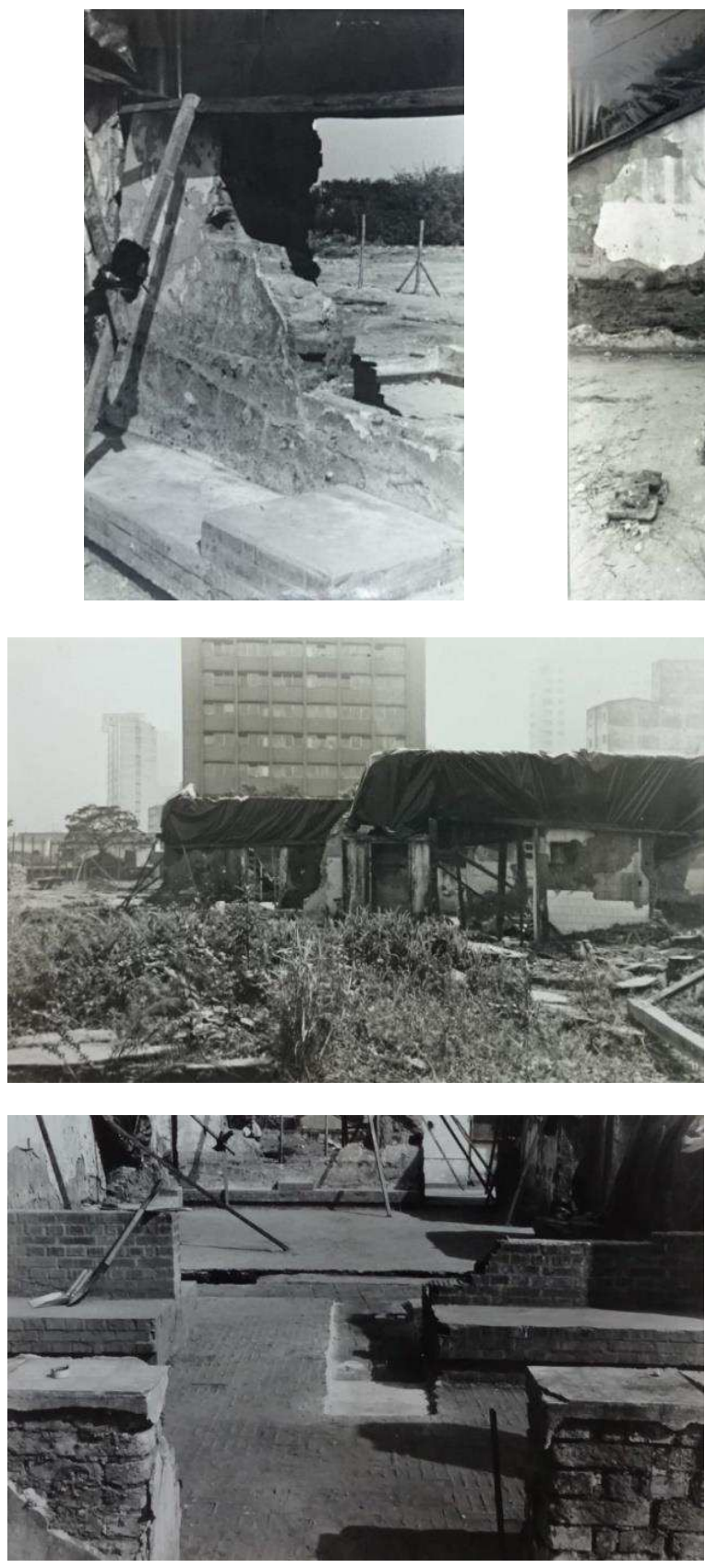
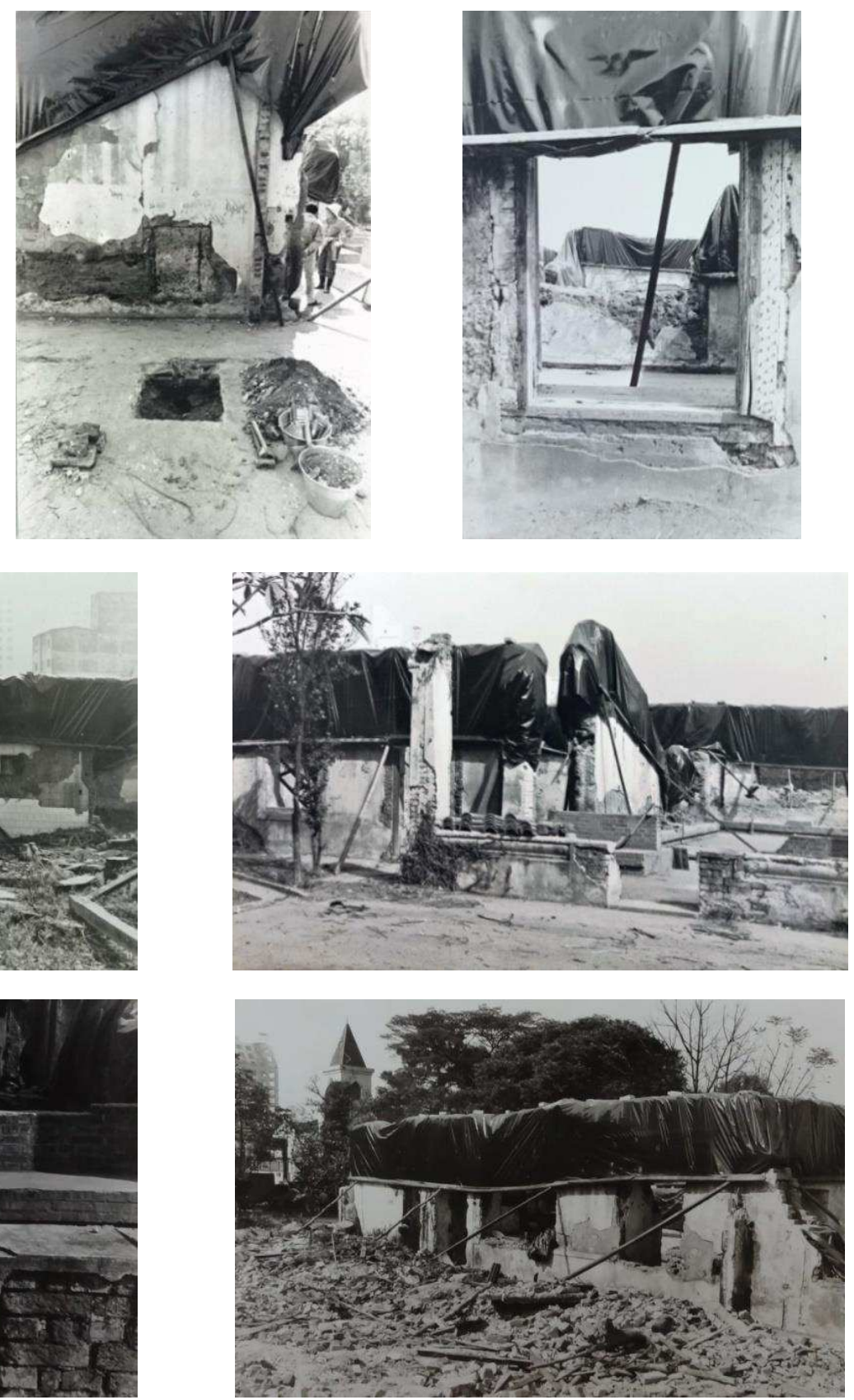

Fig. 92 (i-vii): Sede do Sítio Itaim. Trabalhos de consolidação das ruínas e prospecções arqueológicas, 1988. Fonte: Acervo Fotográfico CONDEPHAAT.

\footnotetext{
${ }^{180}$ A descrição detalhada dos trabalhos consta no: Relatório de Arqueologia In: IPHAN, 2009, s.p. Com essas prospecções houve algumas constatações: a partir dos cortes em diferentes partes do imóvel foi identificada a profundidade da fundação das paredes de taipa de pilão (entre 0,60 a $0,30 \mathrm{~m}$ ); foi evidenciado o uso de dois cômodos: a capela (através de nichos na parede) e a cozinha (pelas evidências de carvão e queima no solo); foram localizados alguns trechos de piso em diferentes acabamentos (lajota e blocos de pedra); houve a limpeza e numeração de peças encontradas. Tanto dos tijolos como das telhas foram guardados cinco exemplares de cada para documentação (CONDEPHAAT, 1978, p. 492).
} 
Após os trabalhos de arqueologia realizados em 1988, a progressão do estado de arruinamento ainda perdurou pelas duas décadas seguintes. Devido a problemas financeiros e judiciais por parte da empresa proprietária as obras somente iniciaram de fato em 2008 quando a Company/Brookfield Incorporações assumiu a propriedade do terreno que englobava as ruínas da antiga casa.

\subsubsection{Projetos desenvolvidos}

Ao longo das décadas em que a casa do Sítio Itaim esteve se deteriorando houve algumas propostas visando a sua conservação. Logo após a promulgação da medida cautelar em 1982, técnicos do CONDEPHAAT elaboraram um projeto de "reforma" ${ }^{181}$ para a casa seguindo a prescrição de restabelecê-la para um uso cultural e partindo da premissa de sua recomposição segundo o partido "bandeirista"; esse projeto foi aprovado, porém, não seguiu adiante.

Em 1984, mediante o estado de ruína da casa, o arquiteto Samuel Kruchin do CONDEPHAAT apresentou outra proposta que vislumbrava a consolidação das ruínas e a instalação de uma cobertura para protegê-las.
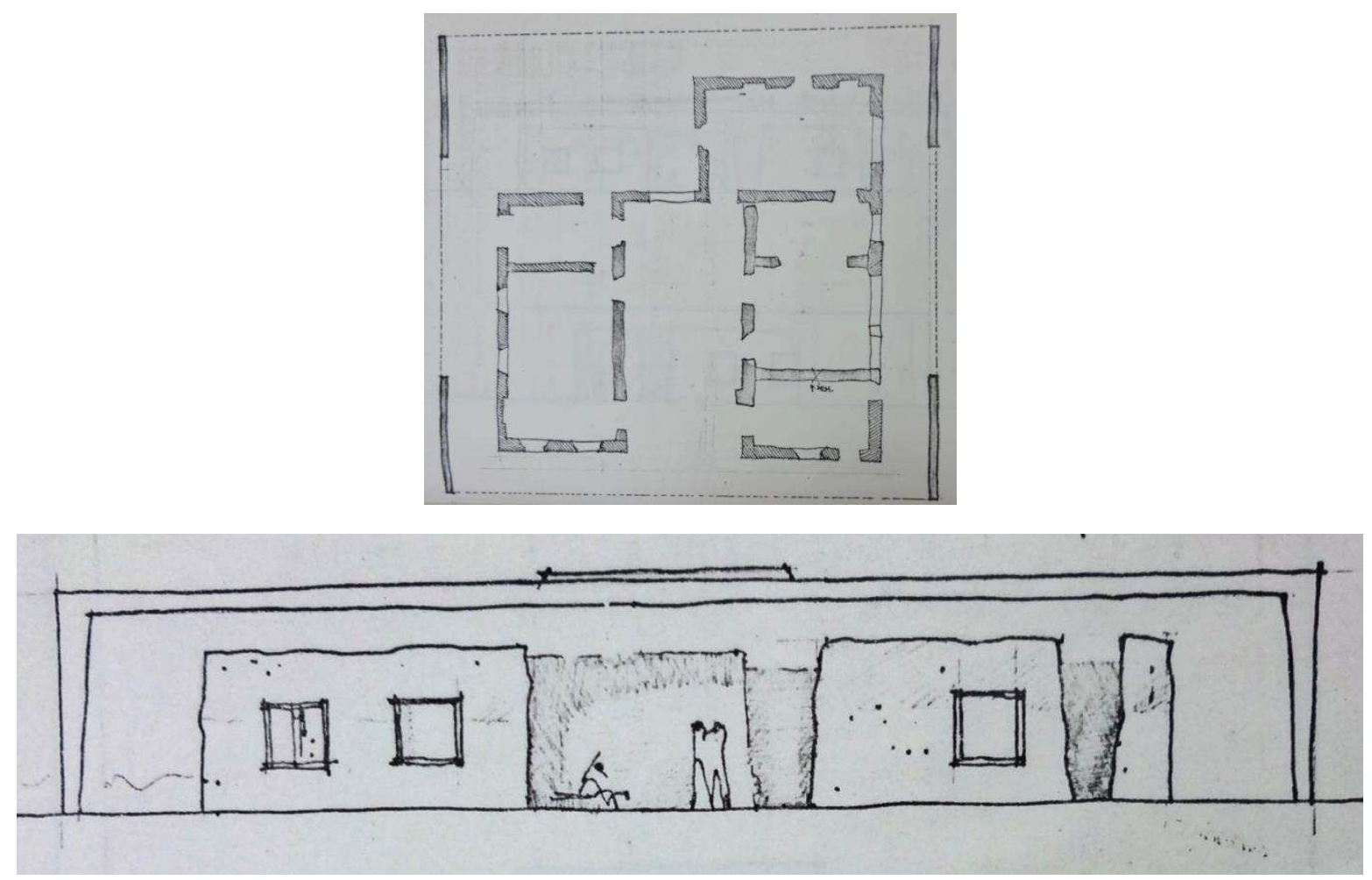

Fig. 93 (i-ii): Proposta do arquiteto Samuel Kruchin -croquis de planta e de elevação. Fonte: SÃO PAULO - Estado, CONDEPHAAT, 1978, p. 320 e 321.

\footnotetext{
${ }^{181}$ Projeto de reforma com redução de área para Galeria de Arte em um edifício setecentista tombado pelo CONDEPHAAT. Alvará N. 05-005.644-82*23 In: SÃO PAULO - Estado, CONDEPHAAT, 1978, p. 380.
} 
Embora apresentasse uma solução alternativa para os remanescentes da casa do Sítio Itaim vislumbrando e valorizando a historicidade de sua condição da ruína como uma prerrogativa a ser desenvolvida, essa proposta não engendrou maiores desdobramentos.

A sanção imposta aos proprietários de "restauração" da casa devido ao estado de ruína deflagrado por uma demolição parcial e acentuado pelo longo período de incúria norteou uma solução de projeto elaborado pela arquiteta Helena Saia em 1997, que foi aprovado em 1999 nos órgãos de preservação CONDEPHAAT e CONPRESP ${ }^{182}$ partindo da seguinte orientação:

A proposta de restauração consiste na recomposição da volumetria do bem tombado, definindo-a com cobertura em estrutura de madeira revestida com telhas de barro, consolidação das paredes de taipa de pilão existentes e recomposição de suas partes faltantes. (SAIA In: SÃO PAULO - cidade SMC/CONPRESP, 1997, p.157 grifo nosso) ${ }^{183}$

Quando esse projeto foi elaborado (1997) as ruínas forneciam elementos mais legíveis para a compreensão da configuração espacial da antiga casa tais como a planta, os pés-direitos e a posição de algumas envasaduras; fragmentos de madeira que tinham sido inventariados nas prospecções arqueológicas de 1988 seriam a base para a reprodução de peças desaparecidas (como caibros, vigas, frechais, cachorros, etc.). Esse projeto previa a consolidação das partes remanescentes da edificação (predominantemente, maciços de taipa de diversas alturas algumas peças do madeiramento do telhado e caixilharia) e a recomposição das partes lacunosas com o uso de materiais e técnicas construtivas atuais. O sistema estrutural misto com esqueleto de reforço de concreto armado (fundações, colunas, vigas e cintas) seria introduzido nos maciços de taipa poupando-as de sobrecarga, nesse sistema se apoiariam as novas vedações de tijolo ou de solo-cimento apiloado e a cobertura.

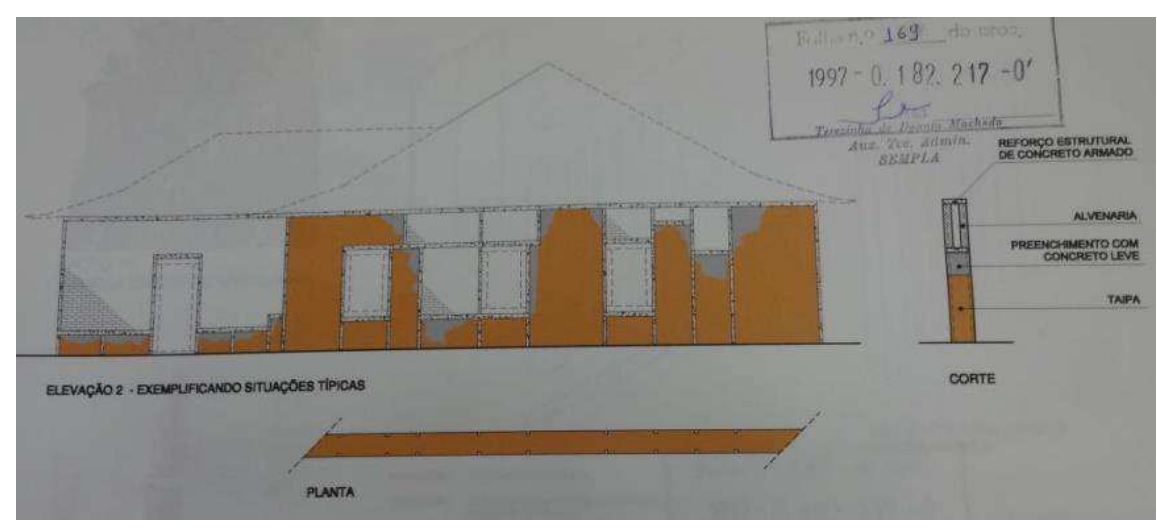

Fig. 94: Proposta de restauração elaborada por Helena Saia, elevação com esquema de cobertura e de preenchimento das lacunas da taipa. Fonte: SAIA, Casa Bandeirista - Proposta de Restauro, 1997 In: SÃO PAULO - cidade, SMC/CONPRESP, 1997, p.164 e 169.

\footnotetext{
${ }^{182}$ Processo administrativo CONPRESP: 1997-0.182.218-0 (Despacho exarado em 2/09/1999).

183 Casa Bandeirista do Itaim - Proposta de Restauro, Helena Saia \& Associados, despacho exarado em 2/09/1999 In: SÃO PAULO - cidade, SMC/CONPRESP, 1997, s.p. (Despacho exarado em 2/09/1999).
} 
Concomitantemente ao desenvolvimento dessa proposta, em 2000 foi aprovado o projeto $^{184}$ do empreendimento imobiliário no terreno de autoria do Escritório Júlio Neves, respeitando as designações judiciais estabelecidas em 1982 que determinavam a conservação da casa tombada.
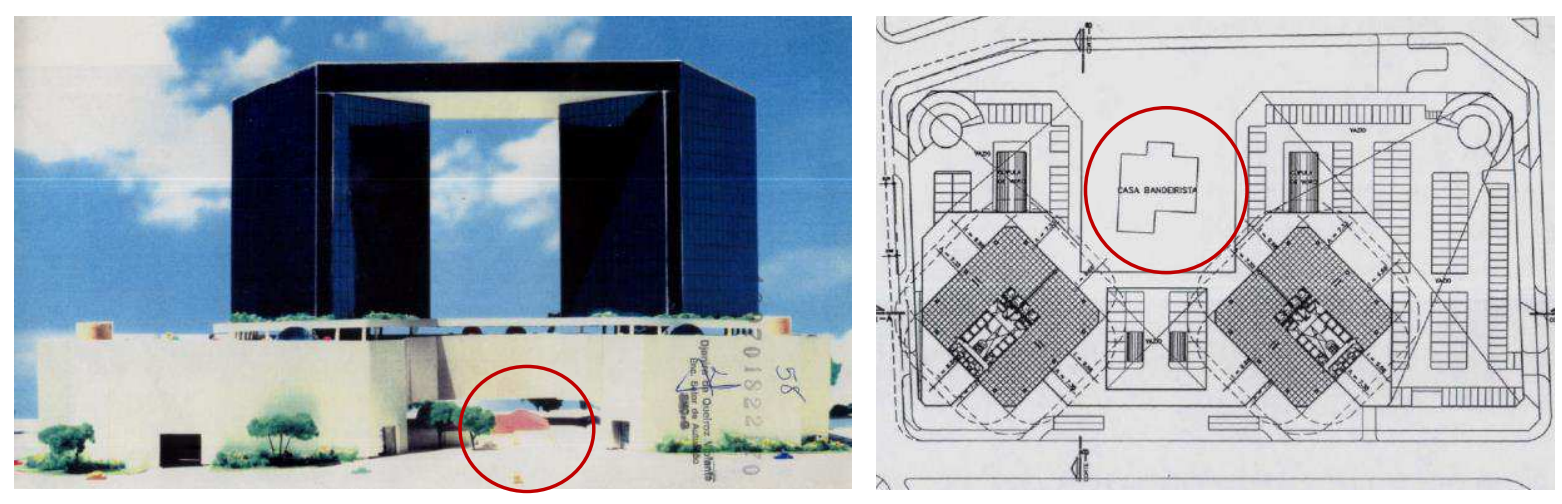

Fig. 95 (i-ii): Escritório Júlio Neves - perspectiva e implantação do centro de serviços (torres de escritório e centro de compras) aprovado, casa Sítio Itaim no centro (conforme indicado). Fonte: MAYUMI, Parecer Técnico, 2012 In: SÃO PAULO - cidade, SMC/CONPRESP, 2011, p.827.

Essas propostas, somente foram retomadas em 2008 com a venda da propriedade à Company/Brookfield Incorporações que apresentou um projeto modificativo - elaborado por Botti Rubin Arquitetos ${ }^{185}$ - para o empreendimento imobiliário que contaria somente com torres de escritório, tal projeto foi aprovado e executado.
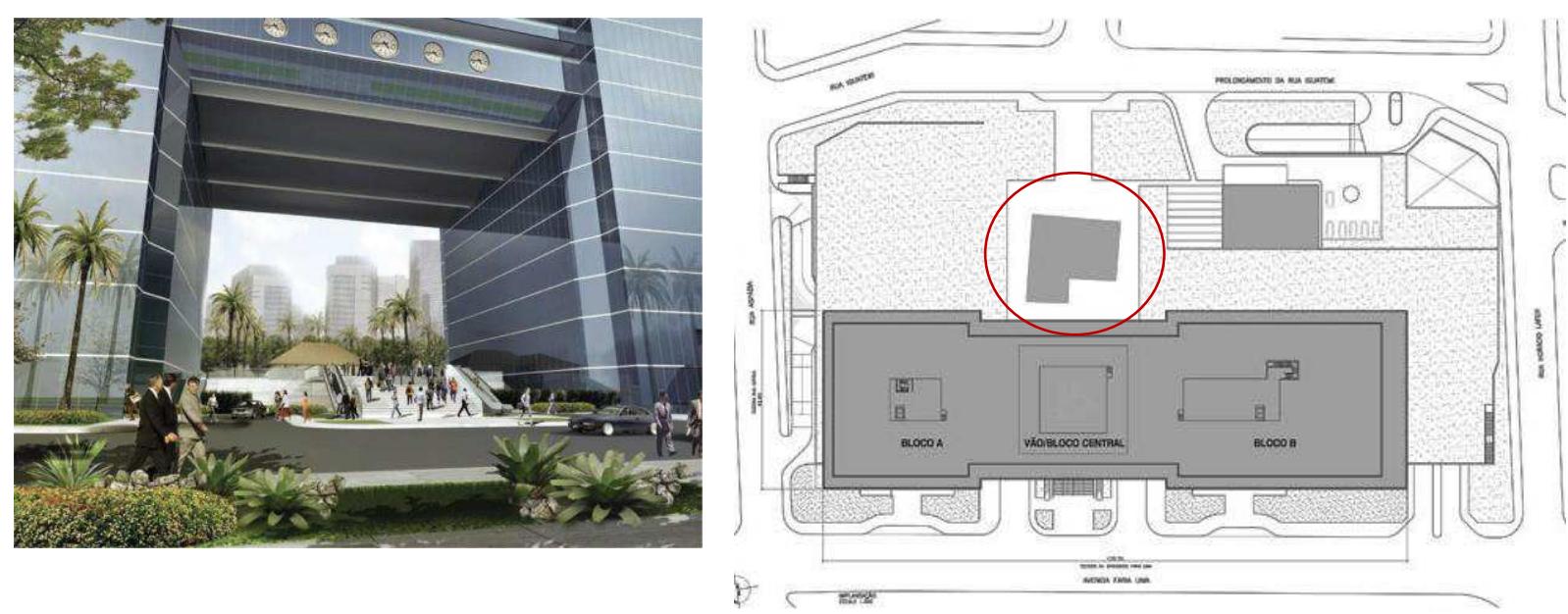

Fig. 96 (i-ii): Projeto Botti Rubin Arquitetos - perspectiva e implantação do projeto de torres de escritório modificativo e que foi executado, casa do Sítio Itaim ao centro (conforme indicado).

Fonte: MAYUMI, Parecer Técnico, 2012 In: SÃO PAULO - cidade, SMC/CONPRESP, 2011, p.828.

\footnotetext{
${ }^{184}$ Processo administrativo CONPRESP: 2000-0.148.672-8.

${ }^{185}$ Processo administrativo CONPRESP: 2009-0.143.969-6.
} 
Em meio às modificações do empreendimento e à sua execução, o projeto referente à "restauração" finalmente seguiria adiante. No entanto, teria que passar por adaptações tendo em vista o agravamento do estado de ruína das estruturas remanescentes de taipa de pilão com uma maior perda de matéria (taipa e madeiras). A arquiteta responsável Helena Saia ${ }^{186}$ precisou ajustar soluções técnico-construtivas e uma nova versão do projeto foi desenvolvida.

A proteção dos maciços de taipa na década de 1980 com lonas plásticas levou à retenção de umidade e à proliferação de fungos agravando o processo de arruinamento. Além disso, para as prospecções arqueológicas de 1988 foram feitas valetas que ficaram desprotegidas aumentando a retenção de umidade junto aos maciços e a progressiva diminuição de sua largura da base para o topo. Diante desse problemático contexto o projeto teve que ser adequado. Em relação ao projeto aprovado em 1999, essa nova versão foi apresentada pela arquiteta Helena Saia como um "ensaio", pois seria atualizado segundo os serviços de prospecção arquitetônica e às situações que demandariam soluções conforme a necessidade. A obra foi acompanhada por técnicos do CONDEPHAAT, DPH e IPHAN/SP.

Conforme o que foi levantado junto ao Relatório Ilustrativo do Restauro ${ }^{187}$ e ao Memorial Descritivo (as built), a princípio foi necessário remover a vegetação de pequeno porte que ocupava o prédio e o entulho do perímetro da casa e foi instalada uma cobertura metálica para a proteção das ruínas e dos trabalhos que seriam executados.

Sobre a solução arquitetônica adotada, buscou-se uma integração e compatibilização dos compartimentos, das esquadrias e do sistema de cobertura ao sistema estrutural remanescente. A técnica e o material a serem utilizados para a substituição dos trechos desaparecidos deveriam utilizar uma mistura leve compatível com a taipa de pilão (em relação ao comportamento estrutural e às alterações físico-químicas), que funcionasse como um maciço portante e como estrutura armada; sendo assim, optou-se pelo uso do solo-cimento apiloado $^{188}$ e o concreto celular.

\footnotetext{
${ }^{186}$ A obra foi executada por Arruda Associados Arquitetura e Urbanismo e Assessoria, cujo responsável era Alberto Magno de Arruda.

${ }^{187}$ Relatório Ilustrativo Restauro - Casa Bandeirista do Itaim. Equipe: Projeto Helena Saia, José Saia Neto; obra: Alberto Arruda In: IPHAN, 2010.

${ }^{188}$ De acordo com o descrito por SAIA, sugestão do arquiteto Walter Fragoni do CONDEPHAAT (Memorial Descritivo, 2011, p.4 In: IPHAN, 2010).
} 

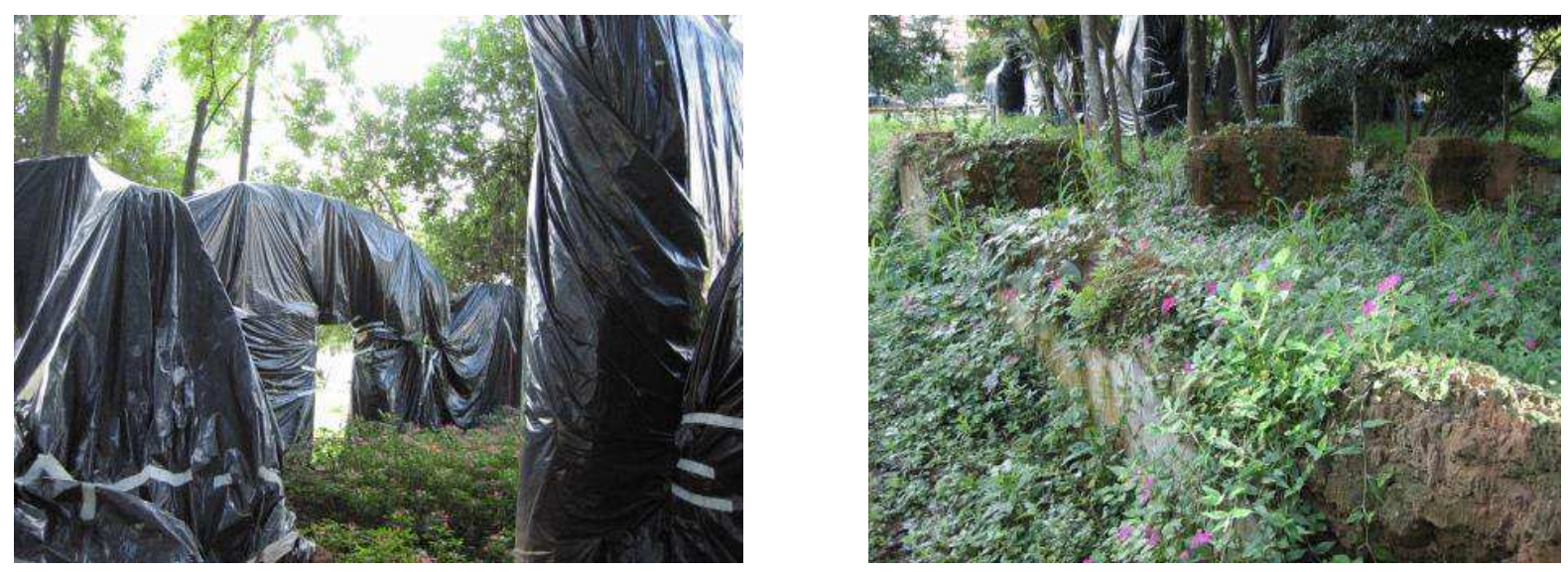

Fig. 97 (i-ii): Situação das ruínas da Sede do Sítio Itaim (esquerda) e da edificação em anexo (direita), 2006. Fonte: Acervo PMSP/SMC/DPH. Fotos: Lia Mayumi.

Para a elaboração dessas soluções foram realizadas prospecções para revelar os restos das fundações, revestimentos de pisos diversos e a posição de vãos (através de decalques deixados nas paredes de taipa e fundações); outras informações foram deduzidas a partir de estudos de simetria, de composição e pelo conhecimento acumulado a respeito da tipologia arquitetônica em questão. No ambiente conhecido como Capela, as prospecções revelavam vazios para acomodar o retábulo do altar, detalhes obstruídos até então pela alvenaria de tijolos e revestimentos cerâmicos. Como a ausência do retábulo não foi possível sanar, para a recomposição dos trechos ruídos nos fundos da capela foi utilizado o solo cimento apiloado aparente em contraponto à taipa original.

Ao lado da casa sede do Sítio Itaim, havia um conjunto de ruínas composto por fundações, arranques de paredes de taipa referentes a uma edificação de tamanho considerável da qual não se sabia exatamente o uso, optou-se pela consolidação e preservação desses remanescentes.

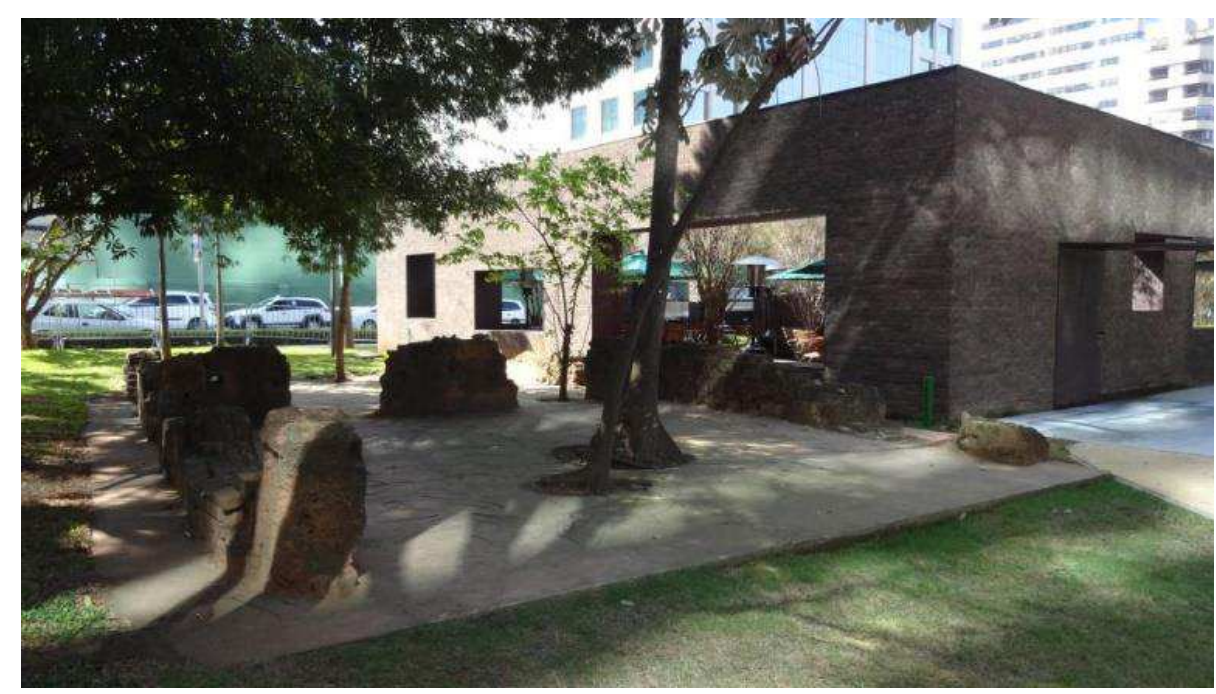

Fig. 98: Ruínas de edificação próxima à casa Sede do Sítio Itaim, 2014. Foto: Autora. 

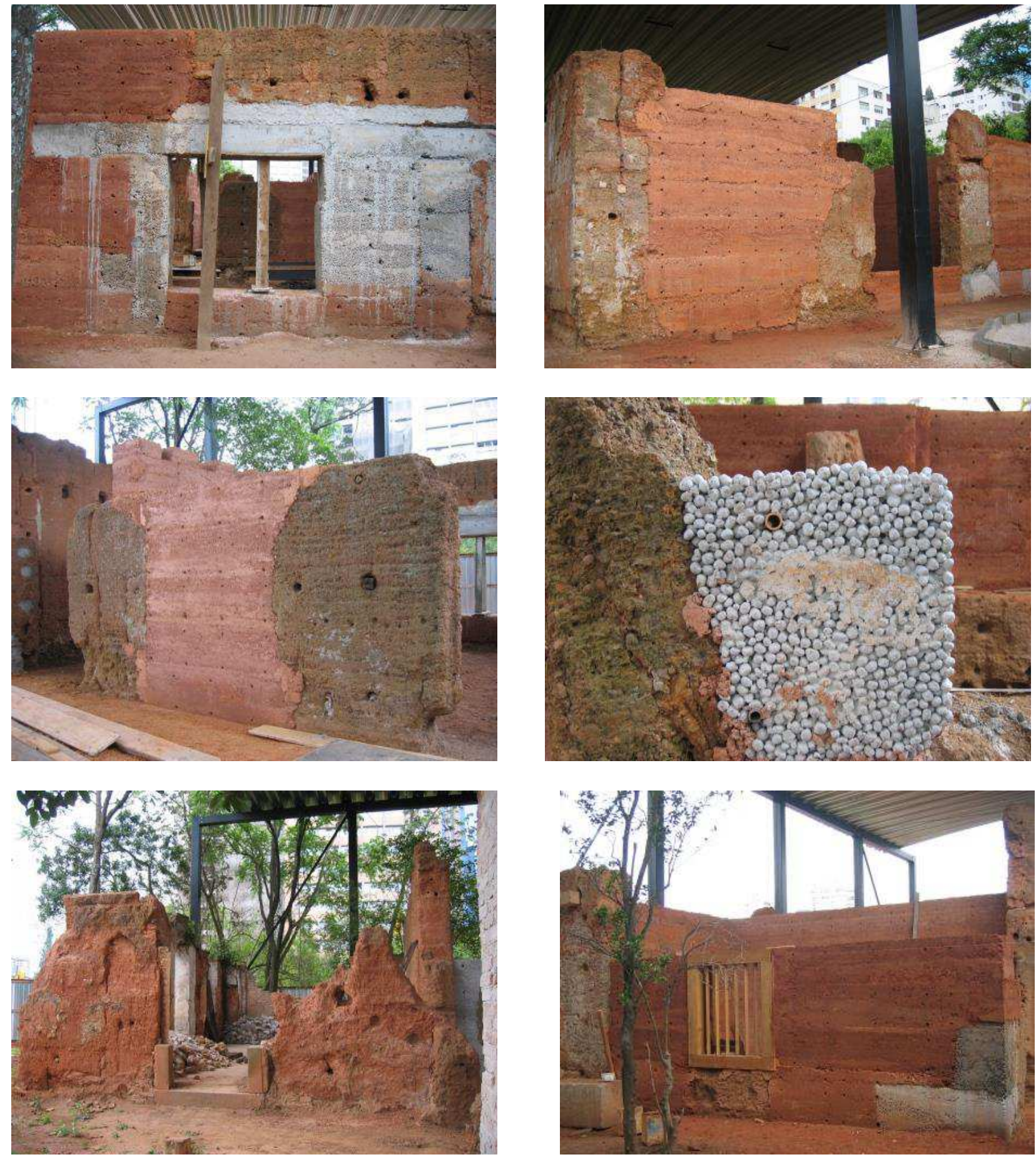

Fig. 99 (i-vi): Trabalhos na antiga Sede do Sítio Itaim, 2008. Fonte: Acervo PMSP/SMC/DPH. Fotos: Lia Mayumi.

Durante o período de execução dessa intervenção, a casa do Sítio Itaim passou por mais vicissitudes. A obra foi embargada em abril de 2009 devido a uma escavação com 20 metros de profundidade para a construção dos cinco subsolos das torres de escritório que abalaram a área da casa e o que constituía o sítio arqueológico do terreno. 
A movimentação de terra para a construção de cortinas de contenção para os subsolos implicou numa desestabilização causando avarias nos remanescentes e no que já havia sido executado da intervenção.

Entre as discussões e decisões judiciais, foram estabelecidas medidas compensatórias e uma nova pesquisa arqueológica ${ }^{189}$ passou a ser realizada no local - coordenada por Paulo Eduardo Zanettini e Paulo Fernando Bava. A intervenção na casa somente foi retomada em abril de 2011 quando foram necessárias alterações no escopo da intervenção, pois as trincas do solo se estenderam pelos maciços de taipa e consequentemente aos requadros de portas e janelas que já estavam prontos.

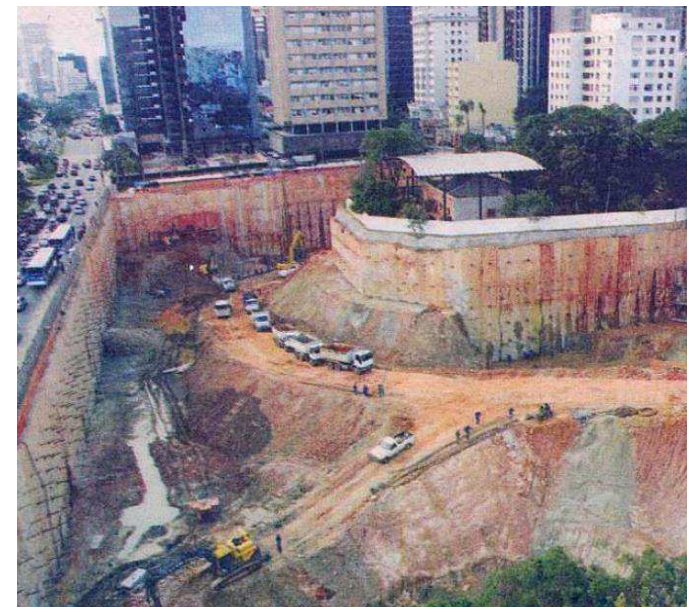

Fig. 100: Situação da casa do Sítio Itaim com a área envoltória comprometida. Fonte: Jornal do Metrô, 2009 In: IPHAN, 2009 , s.p.
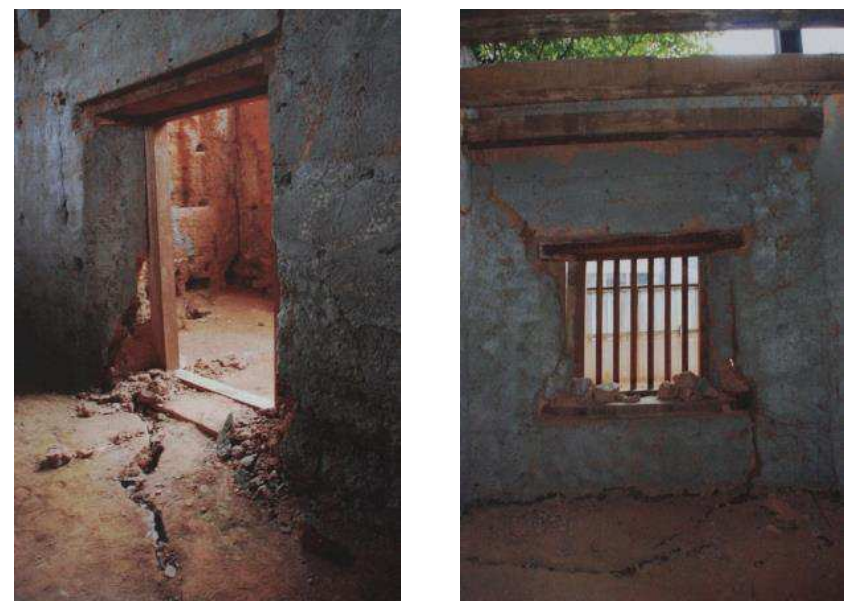

Fig. 101 (i-ii): Detalhes de danos ocorridos durante a paralização da obra. Fonte: Relatório Ilustrativo - Restauro Casa Bandeirista do Itaim, Helena Saia Arquitetos Associados In: IPHAN, 2009, s.p.

A retomada dos trabalhos teve que ser precedida por estudos estruturais para impedir o total colapso dos remanescentes. Em outubro de 2010, a empresa Falcão Bauer foi contratada para realizar os laudos referentes aos danos causados e reorientar a intervenção. A primeira preocupação era estabilizar o solo através da consolidação das trincas e estabilizar os maciços, especialmente nas áreas onde as lesões foram mais severas. Outra preocupação consistia na recuperação das esquadrias, cujos requadros funcionam estruturalmente nesse sistema construtivo; os mesmos tiveram que ser removidos e reinstalados com ajuste de prumo.

\footnotetext{
${ }^{189}$ Programa de Salvamento Arqueológico, conforme Portaria IPHAN 230/02 In: IPHAN, 2009.
} 

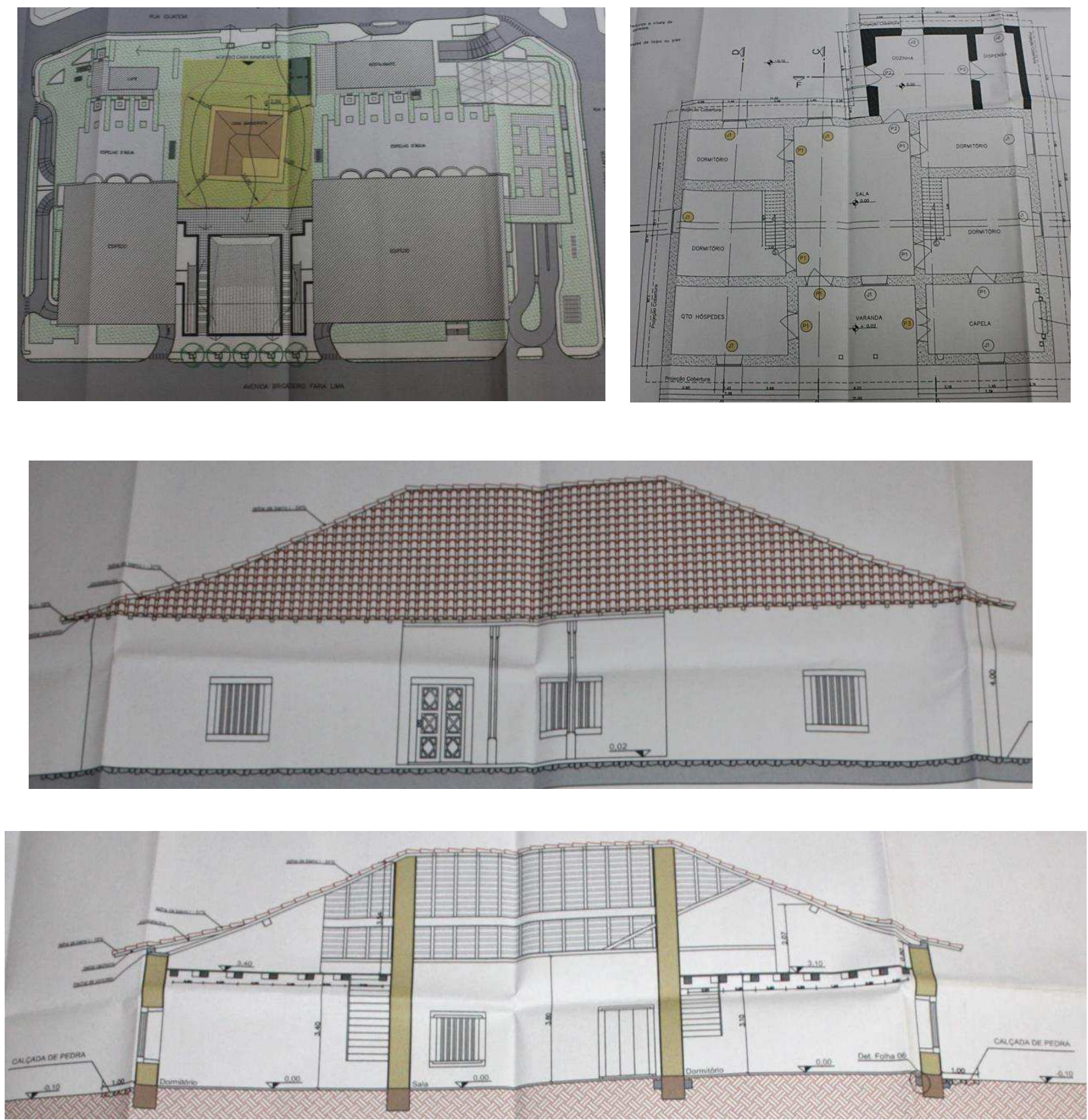

Fig. 102 (i-iv): Sede do Sítio Itaim - implantação, planta, fachada e corte D-D.

Fonte: Projeto Executivo de Restauração, Helena Saia Arquitetos Associados In: IPHAN, 2009, s.p.

Para os revestimentos das paredes, a princípio foi feito um chapisco que permitisse a transpiração da taipa e também a aderência do reboco. Foi aplicado reboco procurando adotar uma distinção para as porções originais (reboco rústico) e para os novos trechos (revestimento liso). Para a pintura de todas as paredes foi usada a cor branca após a preparação das superfícies, com três demãos de cal queimado no canteiro. Os pisos internos foram executados em solo-cimento. O madeiramento original era todo em canela preta, as novas peças são em itaúba e cumaru (assoalhos, barrotes, telhado e beiral). 
As esquadrias receberam tratamento de pigmentação da madeira até obter uma tonalidade padrão e foram finalizadas com a aplicação de verniz naval sem brilho. A obra foi finalizada em outubro de 2011 e atualmente - sem uma definição específica de seu uso - faz parte do conjunto de torres de escritório executado.
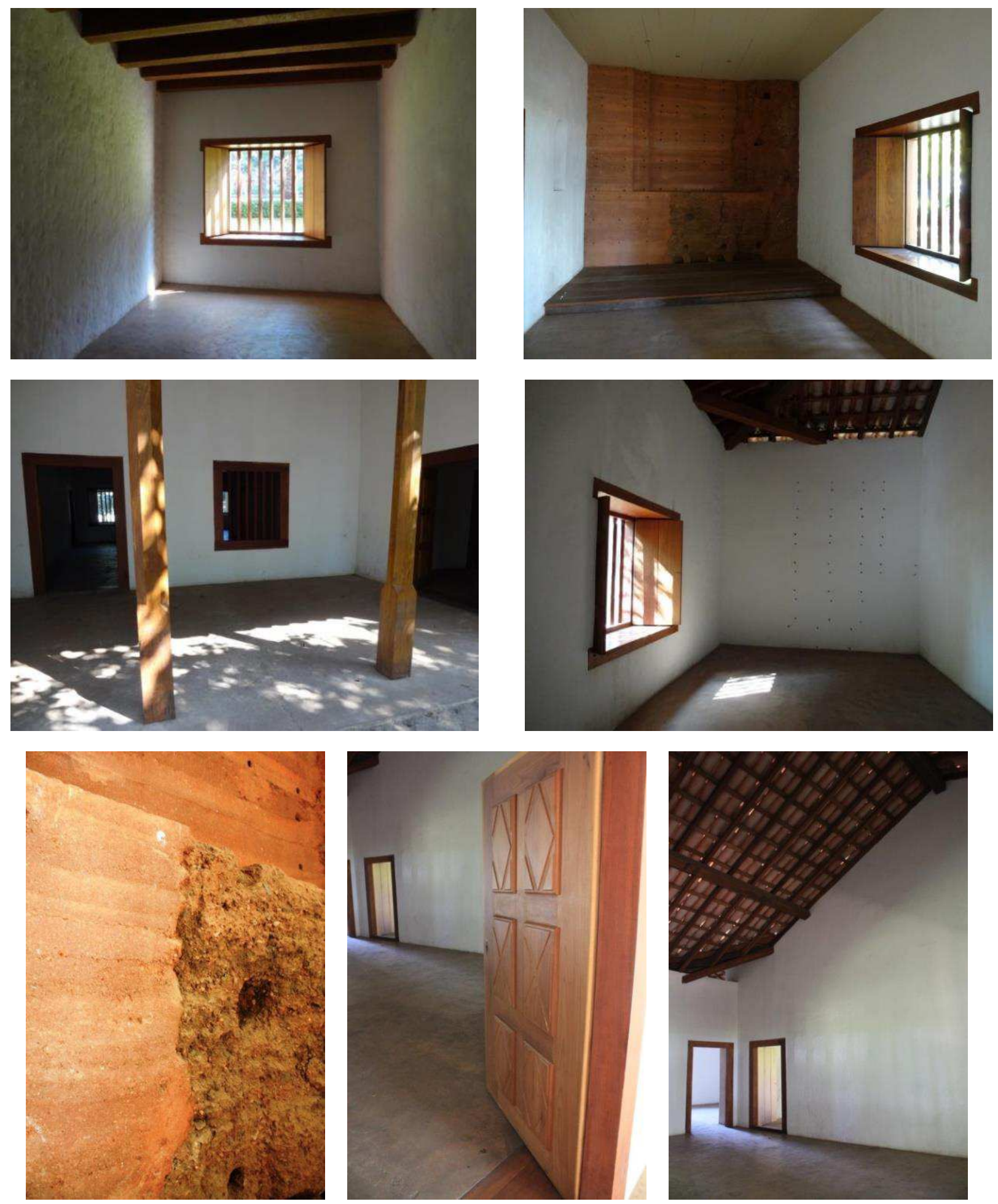

Fig. 103 (i-vii): Sede do Sítio Itaim reconstruída. Parte interna, detalhes construtivos, 2014. Fotos: Autora. 

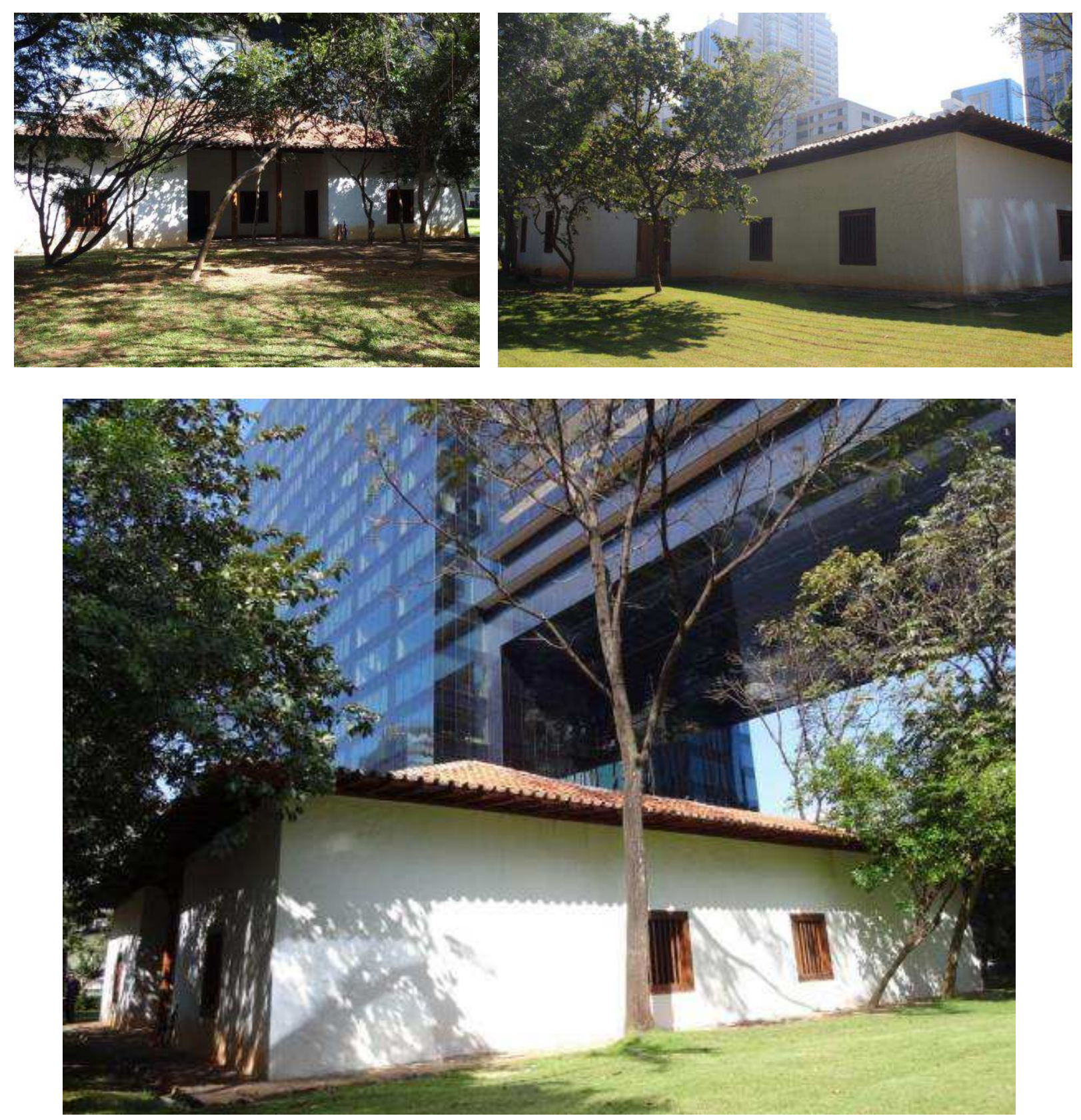

Fig. 104 (i-iii): Sede do Sítio Itaim reconstruída. Área externa, 2014. Fotos: Autora. 


\subsection{Ruínas da incúria: controvérsias e paradoxos}

\subsubsection{Identificação e valorização}

O grupo das ruínas "da incúria" enseja uma série de aspectos pertinentes ao desenvolvimento de nossa tese reforçando a seguinte problemática: em que medida se valoriza a ruína de um patrimônio arquitetônico íntegro que foi deteriorado?

Primeiramente é necessário compreender as motivações que levaram ao tombamento desses imóveis; ambos - Sítio Mirim (tombado em 1973) e Sítio Itaim (tombado em 1983) foram reconhecidos como bens culturais quando constituíam edificações inteiras (apesar das eventuais alterações e degenerações que continham) e a partir da identificação de características arquitetônicas de uma determinada tipologia residencial. O valor histórico desses exemplares está vinculado ao "partido bandeirista". Desde 1944 Luis Saia elaborou estudos sobre as residências rurais paulistas ${ }^{190}$ identificando edificações das quais o Sítio Mirim fazia parte. Esses estudos se aprimoraram ao longo dos anos e culminaram com a denominação da "casa bandeirista". Conforme destacado pela arquiteta Lia Mayumi (2008), a origem dessa expressão foi cunhada por Saia durante as comemorações do IV Centenário da cidade de São Paulo (1954) derivando de uma construção historiográfica em torno da importância do fenômeno das Bandeiras e dos bandeirantes.

Em seu estudo, Saia identificou doze exemplares ${ }^{191}$ de edificações que apresentavam características arquitetônicas semelhantes entre si cujas origens remontam ao período entre fins do século XVI e fins do século XVIII (mas pode se estender até meados do XIX). Segundo Mayumi (2008), Saia elaborou uma caracterização das tipologias do "partido bandeirista" através de algumas constantes:

[...] planta retangular; paredes de taipa de pilão; telhado de quatro águas e coberturas com telhas de canal; implantação sobre plataforma natural ou artificial, a meia encosta nas proximidades de um riacho; planta organizada em três faixas (social, familiar, de serviço, a partir da fachada principal); depósito ou sobrado, aproveitando a acentuada inclinação do telhado; presença de alpendre encravado na fachada principal, entre dois cômodos onde funcionariam uma capela e um dormitório para hóspedes. (Op . cit., p.32)

\footnotetext{
${ }^{190}$ Notas sobre a arquitetura paulista do segundo século. Revista do Serviço do Patrimônio Histórico e Artístico Nacional. Rio de Janeiro, n.8, 1944.

191 Em "As casas bandeiristas - Nascimento e reconhecimento da arte em São Paulo" (1978), Júlio Katinsky contabilizou vinte e dois exemplares documentados até aquele momento, algumas delas encontram-se na área urbana hoje de São Paulo: Butantã, Caxingui, Jabaquara, Tatuapé e Mirim. A do Itaim foi identificada posteriormente, quando do estudo de tombamento.
} 
Com essa base, Saia classificou os exemplares em dois grupos segundo as técnicas e materiais construtivos utilizados: 1 "puros": onde todas as constantes estavam presentes e há o emprego de maior qualidade de mão-de-obra e materiais; 2 "tardios": nos quais se constata a ausência de algumas constantes e a diminuição da qualidade construtiva. A antiga Sede do Sítio Mirim (construção estimada em 1750) foi tombada através de instrução de Saia pela excepcionalidade e unicidade da solução que continha particularidades como o alpendre em "L":

De todos os exemplares de arquitetura residencial paulista correspondente ao período bandeirista, a sede do atual Sítio Mirim é a única cuja planta foge ao esquema paladiano que comparece como solução genérica e característica. [...], a descoberta e proteção de uma peça de exceção num conjunto sistemático como é o da arquitetura residencial do período bandeirista, se afigura mais valiosa como informação e como valor didático, [...] o empenho maior deve incidir sobre este exemplar (Mirim) único, diferente, ilustrativo, e portanto valioso. Sua perda seria irreparável. (Of. 26/65 In: IPHAN, 1965, s.p. - grifo nosso)

A antiguidade, excepcionalidade e unicidade das características "bandeiristas" da antiga Sede do Sítio Itaim (construção estimada em 1846) foram identificadas validando a indicação para o tombamento, conforme as seguintes asserções de Carlos Lemos:

[...] a mesma planta bandeirista, grossas paredes de taipa $[\ldots]$ casa antiquíssima $[\ldots]$ Da velha capela interna ainda existe conservada a mesa do altar característica do século dezoito. Tudo indica seja a construção um exemplar de transição e, por isso, importante, constituindo um elo no desenvolvimento ou na dinâmica da planta da casa colonial paulista. (LEMOS In: SÃO PAULO - Estado, CONDEPHAAT, 1978, p.581 - grifo nosso)

Apesar de terem sido tombadas, essas edificações foram vítimas de progressivos processos degenerativos; uma vez constatado o real estado de ruína se interpôs a necessidade de lidar com a nova situação. Com a descaracterização e as perdas, são as características relacionadas ao partido "bandeirista" desses bens que se pretende resgatar. Na tentativa de colher informações sobre as edificações que se arruinaram, os remanescentes foram amplamente investigados através de estudos que envolveram prospecções arqueológicas. No Sítio Itaim, ainda em 1984 foi aventada a necessidade de elaborar um programa ${ }^{192}$ : “[...] para fins de determinação rigorosa dos elementos possíveis de restauração.” (Op. cit., p.413). Os trabalhos tiveram início em 1988, conforme atestou a arqueóloga Andreatta seria possível efetuar um levantamento espacial e histórico do local evidenciando "pontos de interesse comum, entre a arqueologia e arquitetura" (1988 In: IPHAN, 2009, s.p.).

${ }^{192}$ Responsável: Marlene Suano In: SÃO PAULO - Estado, CONDEPHAAT, 1978, p.424. 
Esse subsídio documental das ruínas seria importante para embasar a justificativa de "restauração" da casa do Sítio Itaim. Segundo o Memorial Descritivo (as built), as informações das prospecções arqueológicas realizadas em 1988 e das prospecções arquitetônicas realizadas em 2008 constituem o "arcabouço documental seguro e fundamental, que legitima a implementação do projeto de restauro" (SAIA, Memorial Descritivo, p.4 In: IPHAN, 2010, s.p.) tendo sido determinante para a orientação dos trabalhos. Antes da execução da intervenção em 2008 as estruturas originais foram registradas fotograficamente: "a fim de tornar bem nítida a leitura entre as técnicas originais daquelas adotadas no restauro." (SAIA In: DPH, 1997, p.2), e foi elaborada uma estratigrafia das paredes identificando o estado em que os remanescentes da casa do Sítio Itaim se encontrava.

Já no Sítio Mirim, a falta de informações precisas sobre o partido "original" da casa foi um dos motivos para o arquivamento da proposta de restauração elaborada por Helena Saia em 1976. De acordo com o relatório da arquiteta Vera Santos Mauro de Menezes de 1983, com as prospecções arqueológicas foram evidenciadas as muitas dúvidas geradas devido ao acelerado estado de arruinamento do sítio, tais como: 1. não localização das colunas do alpendre norte; 2. não localização dos limites das paredes dos dois alpendres, pelo fato da fundação de taipa encontrada ser contínua; 3. não definição da existência de escada de acesso ao jirau e sua localização; 4. não definição da existência de paredes divisórias do alpendre; 5. indefinição do desenho e dimensão exata do armário no salão central; 6. algumas portas e janelas sem indícios precisos (IPHAN, 1965, s.p.).

$\mathrm{O}$ aspecto documental das ruínas como evidências físicas que poderiam suprir informações a respeito da edificação "original" foi um dado fundamental para ambos os casos, porém, os resultados práticos (até este momento) são distintos: abdicou-se do projeto de "restauração" da casa do Sítio Mirim pela falta de evidências físicas conclusivas; e no Sítio Itaim, o levantamento das ruínas foi a base para a justificativa de sua "restauração" (reconstituição).

Sob a perspectiva do aspecto simbólico é relevante considerar que os termos "ruína" ou "restos" foram utilizados para caracterizar a situação calamitosa a que esses patrimônios foram submetidos. Em nossa análise essa conotação mais depreciativa da condição de ruína remete à denúncia de um sistema de salvaguarda que não foi eficiente, como atesta, por exemplo, essa notícia de jornal sobre a situação do Sítio Mirim: 
São Paulo está perdendo um de seus derradeiros exemplares da arquitetura residencial paulista correspondente ao chamado período bandeirista: o Sítio Mirim. Localizado entre os bairros de Ermelino Matarazzo e São Miguel Paulista, junto à avenida Assis Ribeiro, a construção é hoje apenas um amontoado de escombros e ruínas. Só as paredes, semidestruídas continuam de pé. (LIMA, Nélio, Folha de São Paulo, 15.04.1973, p. 14 In: IPHAN, 1965, s.p. - grifo nosso)

Aqui a ruína é interpretada como um produto final que revela de modo perturbador que o conjunto de medidas adotadas para a preservação desses patrimônios não foi suficiente para garantir a sua integridade física. Sendo assim, o grau e a causa do arruinamento são pontos decisivos para a aceitação (ou não) do status quo desses bens.

Do ponto de vista legal, parte-se do princípio que a abertura do tombamento já institui um grau de proteção. No Sítio Itaim, ao ser instaurado o processo tombamento, houve uma pronta comunicação ao proprietário sob essa alegação:

[...] o tombamento ou a simples abertura do processo, assegura a preservação do bem até decisão final da autoridade, sendo proibida, como consequência, qualquer intervenção em termos de destruição, demolição ou alteração, devendo os eventuais projetos de restauração ser previamente aprovados por este CONDEPHAAT. (Of. SE-258/80 In: SÃO PAULO - Estado, CONDEPHAAT, 1978, p.43 - grifo nosso)

O fato é que a mera promulgação do tombamento não foi suficiente para garantir a integridade física desses estudos de casos. Há incontáveis exemplos semelhantes, a título de ilustração podemos mencionar a Sede da Fazenda Conceição ${ }^{193}$ (Paraibuna, SP). Um imóvel que foi tombado pelo IPHAN em 1974 por ser uma edificação típica das fazendas de café do Vale do Paraíba. Essa casa apresentava partido arquitetônico, técnicas construtivas e detalhes legítimos do último quartel do século XIX, sendo constituída por um arcabouço de taipa de pilão e paredes divisórias de pau-a-pique.
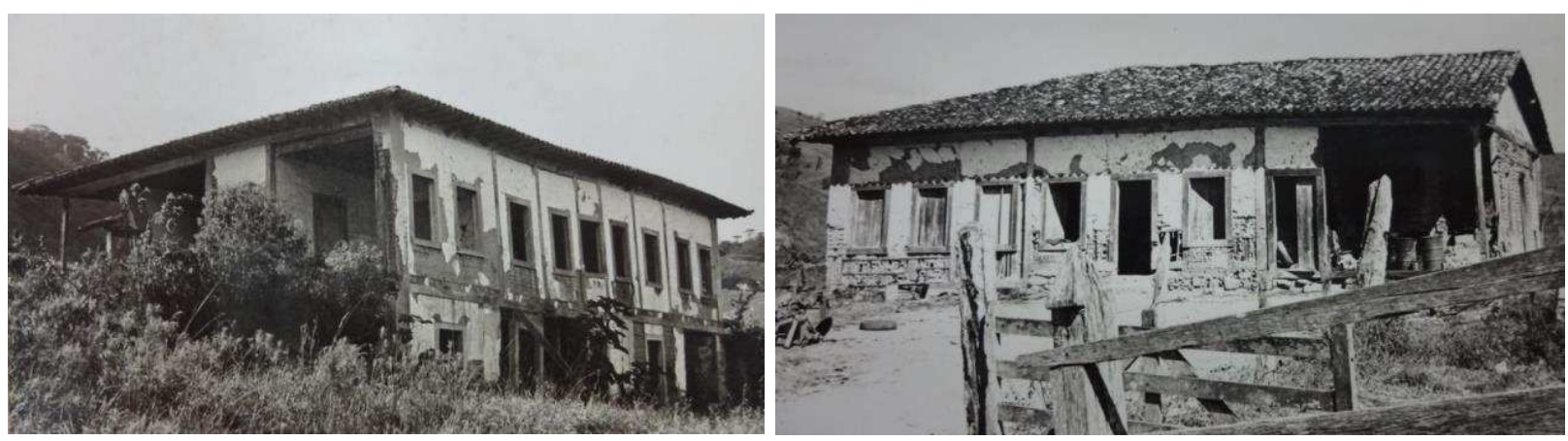

Fig. 105 (i-ii): Sede da Fazenda Conceição, Paraibuna (SP), 1978. Fonte: IPHAN, 1974, s.p. Fotos: Odair Carlos de Almeida.

193 Informações consultadas junto ao processo IPHAN 0910-T-74 (tombamento em 1974, Livro do Tombo Histórico). 
O imóvel se encontrava em um crítico estado de degeneração quando foi tombado, mas ainda estava íntegro e reconhecível; com o agravamento do estado de conservação em 1976, o IPHAN executou serviços emergenciais na cobertura e escoramento de pontos vulneráveis. Conforme consta nos autos consultados, a situação do imóvel foi se agravando; outras edificações foram construídas nas imediações e o bem era usado indevidamente. Em março de 1983 a edificação ruiu completamente devido às chuvas daquele verão. O proprietário comunicou ao IPHAN e na vistoria ${ }^{194}$ foi constatado que: “[...] o prédio ruiu completamente, restaram em pé algumas das colunas e partes dos arrimos de taipa e pedra, na porção inferior da fachada." (NETO, 14.03.83 In: IPHAN, 1974, s.p.).
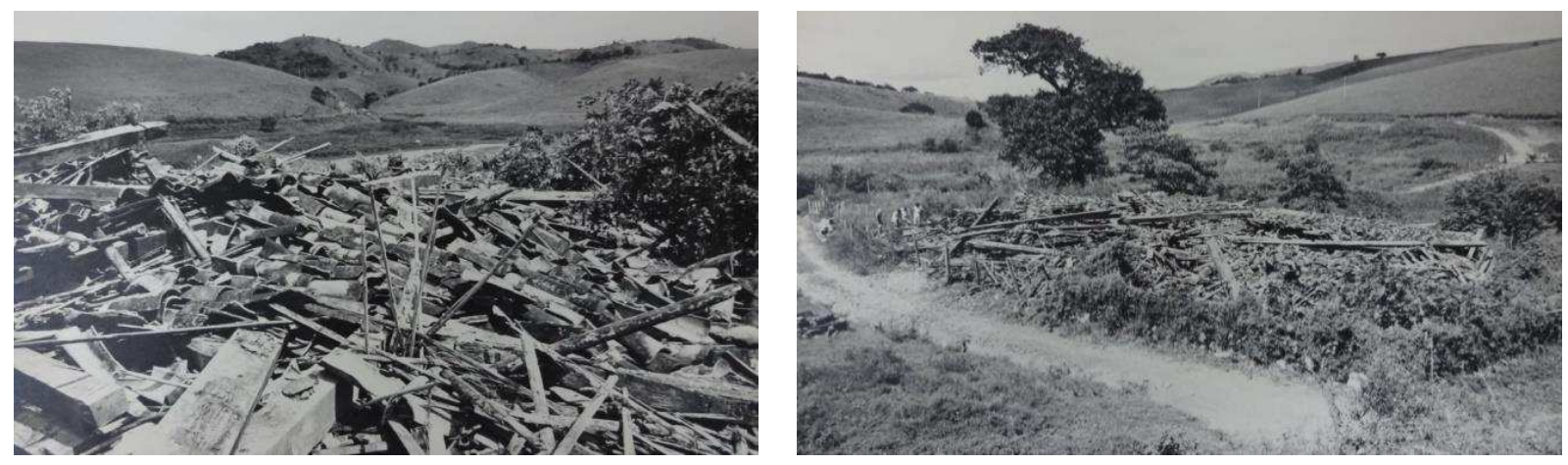

Fig. 106 (i-ii): Arruinamento completo da Sede da Fazenda Conceição, Paraibuna (SP), 1983. Fonte: IPHAN, 1974, s.p. Fotos: Jorge Hirata.

Em face à situação de um completo arruinamento derivado de um conjunto de negligências surgem alegações a respeito da validade de se manter o tombamento do patrimônio. Nesse sentido é interessante mencionar as recentes discussões em torno dos casos do Sítio Piraquara (São Paulo, SP) ${ }^{195}$ e da Fazenda Tenente Carrito (Itapetininga, SP) ${ }^{196}$, bens tombados ou com abertura de tombamento pelo CONDEPHAAT que foram acometidos por um gradativo processo de arruinamento. Os debates no âmbito do órgão de preservação estadual giram em torno da gravidade de efetivar a figura do destombamento, conforme alega Elisabete M. Watanabe ${ }^{197}$ em parecer sobre os casos: “[...] a mera edição de uma resolução de destombamento, sem qualquer encaminhamento investigativo e punitivo, pode abrir precedentes e mesmo criar uma jurisprudência, não muito positiva, de 'caiu, destomba'" (WATANABE, Parecer 19/2010 In: CONDEPHAAT, 1978, s.p.).

\footnotetext{
${ }^{194}$ Realizada em 14.03.1983 pelo arquiteto José Saia Neto - técnico do IPHAN.

195 Processo CONDEPHAAT 20.700/78.

${ }^{196}$ Processo CONDEPHAAT 23.393/95.

${ }^{197}$ Então diretora do Centro de Estudos de inventário e tombamento de conjuntos arquitetônicos e arqueológicos e de áreas naturais - CONDEPHAAT.
} 
Essa controversa situação da aplicação do instrumento do tombamento - ou do destombamento - a estruturas acometidas por graves processos degenerativos pode ser evidenciada através dos casos aqui destacados. O quanto se perdeu fisicamente da legibilidade espacial do patrimônio e a viabilidade em preservá-lo (ou não) embasou a contestação do tombamento por parte dos proprietários do Sítio Itaim alegando ser injustificável preservar a casa devido às alterações e à situação de arruinamento em que o bem se encontrava:

[...] essa obra, alterada, descaracterizada, substancialmente modificada, acabou sendo demolida, de sorte que hoje no local apenas existem restos de paredes de taipa, destroços e entulhos resultantes da demolição levada a efeito como, alias, ficou consignado no relatório elaborado por ocasião da vistoria realizada no local pelo Diretor do Departamento de Patrimônio histórico da Secretaria Municipal de Cultura, no dia 18 de novembro p. passado [...] Se, em tese, se poderia afirmar ter existido algum interesse da CONDEPHAAT pelo imóvel, na verdade tal interesse desapareceu pelo próprio desaparecimento do seu objeto. (SÃO PAULO - Estado, CONDEPHAAT, 1978, p.176 e 178 - grifo nosso).

O tombamento se sustentou, embora essa indagação sobre o grau de arruinamento tenha pautado a postura crítica do arquiteto Víctor Hugo Mori do IPHAN/SP ao mencionar: “[...] o controverso conceito se o imóvel deveria ser ainda considerado arquitetura [...]" (Of. 432/08 In: IPHAN, 2009, s.p. - grifo nosso).

A delegação das respectivas responsabilidades pelo arruinamento foi um tópico debatido nos autos dos processos consultados. No caso do Sítio Mirim, em matéria publicada no jornal em $1973^{198}$ Luis Saia fez explícitas críticas à municipalidade devido à negligência com o bem tombado:

Houve desídia da Prefeitura. Não apenas o prefeito Prestes Maia deixou de atender aos meus sucessivos apelos: todas as administrações que o sucederam, inclusive a atual, também não deram a mínima importância aos pedidos e sugestões do Patrimônio Histórico. É por isso que o Sítio Mirim transformou-se no que é hoje, ruínas e só ruínas. (SAIA apud LIMA, 1973, p.14 In: IPHAN, 1965, s.p. - grifo nosso)

No Sítio Itaim, a responsabilidade sobre a negligência gerou entraves entre o proprietário e o órgão de preservação estadual; após a promulgação da sanção judicial que previa a "restauração da casa", a empresa proprietária apresentou alegações sobre um atraso na entrega do alvará de aprovação da execução juntamente com o projeto detalhado devidamente aprovado; e alegou que não constava por parte do órgão uma fiscalização da situação do bem, uma orientação técnica sobre sua preservação com a designação de um

\footnotetext{
${ }^{198}$ Folha de São Paulo: "São Paulo está perdendo um de seus derradeiros exemplares da arquitetura residencial paulista correspondente ao chamado período bandeirista: o Sítio Mirim", LIMA (1973) In: IPHAN, 1965, s.p.
} 
arquiteto ou engenheiro responsável, bem como a verificação do andamento das obras que deveriam ocorrer (SÃO PAULO - Estado, CONDEPHAAT, 1978).

O CONDEPHAAT, porém, apresentou uma defesa ressaltando que a empresa proprietária tinha uma intenção dolosa de ganhar tempo enquanto a edificação se deteriorava objetivando uma reconsideração de tombamento; também há menções ao entrave jurídico que envolve a preservação do patrimônio cultural no Brasil que diz respeito ao aporte de dinheiro por parte do órgão de preservação. Segundo consta no Decreto Estadual n. 13.426 (16 de março de 1979) que versa sobre o instituto de tombamento, a responsabilidade pela preservação dos bens tombados particulares é exclusiva dos proprietários, a não ser que os mesmos comprovem que não podem arcar com tal ônus. Argumentava-se, portanto, que em nenhum momento o órgão preteriu a cúria do bem, fazendo o que esteve ao seu alcance legal para a manutenção do mesmo.

A análise em torno desses dois estudos de caso engloba um ponto de grande relevância no âmbito da preservação patrimonial que diz respeito à manutenção periódica de um bem cultural para evitar processos degenerativos e consequentes trabalhos de restauro. Esse tema permeia muitas teorias e remete à dialética entre as ações de caráter mais conservativo e a restauração (que implica em uma operação mais incisiva sobre a materialidade remanescente). O teórico Giovanni Carbonara compara a manutenção com a medicina preventiva (KÜHL, 2004) e define que o campo da conservação patrimonial envolve ações de manutenção, prevenção e salvaguarda que são distintas do restauro pelo grau de intervenção no bem (CARBONARA, 2009).

Ainda no século XIX, a proposição de uma manutenção constante e do respeito à condição material original, foram aspectos chaves na abordagem de John Ruskin. Ele estruturou suas recomendações em relação à necessidade de conservação constante dos edifícios como um preceito fundamental em contraponto à necessidade da restauração: “[...] descurar os edifícios primeiro, e restaurá-los depois. Cuide bem de seus monumentos, e não precisará restaurá-los." (RUSKIN, 2008, p.81-82 - grifo nosso). Boito (2002) abordou a necessidade dos cuidados periódicos e o problema da eventual incúria ou negligência que pode levar à ruína dos monumentos embasando a legitimidade da restauração como um ato necessário, quando a manutenção não foi suficiente para garantir a integridade do monumento.

Como apresentado no capítulo 1, na acepção em que se baseia a teoria brandiana e o restauro "crítico" a restauração é definida como um campo disciplinar que fundamenta 
qualquer ação sobre os bens de reconhecido interesse cultural: manutenção, conservação e, inclusive a "restauração preventiva" (BRANDI, 2004, p. 101) que é ainda mais imperativa, pois objetiva impedir as intervenções de extrema urgência. Essas considerações sobre a necessidade da manutenção como uma práxis que antecede a restauração foi reafirmada na elaboração da Carta de Veneza $(1964)^{199}$. Na conferência introdutória, Roberto Pane mencionou que a manutenção é o meio para evitar intervenções mais contundentes no monumento cuja periodicidade torna menos necessárias as obras de restauro. As definições expressas no documento final apresentam de forma clara que: "Art. $4^{\text {o }}$ : A conservação dos monumentos exige, antes de tudo, manutenção permanente." (ICOMOS, 1964 In: CURY, 2004, p.92); e que "Art. 9': A restauração é uma operação que deve ter caráter excepcional" (ICOMOS, 1964 In: Op. cit. , p.93). Posteriormente, a Carta de Burra ${ }^{200}$ (1980) reitera a definição que: “[...] o termo 'manutenção' designará a proteção contínua da substância, do conteúdo e do entorno de um bem [...]" (ICOMOS, 1980 In: Op. cit. , p.242).

Nos autos dos processos consultados foi evidenciado o caráter temporário e urgente de algumas ações esparsas. No "Relatório das obras de emergência realizadas nas ruínas do Sítio Mirim" (1978) ${ }^{201}$ há um destaque ao caráter emergencial das intervenções, mediante a espera de novas definições sobre um projeto mais incisivo: “[...] não são senão providências provisórias e de duração limitada, fazendo-se necessária, por isto mesmo, a periodicidade de visitas para inspeção.” (SÃO PAULO - cidade, 1978, p.4 In: IPHAN, 1965). No Sítio Itaim foram feitos alguns trabalhos em 1988 para a proteção dos remanescentes - cobertura com lonas plásticas das paredes de taipa, o escoramento dos vãos das aberturas e limpeza para a liberação da área para as pesquisas arqueológicas. Porém essas ações não foram revisadas posteriormente e o processo de arruinamento se estendeu por mais duas décadas.

É evidente, portanto, que essas ações pontuais não configuravam um efetivo programa de manutenção conservativa e a falta da periocidade dessas operações contribuiu à ruína dos patrimônios, principalmente tendo em vista a técnica construtiva dessas edificações. Há que se considerar, como apresentado no capítulo 2 através da Capela do Morumbi, que uma das

\footnotetext{
199 Cf.: "Manutenção ou reparos: ações cotidianas e periódicas que visam a sanar e reparar problemas que aparecem na edificação assim que surgem, como reparo de um condutor vertical, de fiação inadequada, substituição de telhas e de vidros quebrados, de balaústres danificados etc., em que se opera, em geral por analogia, com formas e materiais iguais ou semelhantes aos originais; casos, pois, em que os problemas não se consolidam como uma cisão, no tempo, na obra como imagem figurada (caso houvesse uma cisão, esses mesmos problemas deveriam ser tratados como casos de restauração);” (apud. KÜHL, 2008, p.74).

${ }^{200}$ Documento internacional promulgado em reunião do ICOMOS (1980).

${ }^{201}$ Elaborado por João Eduardo Correa Dias de Moraes (Chefe do Laboratório de Restauro, IPHAN).
} 
principais características da arquitetura paulista é a técnica construtiva derivada do manejo da terra - taipa de pilão, taipa de mão e demais variações. De fato, a conservação de remanescentes em terra envolve um grande cuidado devido à sua vulnerabilidade em relação às intempéries do clima tropical; além da cobertura são necessárias medidas para manter condições de temperatura e umidade ${ }^{202}$.

No âmbito das ações para a conservação de um bem a destinação de uma função útil à sociedade é um aspecto determinante para a preservação patrimonial. No processo do Sítio Itaim foi evidenciado o caráter cultural direcionando a utilização do espaço da casa para um centro de exposições ou museu que contasse a história local. No entanto, a casa reconstituída está sem uma definição de um uso específico, embora seja eventualmente aberta a visitações.

Já no Sítio Mirim a questão do uso é mais premente, por estar situado em uma praça pública a preservação dessas ruínas está condicionada à sua inserção no cotidiano local. Essa discussão foi estabelecida no âmbito do DPH em meados dos anos 2000, segundo a arquiteta Lia Mayumi $^{203}$, tendo em vista a necessidade de tomar providências para a mínima conservação das ruínas com recursos financeiros exíguos, os técnicos aventaram a possibilidade de cobrir as paredes de taipa, alguns estudos foram feitos e uma proposta de pórticos em aço com painéis de vidro foi apresentada. Porém, chegou-se à conclusão de que somente essa cobertura não seria suficiente para garantir a preservação do Sítio Mirim; no entendimento dos técnicos seria necessária uma ação mais contundente que envolvesse toda a área introduzindo equipamentos com usos mais efetivos no cotidiano dos moradores locais para que o bem cultural pudesse ser de fato incorporado e preservado.

Desse modo, pode-se colocar em pauta o conceito de conservação integrada estabelecido na Declaração de Amsterdã $(1975)^{204}$, que evidencia a necessidade da leitura da preservação patrimonial de forma conjunta entre técnicas de restauro, funções compatíveis com o objetivo de uma conservação no âmbito do planejamento urbano e territorial definindo

\footnotetext{
${ }^{202}$ O tema do patrimônio em terra é extremamente amplo e profícuo nos debates da preservação patrimonial internacional. Na bibliografia consultada, a problemática do tratamento aos maciços arruinados em terra foi abordada por Thomas Caperton (1990), Frank G. Matero e Angelyn Bass (1994), Harry Myers (1997) e Todd Metzger (1999) que se referem aos procedimentos para a manutenção dos remanescentes de estruturas concentradas no sudoeste dos Estados Unidos que remetem a ocupações anteriores e posteriores à colonização na região, dentre elas o conjunto do Fort Selden, 1865 (New Mexico, EUA). No entanto, por se tratar de referências em uma região extremamente desértica essas análises não oferecem elementos pertinentes que se apliquem à condição de nosso clima tropical.

${ }^{203}$ Em entrevista concedida à autora em 22.02.2013.

${ }^{204}$ Documento elaborado durante o Congresso do patrimônio europeu, pelo Conselho da Europa no ano europeu do patrimônio arquitetônico, Amsterdã, 1975.
} 
uma estratégia única e comum de modo que se possa reconhecer o valor cultural e preservar o bem, tendo em vista sua relação com a cidade. Para tanto, as políticas de conservação envolvem a conjunção de dois valores: o valor cultural de um patrimônio arquitetônico, e seu valor de utilização através de sua integração na vida social da comunidade em que está inserido.

A interpretação e apropriação que a população faz das ruínas do Sítio Mirim é determinante para a preservação desse patrimônio. No âmbito da semantização dos espaços, os processos de depredação e vandalismo que ocorreram na década de 1970 podem ser entendidos pela falta de identificação simbólica e cognitiva que alguns usuários desenvolveram com o bem; por outro lado, ações, discussões, denúncias e petições comunitárias almejando alguma atividade naquela área para a reinserção das ruínas da antiga Sede do Sítio Mirim no cotidiano local é um indicativo de que esses remanescentes possuem algum valor intrínseco para aqueles que convivem com eles.

No Sítio Itaim, mesmo se tratando de uma propriedade particular, a participação social teve expressividade na indicação da casa para o tombamento, pois foi a partir da solicitação da Associação do Bairro que o bem foi estudado; ao longo das décadas muitas das denúncias sobre o estado de arruinamento e petições para medidas de proteção também partiram da sociedade civil. No entanto, os critérios de intervenção ficaram circunscritos aos órgãos de preservação, o peso da opinião pública nas decisões de projeto é exíguo.

$\mathrm{Na}$ interpolação dos aspectos levantados na análise desses estudos de caso foi possível constatar que o grau de destruição, a contemporaneidade e a causa do processo de arruinamento são fatores decisivos que articulam a interpretação, apreciação e aceitação (ou não) dessas ruínas. Com isso, verificaremos agora os resultados derivados dessas abordagens nas orientações para a preservação da materialidade remanescente.

\subsubsection{Intervenções e as digressões sobre a restauração}

Esses estudos de caso têm sido objeto de projetos e intervenções ao longo de seus percursos enquanto bens culturais. No Sítio Mirim: restauração pelo IPHAN (1967); após o arruinamento houve a proposta elaborada em 1976 pelo DPH que previa a reconstituição da casa (não executada); em 1999 uma nova proposta elaborada pelo DPH que previa a consolidação das ruínas com sua musealização e integração a um conjunto de uso cultural no terreno e em 2003, outro projeto com o mesmo teor (não executadas). 
No Sítio Itaim, a proposta de 1982 para uma "reforma" que previa sua reconstituição (não executada); em 1984 a ideia apresentada para a consolidação das ruínas e implantação de cobertura e em 1997 a proposta de "restauração" que foi revista e executada a partir de 2008.

Primeiramente, a casa do Sítio Mirim passou por trabalhos de restauração durante a década de 1960 chefiados por Luis Saia. Essa intervenção buscou resgatar uma suposta unidade estilística original da "Casa bandeirista" utilizando novos materiais (tijolos de barro e concreto) e técnicas construtivas (o emprego de cintas e vigotas de concreto para amarrações e estabilização estrutural). Essas obras devem ser interpretadas dentro do contexto de uma série de realizações chefiadas por Saia na Divisão do Estado de São Paulo do IPHAN nesse período (das quais já analisamos o Engenho dos Erasmos no capítulo 2); e, principalmente, num recorte relacionado à tipologia residencial da arquitetura rural paulista.

Segundo Mayumi, para a casa do Sítio Mirim, Saia se pautou pelo "[...] respeito às legítimas verdades arquitetônicas, que mandam conservar aquelas peças que realmente sejam documentos de uma época e de um povo.” (MAYUMI, 2008, p. 72). Um preceito que acusa uma orientação teórica embasada na Carta de Atenas (1933) dos CIAM (Congressos Internacionais de Arquitetura Moderna) ${ }^{205}$. A busca por uma unidade estilística purificadora que remeta a um passado específico e a utilização de materiais modernos para a restauração de um elemento arquitetônico de importância única por seu valor histórico e sentimental são preceitos que foram utilizados na restauração do Sítio Santo Antônio (São Roque, SP) mencionada no capítulo 2 - e na paradigmática restauração da Casa do Butantã (São Paulo, SP) que ocorreu no contexto da construção historiográfica que envolveu a designação da "Casa Bandeirista"206 entre 1954 e 1955 com a Comemoração do IV Centenário da Cidade de São Paulo. De acordo com Mayumi (2008), os procedimentos técnicos e metodológicos coordenados por Luis Saia na Casa do Butantã seriam balizadores para as operações em outras edificações residenciais do mesmo partido, dentre as quais a intervenção no Sítio Mirim.

\footnotetext{
${ }^{205}$ Os CIAM foram fundados em 1928 pela Declaração de La Sarraz (Suíça) com o objetivo de formular e apresentar o problema da arquitetura no âmbito do Movimento Moderno. Desde sua fundação, houve uma série de Congressos em que foram apresentadas discussões, resoluções e publicações envolvendo renomados arquitetos - Auguste Perret, Erich Mendelsohn, Le Corbusier, Mies Van der Rohe, Tony Garnier, Walter Gropius, dentre tantos outros. O $4^{\circ}$ Congresso teve início em 29 de julho de 1933 a bordo do navio "Patris II" no percurso Marselha-Pireu-Marselha e foi finalizado em Atenas. $\mathrm{O}$ debate dessa reunião se concentrou no problema das cidades e o urbanismo contemporâneo; o resultado desse Congresso foi a denominada "Carta de Atenas". No que concerne às implicações sobre a preservação de uma edificação e sua relação com o entorno, a Carta apresentou alguns preceitos concentrados no final do documento (itens 65 a 70).
}

${ }^{206} \mathrm{Na}$ ocasião desses trabalhos Luis Saia publicou o texto: "A Casa bandeirista - uma interpretação" (1955) (MAYUMI, 2008). 
Com o estado de ruína instaurado, outro projeto de "restauração" foi apresentado pelo DPH em $1976^{207}$ em que as ruínas foram consideradas como base documental para a fundamentação científica de uma reconstituição espacial da "casa bandeirista". Ao apresentar esse projeto Helena Saia se refere às ideias de Ruskin e à recomendação de conservação das ruínas como tal, no entanto a arquiteta impostou argumentos refutando essa possibilidade. Segundo a arquiteta, as desvantagens seriam devido ao material e técnica construtiva paredes em taipa que se decompõe com facilidade; além disso, havia a alegação de que se perderia a leitura espacial do monumento; refutou-se também a possibilidade de meramente cobrir as ruínas para proteção, pois, a leitura de todo o espaço público poderia ser comprometida.

Assim foi apresentada a ideia de uma "restituição espacial" tendo como critério a "reintegração". Para o embasamento teórico e conceitual dessa proposta, Helena Saia expôs uma justificativa que expressa uma preocupação com a segurança da autenticidade das informações mencionando o Artigo $9^{\mathrm{a}}$ da Carta de Veneza ${ }^{208}$ que evidencia a excepcionalidade da operação do restauro e seu estrito embasamento documental na matéria original e autêntica do que está sendo avaliado para conservação. A falta de evidências comprovadas pelas prospecções arqueológicas, foi um dos fatores para a não concretização dessa proposta. Ou seja, as ruínas, não forneciam informações suficientes para que esse trabalho fosse desenvolvido de modo científico.

Embora esse projeto para o Sítio Mirim não tenha sido executado as semelhanças conceituais em relação à proposta que Helena Saia elaborou para o Sítio Itaim anos mais tarde (e que foi executado) são flagrantes e estão embasadas na utilização dos remanescentes como base documental para obter informações que subsidiem o resgate de uma unidade estilística.

Desde o início dos estudos para o tombamento da antiga Sede do Sítio Itaim, se interpôs a ideia de uma possível "reconstituição", como pode ser identificado na definição das ações emergenciais elaboradas em laudo realizado em 1980: “[...] realizar criterioso

\footnotetext{
${ }^{207}$ Apresentação de proposta consultada junto à PMSP/SMC/DPH - Seção Técnica de Projeto, Restauro e Conservação. Pasta: D.O.M. Julho/98.

${ }^{208} \mathrm{Cf}$.: "Art. $9^{\text {o: }}$ A restauração é uma operação que deve ter caráter excepcional. Tem por objetivo conservar e revelar os valores estéticos e históricos do monumento e fundamenta-se no respeito ao material original e aos documentos autênticos. Termina onde começa a hipótese; no plano das reconstituições conjeturais, todo trabalho complementar reconhecido como indispensável por razões estéticas ou técnicas destacar-se-á da composição arquitetônica e deverá ostentar a marca do nosso tempo. A restauração será sempre precedida e acompanhada de um estudo arqueológico e histórico do monumento." (ICOMOS, 1964, In: CURY, 2004, p.93 - grifo nosso).
} 
levantamento métrico e arquitetônico, fotográfico e de técnica construtiva, elemento fundamental para o seu registro documental, análise técnica e subsídio importantíssimo para um projeto de reconstituição.” (SÃO PAULO - Estado, CONDEPHAAT, 1978, p.79 grifo nosso).

A sanção judicial promulgada em 1982 designou a "restauração da Casa Bandeirista" (Op. cit., p. 335) para reparar a degradação que foi deflagrada pela empresa proprietária através de uma indevida demolição parcial. Porém, com o passar dos anos e o agravamento da ruína, não houve uma revisão ou aprofundamento dos termos e critérios dessa operação; a possibilidade de consolidar o estado de ruína não foi aventada em termos judiciais como meio de sanção aos proprietários. Conforme Helena Saia, a proposta de "restauração" estava embasada no objetivo de recuperar o "significado simbólico de origem da ocupação da região [...]” (SAIA In: IPHAN, 2010, s.p.); uma asserção que evidencia a necessidade de resgatar a imagética da origem da identidade "paulista" que está atrelada ao partido bandeirista.

Sob a ótica da preservação patrimonial, a opção pela reconstituição de uma determinada fase do bem pode comprometer a leitura de suas outras fases históricas. Tendo como referência a Carta de Veneza (1964): “Art. 11 As contribuições válidas de todas as épocas para a edificação do monumento devem ser respeitadas, [...] a unidade de estilo não é a finalidade de [...] uma restauração. [...]” (ICOMOS, 1964 In: CURY, 2004, p.93). A Sede do Sítio Itaim sofreu várias adaptações para atender um novo programa - Sanatório Bela Vista que vigorou por várias décadas no local. Sendo assim, a edificação também constituía um importante documento de um equipamento de saúde, um aspecto histórico que não foi contemplado no tombamento e no projeto de restauro que privilegiou uma tipologia habitacional atrelada ao partido bandeirista.

Mesmo estando seriamente embasada nos dados documentais obtidos nas prospecções arqueológicas e nos conhecimentos em relação às outras casas do mesmo partido a reconstituição do que um dia pode ter sido a casa do Sítio Itaim foi alvo de questionamentos, nos órgãos de preservação. Antônio Luiz Dias Andrade após vistorias realizadas no local em 1987 “[...] desaconselha qualquer tentativa de reconstituição ou reconstrução, [...].” (SÃO PAULO - Estado, CONDEPHAAT, 1978, p.434). Em 2008, no momento de efetiva retomada do projeto, o arquiteto Víctor Hugo Mori do IPHAN/SP apresentou uma contundente indagação sobre as ações alegando que o estado ruinoso da edificação exigia, de acordo com as Cartas Internacionais, outro tipo de abordagem: 
Nos termos das definições exaradas pelas 'Cartas Internacionais', em especial a de Veneza 1964, as ruínas são consideradas documentos históricos e arqueológicos e, neste sentido, não podem ser reconstruídas e deverão ser mantidas como sítio arqueológico. (Of. 432/08 In: IPHAN, 2009, s.p. - grifo nosso).

Com essas considerações, Mori fez alusão ao artigo 15 da Carta de Veneza que dispõe que: "[...] Todo trabalho de reconstrução, portanto, deve ser excluído a priori, admitindo-se apenas a 'anastilose', ou seja, a recomposição das partes existentes, mas desmembradas." (ICOMOS, 1964 In: CURY, 2004, p.94). Essas asserções de Mori refletem uma transmutação que deixa de focar o objeto arquitetônico (que não mais existe) e passa a focar e valorizar a ruína; percebe-se que para essa nova apreciação, o caráter arqueológico dos remanescentes é ressaltado, refletindo o incremento das pesquisas arqueológicas no Brasil a partir dos anos 1990 (como apresentado no capítulo 1) e promulgação das Portarias do IPHAN ${ }^{209}$ que atrelam prospecções à aprovação de empreendimentos em potenciais sítios arqueológicos.

A constatação dessa conversão de objeto arquitetônico íntegro de valor cultural para um objeto "arqueológico" também norteou a proposta apresentada para o Sítio Mirim em 1999 pelos técnicos do DPH ${ }^{210}$ - Leila Regina Diêgoli, Cássia Magaldi e pelo engenheiro José Henrique Seraphini. Segundo o relatório de apresentação do anteprojeto, a proposta previa o respeito à substância antiga e aponta para a consolidação dos remanescentes em ruínas afirmando também que as mesmas deveriam ser tratadas como um "monumento arqueológico" (SÃO PAULO - cidade, 1999, p.5 In: IPHAN, 1965) de forma integrada a um projeto paisagístico e educativo. Os autores do projeto explicitam uma orientação embasada nos teóricos italianos (G. Giovannoni e C. Brandi) e ressaltam a seguinte referência conceitual do teórico Carlo Ceschi ${ }^{211}$ :

Quando apontada a impossibilidade de reconstituição arquitetônica do monumento estudado devemos proceder a mais segura consolidação das partes remanescentes e íntegras do edifício. Desse modo pode-se salvar o edifício no seu ambiente, coibir-se a especulação estilística e a invenção arquitetônica, e evitar-se o surgimento dos difíceis e quase insolúveis problemas de harmonização ambiental entre as novas intervenções. Nesse caso fica claro que a preocupação pela conservação da ambiência prevalece sobre os problemas específicos do restauro propriamente dito. (CESCHI, 1970 apud SÃO PAULO - cidade, 1999, p.5 In: IPHAN, 1965)

\footnotetext{
${ }^{209}$ Portaria IPHAN 230/02: “Art. 2: No caso de projetos afetando áreas arqueologicamente desconhecidas, pouco ou mal conhecidas que não permitam inferências sobre a área de intervenção do empreendimento, deverá ser providenciado levantamento arqueológico de campo pelo menos em sua área de influência direta. Este levantamento deverá contemplar todos os compartimentos ambientais significativos no contexto geral da área a ser implantada e deverá prever levantamento prospectivo de sub-superfície."

${ }^{210}$ Anteprojeto de requalificação dos remanescentes do Sítio Mirim (Folhas 1 e 2) In: IPHAN, 1965, s.p.

${ }^{211}$ CESCHI, Carlo. Teoria e storia del restauro. Roma: Mario Bulzoni Editori, 1970.
} 
Verifica-se, portanto, que essa proposta apresentada em 1999, ainda que possa ser questionada pelas opções de linguagem arquitetônica (uso de materiais e configuração da cobertura metálica), está conceitualmente alinhada com o posicionamento de C. Brandi que atesta que o restabelecimento da unidade potencial de uma obra arruinada é inaceitável, pois sobrepõe uma nova realidade inautêntica sobre a antiga concluindo que:

Pelo momento, devemo-nos limitar a aceitar na ruína o resíduo de um monumento histórico ou artístico que só pode permanecer aquilo que é, caso em que a restauração não poderá consistir de outra coisa a não ser na sua conservação, com os procedimentos técnicos que exige. (BRANDI, 2004, p. 67-68 - grifo nosso).

O parecer técnico do IPHAN ${ }^{212}$ sobre essa proposta para o Sitio Mirim apresenta uma série de rebatimentos evidenciado o incomodo mediante às premissas adotadas alegando que o projeto "[...] reserva aos remanescentes uma função quase que decorativa, abrigado sob um galpão metálico, com seus pisos revestidos por questionáveis placas de granito.” (Of. 05/00 In: IPHAN, 1965, s.p.). Além disso, foi ressaltado que ainda haveria elementos suficientes para uma eventual reconstituição. Com esses argumentos, a proposta não teve aprovação do IPHAN e não foi executada.

Esse impasse conceitual sobre a conservação do status quo de ruína ou a sua restauração (que na verdade se refere a uma reconstituição formal de um modelo preexistente) se estende a outros bens. A título de ilustração, ao retomar o caso da Sede da Fazenda Conceição, Paraibuna (SP), que, como apresentado, foi completamente arruinada, também foi enunciada a possibilidade de sua reconstituição. Ao detectar o inexorável estado de arruinamento, o então diretor do CONDEPHAAT Antônio Luiz Dias de Andrade atestou que a reconstrução a partir dos restos e de levantamentos previamente elaborados poderia ser possível: “[...] embora tais reconstruções sejam discutíveis e questionáveis sob vários aspectos." (Of. 90/83 In: IPHAN, 1974, s.p. - grifo nosso). Já, na acepção do arquiteto e técnico do IPHAN José Saia Neto, em relatório derivado de vistoria do local em 2003 há uma resposta direta a essa colocação, alegando que a reconstrução seria uma solução perfeitamente aceitável:

Não podemos concordar com as afirmações do arquiteto Antônio Luiz Dias de Andrade, de que a reconstrução do bem apresentaria aspectos discutíveis e questionáveis, uma vez que entendemos tratar-se de uma anastilose prevista em qualquer compêndio ou carta relacionada à restauração de edificações, especialmente se considerarmos que os painéis de vedação, de pau a pique, seriam substituídos de qualquer maneira. (NETO, 2003 In: IPHAN, 1974, s.p. - grifo nosso).

\footnotetext{
${ }^{212}$ Elaborado pelo arquiteto José Saia Neto (IPHAN/SP).
} 
Porém, devido à falta de evidências materiais, de fato esse patrimônio arquitetônico foi irremediavelmente perdido.

No âmbito dos debates patrimoniais, o tema da "reconstituição" é bastante controverso, pois, incorre na discussão da premissa da distinguibilidade para a leitura daquilo que é novo em relação ao preexistente. Esse preceito foi evidenciado nas teorias de Boito: " $2^{\circ}$ É necessário que os completamentos, se indispensáveis, e as adições [...], demonstrem não ser obras antigas, mas obras de hoje.” (BOITO, 2002, p. 60-61). A Carta de Veneza (1964) condensou claramente essa premissa: "Artigo $12^{\circ}$ : Os elementos destinados a substituir as partes faltantes devem integrar-se harmonicamente ao conjunto, distinguindo-se, todavia, das partes originais, a fim de que a restauração não falsifique o documento de arte ou de história." (ICOMOS, 1964 In: CURY, 2004, p.94).

Para a reconstituição da antiga Sede do Sítio Itaim foram usadas técnicas contemporâneas como o solo cimento; a diferenciação entre os trechos restituídos e os trechos originais se dá por texturas distintas de revestimento (mais antigas: mais rústicas; e as novas: mais lisas). O Memorial Descritivo atesta uma preocupação dos autores do projeto em tratar o "restauro como instrumento de educação" (SAIA, Memorial Descritivo, p.12 In: IPHAN, 2010). Para tanto, algumas paredes ficaram sem revestimento (o exemplo mais legível é no altar da capela) com o objetivo de demonstrar as técnicas construtivas originais em contraponto com as novas. Contudo, no resultado final da obra a pretensa distinguibilidade é pouco visível e muito sutil, dificultando a legibilidade das áreas reconstituídas. A ausência de uma evidente distinção entre as partes antigas (ruínas) e novas foi destacada quando da finalização das obras pelo seguinte parecer técnico do $\mathrm{DPH}^{213}$ :

Um dos três princípios fundamentais da disciplina da restauração arquitetônica - o princípio da distinguibilidade - expressa-se tenuamente na edificação restaurada: nos acabamentos diferenciados (liso $\mathrm{X}$ rústico) das paredes caiadas. As estruturas das paredes, em sua estratigrafia adquirida com a restauração - taipa, concreto leve, solocimento - expressavam, mais do que os revestimentos, o princípio da distinguibilidade; mas jazem por detrás dos revestimentos. (MAYUMI, Parecer Técnico, 2012 In: SÃO PAULO - cidade, SMC/CONPRESP, 2011, p.837)

A discussão sobre a opção da reconstituição incorre em outro ponto: a autenticidade daquilo que nos é apresentado hoje como a antiga Sede do Sítio Itaim em relação ao que de fato um dia ela foi. Logo após o tombamento da casa a situação de arruinamento foi adquirindo contornos periclitantes gerando mobilizações de grupos sociais ${ }^{214}$ que visavam a

\footnotetext{
${ }^{213}$ Elaborado pela arquiteta Lia Mayumi (PMSP/SMC/DPH).

${ }^{214}$ Associação Amigos do Bairro do Itaim Bibi, presidente: Aloysio Soares.
} 
preservação do máximo de elementos que pudessem conferir autenticidade para uma eventual reconstrução do bem que se arruinava:

Outrossim, comunicamos a esse Conselho, que portais, vigas e outras partes que deveriam permanecer no local acima citado, tornando-a mais autêntica, segundo consta, já desapareceram e as chuvas se incumbem da destruição final. Portanto urge providências capazes, a fim de que, esse Patrimônio Histórico de nossa Capital seja reconstruído e preservado. Que o façam cumprir o acordo firmado com o CONDEPHAAT. (Of. n. 092/83 In: SÃO PAULO - Estado, CONDEPHAAT, 1978, p. 324 - grifo nosso)

É possível constatar a importância que é conferida às ruínas como "documentos autênticos" (Art. 90 ICOMOS, 1964 In: CURY, 2004, p.93) para embasar uma proposta de reconstrução. Conforme Choay (1995) o conceito da autenticidade tem se desdobrado em uma multiplicidade de interpretações ao longo dos séculos em diversos campos do saber. Durante a Idade Média o autêntico se referia à legibilidade de um "texto" original que não leva em conta alterações que ocorreram ao longo do tempo. Ao ser aplicado aos artefatos materiais há que se considerar a condição da ação física na materialidade que se transforma segundo as condições externas (tempo, destruições, etc.). Ao ser transposto para o campo da preservação patrimonial (durante o século XIX) o conceito de autenticidade se estrutura a partir de um impasse: o autêntico se refere a uma condição "original" que fundamenta uma identidade estipulada e definida segundo uma determinada construção historiográfica; ou a autenticidade se aplica à condição da materialidade física que se transforma pelo porvir do tempo e demais situações (destruições antrópicas ou naturais).

No âmbito da preservação patrimonial, Renato de Fusco $^{215}$ (1994) fez uma inferência alegando que é necessário pensar a obra como um organismo que nasce em um determinado tempo e depois enfrenta uma existência própria; a sua presença material é tangível a uma constância relativa, modificada em seu percurso histórico. Suas diversas fases são mais ou menos "autênticas" segundo as qualificações e as interpretações que os processos historiográficos lhes conferem. O conceito da autenticidade conforme apresentado no Documento de $\mathrm{Nara}^{216}$ (1994) sintetiza essas acepções:

\footnotetext{
${ }^{215}$ FUSCO, Renato de. Autenticità e restauro. Restauro, Autenticità e patrimonio monumentale, Napoli, n. 129, p. 89-94, 1994.

216 Produto da "Conferência sobre autenticidade em relação à convenção do Patrimônio Mundial" (UNESCO/ICCROM/ICOMOS) realizada em 1994 na cidade de Nara (Japão). Na ocasião, uma série de teóricos apresentaram produções relevantes desenvolvendo o tema da autenticidade que foram consultados no compêndio publicado sobre o encontro científico: Nara Conference on Authenticity. Paris, UNESCO, 1995.
} 
9. A conservação do patrimônio cultural em suas diversas formas e períodos históricos é fundamentada nos valores atribuídos a esse patrimônio. Nossa capacidade de aceitar esses valores depende, em parte, do grau de confiabilidade conferido ao trabalho de levantamento de fontes e informações a respeito desses bens. O conhecimento e a compreensão dos levantamentos de dados a respeito da originalidade dos bens, assim como de suas transformações ao longo do tempo, tanto em termos de patrimônio cultural quanto de seu significado, constituem requisitos básicos para que se tenha acesso a todos os aspectos da autenticidade. (ICOMOS, 1994 In: CURY, 2004, p.321)

Sendo assim, ao retornar à análise do Sítio Itaim, a autenticidade das informações obtidas a partir dos remanescentes enquanto documentos originais é questionável na medida em que não foram localizadas referências definitivas sobre os detalhes arquitetônicos do que um dia foi de fato essa casa "bandeirista". Por outro lado, considerando que a autenticidade implica na soma de uma estratificação de diversas fases, o processo de arruinamento também poderia ser interpretado como parte do histórico da edificação.

Ao longo da trajetória do Sítio Itaim também foi elaborada uma proposta de aceitação do status quo de ruína prevendo uma cobertura para a proteção e a consolidação dos maciços de taipa que foi apresentada em 1984 pelo arquiteto Samuel Kruchin (então técnico do CONDEPHAAT). Através das ruínas ainda era possível induzir uma leitura do contexto espacial do partido bandeirista enfatizando seu funcionamento estrutural básico; assim, o arquiteto se posicionou veementemente contra a recomposição de uma pretensa forma primitiva, que seria considerada como um "neo-bandeirismo" (KRUCHIN, 1984 In: SÃO PAULO - Estado, CONDEPHAAT, 1978, p.318). O partido arquitetônico adotado foi justificado pelo autor através da constatação de dois principais núcleos de expressão da historicidade intrínseca desse bem:

o primeiro aponta para o testemunho de uma espacialidade e de um proceder construtivo tipologicamente inseridos no quadro da arquitetura bandeirista [...] o segundo deriva do atual estado do edifício e que é testemunho de um processo velado de arruinamento [...] Esse dado da história recente da edificação a impregna de um valor de testemunho síntese dos conflitos que envolvem a preservação e do que ela significa socialmente, já que tal procedimento é generalizado entre nós." (KRUCHIN, 1984 In: Op. cit., p.317-318)

As argumentações dessa proposta de Kruchin sintetizam o que tem sido desenvolvido nesta análise: as ruínas preexistentes são consideradas não somente como testemunho de uma tipologia arquitetônica referencial para a identidade paulista (a casa bandeirista), mas também podem ser interpretadas como uma espécie de denúncia em relação às práticas de preservação, refletindo a conturbada relação que se estabeleceu com o bem na contemporaneidade. 
Como apresentado, no Sítio Itaim, há remanescentes de outra edificação contígua à sede que foram conservados em seu status quo demonstrando uma distinção na atribuição de valores e significados em relação às ruínas da casa "principal”. Não se chegou a um consenso sobre a configuração daquela antiga estrutura mesmo com as pesquisas cartoriais e prospecções arqueológicas. Sem uma referência precisa sobre seu uso e finalidade, essas ruínas foram consolidadas sob a argumentação de que: "A preservação destes restos compostos pelas fundações e arranques de paredes de taipa de pilão é, pois, providência indispensável, como único registro conhecido das construções de importância secundária." (SAIA, Relatório Ilustrativo In: IPHAN, 2010, s.p. - grifo nosso).

A alternativa da conservação das ruínas em seu status quo tomou maior vulto no caso do Sítio Mirim, com a recente proposta (2007) de Apiacás Arquitetos. Em entrevista, o arquiteto Anderson Freitas salientou o objetivo de interferir minimamente na ambiência dos remanescentes, propondo uma solução de cobertura que praticamente se "mimetiza" com a topografia do terreno. $\mathrm{O}$ aspecto documental e simbólico dessas ruínas pretende ser valorizado através da atribuição de um papel didático que contasse a história do lugar, das casas bandeiristas e sua relação com a geografia local (desnível do terreno e a vista da várzea do Tietê) através de um projeto expográfico que comporia o percurso dos visitantes. O projeto foi aprovado nos órgãos competentes, com ressalvas, dentre elas a cota da marquise, que deveria ser aumentada caso se optasse pela recomposição da casa; porém, as polêmicas e contestações inviabilizaram a execução do projeto até o presente momento.

É pertinente destacar ainda a exiguidade na apreciação do potencial valor estético das ruínas dos casos aqui analisados. Como detectado pela pesquisadora Ascensión Hernández Martíne ${ }^{217}$ em seu artigo $L^{`}$ Estetica del deterioramento e dell imperfezione: una tendenza in crescita nel restauro arquitetônico (2013) no último decênio houve uma proliferação de um tipo de restauro que conserva a edificação "congelada" em seu estado de deterioração e imperfeição optando pela mínima intervenção a fim de expor um estado "visceral" da arquitetura; sobre esse tema Henri-Pierre Jeudy se refere a "uma estética contemporânea do abandono" (JEUDY, 2005, p.70).

\footnotetext{
${ }^{217}$ MARTÍNEZ, Ascensión H. L` Estetica del deterioramento e dell imperfezione: una tendenza in crescita nel restauro arquitetônico. Palladio: rivista di storia dell architettura e restauro, Roma, n. 51, p. 89-106, 2013.
} 
No contexto dessa abordagem nos referimos ao caso da Penitenciária Eastern State S18 $^{218}$ (Filadélfia, EUA). Conforme destaca Segawa (2014), o conjunto é uma paradigmática e pioneira implantação do sistema penal que ficou conhecido como "pensilvânico" ou "filadélfico" (SEGAWA, 2014, p.20) em que havia uma extrema individualização da clausura. Os primeiros registros dessa edificação são de 1821, a partir de 1829 houve um projeto para ampliação do arquiteto inglês John Haviland (1792-1852). O local foi reconhecido como patrimônio histórico nacional em 1965 e funcionou como penitenciária até 1970. Com o encerramento das atividades, o conjunto acumulou um amplo processo degenerativo; a despeito de seu reconhecimento como bem cultural, sugeriu-se a sua demolição. Em fins da década de 1988, após clamores de ativistas pela preservação do patrimônio optou-se pela criação de um museu. A partir de 1998, o local passou a abrigar atividades culturais, administradas por uma organização privada sem fins lucrativos (Eastern State Penitentiary Historic Site).
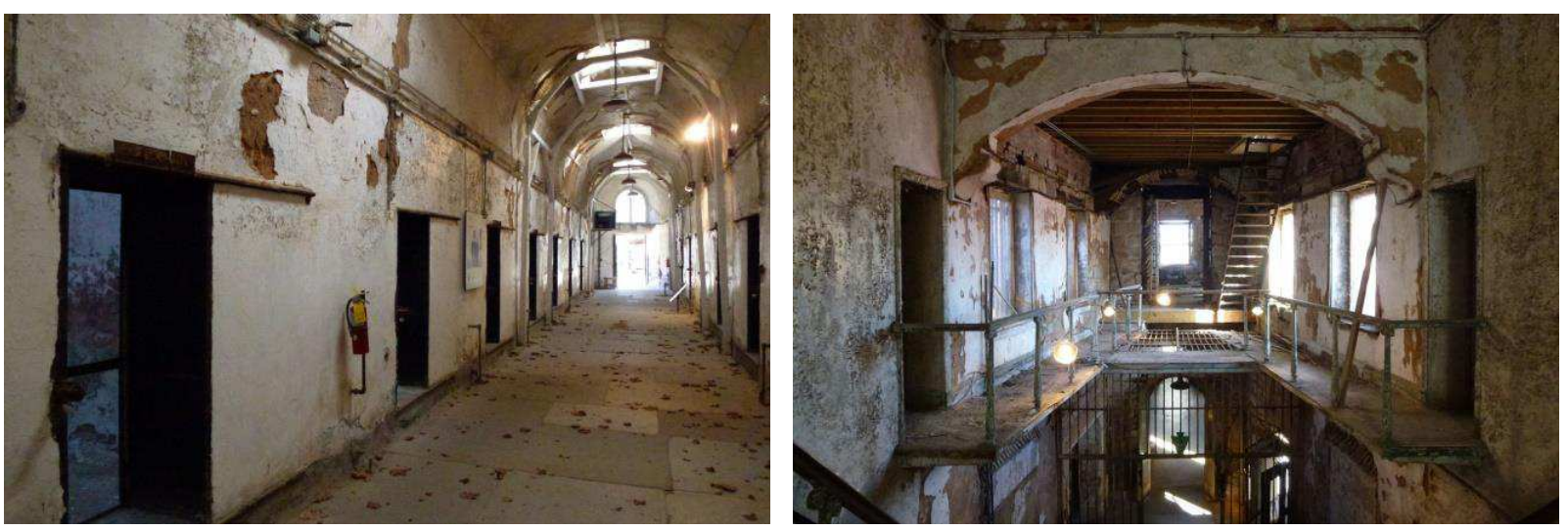

Fig. 107 (i-ii): Penitenciária de Eastern State, Filadélfia (EUA). Fotos: Hugo Segawa.

No que diz respeito à materialidade do conjunto, optou-se pela manutenção das marcas da destruição geradas pelo abandono e interrupção da atividade original (prisão). Essa alternativa de conservação tem um forte apelo simbólico reforçando a leitura desse lugar de memória extremamente conturbada de uma tipologia institucional de grande complexidade pelos aspectos psicossociais envolvidos e, em certa medida amplificando os martírios da reclusão do sistema penitenciário. Ainda que se trate de um objeto arquitetônico diverso dos nossos estudos de caso em um contexto cultural distinto, é pertinente pontuar a referência de intervenções que se valem esteticamente das marcam da degradação.

\footnotetext{
${ }^{218}$ Cf.: SEGAWA, Hugo. Memórias do Cárcere: Penitenciária de San Luis Potosí e Eastern State Penitentiary como lugares de cultura. In: Desenhos da pesquisa: conhecimento / produção. Universidade de São Paulo Museu de Arte Contemporânea, São Paulo, p. 17-24, 2014. Disponível em: $<$ http://aroeira.usp.br/pgeha/livros/DESENHOS\%20DA\%20PESQUISA.pdf>, acesso em 07 de nov. 2016.
} 
Através das trajetórias do Sítio Mirim e do Sítio Itaim foi possível evidenciar duas possibilidades distintas para esse grupo de ruínas da incúria: para o Sítio Mirim, uma edificação pública situada numa área periférica da cidade, há uma proposta para a musealização e consolidação dos remanescentes de taipa; no Sítio Itaim, uma antiga residência rural de propriedade privada situada numa área supervalorizada da capital paulista, fez- se valer uma sanção judicial que previa a "restauração" da casa como uma punição aos proprietários e uma condição para poder explorar o valor imobiliário do local.

Os impasses conceituais que se desenrolaram nos debates dos técnicos dos órgãos de preservação (IPHAN, CONDEPHAAT, DPH e CONPRESP) evidenciam a confluência de duas opções antagônicas (consolidação e reconstituição) que se resumem na aceitação ou não da ruína de um bem arquitetônico tombado e na necessidade de reconstituir um objeto que remete a uma determinada imagem de passado que configura a identidade local. Essas duas posturas contrárias se estruturam a partir de justificativas teóricas fundamentadas em conceitos do restauro crítico que se coadunam com referências à Carta de Veneza (1964), principalmente ao artigo $9^{\circ}$ que estipula os preceitos para a restauração: no Sítio Itaim as ruínas são consideradas como documentos autênticos para um trabalho de "restauração" de uma determinada arquitetura anterior, enquanto que no Sítio Mirim as ruínas não foram interpretadas como documentos conclusivos sobre a casa original, esbarrando na premissa de que a restauração deve "terminar onde começa a hipótese" (ICOMOS, 1964 In: CURY, 2004, p.93). 


\section{Capítulo 4}

Ruínas do incidente: trauma e memória 



\section{Ruínas do incidente: trauma e memória}

Consideramos nesse grupo, aquelas edificações de reconhecido valor cultural que até pouco tempo conhecíamos de forma íntegra e passaram por algum tipo de incidente catastrófico causado por fatores antrópicos (guerras, incêndios, colisões, demolições criminosas, etc.) ou naturais (inundações, terremotos, etc.) que gerou sua destruição (parcial ou total).

Dentre os fatores para a abordagem, interpretação e tratamento desse grupo, pode-se evidenciar: a contemporaneidade ao arruinamento, a dimensão da perda física e simbólica e a aceitação (ou não) dessa perda. Do ponto de vista simbólico, o caráter evocativo dessas ruínas remete à perplexidade diante da tragédia e da destruição, um sentimento que pode ser sintetizado pelas seguintes asserções de Jean Starobinski:

[...] Para que uma ruína pareça bela é preciso que a destruição seja bastante longínqua e que se tenha esquecido suas circunstâncias precisas; [...] Ninguém sonha tranquilamente diante de ruínas recentes que fazem sentir o massacre: estas são logo desentulhadas para reconstruir. (STAROBINSKI, 1994, p.202 - grifo nosso)

Muitas dessas ruínas do incidente podem ser consideradas como os "[...] símbolos que asseguram a rememoração" (JEUDY, 2005, p. 58) adquirindo um papel patrimonial com uma mensagem de sobrevivência em relação ao evento que as desencadeou. Na Era Moderna, a perplexidade de filósofos, artistas e intelectuais de diversas áreas frente às ruínas provocadas por incidentes súbitos e traumáticos (de ordem natural ou antrópica) pode ser constatada através de alguns, dentre tantos, eventos traumáticos. Um caso de grande repercussão foi o terremoto de Lisboa que ocorreu em 1755, destruindo quase que completamente a cidade. Houve algumas digressões intelectuais na Europa sobre o evento como o Poème sur le désastre de Lisbonne (1756) de Voltaire (1694-1778); Immanuel Kant (1724-1804) também dedicou textos ao evento na tentativa de trazer o terremoto da esfera do transcendente para o domínio da ordem natural. As ruínas do Convento do Carmo (Lisboa, Portugal) permanecem até a atualidade como uma referência memorial ao grande terremoto, parte do convento foi reestruturada no século XIX e hoje acolhe um museu arqueológico e a sede da Associação de Arqueólogos Portugueses. 

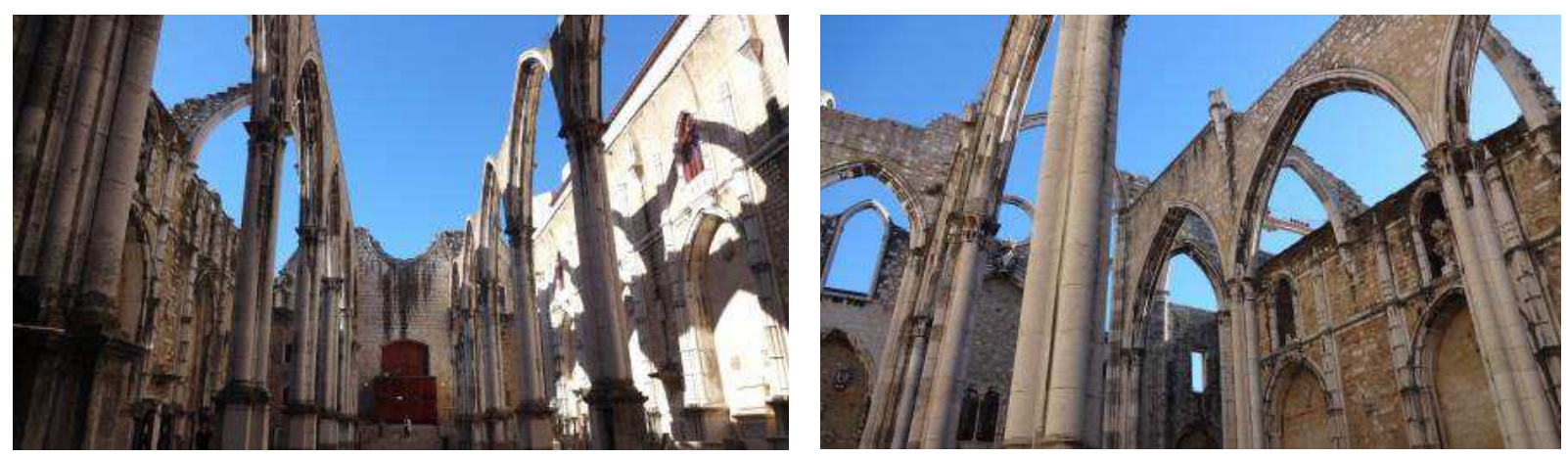

Fig. 108 (i-ii): Convento do Carmo, Lisboa (Portugal), 2013. Fotos: Autora.

No que diz respeito às destruições causadas de forma antrópica o "sentido memorável atribuído a qualquer catástrofe" (JEUDY, 2005, p. 59) pode se amplificar na memória coletiva quando a composição pictórica das ruínas é utilizada para deflagrar a noção do impacto da destruição. No século XIX, a Comuna de Paris (1871) proporcionou incêndios e destruições de grandes proporções, resultando em extensos levantamentos fotográficos como o Guide à travers les ruines: Paris et ses environs (1871) de Hans Ludovic e J. -J. Blanc que documentam a situação procurando exponencializar o caráter estético da ruína.

No âmbito dos debates da preservação patrimonial a situação das ruínas provocadas por incidentes tomou grande vulto com as duas Grandes Guerras. Após a Segunda Guerra Mundial, devido ao grau destrutivo provocado pelo maior potencial bélico, o denominado "patrimônio da guerra"219 (GEGNER, ZIINO, 2012, p. 1) englobou um vasto legado. O emblemático Memorial da Paz em Hiroshima que integra as ruínas do edifício que foi construído para uma exposição comercial da Prefeitura Municipal é um exemplo cabal desse papel memorial. As ruínas dessa edificação foram os únicos remanescentes mantidos da destruição de 1945 na cidade. Em 1966, após uma série de debates, o Departamento de Arquitetura da Faculdade de Engenharia da Universidade de Hiroshima decidiu pela efetiva conservação do aspecto arruinado do conjunto que foi declarado como Patrimônio da Humanidade em $1996^{220}$.

Do ponto de vista documental, esse tipo de ruína pode revelar valiosos detalhes arquitetônicos até então ocultos, como materiais de construção sob as superfícies de revestimento, composição das fundações, etc. Essas informações podem subsidiar e orientar

\footnotetext{
${ }^{219}$ Ver mais informações em: The heritage of war. GEGNER, Martin; ZIINO, Bart (Editor). Abingdon, Oxon: Routledge, 2012.

${ }^{220}$ Conforme consultado em UNESCO - World Heritage, disponível em: <http://whc.unesco.org/en/list/775>, acesso em: 26 jun. 2014.
} 
as respectivas intervenções nas edificações danificadas. Há que se considerar que esses remanescentes não somente evocam, mas documentam o episódio trágico que os acometeu.

A questão que se interpõe é: o quanto se pretende recordar e historicizar o incidente que causou a ruína?

Num contraponto à ideia de se tornar um memorial, as ruínas de uma destruição fulminante ensejam outra abordagem: a força da reconstrução, condensando a capacidade de resiliência de uma cultura, de uma nação, de uma cidade mediante uma perda trágica. A negação da ruína se torna o meio para subverter o evento destrutivo em um momento de convergência e de união aglutinando a força moral de toda uma comunidade. Na maioria das vezes essas edificações que foram arruinadas de forma abrupta faziam parte do cotidiano da vida de pessoas, cidades ou territórios desempenhando um tipo de função até há pouco tempo, as referências e as conexões cognitivas com a edificação "íntegra" ainda são muito recentes o que pode constituir uma grande dificuldade em aceitar essa ruína e mudar a relação que até então se estabelecia com o bem.

Assim como no grupo estudado no capítulo anterior, a contemporaneidade do desafio de afrontar esses arruinamentos se renova constantemente já que diversos bens arquitetônicos são continuamente acometidos por toda ordem de incidentes catastróficos. Há inúmeros episódios cujo arruinamento foi deflagrado de forma consciente e intencional a fim de atingir todo um corpus cultural, como as recentes destruições de patrimônios na Síria; um tema que não faz parte do recorte desta tese, mas, conforme atesta o trabalho de Paolo Matthiae $(2015)^{221}$, não é novo e exclusivo do século XXI e que devido à emergência, tem se ampliado nos debates e investigações da preservação patrimonial.

Ao trazer a análise para o Brasil, tendo como referência o conjunto de bens tombados (ou com abertura de processo de tombamento) do IPHAN há exemplos que foram acometidos por incidentes, alguns com grande repercussão como: a Igreja de Nossa Senhora do Carmo ${ }^{222}$ de Mariana (MG) que ocorreu em 1999 comprometendo o teto da nave com a obra do mestre Francisco Xavier Carneiro (1765-1840) e dois altares laterais - a edificação foi posteriormente reconstituída; a enchente de 2001 que arruinou diversas edificações no centro histórico de Goiás Velho (GO) que acabara de ser declarado como Patrimônio Histórico e Cultural da

\footnotetext{
${ }^{221}$ Cf.: MATTHIAE, Paolo. Distruzioni saccheggi e rinascite - gli attachi al patrimonio artistico dall`antichità all Isis. Milano: Mondadori Electa S.p.a., 2015.

${ }^{222}$ Processo IPHAN: 0075-T-38, tombamento no Livro de Belas Artes.
} 
Humanidade pela UNESCO ${ }^{223}$. No Estado de São Paulo, um incêndio na Estação da Luz ${ }^{224}$ em dezembro de 2015 a destruiu parcialmente comprometendo as instalações do Museu da Língua Portuguesa; medidas para a sua restauração estão tramitando nos respectivos órgãos responsáveis (IPHAN, CONDEPHAAT e CONPRESP).

Para verificar como os aspectos apresentados se interpõem para a identificação da situação e intervenção nesse grupo de ruínas, são considerados para a nossa análise no recorte do Estado de São Paulo os seguintes casos: Teatro Cultura Artística (São Paulo, SP) e Igreja Matriz São Luiz de Tolosa (São Luiz do Paraitinga, SP).

O Teatro Cultura Artística era uma edificação com projeto do escritório de Rino Levi (1901-1965), construído entre 1947-1949 e tinha um reconhecido mérito arquitetônico pela forma com que a espacialidade do programa foi abordada. O imóvel não era oficialmente tombado, mas havia um processo tramitando no CONDEPHAAT desde 1995 reconhecendo seu valor cultural num contexto de obras do arquiteto para a capital paulista. Em 2008 o teatro foi acometido por um incêndio que arruinou parcialmente suas instalações. A Sociedade de Cultura Artística (SCA) apresentou sua decisão pela reconstrução do teatro com um projeto novo e modernizado integrando os remanescentes frontais (foyer e elementos da fachada como caixilhos e o painel de mosaicos) que foram tombados após o incêndio pelas instâncias municipal, estadual e federal.

A Igreja Matriz São Luiz de Tolosa está localizada em São Luiz do Paraitinga (SP) cujo conjunto urbano é listado como bem cultural desde 1982 (CONDEPHAAT) devido à configuração de seu traçado regular e da uniformidade de sua arquitetura proveniente dos séculos XVIII e XIX. Em janeiro de 2010 a cidade sofreu uma enchente de grandes proporções que a destruiu parcialmente arruinando edificações relevantes. Nosso recorte se concentra na perda da Igreja Matriz, um bem de grande significado afetivo e cuja ausência compromete a leitura da configuração da praça central da cidade. Esse caso evidência os debates entre as instituições públicas de preservação patrimonial e a comunidade local que culminou com a decisão de se reconstruir a Igreja.

\footnotetext{
${ }^{223}$ O Centro histórico de Goiás foi inscrito na lista da UNESCO em 2001 por testemunhar a colonização da região central do Brasil e a ocupação urbana derivada da atividade de mineração. Consultado em: Conforme consultado em - UNESCO Horld Heritage, disponível em: $<$ http://www.unesco.org/new/pt/brasilia/culture/world-heritage/list-of-world-heritage-in-brazil/historic-centre-ofthe-town-of-goias/> acesso em 11 jun. 2015.

224 Processo IPHAN: 0944-T-96, tombamento no Livro de Belas Artes e Livro Histórico; processo CONDEPHAAT: 20097/76 - resolução 25/1982; CONPRESP: resolução 05/91 (ex officio).
} 
Para o Teatro Cultura Artística a discussão se estabelece ao verificar o quanto e como os remanescentes da antiga edificação reconhecida como patrimônio cultural foi incorporado à nova proposta. Já a Igreja Matriz São Luiz de Tolosa remete à problemática da reconstrução, considerando o seu significado simbólico para a população local, frente ao dramático desastre. Através desses estudos de caso pretende-se verificar em que medida a perplexidade diante da tragédia, a contemporaneidade ao processo de arruinamento, a dimensão das lacunas e a dificuldade em aceitar as perdas arquitetônicas e urbanas foram pontos cruciais direcionando as discussões e as opções de tratamento às ruínas desses bens. 


\subsection{Teatro Cultura Artística ${ }^{225}$}

Desde a fundação da Sociedade de Cultura Artística ${ }^{226}$ em 1912 foi acalentada a ideia da construção de um teatro sede para acolher suas atividades culturais. Em fins de 1920 foi comprado do terreno na Rua Nestor Pestana (São Paulo, SP), nome dado em homenagem ao primeiro dirigente da instituição. Entre 1942 e 1943, foi elaborado o projeto original do Teatro Cultura Artística pelo escritório "Rino Levi Associados" coordenado por Rino Levi e Roberto Cerqueira Cesar (1917-2003). Devido à Segunda Guerra Mundial e ao contexto do país em plena Era Vargas (1930-1945) o projeto somente foi aprovado pela municipalidade de São Paulo em novembro de 1945 (REIS FILHO In: IPHAN, 2010). A construção foi realizada a partir de 1947 e o teatro foi inaugurado em $1950^{227}$.

A proposta foi desenvolvida a fim de adequar o programa ao terreno com forma irregular. Os principais aspectos que conferiam excelência ao projeto eram: o grande espaço da sala de espetáculos e sua qualidade acústica, a fachada envidraçada e o grande painel de pastilhas, ligeiramente em curva que ampliava a percepção do desenho a partir da rua.

Foi previsto um conjunto de duas salas de concerto e arte dramática, sendo a maior com 1.560 lugares e a menor com 458 lugares. A solução adotada sobrepôs a sala grande à pequena (executada décadas depois) numa base essencialmente triangular; esses ambientes foram objeto de avançados estudos sobre as relações entre acústica e forma arquitetônica. A grande plateia, cuja inclinação atingia seu ponto mais alto junto à fachada, descia em direção ao fundo do terreno num dos vértices do triângulo, onde se localizava o palco.

\footnotetext{
${ }^{225}$ O material consultado sobre o Teatro Cultura Artística foi obtido junto a: Superintendência do IPHAN/SP: processo de tombamento IPHAN 1.603-T-10, processo administrativo: 01450.008323/2010-96, (IPHAN, 2010); CONDEPHAAT - Processo 33.188/95 (SÃO PAULO - Estado, CONDEPHAAT, 1995) e, após o incêndio CONDEPHAAT - 58.145/08 (SÃO PAULO - Estado, CONDEPHAAT, 2008); Prefeitura Municipal de São Paulo/SMC (DPH e CONPRESP): Resolução 14/CONPRESP/2011. Material iconográfico obtido junto ao Arquivo Digital FAU USP (Revista Acrópole) e com Paulo Bruna Arquitetos Associados. Entrevista realizada com: o arquiteto Paulo Bruna em 30.04.2015. Foi realizada visita em 09.06.2014 guiada pelo arquiteto Philippe Metropolo (Escritório Paulo Bruna Arquitetos Associados); não houve autorização por parte da Sociedade de Cultura Artística para fotografar o local internamente.

${ }^{226}$ Sociedade de Cultura Artística é uma instituição privada, sem fins lucrativos, criada por um grupo de intelectuais e artistas no início do século XX a fim de divulgar obras de arte de várias categorias (exposições, concertos, espetáculos teatrais, etc.); as atividades remanescem até a atualidade através da manutenção da Sociedade pelos respectivos sócios. Maiores informações em: <http://www.culturaartistica.com.br/> acesso em 03 de abril 2016.

${ }^{227}$ A cerimônia de inauguração foi realizada nas noites de 8 e 9 de março de 1950 com Heitor Villa-Lobos e Camargo Guarnieri revezando-se na regência da Sinfônica de São Paulo.
} 

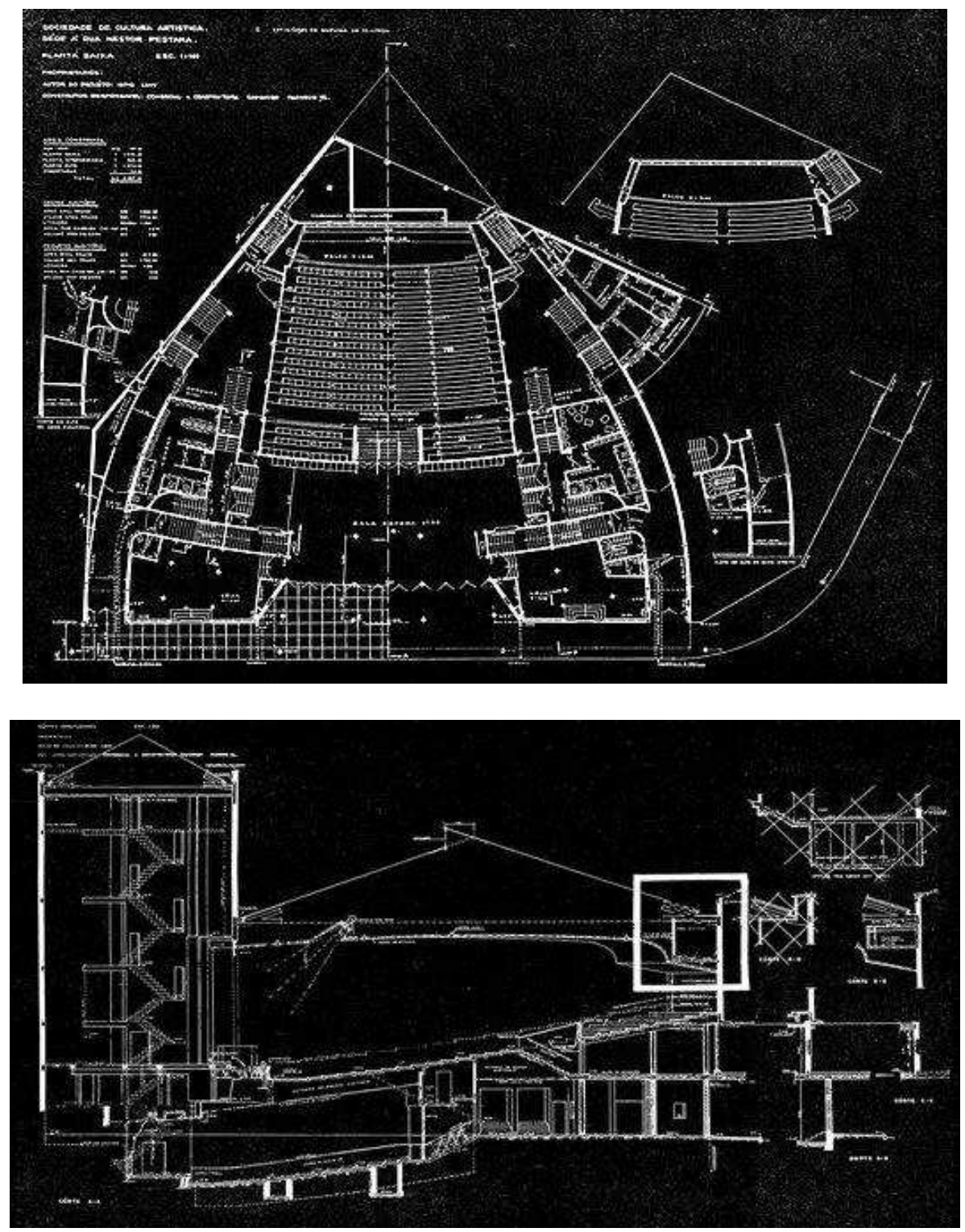

Fig. 109 (i-ii): Teatro Cultura Artística - Planta pavimento térreo e corte do projeto de Rino Levi Associados. Fonte: Revista Acrópole, n. 145, maio/1950. Arquivo Digital FAU USP.

Disponível em: <http://www.acropole.fau.usp.br/edicao/145>, acesso em 04 de mar. 2015.

O desenvolvimento do tema da curvatura paraboloide no piso, paredes e teto da sala principal fazia parte do projeto acústico com o objetivo de difundir o som. O palco giratório expressava o interesse dos arquitetos em aplicar conhecimentos de cenografia. Houve também um minucioso estudo que incluía o mobiliário (com poltronas retráteis especiais para o auditório) e elementos de comunicação visual. Circulações e camarins situaram-se nas laterais da sala, havia uma área liberada para o hall de acesso e uma segunda sala para espetáculos menores ao elevar a plateia principal do solo. Junto à extensa fachada curva desenvolviam-se os saguões e espaços administrativos tanto no térreo quanto no primeiro pavimento. Aproveitando esse desnível da parte superior da plateia, o foyer todo envidraçado no primeiro pavimento constituía um local de observação da cidade, ainda que restrito ao topo das casas vizinhas. 

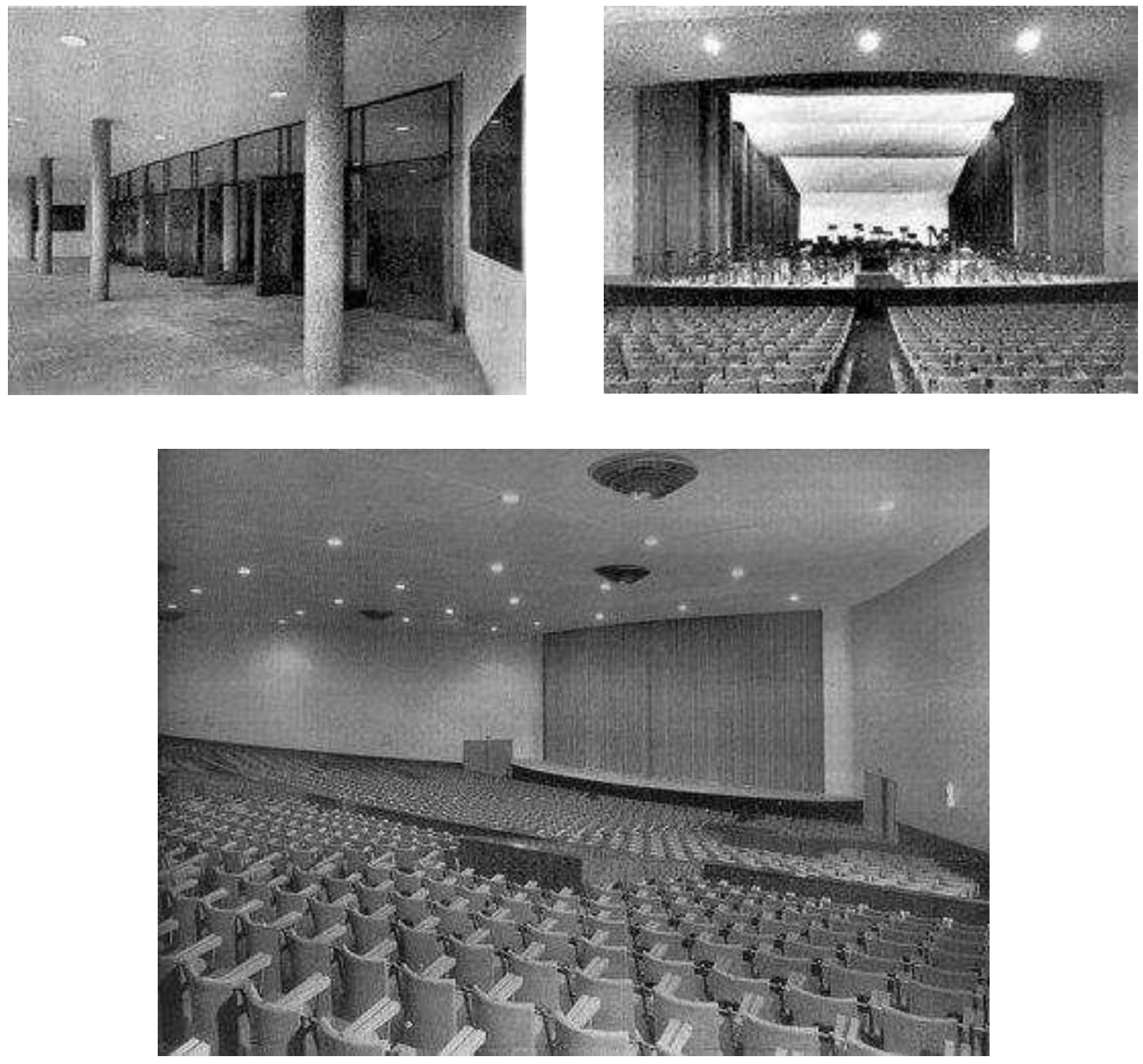

Fig. 110 (i-iii): Parte interna do teatro recém-inaugurado. Fonte: Revista Acrópole, n. 145, maio/1950. Arquivo Digital FAU USP. Disponível em: <http://www.acropole.fau.usp.br/edicao/145>, acesso em 04 mar. 2015.
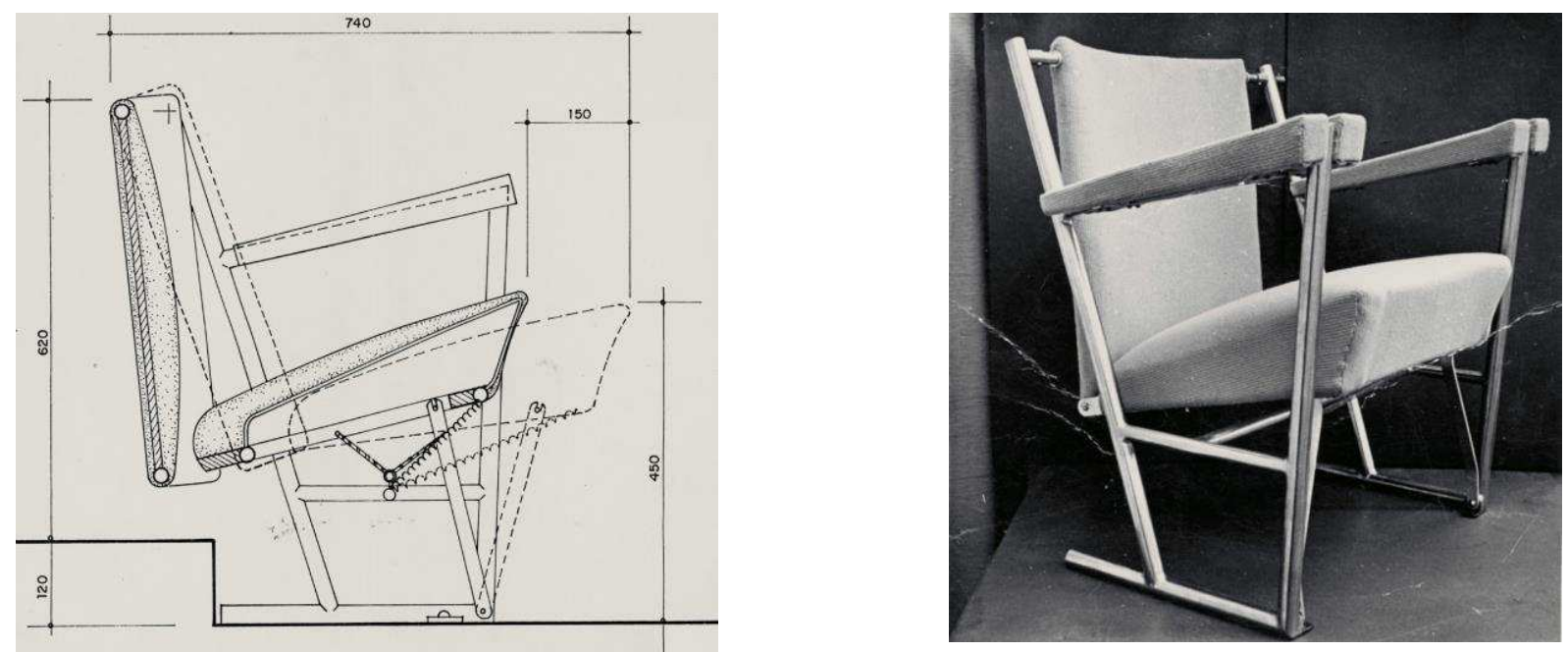

Fig. 111 (i-ii): Teatro Cultura Artística - projeto de poltronas. Fonte: Projeto Rino Levi, cópias In: IPHAN, 2010, p. 146-147. 
Para a grande parede curva dos fundos da sala de projeções foi especialmente encomendado um mosaico de pastilhas de vidro para compor a fachada do teatro configurando movimento e profundidade. Para esse painel foi realizado um concurso do qual participaram Roberto Burle Marx (1909-1994), Jacob Ruchti (1917-1974) e Emiliano Di Cavalcanti (1897-1976) cujo trabalho foi escolhido. O painel media 48 metros de largura por 8 metros de altura e levava à paisagem urbana o tema das musas das artes (intitulado "Alegoria das artes").

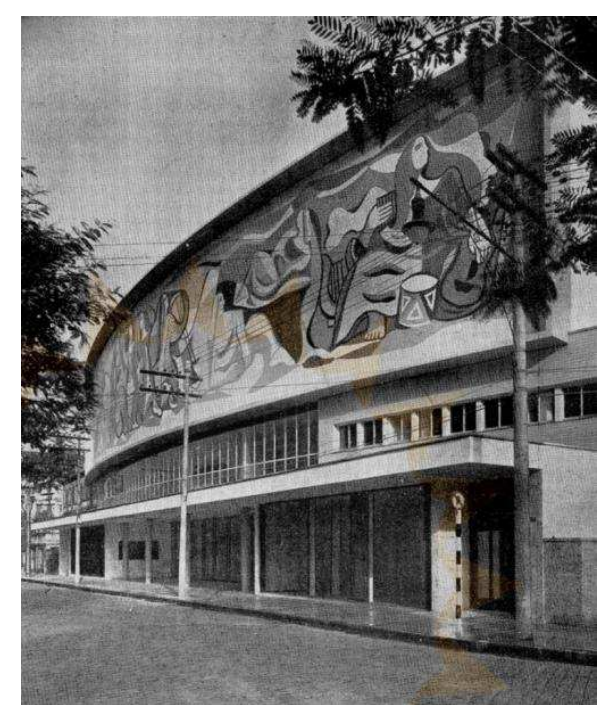

Fig. 112: Fachada do Teatro Cultura Artística. Fonte: Revista Acrópole, $\mathrm{n}$. 145, maio/1950. Arquivo Digital FAU USP. Disponível em:

$<$ http://www.acropole.fau.usp.br/edicao /145>, acesso em 04 mar. 2015.

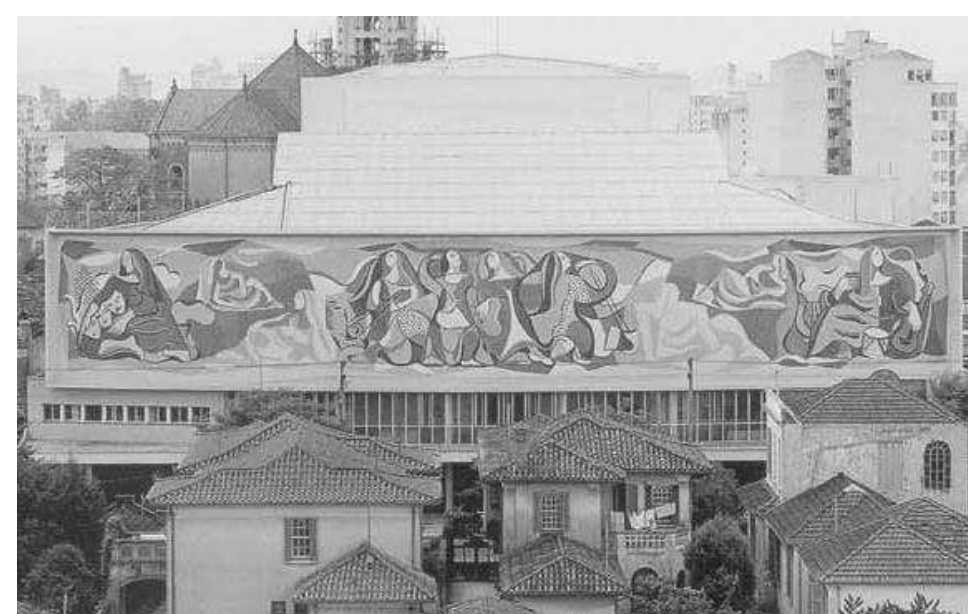

Fig. 113: Fachada do Teatro Cultura Artística no contexto urbano. Fonte: SÃO PAULO - Estado, CONDEPHAAT, 1995, p. 05 e p.86.

A composição do desenho de Di Cavalcanti se estrutura através de grupos de figuras femininas dispostas simetricamente dando uma sensação de equilíbrio a partir de uma linha contínua, bastante irregular, que diferencia a área do painel e o limite da superfície da parede; entre essas duas linhas há uma cor lisa que confere volume ao painel e o emoldura. As cores predominantes funcionam em pares complementares (o roxo e o verde dominando nas figuras humanas) enquanto o marrom aparece com grande peso e o azul cria o fundo. Pelas dimensões e composição de formas e cores, o mural é considerado um marco na obra de Di Cavalcanti.

Devido à excelência de sua conformação espacial e ao tratamento acústico, logo após a inauguração, o teatro foi aclamado em publicações nacionais e internacionais ${ }^{228}$. Ao longo dos

${ }^{228}$ Publicações nas seguintes revistas: Acrópole, n. 145, maio 1950; L’Architecture D`Aujourd hui n. 29, maio 1950; Architectural Record, n.7, jul. 1950; Kunst in Volk, n. 9/10, set. out. 1950; Domus, n. 259, jun. 1951; The 
anos o projeto sofreu adaptações. Quando inaugurado, o teatro já não atendia ao número de sócios da Sociedade de Cultura Artística (2.500), a grande sala não comportava o número necessário de poltronas, levando a Sociedade a instaurar o desdobramento das apresentações, que acabou por constituir uma tradição do programa de assinatura.

Em 1955 parte do telhado em estrutura de madeira desabou, exigindo ações e investimentos imediatos para sua recuperação; para solucionar o problema o Teatro foi alugado à TV Excelsior. A Sociedade de Cultura Artística retomou a administração do Teatro somente em 1971, quando foi necessária uma nova reforma nos espaços. Roberto Cerqueira César coordenou os trabalhos entre 1972 e 1977, neste período foi feita a substituição integral das poltronas originais destruídas pelo mau uso e também foi construída a sala menor, presente no projeto original, mas que não havia sido concretizada até então. Foram executadas algumas adaptações aos acessos das salas e nos sistemas de apoio técnico, além de alterações nas superfícies de reflexão do som (SÃO PAULO - Estado, CONDEPHAAT, 1995).
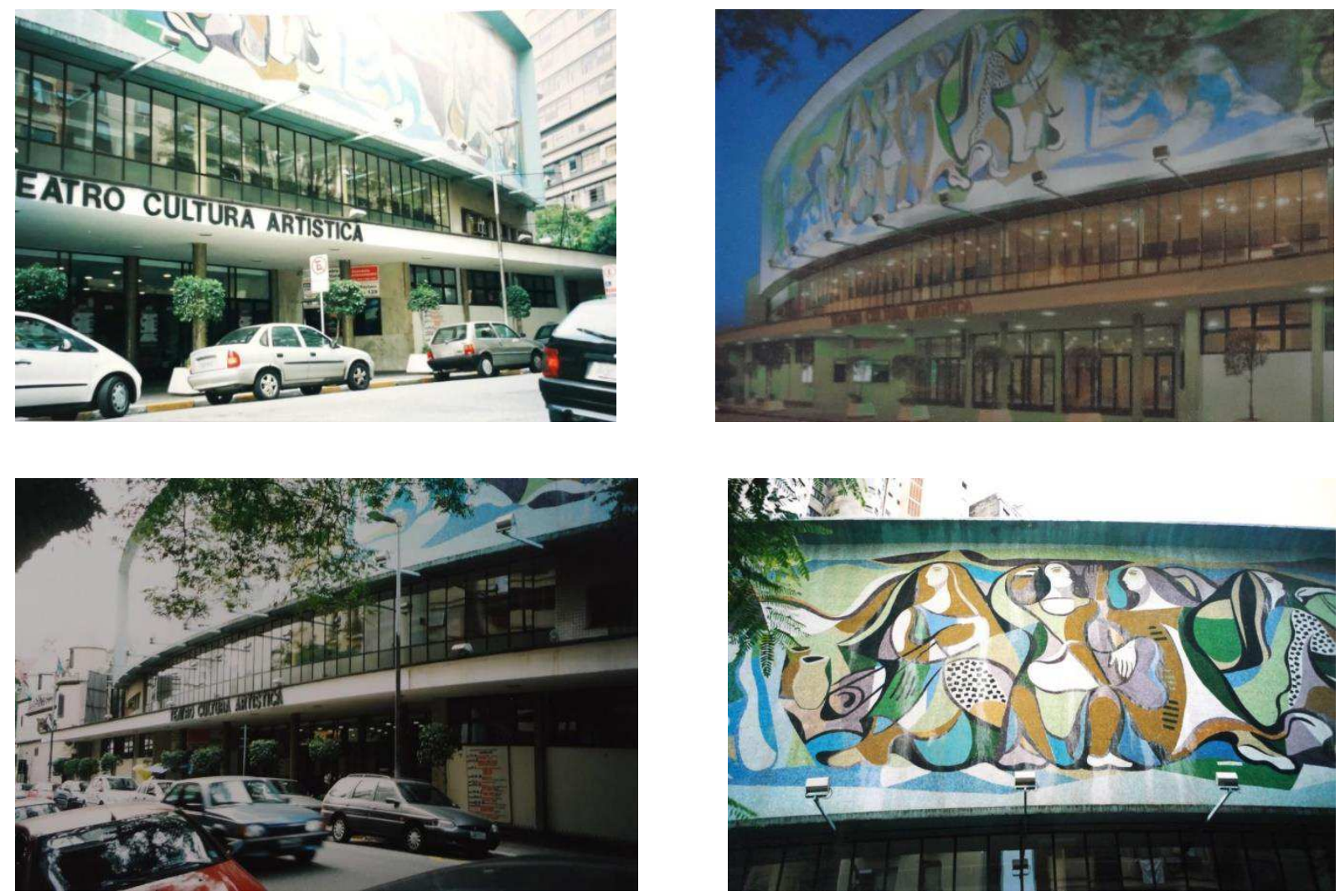

Fig. 114 (i-iv): Imagens da fachada do Teatro, década de 1990. Fonte: SÃO PAULO - Estado, CONDEPHAAT, 1995, p. 69-71. 
O dinamismo da programação e os patrocínios comerciais passaram a demandar espaços de recepção e apoio ao público (como foyer e sanitários) mais amplos. Além disso, com a verticalização da área central da capital paulista, a mudança de tipologia das edificações adjacentes e pela pouca largura da Rua Nestor Pestana, o mural de Di Cavalcanti foi parcialmente eclipsado pela impossibilidade de um ângulo propício para sua visualização plena a partir do espaço público.

Em 1994 foi aberto o processo de tombamento pelo Dr. Modesto S. Barros Carvalhosa e Dr. Lúcio Gomes Machado junto ao CONDEPHAAT ${ }^{229}$. Essa instrução indicava um conjunto de 11 obras de Rino Levi na cidade de São Paulo tendo em vista: “Os [...] exemplos mais significativos das fases de sua carreira, em melhor estado de conservação e elenco mínimo para a compreensão da obra do arquiteto e valorização da cultura paulista." (SÃO PAULO - Estado, CONDEPHAAT, 1995, p.31). Dentre essas obras estava o Teatro Cultura Artística: "Considerado o melhor auditório de música da cidade [...]" (Op. cit., 1995, p. 34), um projeto que se insere num período mais maduro da carreira do arquiteto cujo início foi em 1927 e término em 1965. As reformas que tinham ocorrido ao longo das décadas no Teatro não comprometeram aspectos relevantes como os valores espaciais e acústicos da grande sala e a composição da fachada.

\subsubsection{Incêndio e providências}

Até 2008, o processo de tombamento não teve qualquer definição, quando ocorreu um incêndio em 17 de agosto, que mudou drasticamente a situação do edifício. O fogo teve início durante a madrugada no palco da sala e causou a queda da cobertura de $3.000 \mathrm{~m}^{2}$. O Teatro ficou como uma "caixa oca” (CARRILHO, 2009), áreas internas com seus revestimentos e estruturas foram atingidas. Devido à ação das portas corta fogo, o foyer que compunha a fachada frontal com sua caixilharia não sofreu maiores danos, nem o mural de Di Cavalcanti na fachada. Todo o figurino das peças em cartaz, além de documentos, equipamentos e dois pianos foram destruídos (Portaria 282/08 In: SÃO PAULO - Estado, CONDEHAAT, 2008). Felizmente não houve mortos ou feridos.

Depois desse incidente, a Sociedade de Cultura Artística se manifestou perante o órgão de preservação CONDEPHAAT sobre as providências que seriam tomadas em caráter emergencial e sua inclinação em construir uma nova edificação no local. A prioridade foi a retirada do entulho e das cinzas; com estrita recomendação por parte do Conselho para o

${ }^{229}$ CONDEPHAAT Processo: 33.188/95. 
máximo de atenção com a retirada de peças maiores de modo a evitar danos aos remanescentes da edificação em especial ao painel de Di Cavalcanti (SÃO PAULO - Estado, CONDEPHAAT, 2008).
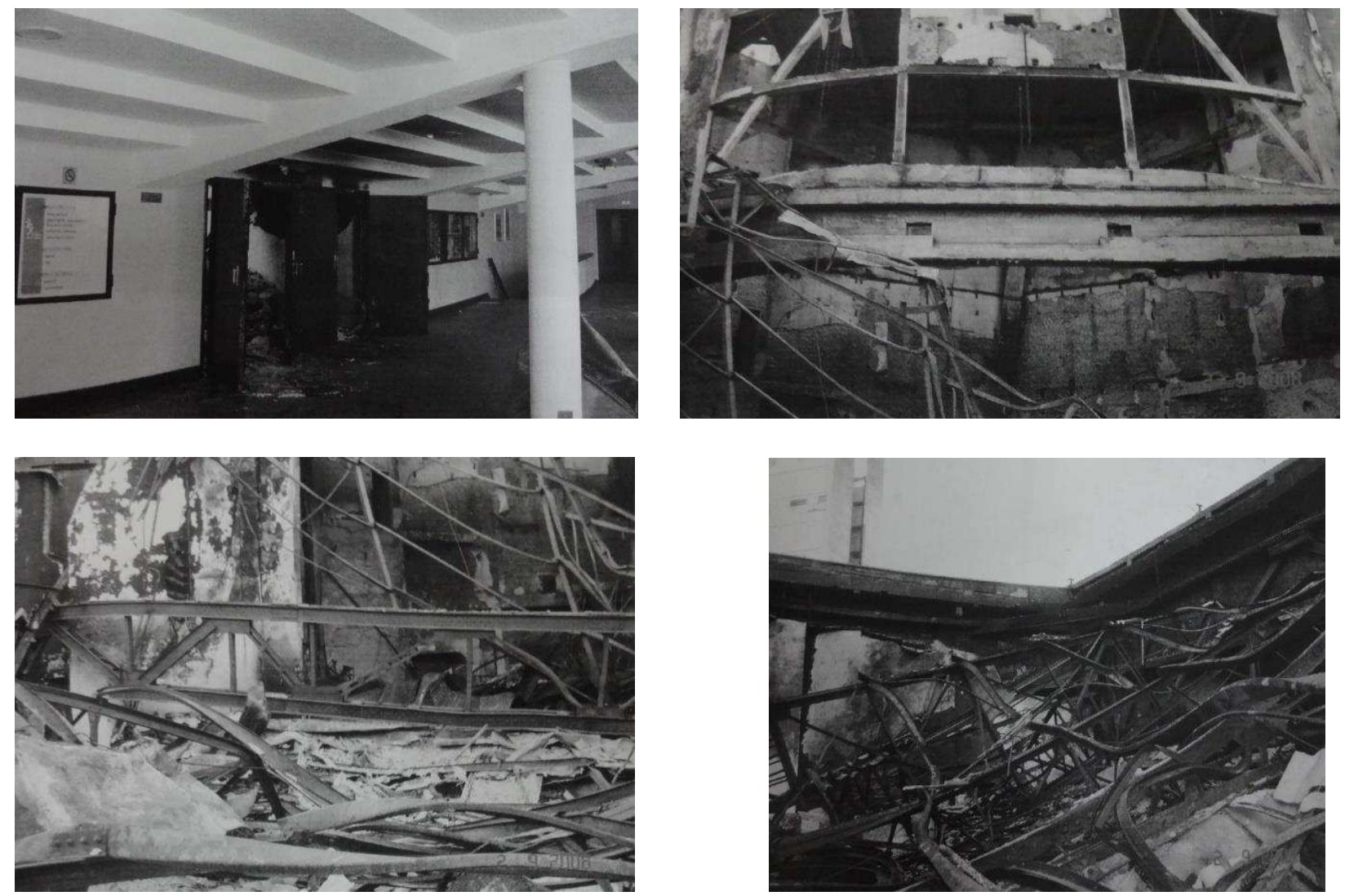

Fig. 115 (i-iv): Situação do Teatro Cultura Artística pós-incêndio. Fonte: SÃO PAULO - Estado, CONDEPHAAT, 2008, p. 22-28.

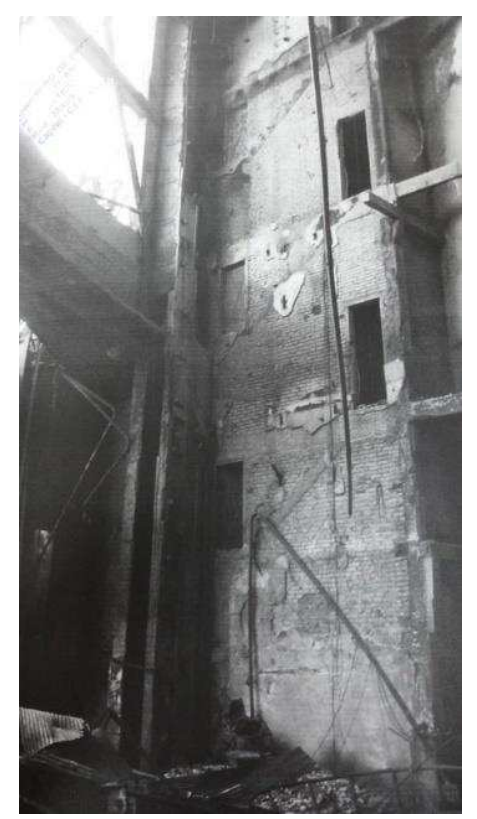

Fig. 116: Situação pós-incêndio. Fonte: SÃO PAULO - Estado, CONDEPHAAT, 2008, p. 29.

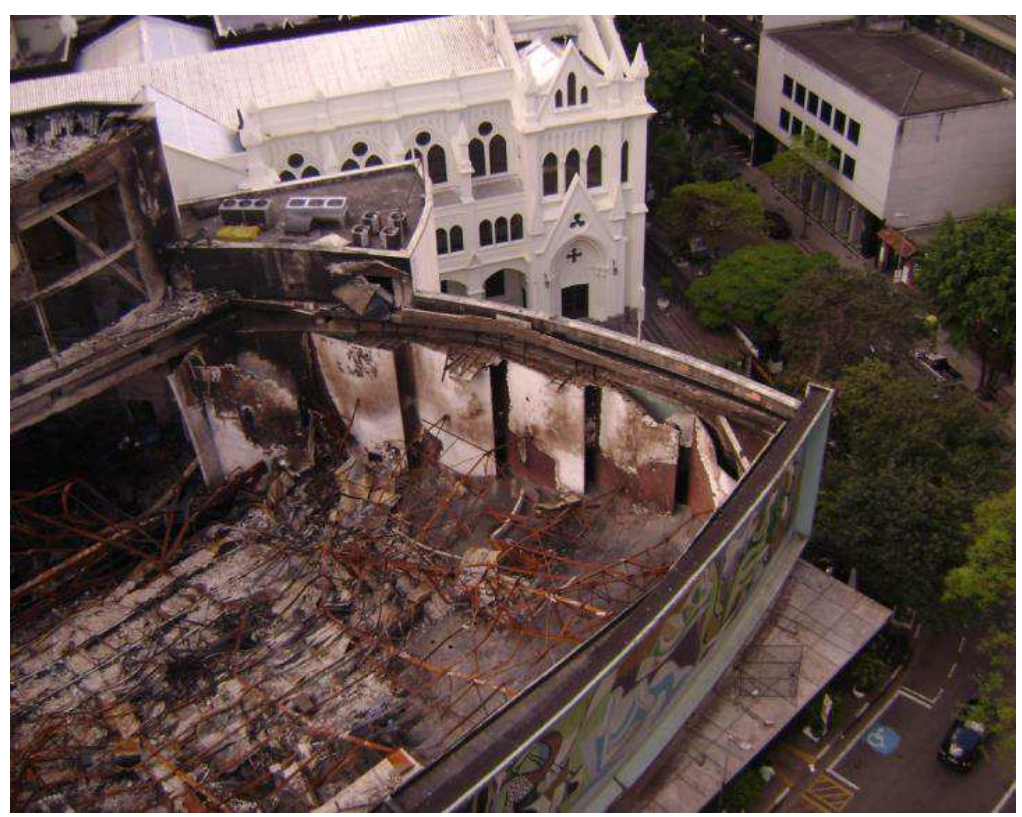

Fig. 117: Imagem pós-incêndio. Fonte: Paulo Bruna Arquitetos Associados. 
Diante do incidente ocorrido e da perspectiva da construção de uma nova edificação no terreno, o estudo de tombamento no CONDEPHAAT foi retomado em caráter de urgência. Na nova justificativa para o tombamento $(2008)^{230}$ elaborada pelos conselheiros Paulo Sergio B. Del Negro e Silvia Ferreira Santos Wolff o Teatro foi analisado no contexto da obra de Rino Levi, autor de uma série de salas de espetáculo, principalmente cinemas ${ }^{231}$, nas quais se empenhou em buscar soluções de visibilidade e acústica. Para o Teatro Cultura Artística, Levi seguia os mesmos procedimentos adotados até então com a justaposição dos cálculos acústicos à pesquisa formal (SÃO PAULO - Estado, CONDEPHAAT, 1995). A justificativa para o tombamento também evidencia: a composição da fachada curva com o painel de Di Cavalcanti enquanto elemento remanescente, e o valor do Teatro como um polo de difusão cultural na cidade de São Paulo e como sede da Sociedade de Cultura Artística, uma entidade que conserva um rico arquivo documental sobre quase um século de história das suas atividades.

Com o interesse da Sociedade de Cultura Artística em apresentar um projeto adaptado às novas demandas do programa para o mesmo terreno, os debates para a definição das diretrizes de preservação envolveram essa possibilidade: "Permite-se a ocupação e renovação do interior do terreno com liberdade de modo a atender necessidades de espaço, tecnologia e funcionamento de um teatro contemporâneo." (Op. cit., p.91). E também vislumbravam o anseio da Sociedade em adquirir o terreno que separa o Teatro da Praça Roosevelt para ampliar e integrar o espaço púbico ao novo projeto. Em novembro de 2008 houve o parecer final favorável ao tombamento dos remanescentes do Teatro ${ }^{232}$.

Em 2010, a Sociedade de Cultura Artística apresentou parecer elaborado pelo arquiteto Nestor Goulart Reis Filho ao IPHAN solicitando abertura de processo de tombamento ${ }^{233}$ de seus espaços físicos e de seu arquivo. Esse pedido foi aceito em termos provisórios contemplando o valor histórico da área do terreno, do painel de Di Cavalcanti e do acervo documental formado pelos programas dos saraus ${ }^{234}$. Em parecer supletivo do IPHAN ${ }^{235}$

\footnotetext{
${ }^{230}$ Consultado In: SÃO PAULO - Estado, CONDEPHAAT, 1995, p.59-66.

${ }^{231}$ Como os cinemas UFA Palace (1936); Universo (1936-1939); UFA Palace de Recife (1937) e Cine Ipiranga (1941).

${ }^{232}$ Resolução SC n. 051/CONDEPHAAT de 05.08.09, publicação no DOE em 03.09.09, inscrição no Livro Histórico (N. 365), realizada em 09.09.09.

${ }^{233}$ Processo IPHAN: 1.603-T-10.

234 "[...] o tombamento da Área do Teatro Cultura Artística, Painel Afresco de Di Cavalcanti e Acervo Documental, [...] em razão do seu elevado valor histórico, a ser inscrito no Livro do Tombo Histórico.” (Op. cit., p. 209).
} 
concluiu-se por uma postura favorável ao tombamento, cujo texto final ficou similar ao texto do CONDEPHAAT: ambos se referem com ênfase à preservação do painel. Como os outros elementos da fachada dão sustentação estrutural ao mural os mesmos foram incluídos na preservação. Após os tombamentos na esfera estadual (CONDEPHAAT) e nacional (IPHAN), os "remanescentes" da fachada do Teatro Cultura Artística (incluindo os elementos de vedação, caixilhos e painel de Di Cavalcanti) também foram tombados ex officio pelo órgão municipal CONPRESP ${ }^{236}$ em 2011.

A tramitação desses processos, depois do incêndio, para o reconhecimento do valor cultural de parte das ruínas do Teatro Cultura Artística ocorreu paralelamente à apresentação de propostas junto aos órgãos e à municipalidade para a restauração do painel de Di Cavalcanti, para a demolição das demais estruturas remanescentes ${ }^{237}$ do Teatro e para a aprovação do novo projeto. Foram concentrados esforços imediatos para a restauração do mural "Alegoria das artes". Após prospecção realizada, foram detectadas trincas, eflorescências e vazios, em praticamente um terço da área total. Devido ao estado de conservação e à dimensão do painel, o restauro in loco tornou-se a opção mais prudente.

Primeiramente, para a realização desses trabalhos foi elaborada uma estrutura metálica (pelo escritório Paulo Bruna Arquitetos Associados) que funcionaria simultaneamente para: garantir a sustentabilidade do conjunto da fachada e painel; possibilitar o acesso ao painel; e dar proteção à fachada contra as intempéries durante os trabalhos a serem realizados. Conforme informações obtidas junto ao arquiteto Paulo Bruna ${ }^{238}$, essa estrutura foi executada em perfis metálicos, os pilares de trás do painel foram apoiados nas fundações existentes e os pilares da frente ficaram no limite entre a calçada e a rua, com fundação própria, de forma a permitir a passagem de pedestres na calçada por baixo da marquise. Os pilares foram travados por vigas metálicas em ambos os sentidos, formando um pórtico coberto por telhas metálicas. No primeiro nível de acesso ao painel havia um tabuado de madeira para a montagem de andaimes móveis de aço, permitindo a mobilidade dos restauradores conforme a necessidade. Entre esse nível e a cobertura foram instaladas placas de policarbonato alveolar transparente para dar proteção e permitir visibilidade aos trabalhos de restauro no painel, as duas laterais ficaram abertas, permitindo a ventilação natural.

\footnotetext{
${ }^{235}$ Elaborado pelo Arq. Mauro David Artur Bondi, Memorando N. 008/2011, In: Op. cit., s.p.

${ }^{236}$ Resolução 14/CONPRESP/2011.

${ }^{237}$ Demolição das estruturas remanescentes do Teatro Cultura Artística: processo administrativo PMSP 2010$0.210 .802-7$.

${ }^{238}$ Em entrevista concedida à autora em 30.04.2015.
} 

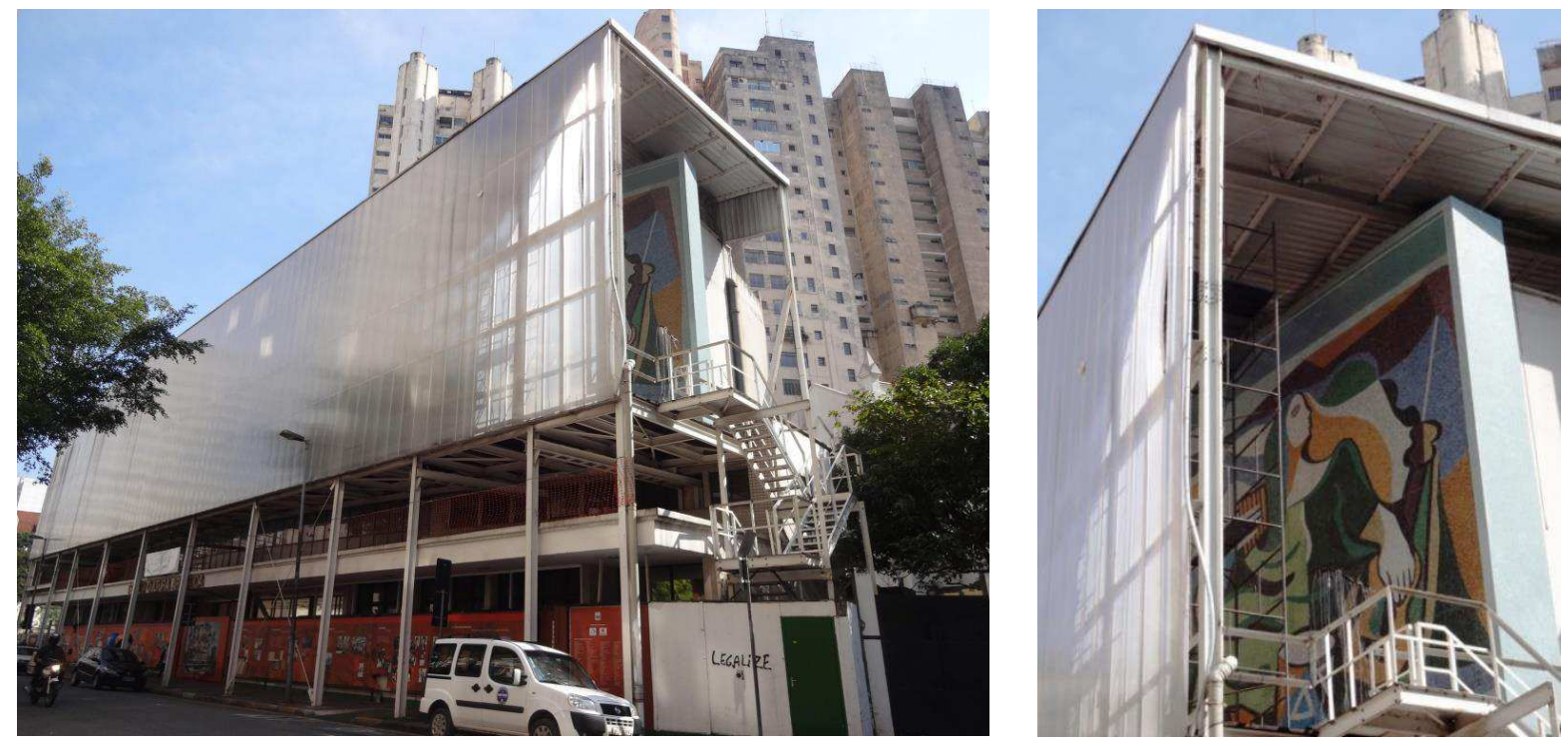

Fig. 118 (i-ii): Vistas da estrutura metálica montada para o restauro do painel, 2014. Fotos: Autora.

Os trabalhos de restauro no painel ${ }^{239}$ iniciaram-se em 2010 e terminaram em 2012; foram coordenados pela empresa Oficina de Mosaicos sob consultoria da restauradora e muralista Isabel Ruas. Segundo o Memorial Descritivo ${ }^{240}$, a metodologia dos procedimentos $^{241}$ se embasou na recomposição do desenho através da investigação de documentação da época da construção; o projeto de restauro eliminou uma intervenção no mosaico realizada nos anos de 1970 que havia descaracterizado partes do desenho original.

As pastilhas de vidro da empresa Vidrotil atualmente ainda são fabricadas, o que facilitou a reposição de materiais para a reintegração de lacunas. Existia uma ligeira diferença de espessura entre as pastilhas produzidas naquela época $(4,00$ a 4,5 $\mathrm{mm}$ ) e as atuais (com cerca de 3,0 mm). Uma diferença que foi compensada com a espessura da argamassa de assentamento. Algumas cores já fora de catálogo foram reproduzidas pelo fabricante para o restauro. A argamassa utilizada também é semelhante à usada originalmente com o processo de hidratação da cal in loco para que o processo de carbonatação se completasse e a resistência mecânica aumentasse (SÃO PAULO - Estado, CONDEPHAAT, 2008).

\footnotetext{
239 Procedimentos de restauro do Painel Artístico e da fachada do Teatro Cultura Artística: processo administrativo PMSP 2009-0.216.570-0.

${ }^{240}$ Consultado In: SÃO PAULO - Estado, CONDEPHAAT, 2008, p. 134-136.

${ }^{241}$ Os procedimentos de restauro apresentados envolveram as seguintes etapas: uma sistemática documentação fotográfica; um mapeamento do mosaico em escala 1:1 copiando tessela por tessela em papel vegetal, com indicação numerada de todas as cores; uma quantificação das cores a serem compradas; a delimitação e compartimentação em setores das áreas a serem restauradas pontualmente; a consolidação das áreas adjacentes com telas de gaze e tecido de algodão; a reposição de cada trecho do mosaico a ser feita imediatamente após a sua retirada, nivelando-o em relação aos trechos do entorno; o restauro de fissuras repondo trechos de mosaico levantados; a reintegração de lacunas com a reposição de tesselas; e o rejuntamento dos trechos restaurados para o mosaico como um todo (SÃO PAULO - Estado, CONDEPHAAT, 2008).
} 
Essa cuidadosa operação foi vencedora da etapa nacional da $25^{\mathrm{a}}$ Edição do Prêmio Rodrigo Melo Franco de Andrade (2012), na categoria Preservação de Bens Imóveis.
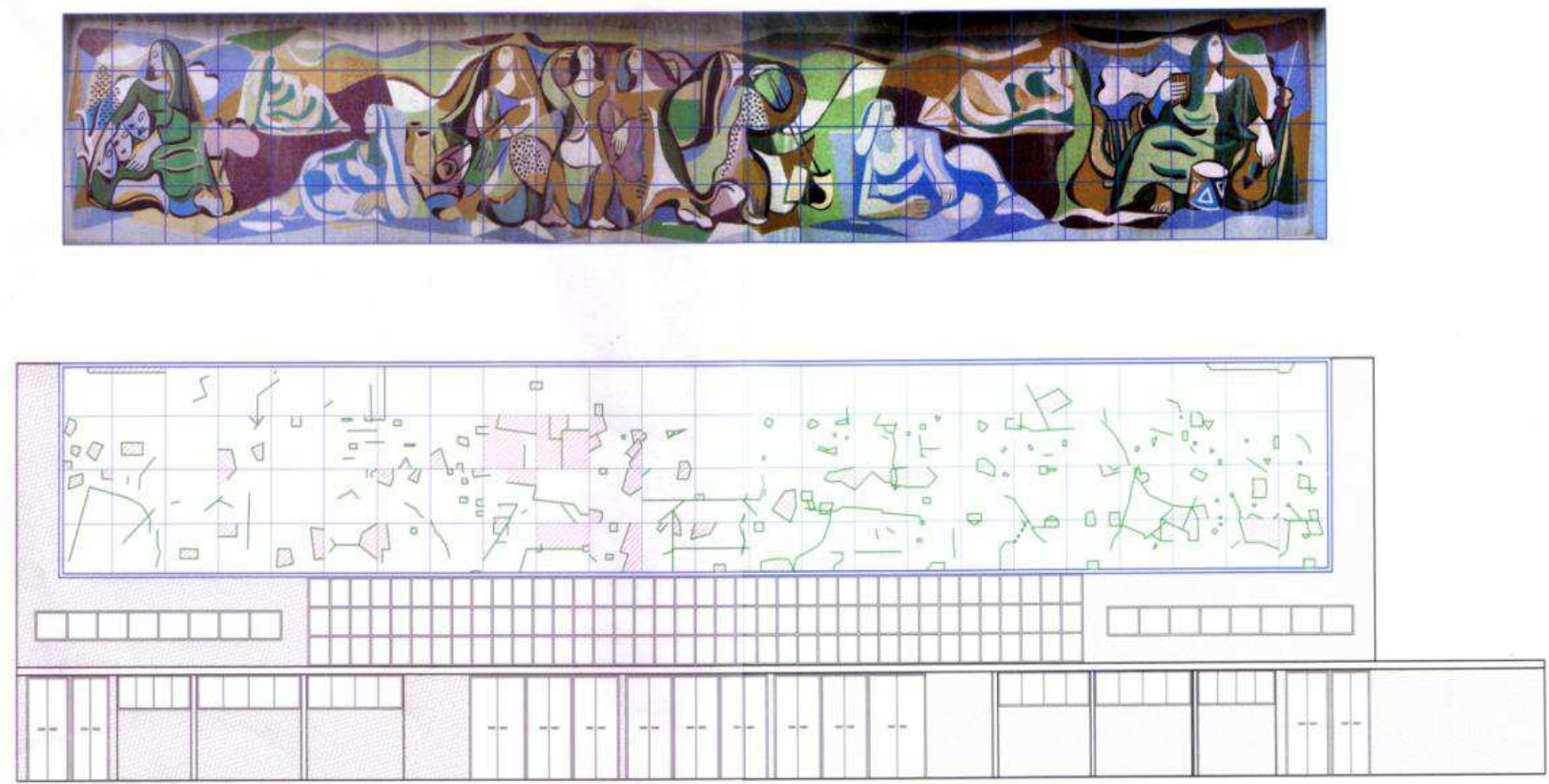

Fig. 119: Prospecção para restauro do painel. Fonte: SÃO PAULO - Estado, CONDEPHAAT, 2008, p. 127.

\subsubsection{Novo projeto}

Com os trabalhos para o restauro do painel em andamento, estava sendo desenvolvido em paralelo o projeto para o novo teatro. Como já mencionado, logo após o incêndio a Sociedade de Cultura Artística demonstrou sua intenção em reconstruir no mesmo sítio um teatro que se mantivesse como a sede da entidade, porém com a opção de um projeto com aprimoramentos tecnológicos e maior área, sob a justificativa de ser mais condizente às demandas contemporâneas. Para desenvolver esse projeto arquitetônico, foi contratado o escritório do arquiteto Paulo Bruna, que durante duas décadas tinha atuado como diretor no escritório "Rino Levi Associados".

A elaboração desse projeto tem tido uma complexa trajetória e passou por uma série de adaptações antes de sua primeira finalização e aprovação junto aos órgãos competentes (IPHAN, CONDEPHAAT, CONPRESP) em 2015. Apresentamos aqui essa versão, conforme as informações obtidas com o arquiteto responsável Paulo Bruna em abril de 2015; mas é pertinente esclarecer que, segundo uma atualização em outubro de 2016 com o mesmo arquiteto, esse projeto está sendo revisado para atender novas demandas, a pedido dos proprietários. 
O projeto que foi aprovado pelos órgãos de preservação e pela municipalidade possui uma área total de 10.424,76 m². Há que se considerar que em 1996, devido a uma Operação Urbana, a Sociedade de Cultura Artística obteve uma certidão junto ao SEMPLA que permitia a construção de um elevado Coeficiente de Aproveitamento ${ }^{242}$ para o terreno.

$\mathrm{Na}$ sala de espetáculos, os espectadores ficam subdivididos em: plateia, primeira fila de camarotes, primeiro e segundo níveis de balcões e camarotes. Segundo o arquiteto, a razão desse arranjo seria dividir o público em pequenos grupos e simultaneamente manter um elevado grau de intimidade. As linhas de visibilidade foram estabelecidas prevendo que o teatro possa ser utilizado para diferentes tipos de espetáculos, inclusive dança, razão pela qual o chão do palco deverá ser visível de forma completa desde o proscênio. A fila mais distante do proscênio na plateia está apenas a $22 \mathrm{~m}$ ao longo do eixo longitudinal.

Para o palco ${ }^{243}$, foi adotada toda a tecnologia compatível para um teatro de múltiplos usos que possa suportar diversas modalidades artísticas, incluindo óperas e musicais com orquestra no fosso para que a Sociedade de Cultura Artística não precisasse locar outros espaços para esse tipo de apresentação. O programa atrelado ao palco é extenso e envolve: coxias, palco de fundo com elevadores e escada para subsolo; depósitos sob o palco e fosso da orquestra. Há ainda camarins e dependências de apoio aos artistas e funcionários; área administrativa com escritórios, salas de reunião, depósitos, arquivos e bibliotecas da Sociedade de Cultura Artística; um subsolo com estacionamento e demais espaços de apoio. Conforme o arquiteto, toda a tecnologia de luz, áudio e vídeo passou pela consultoria de empresas internacionais (Theatre Projects Consultants e Akustiks) e nacionais (Acústica \& Sônica).

Um dos pontos de maior atenção que os arquitetos deram ao novo projeto foi ao foyer, pois se considerava que no teatro original esse ambiente tinha pouco espaço e não comportava todos os espectadores antes ou durante os intervalos. Por esse motivo, o novo partido arquitetônico prevê a liberação de quase todo o pavimento térreo levantando a plateia e permitindo o movimento de todos os espectadores que podem acessar elevadores e escadas rolantes para a circulação vertical. Nos pisos superiores de acesso aos balcões e camarins há pequenos foyers no nível das entradas do auditório sendo que aqueles junto à fachada principal possuem vista ao exterior.

\footnotetext{
242 Área do terreno $=1976,12 \mathrm{~m}^{2}$, Coeficiente de Aproveitamento do novo projeto = 5,41.

${ }^{243}$ Dimensões aproximadas do novo palco: urdimento/profundidade $=14,00 \mathrm{~m}$; largura total $=25,00 \mathrm{~m}$; boca de cena $=13,00 \times 10,00 \mathrm{~m}$.
} 


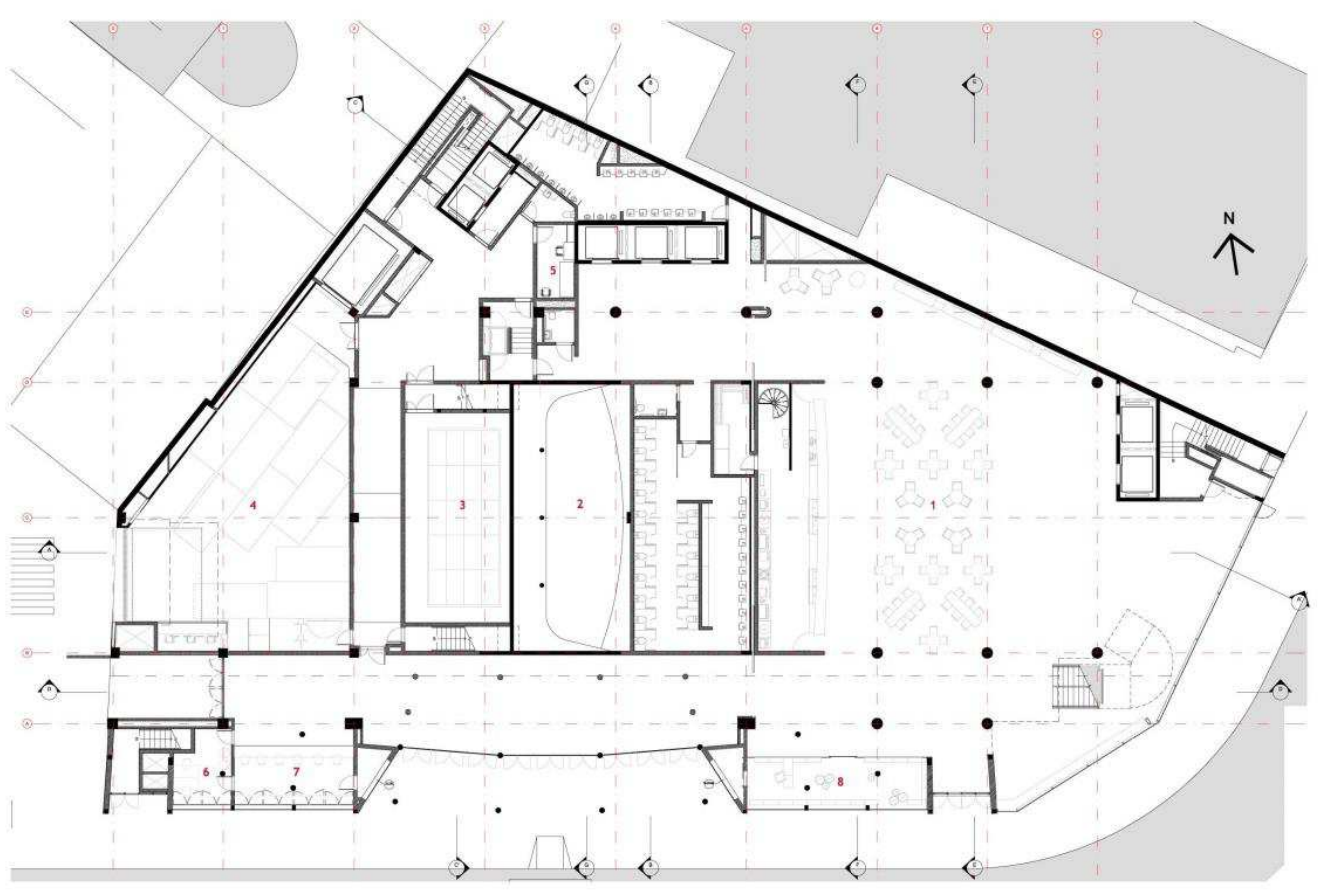

Fig. 120: Teatro Cultura Artística, projeto aprovado em 2015. Planta baixa - cota 100,00. Escala 1:200. Fonte: Paulo Bruna Arquitetos Associados.

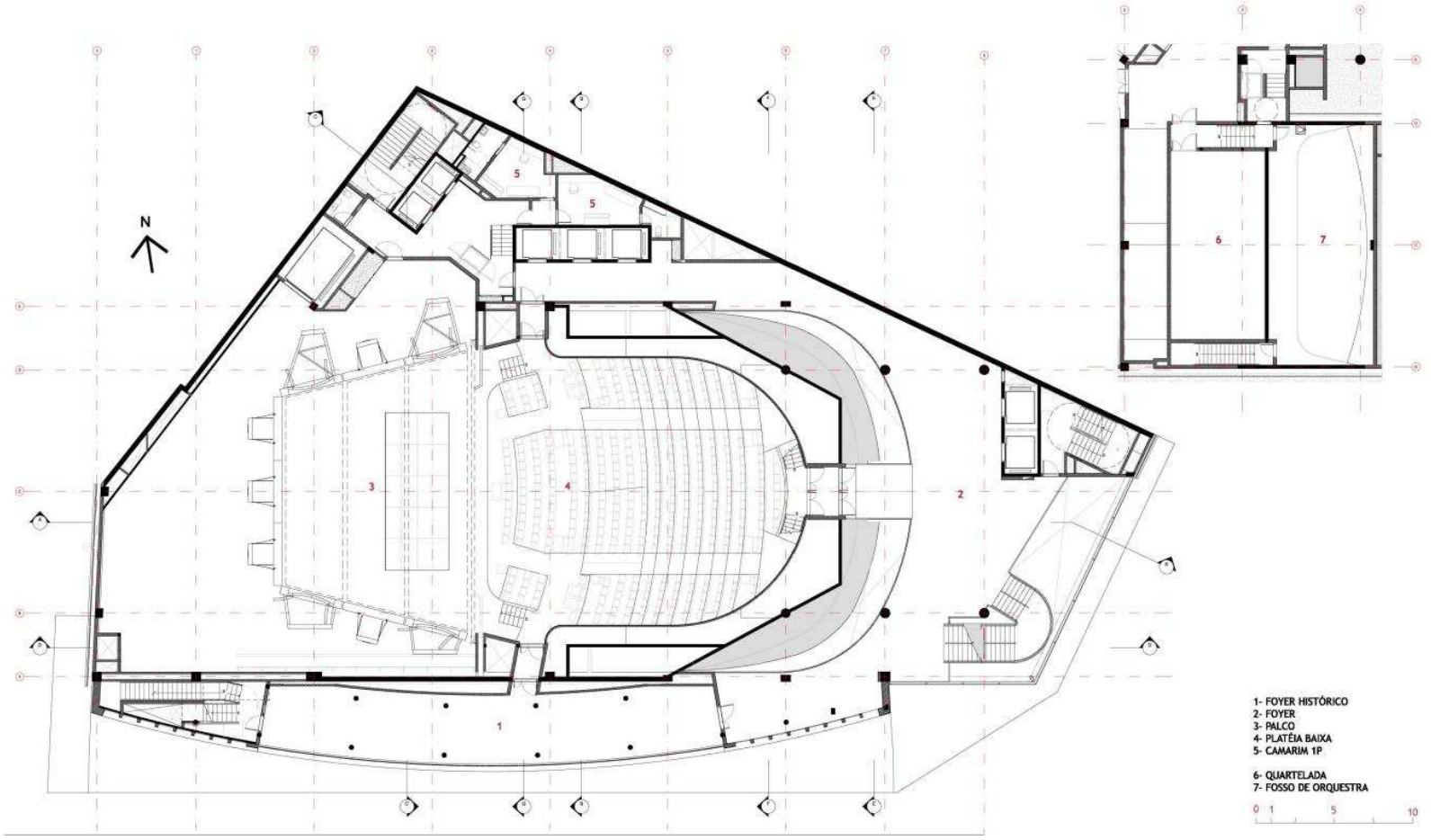

Fig. 121: Teatro Cultura Artística, projeto aprovado em 2015. Planta baixa - cota 103,90. Escala 1:200. Fonte: Paulo Bruna Arquitetos Associados. 


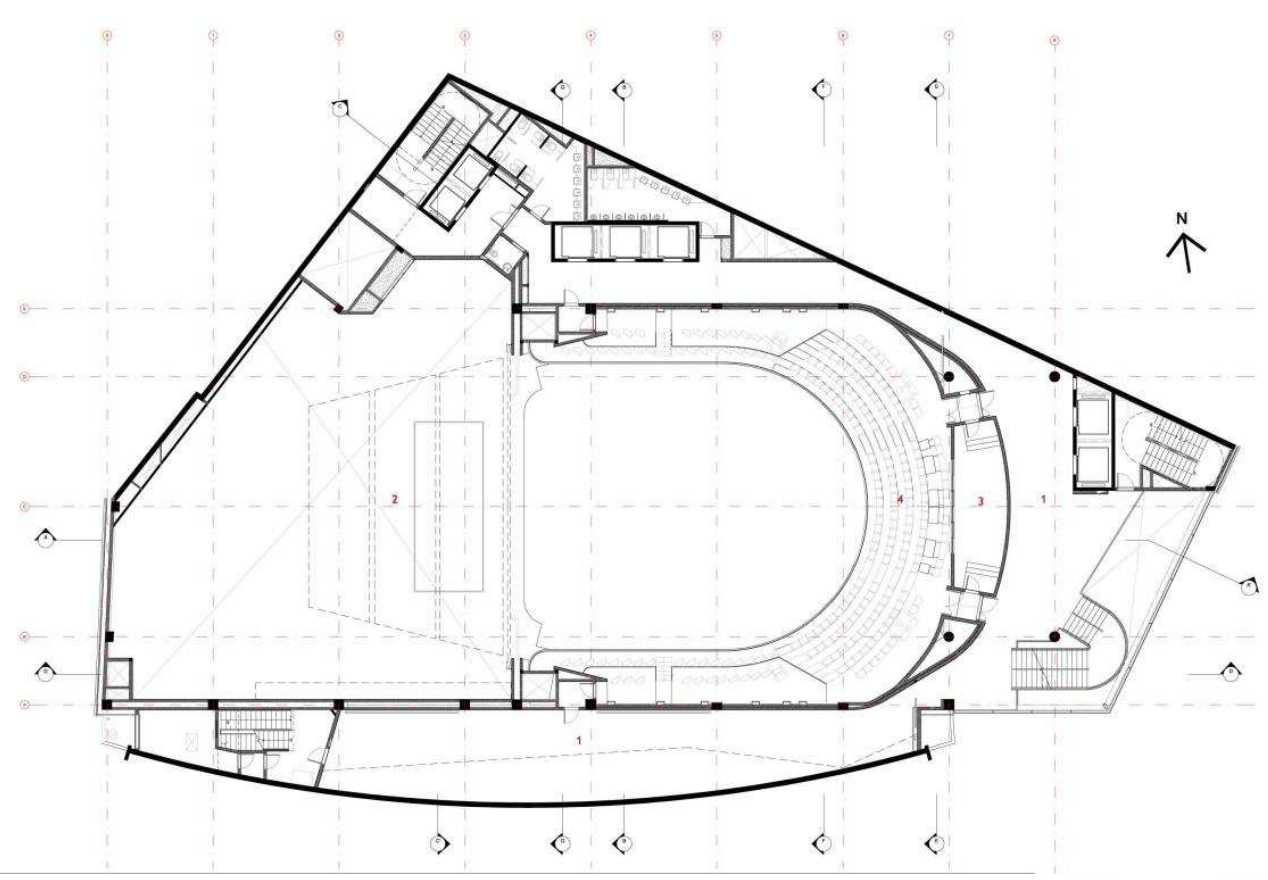

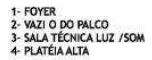

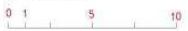

Fig. 122: Teatro Cultura Artística, projeto aprovado em 2015. Planta baixa - cota 107,80. Escala 1:200. Fonte: Paulo Bruna Arquitetos Associados.

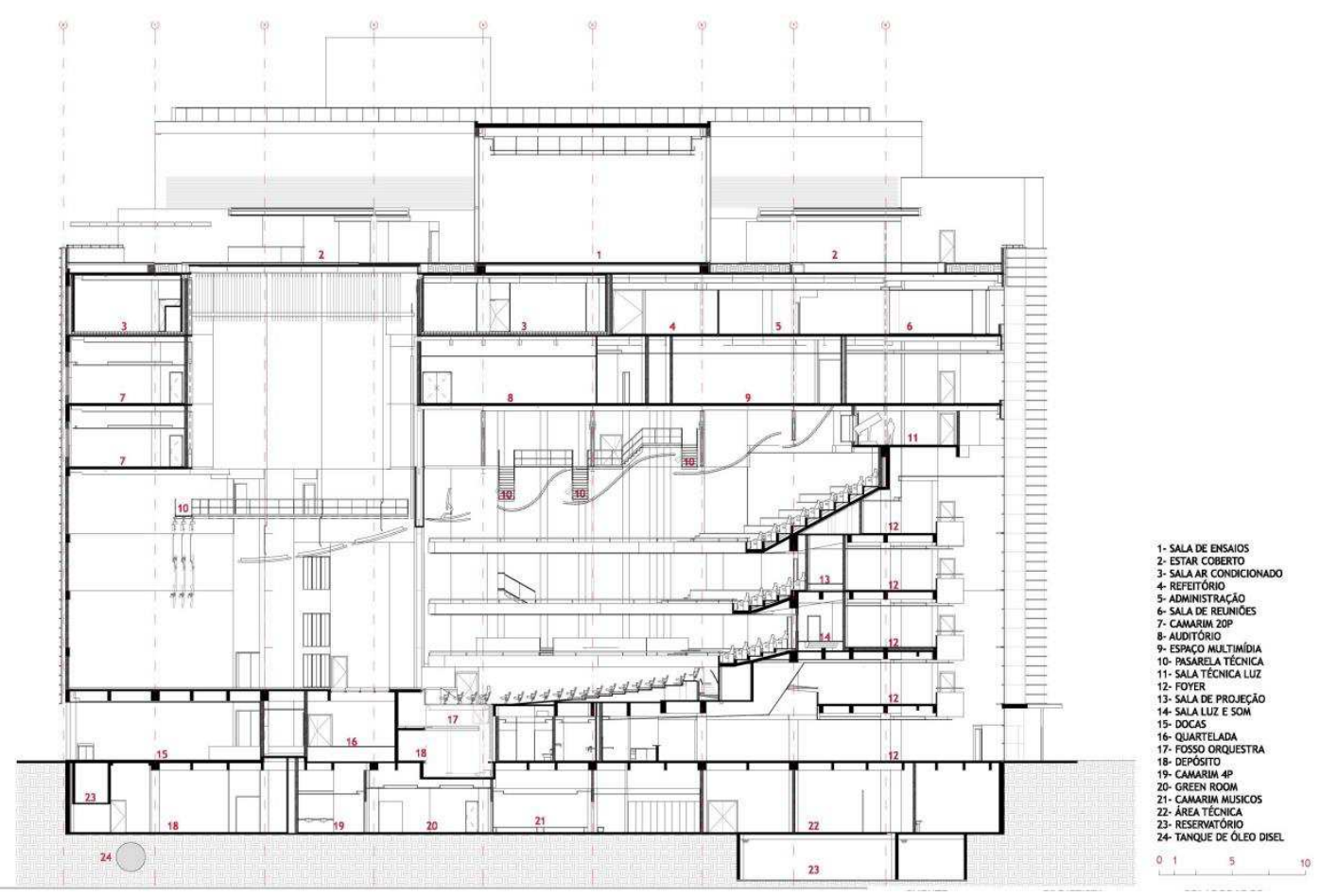

Fig. 123: Teatro Cultura Artística, projeto aprovado em 2015. Corte A-A. Escala 1:200. Fonte: Paulo Bruna Arquitetos Associados. 
Ao verificar o novo projeto é possível constatar que os remanescentes tombados do Teatro original possuem uma maior visibilidade pela fachada voltada à Rua Nestor Pestana. No entanto, a forma com que os mesmos são incorporados não faz menções formais ou referências ao Teatro original. Além do substancial acréscimo de área e da sua total remodelação que conferem um grande contraste em relação ao Teatro que foi acometido pelo incêndio, há outra diferença crucial que se refere à mudança do eixo do palco. Originalmente a sala era transversal à Rua Nestor Pestana, no projeto que foi aprovado, o eixo foi invertido e a sala passou a ser paralela à rua. Com essa mudança, o denominado foyer "histórico" dá acesso a uma das entradas laterais da sala de espetáculos. Além disso, a prefeitura desapropriou os lotes vizinhos ao terreno e adjacentes à Praça Roosevelt o que possibilitaria uma vista mais ampla do novo teatro e a disposição de acessos a veículos e ao subsolo que anteriormente não eram possíveis. Essa proposta estabelece, portanto, uma relação com o espaço público totalmente diversa do antigo teatro, que estava limitado à testada da Rua Nestor Pestana.

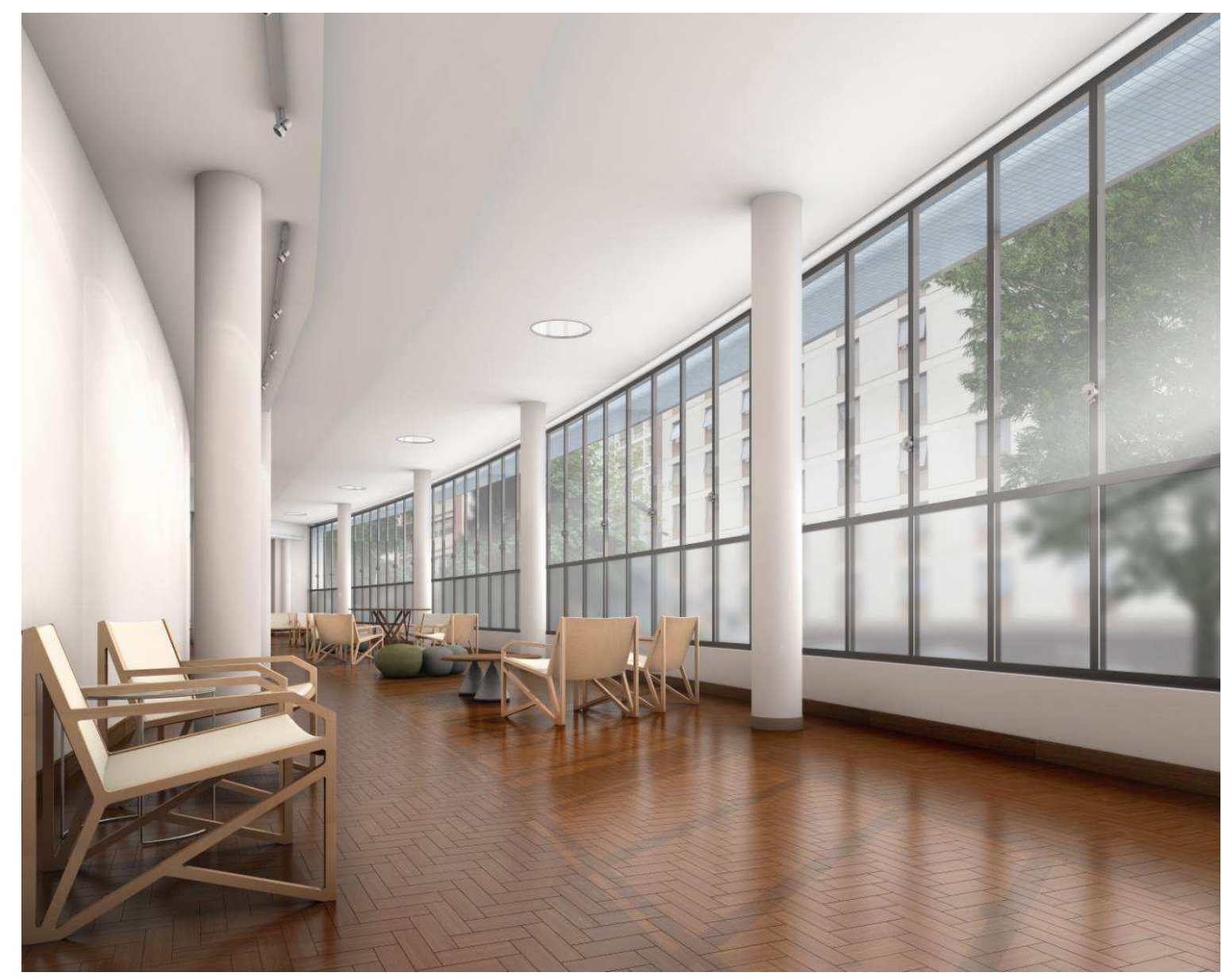

Fig. 124: Teatro Cultura Artística, projeto aprovado em 2015. Perspectiva interna - foyer "histórico". Fonte: Paulo Bruna Arquitetos Associados. 

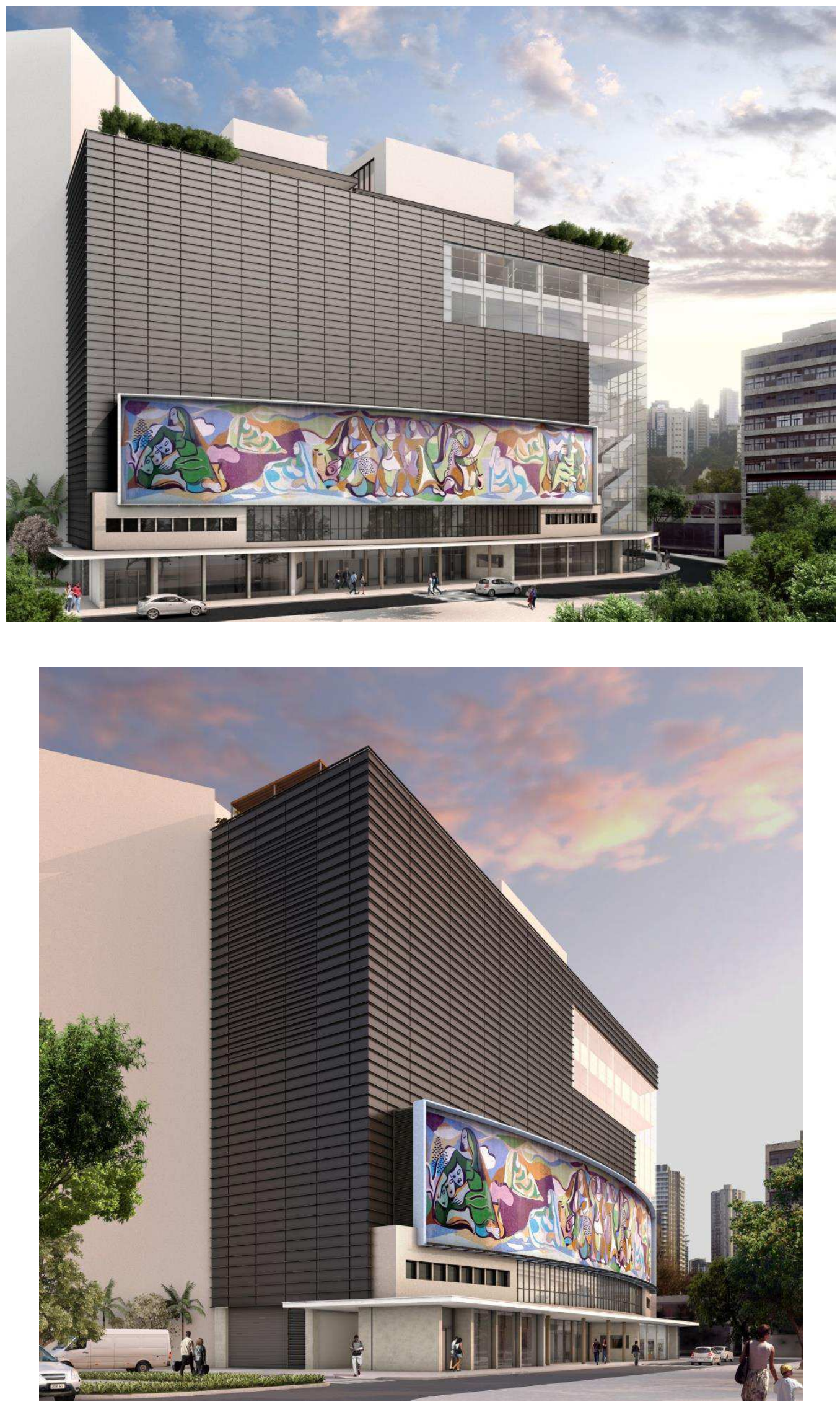

Fig. 125 (i-ii): Teatro Cultura Artística, projeto aprovado em 2015. Perspectivas externas. Fonte: Paulo Bruna Arquitetos Associados. 


\subsection{Igreja Matriz São Luiz de Tolosa ${ }^{244}$}

A Igreja Matriz São Luiz de Tolosa está situada na cidade de São Luiz do Paraitinga, um conjunto urbano-arquitetônico e paisagístico tombado pelo CONDEPHAAT em $1982^{245}$. O processo de avaliação cultural da cidade iniciou em 1969 e teve como principal base conceitual o estudo dos arquitetos Luis Saia $^{246}$ e Jaelson de Trindade (SAIA; TRINDADE, s.d. In: IPHAN, 2010) que ressaltaram o valor do traçado regular da cidade. O povoado de São Luiz do Paraitinga foi fundado em 1769 a partir de uma determinação governamental visando a localização geográfica estratégica entre o eixo do vale do Rio Paraíba do Sul no planalto paulista e o litoral estabelecendo uma conexão entre as capitanias de São Paulo com Rio de Janeiro e Minas Gerais.

A implantação da cidade foi embasada em um plano urbano prévio com determinações sobre o tipo de casas a serem construídas. A partir de 1773, o local já tinha estatuto de vila constituindo a sede do município. De acordo com os estudos de Saia e Trindade, a praça central (Praça Osvaldo Cruz) era um elemento fundamental gerador da malha urbana, consolidando o arruamento e a distribuição de novos lotes; essa configuração de fato se efetivou após acomodações e ajustes a partir de 1840 consolidando um período de crescimento urbano derivado da ampliação da economia cafeeira no Vale do Paraíba. A estética da cidade ficou marcada pelos alinhamentos das edificações e a uniformidade das fachadas térreas e assobradadas de arquitetura oitocentista.

\footnotetext{
${ }^{244} \mathrm{O}$ material consultado foi obtido junto a: Superintendência do IPHAN/SP, processo de tombamento IPHAN 1590-T-10 (IPHAN, 2010), Dossiê São Luiz do Paraitinga, 2010 (IPHAN, Dossiê, 2010), sobre a Matriz processo administrativo 01506.000823/2010 (IPHAN, Matriz, 2010); ao CONDEPHAAT, processo 22.066/1982 (SÃO PAULO - Estado, CONDEPHAAT, 1982). Entrevista realizada com a arquiteta Natália dos Santos Moradei - assessora de Planejamento da Prefeitura Municipal da Estância Turística de São Luiz do Paraitinga durante os trabalhos na Igreja Matriz - em 13.04.2015.

${ }^{245}$ CONDEPHAAT Processo 22.066/1982.

${ }^{246}$ Em momentos anteriores Saia tinha se interessado pelos remanescentes novecentistas de São Luiz do Paraitinga. Primeiramente em 1946, quando elaborou um levantamento das fazendas de café do Vale do Paraíba, inventariando algumas e propondo o tombamento de outras. Em 1963, Saia publicou o ensaio "Quadro Geral dos Monumentos Paulistas", nesse texto São Luiz do Paraitinga foi considerada como representativa de uma nova fase para a antiga Capitania de São Paulo, que se consolidou a partir de meados do século XVIII, assinalando a importância que tiveram as fundações de novos aglomerados no território paulista. Esses estudos foram retomados em 1972, quando Saia passou a se focar na cidade e sua evolução urbana. Nessa ocasião, foi estabelecida uma equipe de trabalho que empreendeu um detalhado levantamento da arquitetura dos casarões, construídos entre 1830 e 1870, e do núcleo urbano, tratado pela primeira vez como um conjunto dotado de um caráter particular que poderia motivar a sua preservação (São Paulo - Estado, CONDEPHAAT, 1982). O produto dessas pesquisas sobre a evolução urbana local foi apresentado em 1973 no seguinte trabalho: SAIA, Luis. Evolução urbana de São Luiz do Paraitinga. In: Anais do VII Simpósio Nacional dos Professores Universitários de História, Belo Horizonte, 2 a 8 de setembro de 1973, São Paulo: s.n., 1974.
} 


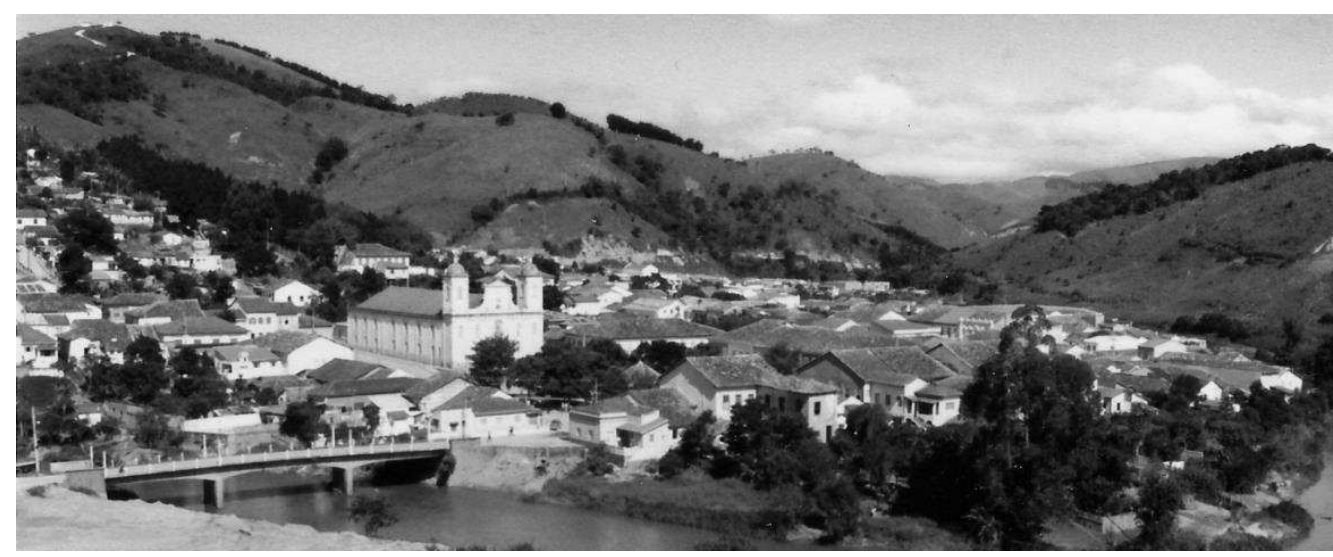

Fig. 126: Vista de São Luiz do Paraitinga, $1^{a}$ metade do século XX.

Fonte: Arquivo da Superintendência do IPHAN em São Paulo. In: IPHAN, Dossiê, 2010, p.8.

Devido à localização geográfica e à relação com o Rio Paraitinga alagamentos na cidade eram periódicos; na documentação constam duas grandes enchentes na área urbana em 1864 e 1882. No final de 2009, o centro de São Luiz do Paraitinga foi atingido por fortes chuvas e cheia do Rio Paraitinga culminado no dia $1^{\circ}$ de janeiro de 2010 quando ocorreu a inundação de parte considerável daquela área histórica e danos físicos em inúmeros imóveis (IPHAN, 2010).

A cidade ficou submersa até aproximadamente a altura do pavimento superior dos sobrados que contornam a praça central. A população local foi extremamente afetada já que a dinâmica socioeconômica local (moradia, comércio e atividades institucionais) foi paralisada ou seriamente comprometida pelos danos aos edifícios. As consequências mais trágicas foram: o arruinamento da Igreja Matriz, da Capela de Nossa Senhora das Mercês, do prédio que abrigava o Grupo Escolar e de um sobrado datado de 1858 localizado numa das faces da Praça Osvaldo Cruz.

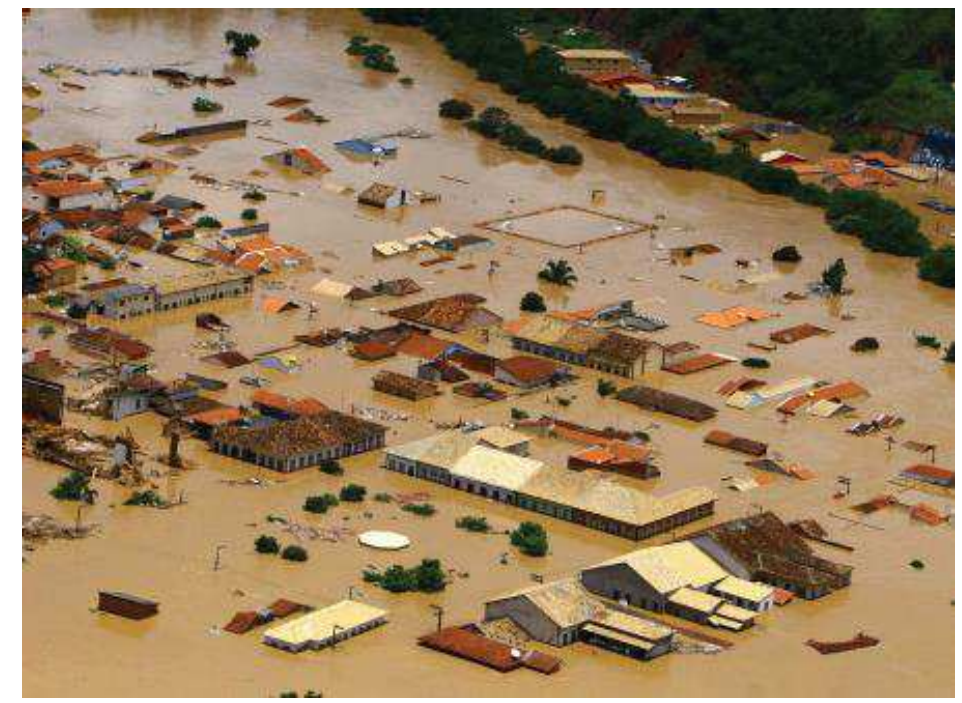

Fig. 127: Vista de São Luiz do Paraitinga sob a enchente do Rio Paraitinga, janeiro, 2010. Fonte: Jornal Folha de São Paulo. In: IPHAN, Dossiê, 2010, p.9. 
Na ocasião da enchente o centro de São Luiz do Paraitinga era objeto de estudo para tombamento no nível Federal desde 2007. Mediante a dimensão dos estragos, os órgãos de preservação foram acionados em caráter de urgência para estabelecer ações e medidas de salvaguarda do patrimônio edificado remanescente, tais como obras emergenciais que incluíam serviços de limpeza, seleção de escombros, escoramentos, proteção e consolidação das ruínas.

O IPHAN deslocou para lá grupos de trabalho das Superintendências de São Paulo e de Goiás, considerando que a cidade de Goiás Velho havia passado por uma situação similar em 2001, quando foi parcialmente destruída por uma enchente. Em São Luiz do Paraitinga, foi instalado um escritório técnico do IPHAN na antiga residência de Osvaldo Cruz e logo no dia 12 de janeiro de 2010, foi realizada uma grande reunião na cidade, promovida pela Secretaria de Estado da Cultura, para discutir os rumos e as responsabilidades em relação às ações para o patrimônio cultural. No dia 26 de março de 2010 o Conselho Consultivo do IPHAN tombou ${ }^{247}$ em caráter provisório cerca de 400 imóveis do conjunto histórico de São Luiz do Paraitinga.

A Igreja Matriz, por sua localização central era considerada um dos maiores referenciais da identidade cultural da cidade; além do grande significado afetivo para a população local, o arruinamento dessa edificação pela enchente também comprometia a leitura da configuração urbana da Praça Osvaldo Cruz. Sendo assim, vamos nos concentrar nesse objeto e nos debates que envolveram as providências para essa edificação ${ }^{248}$.

\subsubsection{Caracterização e arruinamento}

A Igreja Matriz São Luiz de Tolosa tem uma trajetória permeada de demolições, acréscimos e reformas. No início do povoamento, em 1769, foi construído um pequeno templo em taipa de pilão dedicado à Nossa Senhora dos Prazeres configurando o que seriam as balizas para a praça central da cidade.

\footnotetext{
${ }^{247}$ Processo de tombamento 1590-T-10, Livro do Tombo histórico e Livro do Tombo Arqueológico, Etnográfico e Paisagístico - Centro Histórico de São Luiz do Paraitinga. O tombamento foi ratificado em 2012.

${ }^{248}$ É necessário esclarecer que as polêmicas em torno das deliberações aos bens danificados não se restringiram à Igreja Matriz que será detalhada nesta análise, mas se estenderam aos trabalhos na Capela de Nossa Senhora das Mercês, dentre outros bens como o Grupo Escolar e Casarios. Maiores informações podem ser obtidas nos seguintes trabalhos que foram consultados: MARTINS, Leonardo F. Patrimônio e participação em São Luiz do Paraitinga entre o discurso e a prática. In: Anais do Arquimemória 4 - Sobre preservação do patrimônio edificado, Salvador, 2013 (CD-ROM) e MORADEI, Natália dos Santos. A grande enchente de São Luíz do Paraitinga. São Paulo: Faculdade de Arquitetura e Urbanismo da Universidade de São Paulo. Dissertação (Mestrado), 2015.
} 
Essa edificação inicial foi demolida e substituída em 1774 por outra no mesmo local de dimensões maiores. Em 1797, o corpo da Igreja foi demolido para alargar o terreno, conservando somente a capela mor. Entre 1830 e 1840, com o crescimento urbano, econômico e populacional da cidade foi iniciada a construção de um novo templo, com o sistema construtivo de taipa, constituído por uma torre onde em 1875 foi instalado o relógio. A primeira reforma na Igreja ocorreu em 1894 quando foi construída a segunda torre; também houve alterações estruturais internas e externas (colocação de tijolos junto às torres) e de fachada (transformação de elementos coloniais por ecléticos).

Na década de 1920, a Matriz passou por nova reforma. Ainda que parte da sua estrutura em taipa de pilão tenha sido mantida, houve grande modificação no seu exterior e interior, que acentuou o seu caráter eclético ao substituir o beiral antes em estilo colonial por platibandas; janelas do piso superior foram alteradas e internamente foi retirada a divisão que separava os fiéis por classe social. Em 1945 os antigos altares de madeira foram trocados por novos, de mármore, trazidos da Itália. Em 1972 o telhado e o forro foram refeitos; na ocasião o pintor de Taubaté Álvaro Pereira realizou afrescos respeitando estilo e cores originais; a porta principal foi substituída e foram acrescidos nichos nas duas laterais do frontispício para a colocação de imagens (São Pedro e São Paulo).

A despeito das várias adaptações ao longo dos anos a edificação apresentava uma unidade construtiva, não possuindo em seu entorno nenhum acréscimo que não estivesse em harmonia com o edifício existente. Embora possa ser considerado um exemplar de questionável valor arquitetônico ${ }^{249}$, a Igreja é um elemento fundamental na conformação urbana. Antes da enchente, segundo informações obtidas no processo do IPHAN referente à Matriz (IPHAN, Matriz, 2010) $)^{250}$, a edificação apresentava uma tipologia típica das construções ou reformas em prédios religiosos de finais do século XIX e início do XX, com as fachadas adaptadas e revestidas segundo o estilo eclético vigente. A planta basilical simétrica era composta de: nártex, capela do batismo, nave principal, galerias laterais inferiores, sala dos coroinhas, altar e capela do Santíssimo, altar mor e capela mor, depósito abaixo da torre direita, halls laterais, sacristia (hall, banheiro e depósito). A planta superior possuía o hall do coro, coro, acesso para o sino, galerias superiores e tribuna com acesso por duas escadas.

\footnotetext{
${ }^{249}$ Mário de Andrade durante suas incursões no Estado de São Paulo nos anos 30 fez a seguinte observação sobre essa igreja: "Este templo foi de tal forma reformado ou deformado que são desastrosos os prejuízos causados na arquitetura, sob o ponto de vista tradicional." (ANDRADE, M., 1981, p. 91).

${ }^{250}$ IPHAN - Processo técnico administrativo 01506.000823/2010.
} 


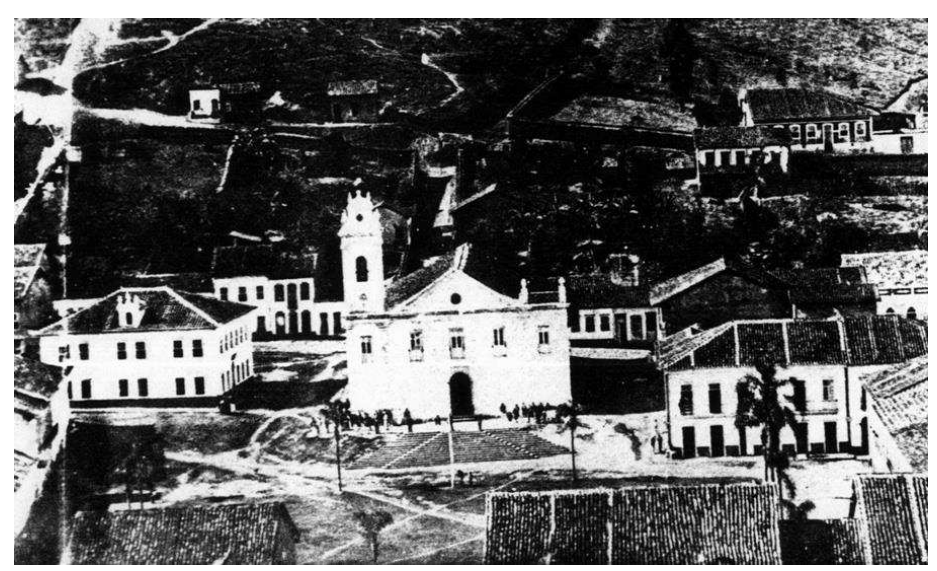

Fig. 128: Igreja Matriz São Luiz de Tolosa somente com uma torre, 1884.

Fonte: Coleção Particular reprodução do arquivo do CONDEPHAAT. In: IPHAN, Dossiê, 2010, p.75.

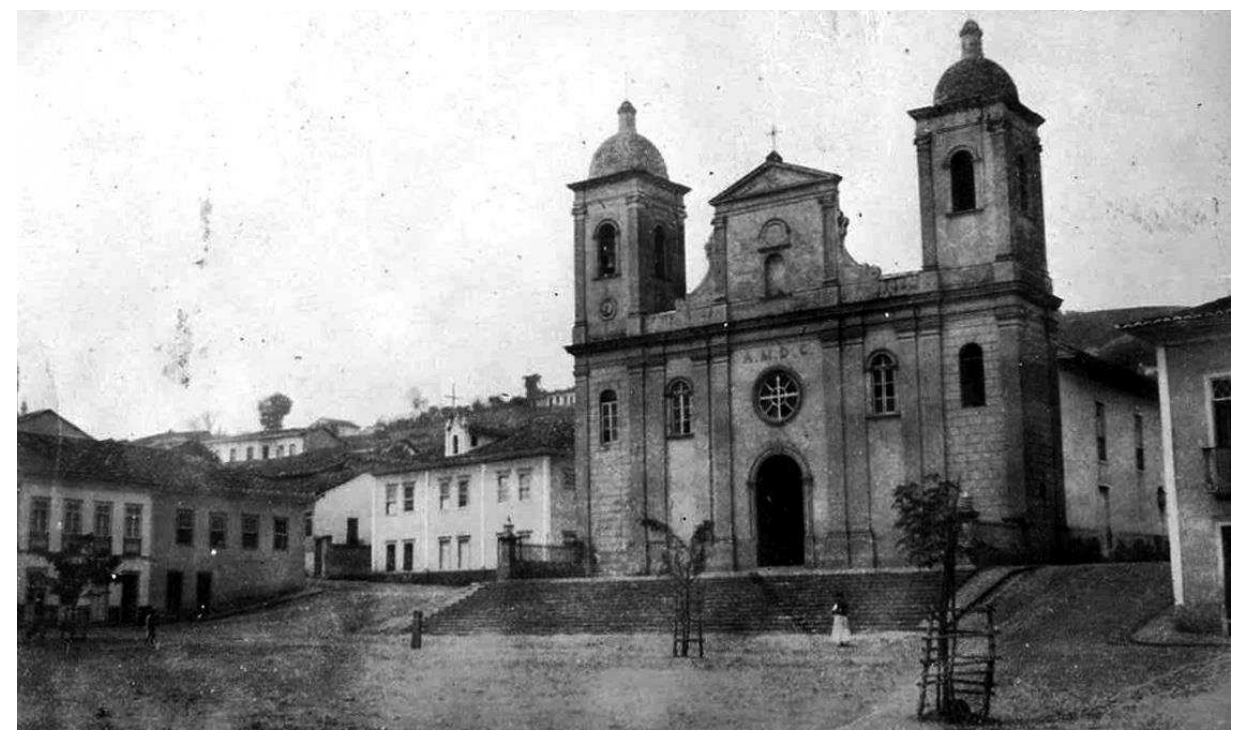

Fig. 129: Igreja Matriz São Luiz de Tolosa reformada na década de 1930.

Fonte: Coleção Particular Cinira dos Santos. In: IPHAN, Dossiê, 2010, p.150.

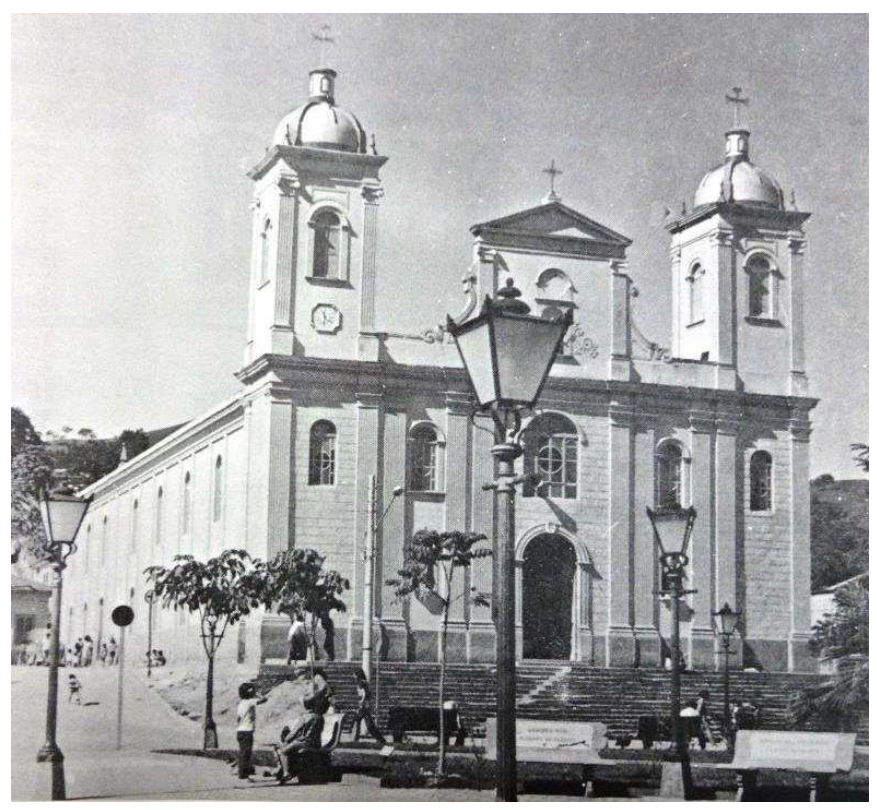

Fig. 130: Igreja Matriz São Luiz de Tolosa, s.d.

Fonte: SAIA, Luis; TRINDADE, Jaelson B. São Luiz do Paraitinga. Pub. N. 2: CONDEPHAAT/Secretaria da Cultura, Ciência e Tecnologia, s.d. In: IPHAN, 2010. 


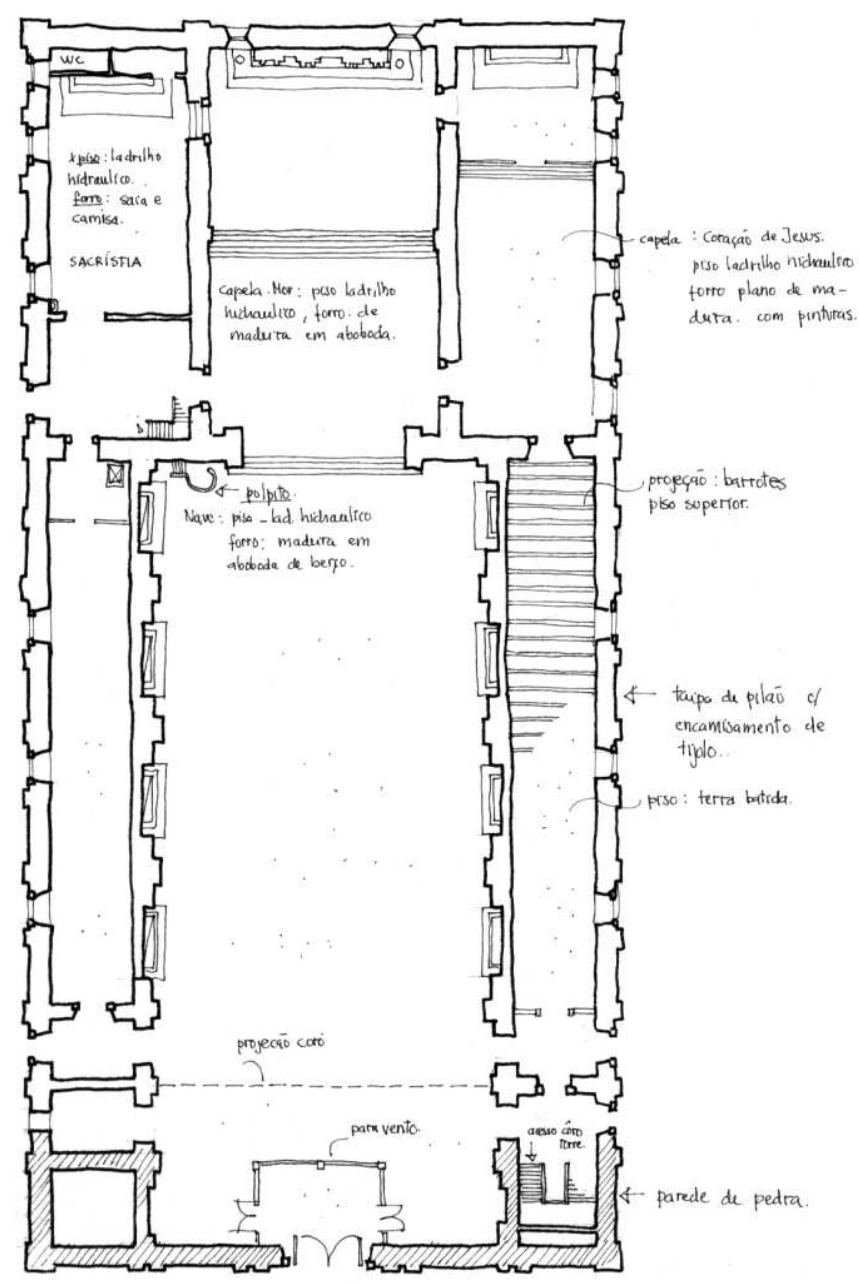

Fig. 131: Croquis da planta da Igreja Matriz, esc. 1:200.

Desenho de Antônio Luis Dias de Andrade, s.d. Fonte: IPHAN, Dossiê, 2010, p.152.

O sistema construtivo original era a taipa de pilão, possuindo paredes autoportantes com espessuras que variavam de $0,80 \mathrm{~m}$ a 1,20 m. O telhado era em duas águas com estrutura de madeira composta por tesouras, ripas e caibros e telhas cerâmicas tipo francesa. As esquadrias eram em madeira, tanto no pavimento térreo como no superior, com vitrais coloridos. Em relação aos revestimentos, todo o conjunto da Igreja possuía acabamento externo e interno em argamassa de areia e cal. Externamente se encontrava pintada com tinta látex na cor cinza claro e cor de concreto; internamente possuía área com pinturas murais efetuadas em diversas etapas. O piso de todo o pavimento térreo era composto por ladrilhos hidráulicos. No pavimento superior somente quatro áreas (a tribuna, o coro e as duas galerias laterais) possuíam piso, que era em tabuado corrido simples. Os forros da Igreja (capela do Santíssimo, capela do batismo, nave, capela-mor e coro) eram em madeira. Em relação aos elementos decorativos, destacavam-se os oito altares e um púlpito em mármore com detalhes em bronze, dois cancelos (do altar mor e da capela do santíssimo) também em mármore, duas grades em ferro do coro e da capela do batismo. 


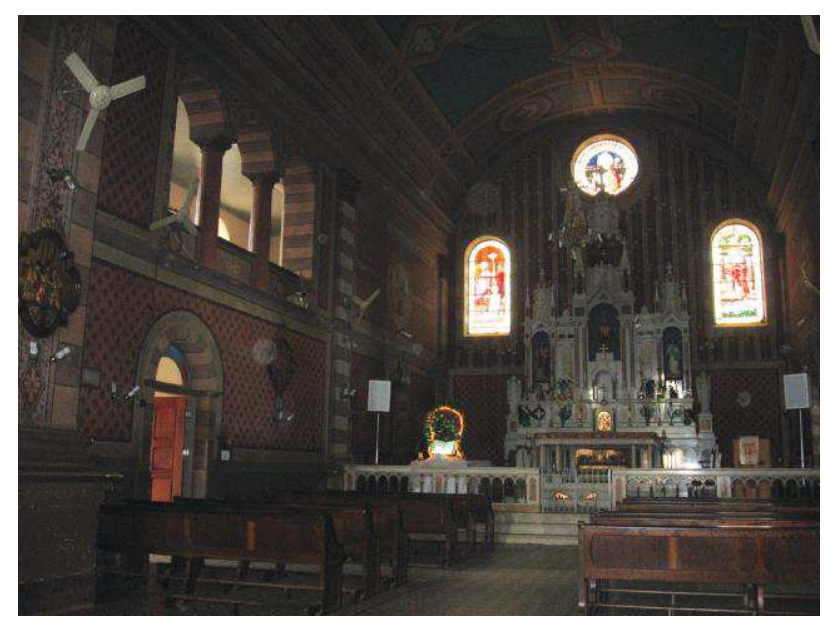

Fig. 132: Interior da Igreja Matriz, retábulo na capela-mor, 2007. Fonte: IPHAN, Dossiê, 2010, p.151. Foto: Jaelson Britan Trindade.

Durante a enchente de 2010, a água se infiltrou por uma fenda existente entre o corpo principal e a torre da direita, desestruturando-a totalmente e que acabou por ruir. Sem a sustentação da parede frontal a segunda torre também desabou; o telhado ficou exposto e as paredes laterais soltas, levando ao colapso total da Igreja.

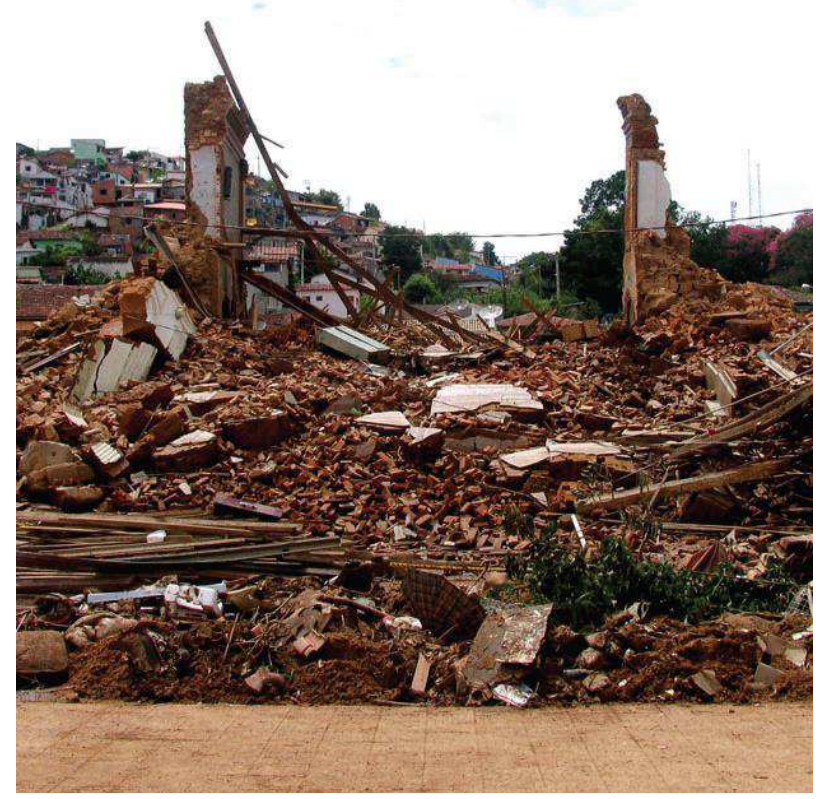

Fig. 133: Estado da Igreja Matriz após a enchente, janeiro, 2010. Fonte: IPHAN, Dossiê, 2010, p.10. Foto: Anita Miriam Hirschbruch.

\subsubsection{Reconstrução}

Logo após o arruinamento da Matriz em janeiro de 2010, a opção por sua reconstituição foi apresentada como uma indicação pelos órgãos de preservação desde as primeiras audiências públicas. A Construtora Biapó foi contratada por intermédio e iniciativa do IPHAN para realizar trabalhos emergenciais de recuperação dos escombros da Igreja. 
A Mitra Diocesana de Taubaté fez um levantamento da situação e propôs um anteprojeto para a reconstrução da mesma, que foi apresentado em audiência pública à população e aprovado.

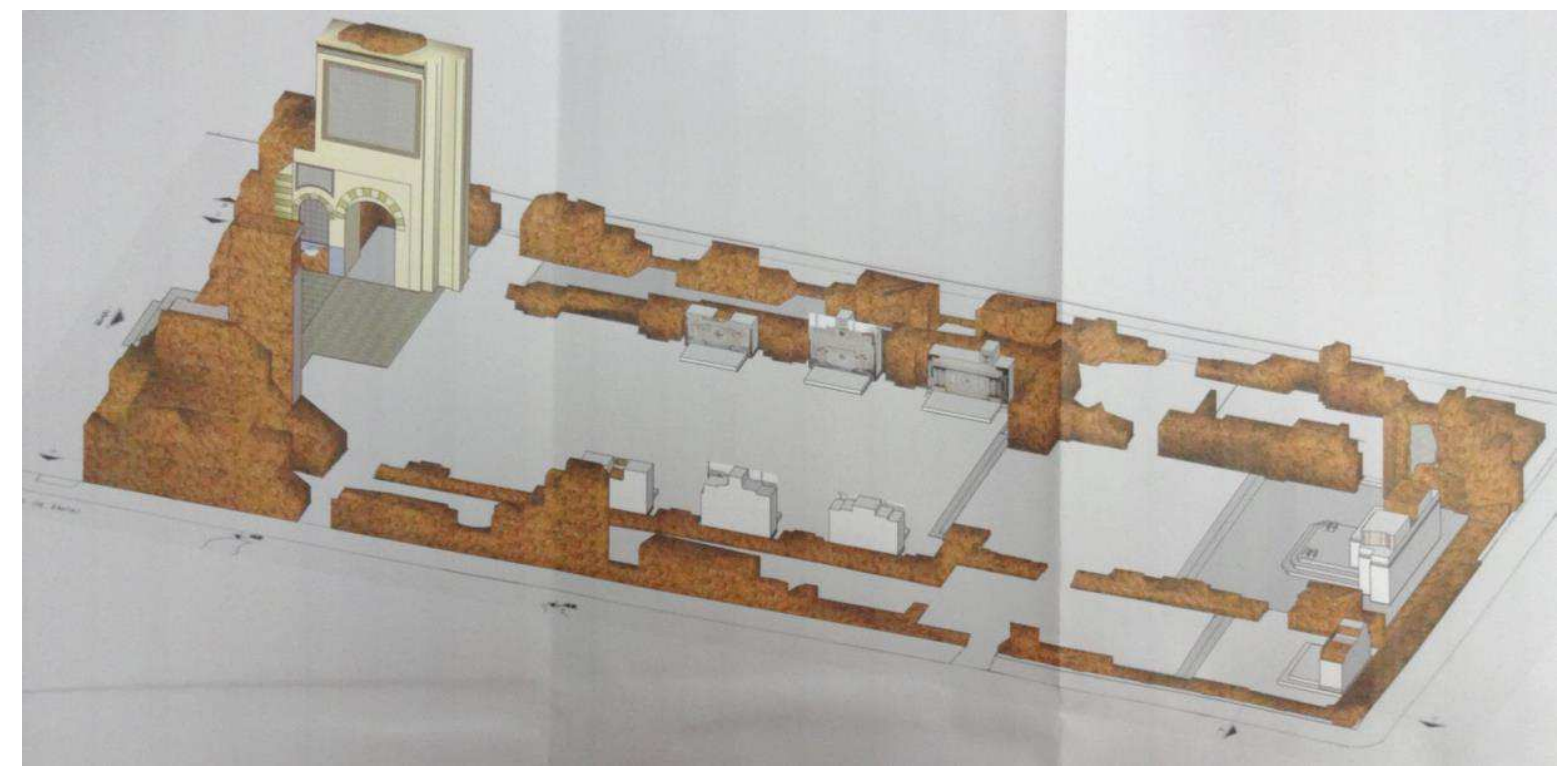

Fig. 134: Levantamento das ruínas da Igreja Matriz.

Fonte: Projeto de Restauração e Reconstrução, F. 02/09 In: IPHAN, Matriz, 2010, p. 166.

De acordo com o Memorial de Reconstrução e Restauro (2011) e o Projeto Executivo de Reconstrução e Restauro (2013) ${ }^{251}$ aprovado pelo IPHAN (elaborado por Formarte Gestão de Projetos Culturais, Restauro e Arquitetura - arquiteta responsável Fabiula Domingues) o partido adotado foi a reconstituição da planta da Igreja com sua volumetria externa tendo como fator temporal de referência o ano de 2010, antes da enchente.

O projeto aprovado propôs o resgate da edificação com todos os remanescentes internos e externos passíveis de restauração. No caso dos elementos que não foram encontrados ou foram totalmente destruídos, foi admitido o refazimento dos elementos originais tendo como referência a documentação gráfica e iconográfica da Igreja.

Em relação à planta, as distribuições dos espaços do pavimento térreo seguiram parcialmente as ambiências anteriores à enchente. Foram mantidos: o nártex, a nave, as galerias laterais, a capela do batismo, a capela e o altar mor e a capela e o altar do Santíssimo. Nas novas galerias laterais estão expostas as taipas remanescentes e painéis expositivos com a trajetória histórica da Igreja.

${ }^{251}$ Respectivamente In: IPHAN, Matriz, 2010, p. 124-164 e p.227-250. 

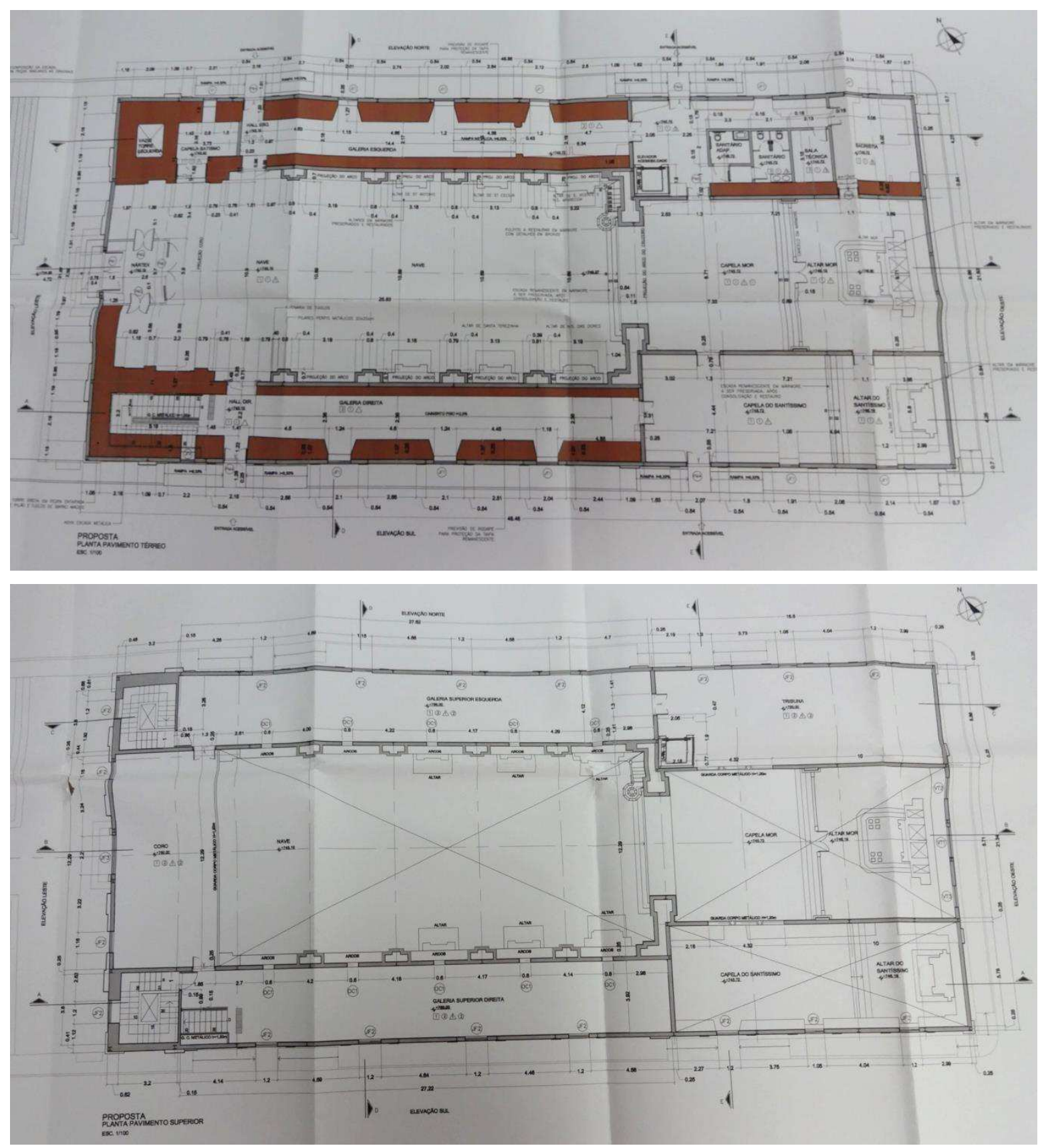

Fig. 135 (i-ii): Igreja Matriz -Plantas Pav. Térreo e Pav. Superior. Fonte: Projeto de Restauração e Reconstrução. F. 03/09. In: IPHAN, Matriz, 2010, p. 167.

As principais diferenças em relação à planta anterior são: o acesso do térreo ao pavimento superior, que antes era por uma escada de madeira e passou a ser por uma escada metálica; novos espaços para sanitários; a dimensão dos ambientes decorrente da adoção de vedações em tijolo maciço em substituição à taipa de pilão e a incorporação das ruínas da Igreja. Para o atendimento às normas de acessibilidade foram incluídas rampas, corrimãos e comunicação tátil visual nas entradas laterais. No acesso principal, a escadaria de granito foi restaurada e complementada em suas partes faltantes, não fazendo parte do percurso acessível. 


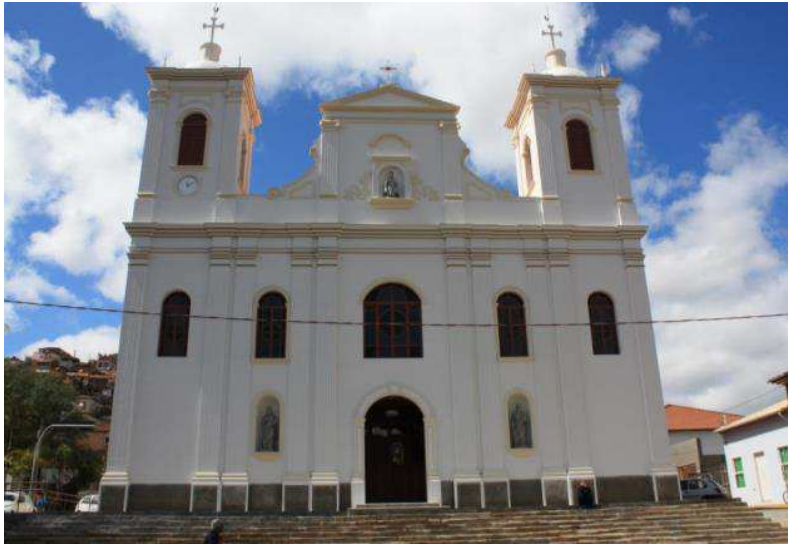

Fig. 136: Igreja Matriz - fachada principal com escada de acesso, 2014. Foto: Autora.
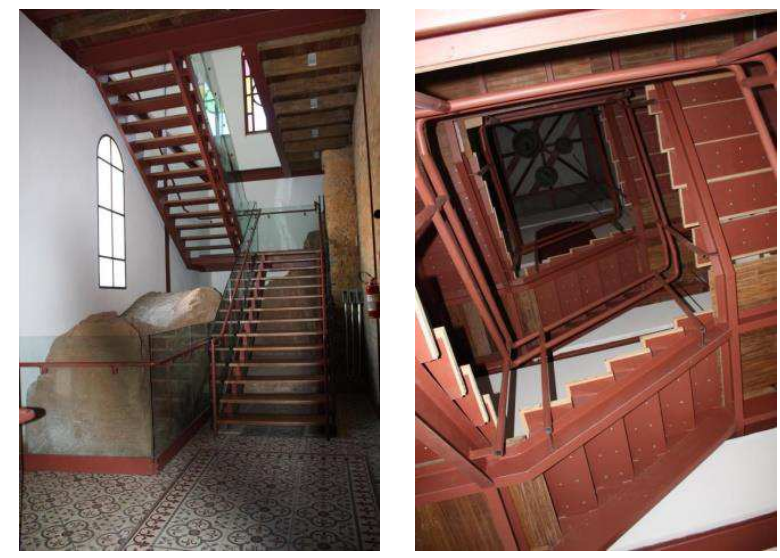

Fig. 137 (i-ii): Igreja Matriz - escada de acesso ao pavimento superior em estrutura metálica, 2014. Fotos: Autora.

O sistema construtivo realizado consiste basicamente em: fundação de concreto (estaca raiz); estrutura metálica com pilares, vigas e barrotes em perfil metálico tipo I, para o piso do coro e demais ambientes do primeiro pavimento foram colocados barrotes metálicos de travamento e suporte para assentamento do assoalho; as paredes são em alvenaria de tijolos maciços. A estrutura da cobertura tem tesouras, caibros e contraventamentos em elementos metálicos; as ripas são de madeira para facilitar a amarração das telhas de barro do tipo francesas que são sobrepostas em uma subcobertura de manta aluminizada.

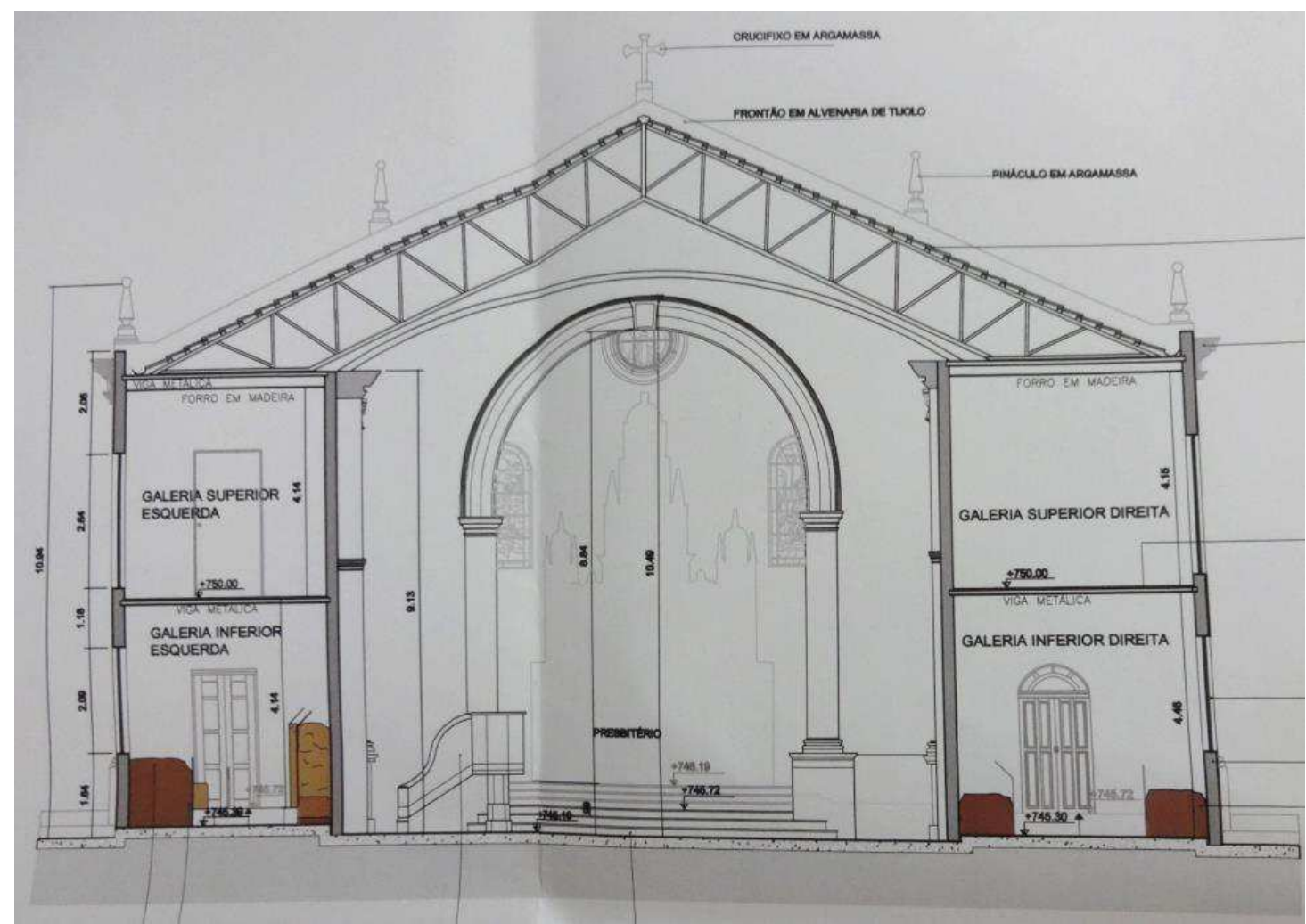

Fig. 138: Igreja Matriz - Corte D-D.

Fonte: Projeto de Restauração e Reconstrução. F. 07/09: Cortes. In: IPHAN, Matriz, 2010, p. 171. 

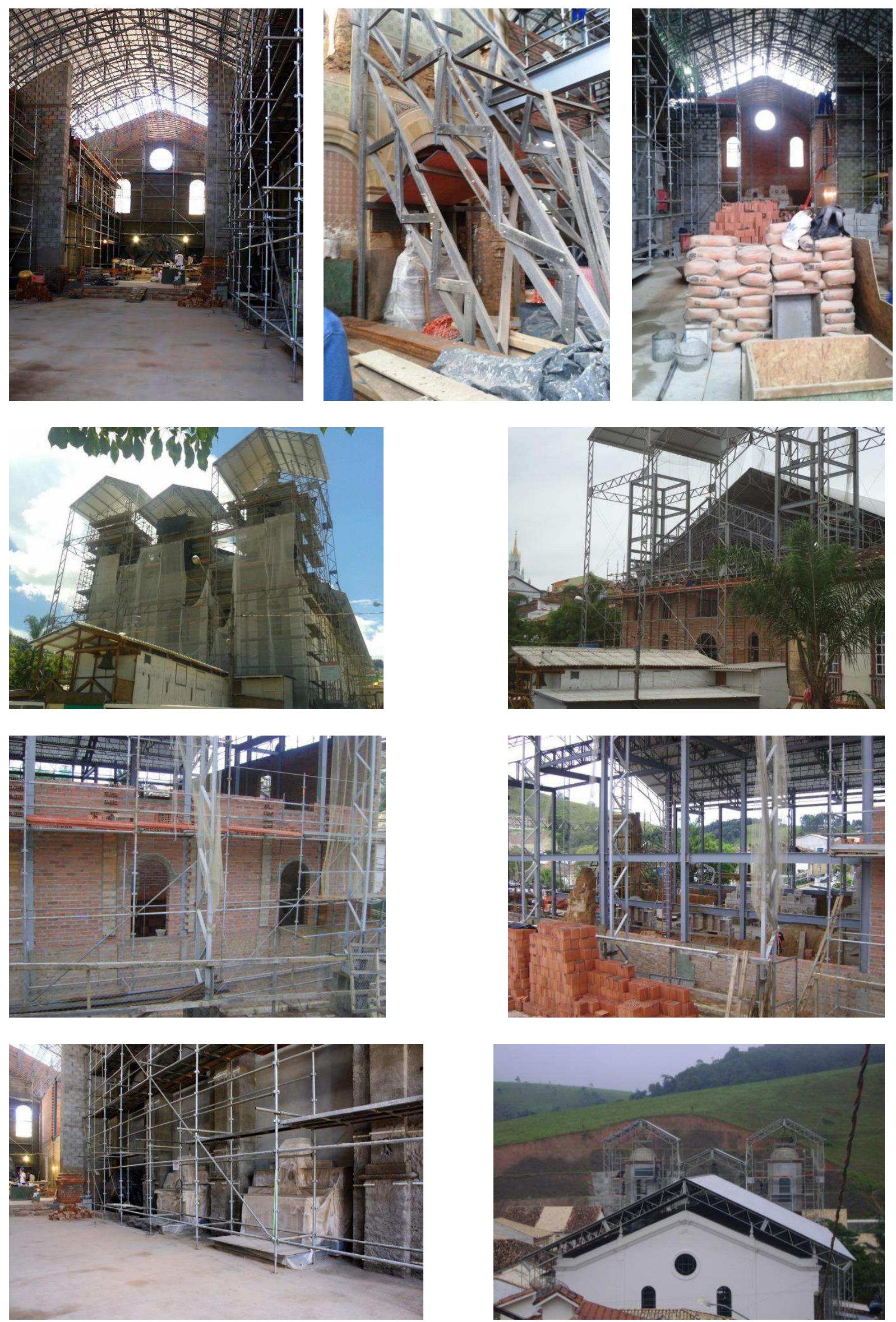

Fig. 139 (i-ix): Igreja Matriz - canteiro de obras, diversas fases em que é possível verificar a técnica construtiva aplicada - estrutura metálica e alvenaria, s.d.. Fotos: Natália dos Santos Moradei. 
Para as esquadrias foi mantido o mesmo sistema original de vãos e ritmos e as novas janelas são de estrutura metálica com vedação em vidro. As portas do pavimento térreo são de madeira com a reprodução dos ornamentos anteriores; no pavimento superior, as portas são de madeira lisa com a aplicação de verniz incolor fosco. Os vitrais das fachadas do fundo e norte foram reproduzidos segundo a iconografia original, mas diferenciados pelo grau de transparência e cores. Em relação aos pisos, no pavimento inferior foi encontrada parte dos ladrilhos hidráulicos; as peças foram removidas, higienizadas, acondicionadas e catalogadas. No pavimento superior o assoalho de madeira original deixou de existir, atualmente o piso é em réguas de madeira. Para as áreas externas foi empregado um novo piso drenante e antiderrapante.

O forro foi em parte resgatado; a recomposição dos trechos artísticos foi empregada no nártex, nave, capela e altar mor, capela e altar do Santíssimo, capela do Santíssimo, capela de Batismo e coro. Nas galerias laterais do pavimento térreo foram empregados barrotes metálicos e no primeiro pavimento assoalho de madeira que foram deixados aparentes, evidenciando os novos materiais utilizados na reconstrução.

No interior da Igreja procurou-se recuperar o projeto de decoração policromada com base nas pinturas remanescentes, nas prospecções pictóricas, no levantamento gráfico dos desenhos, nos registros fotográficos e nas pesquisas em trabalhos dos autores das pinturas originais. Contudo, não foi possível o refazimento de todas as pinturas, somente daquelas nas paredes de taipa de pilão da sacristia e altar mor. As demais salas tiveram acabamento em pintura mineral nas cores definidas por prospecções e fotografias. Os oitos altares de mármore foram restaurados em sua integridade, assim como o púlpito, e os cancelos em mármore. Quando houve a impossibilidade de reaproveitamento de partes danificadas, as peças foram repostas de modo similar às remanescentes.

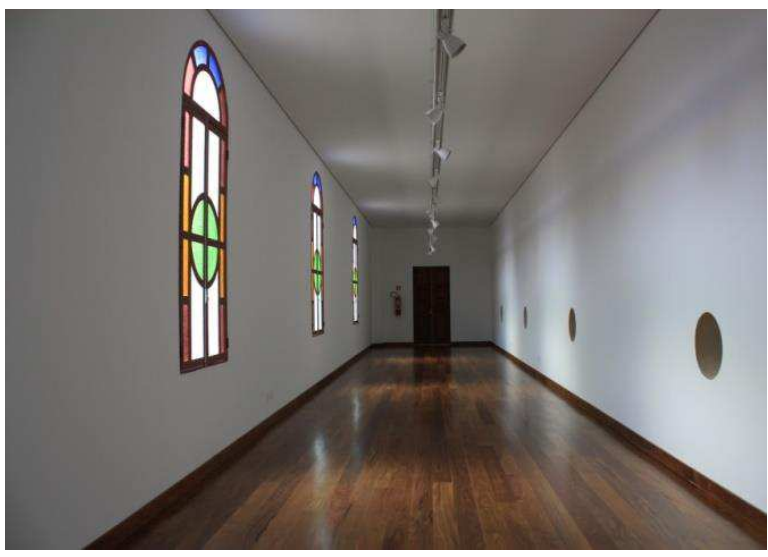

Fig. 140: Igreja Matriz - galeria lateral interna do pavimento superior, 2014. Foto: Autora.

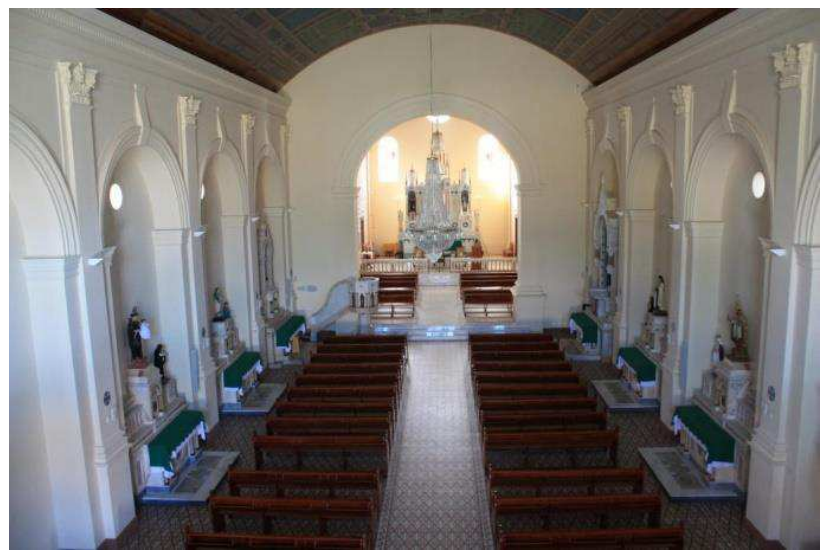

Fig. 141: Igreja Matriz - vista interna da nave principal reconstruída, 2014. Foto: Autora. 

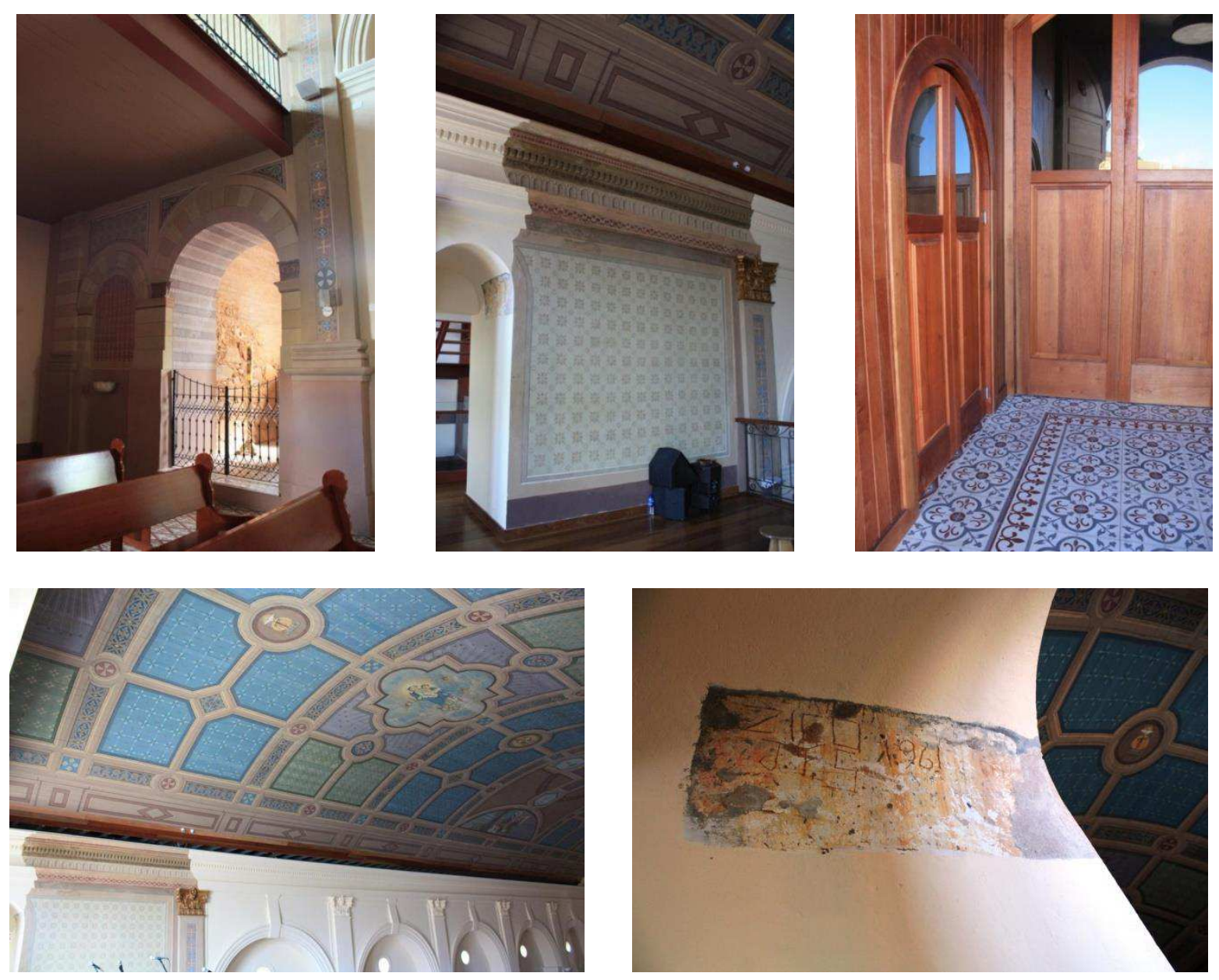

Fig. 142 (i-ii): Elementos decorativos internos, 2014. Fotos: Autora.

Na parte externa não é possível distinguir as partes remanescentes da nova construção. Nas elevações foram adotados os panos lisos de cores claras em tinta mineral seguindo a orientação dos dados de prospecção. As fachadas foram reconstruídas para resgatar a imagem da Igreja antes da catástrofe, reproduzindo todos os possíveis ornamentos arquitetônicos (pilastras, capitéis, cimalhas, cornijas, cúpulas das torres, frontões, platibandas, pináculos, etc.) segundo referências de fotografias e desenhos gráficos.

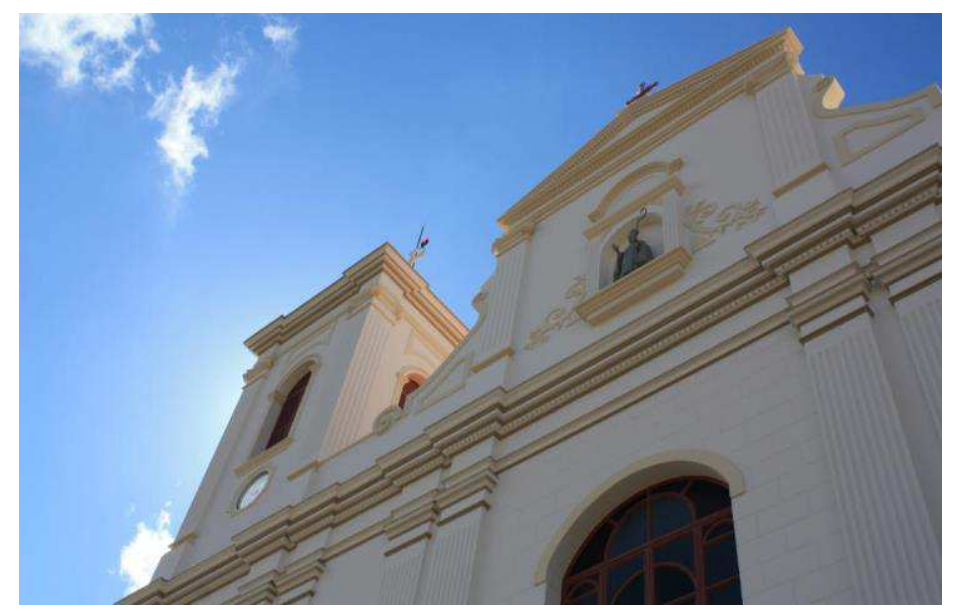

Fig. 143: Igreja Matriz - elementos decorativos na fachada reconstruída, 2014. Foto: Autora. 

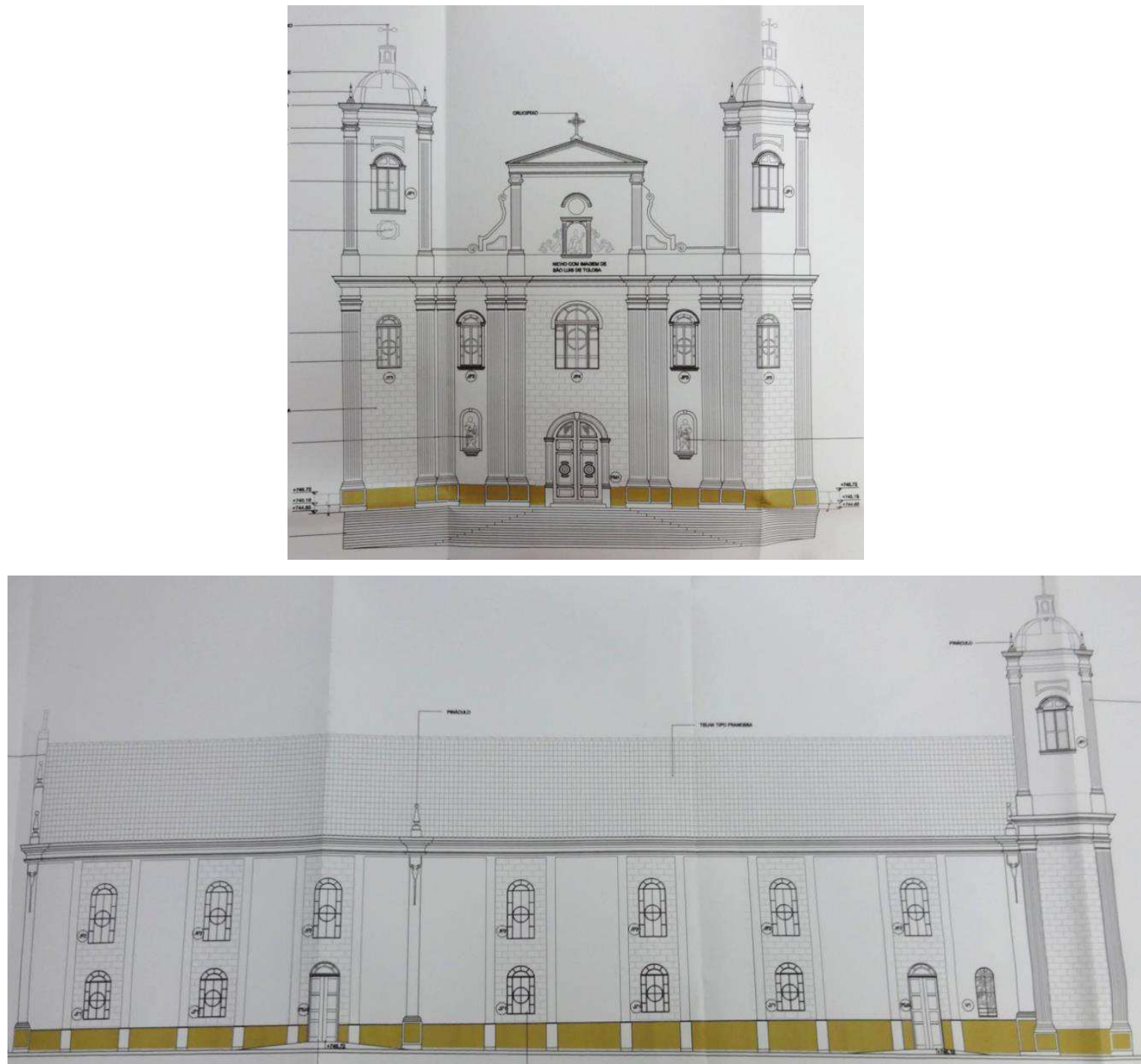

Fig. 144 (i-ii): Igreja Matriz - Fachadas principal e lateral Norte. Fonte: Projeto de Restauração e Reconstrução. F. 08/09. In: IPHAN, Matriz, 2010, p. 172.

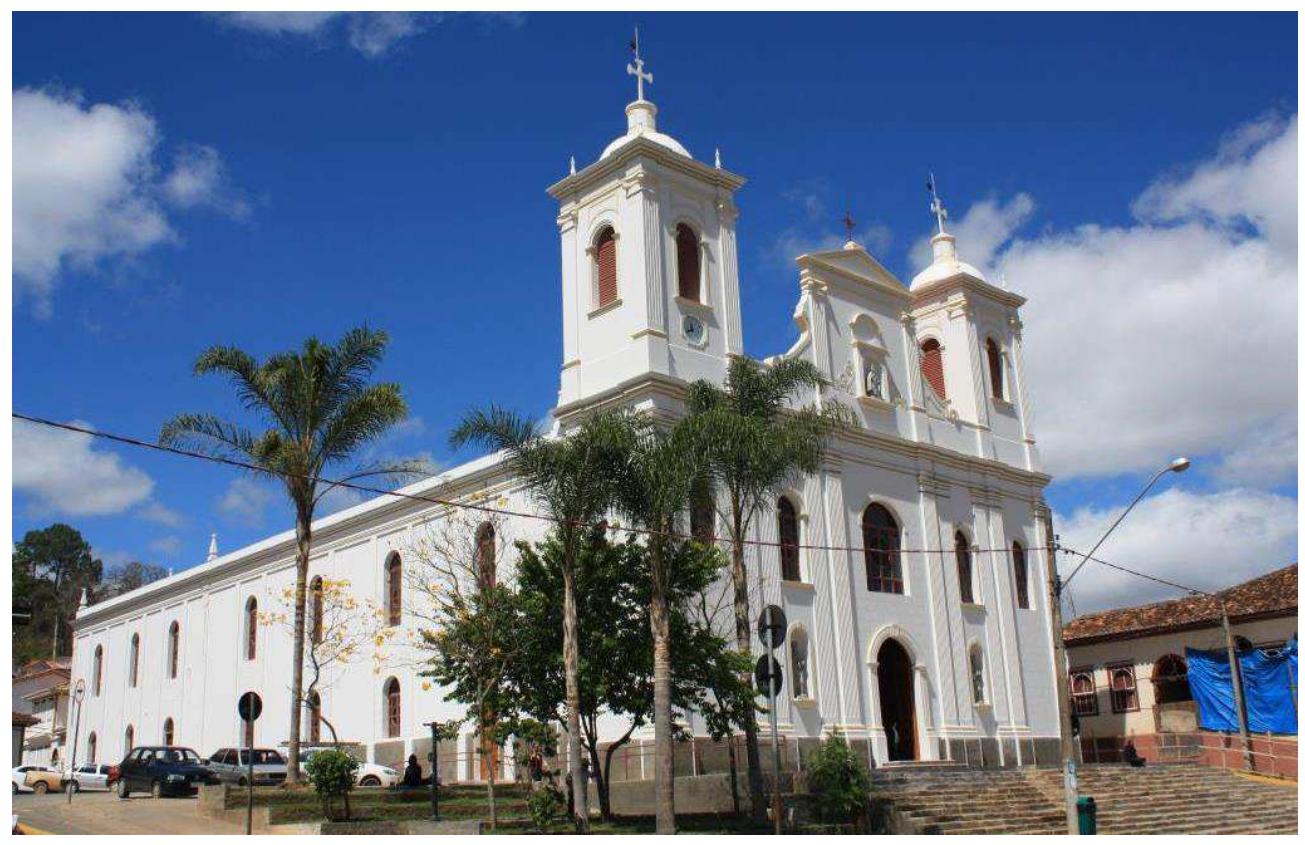

Fig. 145: Igreja Matriz - aspecto externo da após sua reconstituição, 2014. Foto: Autora. 
A recomendação do IPHAN e CONDEPHAAT foi pela correta identificação e adequada consolidação dos vestígios das paredes estruturais de taipa de pilão. O levantamento realizado constatou a variação nas alturas das ruínas da cota zero (onde não sobrou nada mais que a fundação, como o caso das paredes ao fundo do altar mor) até 4,20 m de altura, nos pontos mais altos (caso das paredes das salas da Sacristia, capela e altar do Santíssimo) e 9,61 (da torre lateral). Frente à disparidade dessas cotas, estabeleceu-se o limite de 0,60 m para a remoção do material original, dada a dificuldade de sua inserção na nova estrutura. As ruínas da antiga estrutura em taipa de pilão permaneceram nas galerias laterais, na capela do batismo, no nártex, nos acessos ao pavimento superior e na parede lateral direita da sacristia. O tratamento dessas ruínas, segundo o Memorial Descritivo, seguiu etapas de higienização da superfície; embrechamento das trincas e fissuras com argamassa retirada do próprio local com adição de cal; e proteção final superficial.

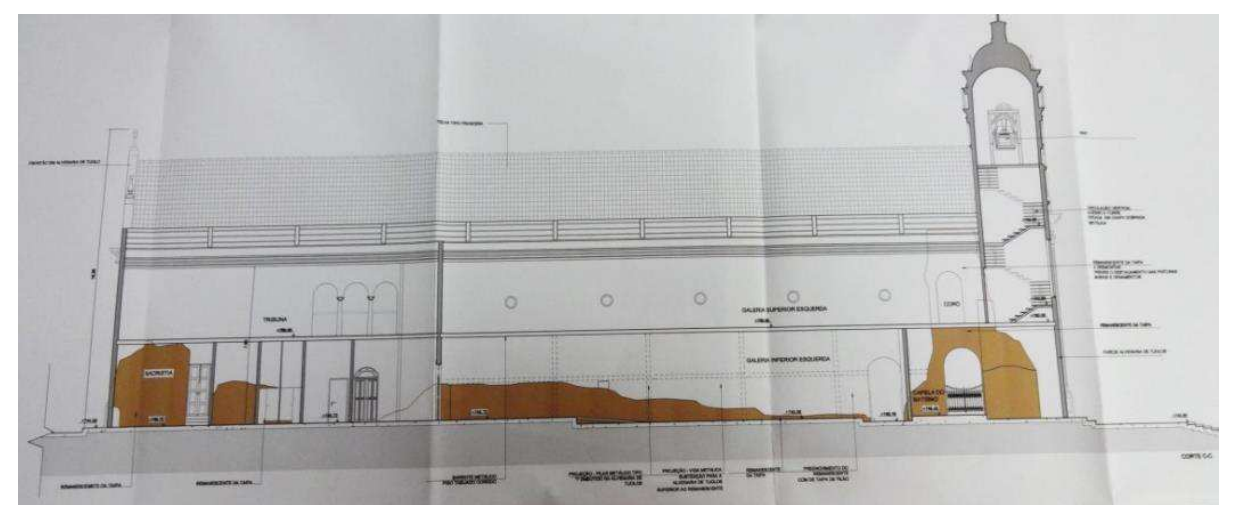

Fig. 146: Igreja Matriz - Corte C-C com elementos que foram mantidos. Fonte: Projeto de Restauração e Reconstrução. F. 07/09: Cortes. In: IPHAN, Matriz, 2010, p. 171.
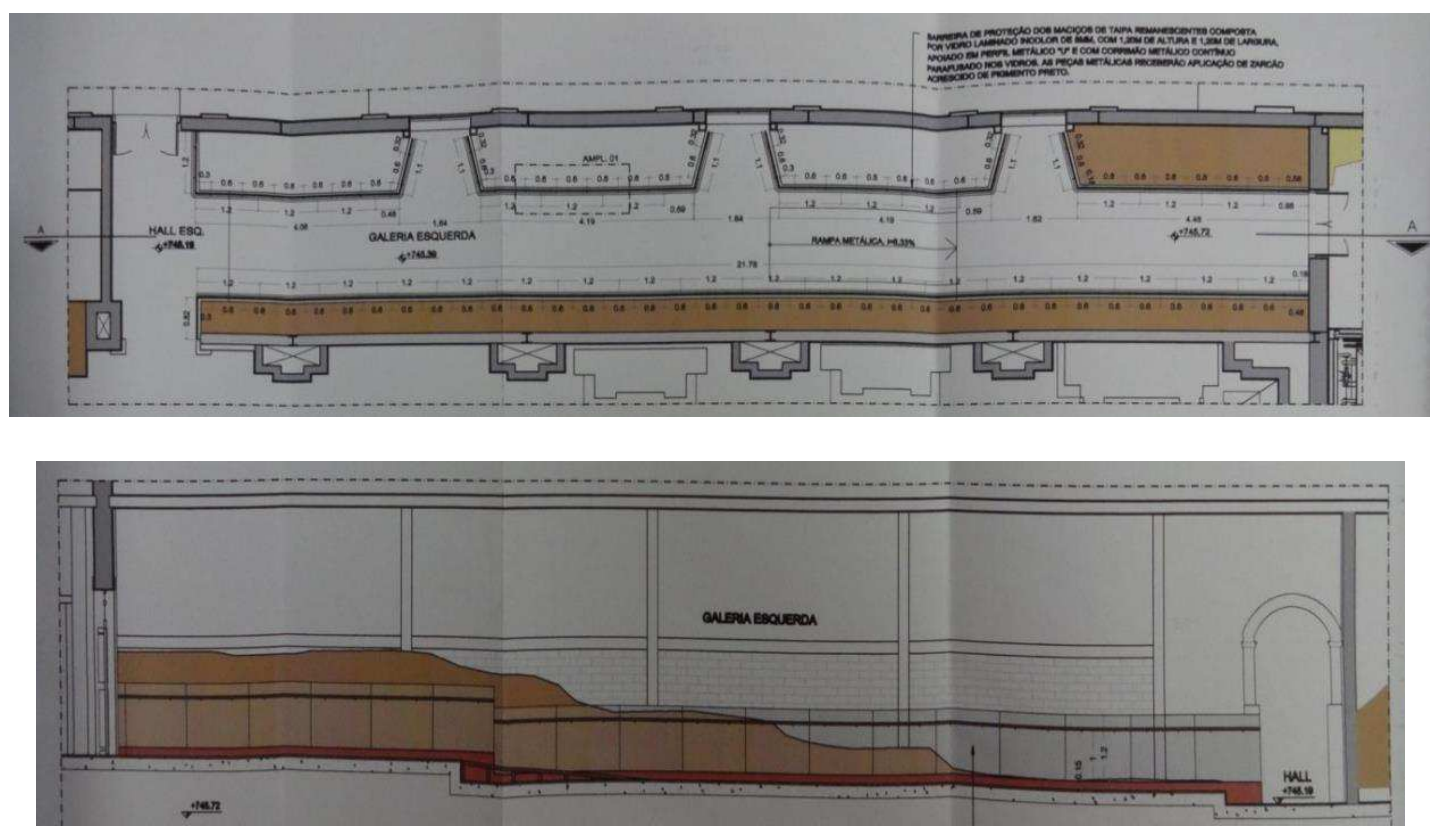

Fig. 147 (i-ii): Igreja Matriz - Galeria lateral esquerda com a indicação das ruínas. Planta e corte. Fonte: Projeto de Restauração e Reconstrução. F. 26: Detalhamento das Taipas Remanescentes. In: IPHAN, Matriz, 2010, p. 211. 

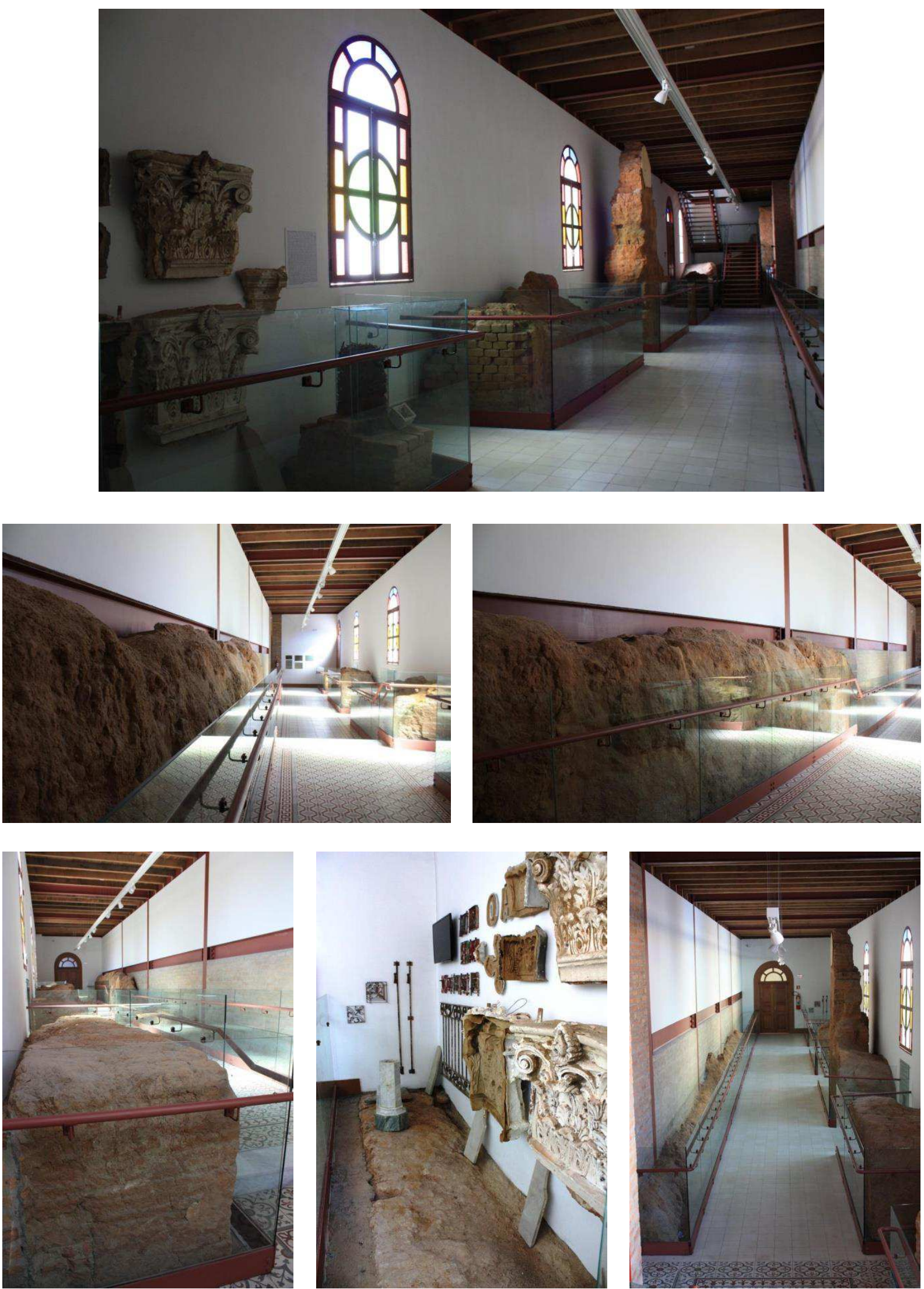

Fig. 148 (i-vi): Igreja Matriz - Galeria lateral com a exposição das ruínas das paredes originais e de fragmentos avulsos, 2014. Fotos: Autora. 

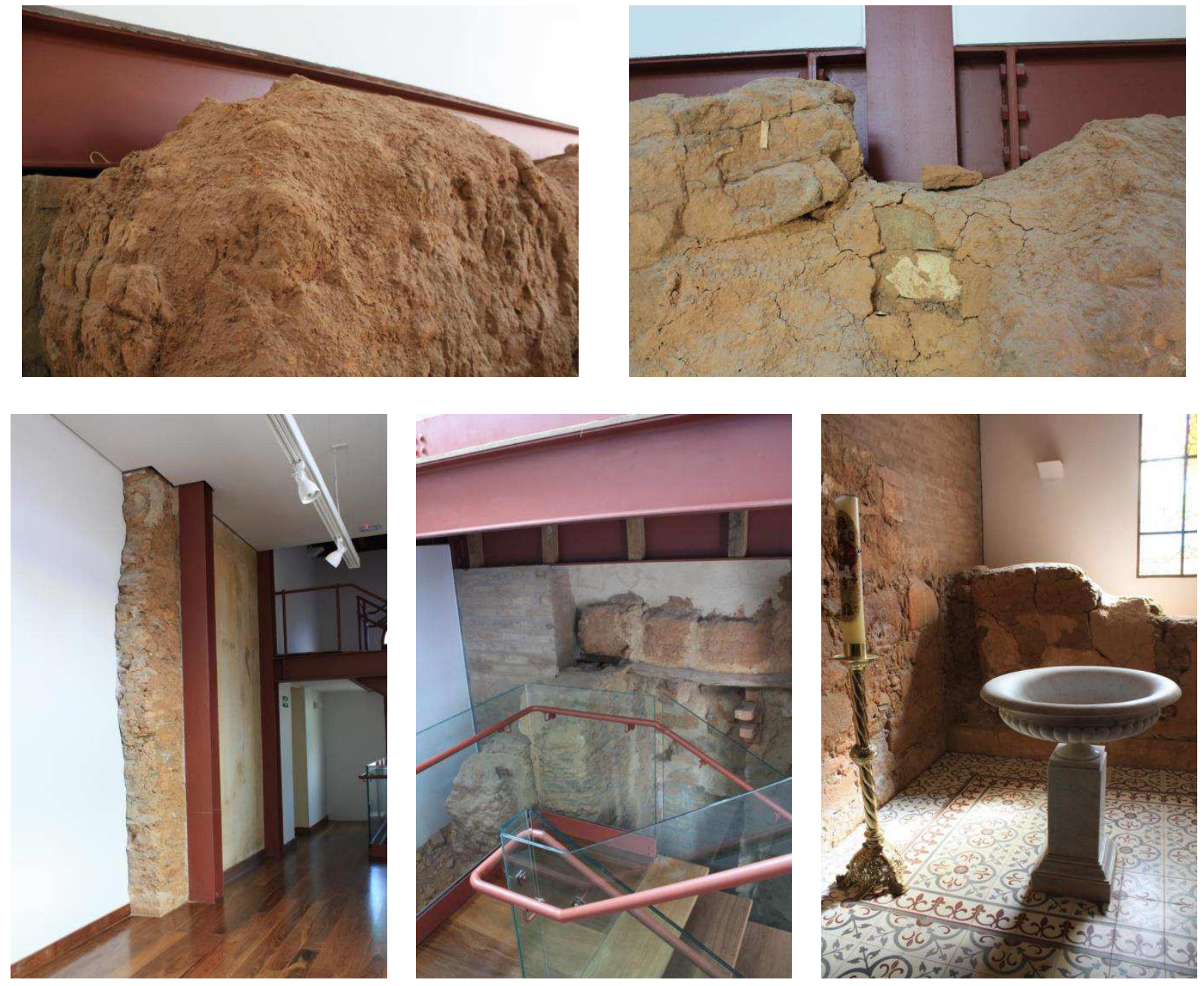

Fig. 149 (i-v): Igreja Matriz - detalhes internos com a integração das ruínas e relação com o novo sistema construtivo, 2014. Fotos: Autora. 


\subsection{Ruínas do incidente: dilemas e premências}

\subsubsection{Identificação e valorização}

Há uma confluência de fatores a serem considerados na análise dos arruinamentos desses bens arquitetônicos: a causa, a contemporaneidade e o grau. Há que se considerar que o objeto de valorização cultural se refere a uma edificação que fazia parte do cotidiano das pessoas e que passou por consideráveis e imprevistas perdas.

Um primeiro questionamento é sobre a validade de reforçar o reconhecimento do valor cultural desses patrimônios através da efetivação de tombamentos após os incidentes. Como apresentado, a Igreja Matriz São Luiz de Tolosa estava no conjunto urbano tombado pela esfera estadual; com as destruições houve uma Resolução Complementar ${ }^{252}$ visando a necessidade de estabelecer diretrizes de ação: “[...] decorrente de uma situação excepcional, provocada pela inundação [...]" (SÃO PAULO - Estado, CONDEPHAAT, 1982, p.234 In: IPHAN, 2010) e o processo de tombamento pelo IPHAN se concretizou. O Teatro Cultura Artística fazia parte de um processo em aberto no CONDEPHAAT que foi finalizado após o incidente, seguido por tombamentos pela esfera municipal e federal, cujo parecer elaborado pelo prof. Nestor Goulart Reis Filho salienta a: “[...] constituição simbólica e referencial do local e dos remanescentes e apesar do incêndio e da destruição [...]" (In: IPHAN, 2010, p. 172 - grifo nosso).

É possível evidenciar a importância que se dá ao tombamento como o instrumento que valida o reconhecimento do valor cultural do patrimônio arquitetônico que foi arruinado. Essas ações após as destruições denotam um caráter de pesar e urgência; não é aventada aqui a alternativa do destombamento (apresentada no capítulo 3); ainda que a perda tenha sido grande, ao menos fica a contrição de autenticar e reforçar o valor do que sobrou desse bem. Além disso, sob a chancela do tombamento é possível balizar as intervenções que ocorreram na sequência para a preservação dos respectivos patrimônios danificados.

As asserções de Riegl apresentadas em Der moderne Denkmalkultus, sein Wesen, seine Entstehung (1903) podem ser uma chave para compreender a complexidade de enfrentamento do impacto desses arruinamentos. Ao evidenciar os possíveis conflitos entre o valor de "antiguidade" (apresentado no capítulo 2) e o valor de "uso" de uma edificação,

\footnotetext{
${ }^{252}$ Resolução complementar a Resolução de tombamento n. 55/82, promulgada em 1 de Fevereiro de 2010, consultada em: SÃO PAULO - Estado, CONDEPHAAT, 1982, p.234-236 In: IPHAN, 2010, s.p.
} 
Riegl se refere à sensação de perda ao ver uma edificação que possuía uma função (como uma casa, uma Igreja ou qualquer outra obra) e passa a não tê-la mais, o que pode proporcionar uma súbita e intolerável impressão de "destruição violenta"253 (RIEGL, 1990, p.59 - trad. nossa). No caso dos edifícios que já conhecemos sem uso, a falta de uma atividade humana não é tão perturbadora (como as ruínas de um castelo medieval ou de um templo romano). Essa consideração de Riegl é crucial para elucidar a distinção de abordagens que podem ser suscitadas por um bem que passou por um processo de arruinamento recente, súbito, inesperado em contraposição a um bem que chega à contemporaneidade em estado arruinado que pode ser apreciado a partir de seu valor de "antiguidade" - como apresentado através das ruínas do tempo no capítulo 2.

Assim como no grupo das ruínas da incúria, um ponto crucial para direcionar esta análise é o grau de destruição. Conforme Brandi (2004), a complexidade em compreender o grau de destruição e aplicar a noção de ruína a um bem arquitetônico danificado envolve o desafio da avaliação sobre o quanto a unidade potencial do objeto foi de fato perdida e não pode ser reintegrada. Brandi apresenta essa problemática a partir do caso da Igreja de Santa Clara em Nápoles bombardeada e incendiada durante a Segunda Guerra; com a destruição ficaram expostos vestígios de uma fase gótica da Igreja. Diante dessa situação Brandi, condensa o impasse do tratamento a partir da aceitação da ruína como o resíduo do monumento.

Os autos dos processos consultados fomentam esse debate sobre o que deveria ser considerado para o tombamento: os remanescentes, a imagem ou a projeção da linha da edificação anterior? Na Matriz, o grau de destruição foi grande e os elementos remanescentes mais significativos eram as torres frontais. Com esse cenário e a necessidade de propor soluções surgiu a seguinte questão: “[...] O que tombamos? O objeto físico ou a sua imagem? [...] A ruína ou a imagem?” (IPHAN, 2010, s.p. - grifo nosso). No Teatro o grau de destruição foi menor, a forma arquitetônica era mais legível através da conformação das paredes originais que permaneceram; porém, durante a tramitação do tombamento pelo IPHAN também surgiram dúvidas a respeito da indefinição do "objeto físico", havia um entendimento que a destruição do Teatro foi praticamente total e, portanto, a listagem do local incidiria somente em uma linha abstrata da antiga edificação, que delimita um sítio historicamente importante, porém, sem efetivos testemunhos materiais:

${ }^{253}$ Trecho original: “distruzione violenta” (RIEGL, 1990, p. 59). 
De fato o tombamento não poderia incidir sobre uma existência totalmente perdida - o teatro, posto que seu remanescente principal lhe é externo, inclusive quanto à atividade teatral, ainda que simbólico ou referencial para a distinção do lugar. (JÚNIOR, J. L. Galvão, Nota Técnica 012/2010, In: IPHAN, 2010, p. 175)

O Parecer supletivo do IPHAN $^{254}$ não incide na linha de projeção da área total do Teatro e engloba os remanescentes do antigo acesso principal e o foyer atingido pelo sinistro, elementos que sustentam o painel de mosaicos, com a recomendação de que tais estruturas deveriam ser preservadas e incorporadas na nova edificação; a área envoltória passou a ser o limite do lote. Por fim, a definição e denominação do objeto a ser listado explicitou que se trata dos: "Remanescentes do antigo Teatro Cultura Artística, [...], incluindo os elementos de vedação e caixilharia que deles fazem parte, bem como o painel de Di Cavalcanti que os integram.” (BONDI, Parecer Supletivo, p. 10 In: IPHAN, 2010, s.p.).

Importante destacar que o termo "ruína" é pouco utilizado para ambos os casos. No Teatro Cultura Artística, não há essa menção, a referência que se faz é sempre aos "remanescentes" tanto nos autos dos processos de tombamento quanto no projeto que foi elaborado. Após algumas revisões do texto, a minuta final do tombamento do CONDEPHAAT publicada em 2009 ficou da seguinte forma:

Artigo $1^{\circ}$ : Fica tombada a fachada remanescente do Teatro Cultura Artística localizado na Rua Nestor Pestana, 196, São Paulo, Capital, inclusive os elementos de vedação e caixilhos que dela fazem parte, bem como o painel de Emiliano Di Cavalcanti que o integra.

Artigo $2^{\circ}$ : Estabelece-se que a área envoltória dos remanescentes da Sociedade Cultura Artística, restringe-se aos limites do próprio lote (SQL 006.012.1019), conforme faculta o Decreto $\mathrm{N}^{\mathrm{o}}$ 48.137, de 7.10.2003. (SÃO PAULO - Estado, CONDEPHAAT, 1995, p.125 - grifo nosso)

Já no caso da Igreja Matriz São Luiz de Tolosa, as menções ao termo "ruínas" são mais recorrentes no âmbito das discussões internas aos órgãos de preservação sobre a definição do objeto e orientação de tratamento; mas há uma grande incidência à identificação dos "remanescentes", como consta nos autos do processo IPHAN: "[...] consolidação dos remanescentes da edificação tombada [...]" (Res. SC-03 In: IPHAN, 2010, p. 257) e na elaboração do projeto final que foi executado (Justificativa, Memorial Descritivo e pranchas finais de apresentação).

Como apresentado no primeiro capítulo, na língua portuguesa a estrita definição de ruína considera "restos ou partes mais ou menos informes de um ou mais prédios

${ }^{254}$ Elaborado pelo Arq. Mauro David Artur Bondi, Memorando N. 008/2011 In: IPHAN, 2010, s.p. 
desmoronados ou destruídos pelo tempo, explosão, incêndio, etc.;”. (HOUAISS e VILLAR, 2001, p. 2482 - grifo nosso).

Sendo assim, entendemos ser adequada para esses casos a utilização do termo "ruína" por se referir a remanescentes de edificações que foram subitamente danificados (total ou parcialmente). Em nossa análise, o termo "ruína" para se referir aos restos de edificações danificadas por incidentes trágicos e recentes pode enfatizar a tragicidade da perda, já o termo "remanescente" - que na língua portuguesa se refere ao que resta enquanto "sobrevivente" (Op. cit., p. 2423) - predispõe uma interpretação sutilmente diversa em que se vislumbra no resto um maior potencial de reintegração. Essa diferenciação no uso dos termos é um aspecto que colabora para verificar como o produto dessas edificações destruídas é identificado e, consequentemente tratado sob as perspectivas documental e simbólica.

A confluência dos fatores analisados aqui - grau, causa e contemporaneidade do arruinamento - foi decisiva na historiografia da preservação patrimonial para a amplificação dos debates. Se antes dos eventos bélicos do século $\mathrm{XX}$ o restauro já constituía um dos campos disciplinares mais fascinantes e delicados, com os anos de destruição o tema se tornou ainda mais intrincado.

Retomando o que foi apresentado no capítulo 1, a teoria da restauração válida até então era a denominada postura "intermediária" (ou restauro filológico) cujos preceitos básicos prescreviam mínimas obras de manutenção, reparação e consolidação nos bens, o respeito a todos os elementos de valor artístico de qualquer época, limitando os acréscimos ao estritamente indispensável e conduzido por dados seguros embasados documentalmente. Diante das destruições maciças provocadas pela Segunda Guerra esses preceitos passaram a constituir questões a serem debatidas do ponto de vista do princípio e método de aplicação, intelectuais ${ }^{255}$ apresentaram algumas considerações sobre a complexidade da situação. A nova conjuntura apresentava de forma mais incisiva o problema de restituir elementos indispensáveis à fisionomia das cidades danificadas, salvando, na medida do possível os preciosos restos da antiga arquitetura.

Com a dimensão das áreas destruídas e da urgência da situação Ambrogio Annoni (1882-1954), em seu trabalho Scienza ed arte del restauro achitettonico - idee ed esempi

\footnotetext{
${ }^{255}$ Alguns títulos consultados sobre o tema: BONELLI, Renato. Architettura e Restauro (1959); em especial no capítulo: Danni di Guerra, riconstruzione dei monumenti e revisione della teoria del restauro arquitetonico, p.41-58. LAVAGNINO, Emilio. Offese di Guerra e restauri al patrimonio artistico dell Italia In: Ulisse, anno 1, fascicolo II, Agosto 1947. PANE, Roberto. Considérations sur la réunion d`experts tenue au siège de l'UNESCO du 17 au 21 octobre 1949 In: Revista Museum, vol. iii, n. i, 1950.
} 
(1946), adicionou para além das já mencionadas distinções entre monumentos "vivos" e "mortos" (ver capítulo 1), outra categoria que vislumbra monumentos em risco: os monumentos “periclitantes"256 (ANNONI, 1946, p. 19 - trad. nossa).

Embora essa classificação possa parecer interessante como um meio de designar a situação de degradação de um patrimônio, não consta nos preceitos do restauro crítico e da Carta de Veneza que parte do pressuposto de que todo o bem cultural deva ser tratado segundo princípios básicos a serem aplicados a partir de um juízo crítico que se faça da materialidade e da configuração de cada caso segundo a determinação das instâncias histórica e estética conforme evidenciado pela teoria de Brandi (1963) e pelos apontamentos de Roberto Pane na conferência introdutória à Carta de Veneza (1964).

Verifiquemos agora o quanto a interposição dos aspectos levantados até o momento contemporaneidade, causa e grau de arruinamento - se coadunam na orientação para as propostas aos estudos de caso.

\subsubsection{Intervenções e os impasses conceituais da reconstrução}

A contemporaneidade em relação à destruição e a urgência mediante a situação trágica e traumática estão presentes nas justificativas das ações para os estudos de caso aqui analisados. Na Igreja Matriz São Luiz de Tolosa, cuja perda para a configuração urbana foi maior que a perda arquitetônica em si, havia um proeminente caráter emergencial. Logo nas primeiras audiências públicas de janeiro de 2010 a opção pela reconstrução apareceu como uma indicação de atuação pelos órgãos de preservação: “f) Em relação às Igrejas que desabaram, defendemos que sejam reconstruídas, reconstituindo-se a volumetria e planta de forma semelhante às que se verificavam antes do sinistro." (SÃO PAULO - Estado CONDEPHAAT, 27.01.2010 In: IPHAN, 2010, s.p.).

No entanto, essa indicação passou por discussões internas nos órgãos de preservação a respeito da viabilidade e da coerência e foram apresentadas três alternativas: "[...] solução contemporânea, reprodução do edifício arruinado, recuperação de solução estilística original, segundo registro documentado." (SÃO PAULO - Estado, CONDEPHAAT, Res. SC-03, 23.02.2010, p.257 In: IPHAN, 2010, s.p.).

\footnotetext{
${ }^{256}$ Trecho original: "pericolanti” (ANNONI, 1946, p. 19).
} 
O conselheiro do CONDEPHAAT Jon Andoni V. Maitrejean atrelou as possibilidades de abordagem em função do entendimento que se faria das ruínas:

[...] as ruínas que sobraram têm valor e potencial para orientar critérios para reconstrução, por exemplo, as fundações que em geral eram de pedra ciclópica poderiam servir de apoio para as novas paredes justificando assim a repetição da planta original. Ou as ruínas que sobraram não têm potencial reaproveitável, neste caso abrem-se algumas direções inclusive a proposta da UPPH que sugere reconstruir a volumetria e planta de forma semelhante às que se verificavam antes do sinistro. Abre-se também outro caminho, tendo em vista que o bem já não mais existe novas ideias poderão ser propostas e não vemos melhor maneira de potencializá-las do que um concurso de arquitetura, com total liberdade de criação, valendo para todo o conjunto da praça, igreja, cadeia, prefeitura, sobrados, etc. (In: IPHAN, 2010, pasta 2, s.p. - grifo nosso).

A alternativa de elaborar um projeto completamente novo, formalmente distinto do original foi, portanto, levantada, mas não foi adiante. A opção mais direta foi pela reconstrução para retomar o aspecto formal da Igreja antes do arruinamento pela enchente, justificada como sendo do "interesse da coletividade" (São Paulo - Estado, CONDEPHAAT, Parecer N.021/2010 In: Op. cit., p.242). De qualquer forma havia uma estrita designação sobre a necessária identificação e consolidação dos remanescentes.

Um dos posicionamentos do IPHAN sobre o projeto aponta que "tal reconstrução possibilitará a retomada econômica da cidade e responderá aos anseios da comunidade diretamente envolvida com a Matriz." (VIEIRA, Mem. 416, 2010 In: IPHAN, 2010, s.p.). Nesse sentido, a manutenção econômica da cidade é atrelada à atividade do turismo ligada ao patrimônio cultural, cuja Igreja é um marco icônico; e a sua restituição formal se interpõe como um fator imperativo em contraposição a uma possível valorização dos sinais de sua destruição.

Como resultado final, houve uma atualização da edificação com uso de materiais contemporâneos (fundações, vedações, estrutura e cobertura) e adaptações em função das atuais normas acessibilidade; e as dimensões da edificação foram alteradas para englobar os remanescentes de taipa. Externamente a Igreja tem as mesmas características que tinha antes de ter sido arruinada, não sendo possível distinguir visualmente informações sobre sua idade e reconstrução recente; internamente a situação é diversa, a reconstrução é evidenciada em alguns ambientes pela visualização do contraste dos antigos maciços de taipa em contraponto às novas técnicas construtivas (galerias laterais e sala do Batismo).

Pode-se evidenciar que os remanescentes da Igreja são vislumbrados pelo seu potencial aspecto documental, a inclusão das ruínas na nova edificação passa por um processo de 
valorização histórica para orientar critérios de reconstrução e justificar a repetição da planta prévia. As ruínas integradas na edificação são referenciais visuais - para quem adentra a Igreja - informando sobre as características materiais e técnicas construtivas que constituíam o edifício anterior - mas é latente que o principal objetivo é restituir a imagem da Igreja para a recomposição da praça tal qual era antes da enchente para que não se perca a leitura do espaço urbano que justificou o tombamento do núcleo pelo CONDEPHAAT em 1982.

Para justificar o partido arquitetônico da reconstrução ${ }^{257}$ os autores do primeiro projeto elaborado pela Mitra Diocesana de Taubaté (arquitetos Lívia Vierno Rodrigues de Moura, Olga Rodrigues Nunes de Souza e Marcos Paulo Martins), fazem menções às Cartas Patrimoniais e aos teóricos referenciais da preservação patrimonial. O Memorial do Projeto que foi efetivamente aprovado pelo IPHAN - elaborado por Formarte (Gestão de Projetos Culturais, Restauro e Arquitetura, arquiteta responsável Fabiula Domingues) ${ }^{258}$ também se refere aos documentos internacionais e às teorias de preservação.

Nessas argumentações, há citações à Carta de Veneza (1964) sobre a impossibilidade de reconstrução de ruínas (aludindo ao Art. 15) e sobre a consolidação que pode ser efetuada utilizando técnicas construtivas atuais para a conservação ou construção em monumentos. Há ainda referências à Carta do Restauro Italiana (1972) no que diz respeito à proibição de aditamentos em estilo e a remoções e demolições que apaguem a trajetória da obra ao longo dos anos. Da Carta de Burra (1980) foi recuperada a limitação da reconstrução à reprodução de características conhecidas graças a testemunhos materiais ou documentais ${ }^{259}$. E do Documento de Nara (1994), a questão da autenticidade do patrimônio. A partir dessas referências teóricas foi possível constatar uma latente percepção por parte dos autores desses projetos para a Matriz da complexidade do tema da reconstrução envolvendo problemas de distinguibilidade dos materiais e de autenticidade (já apresentados no capítulo 3).

Na historiografia da preservação patrimonial a opção pela reconstrução mediante um incidente súbito e trágico tem uma extensa casuística. O colapso do Campanário de San Marco e de parte da Loggetta del Sansovino em Veneza que ocorreu em 14 de Julho de 1902 é um caso emblemático, cujas propostas engendraram inúmeras controvérsias. Optou-se por um

\footnotetext{
${ }^{257}$ Projeto de Reconstrução da Igreja São Luiz de Tolosa, FUNDJAC - Fundação Dom José Antônio do Couto (Mitra Diocesana de Taubaté), Taubaté abril/setembro/2010 In: IPHAN, Matriz, 2010, p.97-113.

${ }^{258}$ Memorial de Reconstrução e Restauro, dezembro/2011 In: IPHAN, Matriz, 2010, p.124-164.

${ }^{259}$ Cf.: “Art. 19: A reconstrução deve limitar-se à reprodução de substâncias cujas características são conhecidas graças aos testemunhos materiais e/ou documentais. As partes reconstruídas devem poder ser distinguidas quando examinadas de perto.” (ICOMOS, 1980 In: Op. cit., p. 251).
} 
processo reconstrutivo especificado por Luca Beltrami ${ }^{260}$ (1854-1933) com um acurado projeto de repristino - "com 'era e dov'era" (Como era, onde estava) (CARBONARA, 1997, p.183). Após a demissão de Beltrami, os trabalhos foram prosseguidos por Gaetano Moretti (1860-1938) que sublinhou a necessidade de se valer de instrumentos técnicos tradicionais e modernos para uma reconstrução que assegurasse a existência de um novo Campanário - uma cópia do antigo com cerca de 2000 toneladas a menos - cujas obras terminaram em janeiro de 1912.

O Campanário de San Marco tornou-se um caso paradigmático do mote com era, dov`era para a cultura internacional da preservação patrimonial, apesar da utilização de materiais diversos dos originais para obter um menor peso estrutural atestar que a reconstrução tal "como era" não tenha sido, de fato, executada. Os argumentos basearam-se na vontade popular que via na reconstrução do Campanário uma necessidade simbólica para o sentimento de coletividade de Veneza.

As duas Grandes Guerras propiciaram cenários decisivos no que diz respeito à opção pela reconstrução. A cidade de Ypres (Bélgica), por exemplo, foi completamente destruída durante a Primeira Guerra; com o armistício, o governo belga iniciou um processo que envolveu a reconstrução de edifícios históricos tendo como referência sua aparência anterior (MARTÍNEZ, 2007).

Após a Segunda Guerra, durante reunião da UNESCO em 1949, Roberto Pane ${ }^{261}$ destacou uma questão que vem sendo evidenciada nesta análise: o apelo popular para a reconstrução de monumentos, uma operação que se não é totalmente justificada do ponto de vista crítico, pretende responder aos imperiosos desejos de toda uma cidade. Nesse contexto, Varsóvia tornou-se um caso emblemático. A reconstrução da capital polaca se estendeu por extensos trechos da cidade que foram totalmente destruídos pelas tropas nazistas em 1945. Logo após o fim da Guerra foram iniciados os trabalhos numa empreitada que seguiu até meados de 1950 constituindo um evento simbólico de superação do povo polaco mediante a tragédia. As reconstruções do centro histórico utilizaram como referência uma extensa documentação iconográfica que havia sido conservada mesmo durante a ocupação nazista; os fragmentos salvos também foram sistematicamente resgatados por civis voluntários.

\footnotetext{
260 Beltrami foi um dos alunos de Camillo Boito na Faculdade de Arquitetura do Politécnico de Milão; posteriormente estudou na École de Beaux Arts, Paris.

261 PANE, Roberto. Considérations sur la réunion d’experts tenue au siège de l'UNESCO du 17 au 21 octobre 1949 In: Revista Museum, vol. iii, n. i, 1950.
} 
Alguns monumentos foram reconstruídos décadas mais tarde, como a Prefeitura e o Castelo Real ${ }^{262}$, que é mencionado como referência na justificativa para os trabalhos da Igreja Matriz São Luiz de Tolosa. Durante a maciça reconstrução de Varsóvia, os resultados foram distintos: cópias fiéis se aplicaram, sobretudo, a exemplos de arquitetura religiosa e à praça antiga do centro histórico; em outros casos aproveitou-se a oportunidade para uma adaptação voltando-se a estilos selecionados, como na Catedral, reconstruída em um estilo que remete às origens medievais, diferente da edificação destruída. A justificativa para todas essas reconstruções sempre se pautou pelo imperativo moral de identidade do povo polonês.

Entretanto, o tema da reconstrução é controverso, e, mesmo nesse período pós Segunda Guerra, foi objeto de enfáticas críticas. Conforme Annoni (1946), ainda que a arquitetura perdida tenha um valor histórico, artístico e sentimental, a opção pela reconstrução deve ser recusada, pois pode constituir uma falsificação:

O que parece ser de suprema importância, entretanto, é não recair em nenhuma fantasia sentimental que pode induzir restauradores a reconstruir aquilo que foi destruído para além da reparação, e isso somente seria a perpetuação de uma fraude. Em alguns casos é mais aconselhável limpar o terreno para a plantação de árvores ou áreas verdes como um memorial da beleza de outrora e dos males da guerra. (ANNONI, 1946, p.21 - trad. nossa - grifo nosso) (263 $^{26}$

Em suas considerações de 1959, Renato Bonelli, alega que:

A reconstrução completa do monumento nas mesmas formas não é admissível, ao menos teoricamente, nem mesmo quando se disponha de todos os velhos pedaços que compõe a estrutura e os precisos levantamentos do estado anterior à ruína, já que a remontagem não poderá refazer perfeitamente e em todas as nuances o processo de edificação. (BONELLI, 1959, 56 - trad. nossa) $)^{264}$

Essas críticas se coadunam à teoria de Brandi que se posiciona contrário ao "refazimento", pois, ao fundir o velho e o novo pode interferir na percepção temporal da obra:

O refazimento, [...], pretende replasmar a obra, intervir no processo criativo de maneira análoga ao modo como se desenrolou o processo criativo originário, refundir o velho e o novo de modo a não distingui-los e a abolir ou reduzir ao mínimo o intervalo de tempo que aparta os dois momentos. (BRANDI, 2004, p. 73)

\footnotetext{
262 O Castelo foi destruído em um bombardeio em 1939 e os trabalhos de reconstrução ocorreram entre 1971 e 1988 com a colaboração de voluntários civis e ajuda financeira da comunidade polonesa de todo o mundo (MARTÍNEZ, 2007).

263 Trecho original: "What seems of paramount importance, however, is not to indulge in any sentimental fancy that may induce restorers to build anew that which has been destroyed beyond repair, as it only be the perpetration of a sham. In such cases it would seem more advisable to clear the ground for the planting of trees or greenery as a memorial of the beauty that had once been and the evils of the war." (ANNONI, 1946, p.21)

264 Trecho original: "La ricostruzione completa del monumento nelle stesse forme non è mai ammissibile, almeno teoricamente, neanche quando si disponga di tutti $i$ vecchi pezzi che componevano le strutture e dei precisi rilievi dello stato anteriore alla rovina, poiché il rimontaggio non potrà rifare perfettamente e in tutte le sfumature il processo di edificazione." (BONELLI, 1959, p. 56)
} 
Ao mencionar o Campanário de São Marcos e a Ponte Santa Trindade em Florença (destruída em 1945 e reconstruída), Brandi se refere à gravidade de se optar pela "cópia" como: “[...] um falso histórico e estético e por isso pode ter uma justificação puramente didática e rememorativa, mas não se pode substituir sem dano histórico e estético ao original." (BRANDI, 2004, p.88-89). E acrescenta de modo contundente: “O adágio nostálgico 'como era, onde estava' é a negação do próprio princípio da restauração, é uma ofensa à história e um ultraje à Estética, colocando o tempo como reversível e a obra de arte como reproduzível à vontade." (Op. cit., p. 89). Essa problemática reaparece na Conferência Introdutória à Carta de Veneza, proferida por Roberto Pane ao comentar que com o propósito de recompor as formas que a guerra destruiu, a restauração dos monumentos tomou um tendencioso rumo à reconstrução estilística (PANE, 1964).

Apesar desses debates nas décadas de 1950 e 1960 que antecederam a formulação da Carta de Veneza, a alternativa da reconstrução estilística tal como a edificação era antes do processo de arruinamento utilizando técnicas construtivas e materiais semelhantes aos originais ou com materiais alternativos condizentes à contemporaneidade da intervenção continua oferecendo um profícuo leque de ocorrências controversas ${ }^{265}$.

Nas discussões para embasar a intervenção da Igreja Matriz São Luiz de Tolosa há referência ${ }^{266}$ à Frauenkirche em Dresden (Alemanha), destruída em 1945 e reconstruída entre 1993 e 2005 . Essa Igreja protestante construída entre 1726 e 1743 colapsou após incêndio decorrente do bombardeio de 13 de fevereiro de 1945. Com o fim da Segunda Guerra e a localização da cidade na República Democrática Alemã (RDA: Alemanha Oriental) as proeminentes ruínas do que havia sido o maior edifício público da cidade permaneceram durante décadas como um potente símbolo sobre os horrores da guerra. Com a queda do Muro de Berlim em 1989 a proposta de reconstrução "como era, onde estava" adquiriu força e os blocos remanescentes foram catalogados. A partir de ampla documentação iconográfica, os trabalhos iniciaram em 1993 sob a direção de Eberhard Burger, em 1999 Günter Blobel doou seu prêmio Nobel de Medicina à Igreja fomentando os trabalhos.

Segundo as justificativas de projeto (MARTINEZ, 2007), a necessidade de utilizar as ruínas da igreja original era fundamental para atender a alguns princípios das teorias da preservação que, poderiam conferir maior "autenticidade" ao projeto: a utilização das peças

\footnotetext{
265 Um recente trabalho consultado que analisa e contabiliza um grande número de reconstruções na historiografia da preservação patrimonial é: NERDINGER, Winfried (org.). Geschichte der Rekonstruktion. Konstruktion der Geschichte. Munique: Prestel, 2010.
}

${ }^{266}$ Cf.: Liliane Vieira de Castro In: Mem. 416, IPHAN, Matriz, 2010, p. 60. 
configurariam uma anastilose e não propriamente a reconstrução como uma mera cópia da original; o princípio da "distinguibilidade" seria garantido justamente pelo uso desses blocos, escurecidos com uma pátina de mais de 200 anos que permite a identificação do material original. Entretanto, a integração das ruínas na nova construção foi muito questionada, pois os blocos foram utilizados de forma arbitrária, sem uma correlação com sua localização original, e muitos não puderam ser usados por não atenderem estruturalmente aos testes de compressão; além disso, com o passar dos anos não haveria como identificar os blocos com e sem pátina.

A Frauenkirche tornou-se um dos exemplos mais controversos e paradoxais no âmbito da construção de significados e ressignificações que envolvem as ruínas do denominado "patrimônio de guerra". O caráter simbólico de sua reconstrução não remete apenas aos malefícios do bombardeio de 1945, mas, sobretudo, às décadas em que a Alemanha esteve dividida. Ou seja, enquanto suas ruínas materializavam uma importante referência aos horrores bélicos, as ações e esforços para sua reconstrução devem ser lidos num âmbito político específico, em que a Frauenkirche se transmuta em um dos maiores símbolos da nova Alemanha reunificada (JOEL In: GEGNER, ZIINO, 2012).
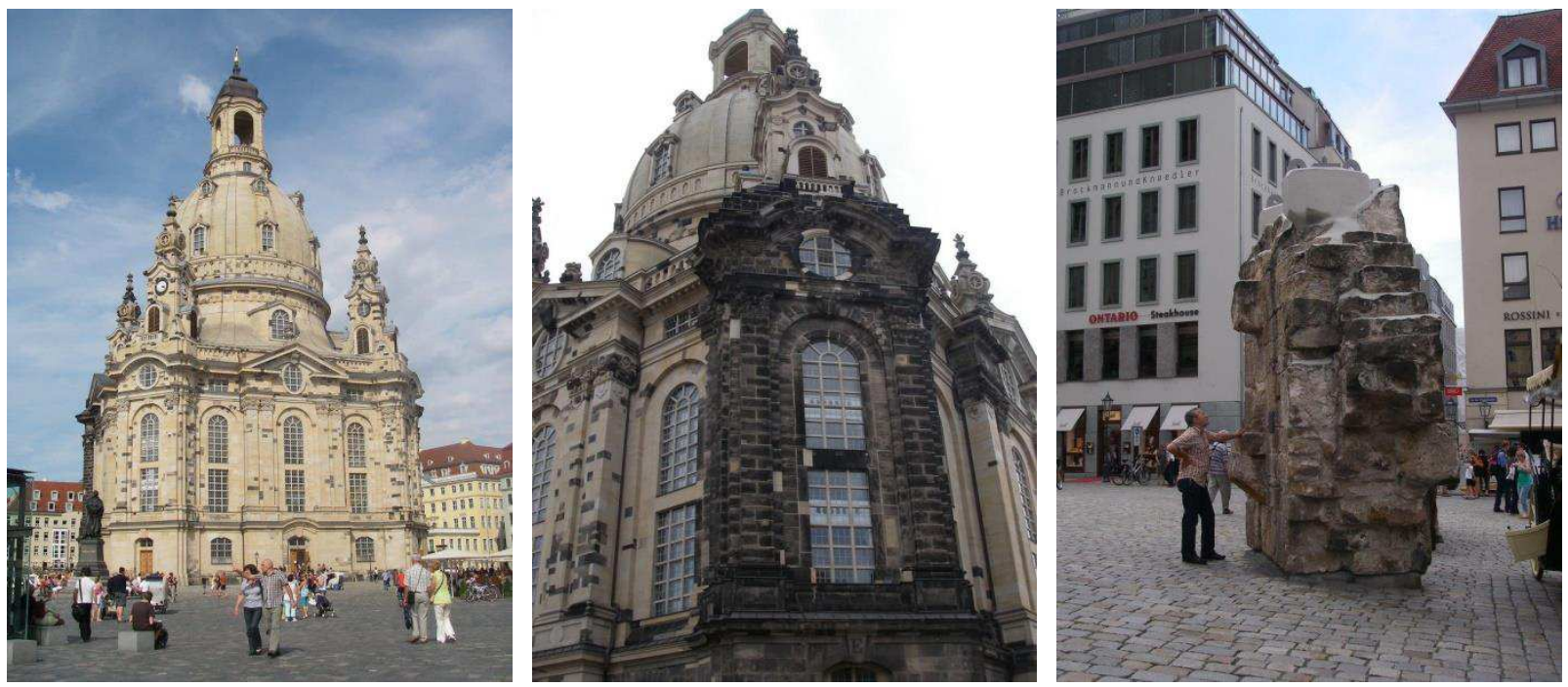

Fig. 150 (i-iii): Frauenkirche, contraste entre os blocos mais escuros (pátina) e elementos novos (mais claros) e fragmento não recolocado, Dresden (Alemanha), 2009. Fotos: Autora.

Tendo em vista que os casos nacionais aqui analisados não derivam de destruições bélicas, podemos nos referir à reconstrução de bens acometidos por outras causas, embora seja pertinente pontuar que do ponto de vista cognitivo conforme destaca Henri-Pierre Jeudy: "Mesmo que as vítimas de uma catástrofe não sejam idênticas aos mortos que a guerra provoca, seu tratamento a posteriori apresenta um bom número de semelhanças.” (JEUDY, 2005, p. 58). 
No território italiano, por exemplo, há inúmeras destruições de bens e cidades inteiras provocadas por terremotos. Noto (Siracusa, Itália), é um caso interessante onde a Catedral (Chiesa Madre di San Nicolò) foi reconstruída após um arruinamento parcial ocorrido em 13 de março de 1996. O colapso ocorreu seis anos após um terremoto que atingiu a região e causou certa instabilidade estrutural na Catedral. Apesar da existência de fundos para sua manutenção, não houve reparos imediatos e as colunas da nave central ruíram provocando o desabamento da cúpula e de parte do teto.

A Igreja era uma referência importante para o conjunto urbano de Noto, cidade catalogada como patrimônio da Humanidade pela arquitetura representativa do tardo-barroco Siciliano; optou-se então por sua reconstituição formal cujos trabalhos foram realizados por uma equipe coordenada por Luciano Marchetti e Paolo Marconi. Os materiais (pedra, argila e madeira) e as técnicas construtivas utilizadas procuraram respeitar ao máximo os originais. A Igreja foi totalmente mimetizada; internamente, foi contratado o artista russo Oleg Supereko para a criação e realização dos afrescos - as pinturas que dão acabamento aos tetos são, portanto, diversas da original. A Igreja foi reinaugurada em maio de 2007 (MARCONI, 2012).
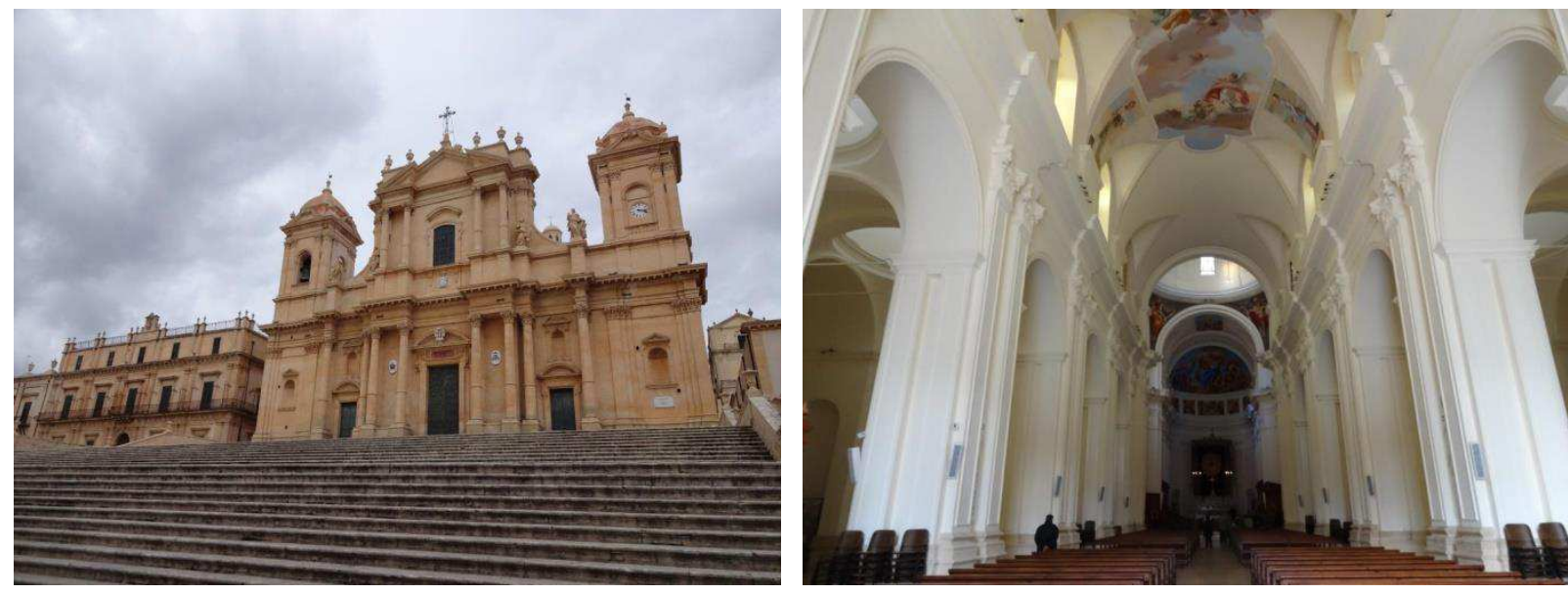

Fig. 151 (i-ii): Chiesa Madre di San Nicolò, aspecto externo e interno após reconstituição, Noto (Itália), 2015. Fotos: Autora.

Sendo da mesma tipologia, a Catedral de Noto nos remete à Igreja Matriz São Luiz de Tolosa, apesar dos contextos diversos e das distintas opções operacionais. Na Matriz de Paraitinga optou-se pela reconstrução com técnicas e materiais completamente diferentes dos originais (alvenaria estrutural e estrutura metálica); no entanto em ambas prevalece a necessidade de restituir a Igreja ao conjunto patrimonial urbano do qual fazem parte.

A despeito das polêmicas e das prescrições das Cartas e teóricos da preservação, a justificativa para a reconstrução da Igreja Matriz São Luiz de Tolosa se estruturou na 
prioridade à preservação da identidade cultural de uma cidade histórica e à importância para a comunidade local da implementação de tal empreitada diante da perda de um patrimônio de um modo violento e traumatizante. No projeto aprovado pelo IPHAN, a justificativa apresentada pela empresa Formarte evidencia que se considerava primordialmente "[...] a realidade da comunidade local, a qual deseja ter sua referência social exatamente da forma como era antes do desastre.” (IPHAN, Matriz, 2010, p. 148). Como justificativa, foi invocada a Carta de Cracóvia (2000) sobre a relevância de um "motivo social" para a reconstrução mediante uma situação catastrófica ${ }^{267}$.

Houve intensa participação popular nas discussões e na execução da Igreja Matriz São Luiz de Tolosa durante todo o processo evidenciando a importância que essa reconstrução tinha para a vida local. Conforme entrevista com a arquiteta Natália dos Santos Moradei ${ }^{268}$, a comunidade esteve envolvida ${ }^{269}$ não somente nas audiências públicas, mas no acompanhamento do passo a passo da obra; tapumes do canteiro foram substituídos por alambrado para que os trabalhos ficassem visíveis a todos. Muitos moradores locais participaram da execução dos trabalhos, num primeiro momento de forma voluntária e, posteriormente foram inseridos em programas de formação técnica para uma especialização de sua atuação no canteiro de obras.

A justificativa para a reconstrução da Matriz procurou fundamentar, com base na Carta de Burra ${ }^{270}$ (ICOMOS, 1980), que essa opção é um meio de preservação e restauro, desde que a integridade do bem e do conjunto avariado seja garantida sem cometer falso histórico. A metodologia de projeto apresentada estabeleceu a premissa da conservação do substrato histórico e a utilização de técnicas e materiais construtivos compatíveis e similares aos originais, desde que proporcionem uma legibilidade sobre a marca do tempo de execução.

${ }^{267}$ Cf.: “4 4 [...] A reconstrução total de um edifício, que tenha sido destruído por um conflito armado ou por uma catástrofe natural, só é aceitável se existirem motivos sociais ou culturais excepcionais, que estejam relacionados com a própria identidade da comunidade local." (UNESCO, 2000 apud IPHAN, 2010, p.148).

\footnotetext{
${ }^{268}$ Atuou como arquiteta e assessora de Planejamento da Prefeitura Municipal da Estância Turística de São Luiz do Paraitinga durante os anos da reconstrução, Informação concedida à autora em 13.04.2015.

${ }^{269}$ Para evidenciar a importância da Igreja na comunidade, segundo informações obtidas em entrevista com a arquiteta Natália: durante as obras, foi erguida uma cobertura para proteger a área de trabalho e foi construído um campanário provisório, onde foram instalados os sinos resgatados para que seu característico toque que sempre marcou a vida local (Matinas: às 6 horas; ângelus: às 12 horas; e vésperas: às 18 horas) fosse recuperado. Além disso, houve a solicitação para a realização de matrimônios no canteiro, porém, esses pedidos foram negados por questões de segurança.

270 “Art. $1^{\text {o }}$ Definições: A reconstrução será o restabelecimento, com o máximo de exatidão, de um estado anterior conhecido; ela se distingue pela introdução na substância existente de materiais diferentes, sejam novos ou antigos. A reconstrução não deve ser confundida, nem com a recriação, nem com a reconstituição hipotética, ambas excluídas, do domínio regulamentado pelas presentes orientações" (ICOMOS, 1980 apud IPHAN, 2010, p.148).
} 
Ainda assim, a opção pelo repristino formal da arquitetura pelo lado externo como era antes da enchente não permite uma real constatação da trajetória histórica do bem esbarrando nos preceitos da distinguibilidade e autenticidade, considerando que conforme destaca Brandi: “[...] não é necessário forçar o restabelecimento da unidade potencial da obra até o ponto de destruir a autenticidade, ou seja, sobrepor uma nova realidade histórica inautêntica, de todo prevalente, sobre a antiga" (BRANDI, 2004, p. 67).

A dificuldade em aceitar as marcas de uma destruição deflagrada por um incidente e a tendência a operações de repristino de uma imagem formal consolidada também pode ser constatada através de outros exemplos das práticas patrimoniais no Brasil. Dos bens tombados do Estado de São Paulo pode-se destacar o Casarão do Valongo (Santos, SP), uma edificação que era constituída por dois blocos edificados entre 1867 e 1872, tombado pelo CONDEPHAAT $^{271}$ em 1983. O casarão neoclássico ocupa uma quadra localizada no Largo Marques de Monte Alegre próximo ao cais do Porto, à antiga estação ferroviária da Estrada de Ferro Santos Jundiaí e à Igreja de Santo Antônio do Valongo.

O Casarão abrigou a Prefeitura Municipal de 1895 a 1939, o processo de tombamento foi aberto em 1974 a pedido da sociedade civil que solicitava providências para atestar a importância do edifício (que na ocasião abrigava um Hotel) à configuração urbana e salvaguardá-lo de reformas indevidas que estavam ocorrendo e poderiam desconfigurar suas características. Em agosto de 1989 a edificação foi acometida por um incêndio que promoveu seu parcial arruinamento; os remanescentes (paredes das fachadas de até 17,00 m de altura) foram reforçados com escoras metálicas para não desabarem completamente (SÃO PAULO Estado, CONDEPHAAT, 1974).

A situação periclitante prosseguiu nas décadas seguintes, em meio a trâmites judiciais sobre a responsabilidade pelo incidente, a desapropriação da edificação e os custos para um projeto de restauração do bem tombado. A partir dos anos 2000, com a necessidade de reurbanização da área e a efetiva desapropriação do terreno iniciou-se uma especulação sobre o que seria feito com as ruínas do patrimônio. Optou-se pela implantação do Museu Pelée ${ }^{272}$, uma obra que teve início em 2008 e foi inaugurada em 2014. O projeto foi desenvolvido pelo arquiteto Ney Cadaltto, com a completa reconstituição das fachadas e da volumetria original; internamente, a ausência de remanescentes liberou o espaço para uma livre apropriação. Os

\footnotetext{
${ }^{271}$ Processo 00429/74, consultado junto ao CONDEPHAAT.

272 A instalação do Museu Pelé está inserida no contexto do Alegra Centro - Programa de Revitalização do Centro Histórico de Santos para a revitalização do local (CALDATTO, 2008).
} 
traços do processo de arruinamento ao longo das décadas não foram incorporados, prevalecendo a reconstrução.

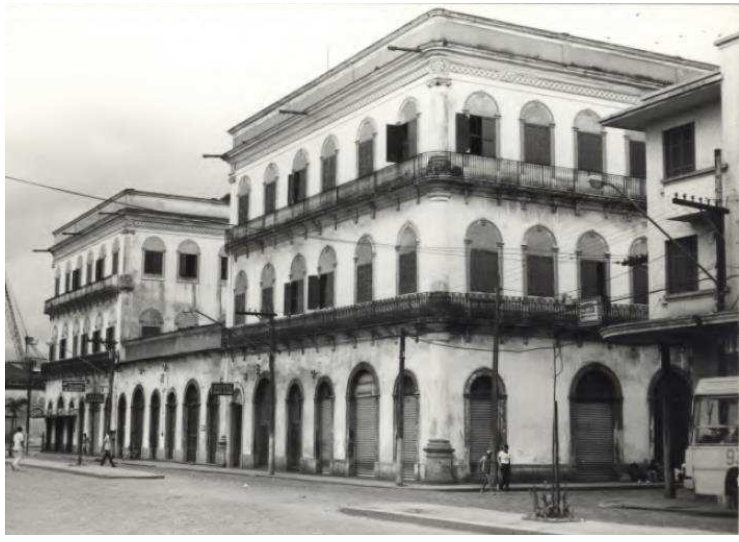

Fig. 152: Casarão do Valongo, Santos (SP), 1982. Fonte: SÃO PAULO - Estado, CONDEPHAAT, 1974, p. 50. Foto: Tania Martinho

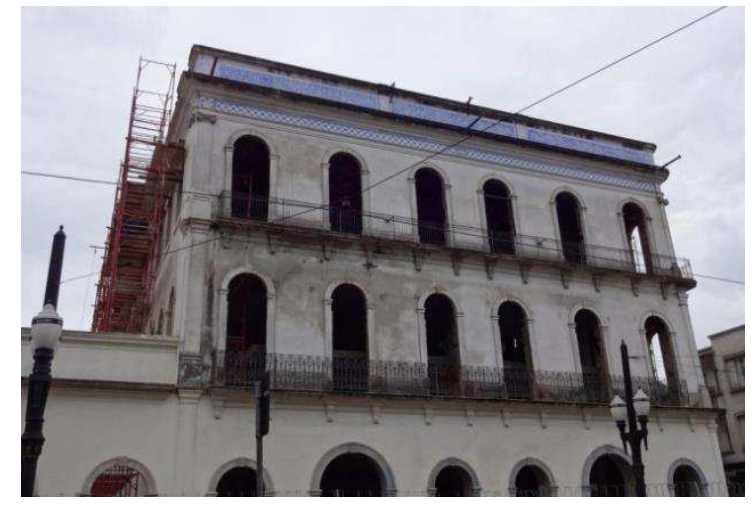

Fig. 154: Casarão do Valongo durante as obras para a instalação do Museu Pelé, 2013. Foto: Autora

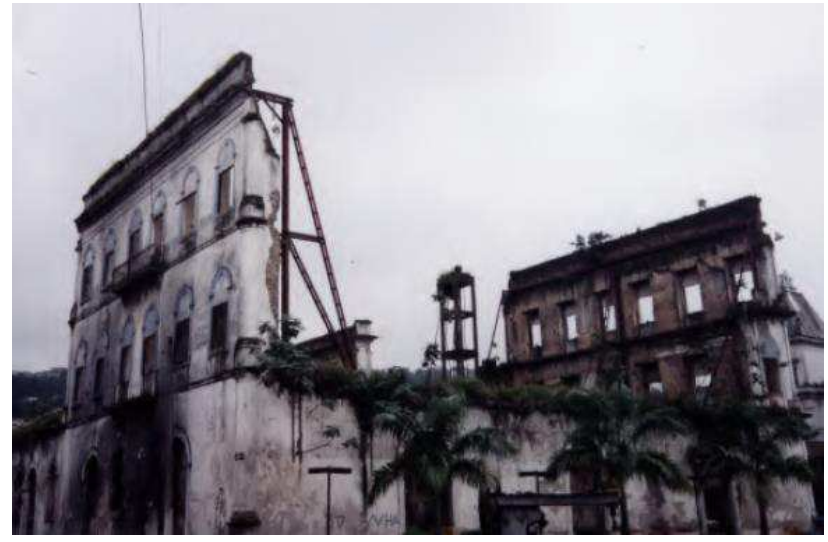

Fig. 153: Casarão do Valongo, Santos (SP), 1997. Fonte: SÃO PAULO - Estado, CONDEPHAAT, 1974, p. 279. Foto: Aldo P. de Carvalho.

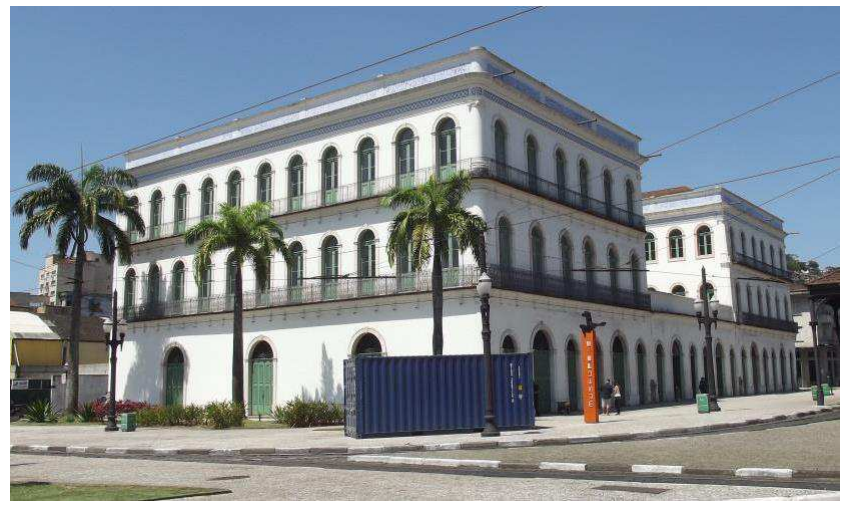

Fig. 155: Museu Pelé, Santos (SP), 2016. Foto: Adriana Jardim Gouveia.

O tema da "reconstrução" também aparece nas discussões do Teatro Cultura

Artística, porém com uma conotação diferente. Como mencionado, logo após o incêndio a Sociedade de Cultura Artística demonstrou publicamente sua inclinação em construir uma nova edificação no local, propondo atualizar o programa do teatro e conservar o painel de Di Cavalcanti:

O momento agora é de olharmos para frente, mas sem esquecer nossas raízes e tradições. Nesse sentido, a diretoria da Sociedade de Cultura Artística deliberou pelo início imediato do projeto de reconstrução do teatro. [...] O projeto é ambicioso e visa criar a melhor e mais moderna sala de espetáculos do país, além de contemplar a revitalização de todo o entorno do teatro. Como premissa básica do projeto foi colocada a preservação do magnífico painel de Emiliano Di Cavalcanti, que sobreviveu ao incêndio sem danos estruturais; [...] (COMUNICADO DA SOCIEDADE DE CULTURA ARTÍSTICA, Estado de São Paulo, 07.09.2008 In: SÃO PAULO - Estado, CONDEPHAAT, 1974, p.56 - grifo nosso) 
A alternativa de seguir o projeto original de Rino Levi sobreveio nos trâmites de estudo de tombamento pelo IPHAN ${ }^{273}$ salientando as possíveis controvérsias:

[...] o tombamento poderia indicar, como primeira opção, a possibilidade de reconstrução com base no projeto original de Rino Levi. Seria fundamental para preservação da referência simbólica? Não há resposta conclusiva possível e, embora pudesse ter valor evocativo para um largo período do teatro, não teria a mesma força do original, e ainda seria questionável perante uma autenticidade impossível. (Nota Técnica 012/2010 In: IPHAN, 2010, p.173 - grifo nosso)

Nos autos dos processos, essas polêmicas sobre uma reconstituição da obra como era antes do incidente foram nutridas com a menção ao célebre caso do Teatro La Fenice em Veneza, cuja construção original de 1792 foi gravemente danificada por um incêndio em 29 de janeiro de 1996. Por ser considerado uma das referências arquitetônicas mais icônicas da cidade, houve uma grande comoção pública em prol da recuperação mimética do Teatro. A opção em reconstruir "como era, onde estava" passou a ser defendida por ir ao encontro do apelo da população veneziana. A solução, porém, não foi unânime, diversos intelectuais italianos ligados à preservação patrimonial como Giovanni Carbonara, Paolo Torsello, Roberto Di Stefano, Sandro Scarrocchia ${ }^{274}$ dentre outros apresentaram argumentos contrários alegando que a reconstrução, não faz parte do compito da restauração, a identidade da edificação perdida jamais pode ser restabelecida (a despeito da reconstituição formal) e a materialidade da preexistência com suas respectivas marcas deveria ser considerada no âmbito metodológico e crítico do campo disciplinar do restauro.

Conforme Martínez (2007), em meio às polêmicas sobre a coerência e exequibilidade da reconstrução surgiram aspectos controversos, como qual fase do teatro deveria ser utilizada como referência. Optou-se pela versão intermediária do Teatro, que remonta a 1836, momento em que se teria configurado a imagem mais uniforme do edifício. A nova edificação eliminaria elementos que eram discordantes com a imagem selecionada para a reconstrução, dentre esses, as marcas do incêndio que arruinou a edificação. O arquiteto Aldo Rossi (19311997), responsável pelo projeto da reconstrução baseou-se numa ampla documentação - fotos e demais materiais iconográficos. Por segurança, houve a modernização de instalações, mas a decoração interna foi cuidadosamente trabalhada para a recomposição segundo o estilo da época selecionada.

\footnotetext{
${ }^{273}$ Nota Técnica 012/2010, pelo arquiteto José Leme Galvão Júnior.

${ }^{274}$ In: Venezia, La Fenice: i fatti, gli atti ufficiali, le opinioni [contributi diversi]. Ananke - Cultura, storia e tecniche della conservazione, marzo, n.13, p.24-49 1996.
} 
Após uma conturbada trajetória devido ao falecimento do arquiteto responsável (Rossi), ordens judiciais e atrasos, o Teatro foi reinaugurado em 14 de dezembro de 2003, sem nenhuma alusão para recordar o incidente ocorrido. A reconstrução teve o papel de apagar as marcas do que não se pretendia recordar acentuando a problemática da autenticidade do produto final.

Ao retomar o caso do Teatro Cultura Artística, a alternativa da reconstrução "como era onde estava" não teve desdobramentos, pois, a Sociedade de Cultura Artística não previa uma reconstituição formal da edificação danificada; a proposta de "reconstrução" do Teatro alude a um projeto contemporâneo com o objetivo de atualizar tecnologicamente o programa de uma sala de espetáculos no endereço do antigo, cuja principal referência simbólica é mimetizada pelo painel de mosaicos, que é plasmado como o elemento por excelência que remete à arquitetura anterior.

Ao longo das décadas, a Sociedade de Cultura Artística passou a ser identificada com seu respectivo Teatro, que além de sua arquitetura era um dos polos culturais mais importantes da capital paulista acolhendo espetáculos dos mais diversificados que atraíam grande público. Na instrução para abertura do processo de tombamento pelo IPHAN elaborada por Nestor Goulart Reis Filho, o valor do endereço como local atrelado à história cultural da cidade desde 1950 é um elemento tão importante quanto os remanescentes em si (REIS Filho, 2009 In: IPHAN, 2010).

Como mencionado, as minutas finais de tombamento nos órgãos de preservação se concentram nas partes da fachada frontal - foyer, caixilharia e, principalmente o painel valorizando o aspecto simbólico da atuação da Sociedade de Cultura Artística em São Paulo e o projeto de Rino Levi pelos remanescentes com maior legibilidade e visibilidade incorporados à nova fachada remetendo a uma imagética fragmentada do projeto anterior. A inclusão desses elementos não teve o objetivo de historicizar ou rememorar o evento traumático que levou à destruição parcial do Teatro. Não há aqui a intenção de compreender o incêndio como parte da história do Teatro, cujas marcas poderiam ser preservadas. Conforme aprovação dos órgãos de preservação, as demais estruturas foram demolidas para a liberação do terreno à nova proposta, cujo embasamento se pautou em seu comprometimento estrutural.

Nos autos consultados sobre o Teatro não há referências às teorias patrimoniais. A preocupação sobre a preservação do substrato remanescente se concentrou nos trabalhos de restauro do painel que foi objeto de um projeto específico. Assim, diversamente do caso da 
Matriz, as ruínas do Teatro não são utilizadas como documentos, informando sobre a edificação anterior e fornecendo eventuais dados para uma "reconstrução".

O incêndio do Teatro causou certa comoção na opinião pública devido ao seu valor histórico e artístico; no entanto, os comentários e reflexões derivadas desses debates não influenciaram as posturas tomadas. Levantou-se, inclusive, a possibilidade de se restaurar a estrutura original, conforme o arquiteto Marcos José Carrilho:

Se for lícito supor com base nas informações disponíveis que parte considerável do arcabouço original resistiu, não se pode em princípio afastar a hipótese de restauração do teatro. Se o teatro sofreu perdas consideráveis pela ação do fogo, isto não significa que não possa ser recuperada a configuração espacial do auditório principal. Para tanto, bastaria, em linhas gerais, proceder aos reforços de consolidação da plateia e promover a recomposição da cobertura. (CARRILHO, 2009, s.p. - grifo nosso)

Nesse sentido, é pertinente retomar a diferença operacional que foi apresentada no capítulo 1, segundo a definição da Carta de Veneza (Art. $9^{\circ}$ ) a restauração é um procedimento de caráter excepcional que visa conservar os valores estéticos e históricos do monumento através do respeito à matéria preexistente. Mas não basta que essa materialidade seja mantida, é necessário verificar o método através do qual se opera esse tratamento. Embora as fronteiras entre a restauração e a reconstrução possam parecer difusas, os objetivos são distintos. E ensejam o entendimento explicitado por Brandi (2004) de que a matéria que compõe o objeto reconhecido como obra de arte é o meio físico para a transmissão de sua imagem; desse modo, a restauração ocorre somente na matéria, visando o: “[...] restabelecimento da unidade potencial da obra de arte, desde que isso seja possível sem cometer falso artístico ou falso histórico, e sem cancelar nenhum traço da passagem da obra de arte no tempo.” (BRANDI, 2004, p.33). Já, operações como o repristino, o refazimento e a reconstrução, cujo principal objetivo é reconstituir uma imagem formal não são consideradas no escopo do campo disciplinar da restauração.

Essas distinções entre as possibilidades de intervenção (restauração, reconstrução e novo projeto) são úteis para a impostação de outro ponto relevante para esta discussão, qual seja a idade da edificação arruinada. No Teatro, a preocupação com a preservação patrimonial é menos latente que na Igreja. Seria a idade da edificação - mais recente e representativa da arquitetura moderna paulista - um fator condicionante para se desconsiderar o restante dos remanescentes do teatro e interpor a necessidade de atualização do programa? 
Tal questão reforça a complexidade que envolve a abordagem do tema da ruína e se insere num recorrente debate na preservação patrimonial relativa à valorização ou não de bens culturais mais recentes e à aplicabilidade (ou não) dos princípios do restauro crítico ao seu tratamento. Conforme aponta Salvo (2007), nessas obras mais recentes, geralmente outros aspectos (formal, construtivo, estrutural ou tecnológico) bem como exigências contemporâneas (imposição do uso, conforto nos interiores, normas de segurança, etc.) são mais determinantes, proporcionando um campo para embate entre diferentes profissionais (arquitetos, restauradores, historiadores e tecnólogos).

O restauro do arranha céu da Pirelli em Milão - alvo de um acidente aéreo em 2002, que danificou parte de seus andares (atingindo principalmente o $26^{\circ}$ andar) - é uma referência pertinente. A torre construída entre 1956 e 1960 foi projetada e construída por uma equipe de arquitetos e engenheiros - dentre eles Gio Ponti (1891-1979) e Pier Luigi Nervi (1891-1979) e era representativa do patrimônio moderno italiano. A necessidade de intervir na edificação em função dos danos causados pelo incidente trouxe à tona a discussão sobre a validade dos princípios do restauro denominado crítico a bens de um patrimônio recente. O restauro ocorreu nos anos subsequentes e a torre foi reaberta em 2005. Os trabalhos de caráter essencialmente conservativo primaram pela recuperação dos perfis de alumínio anodizado das fachadas contínuas e do revestimento de pastilhas cerâmicas. O respeito à conformação histórica das superfícies e à autenticidade dos materiais e técnicas considerou a totalidade da percepção da imagem pela materialidade ${ }^{275}$ (SALVO, 2007).

No Teatro Cultura Artística há que se considerar que os danos e lacunas foram de maior escala na porcentagem total da edificação. Porém, a possibilidade de restauro não foi vislumbrada pelos proprietários e órgãos de preservação, mesmo sendo um exemplar representativo da obra de Rino Levi em São Paulo. A proposta de reintegrar uma parte das ruínas remanescentes a um projeto completamente diverso do anterior - programa, planta, volumetria, composição plástica - que procura redesenhar sua relação com o contexto urbano recoloca a possibilidade de articulação entre o novo e o antigo.

Segundo Roberto Pane, integrar as possibilidades derivadas da formulação de uma arquitetura contemporânea e os limites objetivos do restauro filologicamente concebido expõe a complexidade e abrangência que o ato da restauração pode ter mediante bens total ou parcialmente destruídos:

${ }^{275}$ Ver mais detalhes em: SALVO, Simona. Restauro e "restauros' das obras arquitetônicas do século XX: Intervenções em arranha-céus em confronto. Revista CPC, São Paulo, n. 4, p. 139-157, 2007. 
[...] como proceder, por exemplo, no caso de uma antiga igreja com metade demolida e, todavia preciosa por suas obras de arte e suas recordações históricas? [...] A extrema variedade dos casos a serem resolvidos demonstram como não é possível conter o restauro dentro dos limites rigidamente pré-estabelecidos porque se trata de passar da pura e simples consolidação à reconstrução ex novo de partes significativas de uma edificação, ou seja percorrer toda a distância que surge entre o restauro verdadeiro e próprio e a moderna construção arquitetônica. (PANE apud SETTE, 2004, p.273 e VIVIO, 2010, p.219 - grifo nosso).

Naquilo que se aplica à problemática das ruínas verifica-se que a tônica dessas considerações não é apreciar os seus valores (histórico e artístico) de modo compassivo; essa abordagem está vinculada à noção de perda arquitetônica e urbanística. E se vislumbra com maior ênfase às possibilidades que os conjuntos arruinados oferecem para novos projetos que vão desde meras reconstruções a partir dos remanescentes a uma aceitação e integração da ruína em seu status quo para uma nova proposta. A estrutura do texto perdido da obra pode ser restabelecida sem perder de vista a relatividade da interpretação que poderá ser aperfeiçoada ou substituída por atualizações substanciando, portanto, os princípios da distinguibilidade e reversibilidade das intervenções (CARBONARA, 1997).

Para ambos os casos aqui detalhados - Teatro e Igreja - remanesce a questão: haveria a possibilidade de explorar esteticamente a condição de ruína da forma preexistente de um modo mais legível tanto num projeto de restauração (do ponto de vista crítico e metodológico) quanto para um novo projeto arquitetônico? Como mencionado na introdução deste capítulo, a integração de ruínas consolidadas, aceitando, respeitando e deixando visíveis as lacunas e as marcas da destruição está condicionada a uma perspectiva memorial que enfatiza a historicidade do incidente que levou ao arruinamento. Na Igreja essa opção foi aventada com maior ênfase, mas no Teatro essa possibilidade não foi vislumbrada.

$\mathrm{Na}$ historiografia da preservação há alguns exemplos marcantes em que a referência simbólica da ruína se torna impactante pela exploração de seus aspectos estéticos que remetem à incompletude deflagrada por um incidente trágico. Em Berlim, a igreja comemorativa do imperador Wilhelm I (Kaiser Wilhelm - Gedächtniskirche) foi parcialmente destruída em 1943; a nova edificação projetada por Egon Eiermanm (1904-1970) teve início em 1959 e foi finalizada em 1969. Esse novo projeto procura dialogar de modo memorial com as imponentes ruínas da obra perdida através de uma arquitetura contemporânea. 

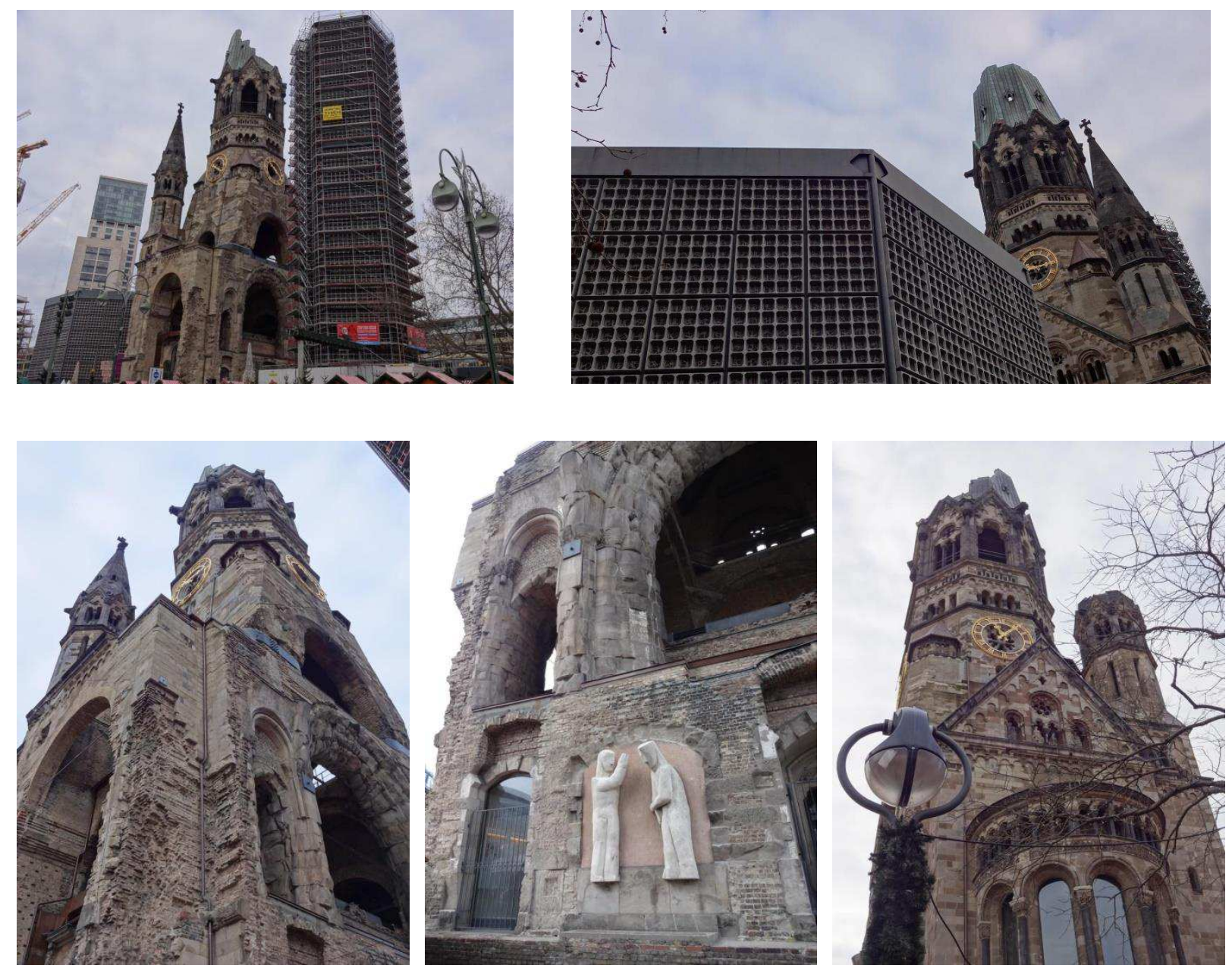

Fig. 156 (i-v): Kaiser Wilhelm - Gedächtniskirche, igreja em ruínas e edificações construídas na década de 1960, Berlim (Alemanha), 2015. Fotos: Autora

$\mathrm{Na}$ Inglaterra, a Catedral de Saint Michel em Coventry (Inglaterra), proveniente dos séculos XIV e XV, as ruínas da antiga edificação destruída em 1940 se mantêm sem cobertura constituindo um adro para o novo complexo edificado entre 1954 e 1962 com projeto de Basil Spence (1907-1976) $)^{276}$. Essas referências, apesar de continuarem cumprindo até hoje uma função de igreja, incorporam pela conservação de suas ruínas o significado de um memorial antibélico.

Retomando o que foi apresentado no capítulo 3 sobre a "estética da deterioração" evidenciada pela pesquisadora Ascensión Martínez há a recente referência do Neues Museum em Berlim, construído entre 1843 e 1855 com projeto de Friedrich August Stüler (1800-1865) e danificado durante a Segunda Guerra. A partir de 1997, o museu passou por um trabalho de remodelação para atender as exigências do programa e foi oficialmente reaberto em 2009.

\footnotetext{
${ }^{276}$ Em 1944, o arquiteto Giles Gilbert Scott (1880-1960) havia submetido um projeto para a reconstrução da Igreja, porém o Royal Fine Arts Comission o rejeitou. Em 1950 foi aberto um concurso em que mais de 200 propostas foram apresentadas e o projeto de Basil Spence foi escolhido (JOKILEHTO, 2005).
} 
Houve a instalação de novas salas expositivas com blocos pré-fabricados com cores claras contrastando com as alvenarias preexistentes; alguns trechos foram reconstruídos e completados a partir de fragmentos subsistentes (CALIARI e PERESSUT, 2014). O arquiteto responsável David Chipperfield salienta ${ }^{277}$ que o objetivo dessa proposta foi ressaltar a referência do edifício histórico com seus materiais e contextos espaciais dialogando com os danos derivados da guerra e dos anos de abandono pelos quais o museu esteve exposto.
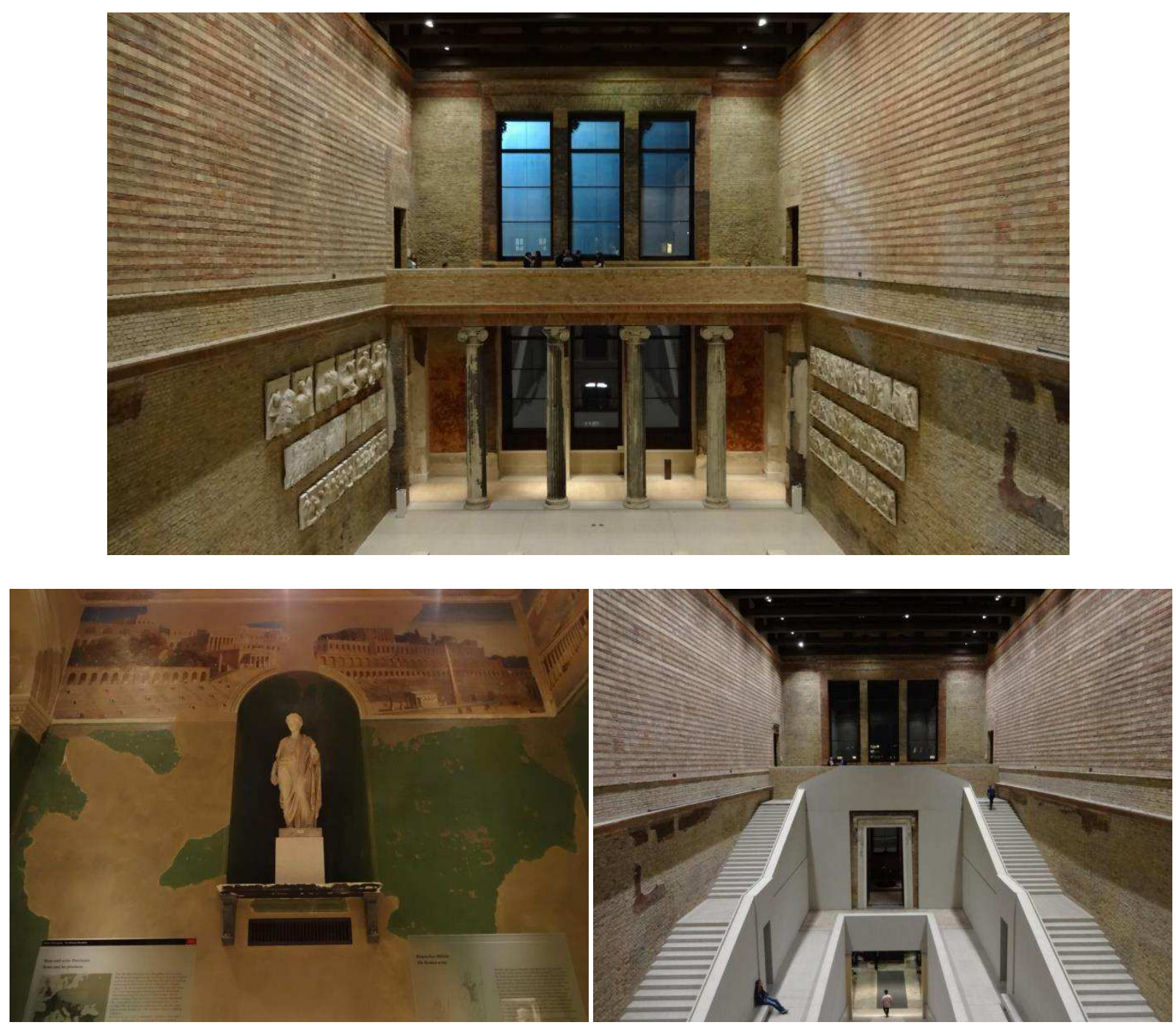

Fig. 157 (i-iii): Interior do Neues Museum, intervenção do escritório David Chipperfield Architects, Berlim (Alemanha), 2015. Fotos: Autora.

Para situarmos um exemplo no cenário brasileiro, cabe mencionar o Santuário do Caraçá (Catas Altas, MG) ${ }^{278}$, um conjunto religioso do século XVIII, tombado pelo IPHAN

\footnotetext{
${ }^{277}$ Informações obtidas pela autora na palestra: Berlin Projects: Building in and around a World Heritage Site. In: International Seminar of Studies on Architecture for Archaeology - "The Design of Archeology" (Casa dell Architettura, Roma - 04.09.2015).

${ }^{278}$ Informações consultadas em: DINIZ (2014).
} 
em $1955^{279}$. O núcleo original composto por uma Capela foi constituído entre 1774 e 1779; em torno de 1820 foi incorporado ao um centro de formação educacional (Colégio e biblioteca) da província de Minas Gerais e outras ampliações ocorreram a partir da segunda metade do século XIX. O Colégio funcionou até 1968, quando um incêndio destruiu parte das instalações destinadas aos alunos.
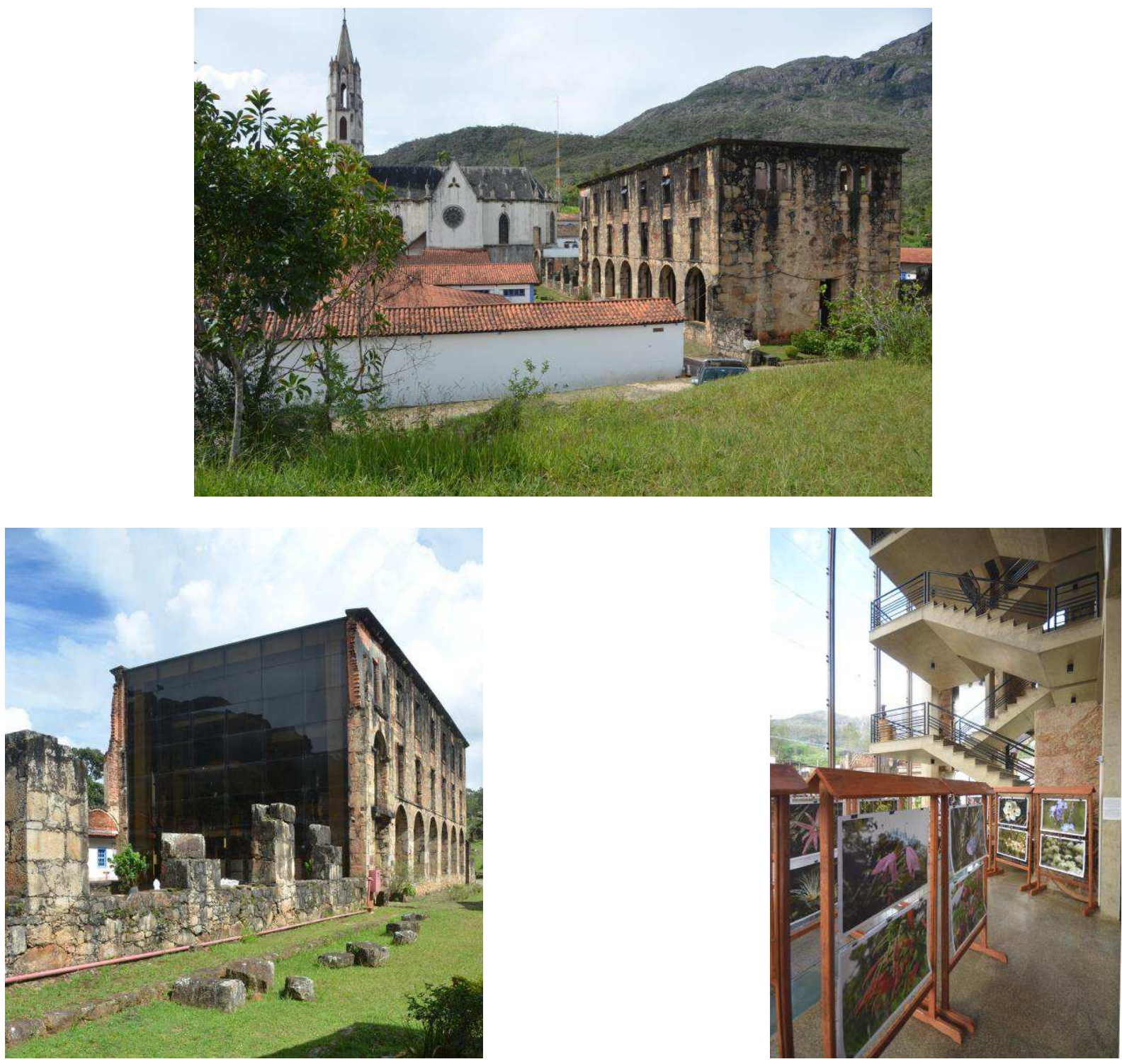

Fig. 158 (i-iii): Santuário do Caraçá, Catas Altas (MG). Área externa e interna, 2014. Fotos: Rodrigo Baeta.

A partir da década de 1970 foram iniciados debates para a restauração do conjunto envolvendo o Estado, a Congregação e os órgãos patrimoniais. Entre 1986 e 1989 foi elaborado e executado um projeto do arquiteto Rodrigo Meniconi em que um dos prédios arruinados passou por um novo agenciamento para acolher atividades de museu, biblioteca e

\footnotetext{
${ }^{279}$ Colégio do Caraçá: conjunto arquitetônico e paisagístico. Listado no Livro Histórico e Livro Arqueológico, Etnográfico e Paisagístico, 27.01.1955, consultado em IPHAN - Arquivo Noronha Santos, disponível em: $<$ http://portal.iphan.gov.br/ans/> acesso em 16 ago. 2016.
} 
centro de convenções. Essa proposta previa a inserção de elementos novos (aço, vidro e concreto armado) em linguagem contemporânea dialogando com a forma e as marcas do incêndio das ruínas do antigo prédio. A forma original não foi recomposta e os novos elementos consolidam os remanescentes e dão o fechamento necessário para o novo programa (LEAL apud DINIZ, 2014). As novas instalações foram inauguradas em agosto de 1990.

Esse projeto, segundo o Inventário Nacional de Bens Móveis e Integrados do IPHAN: "constituiu-se hoje num marco nos trabalhos de restauro no Brasil, caracterizado especialmente pela introdução de novos materiais ao lado das paredes arruinadas e consolidadas, permitindo a leitura dos distintos momentos construtivos do prédio" (apud IPHAN In: Arquivo Noronha Santos - site). Esse caso ilustra, no cenário brasileiro uma ampliação na compreensão do patrimônio cultural em ruínas, vislumbrando nos remanescentes um potencial a ser considerado no exercício projetual.

Através dos estudos de caso aqui detalhados foi possível evidenciar de forma latente as problemáticas que envolvem a abordagem do grupo de bens arquitetônicos acometidos por arruinamentos súbitos. Pôde ser evidenciado que a dificuldade em aceitar e atribuir valores a um estado de arruinamento derivado de uma tragédia recente está atrelada à conjunção dos fatores levantados - grau, causa e tempo de arruinamento; valores históricos e artísticos e idade de construção do patrimônio arquitetônico também são condicionantes para as orientações de tratamento aos objetos danificados.

Tanto na Igreja Matriz São Luiz de Tolosa quanto no Teatro Cultura Artística as propostas procuram integrar partes das edificações danificadas, mas em contextos e com objetivos diversos. A premência da reconstituição da Igreja envolve as polêmicas da reconstrução, um recorrente tópico da preservação patrimonial que incorre na autenticidade do produto final; essas controvérsias são mitigadas pela necessidade de se restituir a edificação à identidade local para atender às solicitações da opinião pública, recompor a vida econômica da cidade e agregar o valor simbólico do refazimento que faz ressurgir o que foi perdido. No Teatro, um patrimônio moderno de propriedade privada, verificou-se a interposição legal instituída pelo tombamento para a preservação de alguns elementos da arquitetura anterior que estão inseridos num projeto de linguagem contemporânea, em que os remanescentes desempenham um papel acessório. Foi possível verificar que não são a tônica dos debates nesses dois estudos de caso as opções mais conservativas, como uma proposta de restauro - em seu estrito senso metodológico - em que o substrato remanescente seja cuidadosamente considerado sob um juízo crítico e criativo para a sua preservação. 


\section{Considerações finais}

O estudo realizado com base nas teorias e historiografia nacionais e estrangeiras permite-nos afirmar que as diferentes formas de compreensão, reconhecimento de valor e significação atribuídos aos bens arquitetônicos em ruínas suscitam abordagens, tratamentos e intervenções distintas que implicam na preservação ou não de sua condição (status quo) de ruína.

A problematização que conduziu o desenvolvimento da tese baseou-se em duas questões: ruínas - o que são? E como intervir? A partir do campo teórico da preservação patrimonial e dos debates e das ações no contexto institucional (órgãos de preservação) brasileiro, propusemos algumas categorias de identificação das ruínas, das quais foram selecionados alguns estudos de caso.

Se numa primeira leitura, é possível tomar como ruína somente o que está associado aos restos de edificações antigas, os estudos nos permitiram identificar uma acepção relacionada ao grau de degradação de um bem arquitetônico cujas características foram gravemente alteradas devido a uma ou mais causas. Assumimos, portanto, neste trabalho a ruína, não como uma categoria ou tipificação específica de um objeto, mas como uma condição de degradação e descaracterização de bens arquitetônicos de qualquer idade acometidos por arruinamentos ocasionados por diferentes causas e com distanciamentos cronológicos distintos.

O escopo do campo disciplinar do restauro prescreve a aplicação da devida quantificação das operações - manutenção, conservação e restauração. Tais intervenções devem partir do estrito juízo crítico e do respeito ao objeto, visando preservar a matéria remanescente sob a dúplice ambivalência das instâncias estética e histórica. Os intrínsecos atributos de incompletude e desarticulação que caracterizam o estado de ruína de um patrimônio potencializam a inerente complexidade no trato com essas preexistências e suas respectivas marcas.

A Carta de Veneza enuncia prescrições específicas às ruínas atrelando-as ao contexto de escavações arqueológicas (Art. 15\%). Porém, ao tomarmos como referência a acepção de ruína enquanto um estado de degradação (independentemente da idade da edificação) pode-se constatar que o tratamento de um bem arquitetônico em estado ruinoso não se diferencia de qualquer outro bem cultural, sendo válidas as mesmas premissas: mínima intervenção, 
distinguibilidade, respeito à materialidade, reversibilidade e utilização de materiais e técnicas compatíveis, conjugados a partir de uma estrita análise de cada caso. A intrincada e difícil constatação da perda da unidade potencial de uma edificação e a impossibilidade de reconstituí-la configuram o grande desafio do tratamento às ruínas: identificar e aceitar essa condição cujas características históricas e estéticas possam ser valorizadas.

O processo de arruinamento, como apresentado ao longo desta tese, envolve uma complexa conjunção de fatores - causa, grau e tempo decorrido - acrescidos da idade das edificações e condição de uso das mesmas. Dependendo de como são associados, esses fatores constituem variáveis que permitem múltiplas possibilidades de abordagem sob a ótica documental e simbólica, sugerindo distintas leituras, seja como testemunhos das características físicas da arquitetura prévia e da destruição que acometeu a edificação, seja como elementos de evocação diversa (morte, destruição, perenidade e permanência). A estruturação em grupos de ruínas facilitou-nos a análise, a partir da qual constatamos nos estudos de caso selecionados, que, de fato, a forma como esses fatores se articulam é determinante para orientar o tratamento aos bens em estado de arruinamento.

No grupo das ruínas do tempo a identificação da condição de ruína é mais legível, levando à adoção de soluções mais conservativas (consolidação primando pela mínima intervenção) que respeitem esse status quo. Mesmo assim, os tratamentos não são unívocos em decorrência do tamanho das perdas, da falta de referências da arquitetura prévia; e, sobretudo, do tempo decorrido do processo de arruinamento e da datação das edificações uma situação que se torna mais pujante quando se compara o tratamento de patrimônios mais antigos e de patrimônios mais recentes (como os provenientes do século XIX e XX).

Nas ruínas da incúria a complexidade para a identificação da condição de ruína se deve: à atribuição de um valor cultural às características históricas ou artísticas de uma edificação que estava íntegra até há pouco tempo; à existência de referências dessa arquitetura prévia; ao grau de degeneração; à conotação negativa da causa do arruinamento (negligência, incúria); e, principalmente à falta de distanciamento cronológico ao arruinamento. Tais casos suscitam muitos debates que apontam para soluções divergentes que vão da mera conservação do novo status quo à reconstituição da arquitetura pregressa. No grupo das ruínas do incidente a situação é similar, com o agravante da dramaticidade associada à perda, uma vez que a edificação estava em uso e fazia parte da vida da comunidade. A conotação trágica do arruinamento pode induzir a posturas que buscam uma reconstituição do bem perdido, ou a busca de soluções completamente novas que desconsiderem os restos da preexistência. 
Independentemente do grupo classificatório, a pergunta recorrente é: o quanto se quer conservar dessa situação de arruinamento?

Para nosso estudo, igualmente determinante para a identificação da condição de ruina é o contexto cultural brasileiro. No levantamento realizado verificamos nas práticas da preservação elaboradas pelos órgãos de preservação no Brasil, uma tendência para que as marcas da degradação sejam minimizadas ou até mesmo canceladas. Essa postura conceitual se aplica, sobretudo, aos bens em estado ruinoso acentuando, a dificuldade em reconhecê-lo como parte do patrimônio arquitetônico e como uma condição da matéria preexistente que possa ser considerada nas intervenções sob o ponto de vista histórico ou artístico.

Se inicialmente o ideário de salvar da ruína permeou a estruturação da instituição da preservação patrimonial no Brasil, os estudos de caso selecionados nos permitiram traçar um panorama do tema das ruínas nos debates dos órgãos de preservação ao longo do tempo chegando à contemporaneidade. Foi constatado, que, na maioria das vezes, a ruína continua sendo entendida como uma situação de degradação que deve ser sanada ou até mesmo eliminada, levando a diferentes propostas de intervenção, que envolvem a conservação ou não desse status quo.

Nos estudos de caso do Engenho São Jorge dos Erasmos e da Capela do Morumbi, ainda que houvesse uma maior aceitação e compreensão da necessidade de conservar a sua condição de ruína, as operações não foram homogêneas. As intervenções para reconstituir uma suposta forma de passado - total como na Capela, ou parcial como no trecho de cobertura do Engenho - podem induzir uma leitura dúbia da matéria remanescente. Além disso, no Engenho dos Erasmos houve os que defendessem a sua restauração (que na verdade se tratava conceitualmente de uma reconstituição). Ou seja, ainda que o arruinamento seja cronologicamente distante e haja ausência de referências da construção anterior, as ruínas não bastam como os únicos elementos físicos de memoração; há, portanto, uma latente necessidade de se reconstruir referências formalmente mais definidas para a constituição da memória para uma identidade cultural. Outros casos como o Sítio Santo Antônio (São Roque) e da Fábrica de Ferro Ipanema (Iperó) também evidenciam essa necessidade de reconstituição, com resultados que cancelam as marcas do tempo.

Já nos casos analisados das ruínas da incúria (Sede do Sítio Mirim e Sede do Sítio Itaim), foi possível verificar que os debates interpõem a opção da conservação do novo status quo de ruína às possibilidades de uma restauração que busca resgatar uma determinada imagem de arquitetura vinculada ao passado pelo qual se atribui o valor histórico das 
edificações - ou seja, a casa rural paulista (Casa Bandeirista). Ficou evidente, principalmente no Sítio Itaim que outros momentos da edificação (como os anos que esteve sediando um Sanatório) não foram considerados; comprovando, portanto, uma clara seleção do tipo de passado a ser considerado. Esses casos também revelam os conflitos das políticas de salvaguarda no Brasil, demonstrando que o instrumento de tombamento é insuficiente, evidenciado por exemplares similares como a casa Sede da Fazenda Conceição em Paraíbuna, que apesar de tombada, foi completamente perdida. A manutenção conservativa dos patrimônios tombados e sua inserção na vida contemporânea através de um uso compatível são medidas estratégicas que deveriam acompanhar as instruções de tombamento, evitando que processos de degradação acumulativos levassem à irremediável perda dos bens.

Nas ruínas do incidente, a situação de arruinamento do Teatro Cultura Artística, seguida da proposição de uma estrutura completamente nova, evidenciou a dificuldade em aplicar as teorias do restauro para patrimônios mais recentes; apesar dos remanescentes terem sido tombados, a destruição da arquitetura prévia foi tratada como uma oportunidade para atualizar o programa em termos técnicos e formais. Já na Igreja Matriz São Luiz de Tolosa ficou latente a necessidade de se resgatar a referência visual da arquitetura preexistente considerada importante para a comunidade local e para a leitura da Praça, recuperando a identidade cultural vinculada à imagem formal que foi perdida.

Foi possível verificar pelo levantamento dos bens tutelados pelos órgãos de preservação IPHAN, CONDEPHAAT e CONPRESP, que não há uma unidade de método na abordagem e tratamento às edificações em estado de ruína nas práticas patrimoniais brasileiras. A pluralidade de resultados, aqui apresentada, para a preservação ou não da condição de ruína, evidencia a complexidade e a dificuldade em abordar o tema no Brasil segundo os estritos preceitos do restauro crítico e suas respectivas quantificações de operações em relação ao grau de degradação do patrimônio cultural.

Os debates nos órgãos de preservação nas últimas décadas, principalmente sobre o Sítio Mirim, o Sítio Itaim e a Matriz de São Luiz do Paraitinga, indicam uma ampliação no entendimento sobre a problemática da ruína. As discussões nos autos consultados fazem pertinentes menções à problematização sobre a validade de conservar ou não a condição de ruína, segundo referências das teorias da preservação.

A despeito dessa maior amplitude de visão por parte de técnicos que atuam nos órgãos de preservação, estudiosos e arquitetos envolvidos nos debates, em termos práticos, as posturas adotadas demonstram uma predominância por escolhas de restauro que, na verdade 
buscam reconstituições formais de uma determinada arquitetura prévia em que princípios como mínima intervenção, autenticidade e distinguibilidade não são completamente incorporados.

Constatamos também que a palavra restauração por vezes é conceitualmente utilizada para se referir a trabalhos em que o grau de reconstituição tende a uma repristinação, ou a uma reconstrução estilística, denotando a falta de clareza em relação à utilização dos princípios e métodos da restauração enquanto um campo disciplinar que tem como escopo o respeito à matéria preexistente sob a ambivalência das instâncias histórica e estética visando sua transmissão ao futuro da melhor forma possível.

O estudo realizado revelou que o tema da ruína é de grande atualidade, integrando recentes discussões no âmbito dos órgãos de preservação brasileiros. A ruína, como abordada nesta tese, faz parte do cotidiano de nossa realidade e de nossas cidades e deve ser devidamente considerada na intrincada rede de significações que compõe os processos de construção da história, memória e identidade cultural. O tema ainda é pouco explorado e este trabalho pretendeu ser uma contribuição para evidenciar a potencialidade das ruínas enquanto objeto de estudo.

Nunca foi nossa intenção fazer uma apologia nostálgica ou fetichista das ruínas. Não há que se preservar tudo, nem edificações íntegras e tampouco ruínas. Mas, quando se trata de reconhecidos patrimônios culturais, como comentado ao longo do trabalho, há meios para prevenir sua degradação; as operações de manutenção (manutenção conservativa ou restauração preventiva) devem ter prevalência no tratamento a esses bens.

Uma vez constatado o grave estado de degradação de um patrimônio cultural, o que fazer? Do ponto de vista do restauro crítico, como apresentado, a intepretação que se faz dessa nova condição dos objetos pode levar a diferentes formas de tratamento que vão desde operações mais conservativas (como a consolidação do status quo) a restauros de completamento. Fora do escopo do campo disciplinar da restauração - quando o propósito não é necessariamente a preservação da matéria remanescente - as ruínas, também podem ser referências documentais do que um dia houve e se pretende reconstruir; e podem ser utilizadas para integrar visualmente projetos contemporâneos estabelecendo um diálogo entre o antigo e o novo. Há ainda a alternativa em que o estado de arruinamento pode ser entendido como a oportuna justificativa para elaborar construções completamente novas em que as reminiscências anteriores sejam canceladas. 
A quantificação dessas posturas divergentes no âmbito das complexas contraposições derivadas do tema se coaduna no desafio de aceitar ou não a condição de ruína como parte da história do patrimônio e tratá-la como uma nova articulação de características que aglutina valores (históricos e estéticos) a serem considerados para a preservação da preexistência.

As ruínas, como patrimônio cultural, não são elementos estagnados que somente remetem a um passado, mas são registros dinâmicos e condensam as possibilidades do presente e futuro enquanto testemunhos vivos (como mencionado na Carta de Veneza); são elementos que se rearticulam espacialmente estabelecendo uma nova fruição na contemporaneidade. A ruína não é uma condição pronta e acabada; deve ser entendida a partir das novas relações que se estabelecem num modo contínuo, renovando-se em cada momento presente. Portanto, a ruína não precisa ser interpretada somente como um fim, mas também pode ser interpretada como um novo começo. 


\section{Referências bibliográficas}

\section{Ruínas}

\subsection{Abordagens filosóficas e estéticas}

ARGAN, Giulio Carlo. História Arte como História da Cidade. São Paulo: Martins Fontes, 1998.

AUGÉ. Marc. Le temps en ruines. Paris: Galilé, 2003.

AZEVEDO, Ricardo M. de. Antigos modernos: estudos das doutrinas arquitetônicas nos séculos XVII e XVIII. São Paulo: FAUUSP, 2009.

BARBANERA, Marcello e CAPODIFERRO, Alessandra (a cura di). La forza delle rovine. Milano: Mondadori Electa S. p. A., 2015.

BIALOSTOCKI, Jan. Estilo e iconografia - contribuición a uma ciência de las artes. Barcelona, Barral Editores, 1972. Arte y Vanitas, p. 185-226.

BIGIOTTI, Stefano e CORVINO, Enrica (cura). La modernità delle rovine - Temi e figure dell architettura contemporanea. Roma: Prospettive Edizioni, 2015.

BURKE, Edmund. Indagación filosófica sobre el origen de nuestras ideas acerca de lo sublime y de lo belo. Madrid: Tecnos, 1987.

CARENA, C. Ruína/restauro. In: RUGGIERO, R. (dir.). Enciclopédia, v. 1 (Memóriahistória). Lisboa: Imprensa Nacional/Casa da Moeda, 1984.

D`AGOSTINO, Mário Henrique S. A arquitetura, o corpo e o espelho. Sobre a beleza e o tempo na arte do Renascimento e em nossos dias. Tempo soc. (online), v. 15, n. 1, p. 113-137, 2003. Disponível em: <http://www.scielo.br/scielo.php?script=sci_arttext\&pid=S010320702003000100007>. Acesso em: 30 maio 2011.

DI BLASI, Viviana; ROBBIATI, Cinzia. Rovine, testimoni del tempo. Ananke - cultura, storia e tecniche della conservazione, Firenze, n.15, p.22-29, 1996.

DILLON, Brian. A short history of decay. In: DILLON, Brian (ed.). Ruins. London: Whitechapel Gallery, Cambridge, Mass: MIT Press, p. 10-19, 2011.

Estetiche e retoriche delle rovine. Estetica, n.8, p.3-167, 1981.

Faut-il restaurer les ruines? Actes des Colloques de la Direction du Patrimoine. Paris: Piccard, 1991.

GILYARD-BEER, Roy. Ruins as documents. Rome, International Centre for Conservation, 1974.

HOUAISS, Antônio e VILLAR, Mauro de Salles. Dicionário Houaiss da Língua Portuguesa. Rio de Janeiro: Objetiva, 2001.

JEUDY, Henri-Pierre. Espelho das cidades. Rio de Janeiro: Casa da Palavra, 2005.

LE GOFF, Jacques. História e memória. Campinas, SP: Editora da Unicamp, 2010.

MACAULAY, Rose. Esplendor de las ruínas. Barcelona: Ediciones Grijalbo S.A., 1965.

MAISTE, Juhan, POLLI Kadi (Editor). Varemed Ruins. Tallinn: Eesti Kunstiakadeemia Restaureerimskool, 2004. 
MARINO, Luigi. (a cura di). Dizionario di Restauro Archeologico. Firenze: Alinea Editrice, 2003.

MENEGUELLO, Cristina. Da ruína ao edifício. Neogótico, reinterpretação e preservação do passado na Inglaterra vitoriana. São Paulo: Annablume / FAPESP, 2008.

MORI, Victor Hugo. Arqueologia e restauração - anotações para debate. In: Patrimônio: atualizando o debate. São Paulo: IPHAN/9ª SR, 2006, p.118-138.

PRESSOUYRE, Léon. Entre l'esthétique et l'histoire symbolique des ruines et conservation. In: Faut-il restaurer les ruines? Actes des Colloques de la Direction du Patrimoine. Paris: Piccard, 1991, p.20-23.

PRETI, Monique; SETTIS, Salvatore (a cura di). Villes en ruines. Images, mémoires, metamorphoses. Paris: Musée du Louvre, 2015.

QUILICI, Vieri. La Vita delle Opere - Una riflessione e vari pretesti sulla durata in architettura. Roma: Palombi \& Partner Srl, 2011.

RIZZI, Gionata. Preface to Conservation of Ruins [2007]. In: MACKAY, Richard e SULLIVAN, Sharon (Editor). Archaeological sites: conservation and management. Los Angeles, USA: Getty Conservation Institute, 2013, p. 82-89.

SALGUEIRO, Valéria. Grand Tour: uma contribuição à história do viajar por prazer e por amor à cultura. Revista Brasileira de História (online), v. 22, n. 44, p. 289-310, 2002. Disponível em:<http://www.scielo.br/scielo.php?script=sci_arttext\&pid=S010201882002000200003\&lng=pt\&nrm=iso >. Acesso em: 15 maio 2013.

SCHNAPP, Alain. La conquête du passé: aux origines de l'archéologie. Paris, France: Editions Carré, 1993.

SERRÃO, Vítor. Portugal em ruínas. Uma história cripto-artística do património construído. In: SILVA, Gastão de Brito. Portugal em ruínas. Lisboa: Fundação Francisco Manuel dos Santos, Gastão de Brito e Silva, 2014, p. 10-46.

STAROBINSKI, Jean. A invenção da liberdade 1700-1789. São Paulo: Unesp, 1994.

WOODWARD, Christopher. In ruins. London: Vintage, 2002.

\subsection{Intervenções}

ALARCÃO, Pedro. Conservación y valorización de las ruinas de Conimbriga: Coimbra, Portugal. Restauración \& rehabilitación, Valência, n. 105, p. 38-45, 2007.

ANDERSON, Mary e SLOCOMBE, Matthew. Reusing ruins. SPAB news, UK, v.19, n.4, p.10-11, 1998.

ARNAUD, José Morais Arnaud e FERNANDES, Carla Varela (coord.). Museu Arqueológico do Carmo - roteiro da exposição permanente. Lisboa: Associação dos Arqueólogos Portugueses/Museu Arqueológico do Carmo, s.d.

ASHURST, John. Conservation of ruins. London: Burlington, Mass.: ButterworthHeinemann, 2007.

AVENT, Jon. Conserving and stabilizing masonry ruins. Journal of architectural conservation 17, UK, n. 1, p. 29-57, 2011.

BENEVOLO Leonardo. Studio per la sistemazione dell area archeologica centrale di Roma. In: Forma. La citta antica e il suo avvenire, Roma: De luca editore, 1985, p.164-173. 
BILLECI, Bruno; GIZZI, Stefano; SCUDINO, Daniela (Editor). Il rudere tra conservazione e reintegrazione: atti del convegno internazionale. Sassari: Università degli studi di Sassari 2003.

BIONDILLO, Gianni. La rovina come dimora: Carlo Levi e la conservazione delle città. Ananke -cultura, storia e tecniche della conservazione, Firenze, n.19, p.34-41, 1997.

BRAAE, Ellen. Beauty Redeemed - Recycling Post-Industrial. Basel: Birkhäuser, 2015. Risskov: Ikaros Press, 2015.

CALIARI, Pier F. e PERESSUT, Luca B. Architettura per l'archeologia - museografia e allestimento. Roma: Prospettive Edizioni, 2014.

CAPERTON, Thomas J. Stabilization of Fort Selden's ruins. APT Bulletin, EUA, v.22, n.3, p.30-34, 1990.

CASTILLO, Alicia (editor). Archaeological dimension of World heritage - From prevention to social implications. New York: Springer, 2014.

CHITTY, Gill. A prospect of ruins. Association for Studies in the Conservation of Historic Buildings Transactions, UK, v.12, p.43-60, 1987.

CIANETTI, Marina M. Il prospetto della Natatio e il chiostro 'Ludovisi' nelle Terme di Diocleziano. Due restauri a confronto. Palladio: rivista di storia dell architettura e restauro, Roma, n. 51, p. 59-88, 2013.

CONFORTO, Maria Letizia; MARTINES, Giangiacomo. Le temps, ce grand sculpteur. La rovina, il nuovo e l'utopia del passato. In: Forma. La citta antica e il suo avvenire, p.161-164, Roma: De luca editore, 1985.

DI MUZIO, Anelinda. Rovine protette: conservazione e presentazione delle testimonianze archeologiche. Roma: L'Erma di Bretschneider, 2010.

FELMINGHAM, Michael; GRAHAM, Rigby. Ruins. London: The hamlyn publishing group, 1972.

FERRARA, Maria Luisa. Il rudere archeologico tra anastilosi, reintegrazione e ripristino: le attuali linee comportamentali del restauro in Grecia. Recupero e conservazione, Italy, v.14, n.82, p.66-71, 2008.

FERRUCCI, Fabiano. Note sul trattamento del rudere. Progetto restauro, Padova, n. 54, p. 22-31, 2010.

GEGNER, Martin; ZIINO, Bart (Editor). The heritage of war. Abingdon, Oxon: Routledge, 2012.

INSOLERA, I., SPADA P., TEMPESTA E., ZACCAGNI P. Roma Capitale d'Italia: demolizioni e "Abbellimenti" In: Forma. La citta antica e il suo avvenire, Roma: De luca editore, 1985, p.78-85.

LAGUNES, María Margarita Segarra (a cura di). Progetto archeologico, progetto architettonico. Seminari di Studi.. Roma: Gangemi Editore spa, 2002.

LAVAGNINO, Emilio. Offese di Guerra e restauri al patrimonio artistico dell Italia. Ulisse, Roma, anno 1, fasc II, Agosto, p.127-228, 1947.

LOUKAKI, Argyro. Living ruins, value conflicts. Aldershot, England: Ashgate, 2008.

MACKAY, Richard e SULLIVAN, Sharon (Editor). Archaeological sites: conservation and management. Los Angeles, USA: Getty Conservation Institute, 2013. 
MAGAR, Valerie. Ruinas y reconstrucción: algunos aspectos históricos y teóricos. Imprimatura: revista de restauración. Mexico City, n. 13, p. 43-46, 1996.

MARINO, Luigi. La conservazione di manufatti edili ridotti allo stato di rudere: protezione delle creste e integrazione delle lacune. In: MASETTI, Luisa Bitelli (Editor). Archeologia: recupero e conservazione. Firenze: Nardini, n.3, 1993, p.129-150.

MARTINELLI, Maurizio. Emergenza Alluvione - Piani a salvaguardia dei Beni Culturali. Arkos - Scienza e Restauro, Messina, n. 17, ott./dic., p. 32-40, 2008.

MATERO, Frank G.; BASS, Angelyn. Orphans of the storm. The preservation of architectural plasters in earthen ruins. CRM: cultural resources management, Washington, v.17, n.4, p.21-26, 1994.

MATTHIAE, Paolo. Distruzioni saccheggi e rinascite - gli attachi al patrimonio artistico dall’antichità all'Isis. Milano: Mondadori Electa S.p.a., 2015.

MELUCCO, Alessandra Vaccaro. La crisi della 'bella rovina': problemi attuali nella conservazione delle aree archeologiche. In: MASETTI, Luisa Bitelli (Editor). Archeologia: recupero e conservazione. Firenze: Nardini, n.3, 1993, p.9-26.

METZGER, Todd R. Vanishing treasures: a legacy in ruins. CRM Cultural resource management, Washington, v.22, n.6, p.63-64, 1999.

MINISTERO per gli Affari Esteri. Ambasciata d'Italia. Sezione culturale. Percorrere le rovine: lo scavo, il museo, il parco archeologico. Pisa: Sezione culturale dell'Ambasciata d'Italia, 2000.

MORGANTI, Giuseppe (a cura di). Gli Orti Farnesiani sul Palatino. Roma: École Française de Rome \& Soperintndenza Archeologica di Roma, 1990.

MYERS, Harry C. Preserving adobe ruins. CRM Cultural resource management, Washington, v.20, n.10, p.12, 1997.

NERDINGER, Winfried (org.). Geschichte der Rekonstruktion. Konstruktion der Geschichte. Munique: Prestel, 2010.

PALLOTTINO, Elisabetta. Cultura della ricostruzione a Roma tra Ottocento e Novecento: precedenti e prospettive. Ricerche di storia dell' arte, Roma, n. 95, p. 6-29, 2008.

PEROGALLI, Carlo (a cura di). Architettura e restauro. Esempi di restauro eseguiti nel dopoguerra. Milão: Goerlich editore, 1955.

RUGGIERI, Maria Clara Tricoli (Editor). Musei sulle rovine: architetture nel contesto archeologico. Milano: Edizioni Lybra Immagine, 2007.

SALVO, Simona. Restauro e ‘restauros’ das obras arquitetônicas do século XX: Intervenções em arranha-céus em confronto. Revista CPC, São Paulo, n. 4, p. 139-157, 2007.

SEGAWA, Hugo. Memórias do Cárcere: Penitenciária de San Luis Potosí e Eastern State Penitentiary como lugares de cultura. In: Desenhos da pesquisa: conhecimento / produção. Universidade de São Paulo - Museu de Arte Contemporânea, São Paulo, p. 17-24, 2014. Disponível em: $<$ http://aroeira.usp.br/pgeha/livros/DESENHOS\%20DA\%20PESQUISA.pdf>. Acesso em 07 de nov. 2016.

SERAFINI, Lucia. La progettazione per gli edifici allo stato di rudere tra realizzazioni e questioni teoriche. In: Conservare il passato: metodi ed esperienze di protezione e restauro 
nei siti archeologici: atti del convegno. Chieti-Pescara, 25-26, set.,2003. Antico Futuro, 1. Roma: Gangemi editore, 2005, p.79-96.

SOHEIL Mehr Azar. Persepolis as monument. In: MAISTE, Juhan, POLLI Kadi (Editor). Varemed Ruins. Tallinn: Eesti Kunstiakadeemia Restaureerimskool, 2004, p. 266-272.

SQUASSINA, Angela. Tiempo que destruye, tiempo que conserva: sentido del tiempo y conciencia conservativa. Loggia, Madrid, n. 24-25, p.26-43, 2012.

STANFORD, Caroline. On preserving our ruins. Journal of architectural conservation, Great Britain, v.6, n.3, p.28-43, 2000.

TAYLOR Arnold J. Ancient monuments and their interpretation. London: Phillimore \& Co. Ltd, 1977.

THOMPSON, Jonathan. Rescuing ruins: regeneration of buildings at risk. English Heritage Conservation bulletin, Uk, n.43, p.44-47, 2002.

THOMPSON, Michael W. Ruins reused: changing attitudes to ruins since the late eighteenth century. Norfolk: Heritage Marketing \& Publications, 2006.

Ruins: their preservation and display. London: British Museum Publications, 1981.

THURLEY, Simon. Men from the ministry: how Britain saved its heritage. Padstow, England: English Heritage, 2013.

TRIGILIA, Lucia. Noto: un`emergenza continua (1986-1996). Ananke - cultura, storia e tecniche della conservazione, Firenze, marzo, n.13, p.66-69 1996.

UNIVERSITÀ di Bologna, Napoli, Firenze e Urbino, Gruppo di ricerca sul restauro archeologico. Conservazione e manutenzione di manufatti lignei ridotti allo stato di rudere. Firenze: Opus Libri, 1989.

VARAGNOLI, Claudio. Ruderi e restauro: sperimentazioni in Abruzzo. In: Conservare il passato: metodi ed esperienze di protezione e restauro nei siti archeologici: atti del convegno. Chieti-Pescara, 25-26, set.,2003. Antico Futuro, 1. Roma: Gangemi editore, 2005, p.53-78.

Venezia, La Fenice: i fatti, gli atti ufficiali, le opinioni [contributi diversi]. Ananke - cultura, storia e tecniche della conservazione, Firenze, marzo, n.13, p.24-49 1996.

WOOLFITT, Catherine. Preventive Conservation of ruins: reconstruction, reburial and enclosure (2007) In: SULLIVAN, Sharon (Editor); MACKAY, Richard (Editor). Archaeological sites: conservation and management. Los Angeles, USA: Getty Conservation Institute, p. 503-513, 2013.

\subsection{Cenário brasileiro}

BAETA, Rodrigo E.; NERY, Juliana C. Escavações arqueológicas, ruínas e arquitetura contemporânea. In: Anais $4^{\circ}$ Seminário Ibero-americano - Arquitetura e documentação, Belo Horizonte, 2015.2 Disponível em: $<$ http://www.forumpatrimonio.com.br/arqdoc2015/artigos/pdf/53.pdf $>$. Acesso em: 28 de set. 2016.

CALDATTO, Ney. Museu Pelé em Santos. Arquiteturismo (eletrônica), ano 02, jul. 2008. Disponível em: <http://www.vitruvius.com.br/revistas/read/arquiteturismo/02.017/1440>. Acesso em: 08 Set. 2016. 
COELHO, Mário C. Ruínas urbanas. Esboços, Florianópolis, v. 4, n.4, p. 39-45, jun/dez 1996.

Discurso recitado no acto de estatuir-se o Instituto Histórico e Geographico Brazileiro, pelo secretário perpétuo e cônego Januário da Cunha Barbosa. In: Revista do IHGB, Rio de Janeiro, n. 1, Tomo I, p. 9-17, 1839. Disponível em: <https://ihgb.org.br/publicacoes/revistaihgb/itemlist/filter.html?category=9\&moduleId=147>, acesso em 28 abr. 2016.

DINIZ, Luciana Nemer. Projetos contemporâneos em ruínas: o passado compartilhado no presente. In: Anais do III Encontro da Associação Nacional de Pesquisa e Pós Graduação em Arquitetura e Urbanismo - arquitetura, cidade e projeto: uma construção coletiva. São Paulo, 2014. Disponível em: <http://www.anparq.org.br/dvd-enanparq-3/htm/Artigos/ST/ST-PCI007-4.pdf>. Acesso em: 28 de out. 2016.

LANGER, Johnni. Ruínas e mitos: a arqueologia do Brasil imperial. Tese (Doutorado) Faculdade de História, Universidade Federal do Paraná, Curitiba, 2001.

Memória: sobre a situação da antiga cidade abandonada, que se diz descoberta nos sertões do Brasil por certos aventureiros em 1753 - Escripta pelo sócio correspondente o Sr. Conego Benigno José de Carvalho e Cunha. In: Revista do IHGB, Rio de Janeiro, n. 10, Tomo III, p. 197-203, 1842. Disponível em: <https://ihgb.org.br/publicacoes/revistaihgb/itemlist/filter.html?category=9\&moduleId=147>, acesso em 28 abr. 2016.

MENDONÇA, Adalton da M. Revisitando as ruínas urbanas. In: XII Encontro da Associação Nacional de pós graduação e pesquisa em planejamento urbano e regional. UFPA, Belém, 2007. Disponível em: <http://www3.ufpa.br/xiienanpur/CD/ARQUIVOS/GT6-695-39120061226171154.pdf>. Acesso em: 30 jun. 2011.

MENESES, Ulpiano B. Identidade cultural e arqueologia, Revista do Patrimônio Histórico e Artístico Nacional, Rio de Janeiro, n. 20, p. 33-36, 1984.

PEIXOTO, Nelson B. Cenários em ruínas. São Paulo: Ed. Brasiliense, 1987.

PONTES, Anna Maria de Lira. Entre fragmentos: os ditos e não ditos das ruínas patrimoniais. Dissertação (Mestrado) - Faculdade de Arquitetura e Urbanismo, Universidade Federal da Paraíba, 2011.

ROCHA, Eduardo. Arquiteturas do abandono: ou uma cartografia nas fronteiras da arquitetura, da filosofia e da arte. Tese (Doutorado), PROPAR, Universidade Federal do Rio Grande do Sul, 2010.

SANTOS, Cecília R. e ZEIN, Ruth V. Rápidas considerações sobre a preservação das ruínas na modernidade. Arquitextos (eletrônica), ano 12, jul. 2011. Disponível em: $<$ http://www.vitruvius.com.br/revistas/read/arquitextos/12.135/3997>. Acesso em: 08 set. 2011.

\section{Patrimônio cultural e preservação}

\subsection{Teorias e cartas patrimoniais - o papel memorial dos bens}

ANNONI, Ambrogio. Scienza ed Arte del Restauro Architettonico: Idee ed Esempi. Milano: Framar, 1946.

BALDINI, Umberto. Teoria del restauro e unità di metodologia. Firenze: Nardini Editore, 1981.

BARBACI, Alfredo. Il Restauro dei Monumenti in Itália. Roma: Istituto Poligrafico dello Stato, 1956. 
BERGEON, Ségolène. Éthique et conservation-restauracion: la valeur d'usage d'un bien culturel. In: La conservation: une science em evolution. Bilan et perspectives. Paris: ARSAG, 1997.

BOITO, Camillo. Os restauradores. Trad. Beatriz Mugayar Kühl. Cotia, SP: Ateliê Editorial, 2002.

BONELLI, Renato; D`OSSAT, Guglielmo de D`Angelis. Due Lezioni di Restauro. Roma: Multigrafica Editrice, 1987.

Verbete: Il Restauro Architettonico. In: Enciclopedia Universale dell'Arte.

Novara: Istituto Geografico de Agostini, 1983, 4. ed. (1. ed. 1958).

Architettura e restauro. Venezia: Neri Pozza Editore, 1959.

BOSCARINO, Salvatore; CARBONARA, Giovanni. Il progetto di restauro. Interpretazione critica del testo architettonico. Trento: Comitato Giuseppe Gerola, 1988.

BRANDI, Cesare. Teoria da restauração. Trad. Beatriz Mugayar Kühl. Cotia, SP: Ateliê Editorial, 2004.

.Teoria del restauro. Torino: Giuliu Einaudi Editore s.p.a., 2000.

Il Restauro. Teoria e Pratica. Roma: Editori Riuniti, 1994.

CAMPANELLI, Alessandro P. Restauro contemporâneo: algumas abordagens. Revista CPC (eletrônica), São Paulo, n. 7, p. 20-42, nov. 2008/abr. 2009. Disponível em: $<$ http://www.usp.br/cpc/v1/php/wf07_revista_interna.php?id_revista=11\&id_conteudo=39\&ti po $=5>$. Acesso em: 30 maio 2012.

27, p.247-252, 2010.

. Antigos exemplos de restauros de cerâmicas gregas. Pós, São Paulo, v.17, n.

. Exemplos difusos de reparos e restaurações de antigos pavimentos com mosaicos. Pós, São Paulo, v.17, n. 27, p.253-259, 2010.

CARBONARA, Giovanni. Architetture d`oggi e restauro - Un confronto antico-nuovo. Turim: Utet, 2013.

Roberto Pane, Cesare Brandi e il "restauro critico". In: Roberto Pane tra storia e restauro Architettura, città, paesaggio. Venezia: Marsilio Editori s.p.a., p.22-27, 2010.

. Alcune riflessioni, da parte italiana, sul restauro architettonico. ICCROM Conservation Studies, Roma, n.10, p.27-35, 2009.

. Brandi e a restauração arquitetônica hoje. Desígnio - Revista de História da Arquitetura e do Urbanismo, São Paulo, n. 6, p. 35-47, 2006.

Antichità archeologiche e periferia. In: CASSETTI R., SPAGNESI G. (a cura di). Roma Contemporanea. Storia e progetto. Roma, 2006, p. 401-407.

Architettura e restauro oggi a confronto. Palladio: rivista di storia dell architettura e restauro - nuova serie. Roma, anno 18, n. 35, p. 99-128, 2005

. Trattado di restauro architettonico. Turim: Utet, 2004.

Avvicinamento al restauro. Napoli: Liguori, 1997.

. Autenticità e Patrimonio Monumentale: Riflessioni sul Saggio di R. Lemaire. Restauro, Napoli, n. 129, p. 80- 88, 1994. 
. Dieci tesi di restauro (1970-1981). Rome University. Scuola di Specializzazione per lo Studio ed il Restauro dei Monumenti; Roma, 1986.

n. 36, p. 5-51, 1978.

Questioni di principio e di metodo nel restauro dell'architettura. Restauro, Napoli, [s.n], 1976

. La Reintegrazione dell'immagine: Problemi di Restauro dei Monumenti. Roma:

CESCHI, Carlo. Teoria e Storia del Restauro, Roma: Bulzoni, 1970.

CHOAY, Françoise. A alegoria do patrimônio. São Paulo: UNESP, 2001.

. Sept propositions sur le concept d'Authenticité et son usage dans le pratiques du patrimoine historique. In: Nara Conference on Authenticity. Paris, UNESCO, 1995, p.101-120.

CURY, Isabelle (org.). Cartas Patrimoniais. Rio de Janeiro: IPHAN, 2004.

D’OSSAT, Guglielmo de Angelis. Restauro: architettura sulle preesistenze. Palladio: rivista di storia dell architettura e restauro - Terza serie, Roma, anno XXVII, fasc 2., p. 51-67, 1978.

DVOŘÁK, Max. Catecismo da Preservação de Monumentos. Trad. Valéria Alves Esteves Lima. Cotia, SP: Ateliê Editorial, 2008.

FUSCO, Renato de. Dov'era ma non com'era. Firenze: Alinea, 1999.

. Autenticità e restauro. Restauro, Napoli, n. 129, p. 89-94, 1994.

GIOVANNONI, Gustavo. Vecchie Città, Edilizia Nuova. Milano: Città Studi Edizioni, 1995.

. Restauro dei Monumenti. In: Enciclopedia Italiana di Scienze, Lettere ed Arti. Roma: Istituto della Enciclopedia Italiana (Treccani), 1936. p. 127-130.

GUERRIERO, Luigi. Roberto Pane e la dialettica del restauro. Pref. Giuseppe Fiengo. Napoli: Liguori, 1995.

HARDY, Mathew (Editor). The Venice Charter Revisited: Modernism, Conservation and Tradition. Newcastle upon Tyne: Cambridge Scholars Pulishing, 2008.

Il Monumento per l'uomo. Atti del II Congresso Internazionale del Restauro. Venezia 25-31 maggio 1964. Padova: ICOMOS, Marsilio, 1971.

JOKILEHTO, Jukka I. A History of Arhitectural Conservation. Oxford: Butterworth-Heinemann, 2005.

. The context of the Venice Charter (1964). In: Conservation and Management of Archaeological Sites, vol. 2, p. 229-233, 1998.

KNUT-EINAR, Larsen (Editor). Nara Conference on authenticity in relation to the World Heritage Convention: Nara, Japan, 1-6 November 1994. Proceedings. Trondheim: Tapir publishers, 1995.

KÜHL, Beatriz M. Notas sobre a Carta de Veneza. Anais do Museu Paulista. São Paulo, v.18, n.2, p.287-320, jul.-dez/2010. Disponível em: <http://www.scielo.br/scielo.php?pid=S010147142010000200008\&script=sci_arttext>. Acesso em 30 maio 2012.

. Preservação do patrimônio arquitetônico da industrialização: Problemas teóricos de restauro. Cotia, SP: Ateliê Editorial, 2008.

Questões teóricas relativas à preservação da arquitetura industrial. Desígnio - Revista de História da Arquitetura e do Urbanismo, São Paulo, n. 1, p. 101-117, 2004. 
Quatremère de Quincy e os verbetes Restauração, Restaurar, Restituição e Ruína de sua Encyclopédie méthodique. Architecture. Rotunda (eletrônica), Campinas, n.2, p.100-117, ago./2003. Disponível em: <http://www.iar.unicamp.br/rotunda>. Acesso em: 30 maio 2010.

. Os restauradores e o pensamento de Camillo Boito sobre a restauração. In: BOITO, Camillo. Os restauradores. Trad. Beatriz Mugayar Kühl. Cotia, SP: Ateliê Editorial, 2002, p.9-28.

. As transformações na maneira de intervir na arquitetura do passado entre os séculos XV e XVIII: o período de formação da restauração. Sinopses, São Paulo, n. 36, p. 2436, 2001.

. Viollet-le-Duc e o Verbete Restauração. In: VIOLLET-LE-DUC, Eugène Emmanuel. Restauração. Trad. Beatriz Mugayar Kühl. Cotia, SP: Ateliê Editorial, p.9-24, 2000 .

LA MONICA, Giuseppe. Ideologie e prassi del restauro. Palermo: Nuova Presenza, 1974.

LAMERS-SCHÜTZE, P. (Coord.). Teoria da arquitectura - do Renascimento aos nossos dias. Itália: Taschen, 2003.

LENIAUD, Jean-Michel. Viollet-le-Duc - ou les délires du système. Paris: Éditions Mengès, 1994.

LEMAIRE, Raymond. Authenticité et Patrimoine Monumental. Restauro, Napoli, n. 129, p. 7-24, 1994.

MACIEL, M. Justino. Vitrúvio - Tratado de arquitectura. Trad. do Latim, introdução e notas por. Lisboa: Ist Press, 2009.

MARAMOTTI, Anna Lucia. La materia del restauro. Milano: Franco Angeli, 1989.

MARCONI, Paolo. Restauro dei monumenti - Cultura, progetti e cantiere 1967-2010. Roma: Gangemi Editore, 2012. . Materia e Significato. Roma: Laterza, 1999.

. Dal Piccolo al Grande Restauro. Venecia: Marsilio, 1988.

MARIANI, Gaetano Miarelli. Restauro e territorio appunti su un rapporto complesso e controverso. Palladio: rivista di storia dell architettura e restauro, Roma, anno XXV, fasc 1., p. 83-100, 1978. n.33-34, p.61-71, 1977.

Aspetti della conservazione fra restauro e progettazione. Restauro, Napoli,

MARINO, Bianca Gioia. Restauro e autenticità - nodi e questioni critiche. Napoli: Edizioni Scientifiche Italiane, 2006.

MARTÍNEZ, Ascensión H. L`Estetica del deterioramento e dell imperfezione: una tendenza in crescita nel restauro arquitetônico. Palladio: rivista di storia dell architettura e restauro, Roma, n. 51, p. 89-106, 2013.

. La clonación arquitectónica. Madrid: Ediciones Siruela, 2007.

MÉRIMÉE, Prosper. Lettres de Mérimée à Ludovic Vitet. Introd. Et notes par Maurice Parturier. Paris: Éd. Du CTHS, 1998.

NORA, Pierre. Entre mémoire et histoire - la problématique des lieux. In: NORA, Pierre (dir.). Les Lieux de Mémoire (3 vols). Paris: Gallimard, vol.1, 1984, p. XVII-XLII.

PANE, Roberto. Attualità dell'Ambiente Antico. Firenze: La Nuova Italia, 1967 
Città Antiche Edilizia Nuova. Napoli: Edizioni Scientifiche Italiane, 1959.

Considérations sur la Réunion d`experts tenue au siege de l'UNESCO du 17 au 21 octobre 1949. Museum, vol. III, p.8-48, 1950.

PEROGALLI, Carlo. Monumenti e metodi di valorizzazione. Milano: Libreria editrice politecnica tamburini, 1954.

PHILIPPOT, Paul. Historic Preservation: Philosophy, Criteria, Guidelines. In: Preservation and Conservation: Principles and Practices. Proceedings of the North American International Regional Conference, September 10-16, 1972. Washington: The Preservation Press, 1976.

PINHEIRO, Maria Lucia B. John Ruskin e as Sete Lâmpadas da Arquitetura - Algumas Repercussões no Brasil. In: RUSKIN, John. A lâmpada da memória. Trad. Maria Lucia Bressan Pinheiro. Cotia, SP: Ateliê Editorial, 2008, p.9-48.

RAFAEL. Cartas sobre arquitetura - Rafael e Baldassar Castiglione: arquitetura, ideologia e poder na Roma de Leão X. Org. Luciano Migliaccio; trad. Luciano Migliaccio, Letícia Martins de Andrade e Maria Luiza Zanatta. Campinas, SP: Editora da Unicamp; São Paulo, SP: Editora Unifesp, 2010.

RIEGL, Alois. Il culto moderno dei monumento - Il suo carattere e i suoi inizi. SCARROCCHIA Sandro (a cura di). Bologna: Nuova Alfa Editoriale, 1990.

RUFINONI, Manoela R. Preservação e restauro urbano - Intervenções em sítios históricos industriais. São Paulo: Fap-Unifesp: Edusp, 2013.

RUSKIN, John. A lâmpada da memória. Trad. Maria Lucia Bressan Pinheiro. Cotia, SP: Ateliê Editorial, 2008.

SETTE, Maria Piera. Profilo Storico. In: CARBONARA, Giovanni (org.). Trattato di Restauro Architettonico (4 vols.). Turim: Utet, vol.1, 2004, p.111-299.

TORSELLO, Paolo. Che cos'è il Restauro? Venezia: Marsilio Editori, 2005.

VIOLLET-LE-DUC, Eugène Emmanuel. Restauração. Trad. Beatriz Mugayar Kühl. Cotia, SP: Ateliê Editorial, 2000.

nobele, 1967.

. Dictionnaire raisonné de l'architecture française du XIe au XVIe siècle. Paris: De

VIVIO, Beatrice. Franco Minissi: musei e restauri - la trasparenza come valore. Roma: Gangemi, 2010.

27, p.217-230, 2010

Reconstrução no pós-guerra e reintegração arquitetônica. Pós, São Paulo, v.17, n.

. O novo no antigo hoje: modalidades de abordagem da intervenção na preexistência arquitetônica. Pós, São Paulo, v.17, n. 27, p.231-246, 2010.

ZANARDI, Bruno (org.) Conservazione, restauro e tutela. Milano: Skira, 1999.

\subsection{Políticas e práticas - cenário brasileiro}

ANDRADE, Antônio L. D. Um Estado completo que pode jamais ter existido. Tese (Doutorado) Faculdade de Arquitetura e Urbanismo, Universidade de São Paulo, São Paulo, 1993.

ANDRADE, Mário de. Mário de Andrade: cartas de trabalho - correspondência com Rodrigo Mello Franco de Andrade, 1936-1945. Brasília: Secretaria do Patrimônio Histórico e Artístico Nacional: Fundação Pró-Memória, 1981. 
A Capela de Santo Antônio. Revista do Serviço do Patrimônio Histórico e Artístico Nacional, Rio de Janeiro, n.1, p.119-125, 1937.

ANDRADE, Rodrigo Melo Franco de. Rodrigo e o SPHAN - coletânea de textos sobre o patrimônio cultural. Rio de Janeiro: Ministério da Cultura, Fundação Nacional Pró-Memória, 1987.

Brasil: monumentos históricos e arqueológicos. México D. F.: Instituto Panamericano de Geografia e História, 1952.

ARANTES, Antônio Augusto. Documentos históricos, documentos de cultura. Revista do Patrimônio Histórico e Artístico Nacional, Brasília, n.22, p.48-55, 1987.

BASTOS, Rossano Lopes. Normas e gerenciamento arqueológico / Rossano Lopes Bastos; Adriana Teixeira. Org.: Marise Campos de Souza. $2^{\text {a }}$ ed., São Paulo: 9a SR/IPHAN, 2008.

BÔAS, Alexandre dos S. V. e COSTA, Heloísa F. Centro de interpretação do pampa: a revitalização de um patrimônio cultural. In: ANPUR - XXVII Simpósio Nacional de História Conhecimento histórico e diálogo social, 22 a 26 de julho, 2013. Disponível em: $<$ http://snh2013.anpuh.org/resources/anais/27/1362018966_ARQUIVO_ArtigoANPUHNacional. pdf $>$ Acesso em 12 maio 2016

CASTRO, Sonia Rabello de. O Estado na preservação de bens culturais. Rio de Janeiro: Renovar, 1991.

COMAS, Carlos Eduardo (org.). Lucio Costa e as missões: um museu em São Miguel. Porto Alegre: PROPAR/UFRGS, IPHAN/12 ${ }^{\mathrm{a}}$ SR, 2007.

CONDEPHAAT. Patrimônio cultural paulista: CONDEPHAAT, bens tombados 1968 - 1998. São Paulo: Imprensa Oficial do Estado, 1998.

DEBLASIS, Paulo. Twenty years of heritage resource management in Brazil, a brief evaluation (1986-2006). In: Cultural Heritage Management - A global perspective. Paul A. Shackel, University of Maryland, 2006, p. 38-47.

FONSECA, Maria Cecília L. O Patrimônio em processo. Trajetória política federal de preservação no Brasil. Rio de Janeiro: UFRJ/Minc/IPHAN, 2009.

GONÇALVES, Cristiane S. Restauração arquitetônica: a experiência do SPHAN em São Paulo, 1937 -1975. São Paulo: Annablume / FAPESP, 2007.

LANNA, Ana L. D. Patrimônio cultural: política e práticas - Relatório da gestão 2013/2015 da presidente do Condephaat. Arquitextos (eletrônica), Ano 16, fev. 2016. Disponível em: <http://www.vitruvius.com.br/revistas/read/arquitextos/16.189/5944>. Acesso em 28 out. 2016.

LEAL, Claudia F. B. (org.). As missões da Unesco no Brasil: Michel Parent. Rio de Janeiro: IPHAN/COPEDOC, 2008, p.42-46 e p.158-164.

LEITE, Rogério P. Contra-Usos da cidade - Lugares e espaço público na experiência urbana contemporânea. Campinas: Editora Unicamp, 2004.

LEMOS, Carlos A. C. O que é patrimônio histórico. São Paulo: Brasiliense, 2006.

MARINS, Paulo César G. Do Luz Cultural ao Monumenta: sobre a opção pela escala monumental na preservação de uma área de São Paulo. In: GAGLIARDI, Clarissa Rosa (org.). Intervenções urbanas em centros históricos: casos da Itália e São Paulo em discussão. São Paulo: Educ, 2012, p.145-169.

MELLO, Joana. Da arqueologia portuguesa à arquitetura brasileira. Revista do Instituto de Estudos Brasileiros, São Paulo, 44, set., p.69-98, 2006. 
MICELI, Sérgio. SPHAN: refrigério da cultura oficial. Revista do Patrimônio Histórico e Artístico Nacional, Rio de Janeiro, n. 22, p. 44-47, 1987.

MINISTÉRIO da Educação e da Cultura (MEC), Secretaria do Patrimônio Histórico e Artístico Nacional (SPHAN). Fundação Nacional Pró-Memória. Proteção e Revitalização do Patrimônio Cultural no Brasil: uma trajetória. Brasília: MEC/SPHAN, 1980.

PESSOA, José (org). Lucio Costa: documentos de trabalho. Rio de Janeiro: IPHAN, 1999.

PINHEIRO, Maria Lucia B. Neocolonial, modernismo e preservação do patrimônio no debate cultural dos anos 1920 no Brasil. São Paulo: Edusp, 2011.

RODRIGUES, Angela Rosch. Estudo do patrimônio industrial com uso fabril da cidade de São Paulo. Dissertação (Mestrado) - Faculdade de Arquitetura e Urbanismo, Universidade de São Paulo, São Paulo, 2011.

RODRIGUES, Cíntia Nigro. Territórios do Patrimônio - Tombamentos e participação social na cidade de São Paulo. Dissertação (Mestrado) - Faculdade de Filosofia, Letras e Ciências Humanas, Universidade de São Paulo, São Paulo, 2001.

RODRIGUES, Marly. Imagens do Passado: a instituição do patrimônio em São Paulo:19691987. São Paulo: Ed. Unesp / Imprensa Oficial / CONDEPHAAT / FAPESP, 2000.

RUBINO, Silvana. As fachadas da história: os antecedentes, a criação e os trabalhos do Serviço do Patrimônio Histórico e Artístico Nacional, 1937-1968. Dissertação (Mestrado) Departamento de Antropologia, Instituto de Filosofia e Ciências Humanas, Universidade Estadual de Campinas, 1991.

SAINT-HILAIRE, Auguste de. Viagem ao Rio Grande do Sul, 1820-1821. São Paulo: Editora da Universidade de São Paulo / Belo Horizonte: Livraria Itatiaia Editora, 1974.

TELLES, Augusto Carlos da Silva. Atlas dos monumentos históricos e artísticos do Brasil. Brasília, DF: IPHAN/Programa Monumenta, 2008.

\section{Estudos de caso}

\subsection{Capela do Morumbi}

FARAH, Ana Paula. Restauro arquitetônico: a formação do arquiteto urbanista no Brasil para preservação do patrimônio edificado - o caso das escolas do Estado de São Paulo. Tese (Doutorado) - Faculdade de Arquitetura e Urbanismo, Universidade de São Paulo, São Paulo, 2012.

INVAMOTO, Denise. Futuro pretérito: historiografia e preservação na obra de Gregori Warchavchik. Dissertação (Mestrado) - Faculdade de Arquitetura e Urbanismo, Universidade de São Paulo, São Paulo, 2012.

SCHMIDT, Carlos Borges. Construções de Taipa: Alguns aspectos do seu emprego e da sua técnica. Boletim de Agricultura. São Paulo: Secretaria de Agricultura, 1946, série 47a.

\subsection{Engenho São Jorge dos Erasmos}

ANDREATTA, Margarida D. Engenho São Jorge dos Erasmos: prospecção arqueológica, histórica e industrial. Revista USP, São Paulo, n. 41, mar./maio, p. 28-47, 1999. 
ANJOS, Fernanda M. F. dos. Engenho São Jorge dos Erasmos: uma abordagem interdisciplinar do documento na Arqueologia Histórica. São Paulo: Faculdade de Filosofia, Letras e Ciências Humanas, Área interdepartamental de Arqueologia da USP. Dissertação (Mestrado), 1998.

CORDEIRO, José P. L. O Engenho São Jorge dos Erasmos. São Paulo: Gráfica Bentivegna, 1945.

CORDEIRO, Silvio L. A Paisagem Histórica do Engenho São Jorge dos Erasmos: o vídeo como instrumento educativo na arqueologia do monumento quinhentista. São Paulo: Museu de Arqueologia e Etnologia da USP. Dissertação (Mestrado), 2007.

GAMA, Ruy. Engenho e tecnologia. São Paulo: Livraria Duas Cidades, 1983.

LOURENÇO, Maria Cecília F.; CHRISTOFOLETTI, Rodrigo; MELlO, André M. Portas Abertas: um programa em debate. São Paulo: Pró-Reitoria de Cultura e Extensão Universitária da Universidade de São Paulo - Monumento Nacional Ruínas Engenho São Jorge dos Erasmos - USP, 2008.

MEURS, Paul. Engenho São Jorge dos Erasmos: Estudos de Preservação. Cadernos de Pesquisa do LAP, n.07, São Paulo: FAU/USP, 1995.

MORAIS, José Luiz; PIEDADE, Silvia R.; MAXIMINO, Eliete P. B. Arqueologia da Terra Brasilis: o Engenho dos Erasmos na Capitania de São Vicente. Revista de Arqueologia Americana, n.23, 2004/2005, p.349-384. Disponível em $<$ http://www.jstor.org/stable/27768495>. Acesso em 07 de out. 2013.

REIS FILHO, Nestor Goulart. Imagens de vilas e cidades do Brasil colonial. São Paulo: EDUSP/IMESP/FAPESP, 2000.

RODRIGUES, Maria Regina da C. O Engenho São Jorge dos Erasmos. Revista de História, n.21, São Paulo: FAU/USP, p.199-201,1960.

STOLS, Eddy. Um dos primeiros documentos sobre o Engenho dos Schetz em São Vicente. Revista de História, São Paulo: FAU/USP, n.37, p.407-419, 1968.

UNIVERSIDADE de São Paulo Pró-Retoria de Cultura e Extensão Universitária. Plataforma Sophia: Ruínas Engenho São Jorge dos Erasmos. São Paulo: PRCEU/USP, 2005.

\subsection{Igreja Matriz São Luiz de Tolosa}

IPHAN. Dossiê São Luiz do Paraitinga. São Paulo, 2010.

MARTINS. Leonardo F. Patrimônio e participação em São Luiz do Paraitinga entre o discurso e a prática. In: Anais do Arquimemória 4 - Sobre preservação do patrimônio edificado, Salvador, 2013 (CD-ROM).

MORADEI, Natália dos Santos. A grande enchente de São Luíz do Paraitinga. 2015. São Paulo: Faculdade de Arquitetura e Urbanismo da Universidade de São Paulo. Dissertação (Mestrado), 2015.

SAIA, Luis; TRINDADE, Jaelson B. São Luis do Paraitinga. Pub. n. 2: CONDEPHAAT/Secretaria da Cultura, Ciência e Tecnologia, s.d.

SAIA, Luis. Evolução urbana de São Luiz do Paraitinga. In: Anais do VII Simpósio Nacional dos Professores Universitários de História, Belo Horizonte, 2 a 8 de setembro de 1973, São Paulo: s.n., 1974. 


\subsection{Sítio Itaim}

KATINSKY, Julio R. Casas Bandeiristas: Nascimento e reconhecimento da arte em São Paulo. Tese (Doutorado) - Faculdade de Arquitetura e Urbanismo, Universidade de São Paulo, São Paulo, 1972.

LEMOS, Carlos A. C.. Casa paulista: história das moradias anteriores ao ecletismo trazido pelo café. São Paulo: Edusp, 1999.

MAYUMI, Lia. Taipa, canela-preta e concreto: estudo sobre o restauro de casas bandeiristas. São Paulo: Romano Guerra, 2008.

SAIA, Luis. Notas sobre a evolução da morada paulista. São Paulo: Acrópole, 1957.

SÃO PAULO (cidade). Relatório técnico. Autoria: MAYUMI, Lia. São Paulo: SMC/DPH, 2012.

ZANETTINI Arqueologia S/S Ltda. Programa de salvamento arqueológico do Sítio Casa Bandeirista do Itaim Bibi. São Paulo: IPHAN, 2009.

\subsection{Sítio Mirim}

KATINSKY, Julio R. Casas Bandeiristas: Nascimento e reconhecimento da arte em São Paulo. Tese (Doutorado) - Faculdade de Arquitetura e Urbanismo, Universidade de São Paulo, São Paulo, 1972.

LEMOS, Carlos A. C.. Casa paulista: história das moradias anteriores ao ecletismo trazido pelo café. São Paulo: Edusp, 1999.

MAYUMI, Lia. Taipa, canela-preta e concreto: estudo sobre o restauro de casas bandeiristas. São Paulo: Romano Guerra, 2008.

SAIA, Luis. Sede do Sítio Mirim. Revista Acrópole. São Paulo, n.358, ano 30, jan./fev., p. 31-35, 1969. . Notas sobre a evolução da morada paulista. São Paulo: Acrópole, 1957.

. Notas sobre a arquitetura rural paulista do segundo século. Revista do Serviço do Patrimônio Histórico e Artístico Nacional. Rio de Janeiro, n. 8, p.268, 1944.

SÃO PAULO (cidade). Anteprojeto arquiteto de requalificação das ruínas da antiga Sede do Sítio Mirim. Autoria: DIÊGOLI, Leila R., MAGALDI, Cássia Regina C., SERAPHIM, José Henrique C. São Paulo: SMC/DPH, 1999.

$\overline{\mathrm{SMC} / \mathrm{DPH}, 1983 .}$

Relatório Sítio Mirim. Autoria: MENEZES, Vera Santos Mauro de. São Paulo:

Relatório das obras de emergência realizadas nas ruínas do Sítio Mirim. Autoria: MORAES, João Eduardo Correa Dias. São Paulo: SMC/DPH, 1978.

Paulo: SMC/DPH, 1976.

Relatório de apresentação de projeto para o Sítio Mirim. Autoria: SAIA, Helena. São

\subsection{Teatro Cultura Artística}

BRUNA, Paulo. An architectural dilemma: conservation or reconstruction of the "cultura artística" theatre in São Paulo. Anais Docomomo Mexico, 2010, DVD.

CARRILHO, Marcos José. Teatro Cultura Artística: novo edifício e restauração. Arquitextos

(eletrônica), Ano $09, \quad$ jan. $2009 . \quad$ Disponível em:

$<$ http://www.vitruvius.com.br/revistas/read/arquitextos/09.104/80>. Acesso em 08 Jul. 2011. 


\section{Processos administrativos}

\subsection{CONDEPHAAT - Estado de São Paulo}

- Capela do Morumbi:

São Paulo (Estado) - CONDEPHAAT. Processo 22263/82 - Capela Morumbi (São Paulo), 1982.

- Igreja Matriz São Luiz de Tolosa:

São Paulo (Estado) - CONDEPHAAT. Processo 22066/82 - Igreja Matriz São Luiz de Tolosa (São Luiz do Paraitinga), 1982.

- Sítio Itaim:

São Paulo (Estado) - CONDEPHAAT. Processo 20640/78 - Sítio Itaim (São Paulo), 1978.

- Teatro Cultura Artística:

São Paulo (Estado) - CONDEPHAAT. Processo 58145/08 - Teatro Cultura Artística (São Paulo), 2008. . Processo 33188/95 - Teatro Cultura Artística (São Paulo), 1995.

\section{- Outros:}

São Paulo (Estado) - CONDEPHAAT. Processo 20075/76 - Ermida de Santo Antônio de Guaíbe (Guarujá), 1976. . Processo 00554/75 - Ruínas do Engenho de Lagoinha (Ubatuba), 1975.

. Processo 00429/74 - Casarão do Valongo (Santos), 1974.

. Processo 09515/69 - Ruínas do Abarabebê (Peruíbe), 1969.

\subsection{IPHAN - Arquivo da Superintendência SP}

- Engenho São Jorge dos Erasmos:

IPHAN. Processo 0678-T-62 - Engenho São Jorge dos Erasmos (Santos, SP), 1962.

- Igreja Matriz São Luiz de Tolosa:

IPHAN. Processo 1590-T-10 - São Luiz do Paraitinga (SP), 2010.

. Processo 01506.000823/2010 - Igreja Matriz São Luiz de Tolosa, 2010.

. Dossiê São Luiz do Paraitinga, 2010.

- Sítio Mirim:

IPHAN. Processo 755-T-65 - Sítio Mirim (São Paulo, SP), 1965.

- Sítio Itaim:

IPHAN. Processo 01506.001662/2008-34 - Sítio Itaim (São Paulo, SP), 2008.

. Processo 0156001873/2008-77, 2008.

. Processo 01506.000803/2009-82, 2009.

. Processo 01506.002274/2010-95, 2010.

- Teatro Cultura Artística:

IPHAN. Processo 1603-T-10 - Teatro Cultura Artística (São Paulo, SP), 2010. 
- Outros:

IPHAN. Processo 0727-T-64 - Real Fábrica de Ferro S. João Ipanema (Iperó, SP), 1964. . Processo 0346-T-c.1941 - Capela do Sítio Querubin (São Roque, SP), c.1941. . Processo 0752-T-64 - Forte São Felipe (Guarujá, SP), 1964. . Processo 0910-T-74 - Sede Fazenda Conceição - (Paraíbuna, SP), 1974.

1939. . Processo 0215-T-39 - Igreja e Convento Nossa Senhora Conceição - (Itanhaém, SP),

\subsection{Prefeitura Municipal de São Paulo - DPH e CONPRESP}

- Capela do Morumbi:

SÃO PAULO - cidade, SMC/CONPRESP. Resolução n. 11/ 2005. . Processo1992-0.007.730-7.

SMC/DPH - Seção Levantamento e Pesquisa: Pasta 03A.004.3.

- Sítio Itaim:

SÃO PAULO - cidade, SMC/CONPRESP. Processo 2011-0.357.476-7. . Processo 2009-0.143.969-6. . Processo 1997-0.182.218-0.

- Sítio Mirim:

SÃO PAULO - cidade, SMC/CONPRESP. Processo 1999-0.224.916-7.

PMSP/SMC/DPH - Seção Técnica de Projeto, Restauro e Conservação (STPRC): Pasta: D.O.M. Julho/98.

- Teatro Cultura Artística:

SÃO PAULO - cidade, SMC/CONPRESP. Resolução n. 14/2011.

- Outros:

SÃO PAULO - cidade, SMC/CONPRESP. Resolução 39/92. Vila Maria Zélia.

\section{Projetos consultados}

Faculdade de Arquitetura e Urbanismo (Seção Levantamento e Pesquisa e Acervo)

- Capela do Morumbi - Projeto de Gregori Warchavchik: PW196 725.65 FM.

\section{Entrevistas}

Antonella Negri (arquiteta no Ministero dei Beni Culturalle, ICCD - Istituto Centrale per il Catalogo e per la Documentazione, Servizio per $i$ beni Architettonici e Ambientali responsável), 15.12.2015.

Carmen Maria Enss (pesquisadora assistente no Institut für Archäologie, Denkmalkunde und Kunstgeschichte, Heritage Sciences, Otto-Friedrich Universität Bamberg, Alemanha), 04.03.2016. 
Daniela Esposito (diretora da Scuola di Specializzazione in Beni Architettonici e del Paesaggio, Facoltà di Architettura, Università degli Studi di Roma La Sapienza e professora do Dipartamento di Storia, Disegno e Restauro dell Architettura, da mesma Universidade), 01.10.2016.

Giovanni Carbonara (professor do Dipartamento di Storia, Disegno e Restauro dell Architettura, Facoltà di Architettura, Università degli Studi di Roma La Sapienza), 05.11.2015 e 22.02.2016.

Jukka Jokilehto (conselheiro do ICCROM, UNESCO), 09.11.2015 e 02.03.2016.

Lucio Altarelli (professor do Dipartamento di Architettura e Progetto, Facoltà di Architettura, Università degli Studi di Roma La Sapienza), 03.11.2015.

Marcello Barbanera professor do (Dipartamento di Scienze dell'Antichità, Facoltà di Lettere e Filosofia, Università degli Studi di Roma La Sapienza), 16.11.2015.

Margarida Davina Andreatta (arqueóloga do Museu Paulista, USP), 09.05.2012.

Martin Gegner (pesquisador no WZB - Wissenshaftzentrum Berlin für Sozialforshung - Berlin Social Science Center, Alemanha), 01.12.2015.

Mehr-Azar Soheil (pesquisadora e membro do ICCROM), 09.11.2015.

Maria Letizia Mancinelli (arquiteta no Ministero dei Beni Culturalle, ICCD - Istituto Centrale per il Catalogo e per la Documentazione, Servizio per $i$ Beni Archeolgici - responsável, Itália), 15.12.2015.

Victor Hugo Mori (arquiteto do IPHAN, Superintendência SP), 22.05.2012.

\subsection{Estudos de casos}

\section{- Engenho São Jorge dos Erasmos}

Apoena Amaral e Vito Macchione (arquitetos do escritório 2A+V), 05.05.2015.

Rodrigo Christofoletti (historiador e educador no Engenho São Jorge dos Erasmos), 05.10.2013.

\section{- Igreja Matriz São Luiz de Tolosa:}

Natália dos Santos Moradei (arquiteta, assessora de Planejamento da Prefeitura Municipal da Estância Turística de São Luiz do Paraitinga), 13.04.2015.

- Sítio Itaim

Lia Mayumi (arquiteta da Seção técnica de Projeto, Restauro e Conservação, PMSP/SMC/DPH), 20.08.2015.

- Sítio Mirim

Anderson Freitas (arquiteto proprietário do escritório Apiacás Arquitetos), 26.02.2013.

Lia Mayumi, (arquiteta da Seção técnica de Projeto, Restauro e Conservação, PMSP/SMC/DPH), 22.02.2013.

Marcos Cartum (arquiteto PMSP/SMC), 05.02.2014.

\section{- Teatro Cultura Artística}

Paulo Bruna (arquiteto responsável pelo novo projeto), 30.04.2015. 


\section{Sítios consultados}

CONDEPHAAT. Listagem dos bens tombados:

$<$ http://www.cultura.sp.gov.br/portal/site/SEC/menuitem.fe8f17d002247c2c53bbcfeae2308ca 0/?vgnextoid=300d6ed1306b0210VgnVCM1000002e03c80aRCRD $>$

CONPRESP. Índice Geral:

$<$ http://www.prefeitura.sp.gov.br/cidade/secretarias/cultura/CONPRESP/indice_geral/index.p $\mathrm{hp}$ ? $\mathrm{p}=1142>$

. Resoluções:

$<$ http://www.prefeitura.sp.gov.br/cidade/secretarias/cultura/CONPRESP/legislacao/resolucoes /index.php? $\mathrm{p}=1137>$

IHGB. Revista do Instituto Histórico e Geográfico do Brasil:

$<$ https://ihgb.org.br/publicacoes/revista-ihgb/itemlist/filter.html?category=9\&moduleId=147>

IPHAN. Arquivo Noronha Santos:

$<$ http://www.IPHAN.gov.br/ans/inicial.htm>

Cadastro Nacional de Sítios Arqueológicos:

$<\mathrm{http}: / /$ www.iphan.gov.br/sgpa/?consulta $=$ cnsa $>$

UNESCO:

$<$ http://whc.unesco.org/> 


\section{Instituições consultadas}

Bibliotecas da Universidade de São Paulo (USP):

- Faculdade de Arquitetura e Urbanismo (FAU)

- Faculdade de Filosofia, Letras e Ciências Humanas (FFLCH)

- Museu de Arqueologia e Etnografia (MAE)

Bibliotecas da Universidade Mackenzie:

- Faculdade de Arquitetura e Urbanismo (FAU)

Biblioteca da Universidade Estadual de Campinas (UNICAMP):

- Faculdade de Filosofia e Ciências Humanas

Bibliotecas da Università degli studi di Roma "La Sapienza":

- Faculdade de Arquitetura:

Biblioteca Centrale

Biblioteca di Storia, Disegno e Restauro dell 'Architettura

Biblioteca do ICCROM (International Centre for the Preservation and Restoration of the Cultural Property, UNESCO) - Roma

Bibliotecas e acervos da Prefeitura Municipal de São Paulo:

- Departamento do Patrimônio Histórico - Secretaria Municipal de Cultura (DPH - SMC):

Arquivo Histórico Municipal Washington Luís

Seção Técnica de Levantamento e Pesquisa

- Secretaria Municipal de Gestão:

Arquivo Municipal

CONDEPHAAT - Conselho de Defesa do Patrimônio Histórico, Arqueológico, Artístico e Turístico do Estado de São Paulo.

CONPRESP - Conselho Municipal de Preservação do Patrimônio Histórico, Cultural e Ambiental da Cidade de São Paulo.

IPHAN - Instituto do Patrimônio Histórico e Artístico Nacional/SP. 